UNIVERSIDADE DE SÃO PAULO

FACULDADE DE ARQUITETURA E URBANISMO

RODRIGO FARIA GONÇALVES IACOVINI

\title{
A POLÍTICA QUE ALIMENTA E A VIOLÊNCIA QUE MATA \\ Elementos para uma economia política da urbanização de favelas em cidades do Brasil e da Colômbia
}

SÃO PAULO 


\section{RODRIGO FARIA GONÇALVES IACOVINI}

\section{A POLÍTICA QUE ALIMENTA E A VIOLÊNCIA QUE MATA}

Elementos para uma economia política da urbanização de favelas em cidades do Brasil e da Colômbia

Tese apresentada à Faculdade de Arquitetura e Urbanismo da Universidade de São Paulo para obtenção do título de Doutor em Arquitetura e Urbanismo. Área de Concentração: Planejamento Urbano e Regional

Orientadora: Prof. Raquel Rolnik

SÃO PAULO 
Autorizo a reprodução e divulgação total ou parcial deste trabalho, por qualquer meio convencional ou eletrônico, para fins de estudo e pesquisa, desde que citada a fonte.

Email: rfgiaco@yahoo.com.br

Catalogação na Publicação

Serviço Técnico de Biblioteca

Faculdade de Arquitetura e Urbanismo da Universidade de São Paulo

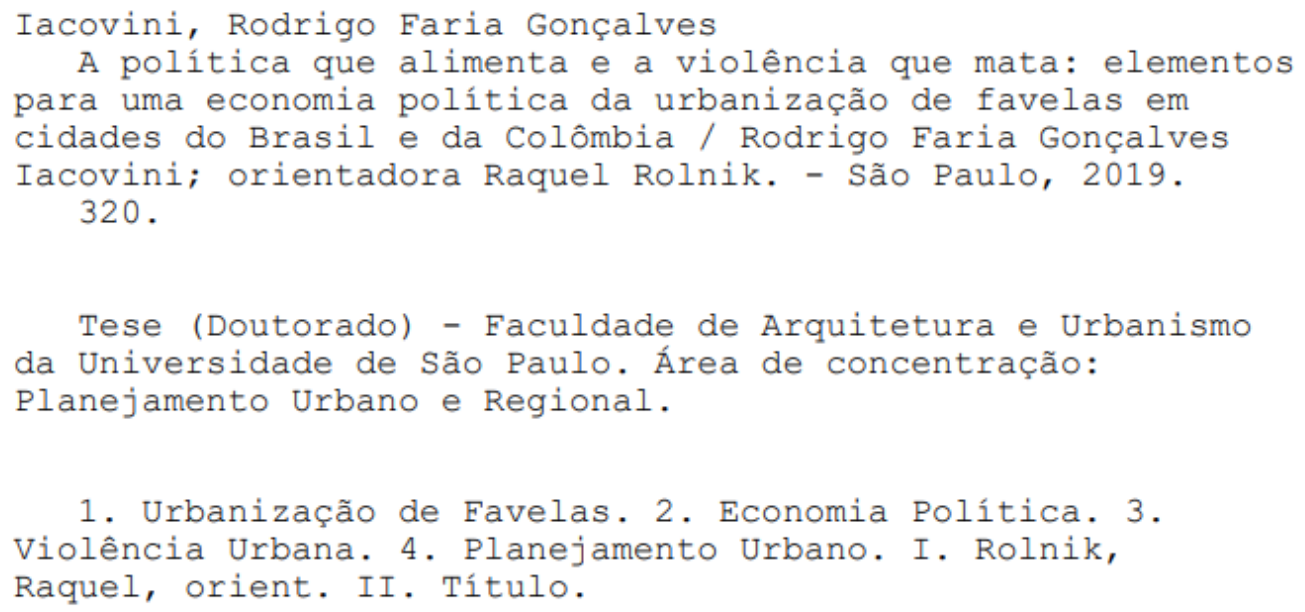

Elaborada eletronicamente através do formulário disponível em: <http://www.fau.usp.br/fichacatalografica/> 


\section{A POLÍTICA QUE ALIMENTA E A VIOLÊNCIA QUE MATA}

Elementos para uma economia política da urbanização de favelas em cidades do Brasil e da Colômbia

Tese apresentada à Faculdade de Arquitetura e Urbanismo da Universidade de São Paulo para obtenção do título de Doutor em Arquitetura e Urbanismo.

Aprovado em:

Prof. Dr. Instituição

Julgamento Assinatura

Prof. Dr. Instituição Julgamento Assinatura

Prof. Dr. Instituição Julgamento Assinatura

Prof. Dr. Instituição Julgamento Assinatura

Prof. Dr. Instituição Julgamento Assinatura 
Marielle Franco, presente! 


\section{AGRADECIMENTOS}

Esta tese sobreviveu a um golpe parlamentar travestido de impeachment, às eleições em que ultradireita volta ao poder no Brasil e aos 60 primeiros dias de seu governo. Ela, em si mesma, já é vitoriosa, tendo em vista que seu próprio objeto - política e violência nas políticas de urbanização - está profundamente embebido das relações estabelecidas nos diferentes níveis da vida política brasileira, os quais passam por grandes transformações nos últimos meses.

Se a política e a ciência são os principais fios constitutivos do tecido deste trabalho, sua trama é costurada pelo componente humano - em sua dimensão afetiva, ideológica, social. Os trabalhos, no âmbito acadêmico principalmente, são muitas vezes avaliados enquanto produtos finais entregues, "depositados", e não enquanto processos. Aliena-se o indivíduo e o contexto em que está inserido; esquecendo-se justamente que esse tear é realizado em meio à vida cotidiana.

Não à toa, surgem nos últimos anos diferentes estudos e notícias sobre os índices alarmantes de casos de depressão, ansiedade e até mesmo suicídio entre pós-graduandos, bem maiores do que aqueles encontrados na média da população. Infelizmente, o estigma de que as doenças mentais ainda são alvo faz com que esse sofrimento seja silenciado, vivido sozinho, cobrando um preço alto demais.

Por isso, gostaria de usar este espaço para agradecer a todos aqueles que tentam enxergar para além do que está escrito e a quem entende que, no fundo, de nada vale um título de doutor sem o seu portador. Uma tese de qualidade deve sempre vir acompanhado de um doutor "de qualidade", e isso significa uma pessoa minimamente satisfeita consigo e com o caminho que percorreu, cujo resultado está apenas parcialmente contido na tese escrita. Sou especialmente grato a Bernardo, que junto comigo trilhou esse caminho colocando questões e pensando possibilidades. Muito obrigado!

Vocês já repararam que "favela" e "família" compartilham a maioria das letras que as compõem? Não deve ser coincidência. Ambas estão ali, como se 
fossem dadas, muitas vezes existindo antes e depois da gente, mas na realidade construímos as duas no nosso cotidiano. Sem muita orientação sobre como fazer, cada um vai construindo sua parte dentro do todo, e o todo vai sendo mais do que a soma do que cada um constrói. Por isso, preciso agradecer à minha favela-família, ou família-favela, em que cada um foi responsável por um importante pedaço de mim.

À minha mãe, não tenho como deixar de agradecer por toda generosidade e força emprestada ao longo do caminho. Aprendi com você a ser crítico, desafiador, inconformado. Seu amor incondicional sempre foi fonte de segurança e estabilidade para navegar águas turbulentas. Como dizem, nada como colo de mãe. E como comida de mãe. E abraço de mãe. Te amo!

Com minha avó, descobri que é possível envelhecer e, ao mesmo tempo, tornar-se cada vez melhor, mais lúcido e aberto a mudanças. As risadas e os papos pouco ortodoxos entre avó e neto me ajudaram a relaxar e a amolecer diante da vida. Obrigado também por me trazer Tico, Tamara e Zeca, queridos que, ainda que longe, estão sempre perto.

Por fim, meu irmão, Victor, foi o maior e melhor companheiro que tive ao longo deste doutorado. Leitor e crítico atento, carinho e atencioso, na saúde e (literalmente) na doença, você é parte fundamental de quem eu sou hoje e desse trabalho. Sua inteligência e capacidade intelectual são únicas, sou profundamente grato por ter podido contar com elas.

À Raquel, com quem aprendi e ainda aprendo tanto desde 2010. Já são 9 anos de convivência e respeito, de uma admiração pelo brilhantismo e pela capacidade de análise, mas principalmente pelos valores e pela defesa incansável de novas utopias para as cidades, sempre com os pés profundamente enraizados na realidade política, econômica e social que vivemos. Obrigado pela sua dedicação incomparável como orientadora, por emprestar sua inteligência e seu valioso tempo, por apostar em mim, mas, acima de tudo, obrigado pela compreensão, paciência e carinho na condução dessa reta final turbulenta do último ano. Se eu não desisti no meio do caminho, foi por poder contar com isso. 
Sou grato também a outros companheiros que me apoiaram na realização deste trabalho, com horas de dedicação a transcrições, traduções, sistematizações e outros tantos "ões”: Vitor Soares Miceli, Gabriela Ortega, Lara Ferreira, Kaori Cabrera, Eunice Remondini. Também cederam gentilmente seu tempo e suas fontes Felipe Moreira, Paula Oliveira, Henrique Frota e Victor lacovini. Vocês foram demais! Não posso deixar de mencionar a compreensão e incentivo de toda a equipe (técnica e administrativa) do Instituto Pólis e do Instituto Brasileiro de Direito Urbanístico, essenciais para a imersão final que possibilitou a conclusão dessa trajetória.

E o que seria dessa vida sem amigos? O que seria dessa tese, gente, sem amigos?! São tantos que dá medo de esquecer alguém (se alguém se sentir esquecido, desculpa, mas a culpa é toda da tese): Annadia, Natasha, Margareth, Tama, Vitor, Bianca, Marília, Fernanda, Luís, Paula, Israel, Valéria, Bárbara, Otávio, Gilson.

Não poderia nunca deixar de agradecer especialmente àqueles que me lembram todo dia de onde vim e do que eu sou feito - de amor e risadas. Aos jeris e fringilídeos: estamos sempre juntos e aprendendo desde o colégio, mas foram as lições de vida já fora dele o que vocês me trouxeram de melhor. Sem falar no meu maravilhoso afilhado, Vinícius, que me inspira a continuar a lutar por uma sociedade melhor para todos.

Àqueles que, junto comigo, formam o melhor trio parada dura dentro e fora do carnaval: Dani e Henrique. Em todos os bares, sushis e blocos; em todas as reuniões, eventos e manifestações; antes e depois da nossa militância cotidiana; juntos somos (de)mais.

Por último, e definitivamente não menos importante, LabLajers: vocês são este trabalho. Se a responsabilidade de todos os argumentos, acertos e erros deste trabalho é exclusivamente minha; toda a crença na sua importância e nos seus fundamentos é nossa. Vocês foram (e são) o vento da minha pipa. 


\section{RESUMO}

A partir de extensa análise bibliográfica, documental e empírica, a tese busca discutir questões tratadas como secundárias pela literatura do campo e contribui para a reflexão sobre os elementos que constituem a economia política da urbanização de favelas em cidades do Brasil e da Colômbia nas últimas quatro décadas. Aprofunda-se, para tanto, na compreensão do processo de urbanização a partir de dois eixos principais: a violência estrutural que permeia e molda nossa sociedade (e como ela é mobilizada politicamente, especialmente no âmbito de políticas de urbanização de favelas) e o entrelaçamento entre as dinâmicas da "Política" (em sentido mais ampliado, do sistema político, da representação, dos governos e da cidadania) e da "política" (no sentido da política pública setorial de urbanização). Longe de ser uma questão meramente técnica ou espacial, a urbanização de favelas se revela enredada em densas e múltiplas redes e campos de força e poder; entre a violência, a política (com ' $P$ ' e com ' $p$ '), os diversos interesses e necessidades. O problema a ser encarado são os conflitos entre as diversas e assimétricas territorialidades que configuram e constituem esses territórios e que produzem e reproduzem não somente o espaço urbano, mas o espaço político como um todo nas cidades brasileiras (São Paulo e Rio de Janeiro) e colombianas (Medellín e Bogotá) estudadas na pesquisa. Desnuda-se, ao final, como estes elementos tem dificultado o estabelecimento de uma agenda pública permanente de atuação do estado no setor, o qual, apesar do desenvolvimento histórico e da ampliação da escala, sentidos e importância na agenda política, continuamente se encontra oscilando em termos de prioridade no interior do estado de forma profundamente imbricada com os contextos social, político e econômico.

Palavras-chave: urbanização de favelas - economia política - violência 


\section{RESUMEN}

A partir de un extenso análisis bibliográfico, documental y empírico, la tesis busca discutir cuestiones tratadas como secundarias por la literatura del campo de estudio y contribuye a la reflexión sobre los elementos que constituyen la economía política de lo mejoramiento barrial en ciudades de Brasil y Colombia en las últimas cuatro décadas. Se profundiza, así, en la comprensión del proceso de urbanización a partir de dos ejes principales: la violencia estructural que impregna y moldea nuestra sociedad (y cómo es movilizada políticamente, especialmente en el ámbito de políticas de urbanización de favelas) y el enredamiento entre las dinámicas de la "Política" (en sentido más amplio, del sistema político, de la representación, de los gobiernos y de la ciudadanía) y de la "política" (en el sentido de la política pública sectorial de urbanización). Lejos de ser una cuestión meramente técnica o espacial, la urbanización de favelas se revela involucrada en densas y múltiples redes y campos de fuerza y poder; entre la violencia, la política (con ' $P$ ' y con ' $P$ '), los diversos intereses y necesidades. El problema a encarar son los conflictos entre las diversas y asimétricas territorialidades que configuran y constituyen esos territorios y que producen y reproducen no solamente el espacio urbano, sino el espacio político como un todo en las ciudades brasileñas (Sao Paulo y Rio de Janeiro) y colombianas (Medellín y Bogotá) estudiadas en la investigación. Queda evidente, al final, cómo estos elementos han dificultado el establecimiento de una agenda pública permanente de actuación del estado en el campo, el cual, a pesar de su desarrollo histórico y de la ampliación en escala, sentidos e importancia en la agenda política, continuamente se encuentra oscilando en términos de prioridad en el interior del estado de forma profundamente imbricada con los contextos sociales, políticos y económico.

Palabras-clave: mejoramiento barrial - economía política - violência 


\section{ABSTRACT}

Based on na extensive bibliographical, documentary and empirical research, the thesis discusses relevant, but not usually addressed, issues on the political economy of slum upgrading policies in cities in Brazil and Colombia in the last four decades. The work is structured on two main analysis axes: the violence that permeates and shapes both societies, emphasizing on how it is politically mobilized, especially with regard to slum upgrading policies; and the relation among Politics (in the broadest sense, meaning the political system, representation, governments and citizenship) and slum upgrading policies. Far from being merely a technical or spatial issue, slum upgrading initiatives are entangled in dense and multiple networks and fields of force and power; between violence, politics and policies, diverse interests and needs. There is a need to address the conflicts between the diverse and asymmetrical territorialities that shape and produce these territories and that produce and reproduce not only the urban space, but the political space as a whole in Brazilian cities (São Paulo and Rio de Janeiro) and Colombian cities (Medellín and Bogotá). In the end, these elements hinder the establishment of a permanent public agenda for action in the sector. Despite the historical development and importance of slum upgrading policies for the inhabitants of informal settlements, they are still oscillating in terms of priority within the state, deeply intertwined with social, political and economic contexts.

Keywords: slum upgrading - political economy - violence 


\section{LISTA DE FIGURAS}

Figura 01 - "Padrões dos homicídios dolosos, São Paulo (SP), Brasil, 20002008"

Figura 02 - "Município do Rio de Janeiro: intensidade da violência por classes do estimador de Kernel"

\section{LISTA DE GRÁFICOS}

Gráfico 01 - "Evolução das taxas de homicídios dolosos, por 100 milhabitantes. Município de São Paulo, 1981 a 2003."

Gráfico $02 \neg$ "Roubo de veículos no Brasil (por 100 mil veículos, de 2006 a 2016)"

Gráfico 03 - "Mortes decorrentes de intervenções policiais (em serviço e fora de serviço) no Brasil, 2009-2016"

Gráfico 04 - "Delito/crime mais frequente no Brasil (em \%)"

Gráfico 05 - "Ações que o Governo deveria tomar para enfrentar a violência no País (em \%)"

Gráfico 06 - "Evolução da taxa de mortalidade por causas externas ajustada por idade, São Paulo (SP), Brasil, 1996-2008" 


\section{LISTA DE SIGLAS}

APP - Área de Preservação Permanente;

BCH - Banco Central Hipotecário;

BID - Banco Interamericano de Desenvolvimento;

BNH - Banco Nacional de Habitação;

CADE - Conselho Administrativo de Defesa Econômica;

CAMACOL - Câmara Colombiana de la Construcción;

CBPO - Companhia Brasileira de Projetos e Obras;

CDHU - Companhia de Desenvolvimento Habitacional e Urbano;

CHISAM - Coordenação de Habitação de Interesse Social da Área Metropolitana do Grande Rio;

COBRAPE - Companhia Brasileira de Projetos e Empreendimentos;

COHAB - Companhia de Habitação de São Paulo;

CV - Comando Vermelho;

DEM - Democratas (Partido Político);

DFI - Desplazamiento Forzado Intraurbano;

EIT - Empresa Técnica Industrial S/A (EIT Engenharia);

EMOP - Empresa de Obras Públicas do Estado do Rio de Janeiro;

FAUUSP - Faculdade de Arquitetura e Urbanismo da Universidade de São Paulo;

FNHIS - Fundo Nacional de Habitação de Interesse Social

FUNAPS - Fundo de Atendimento à População Moradora em Habitação Subnormal; 
GEAP - Grupo Executivo de Programas Especiais de Trabalho de Assentamentos Populares

GPAE - Grupamento de Policiamento em Áreas Especiais;

HIS - Habitação de Interesse Social;

IAB - Instituto dos Arquitetos do Brasil;

IBGE - Instituto Brasileiro de Geografia e Estatística;

ICT - Instituto de Crédito Territorial;

IPEA - Instituto de Pesquisa Econômica Aplicada;

IPHAN - Instituto do Patrimônio Histórico e Artístico Nacional;

LABHAB - Laboratório de Habitação e Assentamentos Humanos;

MIB - Programa de Mejoramiento Integral de Barrios;

MinCidades - Ministério das Cidades;

MPF - Ministério Público Federal;

MUD - Movimento Universitário de Desfavelamento;

OGU - Orçamento Geral da União;

ONU - Organização das Nações Unidas;

ONU-Habitat - Programa das Nações Unidas para os Assentamentos Humanos;

PAC - Programa de Aceleração do Crescimento;

PAC-UAP - PAC Urbanização de Assentamentos Precários;

PCC - Primeiro Comando da Capital;

PCdoB - Partido Comunista do Brasil;

PDT - Partido Democrático Trabalhista;

PIB - Produto Interno Bruto; 
PIDUZOB - Programa Integrado de Desarrollo Urbano de la Zona Oriental de Bogotá;

PMDB - Partido do Movimento Democrático Brasileiro;

PMCMV / MCMV - Programa Minha Casa, Minha Vida;

PMSP - Prefeitura do Município de São Paulo;

PNUD - Programa das Nações Unidas para o Desenvolvimento;

PPB - Partido Progressista Brasileiro;

PP - Partido Progressista;

PRONAI - Programa de Normalização de Áreas informais;

PSB - Partido Socialista Brasileiro;

PT - Partido dos Trabalhadores;

PVCC - Prevenção de Violência e Convivência Cidadã;

PRIMED - Programa Integral de Mejoramiento de Barrios Informales;

PUI - Proyectos Urbanos Integrales;

RDC - Regime Diferenciado de Contratações de Obras Públicas;

SERFHAU - Serviço Federal de Habitação e Urbanismo;

SEHAB - Secretaria de Habitação (do Município de São Paulo);

SMDU - Secretaria Municipal de Desenvolvimento Urbano;

SNHIS - Sistema Nacional de Habitação de Interesse Social

SFH - Sistema Financeiro da Habitação;

UNESCO - Organização das Nações Unidas para a Educação, a Ciência e a Cultura;

UPAC - Unidades de Poder Adquisitivo Constante;

UPP - Unidade de Polícia Pacificadora; 


\section{SUMÁRIO}

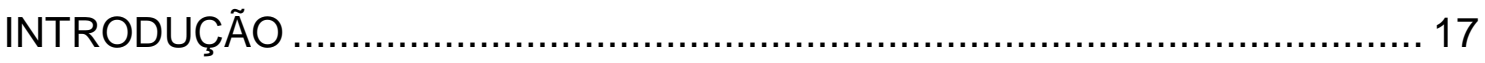

PARTE I - A política que se alimenta da política ............................................ 43

Capítulo 1 - A política de urbanização de favelas que se alimenta da Política 44

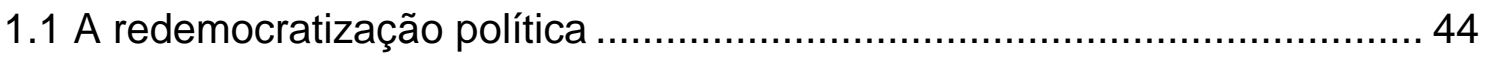

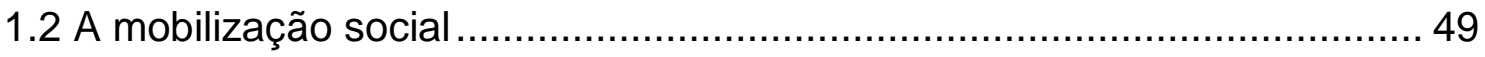

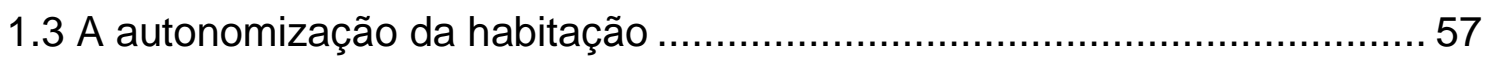

Capítulo 2 - A Política que se alimenta da política de urbanização de favelas 89

2.1 O capital político alimentado .................................................................... 90

2.2 A política alimenta o Capital ................................................................ 147

PARTE II - A política que se alimenta da violência e a violência que mata a

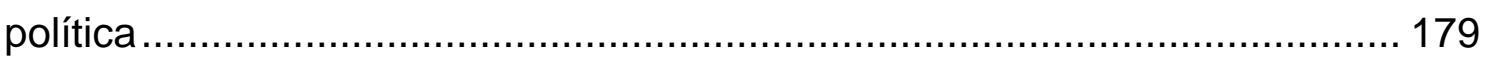

Capítulo 3 - A política que se alimenta da violência: como a urbanização de favelas é impulsionada pela violência urbana ............................................. 186

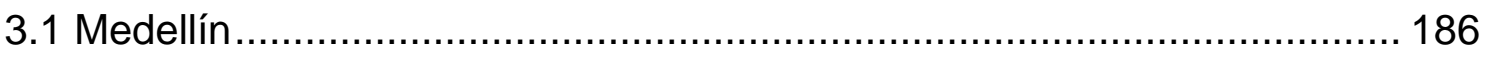

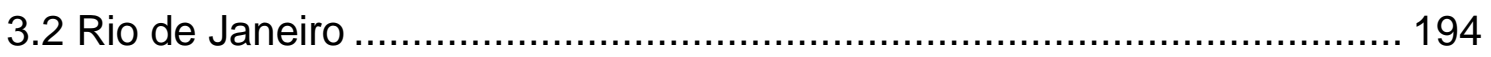

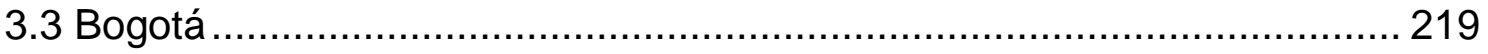

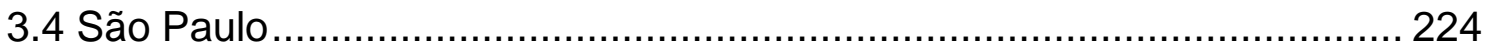

Capítulo 4 - A violência que mata a política: como a violência urbana dificulta e pode dominar a política de urbanização de favelas ....................................... 237

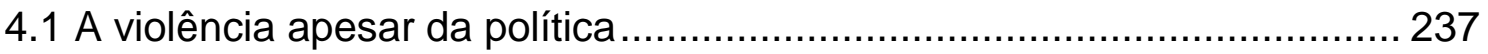

4.2 A violência silencia a política .................................................................... 259

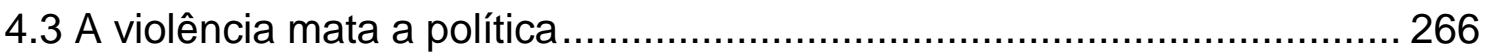

CONCLUSÃO - por que é difícil o estabelecimento de uma agenda permanente

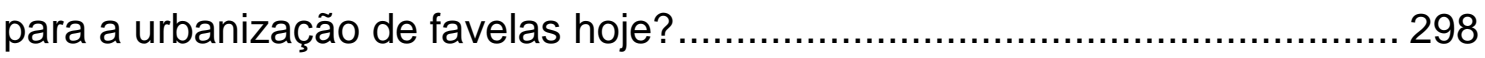

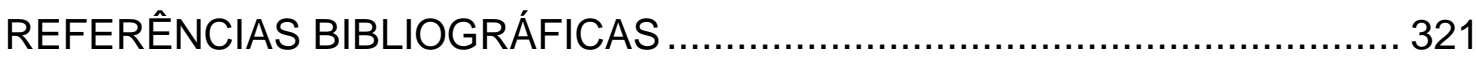




\section{INTRODUÇÃO}

Tão importante quanto uma ideia, é sua trajetória. Essa constatação serve tanto para o objeto desta tese como para o próprio trabalho em si. Explicitar o fio condutor de um raciocínio ilumina os pressupostos sobre os quais ele se fundamenta, situando o leitor acerca das ideologias subjacentes ao trabalho. Situado há anos na fronteira entre Direito e Planejamento Urbano, entre Direitos Humanos e a Produção do Espaço Urbano, busco conjugar as leituras de mundo provenientes de ambas vertentes para compreender as diferentes facetas do urbano. A cidade enquanto direito e o direito na cidade.

Foi no âmbito da equipe de apoio à Relatoria Especial da ONU para o Direito à Moradia Adequada, a convite de Raquel Rolnik (então relatora e querida orientadora), que pude finalmente unir essas dimensões para mergulhos profundos em ações de pesquisa de fôlego. Com essa missão, fomos financiados pelo CNPq para estudar a produção de empreendimentos do programa Minha Casa, Minha Vida - então grande estrela da habitacional brasileira - sob o ponto de vista dos sete elementos do direito à moradia adequada. Foram observados avanços e, principalmente, retrocessos que o programa trazia sob a perspectiva de segurança da posse, habitabilidade, acesso a serviços e infraestrutura, custo acessível, acessibilidade, adequação cultural e localização, situando ainda os conjuntos estudados do ponto de vista de sua inserção urbana.

O trabalhou motivou o aprofundamento e a ampliação do tema: a análise da política habitacional mais ampla do ponto de vista desse direito. A participação na equipe de apoio da Relatoria havia motivado ainda a extrapolar o âmbito nacional, incluindo outros países na análise. O projeto de doutorado apresentado à seleção do programa de pós-graduação tinha por objetivo, dessa maneira, "avaliar se os programas de grande escala voltados a fomentar a produção habitacional social e a urbanização de favelas em cidades latinoamericanas caracterizadas por processos excludentes de urbanização baseados na produção periférica informal e autoconstruída - atendem a todos os padrões estabelecidos internacionalmente para o direito à moradia 
adequada". Partia da hipótese de que, embora apresentassem alguns avanços, eles teriam falhado em efetivar os sete elementos que configuravam 0 conteúdo mínimo da moradia adequada.

Mas o próprio projeto já trazia, nele mesmo, seu fator de mutação.

Além de propor uma metodologia com indicadores para a avaliação, a pesquisa já tinha como objetivos entender os entraves institucionais, econômicos, sociais e urbanísticos que impediam que tais programas/projetos/ações latinoamericanos cumprissem adequadamente com estes padrões. No campo de interesse e no percurso acadêmico, já haviam sido realizadas diferentes incursões no campo da ciência política, desde pesquisas realizadas no âmbito do LabCidade sobre as determinantes das políticas de desenvolvimento urbano até mesmo aquela realizada no mestrado, a qual versou sobre o processo decisório do Rodoanel Mário Covas (também sob orientação de Raquel).

Aos poucos ficou claro, na pesquisa de doutorado, dois fatores decisivos para a mudança do objeto. Primeiramente, a desconexão entre políticas habitacionais e de direitos humanos era evidente e não havia qualquer diálogo efetivamente produtivo sendo feito nesse sentido, tornando-se pouco interessante analisar um processo a que o estado não se propõe. Em segundo lugar, havia naquele período já uma extensa literatura sobre os programas de oferta/provisão habitacional experimentados na América Latina, mas poucos trabalhos recentes agregando a experiência destes países no âmbito da urbanização de favelas.

A presente tese emerge, finalmente, na realização de um trabalho para disciplina Cidade, Governo e Políticas Pùblicas, oferecida pelo professor Eduardo Marques, cujos comentários sobre o tema e sobre a revisão bibliográfica dos principais trabalhos sobre urbanização de favelas em São Paulo efetuada foram valiosos. A revisão demonstrou que a maior parte da literatura ainda era tímida também na análise de aspectos importantes para a consolidação de uma agenda pública da urbanização de favelas e para a implementação de ações concretas. Havia poucas conexões, por exemplo, entre o sucesso ou o insucesso dessas iniciativas e a violência promovida por grupos criminais atuantes nos assentamentos. Apesar de alguns dos trabalhos 
abordarem aspectos importantes da dimensão político-institucional-eleitoral, em geral procediam a análises apenas no âmbito de algum caso específico.

Se por um lado, há vários trabalhos que buscam enquadrar a temática das favelas em um nível mais geral, amplo, macro, poucos realizam esse trabalho para a urbanização de favelas. Com honrosas exceções, as teses, dissertações, livros e artigos enfocam, em geral, casos específicos ou programas específicos; poucos realizam uma leitura do conjunto da obra. Sabemos os limites e as condicionantes impostas a esses trabalhos e, portanto, seria até mesmo injusto que se cobrasse deles algo que se dispõe de poucas condições para realizar, ainda mais no Brasil, em que se oferece pouca estrutura para pesquisas a longo prazo e que requeiram um grande esforço de pesquisa.

Esta tese vem justamente na tentativa de contribuir então para um vôo mais alto sobre questões que, acreditamos, estão intimamente ligadas ao sucesso ou insucesso já mencionado. Igualmente aos outros, este trabalho dispõe de limitações claras. Fomos obrigados a recortar objetos (deixando dimensões essenciais de fora de nossa análise), a tentar reduzir as cidades enfocadas (esperava-se abordar outros centros urbanos em outros países latinoamericanos), e até mesmo a remeter o leitor para trabalhos referenciais em alguns temas fundamentais de nossa análise. De toda forma, nosso intento foi buscar entender de maneira ampla como a sociabilidade violenta (nos dizeres de Machado da Silva) e a Política (entendida na acepção ampla de sistema político de Easton, englobando política institucional, ciclos eleitorais, cidadania, etc.) estão imbricadas com a agenda da urbanização de favelas e a implementação de ações concretas.

O objetivo da pesquisa passa, a partir do exame de qualificação, a ser "identificar e analisar qual o lugar da urbanização de favelas na economia política da cidade a partir dos elementos políticos, institucionais, econômicos e socioculturais que impulsionam ou obstaculizam a formulação e a implementação de programas/projetos/ações". A hipótese principal então era de que a urbanização de favelas teria como função alimentar, através da intervenção no território, a reprodução dos sistemas político, econômico e 
sociocultural já estabelecidos, propiciando a manutenção do status político, econômico e social historicamente reservado a estes assentamentos e à sua população em detrimento da realização do seu direito à moradia adequada. Subjacente a este discurso, estava a concepção de que a urbanização estaria então completamente submetida às necessidades desses fatores, servindo no máximo enquanto colchão de amortecimento de demandas dos moradores de assentamentos populares. Como se verá na conclusão deste trabalho, essa hipótese se mostrou, ao menos parcialmente, inválida na interpretação sobre a submissão, mas as interações que ela apontava eram de fato fundamentais para compreender os limites e possibilidades da consolidação de uma agenda pública da urbanização de favelas.

Acreditamos, portanto, que o trabalho contribui para uma reflexão que vem sendo levantada por diferentes atores (no âmbito da academia, da intervenção social, dentre outros), exemplificado pelo tema do III UrbFavelas (principal evento no tema no Brasil) em 2018 "Por uma agenda pública permanente no campo dos assentamentos precários". O evento pretendia, nesse diapasão, "reforçar a importância dessa temática no Brasil, inserida em um contexto latino-americano, sobretudo em um momento de conjuntura política conturbada e economicamente adversa em que as alternativas de financiamento público a fundo perdido para urbanização tornaram-se escassas"1.

Para efetivamente contribuir com a reflexão acerca desse processo, foram necessárias alguns recortes e decisões pouco ortodoxas na condução da pesquisa. Este trabalho não pretende, por exemplo, realizar estudos de caso ou ainda proceder a um estudo comparado, apesar de enfocar principalmente as dimensões da urbanização de favelas em quatro cidades: Bogotá e Medellín na Colômbia e São Paulo e Rio de Janeiro no Brasil. Não será feita, contudo, uma comparação estrita, ponto a ponto, com o mesmo peso, em todos os elementos nas quatro cidades. Mobiliza-se mais uma experiência do que outras em alguns argumentos construídos, utilizando-se aquela iniciativa que mais dialoga com o tema enfocado.

\footnotetext{
${ }^{1}$ Disponível em: https://www.urbfavelas2018ucsal.com.br/
} 
A tese também não pretende fazer avaliação das políticas, programas e projetos, sem a preocupação, portanto, de se ater a uma cronologia das iniciativas ou a fornecer números exatos para demonstrar seus sucessos ou insucessos. Estamos mais interessados nas ideias e nos processos do que em números e resultados.

Evitou-se, dessa maneira, a utilização de números para qualificar a atuação de gestões públicas e programas porventura abordados. Como salientam trabalhos que objetivavam esta tarefa (MARQUES \& SARAIVA, 2005; MARQUES, PULHEZ \& PAGIN, 2018), trata-se de uma pesquisa árdua em função da indisponibilidade de dados públicos e, até mesmo, confiáveis sobre o tema. Por esse motivo, centrou-se aqui mais na narrativa social reconstruída a partir do depoimento de integrantes das gestões municipais e de atores chaves envolvidos com o tema (acadêmicos, profissionais, moradores, etc.) como forma de compreender os significados e impactos políticos das experiências de urbanização de favelas nas quatro cidades estudadas.

Muito importante também destacar que não se pretende fornecer soluções ou formas de superação dos processos hoje identificados. Embora haja uma extensa literatura no campo da urbanização de favelas que o faça (seja por motivações militantes, seja por objetivos de aprendizado institucional), a aposta deste trabalho é na compreensão profunda dos entrelaçamentos já existentes entre estas iniciativas e o contexto político, social e econômico. A superação destas dinâmicas deve partir dessa compreensão, mas deverá ser alvo de outra pesquisa.

Por fim, é relevante apontar que a tese não irá enfocar temas que usualmente já sejam tratados à exaustão em outros trabalhos. Certamente serão encontrados assuntos que o leitor considerará que deveriam ter sido aprofundados ou melhor explorados. O mesmo considera o autor. No entanto, tratou-se de uma opção metodológica de precisamente buscar abranger um leque amplo de diversas questões envolvendo política e violência na chave da urbanização de favelas. Ao contrário de grande parte da literatura, que está centrada em casos, programas, políticas ou dimensões específicas da urbanização, esta tese tinha como intento a construção de um quadro maior no 
qual estas experiências e questões estão inseridas, de forma a ser possível enxergar linhas de força que incidem sobre a consolidação de uma agenda no tema.

Haverá temas caros aos envolvidos no campo da urbanização - como influência de contextos e agências internacionais no tema, a participação popular em políticas/programas/iniciativas, experiências relacionadas à regularização fundiária, impacto da legislação urbanística na trajetória do setor, dentre outros - que apenas serão mencionados ou tratados superficialmente. De antemão, pedimos desculpas pelo desapontamento, mas trata-se justamente de poder centrar o trabalho em questões não tão exploradas quanto essas ou que a pesquisa forneceu evidências interessantes, inovadoras ou atualizadoras das discussões, como ocorre principalmente na primeira parte da tese, sobre a dimensão política.

Deixaremos, assim, várias dessas tarefas para outros autores. Mesmo assim, algumas primeiras palavras sobre conceitos básicos ao tema são mandatórias. É interessante apresentar, ainda que suscintamente, os conceitos e definições mobilizados pela literatura e entrevistados acerca de barrios/assentamentos precários/assentamentos informais/favelas e mejoramiento barrial/mejoramiento integral de barrios/mejoramiento urbano em cidades colombianas. Destaca-se que, na literatura analisada, há pouca dedicação à conceituação dos assentamentos e mesmo das intervenções, partindo-se geralmente desde o início dos objetivos destas intervenções em função das precariedades ou deficiências daqueles assentamentos.

Um alerta feito por alguns autores é a dificuldade ou até mesmo a impossibilidade de se chegar a uma definição única destes assentamentos, tendo em vista a grande diversidade deste universo (VERGEL, 2010).

En diferentes ciudades del mundo los asentamientos precarios presentan múltiples características con diferentes formas de evidenciar problemas tales como la estructura de la vivienda, el acceso al agua potable y saneamiento básico y la tenencia del suelo y la vivienda, entre otros. Esto permite afirmar que no es posible tener una definición universal para el fenómeno de los asentamientos precarios (VERGEL, 2010, p. 69).

Mesmo com este alerta, os autores buscam estabelecer um patamar mínimo comum entre eles para delimitar o objeto de discussão, sendo em geral 
utilizados basicamente dois eixos característicos/descritivos: 1) sua produção/origem "informal”, explicada esta como aquela realizada por fora do mercado imobiliário formal ou aquela realizada contra as normativas oficiais que regulam a produção; 2) suas diferentes precariedades, sejam elas construtivas (materiais inadequados, ausência de sanitários, alta densidade, etc.), infraestruturais (ausência de saneamento básico, provisão de água potável), urbanísticas (pavimentação incompleta, pouca iluminação, ausência ou baixa qualidade de espaços públicos), jurídicas (irregularidade do parcelamento e das unidades), econômicas (alto desemprego, baixas oportunidades de desenvolvimento econômico, comércio informal), políticas (pouca presença de instituições públicas, descrença nos governos por parte da população), sociais (ausência de equipamentos sociais, baixa escolaridade, presença de criminalidade, etc). Realizaremos a seguir uma síntese dos principais aspectos abordados pela literatura e pelos entrevistados acerca destes dois eixos.

Primeiramente, na Colômbia os diferentes autores (SIERRA, 2013; TOVAR, 2009; PEVAL, 1984) e entrevistados (ENTREVISTADO 10; ENTREVISTADO 25; ENTREVISTADO 02; ENTREVISTADO 20; ENTREVISTADO 08; ENTREVISTADO 15) são praticamente unânimes em atrelar a produção informal dos assentamentos à incapacidade histórica do Estado em produzir ou facilitar alternativas, em escala, para o acesso a uma habitação adequada por parte da população pobre, grande parte dela inserida no âmbito da economia informal sob relações trabalhistas precárias, com regime de baixos salários. Apontam ainda a debilidade do aparato estatal para o planejamento e controle do crescimento urbano, que responde às demandas colocadas tanto pelo crescimento populacional natural quanto pelo deslocamento forçado da população do campo e até mesmo de outras áreas da mesma cidade, fugida de situações de conflito e violência.

La informalidad urbana sería un conjunto de irregularidades -0 (a) regularidades - en materia de derechos: irregularidad urbanística, irregularidad constructiva e irregularidad en relación con el derecho de propiedad de la tierra. En el caso del mercado informal de suelo, la informalidad de la economía del uso del mismo remite a esas tres irregularidades, pero también a otras, relativas a los contratos del mercado que norman las transacciones mercantiles. De esta manera, el mercado informal también sería irregular o (a) regular en relación con los derechos económicos, lo que lleva a que este particular mercado de uso del 
suelo sea la sumatoria de dos dimensiones de la informalidad: la urbana y la económica. La informalidad urbana se comporta como una peculiaridad de los mercados de suelo en América Latina, y se asocia con determinados rasgos comunes y distintivos de la ciudad latinoamericana, entre ellos la existencia de un régimen de salarios bajos, un lento crecimiento económico en contraste con un alto crecimiento poblacional, persistencia de la economía informal, una aguda desigualdad del ingreso, todo esto sumado a un muy rápido crecimiento urbano y una enorme debilidad del aparato estatal (SIERRA, 2013, p. 80 - 82).

Mercado informal é dessa forma uma das principais formas de acesso à moradia para população de baixa renda na Colômbia, havendo estimativas de que entre $45 \%$ e $65 \%$ das áreas urbanas do país são ocupadas por assentamentos de origem informal (MINISTÉRIO DE VIVIENDA, 2010, p. 12). Em síntese, a produção da informalidade e a proliferação de assentamentos na Colômbia, segundo a literatura e entrevistados, estão associadas à incapacidade do Estado em prover moradia em escala para sua população cujo crescimento está associado a diferentes dinâmicas demográficas e sociais - e à existência de um mercado informal pujante e adequado às características sociais, econômicas e familiares da população de baixa renda.

Em relação ao segundo eixo - caracterização dos assentamentos na Colômbia -, o grupo de pesquisa CPU (1984), ao sintetizar os padrões utilizados para caracterização de assentamentos na década de 1980 no país (cuja enorme variedade já expressava a dificuldade em se categorizar a complexidade do fenômeno), caracterizava a urbanização informal como irregular - em função das características físicas apresentadas - e anormais, subnormais ou ilegais, do ponto de vista das normais legais estabelecidas para o tema. Definia-se, na época, assentamento subnormal como "grupo de construcción de vivienda, de densidad variable, limites usualmente no establecidos, ubicación arbitraria, frecuentemente irregular, carente parcial o totalmente de servicios y generalmente con estructura de mala calidad" (CPU, 1984, in MARIN, 1991, p. 7).

Granados (2011) apresenta a informalidade de ocupação do território destes assentamentos como a forma espontânea que tem sido adotada em Bogotá pela população para estabelecer sua moradia por fora das condições formais definidas pelas normas e do mercado habitacional. Seriam caracterizados pelo seu baixo nível de qualidade de vida em função da ausência de serviços adequados de fornecimento de agua potável e saneamento básico, de energia 
elétrica, de pavimentação, de equipamentos educativos e de saúde, baixa qualidade do espaço público, precariedades nas condições de habitabilidade das moradias, baixos níveis de escolaridade, altos índices de violência e escassa presença das instituições governamentais (GRANADOS, 2011, p. 29). Dessa forma, o autor acrescenta novos componentes em relação à definição anterior, já que destaca características sociais e políticas, como a presença da violência e a ausência das instituições estatais.

Ainda para o caso de Bogotá, Cadena (2010), ao analisar a produção do habitat popular na cidade, afirma que a cidade informal independe, desde sua origem, das instituições que conformam a estrutura básica da sociedade, não acolhendo as regras de planejamento e controle urbanos estabelecidas por elas e se desenvolvendo, ao longo do tempo, a partir da participação ativa de seus habitantes. Isso, contudo, originaria duas cidades (formal e informal), devendo a última ser recuperada, transformada e reabilitada em função de suas precariedades, requisito para melhoria da qualidade de vida dos setores marginais (CADENA, 2010, p. 101). Neste caso, é importante destacar que os assentamentos são resultado de um processo que conforma ao mesmo tempo a cidade formal e a cidade informal. Embora seja uma interpretação que de alguma forma separa e dualiza estas duas cidades, avança no sentido de compreendê-las a partir de um mesmo processo de formação.

Também para entrevistados, quando explicavam o que entendiam como assentamentos precários, têm destaque os dois eixos característicos/descritivos e a abordagem pela ausência.

Entonces, volvamos, cuando tú hablas de precariedad del asentamiento, habría que preguntarnos, qué es para nosotros un asentamientos precario. Pues, un asentamientos precario es primer está en un terreno que, a lo mejor, no es de los propietarios, segundo que está hecho en precarias condiciones o en malas condiciones, tercero las construcciones no son las ideales no tienen servicios básicos ni de acueducto, ni de alcantarillado, ni de energía, y es posible que tengan falencia de escuelas, y cosas de esas (ENTREVISTADO 08).

Ao analisar já na década de 1980 os parâmetros para a identificação e intervenção nestes assentamentos adotados na Colômbia desde a década de 1960, o CPU (1984) já apontava as deficiências desta caracterização pelo somatório de ausências em um espelhamento distorcido da cidade produzida pelo mercado formal, em vez de fazê-lo pelas reais características físicas, 
sociais e políticas que conformam aqueles territórios. Se caracteriza sempre pelo que estes espaços deveriam ser e não são, sem caracterizá-los pelo que eles de fato são.

Respecto de lo que inmediatamente se acaba de observar emerge uno de los problemas claves del concepto y sus indicadores: la caracterización del fenómeno no se establece a partir de una noción de la estructura del espacio urbano, los elementos que lo constituyen y las relaciones que los articulan, sino de indicadores heterogéneos pertenecientes a órdenes muy diferentes (...). Por lo mismo se comprende fácilmente que la familia denominada áreas subnormales resulte un conjunto heteróclito. Por lo tanto, la definición del fenómeno no es establecida a partir de la propia estructura que se analiza (o sea, el espacio urbano) sino que la existencia o no del fenómeno se detecta a partir de la sumatoria de sus propios indicadores aislados como si se tratara de elementos conmensurables o de variables continuas e independientes (CPU, 1984, in MARIN, 1991, p. 9-10).

Pesquisador do tema entrevistado aponta que este é uma das causas de diferentes deficiências relacionadas a políticas e programas de mejoramiento integral de barrios, tendo em vista que adotam irrefletidamente os padrões da cidade produzida pelo mercado formal para adequação daqueles assentamentos. Seria importante, para ele, conhecer este território por si mesmo para que seja possível de fato intervir em suas dinâmicas e alterar as condições de vida daquela população.

Lo que siempre ha hecho la institucionalidad, lo que siempre han hecho las políticas públicas es desconocer la informalidad. Y lo que hacen es tratar de formalizarla desde la perspectiva de lo formal, pero nunca reconoce la dinámica de la informalidad en las prácticas de la informalidad, nunca piensan el territorio como lo piensan los habitantes allí. Ni como estructuran, ni como desarrollan, ni cómo crecen, ni como construyen lógicas de construcción social, dinámicas organizativas y construcción de tejido social, redes colaborativas, dinámicas, nada de eso reconocen. Y lo que hago es ponerle el sello de la formalidad, o sea los forzo a que entren dentro de la formalidad. Y por eso termina expulsando población. Porque si no, si la población no ha sido, no se ha formalizado no es porque necesariamente no les interesa, sino que porque no están en condiciones de hacerlo. Lo que terminan es volviendo a la practicas de informalidad (ENTREVISTADO 20).

Adentrando mais especificamente na conceituação e análise das políticas, programas, projetos e ações de urbanização de favelas na Colômbia, cumpre destacar que os poucos autores que buscam de alguma maneira conceituar o mejoramiento de barrios fornecem, muitas vezes, definições vagas ou que são pouco eloquentes. Na análise de Granados (2011, p. 28), se apresentavam ações de mejoramiento de barrios simplesmente como um "sistema de operação" para assentamentos desprovidos de serviços básicos, sem explicitar em que consistiria este sistema de operação. 
Um pouco mais elaborada, Saenz (2013) define o Mejoramiento Integral de Barrios (MIB) como uma estratégia multidimensional, intersetorial e integral de gestão urbana e de política pública para o ordenamento territorial e a inclusão socioespacial, tendo em vista que "agrupa distintas acciones sectoriales (ambientales, legales, físicas y sociales) de forma sincrónica, de acuerdo a las características específicas de cada territorio" (SAENZ, 2013, p. 14).

No livro referência sobre o tema em Bogotá, Tovar, Garcia e Moreno (2009, pp. 155-185) dedicam um capítulo inteiro à tentativa de conceituação do Mejoramiento Integral de Barrios a partir das experiências implementadas entre 1972 e 2006. "A excepción (...) de la literatura del PNUD y las agencias internacionales de crédito, los aportes de todos los documentos analizados para una definición del concepto son exiguos y poco relevantes" (TOVAR, GARCIA \& MORENO, 2009, p. 157).

Os autores chegam, portanto, à conclusão de que não foi possível mobilizar literatura ou documentos colombianos para uma boa análise do tema, tendo em vista que estes, em vez de conceituarem, apenas descreveriam as ações ou resultados destas ações, abordando a partir das normas, procedimentos e estratégias utilizados. O próprio Plan de Ordenamiento Territorial de Bogotá do ano 2000 também define o Mejoramiento Integral de Barrios pelo objetivo do Programa e de suas ações, o qual seria "orientar las acciones de complementación, reordenamiento o adecuación requeridas tanto en el espacio urbano como en las unidades de vivienda que conforman los asentamientos de origen ilegal ubicados en la periferia de la ciudad. Lo anterior para corregir las deficiencias físicas, ambientales y legales generadas por su origen fuera de las normas urbanas y permitir que sus habitantes accedan a la calidad de vida urbana definida para el conjunto de la ciudad' (Art. 286, POT de 2000).

Ainda hoje, mais de 10 anos depois do período da pesquisa de Tovar, Garcia e Moreno (2009), a realidade permanece muito semelhante. Em busca por documentos e informações disponibilizadas em sites oficiais das secretarias de habitação e outros órgãos responsáveis pela formulação, coordenação e implementação de ações de mejoramiento em Bogotá, não é possível 
identificar uma tentativa de conceituar o objeto, sendo sempre definido a partir do que o programa realiza ou quais ações estão incluídas.

El objetivo del PMI es orientar las acciones de complementación, reordenamiento o adecuación requeridas tanto en el espacio urbano como en las unidades de vivienda que conforman los asentamientos de origen ilegal ubicados en la periferia de la ciudad. Lo anterior para corregir las deficiencias físicas, ambientales y legales generadas por su origen fuera de las normas urbanas y permitir que sus habitantes accedan a la calidad de vida urbana definida para el conjunto de la ciudad (SECRETARIA DISTRITAL DEL HÁBITAT, 2016).

A través de la Dirección de Mejoramiento de Barrios (DMB), la CVP cumple su misión con la elaboración de estudios y diseños, construcción de "Obras de intervención física a Escala Barrial" (OIFEB), y con la estabilidad y sostenibilidad de obras, tales como vías peatonales, andenes, escaleras, alamedas, plazoletas, parques, entre otras; previamente priorizadas por la Secretaría Distrital del Hábitat. Desde el proyecto de "Mejoramiento Integral de Barrios" (MIB) además de la construcción de Obras físicas en el espacio público, sirve de medio para garantizar y restituir los derechos relacionados con el bienestar colectivo, a través del mejoramiento integral del entorno, igualmente se promueve el fortalecimiento de las relaciones en la comunidad, el sentido de pertenencia y la identidad con su territorio y la cultura del hábitat " (CAJA DE VIVIENDA POPULAR, 2016).

Salienta-se que esta definição é uma das poucas que dialoga com a ideia de efetivação de direitos, tratando-se, no entanto, de um enfoque mais ligado ao direito como acesso a serviços e processos que garantam o bem estar coletivo, e não ao direito à moradia adequada stricto senso. Dessa forma, se por um lado é importante que esta definição reafirme a importância do acesso a esses serviços; por outro, deixa de avançar em relação a inúmeros outros elementos/dimensões que sua vinculação ao direito à moradia adequada traria, como questões relacionadas à segurança da posse, ao custo acessível, dentre outras.

No caso de Medellín, que não possui uma secretaria específica para habitação e tampouco aborda o significado de MIB no POT, o Instituto Social de Vivienda y Habitat de Medellín (ISVIMED, 2016) define o Mejoramiento Integral de Barrios como uma estratégia que operaria integralmente a partir da intervenção nos territórios para transformar os diferentes desequilíbrios que apresentam do ponto de vista ambiental, socioculturais e econômicos e para incrementar a integração socioespacial e a qualidade de vida da população.

Da análise destes conceitos e de outros apresentados pela literatura (TOVAR, GARCIA \& MORENO, 2009), é importante destacar que nos parece haver, do início das intervenções no país para a atualidade, uma progressiva inclusão de 
componentes sociais, para além da intervenção física. Isto, no entanto, aparentemente está incluído apenas, em alguns casos, no discurso oficial, não constituindo de fato a prática das intervenções, tendo em vista que há cidades no país que executam ações sob o título de mejoramiento barrial que na prática, de acordo com entrevistada (ENTREVISTADO 25), são apenas intervenções de pintura de fachadas, de limpeza urbana pontual, etc.

Para Tovar, Garcia \& Moreno (2009), esse seria justamente um dos motivos que tornariam grave a lacuna existente, tanto na literatura quanto nos documentos oficiais, de conceituar o mejoramiento barrial. A ausência deste exercício, para eles, é que possibilitaria que haja uma diversidade tão grande de ações incluídas sob este título, encarado como um guarda-chuva sob o qual estão abrigadas inúmeras intervenções de escalas e objetivos muito diversos. Diante deste panorama, torna-se mais relevante que a análise dos conceitos a avaliação da evolução dos objetivos e do escopo das ações relacionadas como mejoramiento na experiência das cidades colombianas.

Também é relevante entender como são trabalhados os conceitos de favelas e urbanização no Brasil. Para Bueno (2000, p. 17) "as favelas são aglomerados urbanos em áreas públicas ou privadas, ocupadas por não-proprietários, sobre as quais os moradores edificam casas à margem dos códigos legais de parcelamento e edificação". A autora disserta então sobre o que seria uma, senão a principal, característica das favelas: os diferentes tipos de ilegalidade presentes nelas - da propriedade, edilícia, urbanística, etc. - fazendo a ressalva que algumas dessas ilegalidades também são encontradas no restante da cidade.

Cardoso (2009, p. 118) definiu assentamento precário como "aglomerações com delimitação mais ou menos precisa no tecido urbano, em geral, distintas do entorno quanto às suas características físicas e sociais; e com ocupação inequívoca e majoritária por população de baixa renda". Fazendo uma análise de diferentes conceituações de favela - de acadêmicos, do IBGE e de agências internacionais, Denaldi (2003) conclui então que as favelas marcadamente "são territórios de ilegalidade e exclusão social. São a expressão da desigualdade. As definições de favela traduzem duas de suas 
principais características: a ilegalidade fundiária e urbanística" (DENALDI, 2003, p. 41). Também Carlos Nelson F. dos Santos (1984, p. 31), quando fala sobre o tratamento público dado às favelas, afirma que "Os traços fundamentais são a ilegalidade jurídica da ocupação da terra e a irregularidade urbanística em relação aos padrões oficializados de uso do solo".

Como apontou Bueno (2000, p. 17), contudo, a ilegalidade/irregularidade não é exclusiva das favelas. Mereceria então tamanha ênfase nesse aspecto? Imaginando que em nosso país não houvesse propriedade formal da terra, bastasse a posse como instituto, seriam então as favelas vistas como parte da cidade? Muito provavelmente não, tendo em vista a existência de um "preconceito em relação à paisagem da favela, relacionando a casa, unidade habitacional horizontal precária, com o ambiente rural, decadente" (BUENO, 2000, p. 177). Dessa forma, tão importante quanto a situação jurídica para caracterização dos núcleos como favela é a questão da forma urbana apresentada por eles, inclusive enquanto questão estética, como bem discute Bueno (2000, p. 277-297), o que perpassa claramente pelos padrões construídos socialmente como aceitáveis ou não, os quais não são as balizas das regras estabelecidas pelos próprios moradores (NISIDA, 2017).

Isto suscita então outra questão que é tão importante quanto à conceituação de favela: as visões e representações construídas socialmente acerca dela. Não apenas do ponto de vista estético o olhar externo sobre a favela é relevante, mas também sobre a visão construída de fora acerca de seus moradores e seu estilo de vida, do significado social da favela, da sua relação com o restante da cidade, etc.. Tanto para Santos (1984, p. 28) quanto para Burgos (2006, p. 25), as diferentes representações e visões construídas acerca das favelas implicaram em diferentes formas de intervenção e, a partir disso, seria possível para ele costurar, no resgate da trajetória das políticas destinadas a elas, determinadas visões/representações com sua consequente forma de intervenção.

Pudemos identificar uma miríade de visões e representações construídas sobre a favela ao longo de sua história, a partir da bibliografia sistematizada e dos comentários que os autores tecem acerca da postura apresentada por 
documentos oficiais, pela literatura, pela música popular brasileira, etc.. Assim, a favela é retratada como problema/questão social (ZALUAR \& ALVITO, 2006, p. 10; BURGOS, 2006, p. 27; OLIVEIRA \& MARCIER, 2006, p. 99), um lugar marcado por conflitos e da marginalidade, marcado por estigmas e preconceitos (OLIVEIRA \& MARCIER, 2006, p. 61 e 94). É o espaço do "não" e caracterizado pela "ausência" na MPB (OLIVEIRA \& MARCIER, 2006, p. 73), um espaço urbano deformado (BURGOS, 2006, p. 36), uma aberração urbanística (FERREIRA, 2015, p. 05), núcleo de ociosidade, crime e violência (SANTOS, 1984, p. 31; ZALUAR \& ALVITO, 2006, p. 14; BURGOS, 2006, p. 34), foco de doenças e epidemias (ZALUAR \& ALVITO, 2006, p. 14).

\begin{abstract}
Dessa precariedade urbana, (...) surgiram as imagens que fizeram da favela 0 lugar da carência, da falta, do vazio a ser preenchido pelos sentimentos humanitários, do perigo a ser erradicado pelas estratégias políticas que fizeram do favelado um bode expiatório dos problemas da cidade, do "outro", distinto do morador civilizado (ZALUAR \& ALVITO, 2006, p. 07)
\end{abstract}

Os favelados, por sua vez, são então vistos como degenerados (SANTOS, 1984, p. 31), indolentes natos (SANTOS, 1984, p. 31; ZALUAR \& ALVITO, 2006, p. 14), alcóolatras (BURGOS, 2006, p. 54), promíscuos e sem moral (SANTOS, 1984, p. 31; ZALUAR \& ALVITO, 2006, p. 14; BURGOS, 2006, p. 34 e 36), malandros e criminosos (ZALUAR \& ALVITO, 2006, p. 14 e 34; OLIVEIRA \& MARCIER, 2006, p. 96), sem higiene (SANTOS, 1984, p. 31; BURGOS, 2006, p. 36), inferiores e portadores de atrasos hereditários (SANTOS, 1984, p. 31), analfabetos supersticiosos e adeptos do messianismo (BURGOS, 2006, p. 54), migrantes nordestinos de origem rural atrasados (ZALUAR \& ALVITO, 2006, p. 15), enfim, pobres (OLIVEIRA \& MARCIER, 2006, p. 81).

Há também o outro extremo, em que se constrói uma versão romantizada da favela, com uma "visão idealizada dos pobres" (BURGOS, 2006, p. 53). "A favela sempre inspirou e continua a inspirar tanto o imaginário preconceituoso dos que dela querem se distinguir quanto os tantos poetas e escritores que cantam suas várias formas de marcar a vida urbana no Rio de Janeiro" (ZALUAR E ALVITO, 2006, p. 08).

A favela como comunidade: coesa em diferentes níveis - familiar, associativo e de vizinhança, rica em experiências associativas, imbuídas de amizade e 
espírito cooperativo (PERLMAN, 1976, apud ZALUAR \& ALVITO, 2006, p. 15), símbolo da resistência à ordem político, social e urbana (OLIVEIRA \& MARCIER, 2006, p. 61; SANTOS, 1984, p. 32; ZALUAR \& ALVITO, 2006, p. 07), lugar do companheirismo (OLIVEIRA \& MARCIER, 2006, p. 79) e cheio de vitalidade (OLIVEIRA \& MARCIER, 2006, p. 61). Os favelados são vistos como vítimas (SANTOS, 1984, p. 31), irmãos cristãos (BURGOS, 2006, p. 34), otimistas (ZALUAR \& ALVITO, 2006, p. 15), justiceiros (SANTOS, 1984, p. 34), trabalhadores honestos (SANTOS, 1984, p. 38; OLIVEIRA \& MARCIER, 2006, p. 96).

Diversas dessas construções, nos diferentes meios em que aparecem (posições oficiais ou expressões culturais), foram utilizadas de forma generalizante, como se as favelas e seus moradores constituíssem um todo homogêneo e coeso, sempre de forma relacional em relação ao restante da cidade e ao "cidadão urbano" (ZALUAR \& ALVITO, 2006, p. 14-15).

Feita esta digressão sobre as suas representações e antes de adentrar na conceituação das políticas de urbanização de favela, vale ainda dizer que os trabalhos sobre urbanização de favelas parecem não apresentar, talvez por uma questão de recorte do objeto, uma preocupação na conceituação desses assentamentos, tendo em geral um enfoque maior no processo histórico de constituição destas (SANTOS, 1984, p. 39) e do tratamento a elas dispensado, fazendo em geral também uma análise classificatória de caráter mais operacional. A ênfase recai, portanto, em possibilitar a intervenção nestes espaços, mais do que efetivamente compreendê-los enquanto fenômeno urbano.

Denaldi (2009, 2012a, 2012b, 2013a, 2013b) usa as categorias de núcleos "consolidados", "consolidáveis" e "não consolidáveis", sendo os primeiros aqueles que possuem condições passíveis de recuperação urbanística e ambiental e de reordenamento urbano; os segundos são aqueles que não apresentam tais condições. Isso nos parece demonstrar que se trata de uma postura mais operacional do que propriamente conceitual diante da questão, centrando o foco mais na classificação da favela a partir das possibilidades de intervenção (como veremos adiante) do que na compreensão do significado e 
na conceituação do fenômeno. Na prática das prefeituras, contudo, essa classificação pode adquirir outros contornos mais fluidos, incluindo componentes políticos.

E é bastante comum que prefeituras, ao se organizarem para encarar o problema, utilizem um critério preliminar de classificação das favelas e demais assentamentos precários pelo grau de dificuldade de intervenção. Esta é também uma forma de priorizar intervenções que possam ser finalizadas, inauguradas, medida particularmente pelo cronômetro político-eleitoral. Nessas classificações um dos indicadores determinantes é a quantidade de remoções, cruzado, via de regra, com o grau de consolidação das moradias (SANTO AMORE ET AL, 2014, p. 10-11).

Em geral, as intervenções de urbanização de favelas no Brasil são definidas como aquelas que buscam qualificar os assentamentos precários através de diferentes intervenções in situ: implantação de infraestrutura (pavimentação, saneamento, energia elétrica), melhorias habitacionais, regularização fundiária, ações de desenvolvimento social, etc. Percebe-se, assim, uma grande variedade e extensão de ações incluídas neste leque.

No tocante à conceituação e à classificação das políticas de urbanização, parece haver um aprofundamento maior nos trabalhos analisados do que em relação às favelas em si, como mencionado anteriormente. Ainda na década de 1980, Carlos Nelson F. dos Santos (1984, p. 30-34) já tentava esboçar uma periodização, em que vislumbrava uma omissão/permissividade em relação às favelas nas décadas de 1930 e 1940, uma atuação ambígua na década de 1950 (com a presença tanto de ações repressivas como de promoção) e a repressão/erradicação a partir da década de 1960. Na década de 1990, Zaluar e Alvito (1996, p. 21) dão continuidade e afirmam que "os frágeis barracos, facilmente destrutíveis, desapareceram. Desde o final dos anos 70, a favela tem luz em casa. Durante os anos 80 ela adquiriu serviços, mais ou menos precários de água e esgoto. Ninguém fala mais de remoção".

Diversos outros autores também se preocupam com a periodização desta intervenção pública sobre as favelas.

Um breve apanhado cronológico apresenta que a partir dos anos 40 o governo começa a produção de habitação popular, com ações pontuais através de instituições ligadas aos trabalhadores. Somente nos anos 60 que se articula uma política mais abrangente sobre o tema, porém mantendo distorções que não permitiram sequer o vislumbre de uma solução à questão. No período de 1964 a 1985, vigência da ditadura militar no país, foi criado o Sistema Financeiro de Habitação (SFH) e o Banco Nacional de Habitação (BNH) como parte de uma 
política para a redução do déficit habitacional da população de baixa renda, mas que na prática pouco atingiu este público. Ao final dos anos 80 , no período de democratização, novas ações em urbanização de favelas e tentativas progressistas para a garantia da função social da terra foram implementadas em algumas cidades brasileiras, em virtude da conquista de se incluir este tema na Constituição de 1988. Este período é de importância para a transformação do modo de agir sobre o problema (ZUQUIM ET AL, 2013, p. 2-3).

Para Bueno (2000, p. 162), os três grandes períodos que traduziriam a evolução histórica da intervenção do Estado sobre as favelas Desfavelamento, Aceitação da favela e Urbanização - corresponderiam a três tipologias de intervenção: remoção (ou erradicação), reurbanização e urbanização, as quais também passam a ser adotados por outros autores (DENALDI, 2003; CARDOSO, 2007).

Desfavelamento, remoção ou erradicação de favelas. Esse era o discurso do BNH em seus anos iniciais. Entretanto, essa proposta já havia sido tentada desde os anos 40, em diferentes cidades brasileiras, com sucesso nas áreas centrais. Essa proposta ainda vem sendo implementada em situações específicas relacionadas a grandes interesses imobiliários;

Aceitação da favela enquanto fenômeno urbano, mas não aceitação da forma e da tipologia urbanística e habitacional que ela revelava, levando à demolição da favela e reconstituição de tudo no mesmo lugar, com padrão urbanístico e arquitetônico com linguagem semelhante à linguagem dominante. Esse tipo de intervenção, a que denominaremos reurbanização, também tem sido aplicado em favelas suscetíveis a marés e com problemas de inundação;

Urbanização, ou seja, dotação de infraestrutura, serviços e equipamentos urbanos nas favelas, mantendo-se as características do parcelamento do solo e as unidades habitacionais, postura que tem sido adotada mais amplamente a partir do começo dos anos 80 .

Esses três partidos urbanísticos têm uma sequencia histórica, ligados que estão à aceitação de que a favela não é um fenômeno localizado ou esporádico no processo urbano brasileiro, e à ampliação do espaço das políticas públicas voltadas a essas populações (BUENO, 2000, p. 162).

Embora Denaldi (2003, p. 49-53) use esta classificação como referência, faz algumas ressalvas e observações importantes, que matizam melhor os tipos de intervenção e demonstram que os limites entre elas são tênues. Primeiramente ela destaca que existem diferentes concepções de projetos de "reurbanização", conceito que acabou se tornando polissêmico, já que se podem constatar tanto projetos que utilizam essa denominação para implantação de infraestrutura como outros casos em que se trata de ações focadas na produção habitacional (DENALDI, 2003, P. 49). Também haveria casos de projetos denominados como "reurbanização" que consistiriam de soluções combinadas, em que mais de uma dessas alternativas são utilizadas. 
Segundo a autora ainda, também o partido da "urbanização" engloba diferentes soluções, variando desde a simples melhoria de condições de saneamento e acessibilidade através de intervenções pontuais até aquelas que visam à integração da favela ao bairro, podendo incluir até mesmo estratégias mais amplas de combate à exclusão social (DENALDI, 2003, P. 53).

$\mathrm{Na}$ realidade analisada por Denaldi (2003) em diferentes municípios, é observada a coexistência tanto de soluções de reurbanização quanto de urbanização simultaneamente, sendo comum a combinação entre elas. Essa ressalva também é feita por Bueno (2000, p. 162), quando aponta que "Erradicação, reurbanização e urbanização também convivem no tempo e no espaço. Atualmente, em função de condições fisiográficas específicas e de interesses contraditórios relacionados ao espaço urbano, há cidades adotando, ao mesmo tempo, remoção, erradicação, demolição e reconstrução, e a urbanização integral de favela".

Denaldi (2003, p. 54) enfoca também a classificação de intervenção utilizada em Santo André (DENALDI, 2003, P. 54), de cuja gestão municipal fez parte. Nesta experiência, a tipologia de intervenção é definida em estreita relação com a demanda de cada favela, que pode ser enquadrada como núcleo consolidável ou não consolidável, como explicitado anteriormente.

Nesse sentido, aqueles núcleos considerados "não consolidáveis" devem ser objeto de intervenção do tipo "remoção ou reassentamento em nova área", enquanto os núcleos "consolidáveis" seriam objeto de ações de "urbanização" ou "urbanização integrada". Para ela, "a 'urbanização' compreende a provisão de infraestrutura completa e execução de obras voltadas para a eliminação de situações de risco, regularização fundiária, melhoria do sistema viário. A 'urbanização integrada' compreende as intervenções por meio de ações integradas e multidisciplinares, tanto para promover a melhoria das condições de habitação e a integração da favela à cidade, como para tratar dos múltiplos aspectos da exclusão social por meio do desenvolvimento integrado de programas sociais, de educação, saúde, geração de trabalho e renda.

Como muitos municípios possuem limitada capacidade de investimento, essas ações poderiam ser desenvolvidas, pelo poder público ou pela própria 
população, ao longo de muitos anos em um mesmo assentamento, podendo ser ou não orientadas por um plano geral de urbanização. Isso daria ensejo ao que Denaldi (2003, p. 56) denomina de "urbanização gradual", a qual seria a modalidade mais adotada à época pelos governos municipais em face de suas limitações não apenas financeiras, mas também sociais e políticas.

Bueno (2000, p. 191-193) denomina esse tipo de ação como "urbanização parcial" em contraposição à "urbanização integral". Cardoso (2007, p. 13), ao desenvolver sobre a abrangência das intervenções, as classifica em "pontuais" e "integrais", nas quais as primeiras seriam "usualmente ligadas a práticas clientelistas ou a necessidades emergenciais, como por exemplo, a reconstrução de áreas atingidas por enchentes ou desabamentos de encostas, a realização de obras de contenção, etc.". No segundo caso, se objetivaria a realização de um projeto amplo implementado de uma só vez (CARDOSO, 2007, p. 13).

Os resultados de todas essas ações, segundo Denaldi (2003) poderiam ser identificados em três padrões de qualidade de urbanização: padrão mínimo de urbanização, em que a área passa a gozar de redes de água, esgoto, eletricidade e drenagem, eliminando situações de risco; padrão intermediário de urbanização, o qual, além das características anteriores, seria marcado pela implantação de equipamentos urbanos, pela readequação do viário e intervenção no entorno; e o padrão alto de urbanização, no qual se identifica a adequação da densidade, com definição de parcelamento e a promoção da regularização fundiária (DENALDI, 2003, p. 57; CARDOSO, 2007, p. 15).

É interessante notar que a autora vai desenvolver e revisar daí por diante essa categorização das ações de urbanização, com algumas alterações e aprimoramentos em diferentes artigos e textos sobre o assunto (DENALDI, 2009, 2012a, 2012b, 2013a, 2013b). No livro "Planejamento habitacional notas sobre a precariedade e terra nos planos locais de habitação", a tabela e os conceitos correspondentes apresentados são diferentes daqueles incluídos na sua tese:

Tipologias de assentamento e intervenção 


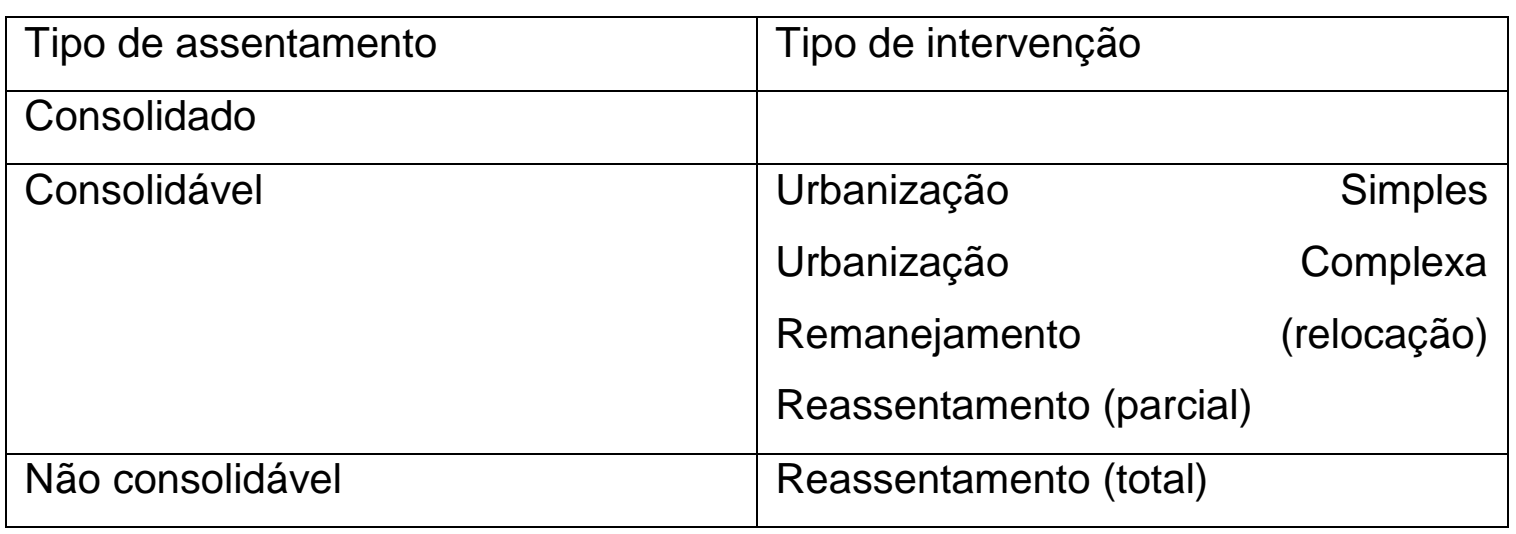

Fonte: DENALDI, 2013, p. 116

Primeiramente verifica-se 0 reconhecimento dos assentamentos "consolidados", os quais seriam urbanisticamente integrados e dotados de infraestrutura, mas que podem não estar regularizados ou ainda apresentar demandas por programas sociais ou equipamentos e serviços públicos. Nesse sentido, acredito que talvez fizesse sentido incluir como tipologia de intervenção para esses casos "Regularização fundiária" ou, se se intencionasse ser mais específico, "Regularização jurídica" do núcleo, tendo em vista que também se tratam de tipos de intervenção em favelas. Além disso, mesmo esses núcleos consolidados exigem, ao longo do tempo, tanto ações de manutenção e gestão do território quanto possíveis readequações futuras em função das dinâmicas territoriais que continuam a se estabelecer mesmo depois das ações de urbanização (KLEIMAN, 2010, p. 12-13).

É interessante notar o refinamento da classificação das intervenções em Urbanização Simples e Urbanização Complexa. A primeira seria aquela realizada em assentamentos que já apresentam baixa ou média densidade e traçado regular, prescindindo da realização de obras complexas de infraestrutura urbana e de ações de consolidação geotécnica, apresentando ao final baixo índice de remoções. O segundo tipo seria aquele efetivado em assentamentos com alto grau de densidade, com traçado irregular e/ou que requerem de obras geotécnicas complexas ou de drenagem urbana, apresentando alto índice de remoções (DENALDI, 2009, p. 158; 2013, P. 118).

Também é apresentado uma diferenciação entre "Remanejamento/Relocação" e "Reassentamento/Realocação". Enquanto na primeira forma de intervenção a população permanece no perímetro da favela após a substituição das moradias 
e do tecido urbano; na segunda, ela é realocada para outros terrenos fora da favela em novas unidades produzidas.

Deve-se salientar que toda essa classificação tem uma forte relação com planos e políticas nacionais, assim como com documentos e cadernos publicados pela Secretaria Nacional de Habitação do Ministério das Cidades, nos quais a autora é uma das principais referencias, tendo inclusive escrito muitos deles (DENALDI, 2009). A formulação acadêmica está, portanto, imbricada com a própria discussão da política nacional para urbanização de favelas, demonstrando novamente uma tendência operacional na formulação dos conceitos e tipologias.

Por fim, merece destaque um importante alerta que Denaldi (2013, p. 124) faz sobre a definição de tipologias de assentamentos e intervenções: a realidade das favelas no Brasil é complexa e são muitas as especificidades locais e regionais que precisam ser consideradas quando se faz esta discussão. Dessa forma, é preciso ter em mente que estas classificações precisam de constante revisão e devem estar abertas à incorporação de novas situações que podem não se enquadrar no esquema previsto.

Ao mesmo tempo em que esse pressuposto é verdadeiro, a pouca precisão ou a revisão constante das definições e classificações relativas a favelas e urbanização de favelas, no Brasil e na Colômbia, contribuem para tornar mais difícil a construção de parâmetros de análise ao longo da trajetória de existência desses assentamentos. Buscamos, nesse sentido, como forma de demonstrar a relevância da intervenção, constituir um panorama da evolução da população nas quatro cidades. Diversas dificuldades metodológicas foram encontradas, no entanto, principalmente para o caso colombiano. A tabela 01 ${ }^{2}$ abaixo serve, portanto, apenas para identificar ordens de grandeza da população moradora diante do total de habitantes das quatro cidades.

São Paulo: IBGE - Censos estatísticos; SARAIVA \& MARQUES, 2005.

Rio de Janeiro: Prefeitura do Distrito Federal, 1949; CEZAR, 2002; BANDERA, 2013; CAVALLIERI, 2012; VIAL, 2001

Medellin: TOVAR, 2009; DANE, 1993; DANE, 2005; CARDONA, 1993; Alcaldia Medellín, 2014

Bogotá: TOVAR, 2009; DANE, 1993; DANE, 2005. 
Da mesma forma, a tabela 02 sistematiza os principais programas de urbanização de favelas apontados como significativos pela literatura e por entrevistados. Observa-se que os escopos de cada programa variam muito, demonstrando a polissemia que os conceitos de "mejoramiento barrial" e "urbanização de favelas" comportam.

\begin{tabular}{|c|c|c|c|c|c|c|c|c|}
\hline \multirow[b]{3}{*}{ Ano } & \multicolumn{8}{|c|}{ Evolução da população residente em favelas } \\
\hline & \multicolumn{2}{|c|}{ São Paulo } & \multicolumn{2}{|c|}{ Rio de Janeiro } & \multicolumn{2}{|l|}{ Medellín } & \multicolumn{2}{|l|}{ Bogotá } \\
\hline & Pop. Favelada & Pop. Total & Pop. Favelada & Pop. Total & $\begin{array}{l}\text { Pop. Favelada }(p) / \\
\text { resid. faveladas ( } r)\end{array}$ & Pop. Total & $\begin{array}{l}\text { Pop. Favelada }(p) / \\
\text { resid. faveladas }(r)\end{array}$ & Pop. Total \\
\hline 1949 & & & 138.837 & $1.983 .000 *$ & & & & \\
\hline 1950 & & & 169.305 & $2.337 .000 *$ & & & & \\
\hline 1957 & 50.000 * & 3.800 .000 * & & & & & & \\
\hline 1960 & & & 337.412 & $3.307 .000 *$ & & & & \\
\hline 1970 & & & 563.970 & $4.251 .000 *$ & & & & \\
\hline 1973 & 71.840 * & 6.530 .000 * & & & & & & \\
\hline 1974 & 71.840 * & 6.530 .000 * & & & & & & \\
\hline 1975 & 117.237 & 7.327 .000 * & & & & & & \\
\hline 1980 & $439.721 / 435.344$ & 8.456 .000 * & $628.170 / 722.424$ & $5.093 .000 *$ & & & & \\
\hline 1985 & & & & & $42.928(r)$ & 1.506 .050 & $185.423(r)$ & 4.185 .174 \\
\hline 1987 & 812.764 & 9.132 .000 * & & & $151000 *(p)$ & & & \\
\hline 1990 & & & 882.483 & $5.480 .000 *$ & & & & \\
\hline 1991 & 711.032 & 9.646 .000 * & 881.882 & $5.473 .000 *$ & & & & \\
\hline 1992 & 1.071 .000 * & 9.477 .000 * & & & & & & \\
\hline 1993 & 1.901 .894 & 9.595 .000 * & & & $83.516(r)$ & $388.688(r)$ & $555.500(r)$ & $1.255 .091(r)$ \\
\hline 1996 & 747.322 & $9.839 .000 *$ & 952.429 & $5.551 .000^{\star}$ & & & & \\
\hline 1997 & & & & & $250.000 *(p)$ & & & \\
\hline 2000 & 896.005 & 10.434 .000 * & 1.092 .958 & $5.867 .000 *$ & & & $2.166 .939(p)$ & \\
\hline \multicolumn{9}{|l|}{2004} \\
\hline 2005 & & & & & $84.725(r)$ & $605.192(r)$ & $369.874(\mathrm{r})$ & $1.931 .372(r)$ \\
\hline 2007 & & & & & & & 220.277 / 307.946 (r) & \\
\hline 2010 & 1.988 .000 & 11.253 .000 * & $1.393 .314 / 1.443 .773$ & $6.323 .000 *$ & & & & \\
\hline 2011 & & & & & & & 258.046 / $267.447(r)$ & \\
\hline 2017 & & & & & & & $299.831(r)$ & \\
\hline
\end{tabular}

Em função do panorama amplo objetivado neste trabalho, buscou-se não restringir as análises aqui efetuadas a um determinado tipo de assentamento (caracterizado estritamente como favela) ou a um determinado tipo de intervenção dentro desse universo de conceitos apresentados. Mais importante, para os fins da tese, do que uma definição precisa do que seriam estes assentamentos e do que seria a urbanização de favelas, buscamos enfocar os processos políticos e sociais que os atravessam, tentando compreender os limites e potencialidades do estabelecimento de uma agenda pública no campo.

Usa-se aqui a noção de "agenda pública" ou "agenda governamental" aquele delimitado por Kingdon (2003) e Capella (2015), o qual abrangeria "o conjunto de questões relevantes para os formuladores de políticas governamentais e grupos próximos a estes" (CAPELLA, 2015, p. 60). Trata-se, portanto, do conjunto estabelecido, dentre o grande volume de questões às quais o estado 
poderia/deveria enfocar, daqueles temas que gozarão de atenção e prioridade no âmbito do governo.

O processo de reconhecimento, pelos governos, da importância de uma questão está diretamente relacionada à percepção sobre a existência de um problema que demande ações governamentais concretas. Nesse sentido, entende-se que os problemas são socialmente construídos, ou seja, são passíveis de distintas representações, dependendo dos interesses e das oportunidades daqueles indivíduos ou grupos que, de forma persuasiva e por meio das estruturas sociais e políticas existentes, definem estrategicamente um problema (CAPELLA, 2015, p. 60).

Nesse sentido, a tese enfocará justamente esses interesses e oportunidades verificados no contexto político e social do Brasil e na Colômbia nas últimas décadas que ora empurram a agenda da urbanização de favelas mais para o centro da atuação pública, ora afastam o tema da lista de prioridades governamental. Para tanto, o trabalho está dividido em duas grandes partes, as quais contam com capítulos e seções.

$\mathrm{Na}$ primeira parte, será enfocado o entrelaçamento entre a urbanização de favelas e processos e dinâmicas políticas verificados, principalmente, a partir da década de 1980. O primeiro capítulo dedica-se, principalmente, a identificar o conjunto de fatores políticos e institucionais que impulsionaram, ao longo da década de 1990, a ascensão concomitante do tema nas diferentes cidades. Embora reconheça a importância do contexto internacional vivido naquele momento, relacionado aos temas e financiamentos disseminados por agências e bancos internacionais, o capítulo enfatiza outros aspectos do processo vividos tanto no Brasil quanto na Colômbia, como a luta pela redemocratização do estado, o processo de mobilização social em torno de direitos, o ocaso de sistemas habitacionais que embasavam programas de provisão de unidades habitacionais, a descentralização da política habitacional para governos locais, dentre outros.

O tema do segundo capítulo, diferentemente do primeiro, busca reorientar o vetor de análise, enxergando em que medida a urbanização de favela, enquanto política setorial, nutriu ao longo das últimas décadas a Política, entendida enquanto sistema político, com seus interesses, atores e processos. Verifica-se, para isso, em que medida o tema foi mobilizado politicamente pela classe política, como constitui mecanismo de relacionamento entre esta e 
diferentes atores sociais, desde a população residente em favelas até membros de diversos setores econômicos e empresariais.

$\mathrm{Na}$ segunda parte da tese, é abordado como a violência, mais especificamente a violência urbana, está profundamente entrelaçada em ambos países tanto com os processos de constituição dos assentamentos populares quanto com as intervenções promovidas neles pelo estado. $O$ terceiro capítulo se dedica a demonstrar como a pauta da violência, em um primeiro momento, fomenta a expansão e consolidação da urbanização de favelas, principalmente nos casos de Medellín e Rio de Janeiro, mas também com impactos nas cidades de São Paulo e Bogotá.

No quarto capítulo, assim como na primeira parte, reorienta o vetor de análise, demonstrando que, se em alguns momentos houve esta relação, nas últimas décadas as intervenções em favela vêm crescentemente sendo dificultadas pela violência. Não somente a atuação de grupos criminais conflita e, até mesmo, disputa em várias circunstâncias com as iniciativas de urbanização, como contribuem para um movimento de deslegitimação de lideranças comunitárias e, conjuntamente com a atuação do estado, um processo de silenciamento da população de favelas. A urbanização de favelas assume, assim, um lugar específico diante do crescimento da sociabilidade violenta como mecanismo de interação social e do paulatino espraiamento da militarização da vida propagado pelas políticas de segurança; mas a consolidação da agenda pública em torno do tema torna-se cada vez mais complexa, conforme sintetizado na Conclusão da tese.

Os materiais e métodos empregados na tese variaram de acordo com o objetivo específico que se pretende alcançar em cada momento. Foi realizada, de início, a construção do arcabouço conceitual que embasou a pesquisa e auxiliou no mapeamento das dinâmicas e processos que atravessam as iniciativas de urbanização de favelas. Sistematizou-se, assim, os principais elementos teóricos a partir do fichamento de livros e periódicos nacionais e, principalmente, internacionais especializados em cada uma das temáticas enfocadas. 
Na sequência, foi realizada uma acurada pesquisa documental, a qual incluiu a apreciação de leis, planos, atos administrativos, avaliações, dentre outras fontes que fornecessem informações a respeito dos estudos de caso escolhidos. Também fez parte dessa etapa um levantamento de dados junto a órgãos relevantes para os projetos estudados: ministérios, secretarias, departamentos públicos e outras instâncias relevantes envolvidas.

A sistematização bibliográfica e documental indicou as principais questões abordadas na pesquisa de campo realizada no Brasil e na Colômbia. Foram realizadas 32 entrevistas ao vivo com gestores, técnicos do setor público, profissionais, acadêmicos envolvidos e moradores. Com o objetivo de deixá-los mais à vontade para discutir todos os temas propostos, garantimos aos participantes que sua identidade permaneceria anônima. Desse modo, embora todas as entrevistas tenham registros em áudio e tenham sido transcritas, os trechos utilizados nesta tese foram identificados apenas com Entrevistado 1, Entrevistado 2, etc. Os números foram atribuídos aleatoriamente a partir de sorteio à lista de entrevistados sistematizada pela pesquisa.

Foram feitas também visitas in loco a pelo menos 2 intervenções em cada uma das quatro cidades, com o intuito de estabelecer um contato maior com moradores e com as dinâmicas locais hoje estabelecidas.

Registre-se aqui que todo este trabalho foi possível graças ao fomento recebido através de bolsa e auxílio bancada do Conselho Nacional de Desenvolvimento Científico e Tecnológico (CNPq), apesar dos cortes orçamentários impostos nos últimos anos pelo congelamento dos investimentos sociais. Nada arrisca mais o futuro do Brasil do que o retrocesso temerário dos investimentos na área da ciência e da educação. Esperamos que, de alguma forma, a presente pesquisa contribua para comprovar que o investimento na produção de conhecimento científico é fundamental para a transformação política e social do país. 


\section{PARTE I - A política que se alimenta da política}

Nesta primeira parte da tese, serão abordadas as relações estabelecidas entre as políticas de urbanização de favelas e as dimensões mais amplas da Política. Por Política - com P - está sendo mobilizada a noção de elementos, processos e atores envolvidos no âmbito do sistema político amplo (EASTON, 1970), entendido enquanto conjunto de elementos interdependentes (sistema de governo, instituições, etc.) que se relacionam de modo a conformar a vida política (CODATO, 2015 in GIOVANNI \& NOGUEIRA, 2015).

No primeiro capítulo, serão abordados fatores e dinâmicas que, no interior do sistema político brasileiro e colombiano, propiciaram a emergência das iniciativas de intervenção em favelas nos anos 1990. A reivindicação pela redemocratização de ambos estados, conjugada com o caldo sóciopolítico das mobilizações sociais ascendentes no período, tiveram um significativo impacto nesta direção. Ao mesmo tempo, o ocaso dos sistemas de financiamento da política habitacional nacional em ambos países abre espaço para que, diante dessas reivindicações, os governos locais passem a atuar de maneira autônoma, inclusive financeiramente, desenvolvendo modelos alternativos à provisão habitacional, então em franco descenso.

É importante mencionar que este cenário está inserido em um contexto internacional no qual agendas de combate à pobreza penetraram e cresceram nas ações e narrativas de atores internacionais, como Banco Mundial, Fundo Monetário Internacional, Banco Interamericano de Desenvolvimento, PNUD (FREITAS, 2005). Neste sentido, houve tanto uma circulação de recursos como de modelos de políticas promovida por estes atores que também impactaram essa ascensão, já amplamente abordados pela literatura sobre o tema (DENALDI, 2003; ARANTES, 2004).

O segundo capítulo percorrerá o sentido inverso do primeiro: será analisado de que forma a urbanização de favelas, por sua vez, alimenta o sistema político mais amplo. São enfocados, assim, os elementos relacionados à alimentação dos ciclos eleitorais e à reprodução de mandatos políticos. Os fatores econômicos e as conexões estabelecidas com o setor privado através da 
intervenção em favelas - abordadas na segunda parte do capítulo - também se mostraram relevantes para a alimentação do sistema.

\section{Capítulo 1 - A política de urbanização de favelas que se alimenta da Política}

Conforme abordado na Introdução, serão enfocados, na primeira parte da tese, elementos da dimensão político e institucional que influenciam a ascensão ou o descenso das iniciativas de urbanização de favelas. Para tanto, o ponto de partida adotado é a busca pela compreensão dos contextos políticos e institucionais que propiciaram o primeiro movimento de consolidação de políticas de urbanização no Brasil e na Colômbia a partir do final dos anos 1980 e início dos anos 1990.

\subsection{A redemocratização política}

No contexto de ambos países, trata-se de um período de ampliação da experiência democrática aliada com uma progressiva descentralização de políticas, especialmente no tocante ao tema da habitação. No caso colombiano, chama a atenção o fato de que, ao contrário do Brasil (como será visto à frente) e da maioria dos outros países da América Latina (EVERS ET AL, 1981, p. 110), o país não teria vivido na segunda metade do século $X X$ um regime ditatorial prolongado. Embora tenha vivenciado um período de 05 anos sob 0 controle do General Rojas Pinilla (entre 1953 e 1958), primeiramente colocado e posteriormente tirado do poder por uma coalizão formada por diferentes grupos pertencentes aos maiores partidos à época (Liberais e Conservadores) (FORERO, 2016, p. 140-146), a escala e o tempo deste regime não se igualam àquelas vividas pelos outros países da região. 
Por outro lado, mesmo sem viver um período ditatorial significativo, a estrutura política instalada no país até pelo menos a metade da década de 1980 se caracterizava por um governo nacional forte e centralizador e por governos subnacionais (departamentais e municipais) débeis e com pouca autonomia (VERGEL, 2010, p. 70). As eleições se destinavam à escolha do Presidente, cabendo então ao chefe do governo nacional a indicação de quem governaria os departamentos, aos quais cabia, por sua vez, a indicação dos prefeitos de cada município.

Seu principal papel centrava-se, no caso dos prefeitos, na intermediação política entre os interesses de grupos locais e o governo departamental e, no caso dos governadores, a intermediação entre grupos regionais e o governo nacional. Este esquema, contudo, era marcado pela alta rotatividade destes postos, tendo em vista que se submetiam às constantes mudanças necessárias à composição dos diferentes interesses, e também pelas poucas competências de que os governos subnacionais dispunham, sendo as políticas definidas, em geral, no nível nacional (PATIÑO, 2015, p. 145-174).

A política habitacional do período, como será aprofundado adiante, era fortemente controlada a nível nacional através de diferentes instituições (como o Banco Central Hipotecário - BCH - e o Instituto de Crédito Territorial - ICT) responsáveis pelo seu lineamento e implementação desde a década de 1930 (PEREZ ET AL, 2017), como a construção de conjuntos habitacionais e outras formas de intervenção na temática (PATIÑO, 2015, p. 78). No tocante aos assentamentos precários, depois de um longo tempo de completa omissão, a diretriz nacional de intervenção até o final dos anos 70 e início dos 80 era, como vimos, prioritariamente a sua remoção, vistos até então como uma doença a ser extinguida (PEVAL, 1984; ENTREVISTADO 20; ENTREVISTADO 10).

Desde principios de la década de los setenta no existían respuestas claras ni estrategias formuladas frente al fenómeno de los asentamientos precarios por parte de autoridades nacionales o locales, es decir, la postura en ese entonces se caracterizó por la negligencia, basándose en dos acepciones: los asentamientos precarios son ilegales e inevitables temporalmente, pero pueden ser superados mediante el desarrollo económico tanto en áreas urbanas como rurales. Posteriormente, la respuesta hacia finales de los setenta y principios de los ochenta fueron los desalojos forzados, debido a que el desarrollo económico claramente no integraba los asentamientos precarios a la ciudad legal. Esta 
respuesta se dio en contextos de centralidad gubernamental, con gobiernos locales débiles y sin ninguna participación de la sociedad civil y las comunidades afectadas (VERGEL, 2010, p. 70).

No Brasil, o golpe que instalou a ditadura militar em 1964 é um marco também no que se relaciona à política habitacional brasileira (BONDUKI, 2014) e, também, no tocante à atuação do estado perante as favelas. No bojo da centralização de políticas públicas, o golpe proporcionou as condições necessárias para a centralização da definição da política habitacional no plano federal (ARRETCHE, 1990, p. 23), concentrando no Banco Nacional da Habitação (BNH - principal agência do período) as atribuições exclusivas de formulação e o desenho dos programas habitacionais, as definições acerca das modalidades de financiamento e da forma de distribuição dos recursos, o poder decisório sobre as iniciativas específicas a serem financiadas, etc. (ARRETCHE, 1996, p. 108). A política federal estabelecida a partir da atuação do Banco alavancou a produção habitacional no país, fortalecendo os setores da construção civil e imobiliário (KLINTOWITZ, 2015, p. 76).

A partir de 1964, com a instalação do golpe militar, o setor habitacional torna-se protagonista nas políticas públicas do Estado brasileiro, sendo que a indústria da construção civil desempenha um papel fundamental no processo decisório da formação da agenda e da nova política habitacional do regime. Criado após 5 meses da instalação do novo governo, o BNH refletiria a intensa agitação em torno da questão habitacional ocorrida no regime anterior, marcada por pressões dos vários segmentos organizados da sociedade civil, desde empresários do setor até movimentos sociais emergentes. Neste momento, os setores empresariais demandavam fundamentalmente a adoção legal de mecanismos de correção monetária e o estabelecimento de uma "autoridade habitacional de nível nacional" que pudesse iniciar uma "imediata ação governamental" no setor e que os recursos públicos fossem canalizados para o setor das edificações à semelhança e com maior amplitude do tratamento dado ao setor automobilístico. Buscava-se, por um lado, criar uma política permanente de financiamento capaz de estruturar em moldes capitalistas o setor da construção civil habitacional segmento que era uma das principais bases de sustentação do regime -, e por outro, angariar apoio entre as massas populares urbanas. Neste contexto, 0 modelo de política habitacional desenvolvido pós-64 supôs uma pesada intervenção estatal no processo de provisão habitacional e, a partir deste momento, esta área passou a se constituir como um dos setores privilegiados de atuação no novo regime (KLINTOWITZ, 2015, p. 77).

Através da constituição do BNH, do Sistema Financeiro da Habitação (SFH) e do Serviço Federal de Habitação e Urbanismo (SERFHAU), o regime militar pode justamente formular e implementar a política de habitação e urbanização em território nacional, a qual se torna uma de suas políticas prioritárias (ARRETCHE, 1990, p. 23) e consolida sua base de apoio político (FARAH, 1996). Enquanto objetivava alimentar os setores ligados à construção civil, 
utilizando a política habitacional enquanto mecanismo macroeconômico; o governo necessitava ainda dar uma resposta às tensões sociais que ganharam corpo na década de 1960 e abafar a mobilização social de esquerda. Assim, setores empresariais são amplamente favorecidos, classe média é atendida e a população de baixa renda, além de reprimida (como apontado anteriormente), tem o sonho da casa própria alimentado (KLINTOWITZ, 2015, p. 78), mesmo que a realidade e as análises demonstrem que não gozasse de prioridade (ROYER, 2014, p. 14).

No tocante às favelas, a política implementada pelo regime significou direcionar os esforços dos atores envolvidos, pelo menos em um primeiro momento, em torno da proposta remocionista como via única para solução do problema da favela (BURGOS, 2006, p. 34). Dessa forma, particularmente entre 1966 e 1974, é instaurada uma política massiva de remoções (CARDOSO \& DENALDI, 2018, p. 18).

Cria-se, por exemplo, em 1968 a Coordenação de Habitação de Interesse Social da Área Metropolitana do Grande Rio (CHISAM) com a missão de estabelecer uma política única para as favelas da região: sua erradicação (BURGOS, 2006, p. 35-36). Outras capitais também contaram com diferentes políticas de remoção no período, nas diferentes regiões do país (IACOVINI, 2017). No entanto, como salienta Gonçalves (2013, p. 247 e segs.), essa política de remoções teria resultado em um "fracasso retumbante" no Rio de Janeiro, em função da incompatibilidade das soluções propostas para a problemática habitacional dos moradores removidos (sem condições de arcar com o financiamento do $\mathrm{BNH}$, com dificuldades para conseguirem trabalho na nova localidade, aumento dos custos de vida com a formalização da vida e da propriedade, etc.) (VALLADARES, 1978; GONÇALVES, 2013, p. 249).

Verifica-se, com isso e outros fatores políticos (novo governo estadual do MDB, primeiros indícios de Geisel para uma abertura política, etc.), uma inflexão no tocante à política habitacional federal. A centralização decisória continuava presente na atuação do $\mathrm{BNH}$, mas, em relação ao tema da favela, busca construir novas formas de atuar. 
As políticas públicas criadas com o BNH compreendem dois momentos distintos. De 1964 a 1973, estavam norteadas pela remoção e inclusão das populações faveladas em conjuntos habitacionais localizados nas periferias metropolitanas, distantes dos locais de trabalho e carentes de infraestrutura, equipamentos e serviços urbanos. Num segundo momento, entre 1975 e 1986, as políticas públicas criadas com o BNH se expressaram na forma de programas de urbanização de favelas, paralelamente à produção e comercialização de habitação popular; como exemplo os programas de: (i) financiamento de lotes urbanizados (Profilurb, 1975): financiamento de lotes urbanizados para famílias com renda de 1 a 3 salários mínimos; (ii) financiamento da construção, conclusão e ampliação ou melhoria de habitação de interesse social (Ficam, 1977): financiamento para construção, de forma conjunta ou não ao Profilurb; (iii) Programa de erradicação de sub-habitação - favelas (Promorar, 1979): de urbanização de áreas consolidadas em processo de conflito por meio de substituição de barraco por embrião ou reassentamento de favelas removidas pela impossibilidade de urbanização no próprio local, famílias com renda de 1 a 3 salários mínimos. Esses programas foram criados para atender preferencialmente às famílias de menor renda - de até cinco salários mínimos mas seus resultados passaram longe da problemática habitacional de baixa renda. Pode-se afirmar que até meados dos anos 1980 , quando da extinção do BNH, a produção de habitação popular não chegou nem perto do problema habitacional da população de baixa renda e a intervenção em favelas e loteamentos irregulares resultou em poucas e pontuais práticas (ZUQUIM, 2012, p. 03).

Embora com um alcance limitado, pode-se considerar tais iniciativas como marcos na forma com a qual o estado tradicionalmente abordava a intervenção em favelas (CARDOSO \& DENALDI, 2018, p. 18). As iniciativas do Banco não atingiam a população de baixa renda e era importante a atenção a este público, de alguma maneira. Dessa forma, iniciativas como o Promorar foram muito comentadas pela mídia e buscavam reconquistar o apoio popular ao regime militar (GONÇALVES, 2013, p. 266), o qual encontrava desgastado por uma crescente pressão popular, pela crise de 74 e pela pressão da indústria dos materiais de construção e estreitamento do mercado de alto padrão. A criação destas linhas de atuação podem ser melhor explicadas à luz do $2^{\circ}$ Plano Nacional de Desenvolvimento, que "procurava conduzir um reformismo conservador como renovação do projeto político do regime autoritário" (ROYER, 2014, p. 61). Estas iniciativas não alcançam, contudo, um resultado expressivo - somando todas menos de $6 \%$ dos financiamentos concedidos pelo BNH entre 1964 e 1986 (ROYER, 2014, p. 69), sendo atribuído a ele um caráter demagógico e propagandístico (DENALDI, 2003, p. 16). 


\subsection{A mobilização social}

O período ditatorial brasileiro teve impactos não apenas no plano das políticas voltadas às favelas, mas também sobre o próprio tecido social que se constituía entre seus moradores. Da mesma forma que no caso colombiano, essa articulação passou por diferentes momentos, de mais intensa e menor articulação, maior e menor escala, etc. (EVERS AT AL, 1981, p. 110). Em um primeiro momento, a própria política federal de remoções, como Gonçalves (2013, p. 242 e segs.) aponta, gera fortes reações sociais promovidas por seus moradores em um primeiro momento, sendo os Congressos realizados em 1964 e 1968 pela Federação das Favelas do Rio de Janeiro, fundada em 1963, exemplos dessa tentativa de articulação e reação.

Com uma série de decretos que limitavam a atuação de organizações comunitárias, colocando-as sob controle do Estado (BRUM, 2014, p. 07), e diante do progressivo fechamento do regime e recrudescimento da repressão promovida a iniciativas da sociedade civil, essa articulação arrefeceu. Um exemplo de golpe duro promovido pelo governo militar aconteceu na finalização do congresso da Federação de 1968 (em que contestavam veementemente a política de remoções), quando oficiais prenderam e torturaram presidente e diretores da associação (GONÇALVES, 2013, p. 243).

O movimento comunitário de favelas, que se encontrava em crescimento, sofre então forte repressão como os demais movimentos sociais existentes naquele momento. Prisões, assassinatos e ameaças a diferentes lideranças comunitárias e moradores engajados indicavam que o enfrentamento ao estado não seria tolerado (BRUM, 2014, p. 05-09). Para Burgos (2006, p. 43), esse teria sido um dos principais motivos do afastamento da população habitante desses assentamentos da vida política e da institucionalidade do estado em função da repressão sofrida por ela desde o início da ditadura, resultando, ao longo da década de 1980, numa permeabilidade dessa população à atuação de grupos criminais ligados ao tráfico, como visto adiante nos últimos dois capítulos. 
$\mathrm{Na}$ Colômbia, esse também é apontado como um dos motivos que permitiram o crescimento dos grupos narcotraficantes. Guardadas as devidas considerações sobre diferenças de escala, as posturas estatais diante da precariedade das favelas (omissão e posteriormente remoção como solução) igualmente não foram isentas de resistência ou pressão por parte da população colombiana e de respostas repressivas por parte do estado, mesmo sem a existência de uma ditadura militar.

Los movimientos barriales son definidos como o una gama de nuevas formas de lucha y de resistencia cotidiana. Su amplitud marca la respuesta a la supresión sistemática de los intereses vitales de todos los sectores populares en beneficio de una reducida minoría, y en algunos países alcanza una envergadura que consigue arrancar sustanciales concesiones a las dictaduras -abiertas 0 disfrazadas- establecidas ahí. La expresión organizativa de esta resistencia es todavía muy dispar: varía con la coyuntura económica y política, puede aparecer como muy aislada e inoperante durante largas fases para de repente confluir en amplias corrientes de oposición, aprovechando posibles fisuras en el sistema dominante (OBANDO, 2015, p. 02).

Se por um lado os autores são cautelosos em falar sobre a existência de processos de mobilização popular, tendo em vista o número não tão expressivo e a sua inconstância, mencionam que existiram desde o final da década de 1950 lutas e protestos populares pela permanência e melhoria das condições de vida nos barrios (CARRILLO, 2013, p. 163; OBANDO, 2015; PATIÑO, 2015). Isto teria se intensificado e ganhado escala apenas em algumas ocasiões, como na segunda metade da década de 1970 (com a realização de paralisações nacionais) e no final dos anos 1980 e início dos anos 1990 (com a mobilização de reivindicava uma maior democratização do Estado).

De acordo com o que relata Carrillo (2013), até quase o final dos anos 70, houve em Bogotá diferentes formas de protestos urbanos - paralisações, fechamento de vias, ocupações de espaços e prédios públicos, marchas, etc. (CARRILLO, 2013, p. 167-170) - ligados à reivindicação de melhorias nas condições urbanas dos barrios da cidade, principalmente no tocante ao transporte público (pela redução das tarifas, extensão e criação de linhas, etc.), à implantação de infraestrutura básica (fornecimento de água, energia elétrica, etc.) e à resistência a despejos e remoções forçadas (CARRILLO, 2013, p. 171-178). Estas novas formas de ação, no entanto, não teriam sido as principais escolhidas pela população perante o Estado, continuando no período a exercer uma centralidade muito maior os processos de implementação de 
melhorias por autogestão e, principalmente, aqueles de negociação e intermediação de interesses através de lideranças comunitários e atores políticos, muitas vezes permeadas por interesses clientelistas (CARRILLO, 2013, p. 163), como em alguns períodos pode ser verificado também no Rio de Janeiro (GONÇALVES, 2013, p. 243-244).

Ao analisar o alcance das mobilizações e o seu significado na Colômbia no período (de 1950 a 1977), Carrillo (2013) considera que, até aquele momento, elas não constituíam uma verdadeira ruptura das lógicas políticas instaladas, tendo em vista que eram iniciativas isoladas, desarticuladas, sem continuidade, realizadas apenas de modo subsidiário (em momentos em que as outras duas formas de interação não surtiam efeito) e o resultado esperado em geral eram negociações e concessões do governo, com alcance, portanto, limitado (CARRILLO, 2013, p. 198). Por outro lado, considera que foram experiências importantes para colocar em evidência as contradições do modelo de desenvolvimento urbano à época, para a construção do repertório necessário à mobilizações mais amplas (vividas a partir de 1977) e para deixar alerta os atores políticos sobre a potencialidade destes conflitos (CARRILLO, 2013, p. 199).

É eloquente para demonstrar essas nuances um dos casos abordados por Carrillo (2013, p. 183-185), no qual aborda as relações entre protestos urbanos e o desenvolvimento daquele considerado, pela literatura e pelos entrevistados, como o primeiro projeto de mejoramiento barrial de Bogotá, PIDUZOB I (TORRES, 2009; ENTREVISTADO 10). Embora concebido e discutido numa época em que era vivida uma ascensão da mobilização popular e dos protestos urbanos na cidade (CARRILLO, 2013, p. 161-182), o autor deixa claro que a concepção do projeto como uma intervenção mais ampla de desenvolvimento urbano não decorre destas manifestações sociais, mas sim de uma estratégia adotada pelo então prefeito para obter um financiamento do BID.

Aquele teria se dirigido ao banco com o intuito de obter crédito para a construção da obra que seria a vitrine de sua gestão, uma ampla via de ligação dos setores norte e sul da cidade através dos cerros orientais, nos quais se situavam inúmeros barrios populares. O BID, no entanto, estava reformulando 
suas linhas de financiamento e afirmou que apenas financiaria planos de desenvolvimento integrado, não apenas para uma via (ENTREVISTADO 20). Para que o Banco aceitasse conceder créditos ao seu projeto, o prefeito anuncia então que se trataria de uma intervenção ampla, incluindo a construção de diversos equipamentos na região (escolas, hospitais, centros esportivos, etc.), melhorias habitacionais, implantação de sistemas de saneamento (água e esgoto), pavimentação de vias, etc..

Apesar de esta mudança incluir diversas demandas históricas da população dos barrios alvo da intervenção, ficou evidente em pouco tempo para elas que não se tratava do principal elemento motivador do projeto (o qual destinaria apenas $35 \%$ do orçamento total para todas as outras intervenções que não a construção da via, praticamente inviabilizando todas as promessas) e que este, assim, representava uma ameaça maior do que os possíveis benefícios, tendo em vista as remoções que ensejaria e o processo de valorização da área que paulatinamente expulsaria a população pobre (CARRILLO, 2013, p. 191), efeito claramente desejado pelo poder público municipal e expresso na postura assumida (OBANDO, 2015, p. 06) e em declaração do principal responsável técnico pelo projeto, quando afirmou "La expulsión de las clases populares originada por la construcción de la Avenida de los Cerros, es un factor positivo y constituye un factor de progreso para la ciudad" (Patricio Samper, 1972, apud CARRILLO, 2013, p. 186).

São construídas, sob muitas dificuldades e idas e vindas no processo de mobilização, articulações de resistência ao projeto, organizando documentos públicos, petições, atos simbólicos e protestos. As divergências internas e reiterados momentos de divisão da articulação, contudo, fazem com que estas iniciativas não obtenham um grande impacto sobre o cancelamento do projeto, o qual teria sido causado, de acordo com Carrillo (2013, p. 196), por rupturas e divergências dentro dos próprios setores políticos que constituíam a sua base de sustentação na prefeitura e na câmara de vereadores e por questões relacionadas ao financiamento fornecido pelo BID. Mesmo assim, essa iniciativa de articulação e resistência desempenhou um papel relevante para este desfecho (ENTREVISTADO 20), tendo em vista que foi responsável por retardar todo o processo de formulação, licitação e contratação da obra e 
mobilizou a opinião pública para o debate sobre a sua necessidade (CARRILLO, 2013, p. 196). Pode-se dizer, portanto, que, se a mobilização social em torno da melhoria das condições de vida dos assentamentos da região não foi a motivação da construção do primeiro programa de mejoramiento, foi sem dúvida um dos fatores que dificultou sua implementação em função de seus verdadeiros objetivos - a construção de uma grande via que se tornasse símbolo da gestão e promovesse a valorização da região.

A partir de 1977 estas manifestações ganham um novo patamar de visibilidade na Colômbia, tendo em vista que nesse ano é realizada a primeira grande paralisação nacional, à qual se seguiram outras grandes manifestações até 1985, num total de 285 paralisações e 416 outros atos de protesto (LOPEZ, 1987, p. 15, apud OBANDO, 2015, p. 05). Esta primeira paralisação, que teve a participação de inúmeros setores da sociedade - como trabalhadores, moradores dos bairros pobres, estudantes, empregados públicos, vendedores ambulantes, etc - foi diferente daquelas que haviam acontecido até então, tendo em vista que foi a primeira que logrou praticamente uma paralisação de todas as atividades nas cidades para reivindicar uma solução para os problemas relacionados à baixa cobertura e qualidade dos serviços públicos (FORERO, 2016, p. 156).

Diante dos processos reivindicativos da época, o governo nacional, embora eleito sob regime democrático, não se abstêm do confronto e utiliza o seu aparelho repressivo para conter o movimento: detenções arbitrárias, sequestro de lideranças, tortura, dentre outros (OBANDO, 2015, p. 07).

La limitación de los espacios de libre expresión llevó a la clandestinidad, pero también a usar otras instituciones consideradas neutrales, como la Iglesia, la educación y los medios de comunicación, lo cual dio paso al trabajo entre pobladores de barrios populares y estas instituciones para dar solución a las necesidades de los asentamientos y al mismo tiempo crear nuevos movimientos sociales urbanos. Como represión frente a estas organizaciones nacientes, el Estado decidió institucionalizar las juntas de acción comunal para tener presencia en todos los barrios de Bogotá y canalizar las iniciativas de los pobladores. Esta institución se convirtió en una relación de clientelismo, razón por la cual se dejó de confiar en el Estado, y al mismo tiempo se reforzó el poder de los líderes que pertenecían a las juntas de acción comunal y se desestimularon otras formas de organizaciones colectivas (OBANDO, 2015, p. 07).

Como será visto mais à frente, estas Juntas de Ação Comunal teriam sido criadas, portanto, como um mecanismo de cooptação da população pelo 
Estado, funcionando até hoje como um espaço de intermediação de interesses entre os moradores dos barrios e a institucionalidade a partir da atuação de lideranças comunitárias eleitas e desestimulando a consolidação de outras articulações barriais independentes ${ }^{3}$.

Paralelamente no Brasil, se por um lado, a instalação do regime ditatorial promoveu inicialmente a desmobilização social e a centralização de políticas; por outro lado, em um segundo momento o processo de luta contra o ele e seu caráter autoritário e centralizador significou o desenvolvimento de um amplo movimento de reivindicação de direitos com a participação de diferentes setores sociais com uma grande diversidade de reivindicações (SANTOS, 1984, p. 36; ZALUAR, 2006, p. 209; LEEDS, 2006, p. 254).

A escalada da repressão acabou por gerar uma polarização no debate político, no Rio de Janeiro, com repercussões nacionais, contrapondo remoção vs urbanização (MACHADO da SILVA, 1981). Como expressão desse debate e da resistência e luta dos moradores contra a remoção, destaca-se a experiência de urbanização das favelas de Braz de Pina, Mata machado e Morro Azul, realizada em 1968-1972, durante o período áureo dos despejos, por iniciativa do Governo do Estado do Rio de Janeiro, que, embora em menor escala, simbolizaram a possibilidade de uma solução que mantinha os moradores nos seus locais de moradia, com o Estado atuando na melhoria das condições de infraestrutura e habitacionais (PATRICIO ET AL, 2018, p. 02).

Nesse diapasão, conquanto o movimento comunitário tenha sido fortemente afetado pela incidência da ditadura militar (GONÇALVES, 2013, p. 243 e 244), a partir do final dos anos 1970 diferentes movimentos voltam a se rearticular. Originalmente engajados na luta por condições básicas (água, eletricidade e saneamento) e na resistência contra as remoções, esses atores avançam posteriormente no sentido de reivindicar a segurança da posse da terra que ocupam e a urbanização destas áreas (PAZ, 2009, p. 86). Podem ser citados diversos exemplos: o Movimento de Defesa dos Direitos dos Favelados (MDDF), em Santo André (DENALDI, 2012, p. 235); o Movimento de

\footnotetext{
${ }^{3}$ São apontados, ainda, para o caso de Medellín outros motivos pelos quais estes movimentos reivindicativos teriam tido pouca presença, apesar das diferentes precariedades vividas nos assentamentos informais. Para Patiño (2015) uma das razões disso seria o desaparecimento do gaitanismo, movimento político que nos anos 40 organizava a população dos barrios e intermediava suas reivindicações junto ao sistema político. Após seu desaparecimento em 1948, em função da morte de seu líder, Jorge Eliécer Gaitan (FORERO, 2016, p. 140), poucas organizações e articulações sobrevivem na cidade, as quais teriam, ao longo do tempo, passado paulatinamente para o controle dos grupos criminais com a ascensão destes (PATIÑO, 2015, p. 79).
} 
Urbanização de Favelas (BUENO, 2000, p. 64); e a Central de Defesa do Favelado (BUENO, 2000, p. 64), em São Paulo. No caso do Rio de Janeiro, há toda uma literatura sobre esta mobilização e sua incidência sobre o sistema político (BRUM, 2018; SANTOS, 1984, p. 36; SHLUGER, 1984, p. 43-45; ZALUAR, 2006. p. 209).

A partir da década de 70 e 80 , um dos debates era o estado de necessidade, que pressupunha ser mais importante do que o estado de propriedade, porque vinculou uma mudança por parte do estado de suas intervenções. Permitiu a entrada da luz, da água, enfim, inicialmente a questão dos mutirões, posteriormente os mutirões remunerados, mas que era ainda uma escala de laboratório (ENTREVISTADO 21).

Além da pauta da reivindicação de melhorias, a redemocratização teve um profundo impacto também na pauta e na estratégia de reivindicação política dos moradores de favela. Nesse momento, a disputa em torno de temas mais estruturais, como a propriedade e o direito à permanência, adquirem força no bojo de uma disputa maior que ocorria na vida política do país, com consequências para os rumos das políticas públicas no tocante a favelas (ENTREVISTADO 18).

Foi em torno da luta pela propriedade da terra que muitas as organizações comunitárias se mobilizaram na Redemocratização, na virada entre as décadas de 1970 e 1980 (como foi o caso da Pastoral de Favelas). Essa luta pela terra envolvia questões que extrapolavam o âmbito local, pois se contrapunha a toda uma lógica quanto ao uso do solo urbano e, por isso, confrontando grandes interesses imobiliários (na disputa pelos terrenos) ou questionando o Estado quanto ao uso dos terrenos públicos ou dos interesses levados em conta quando se tratava de investimentos públicos (...) Tudo isso configurava uma lógica de resistência e a necessidade da luta política travada pelas organizações faveladas se darem numa arena maior, na luta por mudanças jurídicas e políticas mais profundas, de modo que fosse garantida a permanência da favela no local, como as ações na justiça e a luta pelo projeto de usucapião urbano, o que implicava uma mudança nas estruturas de poder que se conjugava à outras lutas maiores (volta ao Estado de Direito, Diretas Já, Constituinte) e a entrada no aparelho do Estado de pessoas comprometidas com as bandeiras das comunidades. (BRUM, 2014, p. 5-9).

Existe, portanto, uma retomada dos movimentos reivindicativos de favela no final da década de 1970 e início dos 1980 no contexto da redemocratização.

Seus moradores "viveram os impactos dos novos tempos através de uma efervescência no movimento comunitário que viu surgir novas lideranças, (re)criando novas bandeiras e formas de mobilização, a ponto dessas novas lideranças acreditarem que surgia nesse período um "novo associativismo"” (BRUM, 2018, p. 415). A atuação dessas lideranças passa a ser menos de uma busca da negociação mediada politicamente e mais a priorização da 
mobilização dos moradores e da pressão permanente dos órgãos públicos, utilizando-se de ações coletivas de impacto, como passeatas, atos públicos. Constitui-se naquele período um movimento combativo, crítico ao Estado e agressivo em relação às políticas clientelistas (SILVA, 1995 apud BRUM, 2018, p. 415).

Assim, quando o estado acena para a possibilidade de permanência dessas famílias e inicia um período de realização de melhorias pontuais que apontavam para a consolidação desses assentamentos, a luta passa a ser centrada cada vez menos no direito à propriedade e mais pela realização da urbanização de favelas (BRUM, 2014, p. 09).

Outros diversos atores da sociedade civil estavam há anos igualmente envolvidos tanto com experiências pioneiras, como com a defesa da permanência dos favelas e melhoria de suas condições de vida, gerando, dessa maneira, um caldo sociopolítico importante para ascensão da pauta. Algumas organizações religiosas, ligadas principalmente à Igreja Católica, como a Fundação Leão XIII, a Cruzada São Sebastião e a Cruzada Pio XII (SANTOS, 1984, p. 34-37; DENALDI, 2003, P. 14; BUENO, 2000, p. 165; BURGOS, 2006, p. 29-30; CARDOSO, 2007, p. 6), embora tenham começado, algumas vezes, com propostas de remoção e desfavelização, posteriormente, passaram a desenvolver ações de melhoria nas favelas e, até mesmo, de apoio à luta pela permanência. Dentre todas essas, as Comunidades Eclesiais de Base e a Pastoral de Favelas tiveram papel importantíssimo na década de 1980 no fortalecimento da pauta (BRUM, 2018; ENTREVISTADO 30).

A sociedade civil organizada, eu acho que ela também cumpriu o papel de incidência política sobre o Estado, pra que o Estado pudesse ter um pouco mais de reconhecimento. Não só reconhecimento, mas de valorização desses territórios como patrimônio da cidade. Então o discurso não é só um discurso mais de remoção, embora aconteça pontualmente, o discurso ainda é um discurso de uma ameaça, mas há também um processo de reconhecimento da produção cultural, da inventividade, de como essas periferias, elas trazem elementos muito ricos da própria sociedade urbana. (...) Houve um movimento também dos próprios moradores, das organizações da sociedade nesse território, do movimento associativo de certo modo também, os intelectuais, os universitários... A universidade, ela foi se aproximando das periferias (ENTREVISTADO 30).

O envolvimento de setores da academia é detectado desde o início de intervenções em favela, como o Movimento Universitário de Desfavelamento 
(MUD) (DENALDI, 2003, P. 14) com viés assistencialista de atuação gratuita nas favelas. Desde então, diversos outros atores ligados a universidades vão se relacionando com estas políticas, indo desde pesquisadores e estudantes individualmente (BUENO, 2000, p. 173) até projetos de extensão atuando em perspectivas mais coletivas e de assessoria (CARDOSO, 2007, p. 14).

\begin{abstract}
Mas há um setor pelo menos da sociedade carioca - o acadêmico - que está preocupado com 0 assunto. Um certo número de arquitetos, urbanistas e cientistas sociais sempre foi crítico em relação às políticas seguidas nas favelas. Desde que começaram os planos intensivos de remoção, denunciaram o seu absurdo. Tiveram coragem de dizer que não solucionariam nada e que só aumentariam o os problemas que pretendiam resolver (SANTOS, 1984, p. 37).
\end{abstract}

Fora das universidades, também foram importantes intelectuais brasileiros e estrangeiros que promoveram a valorização do espaço das favelas sob 0 aspecto estético e socioeconômico, movimento que influenciou ações e políticas públicas, sendo citado o pioneiro Carlos Nelson Ferreira dos Santos no Rio de Janeiro (BUENO, 2000, p. 170). Além disso, devem ser mencionados no campo profissional a relevância de alguns escritórios de arquitetura (BUENO, 2000, p. 79) e de associações profissionais, como a Associação Profissional dos Assistentes Sociais, da qual Luiza Erundina foi presidente e que se posicionava na defesa da população favelada, contra ações de remoções (BUENO, 2000, p. 61).

Todo esse caldo social fermentado no bojo do efervescente processo de redemocratização que colocou fim à ditadura, incluindo a ascensão dos movimentos de reivindicação da reforma urbana (ROLNIK, 2017, p. 53;), foi um fator importantes para ascensão de programas de urbanização de favelas no início da década de 1990, como em São Paulo e no Rio de Janeiro, com o Favela-Bairro (ENTREVISTADO 18; ENTREVISTADO 30; ENTREVISTADO 12; ENTREVISTADO 16).

\title{
1.3 A autonomização da habitação
}

Para além desse caldo social que propiciava um contexto de defesa das favelas e de reivindicação de intervenções, é importante destacar que também 
nas décadas de 1980 e 1990 havia ainda um contexto político e econômico vivido que favoreceram a instalação de políticas de urbanização de favelas. Primeiramente, em paralelo ao ocaso do regime ditatorial, foi verificada também o processo de desmonte da política federal de habitação, com a crise do Sistema Financeiro Habitacional (SFH) e do Banco Nacional da Habitação (BNH), extinto em 1986 (ROLNIK ET AL, 2014; BONDUKI, 1998; AZEVEDO, 2007; MELO; JUCÁ FILHO, 1990).

Toda a estrutura institucional constituída durante o regime militar, uma de suas maiores bases de sustentação política inclusive (KLINTOWITZ, 2015), passa a declinar a partir do momento em que a política econômica assume traços recessivos (ARRETCHE, 1990, p. 24), com a economia brasileira deixando de crescer e a dívida pública federal passando a se tornar problemática (MARICATO, 2014, in ROYER, 2014, p. 10).

Assim como outras políticas públicas afetadas pela crise econômica do período
pós-milagre, a política habitacional foi duramente atingida no seu duplo aspecto
de constituição. De um lado, a crise econômica acarretava altas taxas de
inadimplência e diminuição do nível de empreendimento, pela escassez do
financiamento público e pela progressiva queda do poder aquisitivo da
população. De outro, as políticas do BNH, por estarem diretamente ligadas ao
regime, uma das fontes de sua legitimação, passaram a ser questionadas com
ele, tornando-se símbolo do passado que se queria enterrar (ROYER, 2014, p. 63). A partir de então, observa-se uma "dança das cadeiras" (CARDOSO \& RIBEIRO, 2002, p. 15) ou uma "via crúcis quanto ao espaço institucional de formulação e gestão dos programas habitacionais de baixa renda" conforme descrito por Arretche (1996, p. 110), passando no plano federal por diferentes ministérios e secretarias nos anos seguintes. Uma atuação federal de fôlego no campo da habitação vai ser verificada novamente apenas a partir do governo Lula, já na década de 2000 (KLINTOWITZ, 2015).

É importante mencionar que, nesse período, cria-se no plano federal o Habitar Brasil no Governo Itamar (92/94), que contava com eixo destinado ao financiamento de urbanização de favelas (DENALDI, 2003, P. 19). Apesar disso, o estabelecimento de programas de financiamento da urbanização de favelas como prioritários e não mais como "alternativos" aconteceria apenas no Governo FHC. Mesmo assim, avalia-se que eles contavam com recursos irrisórios e sua destinação se daria através de práticas clientelistas, com 
aprovação de emendas carimbadas feitas por deputados (DENALDI, 2003, P. 23). Dessa forma, até o início dos anos 2000 , avalia-se que a União teria tido pouca atuação na urbanização de favelas, tendo sido o protagonismo na área sido efetivamente exercido pelos municípios, segundo Bueno (2000, p. 28). governo federal viria de fato a incorporar esta modalidade de intervenção e a fazer grandes investimentos nela apenas nesta última década.

A década de 1990 assiste, diante desse processo, uma ascensão do protagonismo municipal e estadual na área habitacional. A extinção do $\mathrm{BNH}$, a diminuição da liderança e financiamento federal para o tema e as pressões concretas a nível local por ações de melhoria nas condições habitacionais incluídas aqui as reivindicações em torno da melhoria das condições de vida nas favelas (ARRETCHE, 1996, p. 114), apontadas acima - induziram um processo de descentralização ou "autonomização" das políticas habitacionais.

O município é pressionado porque ele é mais próximo. Você não sabe exatamente onde está a porta pra bater na porta, onde está o prédio do governo federal, do governo estadual, mas você sabe onde estão as prefeituras. Então o problema da favela, ele está ali muito presente, e você tem então uma necessidade de intervenção. Os municípios começam a intervir principalmente por necessidade, a pressão e aa emergência em lidar com esse problema lá no chão, no local lá do município (ENTREVISTADO 17).

Há diferentes interpretações para esse fenômeno. Enquanto Arretche (1996) afirma que não se tratava de fato de uma descentralização em função do ambiente institucional de competências comuns trazidas pela Constituição de 1988 e da manutenção de esquemas de financiamento centralizados em nível federal; Cardoso e Ribeiro (2002) afirmavam que esse movimento de descentralização haveria sido fomentado pelas novas competências e distribuições de recursos trazidas pela Constituição de 1988, além de reflexo da fragilidade da ação federal no campo. Autonomização ou descentralização, de fato foi observada uma diminuição considerável da atuação federal - com a diminuição do gasto federal em habitação, que em 1990 foi de apenas 22\% do montante de 1980 (ARRETCHE, 1996, p. 112) - e um progressivo crescimento da atuação de estados e municípios.

Quando o setor federal entra em crise, todos os estados brasileiros eram ainda dotados de companhias estaduais de habitação (COHABs), as quais haviam sido constituídas para participar da política implantada pelo $\mathrm{BNH}$ e haviam sido 
responsáveis por aproximadamente $28 \%$ de todos os financiamentos habitacionais viabilizados pelo SFH até o encerramento das atividades do Banco (ARRETCHE, 1990, p. 29). Segundo Melo e Jucá Filho (1990), verificouse uma "estadualização da política habitacional" com a proliferação de ações estaduais e municipais, que passaram a estabelecer prioridades e a delinear novos modelos de políticas sociais de acordo com suas capacidades administrativas e recursos fiscais disponíveis (ROLNIK ET AL, 2014).

No período de abertura democrática - anos de oposição ao regime militar e de grande pressão dos movimentos sociais, especialmente de luta pela reforma urbana - aumenta a reivindicação pela regularização de favelas e loteamentos irregulares. Alguns governos, estaduais e municipais, adotam políticas de descentralização de ações administrativas e abertura à participação da sociedade. Essas iniciativas resultam em outras formas de enfrentar a problemática da precariedade urbana e criam legislações municipais específicas para a regularização urbanística e fundiária, começando a delinear uma política pública de garantia dos direitos à moradia e à cidade; alguns exemplos destas experiências são: Recife com a urbanização e legalização da terra (Prezeis, 1987), Diadema com a urbanização de favelas, regularização fundiária e AEIS aprovada a partir do Plano Diretor (1994), Município de São Paulo com o programa de urbanização de favelas (1989/92) e de produção de habitação de interesse social por mutirão autogerido; Santo André com a urbanização de favelas com participação popular e inclusão social (Banco do Povo, 1989), Cubatão no âmbito do Programa Municipal de Habitação (1983) do estado de São Paulo, com estrutura apoiada no tripé prefeitura (terras e infraestrutura), CDH (projeto e financiamento) e população (participação popular/construção por ajuda mútua), entre outras (ZUQUIM, 2012, p. 04).

Esse momento consolida a primeira grande inflexão no tocante à institucionalização das políticas de urbanização de favelas, verificadas na multiplicação de experiências municipais em torno do tema que foram, ao longo das décadas de 1980 e 1990, constituindo um rico repertório. Conforme levantado e sistematizado por Cardoso e Ribeiro (2002), dentre as 50 maiores cidades brasileiras da década de 1990, 30 desenvolviam programas de urbanização de favelas, enquanto 31 municípios desenvolviam ações de construção de unidades. Enquanto estes programas de provisão responderam por $19 \%$ do atendimento nos programas municipais, os programas de urbanização foram responsáveis por 33\%, seguidos pelos de regularização fundiária com 29\% (CARDOSO \& RIBEIRO, 2002, p. 23 e segs.).

Você não tinha disponibilidade de recursos, o governo [federal] vivia uma crise fiscal terrível, então você não tinha. Não que eu esteja defendendo isso, mas naquele momento não era pauta política você ter um programa de provisão, como tinha sido o BNH com todos os seus problemas, e que depois com o Minha Casa, Minha Vida, de provisão pelo governo federal. Naquele momento não existia recursos públicos financeiros pra garantir isso. Então a política habitacional, ela era evidenciada sob a perspectiva de urbanização de 
assentamentos precários, entendido aquela como a única forma de acesso à moradia que é a população mais pobre. 0 papel do governo, ele acabava se restringindo a isso, mas não tinha uma política forte, consistente, estruturada no campo da provisão habitacional (...) a pauta naquele momento, a pauta legítima era "Eu não tenho muito o que fazer, tenho pouco recurso, o que eu tenho vem de Banco Interamericano, etc. e tal. Então eu vou investir na urbanização" (ENTREVISTADO 04).

A partir de então os municípios foram e continuam sendo os grandes protagonistas das ações de urbanização de favela dentre os entes federados, segundo diferentes autores (DENALDI \& CARDOSO, 2018; DENALDI, 2012, p. 227; BUENO, 2000, p. 28; ABIKO, 2009, p. 394). Para Denaldi (2013a, p. 123), os municípios, inclusive, seriam o ente federativo que têm melhores condições para identificar os assentamentos, quantificar os domicílios e caracterizar o tipo de déficit (quantitativo ou qualitativo) nos assentamentos. Além disso, é quem melhor pode "apontar as possibilidades e limitações para solucionar seus problemas de habitação com apoio dos programas promovidos nacionalmente ou regionalmente, pelos governos estaduais" (DENALDI, 2013b, P. 145).

Nesse sentido, desde as experiências das prefeituras progressistas da década de 1980 (TEIXEIRA, 1996; JACOBI, 2002), as ações de urbanização têm sido tradicionalmente encampadas pelas gestões municipais, as quais cresceram em número e complexidade ao longo da década seguinte. Prefeituras "progressistas", "democráticas" ou "populares" denominam um conjunto de gestões municipais, a partir principalmente da década de 1980, identificadas com o ideário democrático de esquerda ${ }^{4}$, muitas sob a condução do Partido dos Trabalhadores.

Sobre o tema, vale a pena conferir, além de Teixeira (1996) e Jacobi (2002), artigo de Celso Daniel (1990) intitulado "As administrações democráticas e populares em questão", no qual sistematiza como pilares dessas gestões, dentre outros, a inversão de prioridades na captação e uso do recurso público (significando a priorização de investimentos voltados à população de baixa

\footnotetext{
${ }^{4}$ Adota-se nesta tese como critério para distinção entre partidos de direita e de esquerda a proximidade com reivindicações e pautas políticas ligadas à igualdade social. Enquanto aqueles considerados de direita teriam uma tendência maior a adotar posturas liberais, individualistas e privatistas; os partidos de esquerda estariam mais próximos a reivindicações dos direitos de cidadania, de participação popular, de distribuição de renda, de justiça social e de recuperação das funções públicas do Estado (ARAUJO, 2015, in GIOVANNI \& NOGUEIRA, 2015, p. 317).
} 
renda, como em favelas) e a transformação da relação entre governo local e comunidade, a qual deveria estar sustentada por mecanismos de democracia participativa e na chave dos direitos (dando ênfase aos aspectos da implementação de políticas sociais como efetivação de direitos, dentre elas a urbanização de favelas). Um exemplo disso, ainda na década de 1980, foi a gestão implementada em Diadema, com forte prioridade conferida à urbanização. Sofrendo com um acelerado processo de crescimento urbano precário, em que loteamentos irregulares não possuíam condições de infraestrutura muito diferentes das favelas do município, Gilson Menezes (PT) promove uma mudança de atuação ao assumir a prefeitura, invertendo prioridades e tornando a urbanização de favelas o centro da atuação municipal (ENTREVISTADO 12).

Embora não tenha sido eleito e não seja usualmente considerada parte das prefeituras progressistas, a gestão de Mário Covas (ainda indicado pelo governador, conforme procedimento estabelecido no regime militar) também introduziu o tema na cidade, de maneira bem mais tímida, no entanto.

Há, nesse momento, [no Município de São Paulo] uma redução relativa no atendimento com lotes urbanizados e prioriza-se a fixação do morador com implantação de infraestrutura e regularização fundiária. Datam desse período as primeiras ações de concessão (onerosa) de direito de uso, garantindo o direito à terra pelos favelados, mesmo que a propriedade permanecesse em mãos da Municipalidade. A Supervisão Geral de Atendimento à População Moradora em Habitação Subnormal passa a centralizar as ações para favelas, com obras de melhorias das condições habitacionais. Segundo o Plano Habitacional (1984), famílias com menor renda não teriam condições de arcar com os custos de lotes urbanizados ou outras soluções habitacionais (BUENO, 2000, p. 67), o que levou o programa PROFAVELA a trabalhar em alguns projetos piloto, com demolições, implantação de infraestrutura e reconstrução em regime de mutirão (FERRĖRA, 2017, p. 68).

É importante notar, assim, que rapidamente essas experiências deixam de ser restritas às ditas prefeituras progressistas e passam a ser desenvolvidas em um espectro político de gestões municipais maior (DENALDI, 2000). Não se tratava, obviamente, de uma intervenção integrada e complexa de urbanização como preconizada atualmente, mas de uma miríade de tipos de intervenção focadas nesses territórios, pontuais e com as mais diferentes motivações (ENTREVISTADO 17). De toda forma, não se pode olvidar a importância daquelas administrações municipais para o impulsionamento do tema, tendo em vista justamente a centralidade que as ideias de inversão de prioridades e 
da urbanização no bojo do discurso de direitos adquirem como reivindicações sociais diante dos governos locais (ABRUCIO \& COUTO, 1993).

Também é importante considerar que estas experiências iniciais nos anos 1980 e início dos anos 1990 foram fundamentais para a construção da expertise técnica que serviria de base para a constituição de programas e ações de urbanização mais robustas (DENALDI, 2000). Apesar de uma baixa atuação por parte dos entes federados (União, governo estadual e municipal) entre 1986 e 1992 no tocante às favelas (GONÇALVES, 2013, p. 322); o acúmulo do corpo técnico em experiências prévias no caso do Rio (como o Projeto Mutirão e o Projeto $\mathrm{Rio}^{5}$ ) teria sido, segundo diferentes entrevistados, um dos fatores que justamente permitiu a emergência de um programa como o Favela-Bairro no período da gestão de César Maia (ENTREVISTADO 28).

Foram os mutirões, que ninguém fala muito. Eu tenho umas colegas aqui da prefeitura do Rio que falam "A gente fica muito magoado, porque em nenhum momento o Favela Bairro ou pessoas que trabalham com o Favela Bairro, governantes, técnicos e tal, fizeram um reconhecimento do que foi o Projeto Mutirão no Rio [que deu as bases]". Porque entre 84, que acabou o BNH, e 94, quer dizer um período de 10 anos, houve tanto na prefeitura do Rio, os projetos de mutirão, que eram projetos que a prefeitura fazia com comunidades para a regularização, pra saneamento. Eram projetos de muito menos visibilidade, coitados, e técnicos municipais que não tem visibilidade nenhuma. Só sabem malhar a prefeitura, mas os técnicos que trabalham, técnicos concursados que estão lá dentro trabalhando, eles tem pouquíssimo reconhecimento também, eles quase não são citados. Eles tem uma história de vida acompanhando os projetos, tanto no mutirão, no caso do Rio de Janeiro, quanto no Favela-Bairro também, que foram os técnicos municipais que estavam ali, não os que vieram paraquedistas, mas os que estavam ali a frente de uma certa maneira, que continuam (ENTREVISTADO 26).

5 De acordo com Ferreira (2017, p. 70) o Projeto Rio (1979) e Projeto Mutirão (1981), buscavam promover intervenções de infraestrutura sanitária aliadas à urbanização. "No primeiro caso, além de intervenções de esgotamento, destacava-se a elaboração de diretrizes que preconizavam a consolidação dos assentamentos, sua integração urbanística e ações de geração de renda a partir do trabalho na construção civil das redes de infraestrutura. (...) Com a admissão de que o problema da integração dessas comunidades era urgente, tem início o desenvolvimento de metodologias de intervenção para o tecido específico das favelas. Se o padrão urbanístico não permitia, por exemplo, a entrada de grandes equipamentos para a execução das obras, novas formas de se executar canalização e manilhamento dos esgotos passaram a se desenvolver. (...) Já o Projeto Mutirão teve início com projetos piloto, como o "Projeto de Saneamento Básico na Rocinha", ou "Projeto da Rua 3". O programa teve origem na Secretaria Municipal de Desenvolvimento Social (SMDS), em convênio de cooperação técnica com o Fundo das Nações Unidas para a Infância (UNICEF), e seu objetivo primeiro era a melhoria das condições de saúde dos moradores. A proposta experimental se baseava no barateamento das obras graças à participação comunitária na execução, com uso de mão de obra e recursos materiais locais, sendo a prefeitura a responsável pela doação de material e fornecimento de assessoria técnica. Entre 1982 e 1983, 27 comunidades foram atendidas, com implantação de redes para mais de 150 mil moradores". 
No caso do Rio de Janeiro, você começa uma reflexão e parte desse staff da prefeitura da década de 80 , vai ser ele que vai de alguma forma mobilizar a constituição do escopo político e vai dar ênfase ao Favela Bairro na década de 90. Tem um corpo técnico da prefeitura que já tinha uma experiência de intervenção em favelas, via mutirão, mutirão remunerado, enfim, é interessante, ou seja, já existia um conhecimento técnico de intervenção e uma demanda também (ENTREVISTADO 21).

Não apenas a experiência acumulada foi relevante, como a própria iniciativa desses técnicos foi fundamental para o próprio nascimento do programa. De acordo com uma das envolvidas nesse processo entrevistada para esta pesquisa, a gênese do Favela-Bairro se encontraria em iniciativa promovida a partir do envolvimento pessoal de técnicos lotados em diferentes secretarias afeitas à temática. Com variadas experiências e responsabilidades em políticas setoriais diferentes, este grupo de técnicos se propôs a realizar as ações sob sua responsabilidade de maneira coordenada, tendo em vista que muitas vezes convergiam no mesmo território, já marcados pela violência (conforme abordado com maior profundidade na seção 3.2).

Lu Peterson, você já ouviu falar dela? Ela é a mãe do Favela-Bairro. Ela falou "Vamos começar a pensar em uma coisa orgânica, uma coisa em que a gente não atue dentro da favela tão pontualmente". Até então aqui no Rio a ação na favela virou a Secretaria de Desenvolvimento Social, do ponto de vista de dizer "Vai lá, podia fazer uma rede de esgoto, uma pavimentação", mas não tinha ainda essa visão urbana. E aí nós montamos um grupo extraoficial, selecionamos uma comunidade... Eu me lembro até hoje, foi Caracol, o Morro do Caracol, tinham 4 ou 5 favelas nesse morro, lugar super perigoso, dificílimo de trabalhar. Conseguimos com os colegas de outros grupos, de outras secretarias, se juntassem conosco pra tentar ver, cada um na sua área, o que poderia fazer de forma integrada pra tentar começar a escrever alguma coisa sobre gestão integrada dentro de comunidade. Foi assim que fizemos no Caracol, mas era tudo meio clandestino, não era uma coisa oficial. Várias dessas pessoas tinham a capacidade de liderança e de decisão nessas respectivas áreas. Por exemplo, a gente também conseguia fazer um projeto de recolhimento de lixo comunitário, aí o cara da Comlurb tinha o poder de decisão de recolher algumas pessoas e botar lá, a gente tinha um pouco mais de independência nesses termos. (...) Eu me lembro uma vez que o presidente do Instituto de Planejamento do Rio, ele entrou na sala de reunião, eu tinha pedido a sala emprestada. Aí a gente estava fazendo aquela super reunião, ele abriu a porta e falou "O que está acontecendo aqui?". Eu não tinha falado pra ele, tinha medo de ele não deixar [seguir a iniciativa]. Eu falei "A gente está fazendo uma reuniãozinha assim entre nós, está tudo bem". A gente vai estendendo os limites até onde a gente podia, tem um quê de militância (ENTREVISTADO 18).

Burgos (2006, p. 51) corrobora para esta avaliação, afirmando que uma das características que marcam a gênese do Favela-bairro seria justamente o fato de que, pelo pouco interesse político inicial do programa, este teria sido construído principalmente por técnicos do município e por escritórios de arquitetura envolvidos com o tema. Apenas posteriormente ele viria a sofrer 
influência do prefeito, secretários e subprefeitos, a partir da sua criação oficial com o Decreto 14.332 de 1995.

Com a entrada de César Maia na gestão municipal, cuja campanha esteve justamente orientada ao "combate à desordem urbana" (MOTTA, 2008, p. 02), é articulada ainda a formação da Secretaria de Habitação a partir de documento elaborado pelo Grupo Executivo de Programas Especiais de Trabalho de Assentamentos Populares (GEAP), intitulado "Diretrizes da Política Habitacional", no qual sintetiza programas-chave da Secretaria (CARDOSO, 2002, p. 43). Segundo a entrevistada ainda, nesse momento foi colocado diante do grupo a escolha sobre quem recairia a liderança do Favela-Bairro, tendo ficado a cargo de Sérgio Magalhães, o qual gozaria da confiança de todos e uma compreensão ampla do tema (ENTREVISTADO 18). Esse processo foi fundamental para que o programa se tornasse uma das ações prioritárias dentro da gestão municipal.

Como Marques, Pulhez e Pagin (2018), não apenas o perfil do prefeito e de seus secretários são importantes para a predominância de determinados programas no âmbito das gestões municipais, mas os agentes envolvidos até o terceiro escalão tem um poder de influência considerável quanto à definição de prioridades. Nesse sentido, a participação de um dos membros do Grupo que já vinha articulando uma intervenção integrada em favelas na condução do programa certamente atribuiu um alto grau de experiência e, até mesmo, de interesse/compromisso com o tema já no início do Favela-Bairro.

Isso, no entanto, ainda não responde por completo à questão: por que o programa se tornou de interesse de Cesar Maia e gozou de prioridade em sua gestão? As entrevistas realizadas com alguns atores envolvidos com o tema na cidade apresentam um conjunto de fatores que contribuíram para tanto. Alguns deles são aqueles que já vem sendo apontados nesta tese - o contexto político da redemocratização, a mobilização social de favelados e outros movimentos sociais, o declínio do protagonismo e do financiamento federal para habitação (e especialmente para a provisão habitacional), a autonomização / descentralização das iniciativas habitacionais por parte dos municípios -, mas 
os entrevistados também oferecem alguns outros indícios importantes para a composição desse quadro.

Foi um momento político no Brasil, a gente vinha de um processo (...) em que os municípios passam a assumir determinadas atribuições que antes não eram previstas pelo próprio município. É um momento então que ele [César Maia] estabeleceu parâmetros que ele deveria projetar a cidade do Rio de Janeiro, como uma cidade que estava superando esses problemas, e uma delas era a questão da favela; (...) e eu acho que também, eu não sei exatamente, o César Maia vem de uma cultura também política, que era do Brizola, então ele também vinha de uma cultura política de muita vinculação popular. Ele não tem nada de popular hoje, mas na época ele vinha. A vida política do César Maia foi do PDT, foi sob a influência do Brizola, então eu acho que ele também, pela própria formação política dele, ele queria mudar. Acho que ele usou também como estratégia de marketing, implantar um grande programa de urbanização de favela no Rio de Janeiro, que é uma cidade que tem uma projeção internacional, isso também vai contribuir muito para eu projetar o seu nome. De fato, ele ainda, no imaginário da cidade, ele ainda aparece como um prefeito que fez grandes mudanças estruturais (ENTREVISTADO 30).

Naquele momento, década de 90 , os municípios tinham uma condição dada pela Constituição um pouco mais confortável para enfrentar essas questões do que o governo do estado. Não é à toa que, em São Paulo, você tem um governo Erundina fazendo um conjunto de iniciativas e no Rio o mesmo, o governo César Maia ainda não incorporando esse desenho de um governo extremamente conservador que ele passa a ocupar 8 anos depois. Nesse momento, ele se caracteriza como um governo que ele chama de técnico (...) faz um concurso, propostas metodológicas para intervenção em assentamentos precários, onde você passa a ter um conjunto de escritórios. De alguma forma chama a sociedade civil mais pro debate sobre a favela, de uma forma geral, num primeiro momento inclusive da integração da favela ao tecido formal, da imagem que a favela acaba consolidando junto ao tecido, como você deixa, você incorpora a favela como cidade e não mais só como um espaço extremamente segregado (ENTREVISTADO 04).

A literatura sobre o desenvolvimento do programa também reafirma estes elementos. Gonçalves (2013, p. 324), por exemplo, também aponta a filiação política inicial de César Maia ao grupo liderado por Brizola no PDT, mas coloca claramente a limitação de sua filiação partidária e político-ideológica, tornandose uma proeminente liderança da direita na cidade. A questão, contudo, da imagem da cidade do Rio de Janeiro é uma constante e a intenção de promover uma ressignificação internacional dela através de obras de embelezamento e da redefinição do seu lugar a partir do Plano Estratégico ${ }^{6}$.

\footnotetext{
${ }^{6}$ Vivia-se na década de 1990 a ascensão do chamado "planejamento estratégico", que partia da premissa de que as cidades, a exemplo das corporações, estavam submetidas a um ambiente de competição. Os centros urbanos disputariam investimentos, atração de novas indústrias e negócios, força de trabalho qualificada, dentre outros (VAINER, 2002, p. 77). Seriam também mercadorias a serem vendidas, sendo a imagem construída em torno de cada cidade central para sua estratégia de atração. O Rio de Janeiro foi, assim, uma dentre as várias cidades da América Latina que contrataram consultores para a elaboração de planos que traçassem diretrizes para o seu reposicionamento nessa nova ordem global.
} 
Embora o plano se propusesse a estabelecer diretrizes para transformar a cidade numa metrópole pujante economicamente e, ao mesmo tempo, com qualidade de vida e socialmente integrada; diagnosticava sua miséria como um "problema estético e ambiental, em detrimento de seu aspecto social" (GONÇALVES, 2013, p. 325).

Faz sentido, diante dessa perspectiva, que o próprio plano conferisse destaque, portanto, ao Favela-Bairro, sendo considerado um dos seus projetos emblemáticos na dimensão urbana. Também coaduna com essa lógica a interpretação de Cardoso (2002) ao afirmar que o critério básico na construção de diretrizes para a seleção das áreas a serem alvo de intervenção "foi a busca de resultados a curto prazo, produzindo, assim, um efeito de demonstração" (CARDOSO, 2002, p. 46) ${ }^{7}$. Se era importante, enquanto programa, mostrar ser possível o tipo de intervenção proposta para sua sobrevivência, certamente esse critério também contribuía para uma transformação da imagem da cidade e da gestão pública conduzida por César Maia.

No Rio de Janeiro, é interessante a gente tem um discurso muito ambíguo. No Rio de Janeiro a gente sempre vai ter, é muito notório, uma inversão de políticos, que é o político tocador de obras e o político constituidor de serviços públicos. (...) 0 César Maia, ele vai de alguma forma reafirmar esse discurso de um grande tocador de obras, de um grande interventor, uma pessoa que tinha uma capacidade de gestão administrativa importante e que conseguiu captar recursos via BID, via exterior. Então é claro que também existia uma porta política muito clara, simbólica, de uma presença nessa prefeitura, em que a favela vai ser um objeto importante de reflexão (ENTREVISTADO 21).

As iniciativas do Favela-Bairro compreendiam diferentes frentes de atuação: obras de urbanização, modernização da infraestrutura das favelas, construção de espaços públicos e de equipamentos sociais (como escolas, creches e

\footnotetext{
${ }^{7}$ Sobre a construção de critérios para seleção das favelas objeto de intervenção, além de conferir a discussão dos critérios do programa em Cardoso (2002) e Gonçalves (2013), é interessante a afirmação de entrevistada para esta pesquisa (ENTREVISTADO 18) sobre 0 processo, demonstrando a relevância do empréstimo do BID para tanto e a questão de influências políticas sobre o processo. "Quando o Banco Interamericano entrou com o dinheiro, ele falou "temos critérios de seleção". Até então a gente já tinha feito o primeiro cadastro favela, estávamos com o plano cadastro favela na mão, não estava informatizado, nem nada. Com a entrada do Banco Interamericano a gente começou a, primeiro, montar um sistema informatizado desses dados e criar conceitos e critérios de seleção, e assim fizemos. E fizemos tão bem feitinho que fizeram com que aquela lista fosse um decreto pra que políticos não botassem a mão nas áreas que a gente tinha já decidido com esses critérios que a gente já discutiu".
} 
postos de saúde) (CARDOSO, 2002, p. 45). Mais especificamente, o art. $3^{\circ}$ do Decreto 14.332 de 1995, que instituiu oficialmente o programa, trazia:

Art. $3^{\circ}$ No âmbito do PROAP-RIO, entende-se urbanização dos assentamentos populares como a promoção de obras e ações destinadas a permitir a implantação, operação e manutenção de equipamentos e serviços de:

I - abastecimento d'água

II - esgotamento sanitário

III - circulação viária

IV - drenagem pluvial

V - contenção e estabilização de encostas

VI - reflorestamento

VII - coleta de lixo e limpeza pública

VIII - iluminação pública

IX - educação sanitária e ambiental

$\mathrm{X}$ - creches

XI - praças, parques e jardins

$X I$ - esporte e lazer

XII - outros programas sociais

Parágrafo único. Complementam a urbanização, integrando o PROAP-RIO, as ações destinadas à regularização urbanística e fundiária dos assentamentos populares e programas de geração de emprego e renda.

Valia-se, assim, da premissa de urbanização com um componente "social", incorporava aos projetos de intervenção outras políticas sociais, além de iniciativas promotoras de geração de renda (CAVALCANTI, 2013, p. 200 e 201). Não compreendiam, no entanto, a intervenção no espaço privado, a melhoria das residências dos moradores de favelas, chegando a consolidar situações de habitabilidade precárias, um dos aspectos amplamente criticados do programa (ENTREVISTADO 16; ENTREVISTADO 26). É interessante, no entanto, como esse mesmo fato é usado politicamente pelo programa, conforme aponta a seguir entrevistado.

O que o Favela-Bairro fez no próprio discurso? Ele transformou uma restrição num elogio: significando que todo o patrimônio que foi edificado pelas famílias, pelos meios privados, particulares, seria amplamente respeitados. A incapacidade pública de atuar nos espaços privados foi transformado em respeito ao patrimônio privado, ou seja, "eu só atuo sob o espaço público" (...) Transforma a cidade a partir da intervenção no espaço público. (...) Desde o início, a proposta do Favela Bairro não foi trabalhar nos espaços privados, mas fundamentalmente com os logradouros públicos (ENTREVISTADO 04). 
Só que o Favela-Bairro, é bom colocar, ele não atuava nas áreas residenciais. 0 que se propunha naquele momento é de fato o saneamento, urbanização no sentido do saneamento, drenagem, esgoto, água, tratamento dos espaços comunitários. Então a gente fez vários projetos possíveis de fazer numa região, favelas com pouquíssimas áreas, a gente fez várias requalificações nos espaços em si, mas basicamente a melhor coisa no Favela-Bairro era esgoto, drenagem, era o que tinha que ser feito, que a situação de doenças dessas pessoas era muito intensa. (...) Eu acho que na época era o saneamento [que precisava ser feito], se eu tivesse que escolher alguma coisa, eu diria. (...) Então a gente contava casinha por casinha, muitas vezes tinha que botar uma escadaria nova, tinha que implantar, então era contado no dedo pra que não ultrapassasse aquele limite [do BID], e a gente fez os projetos de residências, fez os projetos das habitações de grupos familiares que eram projetos específicos. (...) A gente não entrava requalificando unidades, não existia essa linha dentro do Favela-Bairro na época (ENTREVISTADO 26).

Independentemente do caráter ideológico que a figura política de César Maia dispusesse naquele momento - se ainda mais de centro-esquerda, ou com caráter popular característico de Brizola; ou já mais à direita, como claramente se posicionaria nos anos seguintes - o interessante é que o programa era útil para a construção da imagem de Maia junto a diferentes setores sociais. Para segmentos populares, tratava-se de uma iniciativa que reafirmava o direito de permanência das favelas e a condições de vida e reprodução social mínimas. Afastava-se cada vez mais o fantasma das remoções forçadas características de tantos anos de políticas voltadas a favelas, até mesmo pelo baixo percentual de remoções efetuadas (CARDOSO, 2002, p. 45), as quais poderiam representar no máximo $5 \%$, por determinações impostas pelo BID (ENTREVISTADO 18; ENTREVISTADO 30). A relevância do programa para os moradores chegou ao ponto de gerar uma concorrência entre diferentes favelas pelas intervenções (GONÇALVES, 2013, p. 330).

Por outro lado, com um governo de perfil supostamente técnico e buscando estabelecer uma imagem do Rio de Janeiro moderno, competitivo, mas ainda carioca na essência, valorizando a cultura popular na sua forma de morar (ENTREVISTADO 04), dialogava com setores sociais mais de centro e até com setores da sociedade civil atuantes, como profissionais da arquitetura e do urbanismo engajados na valorização dessa dimensão (FERREIRA, 2017, p. 75). A própria escolha pela realização de concurso através do Instituto de Arquitetos do Brasil (IAB-RJ) para contratação de projetos demonstra essa atenção.

Esse marketing, digamos assim, foi uma coisa muito importante. Os concursos públicos é um fator muito importante, porque vai mobilizando, você não vai 
mobilizar um escritório, você vai mobilizar vários, tentando entrar nesse negócio. $O$ próprio IAB, o IAB é o nosso instituto dos arquitetos, ele ficou muito mais poderoso quando ele começou a cuidar desses concursos, teve muito mais visibilidade (ENTREVISTADO 18).

Como a entrevistada acima partícipe da equipe do Favela-Bairro aponta, a iniciativa fomentava a visibilidade e a circulação do programa como uma espécie de best practice ${ }^{8}$ nacional e internacionalmente. Intencionalmente, segundo ainda a entrevistada, a equipe começou a viajar muito para divulgar o programa, participar de fóruns, apresentar e inscrevê-lo em premiações internacionais - ONU, BID, etc. A estratégia surte efeito.

"A experiência em Diadema circula de um jeito, a do Rio de Janeiro Favela Bairro circula de outro. Eu lembro, eu peguei um avião na Varig e a matéria de capa da Varig era o Favela Bairro. Eu deveria ter guardado aquela revista, eu acho até que eu peguei, mas ai com o tempo... Era uma matéria de capa da revista da Varig, o Favela Bairro, falando ali” (ENTREVISTADO 17). Inclusive, o Favela-Bairro chegou a inspirar experiências internacionais da África do Sul à Colômbia (PATRICIO ET AL, 2018, p. 05), dentre elas a experiência do PRIMED em Medellín, sendo citada em publicações oficiais (ALCADIA DE MEDELLÍN, 1996) e por diversos entrevistados como referência para o seu desenvolvimento, inclusive no tocante ao potencial da urbanização de favela como ferramenta de marketing urbano (ENTREVISTADO 08; ENTREVISTADO 15; ENTREVISTADO 02; ENTREVISTADO 17).

Medellin e Rio, a conexão é total. Eu acho que tem modelos e todos os seus problemas de construção de modelos. Mas eu tenho a impressão - isso é muito dito inclusive, você deve ter ouvido por parte dos colombianos - que o Rio de Janeiro, sobretudo o Programa Favela Bairro, foi um grande modelo, com um grande impacto na América Latina e grande replicação, muitas vezes replicado pelo BID. (...) o Favela Bairro era até mais interessante, mas enfim, foi um grande modelo, o que é interessante é que esse modelo circulou, então Medellin virou o grande modelo de intervenção, com grandes problemas. (...) $O$ que eu observei na Colômbia e que os técnicos e pesquisadores me falaram era isso. Muita gente, não só na Colômbia, mas na América Latina, o Favela Bairro virou uma marca muito forte, talvez até muito romantizada, muito mais do que... Virou uma grande

8 Com "best practice" nos referimos àquelas experiências consideradas à época exemplos divulgados por agências e bancos multilaterais para serem replicados por outras cidades e países. De acordo com Farah (2008), embora existe uma multiplicidade de conceitos, a maioria deles define as best practices com um foco no desempenho do programa, em uma tecnologia social específica e a replicabilidade. As experiências de urbanização de favelas no Rio de Janeiro (CARDOSO \& DENALDI, 2018) e em Medellín ganharam esse status através da divulgação promovida por agências e bancos internacionais a partir dos anos 1990 (DENALDI, 2003). 
marca, as pessoas falam que é um grande projeto, eu tenho a impressão que provavelmente o BID replicou muito isso em outras capitais. Certamente na Colômbia replicou, só que a Colômbia criou outro mecanismo, pela sua história, até pela sua experiência com muitos dos seus prefeitos, enfim, eu tenho a impressão que há problemas na intervenção que eles fizeram, mas eu acho que depois a gente absorveu com muito, muito mais problema [o modelo deles] (ENTREVISTADO 21).

Por fim, além de se conectar com setores populares e com atores relevantes da área e disseminar internacionalmente a experiência, César Maia também se conectava com setores sociais mais à direita ao buscar dinamizar a economia da cidade e enfocar o "problema favela", com um grande apelo ao impacto que isso promoveria na dimensão da violência urbana vivida pela cidade naquele momento (como será amplamente explorado na segunda parte da tese). Tudo isso ainda possibilitando o fomento a empresas contratadas para realização de obras, a captação de recursos e empréstimos internacionais e uma ampliação da projeção nacional e internacional da cidade ${ }^{9}$.

No caso da cidade de São Paulo, aqueles fatores abordados anteriormente - o contexto político da redemocratização, a mobilização social de favelados e outros movimentos sociais, o declínio do protagonismo e do financiamento federal para habitação (e especialmente para a provisão habitacional), a autonomização/descentralização das iniciativas habitacionais por parte dos municípios - são também elementos importantes para compreender a consolidação da primeira intervenção em escala em favelas na gestão de Luiza Erundina. Da mesma forma, a característica de gestões municipais progressistas, principalmente aquelas ligadas ao Partido dos Trabalhadores, de busca pela inversão de prioridades e fatores de progressivo acúmulo institucional em torno da área habitacional.

\footnotetext{
${ }^{9}$ A questão do fomento ao setor empresarial será tratada com maior profundidade na seção 2.2. Quanto à questão de empréstimos e recursos internacionais e a influência deles sobre o direcionamento de programas habitacionais na época, toma-se a liberdade de remeter o leitor a obras que puderam tratar o assunto com maior profundidade, como Denaldi (2003), Arantes (2004) e Viana e Fonseca (2018). É importante destacar, no entanto, que, se no começo o programa foi alavancado basicamente com recursos próprios do município (CARDOSO, 2002, p. 47), posteriormente passa a contar com uma fonte importante de crédito. Assim, o FavelaBairro "Em suas duas primeiras fases, financiadas, cada uma, por um empréstimo do Banco Interamericano de Desenvolvimento (BID) no valor de US\$ 300 milhões" (CAVALCANTI, 2013, p. 200 e 201).
} 
Conforme já mencionado, antes mesmo da gestão de Erundina (1989 a 1992), o município de São Paulo já havia encampado algumas ações voltadas à promoção de melhorias em favelas. Desde Olavo Setúbal até Jânio Quadros ${ }^{10}$ (1975 a 1988), são observadas ações pontuais de melhoria em favelas e uma trajetória de desenvolvimento de estruturas institucionais com alguma incidência no tema: coordenadorias, fundos, programas, dentre outros (D'ALESSANDRO, 1999; MARQUES, PULHEZ \& PAGIN, 2018; MARQUES \& SARAIVA, 2005; AKAISHI ET AL, 2018). É interessante o relato de entrevistada que participou de várias dessas gestões em mais de 30 anos de carreira e destaca alguns pontos importantes do momento.

E a urbanização de favela até então [gestão de Erundina] existia algumas ações pontuais de iniciativa no governo Covas, de melhoria em favela, de melhorias, é uma escadaria... E era com recurso de atendimento, era bem... Não era uma política, era meio que trabalhar no desastre, trabalhar na emergência e no desastre, não era no planejamento de melhorias. Então tinha uma verba e eventualmente fazia uma ou outra dessas ações. A ação do Covas, independentemente da questão partidária eu guardo grande admiração, ele era um visionário realmente, ele também iniciou o trabalho do cortiço, ele também iniciou essa questão da urbanização, enfim, foi uma administração que começou a se voltar para... e a gente ia pras favelas, fazia o trabalho nas favelas, missão de Heliópolis, enfim, fazia algumas obras de melhoria já naquela época. (...) 0 que motivava mais, o nosso grande foco eram as áreas de risco, já naquela época, a gente tinha remoção de área de risco, verba de atendimento, já o velho auxílio aluguel já era utilizado naquela época. A gente construiu muita favela. Quando a gente saia de uma área de risco e tinha uma área pública, a gente construía barraquinho, que virou favela depois, assim, a prefeitura foi uma grande ocupante de terreno também... Ainda hoje a gente ainda herdou muitas dessas favelas que teve origem no próprio Poder Público, que foram encaminhadas algumas famílias... (...) Aí o Jânio trabalhou muito na Habi, a política dele era de erradicação, não era de urbanização, ele não tinha outra visão. Mas a gente trabalhava também no Pró Água, Pró Luz, todos esses programas que na época do Covas começaram e isso continua na época do Jânio, continuaram o que era colocar luz em favela, então isso já existia, mas mais como resultado da luta do que realmente uma política pública (ENTREVISTADO 19).

Tais iniciativas, contudo, não se destacam tanto quanto aquelas implementadas no governo de Erundina. É fato que a questão das favelas na cidade de São Paulo é diferente de outras capitais brasileiras, principalmente do Rio de Janeiro. De acordo com o que pode ser observado na tabela 01 (Introdução), o volume de favelas na cidade passa a ser representativo de fato

\footnotetext{
${ }^{10}$ Embora Jânio tenha priorizado ações de remoção no tocante a favelas, algumas ações de desenvolvimento da estrutura de gestão da Habitação contribuíram de alguma maneira para o período de Erundina, como a transferência de HABI, que tratava da temática de habitação de interesse social e que se encontrava ligada à assistência social, para a SEHAB (D’ALESSANDRO, 1999, p. 47).
} 
apenas a partir do final da década de 1980 e alcança no máximo 19\% da população em 1993. Ainda hoje, comparado com outras cidades, a representatividade de favelas na cidade não é tão alta quanto em outras localidades, sendo bastante expressiva, por outro lado, a presença de loteamentos clandestinos e irregulares em periferias autoconstruídas (ROLNIK, 2017). Nesse sentido, explica-se o fenômeno de que as iniciativas de regularização de loteamentos gozaram de relativa continuidade nas diferentes gestões municipais a cargo do município, ao contrário de outras modalidades na política habitacional (MARQUES \& SARAIVA, 2005; MARQUES, PULHEZ \& PAGIN, 2018).

No tocante à urbanização de favelas, o governo de Luiza Erundina é considerado como a grande inflexão por diferentes autores (D'ALESSANDRO, 1999; BUENO, 2000; DENALDI, 2003; MARQUES \& SARAIVA, 2005; SAMORA, 2009; FERREIRA, 2017; MARQUES, PULHEZ \& PAGIN, 2018; AKAISHI ET AL, 2018) e entrevistados (ENTREVISTADO 19; ENTREVISTADO 09; ENTREVISTADO 17; ENTREVISTADO 12; ENTREVISTADO 28). Nas palavras de entrevistada "Aí veio a gloriosa Erundina e a gente chegou no Nirvana" (ENTREVISTADO 19).

Proveniente do campo da assistência social e com uma trajetória profissional ligada ao tema habitacional ${ }^{11}$, Erundina é eleita com apoio popular e forte mobilização dos movimentos de moradia da cidade (D'ALESSANDRO, 1999).

A Erundina, ela vinha da habitação, então ela destinou uma boa parcela e priorizou muito a habitação. Eu conheço a Erundina quando ela era vereadora, muito antes de ser prefeita, e já na Câmara ela montava os grupos de discussão sobre habitação, então assim, a Erundina era a habitação, por isso que foi muito forte no governo dela... (ENTREVISTADO 19)

Em dezembro de 1988 é eleita a prefeita Luiza Erundina com grande apoio popular, principalmente dos movimentos de moradia. A nova prefeita era técnica da área, tendo trabalhado na Secretaria da Família e Bem Estar Social, de onde saiu para ser eleita vereadora. Ela militou na área por muito tempo, e a política habitacional do município sofreu mudanças substantivas. A nova política em favelas do município desenvolvida nessa gestão foi influenciada fortemente pelo comprometimento da prefeita com o setor de habitação e com a participação dos

\footnotetext{
${ }^{11}$ Cumpre mencionar que o campo da assistência social e de seus profissionais foi estratégico para a conformação da intervenção estatal na habitação em São Paulo. Até o final dos anos 1970, esta política situava-se conectada à Secretaria de Assistência Social, fazendo com que diversos funcionários municipais do setor tivessem sua trajetória entrelaçada com o tema, a exemplo de Erundina.
} 
movimentos de moradia. Pela primeira vez na história da prefeitura de são Paulo a urbanização de favelas passou a fazer parte da agenda municipal integrada à política habitacional. Além disso, outro fator que contribuiu, foi a percepção hegemônica da sociedade da necessidade de se urbanizar as favelas. A favela passara a ser um espaço legítimo de habitação no imaginário social. Dessa forma, houve um compromisso do aparelho estatal para que essa política se efetivasse, que se refletiu num novo desenho institucional ampliado e decentralizado e num grande aumento de seus quadros. Por essas razões, esse fato é um marco na política habitacional e de favelas do município (D'ALESSANDRO, 1999, p. 48).

Sua gestão inovou em diferentes frentes da política habitacional - desde a melhoria da estrutura institucional voltada ao tema à implantação de programas e metodologias inovadoras -, tendo ainda conferido prioridade à urbanização de favelas pela primeira vez. Isso, no entanto, não ocorreu desde o início da gestão, a qual enfocou principalmente a provisão por autogestão, com participação dos movimentos de moradia, em um primeiro momento. Conforme o PT descobriu, mesmo sob a diretriz de inversão de prioridades e de atendimento ao interesse da população pobre, a gestão pública naquele momento deveria priorizar ações, como atesta depoimento de Paul Singer secretário de planejamento à época - para Abrucio e Couto (1993).

A gente quer atender à maioria da população, só que a maioria é uma soma de minorias. Isto é o que eu acabei descobrindo exercendo a função que exerço. Não são a maioria dos pobres que têm necessidades homogêneas e então você satisfaz e está tudo bem (...) Os pobres são grupos especiais que somados são a maioria da população; mas cada um é uma minoria. Então você, por exemplo, os pobres que não têm onde morar. Esses exigem urbanização de favelas, casas em mutirão, construção de habitações e uma série de programas habitacionais. Agora, você tem os pobres que têm onde morar, mas em cuja rua não entra ambulância, não entra polícia, enfim, é um inferno porque a rua não está calçada. Você tem um movimento, uma exigência brutal de se calçar, porque uma grande parte das ruas de São Paulo não têm calçamento. Agora, a grana é uma só, ou você urbaniza favelas ou você calça aquelas ruas. Percebe? Estão disputando o mesmo dinheirinho! (Depoimento de Paul Singer in ABRÚCIO \& COUTO, 1993, p. 21).

A mudança nessa priorização e o destaque conferido à urbanização viria em função de um evento - quase - fortuito (BUENO, 2000), segundo uma das pessoas responsáveis pela ação em urbanização de favelas durante a gestão.

Houve esse evento chuvoso intenso. Na verdade ocorreu o deslizamento da Favela Nova República, no Butantã, onde morreram acho que $\mathbf{3 0}$ pessoas, uma coisa muito traumática. E naquele momento eu era diretora responsável lá na região sul. Aí depois se descobriu que a causa não tinha sido chuva, mas sim um vazamento de uma rede da Sabesp no topo do talude, de um talude clandestino que uma construtora estava fazendo. $O$ fato é que a administração municipal reagiu criando um grupo de atendimento às situações de risco e fortalecendo bastante o programa de urbanização de favelas em relação ao início da administração no qual a provisão de moradia, os mutirões, tiveram um grande protagonismo. Então nesse momento o programa de urbanização de favelas, 
tanto o programa de tratamento das questões de risco, as ações de produzir habitação pra poder receber pessoas removidas de favela, quanto o programa de urbanização de favelas cresceram bastante. (...) 0 nosso desafio era gastar 0 dinheiro com a rapidez necessária ao longo daquele ano e tal. 0 caso das situações de risco da Nova República aumentou a nossa força política pra conseguir recursos (ENTREVISTADO 23) [grifos nossos].

O governo eleito com o compromisso de inversão de prioridades e atuação no campo junto aos movimentos sociais (movimentos em geral no contexto da redemocratização, mas especialmente os de moradia nesse caso) (D'ALESSANDRO, 1999) se vê diante de uma situação emergencial para a qual a chefe do executivo estava sensibilizada, tendo em vista seu histórico de militância. Ainda com a baixa presença do governo federal no campo habitacional (e mesmo estadual) nesse momento, o município se vê como o principal responsável em dar resposta institucional à demanda. Apesar de uma capacidade e estrutura institucional baixa do setor à época, facilitou o processo de constituição da política o fato de que já havia sido criado o FUNAPS (embora com pouco recurso) nas gestões anteriores e que já existiam programas e dotações orçamentárias específicas para investimento em favelas (PRÓ-FAVELA) nas quais a gestão podia alocar recursos a partir de sua priorização (ENTREVISTADO 23).

Com isso, a ação de urbanização de favelas se amplia consideravelmente no município comparada com outras gestões (MARQUES \& SARAIVA, 2005; MARQUES, PULHEZ \& PAGIN, 2018), como boa dotação orçamentária e uso eficiente. Verifica-se tanto um crescimento do orçamento municipal destinado à área (D'ALESSANDRO, 1999, p. 52) quanto a realização de um maior número de intervenções com custo mais baixo do que a média verificada no histórico da cidade (MARQUES \& SARAIVA, 2005, p. 293).

Estavam incluídas diferentes linhas de atuação dentro do programa Ação em Favelas (D'ALESSANDRO, 1999, p. 53): urbanização, melhorias, regularização fundiária e remoção/alojamento/emergência. Propunha assim "o reordenamento de espaços, intervindo o mínimo possível no traçado existente e inserção no contexto urbano, possibilitando o assentamento definitivo dos moradores e garantindo sua participação em todas as etapas do processo" (D’ALESSANDRO, 1999, p. 54). 
A prioridade que foi dada foi no sentido de tentar ampliar o número de pessoas que nós atendêssemos. Ela era muito articulada com a reivindicação do movimento de favelas na época. Era o saneamento, pra isso a abertura de vias, a abertura de vielas, alargamento de algumas vias pra que você pudesse passar por infraestrutura, criação de um arruamento que as pessoas pudessem levar 0 lixo até um determinado lugar, dando $\mathbf{5 0}$ metros no máximo, algumas diretrizes bem objetivas. Nós propúnhamos que a própria prefeitura, dentro do contrato de urbanização de favela (a maioria deles era com empresas privadas, construtoras), no contrato nós incluíamos a execução da ligação da água no lote e a própria ligação do esgoto, pra garantir que de fato a infraestrutura colocada fosse usada e a população se beneficiasse disso. A mesma coisa em relação à energia elétrica, se colocava também iluminação pública e começou-se a se fazer um trabalho, na parte dos arquitetos, das equipes regionais, de acompanhar mais de perto melhorias necessárias nas habitações, dentro das habitações, reforma, ampliação pra ter mais um quarto, no caso de uma família maior, o problema de iluminação, localização de janelas, umidade, diversas coisas ligadas a edificação (ENTREVISTADO 23).

A gestão de Erundina viveu um grande desgaste político ao longo do mandato em função de diferentes fatores, como divergências partidárias e uma relação conflituosa com o legislativo municipal (ABRUCIO \& COUTO, 1993). Não foi possível, assim, que conseguisse eleger um sucessor, tendo Paulo Maluf sido eleito prefeito em 1992.

Se com a gestão Erundina a pauta da intervenção em favelas entra na agenda pública da cidade, há diferenças significativas no modo com que ela permanecerá nas gestões municipais seguintes. Diferentemente do caso do Rio de Janeiro, no qual o Favela-Bairro também consegue colocar o tema em pauta na agenda pública e se torna, inclusive, uma das principais fontes de capital político para a eleição do sucessor de César Maia, Luiz Paulo Conde (FIGUEIREDO, 1997); a atuação municipal se transformará radicalmente com a entrada de Paulo Maluf a partir de 1993. A pauta da favela permanece na gestão da cidade mesmo diante da derrota do PT nas eleições, mas a forma de intervir passa a ser menos sob o caráter de uma urbanização que qualifica e consolida o território já existente para iniciativas de substituição parcial dos tecidos pela construção de novas unidades verticalizadas - o famigerado programa Cingapura (KRAHENBUHL, 1996).

O programa tinha como objetivo "dar condições dignas de moradia para a população residente em favela" (KRAHENBUHL, 1996, p. 50), de acordo com publicação do ex-secretário de habitação responsável à época pelo programa. Como constata Abrúcio (1996), o programa estava ausente das promessas de campanha de Maluf na eleição de 1992. Na realidade, esta se centrava 
principalmente em temas usualmente enfocados pelo candidato, como a segurança pública, sendo a concepção do programa posterior à sua posse.

Lembrando que, no momento em que assume a prefeitura, não apenas o programa de urbanização de favelas de Erundina se encontrava em andamento, mas havia também outras iniciativas, como os mutirões habitacionais no campo da autogestão para provisão e também o programa Guarapiranga, o qual tinha por objetivo a realização de obras para a melhoria do sistema hídrico (UEMURA, 2000). Dentre esses, o único que não sofreu paralisação foi justamente o programa Guarapiranga (MARQUES, PULHEZ \& PAGIN, 2018), tendo em vista que contava com recursos do BID, que pressionou pela sua continuação (ENTREVISTADO 19). Entrevistada pela pesquisa oferece uma versão interessante sobre como o programa Guarapiranga de alguma forma incide sobre a continuidade de ações voltadas a favelas, embora com partidos urbanísticos completamente diferentes.

O Maluf é engraçado. Apesar de todo o conservadorismo dele, ele não impôs nunca um obste ao Programa Guarapiranga. Depois que ele viu que ficava bonito, que a população gostava, ele transformou num programa de governo dele, o Programa CINGAPURA. (...) o Maluf é um super conservador, mas todo dia ia num bairro, etc. e tal. Na primeira vez que ele foi inaugurar uma obra da Guarapiranga, que tinha que ser feito por obrigações de contrato com o Banco e ele viu a receptividade que ele teve com a população, "Opa, vamos urbanizar". Ele viu que tinha um retorno político (ENTREVISTADO 09).

A entrevistada relata, portanto, a visita que acompanhou de Maluf à inauguração de obra do programa Guarapiranga, que desperta no gestor o interesse pela intervenção em favelas. Com a visita de integrantes da gestão municipal à Malásia, que desde 1964 promovia um projeto de erradicação de favelas, foi lançado o programa Cingapura (KRAHENBUHL, 1996). Tendo em vista que a forma de priorização das favelas a serem atendidas no programa se deu notoriamente em função da visibilidade que elas dispunham para a sociedade em geral - como em áreas mais centrais ou lindeiras de grandes avenidas (FERREIRA, 2017; AKAISHI ET AL, 2018; ENTREVISTADO 14) parece ser coerente a interpretação fornecida pela entrevistada: a ideia surge a partir de um amálgama de interesses políticos e de uma concepção higienista de intervenção estatal. 
Além disso, é importante mencionar que o próprio nome do programa havia sido escolhido por Duda Mendonça, publicitário conhecido pela condução de campanhas políticas, dentre elas a de Paulo Maluf a prefeito em 1992 (KRAHENBUHL, 1996). A participação do notório marqueteiro é mais um indício de que o programa visivelmente possuía um viés político e corrobora, assim, para confirmar a priorização de áreas com maior visibilidade. Sobre esta priorização, outra entrevistada participante da gestão municipal naquele momento relata a mesma tendência.

Você percebe que a opção, isso era verbalizado, a opção por aquelas favelas eram, a grande maioria foram nas Marginais, que é a porta de entrada da cidade, então é onde tinha visibilidade. Ele queria construir uma cidade onde as pessoas que chegassem não vissem as favelas, então você percebe que o Cingapura no corredor... todas as favelas que tinham lá, em vez de erradicar, como o Jânio faria, eles transformaram isso em prédio. Expressamente "Vamos embelezar a Marginal fazendo prédios" (...). E ele verbalizava uma coisa que eu nunca esqueci, eu sempre repito, ele falava assim nas inaugurações - eu não estou dizendo porque eu ouvi falar não, eu vi ele falando - ele falava assim "Porque aqui a gente fez um trabalho com as famílias, onde a gente tirou das favelas, pusemos no alojamento, ensinamos a escovar dente, a tomar banho, a pentear cabelo e depois pusemos elas de volta num apartamento". Essa era a visão que ele tinha, e verbalizava ao público, o que dá mais vergonha alheia... Ele achava isso, ele realmente achava que era assim que tinha que fazer, que era ensinar as pessoas a serem cidadãs (ENTREVISTADO 19).

Contribui também para o fato, assim, a visão acerca da favela e de seus moradores entronizada nos membros da gestão. Além do prefeito, os principais cargos da gestão habitacional naquele momento foram ocupados por empresários da incorporação e do setor imobiliário e quadros políticos e técnicos do partido de Maluf, diferentemente do que ocorreu na gestão anterior, em que foram ocupados por professores universitários e quadros do PT ligados a movimentos de moradia (MARQUES, PULHEZ \& PAGIN, 2018, p. 147). Não é de se estranhar, portanto, a mudança de concepção da política, cujo programa passará inclusive a atender os interesses de um conjunto de empreiteiras (MARQUES, PULHEZ \& PAGIN, 2018, p. 150) que haviam apoiado sua campanha (ENTREVISTADO 19), conforme será melhor explorado na seção 2.2.

No momento o que é importante apontar é o fato de que, com diferenças significativas, tanto gestões progressistas (Erundina) quanto outras consideradas conservadoras (César Maia e Paulo Maluf) passam a priorizar intervenções em favelas. Não se trata de uma política mais de gestões 
progressistas, como se apontava e ainda muitos atores consideram (CARDOSO E RIBEIRO, 2002, p. 15; ARRETCHE, 1990; ARRETCHE, 1996; ENTREVISTADO 07; ENTREVISTADO 16). Não apenas isso, mas geraram capital político suficiente, inclusive, para eleger sucessores nas duas cidades nas eleições de 1996, como será visto na seção 2.1. Por que então essa inflexão nesse momento?

Além das condições e fatores econômicos, políticos e institucionais específicos de cada uma das gestões já apontados acima para o Rio de Janeiro e São Paulo (e possivelmente para o restante do Brasil), pode-se vislumbrar um movimento semelhante em Bogotá e Medellín. Variando um pouco entre Bogotá e Medellín, até a década de 1970, a maior parte das ações públicas voltadas aos assentamentos informais visava a sua erradicação. "En los 70 , la acción primordial (...) era la relocalización, había que desaparecer a los pobres, había que llevárselos a otro lado, esa era la orientación de la política". Baseava-se na concepção de que estes assentamentos representavam uma doença, um mal a ser combatido (PEVAL, 1984).

A partir do final desta década e início dos anos 80 (TOVAR, GARCIA \& MORENO, 2009), começam a surgir outras iniciativas, cujo objetivo simples de melhora a qualidade física dos assentamentos abrangia qualquer intervenção pontual e isolada de infraestrutura (pavimentação, implantação de calçadas, etc.) e era visto como uma ação de mejoramiento (ENTREVISTADO 20; ENTREVISTADO 10). A partir principalmente da década de 1990, especialmente na segunda metade, são colocados muitas vezes objetivos mais amplos para estas, ligados não somente a aspectos físicos, mas também de intervenção social (TOVAR, 2012), buscando envolver a população neste processo (ao menos no discurso) (ENTREVISTADO 08).

Inicialmente, el Mejoramiento Integral de Barrios estuvo orientado a la provisión de infraestructura y servicios urbanos en los barrios, garantizando condiciones mínimas de salubridad, regularizando la tenencia de la tierra. Actualmente, incluyen otros componentes orientados a atender las carencias sociales de grupos vulnerables (...). Gradualmente, las lógicas y líneas de intervención del Mejoramiento Integral de Barrios han variado y han pasado de centrarse en la solución de cuestiones como el saneamiento básico y la tenencia de la tierra, a buscar el mejoramiento integral de las condiciones de vida de los beneficiarios, el estímulo a la participación de la comunidad y la mejora en la gestión de los servicios urbanos (TOVAR, GARCIA \& MORENO, 2009, p. 164). 
Da mesma forma que no caso das cidades brasileiras, credita-se a inflexão a esse modelo a variadas causas. Neste trabalho enfocaremos alguns fatores considerados interessantes como paralelismo com a experiência vivida aqui no Brasil. Dessa forma, também na Colômbia há fatores econômicos e políticos que devem ser considerados para a compreensão desse amplo processo de consolidação da pauta de urbanização de favelas, afora aqueles já abordados anteriormente - de mobilização social pela reivindicação de melhorias urbanas e contra a forte centralização promovida pelo governo nacional.

\begin{abstract}
Las décadas del ochenta y el noventa evidencian un tiempo de crisis generalizada con señales de paralización, desesperanza e incertidumbre, pero también de explosión social, inconformidad, protestas y movilización popular. Esa crisis fue provocada por la acción combinada de dinâmicas sociales, políticas y económicas donde la agudización de la exclusión, la desigualdad urbana, las violencias y la incapacidad del Estado para garantizar satisfactoriamente los derechos, llegaron al nivel más alto, poniendo en jaque la legitimidad y la gobernabilidad institucional (PÉREZ ET AL, 2017, p. 21).
\end{abstract}

Assim, em paralelo a todo aquele cenário de [inconstante] mobilização social em torno da questão da melhoria das condições de vida nos assentamentos de origem informal (vide seção 1.2), também havia na Colômbia um movimento que reivindicava, à semelhança do Brasil, maior autonomia dos municípios para efetivação de políticas necessárias aos cidadãos e também uma maior participação destes na formulação e implementação das políticas estatais (ENTREVISTADO 08). Até esta época, as possibilidades de incidência dos colombianos sobre o processo político eram bem restritas, tendo em vista que elegiam apenas parte dos governantes (principalmente o presidente, sendo governadores e prefeitos indicados). O processo eleitoral, por sua vez, era marcado por esquemas clientelistas e de cooptação, não havia espaços ou mecanismos de controle social ou participação popular (MAZO, 2014, p. 23).

A década de 1980 assiste ao início da transformação deste cenário quando começam a ser incorporadas práticas de planejamento urbano participativo e são adotadas eleições diretas como mecanismo de escolha de governadores e prefeitos (PÉREZ ET AL, 2017). Inicia-se ainda a ampliação de competências dos departamentos e dos municípios (sendo transferidas paulatinamente mais funções e recursos, principalmente para os últimos), criam-se os primeiros espaços institucionais de participação na gestão pública, inclui-se a população nas juntas diretivas das empresas municipais de serviços públicos, possibilita- 
se o processo de contratação de grupos e associações comunitárias pelo Estado para realização de obras e serviços de interesse público, dentre outras medidas (MAZO, 2014, p. 24). Todo este movimento, que vinha acompanhado de uma efervescente mobilização social, culmina com o processo de reivindicação de uma nova Constituição para o país, que efetivamente reafirmasse a centralidade dos direitos e adotasse a democracia participativa como eixo político do país (PÉREZ ET AL, 2017).

É a partir desta época (início dos anos 1990) que se dá a primeira grande ascensão dos programas e iniciativas de mejoramiento barrial do país (MAZO, 2014; ENTREVISTADO 08; ENTREVISTADO 15). Embora não pareça se tratar de uma questão estritamente ligada à aprovação de regulamentações e espaços participativos, mas mais a um contexto de mobilização social mais ampla, tendo como tema principal o enfrentamento à violência (conforme explorado na seção 3.1 desta tese); todo este cenário de alguma forma constrói as bases para que seja possível a formulação e implementação destes programas. Em publicação da Alcaldia de Medellín sobre o PRIMED, principal iniciativa desenvolvida à época, coloca-se como contexto de surgimento do programa.

En 1986 se aprobó la elección popular de alcaldes que, acompañada de un estatuto de descentralización, dio a los municipios una mayor autonomía administrativa y los convirtió en protagonistas de su propio desarrollo. En 1991 entró en vigencia una nueva Constitución, producto de una Asamblea Nacional Constituyente, elegida mediante voto popular e integrada por diversos sectores de la vida nacional: representantes de los partidos políticos, de las minorías étnicas, los movimientos cívicos y los grupos subversivos en proceso de desmovilización. Esta nueva carta desarrolla principios fundamentales, tales como la descentralización, la autonomía de las entidades territoriales y la participación ciudadana, principios que permiten una relación directa entre la comunidad y sus autoridades (ALCALDIA DE MEDELLIN, 1996, p. 18).

Desde então, a Colômbia se caracteriza como uma república unitária, descentralizada, com autonomia das entidades territoriais, a qual se constitui como um estado social de direito, onde os gastos sociais são prioritários (CONSTITUIÇÃO DE COLOMBIA, 1991). No esquema construído pela Constituição e pelo ordenamento infraconstitucional, cabe aos municípios a responsabilidade pela implementação de políticas de planejamento e gestão do espaço urbano, ficando sob sua responsabilidade, dessa forma, a formulação e implementação de ações de mejoramiento barrial. Se, por um lado, isso 
cumpriu com as demandas do movimento que reivindicava uma maior proximidade entre o responsável pelas políticas e a população; por outro, isso aparentemente deixou o governo dos departamentos enfraquecido e com poucas competências (ENTREVISTADO 25; ENTREVISTADO 20). A intervenção destes entes no tocante ao mejoramiento barrial, assim, é variável, não ocorrendo em geral nas grandes cidades. Segundo entrevistados (ENTREVISTADO 15; ENTREVISTADO 08), há uma atuação do governo departamental em relação ao tema - como no caso do desenvolvimento dos PUI (MAZO, 2014b, p. 62-64) -, mas mais do ponto de vista da cooperação técnica, sem uma grande intervenção, tendo em vista que concerne mais a ele ficar a cargo dos outros municípios inseridos em seu território (ENTREVISTADO 15).

Não apenas uma ascensão da mobilização social e a descentralização de competências para o município configuram paralelos entre as cidades brasileiras e colombianas no tocante à emergência da urbanização de favelas. Houve também lá uma conexão entre a ascensão das ações de urbanização e inflexões vividas na economia e no sistema de financiamento habitacional colombiano, a exemplo do declínio do $\mathrm{BNH}$ e SFH aqui.

No início da década de 1990, o ICT (Instituto de Crédito Territorial) e BCH (Banco Central Hipotecário) são liquidados na mudança de lógica pela qual passa a política habitacional da Colômbia, quando o Estado (principalmente 0 ente nacional) se retira da operação direta de seus componentes financiamento e produção da habitação social - e passa apenas ao papel de facilitador da operação do mercado na provisão habitacional (MINISTERIO DE VIVIENDA, 2014, p. 39-40).

La vivienda de interés social (Ley 3 de 1991, modificada por la Ley 546 de 1999), formulada en el mismo año que la Constitución Política Colombiana, promulgó el derecho a la vivienda digna, cambiando la intervención estatal em la política habitacional. Puede decirse que los primeros impactos derivados de la transferencia de las funciones públicas al mercado fueron la función de la construcción de vivienda, asumida antes por el Estado, ahora a cargo del mercado inmobiliario y financiero, la eliminación del ICT, y la creación del Instituto Nacional de Vivienda de Intereses Social y Reforma Urbana (Inurbe) (...) (PÉREZ ET AL, 2017, p. 25).

Esse movimento acontece, a exemplo do Brasil, ao mesmo tempo em que se dá o processo de ampliação da autonomia dos municípios e transferência para 
eles da responsabilidade pelo ordenamento territorial e pela política habitacional, conforme abordado anteriormente (MINISTÉRIO DE VIVIENDA, 2014, p. 38). No mesmo período, ocorre a ascensão no país da concepção mais ampla das políticas habitacionais a partir do contexto de luta contra a pobreza, frente à agudização dos problemas sociais derivados da crise econômica vivida (MINISTÉRIO DE VIVIENDA, 2014, p. 38), que inclusive redunda na inclusão do direito à moradia adequada pela Constituição de 1991 (MINISTÉRIO DE VIVIENDA, 2014, p. 41).

Depois do fim do ICT e do $\mathrm{BCH}$, vive-se, na segunda metade da década de 1990, também a crise de outro pilar da oferta/provisão de moradias na Colômbia.

En el año 1999 ocurre el tercer gran cambio de la financiación de vivienda en Colombia (Ley de Financiación de Vivienda - Ley 546 de 1999). La crisis del sistema de ahorro y vivienda UPAC [Sistema indexado de financiación fundamentado en las Unidades de Poder Adquisitivo Constante - UPAC (MINISTERIO DE VIVIENDA, 2014, p. 35)] culminó con su propia caída (...). EI sistema UPAC desaparece después de haber apalancado, desde 1972, aproximadamente 1.5 millones de soluciones de vivienda (MINISTÉRIO DE VIVIENDA, 2014, p. 42).

Além disso, o país, como tantos outros da região e do mundo, viveu uma crise financeira no final dos anos 1990 (1997-1999), resultado de uma combinação de fatores - aumento das importações em função da abertura comercial iniciada na década, escalada dos gastos públicos, choque externo promovido pela crise asiática, etc. - afetando o sistema financeiro e a capacidade de investimento do Estado. Todos estes fatores conjugados - crise financeira vivida no país, crise momentânea e processo de transição dos sistemas de financiamento/oferta/provisão de moradias, transferência da responsabilidade e ampliação da autonomia dos municípios, inclusão da habitação no contexto de luta contra a pobreza - parecem formar um caldo que permitirá que, ao longo da década de 1990, principalmente a partir da segunda metade, se disseminem diferentes iniciativas de urbanização de favelas no país.

No momento em que se torna responsabilidade dos municípios a implementação da política habitacional, estes deveriam de alguma forma intervir no tema mesmo diante das crises mencionadas (ENTREVISTADO 08), tendo sido aparentemente o mejoramiento barrial uma solução encontrada. 
Assim, a ascensão das ações de mejoramiento nesse período de crise foi, a exemplo do que ocorreu no Brasil, justamente uma reação dos municípios à dificuldade de fomentar a provisão em função da crise, sendo, portanto, um período em que o mejoramiento se torna mais viável e interessante do que a provisão/oferta. Com essa responsabilidade e contando com um contexto grande de mobilização social pela melhoria dos barrios como forma de enfrentamento à violência (como será aprofundado na seção 3.1), Medellín dá início ao PRIMED.

Apesar de experiências prévias no tema como o exemplo já citado do Programa Morávia e também o Limonar (MAZO ET AL, 2017), o PRIMED (Programa Integral de Mejoramiento de Barrios Subnormales en Medellín) constituiu na década de 1990 o primeiro programa em que de fato esse modo de intervenção ganha escala e integralidade na cidade, sendo um dos primeiros programas da cidade que não prioriza a remoção e o reassentamento e se constitui numa experiência paradigmática para o restante do país de intervenção in situ (ENTREVISTADO 15). De acordo com publicação oficial do município, o PRIMED, considerado como uma das experiências referência do país no tema na década de 1990 (CONPES, 2009), tinha como objetivo principal "mejorar la calidad de vida de los habitantes de 15 barrios de ladera en tres zonas de la ciudad" (ALCALDIA DE MEDELLíN, 1996, p. 12).

Enfocando a construção de uma cidade segura, pacífica, moderna, competitiva e respeitosa da convivência coletiva (ALCALDIA DE MEDELLín, 1996, p. 07 e 08), o PRIMED interviu em 26 assentamentos situados em quatro comunas (zonas da cidade) (MAZO, 2014, p. 127-128) - equivalente a $22 \%$ do universo dos assentamentos chamados "subnormais" pelo programa na época - através da unificação da cidade (vista como a integração dos barrios ao restante da cidade) e a melhoria da convivência comunitária (enfrentando as questões então colocadas pela violência) (ALCALDIA DE MEDELLín, 1996, pp. 08 - 11).

Sob o guarda-chuva deste objetivo geral, estavam incluídos outros seis objetivos específicos:

1. Estabelecimento de mecanismos adequados de planejamento e gestão que garantam a continuidade do programa; 
2. Promoção e participação comunitária na solução dos problemas comunitários;

3. Melhoria da infraestrutura básica, dos serviços públicos, dos equipamentos comunitários e do espaço público;

4. Melhorias habitacionais e realocação das moradias situadas em zonas não recuperáveis;

5. Legalização da posse da terra urbana;

6. Mitigação do risco geológico (ALCALDIA DE MEDELLín, 1996, p. 59).

A exemplo também posteriormente dos PUI (ver seção 3.1), já se buscava no PRIMED uma intervenção completa, articulando diferentes políticas em uma ação coordenada do município. Conquanto estivesse baseada em aprendizados provenientes das experiências anteriores (MAZO ET AL, 2017), colocava a urbanização de favelas em um novo patamar, inclusive de projeção internacional da cidade, como será visto adiante na seção 2.1.

Para entrevistados e autores (MAZO, 2014b; ENTREVISTADO 15), no caso do PRIMED, houve um alinhamento de interesses entre o disposto na Constituição - que a partir de 1991 incluiu o direito à moradia em seu texto - e nos documentos acerca da intervenção em favelas (ALCALDIA DE MEDELLín, 1996) e o contexto de violência que vivia Medellín na década de 1990. Os autores não acreditam que tenha sido esta inclusão no texto constitucional ou a aprovação da Agenda Habitat (resultante da $2^{\mathrm{a}}$ Conferência da ONU sobre o tema, em 1996) que impulsionaram a implementação do referido programa (referência internacional sobre o tema), mas afirmam que, de alguma forma, estes dois elementos serviram como legitimadores daquelas intervenções propostas pelo poder público à época, o qual se empenhava em alavancar a intervenção nos assentamentos da cidade como forma de retomar os territórios dominados ao longo das décadas anteriores pelo narcotráfico e restituir sua legitimidade junto à população, como será abordado mais à frente na seção 3.1 sobre a relação entre mejoramiento e violência na Colômbia. 
Em Bogotá, são encontradas também experiências piloto ou iniciativas parciais de melhoria dos barrios desde a década de 1970, mas apenas na década de 1990 e 2000 elas evoluíram para o conceito de Mejoramiento Integral de Barrios que se aproximaria da urbanização de favelas (TORRES TOVAR, 2009, p. 187). É importante notar que, a exemplo de São Paulo, a cidade de Bogotá tem uma composição fortemente marcada por loteamentos irregulares/clandestinos mais do que a forma "favela" como construída em nosso vocabulário morfológico desde o Brasil. Mesmo assim, são barrios com uma infraestrutura precarizada, muitas vezes sem pavimentação e com deficiências de infraestrutura urbana e de habitabilidade.

Diante disso, Bogotá contou com diferentes programas e projetos ao longo das últimas décadas tendo sido o tema da elevação da qualidade de vida e da superação dos indicadores negativos uma constante, apesar das diferentes perspectivas e enfoques destes programas (AVILA, CASTANEDA ET AL, 2012, p. 14). O programa Desmarginalización de Barrios, implementado entre 19982001 no contexto do Plano de Desenvolvimento "Por la Bogotá que queremos" tinha expressamente como objetivo estabelecido pelo Acuerdo $\mathrm{N}^{\circ} 06$, de junho de 1998, "Elevar la calidad de vida de la población residente en barrios con deficiencias en infraestructura y servicios sociales, a través de la intervención sobre aquellos aspectos que permitan superar dichas deficiencias y dinamizar en la comunidad la apropiación de la construcción de su destino".

O projeto Sur con Bogotá, iniciado em 1998 como um projeto específico dentro da primeira gestão de Enrique Peñalosa com um enfoque de intervenção física, é reformulado na administração de Antanas Mockus (2001-2003) (GRANADOS, 2011, p. 31-33), passando a ter como objetivo contribuir para a melhoria sustentável da qualidade de vida da população em condições de pobreza na área alvo através da ampliação do seu enfoque para abranger a inter-relação entre os diferentes atores na formulação, implementação, acompanhamento e avaliação de todas as intervenções (CADENA, 2010, p. 110).

Como se pode observar, portanto, houve na década de 1990 também uma inflexão no tocante às políticas e programas de mejoramiento barrial tanto em 
Bogotá como em Medellín no sentido de ampliarem o escopo da intervenção e mesmo sua escala de abrangência. Essa mudança, da mesma forma que no contexto brasileiro, esteve atrelada a uma crise/mudança das iniciativas de provisão habitacional, além de estar mergulhada num ambiente social propício a ela.

Diante dos casos abordados para as cidades brasileiras e colombianas, é possível traçar alguns pontos de convergência que talvez elucidem, ao menos parcialmente, a emergência de políticas e programas de urbanização de favelas simultaneamente em ambos países. Primeiramente, no plano nacional dos dois, vivia-se um contexto político de ampla mobilização social em torno da ampliação da democracia e do discurso de direitos. A melhoria das condições das favelas situava-se, portanto, embebida de um processo social em que se reivindicava do estado uma maior atenção para com as condições de vida da população em geral, a qual vinha há anos pressionando as instâncias governamentais por mudanças e por maiores possibilidades de participação. Com isso, a urbanização de favelas ganha momentum justamente como uma das formas de permeabilidade do estado a reivindicações populares e, ao mesmo tempo, como forma de demonstração visível e pública de alterações no contexto urbano vivido.

Isso também foi possível em função do processo do ocaso ou descenso (no caso colombiano) de sistemas de fomento à provisão habitacional. $O$ desmonte das estruturas estatais incumbidas do planejamento, coordenação e financiamento dessa modalidade de política abriu, em ambos os casos, espaço para outras modalidades de atuação. Acentuou esse fato a descentralização de competências para os governos locais no tocante à política habitacional, fortalecendo o impulso à intervenção sobre favelas em detrimento da provisão. Mesmo no caso de governos conservadores em que a provisão entra em cena novamente (como Maluf e Pitta em São Paulo), busca-se atrelá-las a uma atuação no campo das favelas.

Ainda foi importante fator - subdimensionado muitas vezes em diferentes trabalhos (conforme apontado por alguns entrevistados) - de que em todos os municípios estudados são encontradas experiências de intervenções em 
favelas anteriores aos mais conhecidos programas e políticas. O Favela-Bairro, o PRIMED e outros programas referência abordados apenas puderam emergir porque já havia alguns acúmulos e aprendizados institucionais prévios que favoreceram sua constituição. Esses programas de grande porte - e mesma a mudança de escala que promoveram nas ações de urbanização em favelas são resultado de anos (e talvez mesmo uma década ou mais) de acúmulos a predizados institucionais nas Prefeituras brasileiras e Alcadias colombianas (MARQUES, PULHEZ \& PAGIN, 2018). As experiências 'precárias', de baixa institucionalidade, de escopo local corformaram um "caldo" suficiente para emergir posteriormente como programas estruturados de grande porte, recurso e impacto.

Como outros trabalhos relevantes da área demonstram, existem ainda outros fatores que contribuíram para a ascensão das iniciativas no período, desde a evolução de ideias e agendas acerca das favelas nos âmbitos nacionais e internacionais, a existência de financiamentos por parte de bancos multilaterais e até o amadurecimento de legislações urbanísticas e de estruturas institucionais (ARANTES, 2004; DENALDI, 2003; GONÇALVES, 2013; MARQUES \& SARAIVA, 2005).

O foco nas questões aqui destacadas tinha por objetivo demonstrar que estes fatores, contudo, não explicam por si só esse movimento em diferentes países. Respondendo à questão que dá título a este capítulo, há, portanto, componentes políticos e institucionais mais amplos que perpassam a história de Colômbia e Brasil que apresentam correlações positivas com a ascensão da agenda da urbanização de favelas, como a ampliação da democracia, a busca pela efetivação de direitos e até mesmo a situação dos sistemas de fomento à provisão habitacional. Esses e alguns outros serão ainda explorados em maior profundidade nos próximos capítulos, tentando colocar mais luz ainda sobre aspectos políticos que impactam na consolidação dessa agenda. 


\section{Capítulo 2 - A Política que se alimenta da política de urbanização de favelas}

Ele subiu o morro sem gravata / dizendo que gostava da raça / foi lá na tendinha bebeu cachaça / até bagulho fumou / jantou no meu barraco / e lá usou lata de goiabada como prato / eu logo percebi, é mais um candidato / para a próxima eleição (trecho da música Candidato caô caô de Walter Meninão e Pedro Butina, 1992).

A literatura brasileira e colombiana já vêm apontando há décadas uma relação entre a precariedade do território das favelas e a manutenção de esquemas clientelistas, através do qual membros da classe política angariam apoio com base na promessa de melhorias (PERLMAN, 1977; SANTOS, 1984; SHLUGER, 1984; MARICATO, 2003; ALVITO, 2006; BURGOS, 2006; LEEDS, 2006; ZALUAR, 2006; BUENO ET AL, 2009; SANTO AMORE ET AL, 2014).

Nesse sentido, é essencial que sejam feitas análises que relacionem a definição e a implementação de políticas de urbanização de favelas com processos políticos mais amplos - como aqueles ligados à reprodução dos mandatos eleitorais, à definição das agendas políticas de cada gestão, dentre outros, de forma a compreender a relevância desses fatores para a consolidação da agenda no tema. Novamente, serão priorizados temas nem sempre abrangidos pela literatura ou que são avaliados sob enfoques diferentes dos propostos aqui.

Alerta-se que é compreensível que se espere que a implementação de boas políticas públicas renda dividendos políticos. Este certamente é um resultado esperado dentro de um sistema político democrático representativo, no qual a população elege seus representantes de acordo com a representação de seus valores e interesses. No entanto, a questão a ser avaliada é como a orientação a esse ganho (rendimento eleitoral) vai modelar a política pública, fazendo com que esse efeito político seja considerado prioritário em detrimento de outras finalidades, como a efetivação do direito à moradia adequada, por exemplo. 


\subsection{0 capital político alimentado}

Na presente sessão, serão abordados principalmente aspectos da urbanização de favelas mobilizados para produzir capital político a membros da classe política, tanto aqueles pertencentes ao Poder Executivo quanto ao Legislativo. Percebe-se que as iniciativas no tema podem ser estrategicamente mobilizadas de diferentes formas para gerar dividendos eleitorais estratégicos, seja através do atendimento a interesses de moradores, do seu uso político em campanhas eleitorais ou da sua utilidade para a construção de novas imagens para as cidades como estratégia de marketing urbano. Ainda há outras maneiras de mobilizá-las para tanto, como a atualização de padrões de relação entre Estado e setor empresarial e entre Estado e lideranças comunitárias, mas essas formas serão tratadas nas seções 2.2 e 4.2 respectivamente.

A partir do caso de Bogotá e Medellín, é seguro afirmar que o mejoramiento de barrios cumpre um papel no processo de reprodução dos mandatos eleitorais, com momentos e pesos variados. Os assentamentos informais, conforme colocado por entrevistados (ENTREVISTA 20; ENTREVISTADO 08; ENTREVISTADO 05; ENTREVISTADO 15), ainda fornecem um importante mercado de votos, tendo em vista que são constituídos por uma população historicamente vulnerável (renda familiar baixa, baixo nível de emprego e de escolaridade, etc.) e apresenta um tecido urbano precário, com necessidade de inúmeras intervenções. Eles representam, portanto, um "contingente enorme de mano de obra barata, un fuerte potencial electoral y una población propicia para seducir con la idea del consumo" (FRANCO, 2005, p. 93).

As promessas de intervenção ainda são nos dias de hoje utilizadas como moeda eleitoral na maioria das cidades do país (GARCIA, 2010; TOVAR, 2012, p. 17), havendo a presença de candidatos (tanto a prefeitos quanto a vereadores) nestes assentamentos em períodos eleitorais, conforme atestado em conversa com moradores (ENTREVISTADO 05).

Como no Rio de Janeiro, o caso de Medellín traz ainda uma particularidade: as intervenções de mejoramiento também possuíam como objetivo a transformação da imagem da cidade de forma a incentivar a retomada de 
investimentos internacionais na cidade (ALCALDIA DE MEDELLÍN, 1996; ENTREVISTADO 08) assim como incrementar o setor de turismo da cidade (ENTREVISTADO 15) e, com isso, também promover um maior capital político com a intervenção.

Segundo entrevista com representante da prefeitura da cidade (ENTREVISTADO 08), esta foi uma estratégia construída deliberadamente pelas administrações municipais, as quais se esforçaram ainda em promover a cidade em diversos espaços de discussão e promoção internacional, citando principalmente feiras internacionais e fóruns organizados pela ONU e ONUHabitat. Este fato (de se construir uma estratégia de marketing), segundo ele, não quer dizer que o que foi divulgado ou propagandeando não aconteceu de fato, apenas que se capitalizou em cima de uma intervenção.

Apesar de todos estes esforços por parte do Executivo municipal em gerar uma visibilidade dos programas, esta presença parece ser mais forte e obter mais impacto para a reprodução dos mandatos de vereadores do que dos candidatos a prefeito, se fazendo os primeiros muito mais presentes e mais estreitamente articulados com lideranças comunitárias (ENTREVISTADO 15).

\begin{abstract}
Además porque el Estado, con la herramienta de la legalización y el mejoramiento de barrios, va prever servicios públicos y esto en última se ha vuelto en negocio político tremendamente importante. Porque es que, digamos, eses familiares que llegan compran el suelo muy barato, pero sin servicios públicos, con los mínimos que son los días y sin asfaltar. Lo primero que requieren es servicios públicos y la cobertura de servicios del Estado, sobretodo la agua y luz, entonces aparece el político que se candidata al consejo [equivalente à câmara de vereadores no Brasil] y les prometen: "Yo los legalizo el barrio". "Yo tengo por mí que cuando yo sea concejal voy a proponer que legalicen su barrio". (...) No tanto los alcaldes, casi no. Y ellos utilizan a través de los concejales también. (...) Entonces, para los candidatos al Consejo es más importante esta... El Sur de Oriente, es la Ciudad Bolívar, (...) Carulla de los políticos. (...) Carulla es aquí una red de supermercado famoso. (...) es Carulla de los políticos, donde mercan votos los políticos, al Sur de Oriente (ENTREVISTADO 24).
\end{abstract}

No caso de Bogotá, a própria representante da secretaria de habitat envolvida com mejoramiento coloca que o programa teria virado uma "feira", onde diversos políticos eleitos se dirigem para solicitar obras de pavimentação. Os vereadores fariam o papel de mediação de demandas como forma de angariar capital político, numa estreita relação com as lideranças comunitárias dos assentamentos. "Muchas partes de la ciudad no tiene vías en bueno estado y el programa se volvió a, el programa que viene todo mundo a pedir una vía. (...) 
Eso programa tiene un peso muy político y es que aquí viene el, venían el concejal, que aquí son los que ganan al voto en frente a la casa de la mamá o el presidente que es líder de los barrios" (ENTREVISTADO 10).

Também no caso de Medellín a orientação territorial das intervenções estaria relacionada com o processo eleitoral, sendo a escolha das áreas prioritárias mediada por interesses políticos de forma a atender aquelas mais propensas a fornecer mais votos (ENTREVISTADO 15). Governo / mandato / processo eleitoral constituiriam uma forte territorialidade (campo de poder, ou melhor, de disputa pelo poder e pela representação política) num processo cujo resultado produz ou subtrai capital politico dos candidatos - o que impacta também na priorização dos assentamentos para intervenção: o lugar politico que ocupam dentre o Sistema, e não somente questões técnicas (risco, precariedade, etc.). Há um processo politico que (re)produz geografias políticas não só pelas espacialidades mas, principalmente, pelas territorialidades.

Dessa forma, é possível concluir que, no caso colombiano, a oferta/provisão de novas unidades e outros grandes projetos tem maior importância do ponto de vista de capital político para os prefeitos (que conseguem vincular seus nomes à sua execução e assim constituir a marca de suas gestões). Por outro lado, 0 mejoramiento é importante hoje para os vereadores das cidades da Colômbia. Estes precisam conseguir vincular seus nomes a ações mais específicas que dialoguem diretamente com seus eleitores, tendo em vista a maior disputa para estes cargos (número maior de candidatos) e a dificuldade de serem reconhecidos pela implementação de grandes políticas e projetos. Para esta função, o mejoramiento goza ainda de outras características que o tornam interessantes para vereadores: em geral é um programa que pode comportar a satisfação de diferentes necessidades (pavimentação, implantação de infraestrutura de saneamento e energia, melhorias habitacionais, etc.), sendo possível atender a diferentes interesses; e, pelo fato de não serem prioritários para os prefeitos, podem atender estes diferentes interesses sem contrariar a agenda política destes, os quais podem utilizar o programa como forma de atender a interesses de vereadores e, assim, lograr a construção de uma base de apoio junto a eles. 
Para encerrar este ponto sobre as conexões entre mejoramiento barrial e sistema político em Bogotá e Medellín, deve-se enfocar também as diferentes relações estabelecidas neste sistema através de lideranças comunitárias. Embora existam diferentes formas de relacionamento, pode-se perceber que estas lideranças ainda fazem em alguns casos o papel de intermediação entre moradores e políticos - principalmente vereadores (ENTREVISTADO 10) - e entre moradores e burocracia - gestores, secretarias, etc. (ENTREVISTADO 05).

\begin{abstract}
Se conforma una Junta de Acción Comunal y esa Junta de Acción Comunal establece los contactos y gestiona para llevar los servicios básicos a los pobladores que están ahí. Entonces ellos hacen vínculos con políticos, la clase política, y esa clase política en particular es muy hábil en aprovechar los periodos electorales para gestionar el asunto de las necesidades que están reclamando esa población. Es como una especie de alianza. El presidente de la Junta de Acción Comunal quiere mantenerse en su lugar o quiere generar lo que necesita el barrio. Entonces se alía con un partido político y le dice - yo le tengo tantos votos en el sector y usted me trae el acueducto. Entonces es una promesa de campaña de un político para llevar ciertos servicios allí. También pasa que la misma institucionalidad dice - listo, yo igual tengo que hacer algo mientras tanto. Y la población organiza gestión ante las empresas públicas de Medellín. -Vea, estamos necesitando no sé qué, los servicios públicos de acueducto, de alcantarillado, entonces las empresas publicas le dicen - yo por allá todavía no puedo intervenir porque el gobierno no me deja, el Plan de Ordenamiento Territorial no me deja subir, yo por mi encantado pero todavía no puedo. Entonces entran en un proceso de gestión desde la misma población de ir a hablar a la secretaria encargada, en el departamento administrativo de planeación, a la Secretaria de Servicios Públicos, a la misma empresa de servicios públicos, buscar las formas de mediar con la norma y llevar esa provisión de servicios públicos hasta allá (ENTREVISTADO 15).
\end{abstract}

As lideranças comunitárias ainda parecem desenvolver, portanto, um papel central no âmbito da negociação das pequenas intervenções de mejoramiento barrial, cumprindo uma função de mediação de interesses entre a população e as instituições. Nas palavras de uma liderança entrevistada (ENTREVISTADO 05), "as lideranças fazem toda a diferença, o barrio só é bom quando há uma boa liderança, que dialoga com todos e conhece todas as demandas". Segundo ele ainda, caberia, por exemplo, às lideranças comunitárias (que inclusive trabalham nestas campanhas) cobrarem destes vereadores a implementação as promessas feitas em períodos eleitorais (ENTREVISTADO 05).

Exercem ainda um papel de coordenação das ações comunitárias, tendo em vista que, em muitos casos, mesmo após a urbanização de diferentes barrios, diversas ações são realizadas pela própria comunidade (ENTREVISTADO 05). A liderança, assim, se encarrega de, muitas vezes, angariar recursos entre os 
moradores, empresários e outras pessoas sensíveis à situação para compra de materiais e coordena a execução de melhorias. Também promovem ações de denúncias junto à mídia, segundo entrevistados (ENTREVISTADO 05; ENTREVISTADO 08), usando os meios de comunicação como meio de pressão sobre o poder público, mais especificamente mídia local e departamental, tendo em vista que os meios de comunicação nacionais já não se interessariam tanto.

Estas lideranças se fortalecem com estes laços de diferentes formas, tendo em vista que ganham poder junto a suas comunidades (reconhecimento, legitimidade de representação, importância da opinião, etc.) e até mesmo se fortalecem economicamente, como em casos relatados em Medellín (ALCALDIA DE MEDELLIN, 1996, p. 68 e 69) em que a liderança solicitava em nome da comunidade - melhorias que não eram reivindicadas e adequadas a todos apenas para seu próprio benefício e outros casos em que até mesmo indevidamente cobrava pelo benefício que seria realizado pelo programa, lucrando em cima do desconhecimento ou falta de informação dos moradores.

A ligação entre lideranças e políticos também não funciona apenas como via de mão única, servindo igualmente ao fortalecimento da própria liderança, que quanto mais demonstra acesso à classe política e às instituições, mais se consolida como referência dentro do assentamento. Na própria visita realizada a Santo Domingo, foi possível perceber como a liderança que nos acompanhava utilizava a visita também para se fortalecer, para mostrar aos moradores que estava trazendo estrangeiros para conhecer e escrever sobre 0 barrio.

Esta relação entre estes atores não se dá única e exclusivamente de maneira informal e motivada por interesses individuais, há também processos públicos de negociação em espaços formais construídos para estas finalidades (orçamento participativo, consejos, etc.), nas quais atuam a comunidade enquanto grupo e negociam às claras com os gestores e políticos. No entanto, mesmo quando a negociação de recursos ocorre em fóruns públicos (como orçamento participativo em Medellín), sua liberação e a implementação de projetos depende da capacidade de negociação política da comunidade, na 
maioria das vezes pela ação individual de uma liderança e em contato com algum político específico (ENTREVISTADO 15).

No Brasil, a histórica conexão entre a intervenção nesses territórios e processos político-eleitorais tem sido apontada por diferentes autores (SANTOS, 1984; SHLUGER, 1984; MARICATO, 2003; ALVITO, 2006; BURGOS, 2006; ZALUAR, 2006; BUENO ET AL, 2009; SANTO AMORE ET $A L, 2014)$. Embora em alguns momentos excepcionais não seja tão forte ou tão evidente tal ligação, como lembra Burgos (2006, p. 27) acerca do fato de que no início do século XX os moradores de favela sequer possuíam direito ao voto (que não era universal) e que na era Vargas sua base de apoio era constituída sobre o trabalhador formal (poucos dentre os favelados); mesmo em momentos de restrição democrática (como no caso da ditadura militar) essa conexão persistia visível nas práticas clientelistas ainda presentes durante o período (BURGOS, 2006, p. 39; ZALUAR, 2006, p. 209).

Em diferentes momentos ou mesmo em diferentes níveis políticos (principalmente locais e regionais) a intervenção pública em favela constituiu uma moeda de troca para períodos eleitorais, servindo de mecanismo de articulação entre a classe política e moradores de favela. "Especialmente a partir dos anos 50, nota-se o estabelecimento de ligações mais consistentes entre a favela e a política, inclusive com o surgimento de lideranças que estabelecem vínculos orgânicos com os partidos” (BURGOS, 2006, p. 29).

Assim, não se pode falar, como alguns autores ainda insistem (KLEIN, 2010), em completa ausência do estado diante das favelas e vice-versa. Melhor seria adotar a perspectiva de Leeds (2006, p. 235) ao defender uma "presença e ausência seletivas do Estado".

Dificilmente podemos falar numa ausência anterior do Estado nas favelas. Ainda que de maneira pontual ou incipiente, desde a década de 1940, o Estado, em todos os seus níveis, esteve presente realizando pequenas obras nas favelas cariocas, tais como uma escadaria, a instalação de bicas d'água e redes de encanamento, entre outras pequenas ações. Mas a cada novo governo ou nova ação, o mito é reatualizado pelo próprio Estado (ou mais especificamente, por quem o ocupa) que apresenta quase sempre que a 'nova ação marca a entrada definitiva do estado nas favelas' (BRUM, 2014, p. 03).

Já então desde antes da metade do século $\mathrm{XX}$, trocava-se votos pela implantação de bicas de água no Rio de Janeiro (SHLUGER, 1984), por 
exemplo, sendo a simples promessa de intervenção, portanto, uma poderosa arma de arrecadação de votos mobilizada por candidatos à época. "A favela elege políticos (ou os faz cair em desgraça)" (ZALUAR \& ALVITO, 2006, p. 21), como demonstrou a eleição para governador do estado em 1965 (BURGOS, 2006, p. 34) e para prefeito da cidade em 1982 (BURGOS, 2006, p. 41).

Nesse contexto, as lideranças comunitárias assumiam um relevante papel, tendo em vista que muitas vezes negociavam as melhorias a serem realizadas e também se tornavam cabos eleitorais dos candidatos no âmbito do assentamento (ZALUAR, 2006, p. 218). "Um dos poucos recursos políticos à disposição das favelas eram as relações clientelistas estabelecidas com os políticos. Os votos eram dados (ou pelo menos prometidos) em troca de pequenos favores concedidos pelos políticos, seja a determinados indivíduos nas favelas, seja à comunidade em geral. A relação entre as favelas e o sistema era simbiótica, cada lado procurando obter do outro algum benefício ou serviço" (LEEDS, 2006, p. 253).

Ainda hoje as associações de moradores em favelas são frequentemente parte dos atores envolvidos nas ações de urbanização (COLOMBAS, 2014; BUENO, 2000, p. 32; PAZ, 2009, p. 86) e assumem papéis importantes em determinados momentos do processo, sendo muitas vezes a mediadora de conflitos entre o poder público municipal e a população (DENALDI, 2012b, p. 267; ALVITO, 2006, p. 186). Isso frequentemente ocorre de modo centralizado pelas lideranças comunitárias que constituem uma espécie de "elite" dentro da favela, para alguns autores (BURGOS, 2006, p. 56), a qual exerceria o papel de porta-voz e de negociadora, concentrando a utilização dos recursos econômicos e políticos da favela (ZALUAR, 2006, p. 211).

Contudo, diante da emergência e aumento de centralidade política de outros atores sociais (igrejas evangélicas ${ }^{12}$, coletivos, grupos ligados à criminalidade,

\footnotetext{
${ }^{12}$ Sobre o crescimento de lideranças ligadas a igrejas evangélicas pentecostais em favelas, conferir o trabalho de Cunha (2009). "a perspectiva teológica e doutrinária dos evangélicos pentecostais, perspectiva essa que compreende o "mundo" como o lugar da guerra; que fala do inimigo; do chamamento ao "exército do Senhor"; que ritualmente lança mão de arroubos emocionais e de um linguajar bélico, se comunica muito com o ethos dos moradores de favelas, dentre eles os "bandidos"” (CUNHA, 2009, p. 150).
} 
etc.), o papel dessas associações e lideranças mais tradicionais tem aparentemente declinado (ENTREVISTADO 30; ENTREVISTADO 27), perdendo tanto poder de representação perante o poder público como legitimidade diante dos moradores. O assunto será enfocado com maior profundida na seção 4.2, no qual abordaremos esse papel vivido hoje pelas lideranças em função do contexto político relacionado à violência urbana e políticas de segurança.

No tocante à mobilização de votos e capital político ${ }^{13}$ em favelas e nas intervenções que nelas se realizam historicamente, essa conexão cresce fortemente a partir da década de 1980, com o processo de redemocratização e com o movimento de autonomia dos municípios no país, fazendo com que se torne ainda mais relevante no plano local.

O quadro se modificou um pouco desde em 1985, com as eleições para prefeito das capitais do país. É que desde então os prefeitos das grandes cidades passaram a encarnar os anseios mais imediatos da população. A maior proximidade com os problemas e a maior capacidade para dar respostas rápidas e adequadas passam a ser consideradas vantagens indiscutíveis em relação ao modelo centralizador de recursos e responsabilidades vigente durante o regime militar. Essa leitura é consagrada pela Constituição de 1988, que dota de autonomia financeira os municípios, ao mesmo tempo em que Ihes atribui uma ampla gama de responsabilidades (BURGOS, 2006, p. 47).

Nesse sentido, são fortalecidas as conexões tanto no âmbito do Poder Executivo (visto adiante) quanto no âmbito do Legislativo municipal.

Primeiramente, no âmbito do legislativo, diversos entrevistados (ENTREVISTADO 30; ENTREVISTADO 26; ENTREVISTADO 18; ENTREVISTADO 09; ENTREVISTADO 19; ENTREVISTADO 01; ENTREVISTADO 28) forneceram reiterados depoimentos sobre a mobilização política de iniciativas de urbanização de favelas (ou ao menos de algumas dimensões dentro delas) por parte de vereadores, desde a década de 1980 até os dias atuais, tanto no Rio quanto em São Paulo. Em sua maioria demonstram a permanência não apenas da defesa de interesses de seus constituintes - 0 que é válido e esperado como forma de obtenção de capital político no jogo

\footnotetext{
${ }^{13}$ Como mobilização de capital político, refere-se à concentração e/ou dispersão do poder ou potencial político representado sob a forma do voto (individual) concentrado (quantitativamente) em determinados candidatos/representantes. Para tanto, são utilizadas diversas estratégias, desde aspectos mais subjetivos (mobilização do imaginário, valores, símbolos, etc.) quanto aspectos mais pragmáticos (distribuição de benefícios, etc.).
} 
eleitoral estabelecido pela democracia representativa brasileira -, mas também manobras para manipulação de políticas promovidas pelo Executivo de forma a favorecer seus nichos eleitorais prioritariamente, a despeito de ações planejadas e universais sobre 0 conjunto dos assentamentos (ENTREVISTADO 19).

Quando o Banco Interamericano entrou com o dinheiro [no Favela-Bairro], ele falou "Temos critérios de seleção". Até então, a gente já tinha feito o primeiro cadastro favela, estávamos com o plano cadastro favela na mão, mas não estava informatizado, nem nada. Com a entrada do Banco Interamericano, a gente começou a, primeiro, montar um sistema informatizado desses dados e criar conceitos e critérios de seleção, e assim fizemos. E fizemos tão bem feitinho que fizeram com que aquela lista fosse um decreto pra que políticos não botassem a mão nas áreas que a gente tinha já decidido com esses critérios que a gente já discutiu. [Para que] não passassem na frente, o vereador tal dizer "Vai para a comunidade tal...". Porque hoje em dia é assim, o vereador tal e a comunidade dele, e como todo mundo precisa tanto, às vezes nem tem como reagir a uma manobra dessas. Mas, se você tem um critério, discute isso com a associação de moradores, discute isso na federação, a gente discutia com eles, a gente levava todos esses assuntos para a federação de moradores (ENTREVISTADO 18).

Vereadores do Rio de Janeiro, portanto, buscavam influenciar as favelas atendidas no âmbito do Favela-Bairro e outros programas de urbanização, tendo sido importante para diminuir essa influência a exigência do BID da construção de uma lista de prioridades baseada em critérios técnicos, de acordo com a gestora pública do programa entrevistada acima. Esta tentativa de influência se estende para além da década de 1990, sendo abordada em pesquisa produzida por D'Ávila Filho (2014), que sistematizou as indicações promovidas por parlamentares no âmbito da Câmara dos Vereadores no início dos anos 2000, demonstrando justamente a sua relevância para alimentação das conexões eleitorais em suas redes políticas. Nos resultados, demonstra que praticamente todos os vereadores fizeram uso das indicações e que, em sua maioria, destinavam-se a itens como melhoria e manutenção de infraestrutura (pavimentação, iluminação pública, etc.), com uma ênfase em Zonas da cidade com piores condições (Zona Norte e Oeste).

As indicações de obras ou serviços que são realizados pelo poder Executivo parecem mais vantajosas em função da rapidez dos resultados e da facilidade de reivindicar o crédito pela autoria da proposição se comparadas aos projetos de lei, por exemplo, que precisam obter o apoio da maioria dos legisladores e correm o risco de serem vetados pelo poder Executivo. (...) Na relação entre o Executivo, o Legislativo e os eleitores, o primeiro precisa do segundo para governar. Por isso, o primeiro precisa obter o apoio do segundo ou ao menos de sua maioria. Uma possibilidade aqui apresentada é que, na política municipal, uma das formas de conquistar esse apoio é atender às indicações dos vereadores. Por outro lado, as propostas dos vereadores precisam do poder 
Executivo para sua efetivação, sua execução. Para além das negociações que esse arranjo engendra (a partir muito mais do jogo político do que das atribuições normativas que constituem os dois poderes), o cenário desenhado possibilita a construção de uma rede eleitoral. Rede que envolve o terceiro ator, o eleitorado. A interferência do vereador na consecução de suas demandas poderia denotar não só a preocupação do representante para com as "necessidades" de seus representados como, também, sua capacidade de obter ação efetiva do Executivo, ou seja, sua eficácia. Em suma, sugerimos um modelo de conexão eleitoral local formado por uma tríade de atores (prefeito, vereadores e eleitorado) que, em um contexto de competição político-eleitoral, realizam trocas políticas assimétricas de dois níveis. As indicações sugerem um esforço do representante em atender às expectativas daqueles que o elegeram ou podem vir a eleger. Com as indicações, o vereador cumpre o papel que lhe foi designado pelos que o elegeram, que é o de representar e defender os interesses destes perante os demais vereadores e o poder Executivo. Dessa forma, o eleito cumpre a promessa feita durante a campanha eleitoral, assinalando para os que 0 elegeram que não os abandonou. Para os que não o elegeram, assinala que se preocupa com a comunidade onde vivem, independentemente da sua opção eleitoral (D'AVILA FILHO, 2014).

$\mathrm{Na}$ pesquisa, foram ouvidos depoimentos do quanto ainda hoje estas indicações realizadas por vereadores e outras iniciativas de intervenções em favelas são vinculadas à reprodução de mandatos parlamentares como forma de angariar apoio político. Destaca-se aqui testemunho fornecido por pesquisador inserido no cotidiano das favelas da cidade.

Eu vou pegar um exemplo que teve na última eleição, aqui a gente ainda tem aqueles políticos, parte da política clientelista, ainda temos (...) Nos períodos eleitorais, o discurso recorrente de comunidade carente, de "Precisamos olhar por aquelas pessoas" e tal, a quantidade de gente que vem às favelas pra poder angariar votos, isso permanece a mesma lógica, isso é muito comum. Então você tem políticos por exemplo com aquela lógica, clientelismo mesmo, de patrocinar os eventos, de realizar as atividades. Tem algumas lideranças cooptadas pela política que ainda se candidatam, isso ainda existe. (...) É por isso que ainda tem a faixa "queremos agradecer o vereador tal pela pavimentação da rua tal". Isso ainda é presente, "pelo baile não sei o que", "pela festa não sei o que lá", isso ainda está presente nas favelas (ENTREVISTADO 30).

Para o caso de São Paulo, essa possibilidade de implementação de indicações parlamentares de melhorias em favelas tem sido medida eficiente para a constituição, pelo Executivo, de base de apoio parlamentar necessária ao andamento da gestão municipal. Analisando o caso da cidade, Meneguello (2016, p. 285) demonstra como progressivamente, desde a redemocratização, a composição da Câmara de Vereadores da cidade vem se mostrando mais fragmentada. De nove bancadas partidárias provenientes das eleições municipais de 1988, passa-se para 16 bancadas em 2012, na qual os partidos que conseguem obter as maiores delas (PT e PSDB) chegam no máximo a ocupar pouco mais de $20 \%$ das cadeiras. Com isso, tanto a disputa entre os candidatos a vereador se torna mais acirrada (necessitando de constante 
mobilização de capital político através do atendimento a interesses de suas bases), quanto o Executivo se vê na obrigação de atender a um maior número de interesses para compor a maioria na Câmara. Como lembra Meneguello (2016), "as implicações de uma casa legislativa fragmentada sobre a governabilidade são conhecidas. A lógica da negociação e aliança com as forças políticas parlamentares é parte do roteiro do presidencialismo de coalizão em todos os níveis" (MENEGUELLO, 2016, p. 285).

Os programas de urbanização mostram-se, diante desse cenário, uma fonte estratégica para essas negociações. Facilita 0 atendimento a demandas pontuais dos parlamentares sem, muitas vezes, necessariamente comprometer políticas e projetos maiores, como demonstra o depoimento de coordenadora de programa de urbanização de favelas a seguir.

A gente construiu um sistema de informações, o HABISP, porque a gente lá publicou online as prioridades de atuação. Então quando um vereador vinha com aquele ar "eu quero que urbanize a minha favela", a gente falava "Muito bem, vereador, vamos então ver aqui a prioridade da sua favela... 528, vai demorar um pouquinho, ok?". Ele não tinha como dizer "Eu vou falar com o prefeito pra furar a fila e não sei o que", não tinha. Agora, com o Legislativo você também tem que saber lidar, porque o Legislativo libera verbas, por isso que o nosso orçamento era alto. Você tem que explicar "Olha, não é bem assim, tem programas, logo vai entrar". Eu acho que a gente tem uma relação legal com os vereadores, tanto é que eu tenho uma bancada lá na Câmara. Quando eu quero aprovar um projeto, todos os partidos costumam me apoiar, porque é isso, você tem que saber lidar. A gestão pública, ela é pública, ela não é de partidos, então você tem que atender todo mundo, eles tem também que dizer não. Agora, se o cara quer liberar uma emenda dele pra fazer uma rua, uma escada, não vejo problema você ajudar, fazer projetos, essas coisas. Isso ocorria muito, mas o grosso da grana do nosso orçamento que a gente conseguiu, ia para as prioridades. (...) Tem que saber mediar, eu acho, as questões, mas quando a gente pôs no HABISP a lista era por conta disso, porque era o dia inteiro, "Ai, porque o meu bairro, não sei o que, pápá-pá" (ENTREVISTADO 09).

É interessante perceber que, enquanto não causasse um grande obste ao programa que vinha sendo implementado pela gestão, pequenas obras eram negociadas como forma também de costurar apoios na Câmara de Vereadores, sem os quais se torna mais difícil, por outro lado, a aprovação de projetos e orçamentos que dependem do Legislativo. Outro depoimento interessante 
sobre São Paulo se relaciona a uma experiência recente no âmbito do Renova ${ }^{14}$.

Por exemplo, lá [área em que o entrevistado atua no âmbito da contratação pelo Renova] está com uma questão: uma área contígua ao loteamento, que é uma área bastante precária, com ocupação recente. Aí fomos discutir [com a PMSP] se essa área não poderia ser alvo da intervenção. E aí por uma questão burocrática - que está fora do limite do perímetro - não dava pra fazer essa contratação. Depois, de repente ligam e falam "Vamos fazer esse projeto, sim, porque tem um vereador querendo asfaltar aquilo com o asfalto mais vagabundo, sem projeto". Quer dizer, vai fazer uma obra de consolidação daquele assentamento. Aí agora nessa semana recuou de novo, falou "Vai ser feito com a verba lá da subprefeitura, não sei o que, segundo a indicação do vereador" [e não mais no âmbito do Renova] (ENTREVISTADO 28).

Reitera-se que se trata do jogo político como delimitado pelo sistema de democracia representativa atual, mas é importante demonstrar como essas mediações políticas efetivadas por parlamentares trabalham mais na lógica do atendimento à clientela do que da urbanização como um processo de efetivação de direitos. Trata-se do atendimento à solução de uma demanda imediata (mesmo que legítima) em troca de capital político em detrimento à um processo de efetivação de direitos, o que implicaria em intervenções mais duradouras. "Essas formas clientelistas são diretamente responsáveis pela fragmentação das ações de programas e projetos, além de estabelecerem uma percepção ofuscada do direito social por indivíduos e grupos sociais, particularmente os residentes em espaços populares" (BARBOSA, 2012, p. 120)

Para além da negociação propiciada com os membros do Legislativo descrita acima, a urbanização de favelas também é uma fonte estratégica de mobilização de capital político por parte do Executivo. Na década de 1990, como visto anteriormente, a ascensão das iniciativas de urbanização se dá atrelada ao movimento de fortalecimento do papel dos governos locais, principalmente no tocante à política habitacional. Se os movimentos de moradia tornam-se atores políticos importantes na demanda de políticas que contemplassem setores populares (D'ALESSANDRO, 1999), continuavam a ser reiterados os padrões de utilização da pobreza e da negociação de melhorias como fontes de capital político, mobilizadas em períodos eleitorais.

\footnotetext{
${ }^{14}$ Nome como foi rebatizado o programa de urbanização de favelas em São Paulo a partir de 2011.
} 
Então essas questões eleitoreiras, elas influenciam diretamente, diretamente. A gente a cada dois anos para tudo só pra eleger alguém. $E$ eu te digo que eu, como funcionária pública republicana, independente do que eu acredito, eu tenho que trabalhar, afinal eu sou paga pelo dinheiro público. Eu tenho feito o meu trabalho, já ajudou a eleger de A a Z, não tem jeito. Então a ação pública, ela é também uma ação partidária forte, ela elege ou deselege, a urbanização de favelas (ENTREVISTADO 19).

Não é à toa, portanto, que as iniciativas de urbanização tornam-se então parte estratégica da intervenção dos governos do Rio e São Paulo e parte do jogo político-eleitoral da década. De acordo com análise de Aldé e Dias (1996), tanto o Favela-Bairro quanto o Cingapura foram instrumentos valiosíssimos, por exemplo, na campanha eleitoral de ambas no pleito de 1996.

Ainda sem a possibilidade de reeleição para prefeitos (que apenas ocorrerá a partir de 2000), os então prefeitos César Maia (Rio de Janeiro) e Paulo Maluf (São Paulo) tentam eleger como seus sucessores Luiz Paulo Conde e Celso Pitta, respectivamente, utilizando-se para isso campanhas que enfatizavam a ligação do candidato com a administração em curso (79\% dos anúncios eleitorais no caso de Conde, 77\% no de Pitta) (ALDÉ \& DIAS, 1996, p. 01-08). A estratégia utilizada descrevia imagens de cidades transformadas pela intervenção redentora dos então prefeitos e sugeriam o risco que seria a mudança de gestão. Conferem destaque, para tanto, ao perigo que corriam políticas sociais (principais temas mobilizados naquele pleito - presentes em $21 \%$ dos comerciais de Conde e $18 \%$ dos de Pitta) em curso, como o FavelaBairro e o Cingapura, sempre vinculando a imagem dos candidatos aos projetos em andamento na gestão de seus antecessores (ALDÉ \& DIAS, 1996, p. 01-08).

Nesse sentido, as propagandas de Pitta reafirmam seu vínculo com a administração Maluf (na qual era secretário de finanças) e descrevem a cidade como perfeitamente administrada, tendo sido regenerada pelos projetos de Maluf em oposição ao caos que teria dominado no período de Erundina, exprefeita e candidata do PT ao pleito. A propaganda eleitoral de Pitta enfocam, em diversas ocasiões, o suposto estado calamitoso da população favelada antes do Cingapura, e sua felicidade depois (ALDÉ \& DIAS, 1996, p. 08-11).

Se uma boa parte da vitória do PPB (hoje PP) naquela eleição se deveu ao desgaste da imagem do PT e ao fato de ter capturado boa parte do eleitorado 
do PMDB (então em declínio no estado) (MENEGUELLO, 2016, p. 284), o sucesso também esteve vinculado ao programa Cingapura e a imagética construída com o programa junto à população, de acordo com entrevistados (ENTREVISTADO 16; ENTREVISTADO 19). Resgatando os posicionamentos dos candidatos ao longo da disputa, Aldé e Dias (1996) e Figueiredo (1997) inclusive apontam que uma das debilidades da campanha de Erundina foi justamente não conseguir construir um real contraponto ao programa implementado por Maluf. Em alguns momentos tecia críticas ao Cingapura e dizia que resgataria algumas das ações implementadas em sua gestão, mas logo em seguida tranquilizava os eleitores e enfatizava que daria continuidade ao programa. A ambiguidade da postura da candidata deixava claro o sucesso e o apelo político que o programa gozou naquele momento.

Na mesma eleição, o Favela-Bairro também foi estrategicamente utilizado pela campanha de Conde à eleição (ENTREVISTADO 16). Tendo sido secretário de urbanismo na gestão de César Maia, o candidato ainda era relativamente desconhecido do eleitorado, tendo sido uma constante em sua campanha buscar conectá-lo ao então prefeito - $79 \%$ dos comerciais veiculados associavam a imagem de Conde à administração de Cesar Maia. Da mesma maneira que em São Paulo, a estratégia de persuasão utilizava-se da ameaça que representaria a interrupção desse projeto administrativo de sucesso.

[Confere] ao prefeito César Maia a condição de "marca registrada" de uma administração bem-sucedida, associando 0 político e 0 administrador a um modelo de cidade. (...) Imagens de fundo são utilizadas para mostrar as realizações da "marca César Maia" e vincular o candidato à construção dos diferentes projetos, usando inclusive o logotipo da prefeitura. 0 formato enfatiza uma "colagem" entre César (que é Conde) e Conde (que é César), tornando explícita esta ligação na própria letra do jingle. (...) Não há preocupação com o background pessoal ou familiar, nem com envolvimentos políticos anteriores. A pessoa do candidato se confunde com as suas realizações, por isto atributos pessoais como "competência", "inteligência" e "paixão pelo Rio" vêm associados aos diferentes projetos da prefeitura. Três comercias são bom exemplo da associação entre o candidato e sua atuação na prefeitura. São exibidas imagens dos projetos Rio Cidade, Favela-Bairro e Linha Amarela, enquanto Cesar Maia faz a ponte entre os projetos e Conde, dizendo (...) "Só mesmo um homem apaixonado pelo Rio, como o Conde, poderia ter criado o Favela-Bairro..." (ALDÉ \& DIAS, 1996, p. 11-14).

Os programas de urbanização de favelas forneceram, assim, naquela eleição de 1996 importante capital político para eleição de sucessores nas duas principais cidades do país. São componentes importantes da constituição de imagens de gestões administrativas bem sucedidas, modernas e com apelo 
popular. A ameaça à sua continuidade é, inclusive, mobilizada contra os outros candidatos, os quais são obrigados a dialogar com o tema. Além da postura de Erundina já mencionada, Sérgio Cabral (principal adversário de Conde na disputa) também propunha a continuação do Favela-Bairro. Tendo em vista a visibilidade nacional que o programa adquiriu, Romeu Tuma, também candidato em São Paulo, propunha a importação do Favela-Bairro para a cidade, o qual havia sido implantado com sucesso pelo seu correligionário carioca (REIS, 2003).

Obviamente vários outros fatores também influenciaram o resultado, mas tratase de exemplos em que claramente se pode observar o poder de intervenções do gênero em gerar dividendos positivos na disputa pelos cargos no executivo. Como aponta entrevistada que fez parte de diferentes gestões municipais em São Paulo (ENTREVISTADO 19), a urbanização de favelas constitui, sob determinadas circunstâncias, uma importante vitrine eleitoral, tendo em vista que consolida moradores em residências que levaram anos para construir. "Numa urbanização bem feita, leva asfalto, leva esgoto para a casa de alguém, não tem preço uma coisa dessas (...) as pessoas falam, 99\% das vezes que você vai em uma comunidade, eles falavam como construíram essas casas, como era antes e como eles estão agora". Caberia ao gestor, no período eleitoral, "lembrá-las" dos benefícios promovidos pelas intervenções, sendo uma ferramenta útil se bem trabalhada pelos candidatos, conforme aponta outra entrevistada envolvida com coordenação de programas de urbanização (ENTREVISTADO 09).

Esse efeito pode ser verificado nos primeiros 08 anos de gestão municipal no Rio de Janeiro (2001 a 2008), conduzidos novamente por César Maia, depois de conseguir vencer em 2000, com uma margem estreita de votos, o candidato à reeleição Luiz Paulo Conde, seu apadrinhado na corrida pela sucessão na prefeitura nas eleições de 1996. Neste pleito, o comportamento do eleitor no Rio de Janeiro seguiu a polarização que já se construía entre os valores de ordem, eficiência e justiça social, sendo o Favela-Bairro uma menção constante entre todos os candidatos na disputa eleitoral (SILVEIRA \& CHAIA, 2002, p. $70)$. 
No caso destes dois principais candidatos (Maia e Conde), a intervenção em favelas foi ainda mais fortemente utilizada e, inclusive, disputada. Conde se utilizava da alta popularidade construída a partir das transformações que haviam sido promovidas nas favelas da cidade e as utilizava como imagens nos materiais de campanha, fixando a imagem da população feliz com a melhoria da cidade como um todo. César Maia, que não podia desqualificar a gestão de Conde pelo fato de ter sido seu afilhado político, buscava reafirmar a paternidade do Favela-Bairro, demonstrando ainda que poderia fazer melhor do que Conde e avançar mais nas transformações (SILVEIRA \& CHAIA, 2002, p. 72). Procurava ainda atrelar sua imagem à população favelada, utilizando diversas cenas em que subia os morros da cidade e dialogava carinhosamente com moradores.

Mesmo os demais candidatos, atrelando-se à defesa da justiça social, também fizeram uso do programa para demonstrar os limites da atuação da gestão de Conde, retratando favelas ainda não atendidas pelo Favela-Bairro ou nas quais as obras realizadas já se encontravam deterioradas ou que haviam sido completadas apenas no limite com o "asfalto". Conde rebatia as críticas à falta de investimento em políticas sociais justamente apresentando os resultados do programa, o "Favela-Bairro aparece como um verdadeiro escudo" (SILVEIRA \& CHAIA, 2002, p. 74).

Em 2004, o então prefeito César Maia não encontrou dificuldades em se reeleger em primeiro turno em função da boa avaliação de que seu mandato dispunha (ABRUCIO ET AL, 2013, p. 196), derrotando facilmente Marcelo Crivella e Luiz Paulo Conde, segundo e terceiro colocados respectivamente (SANTOS \& TRAVAGIN, 2015). Trata-se de um período relevante para a intervenção em favelas no Rio de Janeiro, tendo em vista que a sequência de quatro gestões entre 1993 e 2008 (César Maia, Conde e depois novamente Maia por mais duas gestões) propiciou a continuidade do programa FavelaBairro, tornando-se um dos programas do gênero com maior sobrevida e visibilidade internacionalmente. Encerra seu ciclo apenas em $2010 \mathrm{com}$ a criação do Morar Carioca, pensado como uma forma de aprimoramento do Favela-Bairro (CARDOSO ET AL, 2018). 
O caso de São Paulo, no entanto, apresenta flutuações em relação à mobilização política da agenda de urbanização de favelas nesse período. Nas eleições de 2000, Maluf tentou resgatar a marca do Cingapura na campanha a prefeito (utilizando imagens do programa em suas peças publicitárias), mas o dano causado pela gestão desastrosa de Pitta era demasiadamente forte, de modo que a estratégia não surtiu efeito (REIS, 2003). Marta Suplicy, por sua vez, apesar de contar em peso com adesão de movimentos sociais à sua campanha (ENTREVISTADO 14), não pode utilizar o tema da urbanização de favelas e as iniciativas levadas a cabo pelo PT na gestão de Erundina pelo fato de que esta também era candidata à prefeitura, mas agora pelo PSB, e usava da sua experiência à frente da gestão como argumento de persuasão (REIS, 2003).

Com a vitória de Marta Suplicy no pleito, são estabelecidos novos rumos para a política relacionada a favelas em São Paulo. Buscou-se resgatar vários elementos da experiência de urbanização de favelas (conforme compromisso assumido em seu programa de governo) sob a ideia de integrá-las no âmbito do programa Bairro Legal (SAMORA, 2009), com os seguintes subprogramas: i) urbanização de favelas; ii) provisão de HIS; iii) regularização fundiária; e iv) construção de equipamentos públicos (MARQUES, PULHEZ \& PAGIN, 2018, p. 156).

Esbarrando supostamente em restrições orçamentárias (ENTREVISTADO 14; SAMORA, 2009, p. 87), a atuação da gestão de Marta no tocante à urbanização teria sido menos expressiva do que o esperado, segundo diferentes entrevistados (ENTREVISTADO 01; ENTREVISTADO 14; ENTREVISTADO 19). Embora a questão orçamentária evidentemente possa ser um óbice (desde que devidamente enfocada, como será feito na Conclusão); para alguns entrevistados que fizeram parte da gestão de Marta tratava-se de uma baixa priorização pelo próprio perfil da prefeita.

Na época, a Malu [responsável pela coordenação da urbanização de favelas na gestão] viajou pro Rio, foi conhecer de perto o Favela-Bairro, como ele se estruturava internamente na prefeitura do Rio de Janeiro, e era uma estrutura muito maior. O Favela-Bairro sempre foi um programa estratégico pra cidade, coisa que nenhum programa de urbanização de favela em São Paulo conseguiu, a meu ver. Ter uma visão estratégica pro programa de urbanização era uma luta meio inglória, setorial da galera da habitação, mas se a gente for olhar do ponto 
de vista de recursos, recursos tanto financeiros como institucionais, quanto a prefeitura está apostando nisso aqui, a gente vê que era muito pouco. 0 Paulo Teixeira tinha essa visão, mas política é disputa. A própria Marta Suplicy não tinha muito essa sensibilidade, então na gestão da Marta isso não era tão central como era pra Luíza Erundina, porque pra Luíza Erundina, ela era uma assistente social que tinha trabalhado nos movimentos de moradia, então ela conhecia muito bem o problema. (...) Ela [Marta] tinha outra visão de cidade, de prioridade, enfim (ENTREVISTADO 14).

É preciso apontar, contudo, que há publicações institucionais da gestão (PREFEITURA MUNICIPAL DE SÃO PAULO, 2004) e autores (MARQUES, PULHEZ \& PAGIN, 2018) que apontariam uma expressiva ação de urbanização de favelas, chegando a beneficiar até 153.000 famílias ${ }^{15}$. Os números apresentados, no entanto, não são claros no sentido de elucidar qual subprograma (elencados acima) de fato beneficiou quantas famílias.

Por outro lado, a unanimidade dos entrevistados, mesmo aqueles que haviam participado da gestão de Marta, afirmou que pouco de urbanização de favelas foi promovido de fato neste período. Ainda, há literatura que afirma que o "programa de urbanização foi denominado Bairro Legal, mas não chegou nem mesmo a iniciar uma única obra até o final do último ano de governo" (MARQUES \& SARAIVA, 2005, p. 288). O que se destaca nas entrevistas foi principalmente o atendimento no âmbito da regularização fundiária, tendo em vista inclusive o perfil do secretário, cuja profissão é advogado e historicamente esteve ligado aos movimentos de moradia.

\begin{abstract}
A Marta, ela só atendeu a questão política, ela foi menos tecnicista. Nesse caso, ela foi mais clientelista. (...) [0 secretário], então, na regularização fundiária, que ele levou. Isso é dele, ele que institui a regularização fundiária, mas a escolha de áreas se deu também por critérios políticos e não viários. Ele colocou na lista de regularização áreas de risco horrendas, que não cabia fazer regularização fundiária, mas eram nichos eleitorais. E aí, eu posso dizer também, porque eu quase me dediquei de corpo e alma naquela época. Era tipo, a eleição foi em 2004, que ele se elegeu deputado, e aí em novembro [de 2003] a gente tinha que entregar 43 mil títulos até abril [de 2004]. Acabou, tem que fazer. Tem que fazer, porque ele precisava desses eventos pra poder participar desses eventos antes de se desincompatibilizar. Aí a gente fez praticamente sem critério, mas entregamos 43 mil títulos. Eu trabalhei de sábado e domingo, feriado, noite e dia, mas a gente entregou os 43 mil títulos (ENTREVISTADO 19).
\end{abstract}

Ao longo da gestão de Marta, se a intervenção física não foi significativa, buscou-se estruturar o setor e planejar as ações necessárias diante do

\footnotetext{
${ }^{15}$ Não apenas para o caso de São Paulo, mas para todas as cidades enfocadas nessa tese, tem-se buscado evitar a utilização de números para qualificar a atuação do programa, como já mencionado na Introdução.
} 
contexto urbanístico das favelas no município, construindo diretrizes e instrumental necessários para intervenção (ENTREVISTADO 01; SAMORA, 2009). No final de seu mandato, já contando com várias dessas ferramentas construídas e diante da possibilidade de alavancar financiamentos do governo federal (tendo em vista a entrada de Lula na presidência em 2003), a decisão do secretário de investir o recurso existente na contratação de projetos de urbanização e na tramitação de processos licitatórios (MARQUES \& SARAIVA, 2005) se mostrou acertada. Ironicamente, a decisão mostrou-se eficaz apenas a tempo da gestão do adversário político de Marta $^{16}$, José Serra, que obtém a vitória nas eleições de 2004 e assume em 2005 já com toda uma gama de projetos realizados e em licitação (ENTREVISTADO 14).

Antes de passar à análise da gestão de Serra/Kassab, é interessante notar o uso (ou a quase ausência) do tema da urbanização nas eleições de 2004. De acordo com a sistematização feita por Veiga (2007), os principais candidatos no pleito - Marta e Serra - praticamente não tocaram na questão habitacional. Enquanto Marta procurava enfatizar aspectos positivos de sua gestão em relação a políticas de mobilidade e de educação (VEIGA ET AL, 2007, p. 63); José Serra foca principalmente no tema da saúde, considerada problemática pelo eleitorado e na qual possuía experiência como ministro no período da presidência de Fernando Henrique Cardoso. Dentre os principais temas em comerciais e pronunciamentos, apenas Serra em algumas ocasiões citou a questão habitacional, mas com um foco maior em propostas de provisão habitacional a ser realizada em parcerias entre COHAB (municipal) e CDHU (estadual), como forma de demonstrar os ganhos que um prefeito do mesmo partido do governo estadual poderiam ter no setor (VEIGA ET AL, 2007).

Apesar da baixa centralidade conferida no período eleitoral, a nova gestão começando com José Serra em 2005 e continuando com Gilberto Kassab de 2006 a 2012 - foi caracterizada por uma ação expressiva (ENTREVISTADO

\footnotetext{
${ }^{16}$ Apesar de já contar com o apoio do grupo político no comando do Governo Federal, tendo Lula como presidente à época, Marta não consegue se reeleger em função do alto desgaste sofrido ao longo do mandato frente às camadas médias. O discurso de que, sendo do mesmo partido que o governo federal, conseguiria obter mais recursos (dentre eles para urbanização) não foi suficiente para garantir a vitória (ABRÚCIO ET AL, 2013, p. 195).
} 
14; ENTREVISTADO 19; ENTREVISTADO 09). Além dos projetos já licitados e da estrutura e recursos institucionais entregues prontos pela gestão anterior, o novo governo se beneficiou dos recursos liberados progressivamente pelo governo federal para obras em favelas (MARQUES, PULHEZ \& PAGIN, 2018, p. 156), principalmente a partir do lançamento do Programa de Aceleração do Crescimento.

Neste ponto, cumpre fazer um parêntese na trajetória de mobilização das experiências locais de urbanização de favelas em São Paulo e Rio de Janeiro como forma de construção de capital político para abordar o que acontecia em âmbito nacional, com grandes impactos no âmbito local das duas cidades. A partir de 2003, com a eleição de Luís Inácio Lula da Silva, o governo federal passa a ser comandado pela primeira vez pelo Partido dos Trabalhadores.

Com uma trajetória conectada a movimentos sociais urbanos e de moradia (ABRUCIO \& COUTO, 1996), a gestão do PT implementa mudanças na postura e na presença da União no tocante a políticas do setor, incluindo urbanização de favelas. Diferentemente do que foi relatado no capítulo anterior para a década de 1990 (na qual houve apenas a iniciativa ainda tímida do HBB), o governo federal retoma a presença na definição e financiamento de políticas, com uma clara estratégia de concertação de interesses, presente desde a concepção do Projeto Moradia, um dos fundamentos do programa de Lula à corrida presidencial de 2002 (KLINTOWITZ, 2015).

Dessa forma, o novo governo passa a construir uma agenda no campo habitacional que coordenasse interesses de uma tríplice aliança "Estado setor empresarial - movimentos sociais", com uma ênfase na proposta de "redução do déficit habitacional por meio da agenda de fomento do setor da construção civil, que geraria crescimento econômico e criação de novos empregos" (KLINTOWITZ, 2015, p. 191). Embora trouxesse novidades para a equação nacional a comandar a política habitacional a nível federal, havia também muitas permanências.

Dentre as novidades, a criação do Ministério das Cidades e da Secretaria Nacional de Habitação, em geral, e especificamente a constituição institucional do tema (PATRICIO ET AL, 2018, p. 05). Lançado em 2004, documento com a 
Política Nacional de Habitação dispunha como um dos componentes principais "Integração Urbana de Assentamentos Precários, a urbanização, a regularização fundiária e a inserção de assentamentos precários, a provisão da habitação e a integração da política de habitação à política de desenvolvimento urbano" (MINISTÉRIO DAS CIDADES, 2006). Posteriormente, em 2005, é aprovado o Sistema Nacional de Habitação de Interesse Social (SNHIS) e o Fundo Nacional de Habitação de Interesse Social (FNHIS), os quais disponibilizariam recursos para estados e municípios investirem, dentre outras modalidades, em ações de urbanização de favelas (art. 11, inciso III, Lei oㅡ 11.124/2005). Conquanto essas novidades fossem estratégicas para a manutenção da base de apoio popular do governo e propiciassem um fluxo regular de recursos aos governos locais para urbanização (CARDOSO \& DENALDI, 2018, p. 24), vivia-se ainda um período de manutenção de uma política econômica gestada no governo de Fernando Henrique Cardoso, em que os investimentos em políticas sociais ainda sofriam com ajuste fiscal e uma política de superávit primário (PAULANI, 2008).

Na verdade assim, os anos de 2003 - 2004, foi, no ministério em geral, de organização e elaboração das politicas setoriais. Você teve nesses anos, no caso da Secretaria de Habitação, toda a discussão da nova lei do Fundo, do FNHIS, do SNHIS, como um passo inicial para a construção da política da habitação nos 3 ministros de governo, foi uma coisa bastante interessante. (...) Foi muito uma coisa de construir as politicas e os novos marcos legais com os estudos que a gente podia fazer naquele momento. Então eu acho que esses dois anos foram anos que foram praticamente de estruturação dessas politicas. Foi um período em que quase nos matam com o remédio. Quer dizer, a história de organizar do ponto do macroeconômico o país, praticamente deixou sem investimento essas áreas (ENTREVISTADO 07).

O segundo mandato de Lula, contando com a melhoria do ambiente econômico e com a troca na condução do Ministério da Fazenda (CARDOSO \& DENALDI, 2018, p. 24), irá introduzir algumas modificações significativas nesse cenário. Não são alteradas as condições estruturais de inserção do país na economia mundial e algumas de suas principais diretrizes (PAULANI, 2012), mas são observadas modificações principalmente no tocante a investimentos promovidos pelo Estado com potencial de fomentar a economia nacional.

A criação do PAC em 2007 é um dos exemplos mais claros dessa mudança e, juntamente com o programa Minha Casa, Minha Vida (criado em 2009), impactarão as ações de urbanização de favelas em inúmeras cidades do país 
(CARDOSO \& DENALDI, 2018). Conforme Klintowitz (2015) argumenta, o esquema constituído atendia simultaneamente o segmento empresarial (da construção civil/imobiliário, importante para a economia nacional e para a sustentação do governo) e aos movimentos de moradia, uma das bases políticas do mandato.

O PAC se configura como um conjunto de ações, programas, e fontes de recursos oriundos de e geridos por diferentes órgãos do governo. Nesse sentido, pode ser visto como um "guarda-chuva", ou uma "marca", onde cabe uma série de modalidades ou subprogramas. A título de exemplo o PMCMV, quando anunciado também recebe a chancela de PAC. Para além do significado de "marca" na narrativa do discurso político, receber a chancela de PAC trouxe implicações objetivas: significa que ele será incluído em um processo de monitoramento intensivo, coordenado pela Casa Civil e por vários outros colegiados de acompanhamento; de outro lado, que ele estará isento de quaisquer contingenciamentos orçamentários. Além disso, mais recentemente, os projetos do PAC foram beneficiados com o Regime Diferenciado de Contratações de Obras Públicas (RDC), que reduz exigências da Lei de Licitação Pública (Lei no 8.688) (PATRICIO ET AL, 2018, p. 07).

Como Klintowitz (2015) demonstra em sua tese, vários agentes (econômicos, empresariais e do setor público) concorreram para essa conformação do PAC (do pacote completo do programa), sendo grande parte dele baseado em estudos e documentos com contribuições desses setores ao núcleo político central do governo federal, especialmente através do Conselho de Desenvolvimento Econômico e Social (KLINTOWITZ, 2015, p. 208). Dentre os itens sugeridos para incidência estatal, constavam saneamento e habitação, com apelo aos setores da construção civil e empreiteiras, portanto.

No entanto, é preciso compreender melhor o que levou à inclusão de ações de urbanização de favelas nesse pacote, tendo em vista que 0 atendimento habitacional poderia se dar sob outras formas - exclusivamente provisão, etc.. O que leva então a essa inflexão positiva no tocante à atuação federal em favelas?

Um dos fatores apontados por Klintowitz (2015) e também por entrevistados que participaram da gestão federal (ENTREVISTADO 01; ENTREVISTADO 16; ENTREVISTADO 07) seria o próprio empenho do então presidente Lula em incluir a urbanização de favelas como investimento prioritário no âmbito do aquecimento da economia nacional. A entrevista a seguir, com uma das principais responsáveis pela política habitacional federal no período, reforça essa análise. 
Começando essas discussões, a gente começa a fazer o estudo das regiões metropolitanas, dos assentamentos precários das regiões metropolitanas, era um Lula muito... tem uma proximidade, é uma coisa pra ele muito forte o tema das palafitas, das favelas como um desafio importante... Isso era um tema, até pela história pessoal dele. Então pra ele o negócio das palafitas ele constantemente perguntava "quantas palafitas tem? como é que a gente acaba com isso?". Era uma discussão meio difícil porque a palafita nunca é um processo sozinho, nunca existe só a palafita, ela sempre está inserida numa favela mais ampla, com outros problemas, era sempre uma discussão. "Eu quero que você me diga quantas favelas, quantas palafitas tem", então toda essa discussão, então toda essa demanda acaba se materializando em algumas coisas importantes que você tem até hoje - a alteração da MUNIC, da pesquisa do perfil municipal, a gente vai e começa a trabalhar isso com o IBGE; o estudo sobre a mensuração das favelas do CEM/CEBRAP, que foi um insumo super importante pro Censo 2010 (ENTREVISTADO 07).

O empenho de Lula podia ser visto também na condução de negociações nacionais e internacionais sobre mecanismos econômicos que dificultavam essa transformação, sob a tese de que os investimentos em saneamento em favela (considerado investimento estratégico para o crescimento econômico) não deveriam contar como superávit (ENTREVISTADO 07). Outra entrevistada confirma e relata esse empenho pessoal de negociação de Lula.

O Lula tomou pessoalmente, internamente com os nossos economistas do governo, porque eles nem sabiam o que era urbanização de favela, nem sabiam o que era favela. Então ele abriu isso, falou "Como não pode? Como não é investimento? Deixa eu explicar pra vocês". E fez essa troca [de gasto para investimento], e foi positiva, então ampliou essa conscientização dentro do governo, principalmente com os economistas. (...) Ele fez esse trabalho interno, dentro do governo. "Não, então vamos negociar com o FMl", e topou essa negociação, e o FMI aceitou, Isso abre, aí abre para PAC, que foi um investimento incrivel historicamente no país (ENTREVISTADO 01).

Klintowitz (2015, p. 212) aponta a importância da inserção dos investimentos em habitação no Projeto Piloto de Investimento (PPI) que permitia ao Executivo "abater do cálculo do superávit primário os investimentos de infraestrutura considerados prioritários", transformando definitivamente o que era considerado gasto agora em investimento. Foi importante também a atuação interna do Presidente na aprovação de alterações em normativas nacionais que dificultavam a realização de investimentos em favelas (ENTREVISTADO 01), como a aprovação da Instrução Normativa 01 de 2007 da Secretaria do Tesouro Nacional, que passou a permitir o uso de recursos do OGU em imóveis ocupados ou com questões pendentes do ponto de vista da propriedade (ROSSBACH \& MAGALHÃES, 2016, p. 95). Vencidas essas questões, todo esse empenho refletiu-se também na definição da urbanização como componente do PAC. 
Aí quando começa a ser a discussão do PAC, a gente apresenta esses estudos do problema das favelas nas regiões metropolitanas e acaba as favelas sendo, acaba a urbanização de favelas sendo o eixo escolhido pra entrar no eixo de infraestrutura urbana como um investimento prioritário. Então o eixo de infraestrutura urbana no PAC, eu estou resumindo, porque isso foi mais de um ano, no eixo de infraestrutura ficou saneamento, luz pra todos, urbanização de favelas... (...) Eu acho bastante simbólico que o primeiro investimento que a gente tenha tido em volume, em escala, tenha sido pra favela. Eu acho que essa foi uma decisão muito importante do governo, uma coisa muito aderente com um pouco do conceito de nós estamos estabelecendo um projeto de desenvolvimento do país, em que a diminuição das desigualdades é um eixo fundamental, repartir antes de crescer. Então o tema dos passivos de tentar, enfim, pagar as dívidas, começar pelas favelas é uma coisa simbólica importante, do meu ponto de vista, muito condizente com o projeto político de diminuição das desigualdades e tal (ENTREVISTADO 07).

Trata-se assim de uma formulação que agradou, ao menos em um primeiro momento, à base política do governo ligada ao campo da reforma urbana (KLINTOWITZ, 2015). Isso não significada, entretanto, que se estava diante de um processo puramente redistributivo, havendo diferentes interesses empresariais articulados no processo de elaboração do programa como um todo, inclusive no tocante à sua vertente de urbanização de assentamentos (KLINTOWITZ, 2015), afinal, do total de R $\$ 619$ bilhões investidos no PAC-1, a modalidade de urbanização realizou um investimento de $R \$ 20,8$ bilhões em

\subsection{3 assentamentos precários em todo o país}

Como relembra Caldas (2015, p. 194), o programa foi construído assim, no discurso oficial, com o objetivo de promover investimentos em infraestrutura como um "instrumento de universalização de benefícios econômicos e sociais para todas as regiões do país, para que elas sejam capazes de trazer riquezas a todos e não apenas lucro para poucos" (BRASIL, 2007). É importante, ressalvar, contudo, que análises críticas ao programa (LEITÃO, 2009) apontam a existência de diferenças significativas entre o discurso oficial estabelecido para o programa e a prática implementada a partir de sua concretização.

Se a priorização implementada para a área de infraestrutura claramente privilegiava a lógica dos grandes empreendimentos produzidos através da contratação de grandes empresas (LEITÃO, 2009, p. 229); a análise do eixo de urbanização de favelas, inicialmente, sugeria a preferência por projetos em favelas de grande porte "com impacto na articulação e integração do território; com necessidades de recuperação ambiental e eliminação de gargalos de infraestrutura logística (ocupações em áreas de aeroportos, portos e ferrovias); 
para prevenção ou mitigação do impacto de grandes instalações de infraestrutura nacional e complementação de obras já iniciadas" (LEITÃO, 2009, p. 240) $)^{17}$.

Enfim, feito o PAC, nós tivemos assim rodando o Brasil todo. Se criou uma sistemática de seleção de projetos que acho que incorpora umas coisas interessantes de tentativas de pactuação dos projetos, colocando na mesa governadores, prefeitos, uma sistemática de seleção anual, dando uma certa previsibilidade pras discussões, pra as prefeituras licitadas pra organizar a sua agenda e tal. E também expõe uma questão das vulnerabilidades, das debilidades de todos os atores envolvidos, do ponto de vista da execução, dos limites que tem (ENTREVISTADO 07).

Como apontado por gestores do Ministério do Planejamento e da Casa Civil em entrevistas realizadas por Klintowitz, o processo de seleção do primeiro PAC Favelas em 2007 teria se caracterizado como uma "colcha de retalhos". Os municípios não dispunham de muitos projetos já elaborados ou possuíam projetos muito desatualizados (LEITÃO, 2009). A escolha das áreas consideradas prioritárias por eles se dava, muitas vezes, por critérios políticos que não dialogavam necessariamente com as necessidades dos assentamentos. "O governo federal, por sua vez, queria garantir a celeridade, a visibilidade dos processos de intervenção do PAC e os ganhos de capital político, e, com estas premissas, as escolhas dos projetos do PAC também dialogavam pouco com as necessidades locais e com uma distribuição regional equitativa” (KLINTOWITZ, 2015, p. 216). Reforça essa análise a entrevista colhida pela autora junto a gestor público federal da época, a qual claramente coloca a preferência por intervenções em grandes favelas e de visibilidade.

O problema é que o governo federal não deu tempo. De repente, imagine que você prefeito você precisa fazer obra de urbanização, só que não tem dinheiro, aí de repente o governo federal anuncia que vai abrir uma seleção pra municípios grandes, você é prefeito de um município grande, o governo vai te chamar, que é - que foi feito. Na época os governadores dos municípios de regiões metropolitanas e acima de $100 \mathrm{mil}$ habitantes, $150 \mathrm{mil}$ habitantes, foram chamados em Brasília para apresentar as suas demandas. E aí houve uma orientação: "tragam os seus projetos, não tragam uma lista de coisas que vocês querem fazer". E aí, claro que você prefeita pensa: "vou levar tudo o que eu tenho aqui, qualquer papel de pão". Então na verdade quando eles chegaram em Brasília o que a gente viu é que os municípios não tinham estoque de projetos,

\footnotetext{
${ }^{17}$ Nesse momento, em que se está resgatando a trajetória, não será aprofundada uma leitura atualizada dos investimentos realizados pelo PAC no tocante à urbanização de assentamentos. Para tanto, remete-se o leitor a obras referência no tema (CARDOSO \& DENALDI, 2018). Merecem ser conferidos não apenas o capítulo de balanço geral do programa (CARDOSO \& DENALDI, 2018), como aqueles específicos sobre os investimentos em urbanização nas cidades de São Paulo (AKAISHI ET AL, 2018) e Rio de Janeiro (CARDOSO ET AL, 2018).
} 
ou quando tinham, abriam lá a gaveta, projetos de 10 anos passados já, 15 anos, e a realidade já tinha mudado. Eu lembro muito bem que o pessoal da habitação tinha mais dificuldade porque quando eles iam falar de urbanização de favela, um projeto vindo com uma defasagem de $\mathbf{1 0}$ anos em uma favela, não serve mais pra nada, porque você entra na favela 2 anos depois, a favela já vai estar totalmente diferente, então assim, principalmente com a explosão demográfica justamente nessas grandes favelas, onde o PAC pretendeu intervir no início, ele queria começar pelas maiores, Paraisópolis, Heliópolis, tudo o que você pensar no país que for de grande, que todo mundo conhece, é o que o PAC queria (ENTREVISTA COM GESTOR FEDERAL in KLINTOWITZ, 2015, p. 216).

Diante dessa sistemática de seleção ${ }^{18}$, o programa obteve, como salientado pelas entrevistas e pela literatura (LEITÃO, 2009; CARDOSO E DENALDI, 2018), uma melhor performance em municípios com maior capacidade institucional no setor habitacional e possibilitou a continuidade de ações que já haviam sido iniciadas ou em territórios com histórico prévio de intervenção. Trata-se justamente de casos como as cidades de São Paulo e Rio de Janeiro, objetos desta tese, nos quais, inclusive, os investimentos do programa cumpriram outro papel essencial para além da aceleração da economia: a inscrição das favelas na paisagem das cidades nesse período através de intervenções produtoras de fortes imagens de transformação. Sob contextos e processos diversos, com atores diferentes, ambas cidades fizeram uso do programa para realizar intervenções com impacto visual e, com isso, renovar as imagens da cidade e assim poder mobilizar as intervenções como capital político para seus gestores.

No caso de São Paulo, como vinha sendo narrado antes do parêntese para discussão da inclusão da urbanização no PAC, o advento do programa ocorre durante o mandato de Gilberto Kassab, a quem o PT fazia oposição no plano municipal. Após a baixa intervenção em favelas no governo Marta Suplicy (então pertencente ao PT), Kassab soube aproveitar a estrutura institucional herdada (com vários projetos e licitações já realizados) e também a conjuntura propiciada pelo PAC-UAP para realizar investimentos em grandes favelas da cidade (FERREIRA, 2017), promovendo obras de impacto e visibilidade, inclusive com a assinatura de renomados escritórios de arquitetura (MOREIRA, 2017; MARQUES, PULHEZ E PAGIN, 2018). ${ }^{18}$ Conferir Rolnik, Klintowitz e lacovini (2011) para mais detalhes sobre o processo decisório do
PAC. 
Isso o Kassab fez muito bem pra se reeleger, ele é um baita de uma ação eleitoreira, uma coisa que o Haddad não soube fazer. Ele [Kassab] pôs a prefeitura nas periferias, ele pôs a ação da prefeitura. Ele podia não estar urbanizando na sua favela, mas você via que a favela do lado estava sendo urbanizada, então ele soube capitalizar muito bem essas urbanizações (ENTREVISTADO 19).

Como atesta a entrevista acima, concedida por integrante da gestão à época, o prefeito e sua equipe souberam mobilizar a urbanização de favelas para gerar capital político. Há outros fatores, evidentemente, que também influenciaram o sucesso eleitoral, como o declínio na época das votações experimentado pelo PT e a migração de eleitores do PP para DEM e PSDB (MENEGUELLO, 2016, p. 284). Não se está, assim, afirmando que as ações de urbanizações tenham sido determinantes para o sucesso eleitoral ou que tenham sido orientadas por critérios puramente eleitoreiros. Salienta-se apenas que compuseram o capital político do prefeito no pleito à reeleição.

Um dos elementos controversos que contribuiu para essa estratégia, sem dúvida, foi o formato adotado para as intervenções, que privilegiava expressamente um componente estético.

A outra coisa que a gente apostou, é que a gente contratou boa arquitetura. Aí eu não tenho como explicar, porque fiz curso de arquitetura e a minha missão na sociedade é fazer projetos com arquitetos e não projetos do Minha Casa, Minha Vida. E, claro, a gente tinha por trás disso, saiu em revista, capa de jornal. É um conceito que o Rio também usou, de pertencimento. Ora, se eu moro num lugar que é horrível, que não tem serviços públicos e ainda me botam num prédio que vai cair aos pedaços, eu não estou nem ai pra esse lugar. Agora, se eu vejo que o poder público está me tratando bem, que o prédio que eu vou morar é tão bom quanto um outro vizinho ali, ou até melhor que os vizinhos no Morumbi, eu crio um sentimento de pertencimento com isso, então eu vou cuidar (ENTREVISTADO 09).

Não se tratou apenas de questões estética, havia uma preocupação também com a infraestrutura e os espaços públicos (ENTREVISTADO 09), mas expressamente se coloca como a "boa arquitetura" era um componente estratégico na constituição dos projetos de intervenção. Alguns entrevistados reconhecem esse esforço (ENTREVISTADO 14), mas criticam fortemente o significado de "boa" para qualificar o padrão escolhido, tendo em vista que já haveria um grande repertório de projetos de qualidade contratados e elaborados pela gestão de Marta Suplicy.

O que é mais relevante, chegar na efetivação do direito à cidade ou ter um predinho de cada arquiteto famoso em cada favela? Porque a diversidade de soluções que eu vi nesse programa da prefeitura de São Paulo nas gestões Serra e Kassab, é que me parece que essa diversidade tipológica, ela era per se. Ela 
não era, "precisa ser diferente", mas "como se constrói essa diferença?", "respondendo ao que essa diferença?". (...) quantos ficaram de fora dessas urbanizações? Porque remove, faz aquela limpa, mas os predinhos abrigam $30 \%$ dos moradores iniciais. (...) a diversidade para que? Esse é um processo que começa no diagnóstico. Primeiro eu tenho que saber quais eu removo e por que, sabendo que remoção é uma encrenca, ninguém quer ser removido, ninguém quer. (...) Onde você remove? Risco tem que remover, mas o Rio de Janeiro remove muito menos por conta de risco do que nós, eles conseguem resolver com obras geotécnicas de menor porte, aqui as nossas construtoras se recusam fazer. (...) Essa é uma diferença de São Paulo que o Rio nunca investiu na habitação. O Rio tinha uma coisa que era assim, urbanizar favelas é criar espaços públicos, isso é uma diferença conceitual muito grande do programa de São Paulo e do programa do Rio, que um pouco a Elizabete França adota também. Eu tenho todos os projetos do Bairro Legal, todos têm projetos de habitação lindos, não foi por isso que ela mudou os projetos, não foi. (...) ao invés de eu remover um aqui, um aqui e um aqui, remove tudo isso aqui e ai a gente constrói um predião bacana novo, mas é um trauma pras pessoas. (...) 0 mérito da Bete França foi trazer esse tema para a arquitetura de novo, que ele era muito marginal. Agora, no meu entender, depois de ter passado por essa experiência, eu acho que ele tem equívocos que a arrogância, infelizmente, não deixa ver, não deixa debater, para a gente dar um passo melhor (ENTREVISTADO 14).

A própria afirmação de que pobres também teriam direito a morar em lugares "bonitos" já demonstra um julgamento estético que exclui o tecido constituído nas favelas dos padrões considerados aceitáveis (ENTREVISTADO 19). Outros também colocam que, dentro do adjetivo "boa" estaria incluído a ideia de "grife", uma concepção de arquitetura elitizada e que traria como concepção uma estética baseada não na própria morfologia e culturas locais, mas externas. Nesse sentido, parece haver um investimento pessoal da responsável pela coordenação das ações de urbanização à época, além dos objetivos da própria gestão.

E assim, a Coordenadora da Urbanização na época, em especial, é uma pessoa que tem uma ambição muito grande no âmbito da arquitetura (...) E aí ela tem uma ambição no ambito que é mostrar que ela faz habitação de interesse social, que é reconhecida internacionalmente, tanto que na gestão dela teve lá vários seminários internacionais, que traziam o pessoal da Índia, Bombain, junto com o pessoal do Cities Alliance, que é justamente pra fazer esse intercambio que o Banco Mundial faz dos padrões e traz pra virar best pratice (ENTREVISTADO 19).

Deve-se apontar que a análise de materiais institucionais (SECRETARIA DE HABITAÇÃO, 2008) ${ }^{19}$ demonstra uma maior preocupação com as "preexistências ambientais e culturais" que se configuram no território. Os

19 Um indício importante da estratégia de disseminação das experiências de urbanização realizadas pela gestão é dado pelo número de publicações realizadas em torno delas (11 dentre as 14 publicações institucionais sobre habitação entre 2008 e 2012), sendo a maioria delas inclusive publicadas em versões bilíngues para circulação internacional. Entrevistado (ENTREVISTADO 28) brinca que era até mesmo conhecida não como Secretaria de Habitação, mas como Secretaria de "Publicação". 
projetos realizados para urbanização teriam como diretriz a consideração da morfologia urbana e arquitetônica existente, objetivando diluir "as fronteiras urbanísticas e simbólicas entre a área antes marginal e o bairro formal" (SECRETARIA DE HABITAÇÃO, 2008, p. 19).

Além do componente estético, estes projetos têm sido criticado pelo impacto causado no tocante ao reassentamento. Conforme demonstrado por Akaishi (ET AL, 2018), a produção habitacional realizada no âmbito das intervenções não foi suficiente para abrigar todas as famílias removidas. O descompasso entre remoções e provisão habitacional teria ocasionado que, enquanto foram produzidas 14 mil unidades para famílias reassentadas, outras 9 mil famílias aproximadamente foram alocadas no aluguel social como solução transitória.

Independentemente do partido urbanístico (se estéticas ou de valorização do habitat popular) que de fato embasou as intervenções, está claro o ponto central da argumentação aqui pretendida: as intervenções realizadas na gestão de Kassab, conforme expressa em documentos e nas entrevistas, possuíam uma forte preocupação com a construção de uma imagem da cidade, dos assentamentos e da intervenção pública (afinal, o programa passa a se chamar "Renova", em possível alusão a um processo de renovação a ser implantado na cidade através da urbanização de favelas). Além de fazer referência até mesmo à utilização que o Rio de Janeiro havia feito nesse quesito, demonstra isso a intenção expressa da gestão também de participar de feiras, concursos, fóruns internacionais para dar visibilidade a esse componente. $E$ pode ser considerada bem sucedida.

Eu acho que de fato na gestão do Serra e Kassab, eu reconheço isso, eu acho importante haver esse reconhecimento, houve um avanço institucional do tema. Houve um fortalecimento da Secretaria, mais pessoas, um desenvolvimento da expertise. Talvez boa parte não tenha ficado, mas se espalhou por aí, ou seja, se cria ai uma capacidade técnica, uma expertise e o assunto passa a virar pauta positiva na imprensa, um trabalho com as universidades internacionais e tal, então sai pra fora, o mundo começa a ver. Se você conversa, por exemplo, com o Luís Eduardo Bresciani, ele dá aula em Harvard, ele está sempre lá, ele falou assim "Vocês mudaram a forma da gente ver favela, o Brasil mudou isso". Boa parte foi um trabalho de São Paulo e da própria Bete, de engajar as universidades norte-americanas, que acabam sendo opinial maker, coisa e tal. Depois a coisa acaba indo influenciar outras universidades em outros países e tal. (...) E foram realizadas obras, foram realizadas obras com um bom investimento do município, se você olhar alocação do orçamento é claro, mas também era um momento bom pra investir, porque os projetos já tinham, boa parte do trabalho já tinha sido feita, estava ali... (ENTREVISTADO 01). 
Em 2008, Kassab mobiliza sutilmente o tema em spots e propagandas eleitorais como ambiente de fundo para discussão de suas propostas. Marta Suplicy, que novamente disputa a prefeitura pelo PT, também aborda o tema, mencionando que já havia construído 23.000 casas populares quando prefeita e iria continuar atuando para transformar favelas em bairros (RIBEIRO, 2011, p. 52). Sua veiculação da intervenção em favelas, portanto, está mais atrelada à concepção da provisão habitacional e da ideia da transformação da favela na representação do que seria um bairro, próxima assim do que vinha sendo implementado pela gestão Kassab.

As possibilidades abertas, assim, pelo PAC-Urbanização para a atuação da prefeitura no tema possibilitou em São Paulo o estabelecimento da agenda de intervenção em favelas, mobilizada no próprio pleito eleitoral. Essa forma de atuação continua no segundo mandato, o qual inclusive realiza, no âmbito do programa Renova, um concurso nacional para contratação de projetos de urbanização por escritórios de arquitetura para 22 perímetros, causando mobilização nacional na área em torno do tema. Baseava-se na expectativa que o PAC fosse continuar a financiar essa modalidade de intervenção, então cabia à Prefeitura contratar os projetos para posterior obtenção de recursos no âmbito do programa (ENTREVISTADO 12). A estratégia, entretanto, não se mostrou efetiva, tendo em vista que, como será abordado com maior profundidade ao final desta seção, o PAC-Urbanização entra em declínio a partir da ascensão do programa MCMV.

Conforme mencionado anteriormente, em paralelo ao contexto paulistano, o PAC e as intervenções fomentadas por ele também propiciaram importante capital político no Rio de Janeiro. É relevante destacar, por exemplo que César Maia (de volta ao DEM) fazia oposição aberta à administração do PT no plano nacional, tendo como vice-prefeito ainda Otávio Leite, pertencente ao PSDB (SANTOS ET AL, 2015). O governo federal havia fortemente apoiado seu principal oponente, Marcelo Crivella, na disputa pela prefeitura (ABRUCIO ET AL, 2013, p. 196). Entretanto, isso não significou a ausência da prefeitura no âmbito dos financiamentos do PAC, tendo sido firmados vários contratos de financiamento pela prefeitura municipal, como aponta Cardoso (ET AL, 2018, p. 120). 
Por outro lado, essa oposição de Maia talvez explique, ao menos parcialmente, a caracterização peculiar dos investimentos do PAC-Urbanização na cidade, os quais, desde o início, contavam com forte protagonismo do Governo Estadual, a cargo de Sérgio Cabral. Pertencente ao PMDB, partido então já aliado orgânico do PT em nível federal a partir do segundo mandato de Lula (SANTOS ET AL, 2015), o governador concentrou boa parte dos recursos liberados pelo programa para intervenção em favelas na cidade, de acordo com sistematização de Cardoso (ET AL, 2018), com o intuito de canalizar pra si uma parte do capital político proveniente do programa (ENTREVISTADO 04).

Como destacam entrevistados (ENTREVISTADO 21; ENTREVISTADO 04), o governo estadual, entretanto, não dispunha de uma equipe técnica efetivamente preparada e não gozava da mesma experiência que o município no tema (CARDOSO ET AL, 2018). Mesmo assim, ficou responsável pela maior parte das intervenções definidas para os três maiores complexos de favela no Rio: Rocinha, Manguinhos e Alemão, os quais somados representaram pouco mais da metade de todo o investimento do programa na cidade (CARDOSO ET AL, 2018, p. 112). E ainda promoveu isso através da sua empresa de obras públicas, a EMOP, especializada em grandes obras e com grande prestígio político na gestão, mas sem experiência em urbanização de favelas (CARDOSO ET AL, 2018, p. 118; ENTREVISTADO 21).

Vivia-se naquele momento um período de confluência positiva de interesses no estado e na cidade, tanto do ponto de vista econômico de aquecimento da economia fluminense (PINHEIRO \& VELOSO, 2012), quanto também políticos. $\mathrm{Na}$ eleição de 2008 para prefeito, impedido de concorrer à reeleição e desgastado politicamente por tantos anos à frente da prefeitura, César Maia ${ }^{20}$ não consegue fazer sua sucessora, sofrendo uma forte derrota (SANTOS ET AL, 2015).

${ }^{20}$ O capital político constituído por Maia com o Favela-Bairro é novamente mobilizado quando vai disputar em 2010 uma das duas vagas ao Senado Federal pelo Rio de Janeiro, utilizando largamente (em $84 \%$ da sua propaganda eleitoral) as suas realizações enquanto ex-prefeito no Rio de Janeiro, dentre elas o Favela-Bairro. Na priorização de temas escolhidos para a campanha ainda, o candidato pulverizou sua abordagem, sendo, no entanto, "políticas para o desenvolvimento urbano" o tema mais mencionado por ele (DE PAULA, 2013, p. 13 e 19). 
PT e PMDB não se aliam de início, aquele na expectativa frustrada de que este apoiasse seu candidato, Molon. Esperava-se que, junto com o governo do estado, "o presidente Lula, ao investir vultosos recursos do PAC na recuperação de áreas da cidade com grande concentração de votos, torna-se um eleitor disputadíssimo pelos candidatos à prefeitura carioca" (MOTTA, 2008 , p. 03)". Entretanto, o PMDB, com a máquina política do governo estadual de Cabral, decide lançar a candidatura Eduardo Paes (seu secretário de esportes e turismo) e obtém a vitória (SANTOS ET AL, 2015, p. 124). Assentados os resultados e restaurada a aliança entre PT e PMDB vigente no plano nacional, forma-se assim o alinhamento "município-estado-governo federal" que impactaria as políticas no Rio de Janeiro e no Brasil nos anos seguintes, tanto do ponto de vista da escala de recursos destinados à cidade quanto no uso midiático e político das intervenções promovidas.

O Rio, cumpre mencionar, concentrou uma importante parcela do montante destinado à modalidade de urbanização de favelas no âmbito do PAC, sendo a cidade brasileira que mais investimentos recebeu, contabilizando quase $R \$ 3$ bilhões dentre os recursos coordenados pelo governo estadual e municipal (CARDOSO ET AL, 2018, p. 108). Tão ou mais importante quanto o montante investido é a forma como este recurso foi utilizado, tendo sido a cidade palco de alguns dos principais exemplos de "projetos emblemáticos" do PAC (CARDOSO ET AL, 2018, p. 118), ou seja, com uma acentuada característica de monumentalidade ou espetacularização dos investimentos ${ }^{21}$.

No PAC-UAP são consideradas como intervenções emblemáticas três grandes obras: Teleférico do Alemão, Elevação da linha do Trem em Manguinhos e Passarela Niemeyer, na Rocinha, correspondendo a cerca de $19 \%$ do investimento total. A introdução destas obras foi feita à margem da legalidade num esquema clientelista articulado por um cartel de grandes construtoras. Isto revela que, no Rio de Janeiro, a Urbanização de Favelas tem um peso que

21 Como sistematizado em Cardoso (ET AL, 2018), não houve apenas intervenções emblemáticas no âmbito desse programa na cidade, sendo encontrados também projetos caracterizados como "urbanizações integradas" (com uma abordagem mais compreensiva das configurações do território e de suas necessidades do que as consideradas emblemáticas, segundo os autores), "urbanizações parciais" (a maioria contratada pela Prefeitura no âmbito do programa Pró-Moradia para complementação de projetos de urbanização em assentamentos que já haviam passado por intervenções, como no âmbito do Favela-Bairro) e "modelos específicos" (denominação dos autores para dois financiamentos com escopos bem específicos e diferentes dos demais, seja no tocante à intervenção promovida, seja no tocante à gestão social do projeto). 
transcende a resposta às necessidades da população, e ao escopo original definido pelo MinCidades para o PAC, transformando-se num símbolo da atuação do poder público enquanto política social, meio de fortalecimento das alianças partidárias, legitimadora do legado dos megaeventos para além de forma de rentabilizar o capital do setor da construção civil. É importante destacar que o efeito emblemático seria um elemento qualificador da intervenção, havendo literatura sobre o potencial de equipamentos de porte em regiões periféricas. No entanto, o que percebemos é que esta estratégia é feita à custa de desinvestimento em áreas prioritárias. $O$ nível de recursos destinado às obras emblemáticas supera por exemplo o investimento em habitação, que conta com $18 \%$ dos recursos. Não foi possível obter dados nacionais de controle para comparar esses dados; no entanto, na região do ABC paulista, que conta com um volume de investimento na mesma ordem de grandeza do Rio, os valores destinados à habitação são em torno de $40 \%$, chegando a $60 \%$ em alguns casos (PATRICIO ET AL, 2018, p. 16-17).

A relação entre estado e setor empresarial na urbanização será tratada com maior profundidade na seção 2.2, mas é importante no momento apontar como as intervenções em favelas na cidade propiciam a reiteração de uma histórica relação simbiótica entre estes atores (IACOVINI, 2013), com uma especial ênfase em função da monumentalidade adquirida por parte desses investimentos. Essa convergência é facilitada também graças à escolha do Rio de Janeiro para sediar as Olimpíadas de 2016 e alguns dos principais jogos da Copa do Mundo da FIFA de 2014, tornando-se assim um projeto de interesse e impactos nacionais e internacionais. Como relembra entrevistado, essa estratégia de atração de interesse e investimento para a cidade já vinha sendo mobilizada por Maia.

Acho que na década de 2000, sobretudo a partir de 2008, o Rio de Janeiro entra em um outro modelo, modelo esse que já nasce com o César Maia: o modelo de grandes eventos. Modelo de intervenção no Rio de Janeiro sobretudo vinculado a grandes eventos e intervenção urbana. Enfim, isso nasce desde lá, com algumas tentativas iniciais, começa com o César Maia, ele ganha os jogos panamericanos. Dos jogos pan-americanos aos jogos olímpicos, a gente recebeu tudo pro Rio de Janeiro em 10 anos. Talvez o único caso histórico mundial que a gente tenha tido tantos grandes eventos de uma maneira tão sequencial (ENTREVISTADO 21).

Não é intuito deste trabalho aprofundar os significados e alcances da era dos megaeventos esportivos na cidade e no país, tendo em vista que vasta literatura já se dedicou ao tema na última década, tanto do ponto de vista do entrelaçamento entre o modelo de espetáculos esportivos e interesses privados e políticos colocados no atual modelo de planejamento das cidades, quanto do ponto de vista de mobilizações sociais de resistência às ameaças impostas por estes modelos (MASCARENHAS, 2007; MASCARENHAS, BIENENSTEIN \& SANCHEZ, 2011; SANTOS JR, 2015; ROMEIRO \& FROTA, 2015; VAINER, 
2016; IACOVINI, 2017). Alguns pontos importantes, no tocante a políticas de intervenção em favelas, merecem ser destacados.

Primeiramente, entrevistados que fizeram parte da gestão estadual e municipal no período (ENTREVISTADO 18; ENTREVISTADO 13) confirmam a literatura no sentido de ter havido uma submissão de todos os esforços e políticas a um "curto prazismo e às limitações de uma agenda pública absolutamente atrelada aos grandes eventos naquele momento, como as Olimpíadas" (ENTREVISTADO 13). Como será abordado na segunda parte desta tese, isso teve grandes impactos, inclusive, na intervenção em favelas no ponto de vista da segurança, com uma reverberação sobre todo o sistema político.

Do ponto de vista da política habitacional e de desenvolvimento urbano praticada em assentamentos populares, a adoção dessa agenda teve um duplo impacto. De maneira ambígua, mas completamente conectada, são amplificadas tanto iniciativas de urbanização de favelas (através do PACUrbanização principalmente) quanto ações de remoção de assentamentos (também no âmbito de outros investimentos do PAC, muitos dos quais ligados a projetos de mobilidade, etc.), como aponta entrevistado.

A gente retomou uma política de remoção como nunca antes desde a década de 60 . Então a gente não está falando da década de 90 e 2000 , onde as remoções eram extremamente limitadas e pontuadas, a gente volta com uma dimensão e uma escala importante de remoções, com violências absurdas (...) Mas ao mesmo tempo, a abertura da Copa do Mundo, quando a bola chega no Rio de Janeiro, era numa favela, na entrada da favela. A abertura dos Jogos Olímpicos no Rio de Janeiro, a decoração o tempo inteiro era uma favela. Enfim, é uma relação muito ambígua (ENTREVISTADO 21)

Verifica-se, portanto, nesse contexto uma nova bifurcação das atuações públicas na cidade no tocante às intervenções em favelas, promovendo uma retomada das remoções como há décadas não se praticava (MAGALHÃES, 2013). É interessante verificar que, se foi na gestão de Eduardo Paes que se lançou o Morar Carioca com o discurso de aprimorar as ações de consolidação de favelas na cidade, foi na mesma gestão que se ampliou muito a escala de remoções (MAGALHÃES, 2013, p. 95-96).

Se o contexto de preparação de diversas cidades brasileiras na última década para a recepção de megaeventos esportivos, fomentada e coordenada pelo Governo Federal, poderia significar um momento de valorização e aumento do 
investimento nas favelas como uma forma de mostrar ao mundo a experiência do país em avançar nas suas condições de efetivação do direito à moradia (como o Morar Carioca prometia, sendo até planejado como um dos legados dos megaeventos), não foi isto o que se verificou. Mesmo naqueles casos em que inicialmente se sinalizava uma atuação diferente em relação ao tema, o resultado, ao contrário, foi a ampliação das remoções.

Portanto, além de ser um momento em que se constitui justificativas claras para a priorização de outras políticas e projetos (de mobilidade, de infraestrutura aeroportuária, etc.) em detrimento da urbanização de favelas, promoveu-se um ambiente mais propenso à retirada/remoção de favelas do que à sua consolidação, tendo em vista que seria mais adequada à implantação dos projetos considerados prioritários do ponto de vista da promoção do desenvolvimento local e nacional. Sobre o tema, além de publicações promovidas por articulações de organizações e movimentos sociais denunciando as violações a direitos verificadas nesse processo (ARTICULAÇÃO NACIONAL DOS COMITÊS POPULARES DA COPA, 2014; COMITÊ POPULAR DA COPA E DAS OLIMPÍADAS DO RIO DE JANEIRO, 2015), é preciosa a análise desenvolvida por Faulhaber e Azevedo (2015) na qual concluem, com base em dados da própria prefeitura, como 60 mil o número de removidos na cidade no contexto da preparação para a Copa de 2014 e as Olimpíadas de 2016. Com o lançamento em 2009 do programa Minha Casa, Minha Vida, recrudescem em nível nacional as ações de remoção de favelas no período, novamente colocando socialmente em xeque a permanência e o modo de autoproduzir de seus moradores.

Reconhecendo que a vulnerabilidade socioeconômica está diretamente associada às condições de moradia, as remoções de favelas e assentamentos precários ocorrem sem maiores mediações, sem respeito aos direitos dos ocupantes. As comunidades representam uma espécie de empecilho para 0 "desenvolvimento", "enfeiam" a paisagem, desvalorizam a região e prejudicam o sucesso dos futuros empreendimentos. Cresce a pressão para que as favelas sejam removidas e essas remoções vêm a cabo, não raro de maneira violenta, provocando traumas irreversíveis para os moradores: lideranças ameaçadas, cortes no abastecimento de água e luz, incêndios criminosos e, enfim, as reintegrações de posse, com ações da polícia para que se cumpram as ordens judiciais e que os "riscos" (a quem?) sejam eliminados. Às famílias removidas, na realidade atual da política de muitos municípios, resta o "atendimento" através de indenizações espúrias (popularmente denominadas "chequesdespejo") ou da bolsa aluguel, paga pelo poder público enquanto os novos 
empreendimentos habitacionais, em geral distantes, não são viabilizados (SANTO AMORE ET AL, 2014, p. 06-07).

Portanto, sob o discurso da preparação para os megaeventos, está subjacente o retorno à ideia de que a favela é menor ou menos relevante do que o tecido urbano formal, tendo em vista que ela poderia ou deveria ser removida para a realização de tais projetos, os quais consideram menos a possibilidade de retirada de assentamentos formais ou de classe média e alta. O que pode causar estranheza é que, embora aparentemente conflitando com este processo, ainda se continuava a investir nos projetos financiados pelo PACUrbanização e sob um discurso de valorização da favela até mesmo enquanto paisagem e monumentalidade.

Trata-se, entretanto, de um processo combinado, duas faces da mesma moeda de construção de uma nova imagem das cidades através da qualificação e valorização de apenas partes dela, principalmente no Rio de Janeiro (mas também em São Paulo, com os projetos de "boa arquitetura"). Buscava-se constituir imagens de partes da cidade que simbolizariam 0 todo (ENTREVISTADO 30), em uma metonímia urbana, enquanto os dados demonstravam outra realidade para milhões de favelados que ainda hoje sofrem com condições insalubres de moradia e para milhares de famílias removidas com violência física e psicológica de suas residências (FAULHABER \& AZEVEDO, 2015). O PAC e a monumentalidade fomentada por seus investimentos foram essenciais para isso.

No que diz respeito às intervenções [do PAC], o escopo, eu acho que existe uma questão da monumentalidade muito complexa, ou seja, numa dimensão muito mais pra fora do que pra dentro. Um outro problema, a gente tem um volume de recursos como nunca antes, então, se a gente comparar, o PAC 1 da Rocinha foi mais de 1 bilhão de Reais. Um bilhão de Reais é muito dinheiro. O PAC 2 na Rocinha era 1 bilhão e meio, é um negócio, um volume de recursos muito absurdo e que talvez a gente tenha perdido uma oportunidade histórica, sem reverter de fato as condições de habitabilidade demandadas pelos moradores (...) Então se fez o PAC a partir de grandes eventos, a partir de grandes equipamentos com um grande caráter de monumentalidade, completamente desvinculado às demandas da população (ENTREVISTADO 21).

A paisagem passa, inclusive, a fazer parte estratégica da política urbana na cidade, como aponta entrevistado (ENTREVISTADO 21). Nesse sentido, por exemplo, o Plano Diretor aprovado em 2011 (Lei Complementar no 111/2011) no governo de Eduardo Paes dá ênfase nas diretrizes e constitui instrumentos para proteção da paisagem (mencionada mais de 55 vezes na lei). Entendida 
como "a interação entre o ambiente natural e a cultura, expressa na configuração espacial resultante da relação entre elementos naturais, sociais e culturais, e nas marcas das ações, manifestações e formas de expressão humanas" (art. $2^{\circ}, \S 3^{\circ}$ ), a paisagem chega a ser classificada como "o mais valioso bem da Cidade, responsável pela sua consagração como um ícone mundial e por sua inserção na economia turística do país, gerando emprego e renda" (art. $2^{\circ}, \S 4^{\circ}$ ). Integram a paisagem na visão do plano tanto aquelas atributos naturais excepcionais como "as paisagens decorrentes das manifestações e expressões populares" (art. $2^{\circ}, \S 5^{\circ}$ ).

No ano seguinte, 2012, chegou a ser a primeira cidade no mundo a receber 0 título da UNESCO de Patrimônio Mundial como Paisagem Cultural Urbana, com uma candidatura fomentada pelo governo federal através do Ministério da Cultura e do IPHAN. Mobilizava, portanto, interesses nacionais a constituição do Rio como um bem nacional de visibilidade global, representando um país que há anos trabalhava para consolidar sua imagem de liderança global e simbolizando ainda o sucesso do próprio projeto político do governo do PT à frente do governo federal.

As obras do PAC-Urbanização operam, assim, como um dos elementos desse processo político maior, o qual conecta e alimenta, inclusive, elementos da política de segurança (como as UPPs, abordadas à frente na seção 4.3) e o gradual processo de fortalecimento da militarização da vida política na capital fluminense. "Se colocarmos em perspectiva o total de investimento de 2007 a 2016 do PAC em urbanização de favelas [no Rio de Janeiro], R\$27,3 bilhões (MinCidades) equivaleria grosso modo ao investimento empenhado para a Copa do Mundo de 2014 (R\$25,8 bi), mas inferior ao investimento para as Olimpíadas (R\$37,5 bi)" (PATRICIO ET AL, 2018, p. 07).

O capital político gerado por esse processo pode ser observado nas eleições de 2012. Nesse pleito municipal, pela primeira vez, as forças aliadas a nível nacional na base governista compuseram uma coligação local desde o início nas eleições do Rio de Janeiro. Nos pleitos anteriores, as alianças partidárias realizadas no âmbito federal não se reproduziam nas candidaturas a prefeito, como demonstram Silveira e Chaia (2003), Motta (2008) e Santos e Travagin 
(2015). A disputa de Eduardo Paes à reeleição em 2012 foi, assim, um fato inédito, agregando PMDB, PT, PC DO B, PSB, PDT e PP em torno de sua candidatura. Esse talvez seja um dos mais fortes indícios de que realmente havia se consolidado no Rio de Janeiro um projeto político de amplitude nacional a partir das ações e investimentos conjugados entre município, estado e União na cidade, com ganhos para os mais diversos agentes.

Em meio a tudo isso, o programa Morar Carioca vai se perdendo enquanto proposta de uma nova metodologia para pensar as intervenções em favela. Lançado em 2010 e criado oficialmente em 2012 (DECRETO 36.388/2012) com a meta de urbanizar todas as favelas da cidade até 2020 e constituir um dos legados positivos dos Jogos Olímpicos de 2016 (CARDOSO ET AL, 2018, p. 121), o programa foi formulado como um aperfeiçoamento do Favela-Bairro, baseando-se em críticas recebidas por este programa ao longo das décadas e utilizando-se do restante de recursos de que ele ainda dispunha (ENTREVISTADO 18; ENTREVISTADO 21; ENTREVISTADO 04).

Mais recentemente, com a realização dos grandes eventos esportivos na cidade, - governo municipal apontava para a urbanização de todas as favelas da cidade, através do programa Morar Carioca, que seria o principal "legado" dos Jogos Olímpicos para a cidade. $O$ Morar Carioca apresentou inovações interessantes na metodologia de intervenção nas favelas, colocando em outro patamar a problemática da integração com a cidade e mais uma vez ampliando a escala da intervenção, incorporando as reflexões e o acúmulo da equipe técnica da Prefeitura, assim como do setor privado. No entanto, após um movimento inicial que indicava avanços significativos, o programa perdeu centralidade na agenda governamental e, paralelamente, ampliou-se a política de remoções (DENALDI, 2015, p. 04).

Em números, o programa aconteceu: de acordo com informações da Prefeitura, o Morar Carioca já teria beneficiado cerca de 500 mil moradores de 122 mil domicílios de 226 comunidades e loteamentos de toda a cidade (PREFEITURA DA CIDADE DO RIO DE JANEIRO, 2016) ${ }^{22}$. No entanto, como apontam

\footnotetext{
${ }^{22}$ O programa já teria promovido de intervenção: 380 mil metros de extensão de pavimentação (o equivalente a $957.992,20 \mathrm{~m}^{2}$ de pavimentação), 284 mil metros de redes de água potável, 48.309 mil ligações domiciliares de água, 13 elevatórias de água (8 prontas, 3 em construção e 2 a iniciar), 305 mil metros redes de esgoto, 42.182 ligações domiciliares de esgoto, 12 elevatórias de esgoto (7 prontas, 3 em construção e 2 a iniciar), 190 mil metros de redes de drenagem, 6.938 pontos de iluminação pública, 98.676 metros quadrados de contenção de encostas2.567 novos pontos de coleta de lixo, 40 Espaços de Desenvolvimento Infantil (EDIs), sendo 38 concluídas e 2 em construção, 4 creches (3 concluídas e 1 em construção), 6 escolas, sendo 4 prontas e 2 em construção, 833 novas moradias, Reservatórios totalizando
} 
entrevistados (ENTREVISTADO 21; ENTREVISTADO 04; ENTREVISTADO 28) e a literatura (CARDOSO ET AL, 2018), o programa perdeu enquanto proposta metodológica integrada, tornando-se apenas uma marca ou uma label (CARDOSO ET AL, 2018, p. 122) sob a qual todas as intervenções em favela estavam agrupadas, sem uma articulação de fato e rompendo com as propostas formuladas no âmbito do concurso de metodologias promovido pela Prefeitura com o IAB em 2011.

(...) o Rio de Janeiro entra com uma proposta do Morar Carioca, um engodo. Tinha sido colocado em 2011 como uma proposta, grande legado urbanístico das Olimpíadas. E foi pra enganar mesmo, é impressionante como usou aquilo, mas foi um engano que botou o IAB de sócio, botou um conjunto de instituições respeitadas na sociedade, dentro daquele esforço. Todas as 40 equipes selecionadas, entre as quais eu estava, estavam totalmente engajadas em construir um discurso que fosse o mais perfeito possível, considerando mais de 20 anos, pelo menos 20 anos de experiência acumulada dentro já de uma perspectiva mais sofisticada, e que portanto a gente tinha uma grande chance de fazer uma contribuição pro Rio, pro país (ENTREVISTADO 04).

(...) A prefeitura colocou o Morar Carioca em alguns projetos que ainda eram resquícios de pagamento do Favela Bairro 3, que foi o Babilônia, o Morro da Mangueira, que ele até falou que foi o Morar Carioca Verde. Então dentro, da Rio 2012, da Rio+20 [Conferência da ONU], ele fez essa intervenção no Babilônia e colocou uma coisa verde, porque de verde não tinha nada, mas a ideia era pra vender. E claramente uma favela em Copacabana, no Leme, tinha todo o impacto visual político importante (ENTREVISTADO 21).

O que aconteceu no Rio [no Morar Carioca] foi uma sucessão de equívocos em relação ao programa, retrocessos. Está documentado já, um monte de arquitetos do Rio estava numa situação parecida com a nossa, de chegar numa hora e falar "Eu vou desistir desse projeto porque não está fazendo sentido". A gente passou a ser visto como agenciador de projetos complementares. (...) 0 que pegou mesmo foi a fragmentação do programa, a falta da centralização que a Secretaria de Habitação antigamente fazia. A Secretaria da Habitação perde o poder, depois que o secretário ligado ao PT sai, então colocam um cara lá de um partido XY e tiram a atribuição da secretaria. Não querem que aquele partido domine aquela determinada política. Aí você vai separando e vai fragmentando a política pública. Então o resultado do Morar Carioca, se você perguntar pros arquitetos do Rio, hoje em dia é muito negativo, ai virou uma etiqueta pra qualquer obra em favela que se fazia (ENTREVISTADO 28).

Essa perda de centralidade e a fragmentação do programa Morar Carioca é acompanhada, na capital paulista, igualmente pelo declínio da centralidade de ações de urbanização de favelas, verificado principalmente na gestão de Fernando Haddad. Para entender a agenda de Haddad à frente da prefeitura

4,55 milhões de litros de água, 357 praças e áreas de lazer. (disponível em http://www.rio.rj.gov.br/web/smhc/conheca-o-programa em janeiro de 2019). 
no tocante à política habitacional, é necessário também compreender o contexto político amplo.

Ao longo da década anterior, o PT estava em declínio na sua votação na capital, com isso a necessidade de fazer alianças para cada pleito aumentava. Apesar do desgaste do governo de Kassab na cidade de São Paulo (ABRUCIO ET AL, 2013), este declínio de eleitores do PT e a já tradicional polarização entre PT e um bloco protagonizado naquele momento pelo DEM/PSDB (LIMONGI \& MESQUITA, 2008), fazem com que aumente a necessidade de promoção de alianças com partidos de outros espectros político-ideológicos.

É importante mencionar que o PT não reflete de forma significativa no âmbito local [de São Paulo] a proeminência que a sigla adquire no nível nacional após 2002, com a presença na Presidência da República. Entre os pleitos de 2000 e 2004, apesar da vitória em 2o turno com Marta Suplicy, o partido perdera votos na cidade no primeiro turno, em uma tendência declinante que segue até 2012, embora neste pleito tenha obtido no 2 o turno a terceira vitória na cidade, com Fernando Haddad. O ponto a destacar, portanto, é a perda crescente do espaço natural do partido na cidade, o que o tem levado a estratégias mais amplas de agregação de apoio e alianças na competição para a Prefeitura, seguindo a direção ao centro, que marca sua política de alianças em todos os níveis desde 2002 (MENEGUELLO, 2012).

Uma dessas alianças promovidas foi com o PP, liderado por Maluf, com a condição de que este pudesse comandar a pasta da habitação. Com uma virada inesperada e no último momento da eleição, a vitória de Haddad não proporcionou grande força e momentum político do prefeito, o qual precisaria então consolidar ainda mais tais alianças através do atendimento de interesses dos diferentes partidos e lideranças políticas em setores e cargos estratégicos.

Diante dessa situação política, em alguns casos, para que não se perdessem políticas consideradas prioritárias para a gestão, algumas delas foram remanejadas, saindo de secretarias loteadas a outros partidos e sendo alocadas em pastas sob o comando de quadros de confiança. Segundo entrevistados, isso chegou a ser cogitado para a urbanização de favelas, remanejando da SEHAB (a cargo do PP) para a SMDU (conduzida por pessoa de confiança de Haddad), o que não ocorreu, entretanto (ENTREVISTADO 28).

Ao contrário, comandada pelo PP com uma equipe formada durante os três primeiros anos por quadros provenientes do setor da construção civil (MARQUES, PULHEZ E PAGIN, 2018), a Secretaria de Habitação optou por 
apenas manter as ações de urbanização do Renova já iniciadas pela gestão anterior, e ainda assim a ritmo lento (ENTREVISTADO 28). A perspectiva era que, no contexto de liberação de recursos e alta visibilidade por parte do MCMV, a atuação da prefeitura deveria estar direcionada à provisão habitacional (ENTREVISTADO 12), parte inclusive do programa de governo de Haddad durante a campanha eleitoral - construção de 55 mil unidades habitacionais e beneficiar 70 mil famílias no âmbito da urbanização de favelas.

Conforme Marques, Pulhez e Pagin (2018) apontam, a predisposição dos integrantes da gestão de Haddad à frente da Habitação nos três primeiros anos, compostos de pessoas que inclusive haviam feito parte da gestão de Maluf e Pitta, significaram praticamente a paralisação do Renova após o primeiro ano de mandato e a preferência pela provisão.

E aí no Haddad a gente teve duas questões importantes, que é importante falar pro desastre que foi a Sehab, a habitação no governo Haddad. Primeiro, os recursos federais estavam bombando somente nesse 1 ano e meio, no comecinho, depois desapareceu. O PAC já estava rodando em falso, a gente estava subindo no telhado já, a Bete [França] tinha contratado vários projetos do Renova, de urbanização... (...) E o governo Haddad, ele deu prioridade pra onde tinha dinheiro federal, ele fez uma opção "Eu tenho $X$ recursos, eu tenho que fazer saúde, educação, ciclovia, ba-ba-ba, tinha que aumentar o subsídio do transporte, de onde eu vou tirar o dinheiro? Olha, habitação tem dinheiro federal, então eu vou tirar todo o orçamento público municipal da habitação e deixar só com o governo federal, Minha Casa, Minha Vida e PAC". (...) Então quando foi pra contratar as obras do Renova, com os projetos do Renova, precisaria recorrer ao PAC e o PAC acabou. Pra contratar as obras do Minha Casa, Minha Vida, unidades em construção, precisava do Minha Casa, Minha Vida e o Minha Casa, Minha Vida acabou. Então o que aconteceu no governo Haddad? Habitação acabou. Então como estava totalmente dependendo do governo federal, foi pro saco, então habitação foi um zero. No último ano que tirou o PP de lá e colocou o pessoal do João Whitaker, que fez o plano municipal de habitação e que deu uma retomada de coisas alternativas, mas os 3 primeiros anos... (ENTREVISTADO 19)

É eloquente que, em artigo destinado à análise dos investimentos em urbanização de favelas realizados em São Paulo no âmbito do financiamento do PAC-UAP, a gestão Haddad sequer é mencionada (AKAISHI ET AL, 2018). Embora as autoras dediquem uma seção ao resgate da trajetória da política habitacional na capital paulista, abordando a ênfase dada à urbanização em cada administração desde a década de 1970, nem mesmo nessa seção há menção sobre o enfoque da gestão petista de 2013 a 2016.

A urbanização, eu não sei, eu acho que algumas gestões, algumas autoridades, alguns gestores não acreditam que a urbanização é programa habitacional, não acreditam. (...) eu lembro que o secretário falava que era um programa de assistência social, que deveria estar na secretaria de assistência social, que não 
é habitação. Habitação é dar casa, apartamento, essas coisas (ENTREVISTADO 09).

É importante, no entanto, apontar que a baixa prioridade conferida à urbanização de favelas na gestão não deriva unicamente da entrega da SEHAB ao PP, mas também de uma menor atenção ao tema pelo restante da administração municipal como um todo, da Secretaria Municipal de Desenvolvimento Urbano (que não avocou ou não conseguiu trazer para si a responsabilidade sobre o tema) ao próprio prefeito, como indicam depoimentos de integrantes da gestão municipal.

A gente fez um evento muito lindo que o Haddad foi. Raro ele ir, não ia para a periferia de jeito nenhum, não ia para as áreas de jeito nenhum. Não ia, ele não ia! Ele preferia fazer a feira com a mulher no sábado do que entregar título. E aí... não sabe porque não se reelege (ENTREVISTADO 19).

Eu lembro que falavam assim "Vamos entregar 40 unidades lá e não sei o que, vamos jogar todo o recurso lá". E eu discutia no orçamento, os caras queriam tirar todo o dinheiro do Renova pra colocar na produção, eu falava "Espera aí, não! Não vamos jogar tudo naquele empreendimento, vamos dividir. Tem algumas obras que estão paradas, que a gente tem que retomar, porque entregar 40 unidades e não entregar nada é a mesma coisa", eu falava. Politicamente era ridículo o Haddad entregar 40 unidades, e eu defendia que o recurso fosse mais esparramado pelas obras e projetos [de urbanização]. (...) É complexo, ainda mais no último ano de governo, no período eleitoral, isso vira uma panela de pressão, e aí a gente tem que se expor a algumas determinações do governo, aliás a gente está lá pra fazer o governo dar certo. A secretaria de governo tem um pessoal responsável pelo planejamento do governo, ai no final, no último ano foi uma disputa por recurso de outras secretarias, ai acabou comprometendo as metas da habitação. (...) A gente tinha que cortar orçamento nosso pra passar para obras, em parte porque a secretaria de habitação se mostrou incapaz de utilizar os recursos que estavam destinados a ela. (...) Como nos anos anteriores não houve a aplicação dos recursos, daí eles foram diminuindo os recursos da habitação, então também não é culpa dele não, é culpa da própria secretaria que não demonstrou... é isso, você não vai usando, os outros vão usar. (...) [0 recurso acabou indo para] infraestrutura urbana e do Hospital de Parelheiros. Esse do Hospital de Parelheiros não era nem recurso da prefeitura, era um dinheiro do PAC que a gente tinha, que poderia estar usando pra urbanizar favela lá na zona sul. Como não foi gasto, o prefeito mandou "Os caras não gastaram esse dinheiro, vamos gastar lá no hospital”. A gente fez um aditivo na Caixa Econômica, no Ministério das Cidades, pode o PAC para a organização investir em equipamento público pra complementar custos e tal (ENTREVISTADO 12).

Vê-se assim que, não apenas o prefeito não estava pessoalmente empenhado com a política habitacional do município e distante principalmente no tocante aos eventos realizados nos territórios, como também havia a diretriz de redirecionamento de recursos de urbanização para equipamentos e provisão habitacional. Além disso, contribuiu também para uma menor prioridade da urbanização na gestão de Haddad a baixa reivindicação promovida por movimentos naquele momento em relação ao tema, de acordo com entrevistado integrante da gestão. 
Outra forma de ver o bloqueio de forma um pouco mais ampla é de ordem de prioridade, inclusive nas gestões, porque a urbanização não entra como prioridade em algumas. Por exemplo no governo do Haddad não foi prioridade. (...) Eu acho que houve um encolhimento talvez da pressão popular pra esse tipo de ação. Esse encolhimento da pressão popular pode até ter surgido porque houve uma certa acomodação do movimento, porque num determinado momento começou a ser atendido, não sei, pode ser, tem aquela coisa meio que, a contradição que existe na reação dialética: conforme o Estado vai assumindo uma postura de atendimento, vai reduzindo assim a atuação, como poderia se dizer, ativa dos movimentos, os movimentos vão se tornando passivos e o Estado vai se tornando mais paternalista. Então quando acontece isso, enfraquece o movimento, não tem mais pressão, eles estão lá sentados esperando, e ai o Estado, paternalista até certo ponto, se o bebê não chora, não vai dar de mamar (ENTREVISTADO 12).

Como apontado por Klintowitz (2015), tratava-se de um movimento de coordenação de interesses promovido pelo governo Lula em que esses movimentos, principalmente aqueles de moradia ligado ao campo da reforma urbana, passam a ser atendidos pela modalidade Entidades do MCMV. No caso de São Paulo, o baixo peso de movimentos de favelados e a grande presença do movimento de moradia também teria impactado nesse direcionadomento da gestão de Haddad em relação à política habitacional.

Não se trata de um caso isolado o exemplo de São Paulo, em que progressivamente são diminuídas as iniciativas no campo da urbanização de favelas, migrando os esforços públicos para a provisão propiciada pelo MCMV. Como a literatura atesta, o Governo Federal pode desempenhar um forte papel indutor no campo das políticas habitacionais (ARRETCHE, 2012), pautando assim o comportamento dos governos subnacionais no tema (MARQUES, PULHEZ \& PAGIN, 2018, p. 142), como verificado principalmente a partir do lançamento do MCMV em 2009 (ROLNIK, KLINTOWITZ \& IACOVINI, 2014).

Da mesma forma que feito para o PAC acima, o advento do programa Minha Casa, Minha Vida enseja um parêntese explicativo. No entanto, não será empreendida uma análise aprofundada do programa, remetendo o leitor a diferentes obras referências sobre a constituição do programa, sua trajetória e os interesses do setor empresarial contemplados com ele (SANTO AMORE, SHIMBO \& RUFINO, 2015; KLINTOWITZ, 2015; EMILIANO, 2016; ARAGÃO, 2017; FIX, 2011), restringindo a abordagem ora empreendiada apenas aos aspectos mais importantes para compreensão do seu impacto sobre as iniciativas de urbanização de favelas. 
A crise internacional de 2008 foi o pretexto para o lançamento do $\mathrm{PMCMV}^{23}$ no início de 2009, ampliando o volume de recursos destinados ao setor (ARAGÃO, 2017) e recolocando oferta/provisão de novas habitações como uma questão central da agenda nacional (KLINTOWITZ, 2015). Concebida desde o início como política de grande escala, tinha como meta inicial a construção de 1 milhão de moradias, posteriormente ampliada para 3,4 milhões na sua segunda fase, em 2011. Seu objetivo era criar condições de ampliação do mercado habitacional para atendimento das famílias com renda correspondente a, no máximo, 10 salários mínimos. Com uma meta ambiciosa e um grande volume de recursos (quase 3\% do Produto Interno Bruto (PIB) nacional em 2012), o PMCMV se tornou o grande protagonista da produção habitacional no início da década de 2010 (ROLNIK, KLINTOWITZ \& IACOVINI, 2014).

As facilidades que o programa oferecia fizeram com que se tornasse também o centro da política habitacional municipal. Assim, paralelamente à ascensão desses investimentos federais, constata-se que os municípios deliberadamente abrem mão da possibilidade de autonomia na definição da política habitacional (ou seja, realizar ações aderentes à realidade de seus territórios, como a intervenção em favelas, por exemplo) e redirecionam suas ações no sentido de apenas potencializar sua capacidade de captação de verbas federais. Muitos

\footnotetext{
${ }^{23}$ Sobre o lançamento do MCMV, é importante conferir o trabalho de Klintowitz (2015), a qual demonstra como as bases estabelecidas para o programa vão sendo construídas antes mesmo da eleição de Lula em 2002, estando presentes já no Projeto Moradia formulado no âmbito do Instituto Cidadania. "Após a campanha derrotada de 1998, Lula propôs a ideia de formular um plano habitacional que permitisse equacionar, em um período determinado pelo estudo, o problema habitacional no Brasil. A proposta fazia parte de várias iniciativas que o Instituto Cidadania, criado por Lula, vinha formulando, a fim de construir projetos de desenvolvimento nacional que associassem o enfrentamento da questão social com o crescimento econômico e geração de empregos, visando as eleições de 2002. (...) O documento continha uma proposta para "reconstruir as cidades" e viabilizar a habitação social para a baixa renda em larga escala, por meio de um projeto construído e pactuado entre diferentes setores, como políticos, empresários da construção civil, profissionais, sindicalistas e movimentos sociais (INSTITUTO CIDADANIA, 2000). (...) Para os agentes envolvidos na política - públicos e privados - foram definidos papéis e esclarecidas as necessidades de articulação. Assim, a produção privada lucrativa deveria ser estimulada a produzir moradias para as faixas de rendas mais baixas, excluídas do mercado até aquele momento, de forma a aumentar mais rapidamente a oferta de moradias para essas camadas da população, o que simultaneamente ocasionaria ganhos de produtividade e redução de custos para as empresas. (...) Na proposta do Projeto Moradia, o setor produtivo da construção civil ganhou destaque por seus "efeitos multiplicadores facilmente mensuráveis" e por sua importância no cenário econômico nacional (KLINTOWITZ, 2015, p. 127-130).
} 
deles têm, no máximo, centrado seus esforços em usar seu capital político em articulações para fazer "rodar" tais programas e políticas em seus territórios (ROLNIK ET AL, 2014).

Com a produção numa mão [PMCMV] e a urbanização na outra [PAC] o governo federal cumpriria o seu papel de financiador da política urbana e habitacional, reservando aos municípios a tarefa de alimentar fundos e políticas próprias, de assumir o comando da política urbana, conforme determina a Constituição Federal, conforme se delineou na construção histórica do Sistema Nacional de Habitação de Interesse Social, e como (de algum modo) se fez durante os quase 20 anos que separaram a extinção do BNH e a criação do Ministério das Cidades. Mas não é bem assim: os dois programas são mandatórios e acabam confinando os outros entes federativos a funções operacionais, à tarefa de "fazer rodar" as iniciativas federais - prevalecendo o MCMV que praticamente "roda" sem a interferência e o controle dos poderes públicos, submetendo o desenvolvimento das cidades a lógicas determinadas pelos proprietários de terras, pelos interesses do setor imobiliário e das empresas de construção civil. E nesse círculo de interesses privados, as reais carências e necessidades habitacionais da população são absolutamente escanteadas - e particularmente da população mais pobre, afinal, na trilha de Bolaffi, a baixa renda (e a desigualdade social) é a raiz do problema (SANTO AMORE ET AL, 2014, p. 03-04).

Ao reassumir o protagonismo no financiamento de ações no campo habitacional na década de 2000, o Governo Federal retoma seu papel de histórico indutor dessas políticas e, com isso, impacta as ações de urbanização de favelas ao progressivamente priorizar o MCMV e diminuir peso do investimento no PAC-UAP, conforme observado nas tabelas abaixo. Se o valor bruto investido em urbanização de favelas oscila ao longo dos anos, havendo acréscimos e decréscimos, verifica-se, contudo, que esteve sempre inferior ao montante destinado ao MCMV desde o lançamento deste. De 87\% do orçamento executado em 2007 no segmento habitacional, o PAC-UAP caiu para apenas 13,8\% em 2014. 
Tabela 6 - Recursos orçamentários executados do FNHIS, PAC e PMCMV (2006 - 2014) (em bilhões R\$)

\begin{tabular}{lcccc}
\hline $\mathbf{A N O}$ & FNHIS & PAC FAVELAS & MCMV & TOTAL \\
\hline $\mathbf{2 0 0 6}$ & 1,00 & 1,52 & - & 2,52 \\
$\mathbf{2 0 0 7}$ & 0,30 & 1,97 & - & 2,27 \\
$\mathbf{2 0 0 8}$ & 0,80 & 2,70 & - & 3,50 \\
$\mathbf{2 0 0 9}$ & 1,01 & 3,88 & 5,25 & 10,14 \\
$\mathbf{2 0 1 0}$ & 0,17 & 1,88 & 6,68 & 8,73 \\
$\mathbf{2 0 1 1}$ & 0,51 & 2,15 & 10,98 & 13,64 \\
$\mathbf{2 0 1 2}$ & 0,13 & 3,20 & 12,55 & 15,88 \\
$\mathbf{2 0 1 3}$ & 0,21 & 3,65 & 15,63 & 19,49 \\
$\mathbf{2 0 1 4}$ & 0,05 & 2,70 & 16,80 & 19,55
\end{tabular}

Fonte: Klintowitz, 2015, p. 239 (com dados do SIGA Brasil - Acompanhamento da execução orçamentária da União, entre 2006 e 2014. Disponível em: http://www12.senado.gov.br/orcamento/sigabrasil).

Tabela 7 - Recursos orçamentários executados do FNHIS, PAC e PMCMV (2006 - 2014) (em \%)

\begin{tabular}{ccccc}
\hline ANO & FNHIS & PAC FAVELAS & MCMV & TOTAL \\
\hline $\mathbf{2 0 0 6}$ & $40 \%$ & $60 \%$ & - & $100 \%$ \\
$\mathbf{2 0 0 7}$ & $13 \%$ & $87 \%$ & - & $100 \%$ \\
$\mathbf{2 0 0 8}$ & $23 \%$ & $77 \%$ & - & $100 \%$ \\
$\mathbf{2 0 0 9}$ & $10 \%$ & $38 \%$ & $52 \%$ & $100 \%$ \\
$\mathbf{2 0 1 0}$ & $2 \%$ & $22 \%$ & $77 \%$ & $100 \%$ \\
$\mathbf{2 0 1 1}$ & $4 \%$ & $16 \%$ & $80 \%$ & $100 \%$ \\
$\mathbf{2 0 1 2}$ & $1 \%$ & $20 \%$ & $79 \%$ & $100 \%$ \\
$\mathbf{2 0 1 3}$ & $1 \%$ & $19 \%$ & $80 \%$ & $100 \%$ \\
$\mathbf{2 0 1 4}$ & $0,2 \%$ & $13,8 \%$ & $86 \%$ & $100 \%$
\end{tabular}


Fonte: Klintowitz, 2015, p. 240 (com dados do SIGA Brasil - Acompanhamento da execução orçamentária da União, entre 2006 e 2014. Disponível em: http://www12.senado.gov.br/orcamento/sigabrasil).

Mais do que isso, não se tratava apenas de uma questão orçamentária. Houve um verdadeiro um redirecionamento também do investimento político e institucional da gestão federal para a provisão habitacional. Como descrito por Klintowitz (2015), a União passa a fixar sua atenção apenas no componente da provisão, relegando a segundo ou terceiro planos outras modalidades de enfrentamento às diferentes necessidades habitacionais, incluídas no SNHIS/FNHIS e no PAC-Favelas. O programa não rodava na velocidade que 0 governo federal desejaria, segundo apurou a autora em entrevistas com gestores federais.

Em diferentes trabalhos (ROLNIK, KLINTOWITZ \& IACOVINI, 2014; PETRAROLLI, 2015; CARDOSO \& DENALDI, 2018) são apontadados fatores que se somam a esse nas "desvantagens" oferecidas pelo PAC-UAP (e na urbanização de favelas como um todo) frente às "vantagens" apresentadas pelo MCMV (e historicamente pela provisão habitacional). Primeiramente, a implementação do PAC-UAP, desde o tempo até seus resultados, teriam sido mais influenciados pelos contextos locais encontrados, tanto em relação à experiência prévia com o tema pelo ente federal responsável pela implementação da iniciativa (CARDOSO \& DENALDI, 2018), quanto pelas condições e arranjos político e econômicos verificados em nível local (PATRÍCIO, 2017; ENTREVISTADO 07), como pelas próprias configurações territoriais dos assentamentos (CARDOSO \& DENALDI, 2018).

Dependia também das condições institucionais do próprio Governo Federal, o qual possuía um papel maior na seleção dos projetos a serem apoiados no PAC-UAP em relação ao $M C^{24}$. "O próprio processo de seleção dos projetos, por tratar-se de uma seleção pública, é muito moroso e passa por

\footnotetext{
${ }^{24}$ Conferir Klintowitz (2015) para comparação aprofundada dos processos seletivos do PAC e do MCMV.
} 
muitas esferas de decisão" (KLINTOWITZ, 2015, p. 240-241). De acordo com entrevista de partícipe da gestão federal na época para esta tese, o próprio Ministério das Cidades estava congestionado com a análise das solicitações apresentadas no âmbito do programa (ENTREVISTADO 07). As condições de capacidade institucional dos entes federados no setor da habitação e, mais especificamente, no campo da urbanização de favelas foram fatores que impactaram, muitas vezes, negativamente a eficiência de iniciativas no âmbito do programa. Torna-se irônica essa conclusão diante do fato de que, tanto o lançamento do PAC-UAP quanto do MCMV, haviam atropelado 0 desenvolvimento do SNHIS/FNHIS (KLINTOWITZ, 2015), o qual apresentava, como um de seus fundamentos, justamente o fomento à constituição de capacidades institucionais no campo nos diferentes entes da federação.

O próprio escopo da intervenção financiado pelo PAC-Urbanização era em si mais complexo do que o esquema de provisão preconizado pelo MCMV. Aquelas iniciativas demandam processos mais complexos do ponto de vista do diagnóstico, do exercício projetual, da negociação das intervenções, da realização das obras físicas (já que muitas vezes os moradores permanecem no local), dentre inúmeros outros fatores. Há um ritmo mais lento de apresentação de resultados apresentados pelas intervenções em assentamentos precários (PETRAROLLI, 2015).

Não é à toa que, na segunda fase do PAC, o MCMV entrou como componente da intervenção, já que era visto como mais bem sucedido desse ponto de vista. É simbólico, nesse sentido, que o nome do eixo do PAC no qual a urbanização de favelas estava incluída foi até mesmo alterado de "Infraestrutura Social e Urbana" (PAC-1) para eixo "Minha Casa, Minha Vida" no PAC-2. Isso, no entanto, desconsiderava que a lógica deste programa - fortemente estandardizada (SHIMBO, 2010) - pouco dialogava com as inúmeras realidades e necessidades dos assentamentos, sendo sua inclusão, portanto, questionada (PATRÍCIO, 2017; CARDOSO \& DENALDI, 2018).

Entre as mudanças estabelecidas para o PAC-UAP na gestão da Presidente Dilma Rousseff, destaca-se a adoção do PMCMV como o meio para a produção de habitações novas nos contextos das urbanizações de favelas executadas com recursos do Programa de Aceleração do Crescimento (PAC), justificada em função de sua maior agilidade na elaboração de projetos e realização das licitações de obras. Essa mudança tem forte impacto na qualidade das novas 
moradias produzidas no âmbito da urbanização de favelas para desadensamento, uma vez que as experiências que vinham se desenvolvendo na primeira fase do PAC-UAP mostravam maior qualidade de projeto $e$ maior adaptação às necessidades dos moradores. Com a mudança, as soluções passam a ser padronizadas e produzidas em grande escala, o que implicou também em mudanças na localização das novas unidades produzidas. (PATRícIO ET AL, 2018, p. 08).

Apesar desses impactos, o MCMV apenas ganha maior visibilidade e sucesso político desde então. Se em 2010 foi um importante capital para a eleição de Dilma Rousseff à presidência, conhecida como a "mãe" do MCMV; isso significava que gerava um grande capital político junto à população. Ainda mais do que o BNH, o impacto do MCMV foi muito além da ampliação das condições de aquisição de unidades habitacionais por parte de milhares de famílias de classe média e baixa. Mesmo aquelas famílias que não puderam aceder ao programa foram, de alguma forma, conquistadas pela simples possibilidade de um dia se tornarem beneficiárias dos programas. O MCMV conseguia canalizar de forma mais eficiente, portanto, toda a imagem simbólica conferida pela construção do papel ideológico da moradia (ROLNIK, 2015; RONALD, 2008) no imaginário popular como o "sonho da casa própria". Diante da trajetória instável da economia brasileira, isso possui um grande apelo, tendo em vista que pode vir a constituir um lastro que amenize possíveis oscilações do poder aquisitivo destas famílias (ROLNIK, 2015; ENTREVISTADO 01). Ganhava-se ainda mais politicamente, portanto, com um programa mais simples e desgastava-se menos no processo de financiamento, conforme gestor público do Ministério do Planejamento entrevistado por Klintowitz (2015, p. 242).

O que aconteceu com a área de urbanização de favela do PAC é que o resultado da urbanização de favela foi muito ruim, sob o aspecto da execução, não sob o aspecto de seu resultado qualitativo, mas a sua execução mesmo. Então a gente pega a carteira do Minha Casa [Minha Vida], a urbanização de favela, é $0,5 \%$ ao mês do Minha Casa. E o PAC é um programa que tem meta, então isso é muito ruim para o país. O PAC tem meta, a gente se compromete a fazer tantos bilhões de execução no período de 4 anos, e a gente tem um conjunto de obras muito grande do PAC 1 ainda, que não saiu do lugar. Agora, por que não sai? É complexo investir em favela, é muito complexo, nem preciso falar. Embora o governo tenha consciência disso, eu não nego que houve um, "Põe o pé no freio, vê se vocês conseguem acabar isso, e vamos investir mais no Minha Casa [Minha Vida]" (DEPOIMENTO DE GESTOR A KLINTOWITZ, 2015, p. 242).

Essa perspectiva partia, além da análise dos elementos quantitativos de execução do programa, também da própria visão e sensibilidade (ou pouca sensibilidade) que a presidente dispunha para o tema. Para o gestor público comprometido, acima de tudo, com a entrega de metas (ENTREVISTADO 17) 
- lembre-se que essa foi a característica que faz Dilma ascender dentro do governo Lula (ENTREVISTADO 28) - e, ao mesmo tempo, ciente da necessidade de construção de capital político a partir da implementação de

políticas habitacionais, a escolha pareceria lógica - redirecionar a maior parte dos esforços para o MCMV - e assim a presidente Dilma determinou, conforme gestores entrevistados, alguns deles envolvidos diretamente nesse processo de redirecionamento na gestão federal (ENTREVISTADO 16; ENTREVISTADO 28; ENTREVISTADO 09; ENTREVISTADO 07).

A Dilma, por exemplo, ela deixou isso claro. Ela achava que urbanização de favelas não era programa habitacional, então ela se recusava a falar no assunto. Se você entrevistar a Inês Magalhães, ela vai te contar isso, não tinha espaço pra esse tema. Por quê? Porque por formação dela mesmo, ela não é uma pessoa do urbano, ela não conhecia os problemas urbanos, como eles são na realidade. Não é uma pessoa que foi eleita vereadora, depois prefeita, e isso influencia nas decisões dos políticos. E aí quando chega no governo federal e você tem um presidente que diz "Não, eu não gosto disso, não é programa habitacional"? 0 que você vai fazer? Não há o que fazer. (...) Pelo amor de Deus, não tem comparação [entre a compreensão do Lula em relação a Dilma para o tema] (ENTREVISTADO 09).

Aí são as escolhas politicas. A escolha política do Lula era uma escolha mais integrada que a dela e ela [Dilma Roussef] não entendia urbanização de favela. Ela não deu prioridade, ela priorizou o Minha Casa (...) [Tinha uma questão] de entender a temática, de ter uma sensibilidade para o tema, e a questão do econômico, eu acho que ele entendia a temática, ele tinha sensibilidade para o tema e ele tinha uma visão diferente do que isso significava. Ela não (ENTREVISTADO 16).

Aí você tem em 2009 o lançamento do Minha Casa, que eu acho que claramente impacta nas decisões futuras de investimento em urbanização. A presidenta tinha uma posição diferente do Lula. Não de achar menos importante, mas de ter uma dificuldade de entender o processo de urbanização como um processo integral, tinha uma visão assim de "Eu já dou saneamento, dou a casa, o município que arrume lá e faça", uma coisa de que os municípios poderiam e deveriam fazer a urbanização a partir dos programas setoriais de habitação, saneamento e tal. Nós continuamos com os investimentos e tal, nós tivemos o PAC 2, já um processo de seleção na Dilma, tudo bem, mas com questionamentos mais por conta das dificuldades de entrega que esses projetos tinham também. Enfim, é um tema que não dá pra ignorar totalmente. É essa coisa, você tinha uma coisa de execução as vezes de $5 \%$ de execução em 6 meses, quer dizer, se você olha o gráfico de execução... (ENTREVISTADO 07).

Quando a Dilma busca acelerar o programa Minha Casa, Minha Vida e gerar indicador com isso, independente da qualidade cidade que ela está gerando, tinha um ponto nobre: enfrentar o deficit quantitativo. Ela busca capturar recursos de tudo quanto é lado, e como o que importava era indicador, e não se discutia efetividade, mas se discutia indicador, obviamente as iniciativas que foram iniciadas com o PAC não conseguiria responder com indicadores de eficácia, e nesse sentido eles começaram a ficar relegados a segundo plano. Então não foi uma decisao que poderia ser até de caráter ideológico, "eu quero botar mais força aqui, então retira aqui". Não, foi uma decisao de indicador de eficácia, "Olha, eu não estou conseguindo resultado aqui, enquanto isso não gera resultado final, eu estou gerando novas unidades e estou gerando publicidade com isso também". (...) [Está gerando] resultado, publicidade, enfim, gerando, de alguma forma gerando algum tipo de dividendo para a sociedade e 
entendendo as contradições que já estavam acontecendo num conjunto de PACs dado o nível de complexidade que foi assumido (ENTREVISTADO 04).

Como os entrevistados apontam, toda a lógica de intervenção federal passa a ser dominada pela lógica que Dilma operava desde que se tornou chefe da Casa Civil ainda no governo Lula, sob a qual fazia muito mais sentido o número de unidades entregues pelo MCMV do que a abstração do atendimento por ações de urbanização de favela através do PAC-UAP (ENTREVISTADO 28). O que ainda resiste no âmbito do PAC 2 havia sido uma luta travada por integrantes do Ministério das Cidades que defendiam esta forma de intervenção (ENTREVISTADO 07; ENTREVISTADO 28).

Além dos números propiciados pelo programa, a própria visibilidade promovida pelas novas unidades do MCMV (inclusive mesmo no aspecto fotográfico) também são mencionados por entrevistados como fator que pesa no balanço político entre a priorização de agendas "provisão x urbanização".

Produzir casa, entregar a chave, ela tem uma visibilidade maior, ela tem uma governabilidade maior. Você constrói em um terreno limpo, você licita, você entrega, ela tem uma velocidade maior do que a urbanização da favela, ela mostra resultados "mais rápidos". A sociedade de uma certa forma, inclusive olha e fala "Está lá, construiu essas moradias". Mas a favela você sabe quando você vai começar e você não sabe quando você vai terminar, é super complexo, é super demorado. (...) Visualmente, na hora que você mostra, há uma certa preferência, uma preferência política pela rapidez, pela visibilidade, pela facilidade e eu acho que há uma maior aceitação da sociedade com as outras classes sociais, muita gente ainda acha que a favela tem que ser banida do mapa (ENTREVISTADO 17).

Conquanto essa visão tenha influenciado diretamente as ações federais no campo e, consequentemente, nos governos locais; trata-se efetivamente de uma questão mais ampla do reconhecimento social e político da urbanização de favela como forma estratégica de intervenção estatal no campo habitacional. É uma disputa com a provisão habitacional que já vem acontecendo há décadas no Brasil, mesmo em gestões progressistas reconhecidas pela sua intervenção em favelas, como a de Erundina (ENTREVISTADO 23). Disputa essa que também se verifica na Colômbia, como se aborda a seguir.

A partir das entrevistas e da literatura sistematizada para o caso colombiano, parece ser possível identificar ambiguidades no tocante à disputa "provisão $\mathrm{x}$ urbanização". No tocante ao discurso dos entrevistados e dos autores analisados, é possível perceber, por um lado, a importância conferida à adoção 
de ações complementares no campo habitacional, afirmando que há que se preconizar uma abordagem que tanto promova a melhoria das condições dos assentamentos existentes quanto amplie o acesso da população pobre a alternativas de novas moradias adequadas (ENTREVISTADO 25; ENTREVISTADO 02; ENTREVISTADO 24; ENTREVISTADO 20). Nesse sentido, não parece haver uma priorização de qualquer uma das formas sobre a outra, sendo ambas necessárias e complementares.

No entanto, o discurso se torna veemente, tanto para o caso de Bogotá quanto de Medellín, ao afirmar que a produção dos assentamentos informais está diretamente conectada com a incapacidade de o estado prover moradia adequada para as famílias pobres, as quais também estão excluídas do mercado formal. Nesse sentido, atrelam fortemente o discurso da urbanização de favelas à provisão de moradia, a qual seria essencial para que se combata as raízes do "problema" da informalidade, sob o perigo de não se resolver a questão e haver constantemente a demanda pela urbanização. Assim, se este discurso coloca a necessidade de iniciativas de urbanização, ele também coloca a provisão como central e estrutural para a resolução do crescimento informal e precário, gozando de um status superior à urbanização, que seria apenas a remediação da situação já instalada. A disputa entre ambas formas de intervenção no campo habitacional, portanto, parece ser uma causa já ganha pela provisão (alçada ao lugar de solução estrutural da problemática) mesmo no campo acadêmico e de setores profissionais que não fazem parte neste momento de gestões públicas.

Da mesma forma, é reforçado no âmbito do discurso dos municípios a importância do mejoramiento barrial (ENTREVISTADO 10; ENTREVISTADO 08) e sua complementaridade em relação à oferta/provisão, mas a avaliação da implementação demonstraria que na prática o mejoramiento gozaria de uma baixa prioridade na agenda política dos governos e a oferta/provisão teria historicamente uma primazia em relação ao primeiro por diferentes fatores (ENTREVISTADO 25; ENTREVISTADO 02; ENTREVISTADO 15).

Um destes primeiros fatores apontado pelos entrevistados é a seletividade em função da rentabilidade política, recaindo a escolha sobre aquela forma de 
intervenção que requer menor esforço e oferece maior retorno eleitoral. "En general los políticos el tema del mejoramiento, eso no los interesa porque eso no les da votos. Entonces, los políticos, en el caso nuestro, lo que les interesa es la vivienda nueva" (ENTREVISTADO 20).

A explicação fornecida pelos entrevistados para esta menor rentabilidade do mejoramiento em relação à oferta/provisão de novas unidades estaria ligada a duas questões importantes para a reprodução dos mandatos eleitorais nas cidades colombianas: o financiamento das campanhas eleitorais e a visibilidade dos investimentos realizados. Ambos os fatores impactariam diretamente no capital eleitoral fornecido por cada uma delas e consequentemente na priorização realizada.

Primeiramente, a disputa entre urbanização e oferta/provisão apresentada com relação aos processos eleitorais e períodos de campanha está diretamente atrelada ao fator da visibilidade propiciada por cada uma destas modalidades. Este elemento goza no país de uma centralidade no processo de reprodução/manutenção de grupos políticos por consubstanciar a expressão de seu poder, uma das funções materiais das cidades colombianas (PATIÑO, 2015, p. 42).

Nesse sentido, o mejoramiento novamente ofereceria menores vantagens do que a modalidade de oferta/provisão de novas unidades, fornecendo créditos políticos diferentes. A materialização propiciada pela produção de novas unidades seria mais emblemática, despertaria maior atenção dentre os eleitores (ENTREVISTADO 02) e seria mais expressiva quantitativamente, gerando capital político mesmo entre aqueles não diretamente beneficiados por ela. Assim, mesmo que muitas vezes não atinja, por exemplo, a faixa de renda mais baixa da população, como aconteceu ao longo das últimas décadas (MINISTERIO DE VIVIENDA, 2014), esta população de alguma maneira se vê seduzida por estes números, na esperança de ser contemplada em algum momento. A oferta/provisão de novas unidades, portanto, atinge tanto aqueles que são quanto aqueles que não são contemplados por ela.

Por outro lado, o mejoramiento teria uma menor potência para constituir uma imagem síntese de realização, oferecendo uma menor visibilidade e 
usualmente gerando capital político apenas entre aqueles diretamente impactados pelas intervenções (ENTREVISTADO 02). "Lo mejoramiento barrial dan votos, pero ellos [alcaldes] no lo consideran. Por eso no hay inversiones allá. (...) Porque para ellos no tiene la visibilidad suficiente, ni la capacidad de amargo político. Entonces no hacen inversión allí. Lo importante para ellos no son las personas que van a ser beneficiadas, pero la visibilidad política de las obras o de los megaproyectos" (ENTREVISTADO 20).

Em relação ao segundo fator, o financiamento de campanhas eleitorais, é colocado que existe uma forte dependência do setor privado (ENTREVISTADO 20), desempenhando a indústria da construção - principalmente as grandes empresas do setor - um papel central no financiamento dos partidos políticos (Torres, 2013). As construtoras/empreiteiras são, portanto, importantes para os governos, tanto nacional quanto locais, não apenas pela sua atividade ser um importante mecanismo de aquecimento da economia, mas também pelo seu apoio político, tanto utilizando suas redes pessoais e seu alcance enquanto grupo empresarial quanto em recursos para financiamento de campanhas eleitorais (ENTREVISTA YENCY ENTREVISTADO 25).

Esa diferencia entre producción de vivienda nueva y mejoramiento barrial creo que tiene que ver con los intereses de los electores. Creo que [la vivienda nueva] tiene un mayor impacto en el capital electoral. (...) Hay mayores efectividades frente unas prácticas que frente a otras, mientras que cuándo generas vivienda nueva políticamente sigue siendo correcto, pero si además les da condiciones, les abre el mercado para el sector de la construcción que es uno de los que más te financian campaña. En Bogotá esas administraciones son muy evidentes y es que setenta y cinco por ciento de los ingresantes en la campaña Peñalosa [actual alcalde] vino del sector de la construcción (ENTREVISTADO 02).

Este interesse também estaria por trás da atuação do governo nacional, que basearia toda sua estratégia política em relação ao Ministério de Vivienda de acordo com os acordos estabelecidos com a CAMACOL (Câmara Colombiana de la Construcción), associação que reúne as maiores empreiteiras e construtoras do país e que tem sido a responsável pela indicação dos ministros a ocupar a pasta (ENTREVISTADO 25; GIRALDO, 2015).

En tal circuito administrativo y político el Ministerio de Vivienda selecciona los proyectos, define los diseños y escoge los contratistas para la construcción. Finalmente, el Vicepresidente inaugura y entrega personalmente las viviendas. Nunca antes como en este periodo ha habido tal cantidad de cambios normativos atemperando la vivienda a los circuitos de los cuales ha entrado a hacer parte. Leyes, decretos, documentos del Consejo Nacional de Política Social CONPES, entre otros, son adaptados a las necesidades y al ritmo en que el Gobierno 
Nacional agencia su política (...) De esta manera se consolida un sector de la construcción beneficiario, tanto del presupuesto que el Estado destina a la política de vivienda, como de la captura de la casi totalidad de la renta del suelo, producto de esa misma dinámica. Esto ha consolidado un circuito económico del cual hacen parte los promotores y constructores de vivienda, los terratenientes urbanos, los productores de insumos para la construcción y la banca privada. En algunos casos no son varios actores, sino una única hidra que conforma dicho circuito y acapara varios proyectos (Plataforma del Derecho a la Ciudad de Bogotá, 2016).

A justificativa para esta postura do governo nacional, portanto, estaria na centralidade que a indústria da construção teria do ponto de vista macroeconômico. Há décadas, esta é considerada, sob um enfoque produtivista, um dos principais mecanismos de fomento ao crescimento da economia nacional (MINISTÉRIO DE VIVIENDA, 2014). Isto se intensifica a partir da década de 1990, quando se adota um enfoque neoliberal para a política habitacional (TOVAR, 2012, p. 22) que transfere para o mercado a sua promoção, fase denominada pelo próprio governo nacional, no resgate dos últimos 100 anos de política habitacional, como a de "La concepción de mercado y los subsídios a la demanda (1990 - dias atuais)" (MINISTERIO DE VIVIENDA, 2014, p. 39).

En Colombia su aplicación [de la política de vivienda] adquiere un manifiesto énfasis económico, puesto en evidencia en las consideraciones, definiciones y justificación de las inversiones públicas en los Planes de Desarrollo nacionales, específicamente desde "Las Cuatro Estrategias" (1970), donde la vivienda, en general, y la de interés social, en particular, es percibida como una actividad edificadora que simultáneamente cumple un papel dinamizador de la economía y promueve el ahorro interno satisfaciendo la demanda social y de generación de empleo.(...) Este enfoque ha trascendido a las políticas habitacionales públicas del Estado colombiano y durante cerca de medio siglo muestra una tensión no resuelta entre mercado y demanda. (...) El énfasis de las políticas ha estado, entonces, en la producción de viviendas nuevas, antes que en el mejoramiento del stock existente, puesto que el mejoramiento de barrios es una actividad poco reconocida y apoyada institucionalmente; más bien es desarrollada de manera espontánea por los habitantes. (...) como consecuencia de las últimas decisiones del Ministerio de Ambiente, Vivienda y Desarrollo Territorial, el énfasis se mantendrá particularmente en la titulación (País de Propietarios) y en la asignación de subsidios a las familias más vulnerables para la construcción y adquisición de viviendas nuevas, con la regularización y estandarización de la vivienda de interés social, VIS, de acuerdo con los Decretos 975 de 2004 y 2060 de 2004 (TOVAR, GARCIA \& MORENO, 2009, p. 177-178).

Esta conjunção de interesses, tanto nacional como local, influenciaria para que sejam destinados, historicamente, menos recursos ao mejoramiento (PINTO, 2012, p. 82; ENTREVISTADO 20). Isso estaria evidente, por exemplo, no plano de desenvolvimento apresentado pelo atual prefeito de Bogotá, com um evidente foco em novas unidades (ENTREVISTADO 02). 
La verdad no hay muchas expectativas porque este alcalde, lo que viene planteando es que la ciudad tiene que seguir expandiendo, que tiene que prever las viviendas que se necesitan de aquí a 2050 y está planteando que de aquí a allá se necesitan, por lo menos, 1.800 .000 viviendas más en esta ciudad. Entonces está planteando urbanizar el río Bogotá, que hay que urbanizar una zona de reservas forestales. 0 sea, digamos, eso me ratifica la idea que le digo, que en términos de votos, si en política lo que importa es la producción de viviendas nuevas (ENTREVISTADO 20).

Isto não significa que o mejoramiento barrial não possua qualquer importância para o financiamento de campanha e dos grupos políticos nas cidades. Conforme será visto na seção 2.2, os contratos efetuados com pequenas e médias empresas para urbanização nas cidades colombianas também contribui para alimentar a reprodução dos mandatos eleitorais. De toda forma, o setor interessado na provisão habitacional possui um peso maior nesse processo e, assim, um poder de influência maior.

No Brasil, o entrelaçamento "estado-setor privado da construção" também teve como uma de suas bases a utilização durante décadas do financiamento de campanhas. Dentre essas, as macro-empreiteiras (envolvidas no PAC-UAP) possuem um lugar de destaque dentre os doadores, como demonstrado por lacovini (2013). Dessa forma, o PAC-UAP proporciona, pela primeira vez, um volume de recurso realmente significativo direcionado pelo Governo Federal à urbanização de favelas de caráter redistributivo (CARDOSO \& DENALDI, 2018), mas atendendo simultaneamente a interesses do setor empresarial, como o caso do Rio de Janeiro e São Paulo demonstram na seção 2.2.

Todas essas formas de intervenção, não somente no Rio de Janeiro, mas no país como um todo, foram importantes para que o PAC-Urbanização pudesse cumprir com seu papel na coordenação de interesses promovida no âmbito da política habitacional do governo Lula, como observado por Klintowitz (2015). Era de se esperar, portanto, que buscassem influenciar na continuidade deste programa, já que estavam sendo beneficiadas através dele. Esses atores, contudo, tem uma trajetória atrelada mais fortemente a outras espécies de obras públicas (rodovias, usinas, etc.), sendo a urbanização de favela interessante apenas quando atrelada a uma intervenção maior e como forma de diversificação de atuação, como visto na seção 2.2. O PAC, com seus outros eixos de investimento, podia continuar atendendo ao interesse desses grupos independentemente dos investimentos em favela. 
Dessa forma, toda a reorientação operada em nível federal, guinando do PACUAP para o modelo MCMV, continua atendendo a interesses do setor da construção e com isso mantendo seus integrantes na base de apoio do governo. Além disso, havia o outro lado da coordenação de interesses promovida pela política habitacional do período Lula: o programa Minha Casa, Minha Vida. Nesse sentido, o governo aumenta ainda mais o leque de grupos empresariais atendidos, os quais já vinham sendo beneficiados pelas reformas no setor imobiliário, mas que passam a gozar também de um grande financiamento de suas atividades (KLINTOWITZ, 2015).

Os empreiteiros da construção que mobilizam o Minha Casa, Minha Vida não tem o menor interesse em fazer urbanização em favela. (...) Essas empresas que venderam a ideia do Minha Casa, Minha Vida, você sabe que elas se transformaram, as empresas, as maiores empresas de construção do Brasil. Eles gostam de fazer isso: você vai lá com o terreno vazio, eles tem $100 \%$ de lucro em cada casa, e faz rápido, a prefeitura tem que aprovar e tal. Agora imagina uma urbanização, tem que chegar lá, conversar com a comunidade, de vez em quando chove e para, cai casa, o cara reclama... (ENTREVISTADO 09).

A reorientação promovida, portanto, atende a esse setor sem necessariamente desamparar as macro-empreiteiras. Ainda por cima, essa guinada realiza ainda uma mudança estrutural perceptível: o grosso do protagonismo das iniciativas habitacionais passa das mãos dos governos locais para o empresariado.

O PMCMV, lançado em 2009 como medida de combate à crise internacional, vai alocar um nível de recursos sem precedentes, implementando uma nova estratégia de combate ao deficit habitacional pela produção em massa de novas habitações. Já com as primeiras avaliações do PAC-UAP, mostrando dificuldades na execução na execução do programa e com o objetivo de cumprir metas de produção elevadas, o Governo desenha um modelo institucional orientado para e pelo mercado. O PMCMV retira das esferas estaduais e municipais o papel de agente promotor, como acontecia no PAC-UAP, passando o poder de definir a oferta (localização, faixa de renda e projeto) para as empresas de construção civil (PATRICIO, 2017, p. 108).

Não que muitos governos locais tenham se ressentido dessa mudança. Ao contrário, como pode ser visto em pesquisa realizada por Rolnik, Klintowitz e lacovini (2014), diversos municípios aparentavam conformados com o novo papel atribuído a eles, gozando de capital político gerado pelo MCMV sem tanto dispêndio de energia. Por outro lado, isso significava uma maior satisfação de interesses de grupos empresariais, cujas operações encontravam-se mais fortemente sob seu domínio. Isso significa que as ações de urbanização de favelas não atendiam aos interesses de setores econômicos 
da construção civil? Nada mais longe da verdade do que essa hipótese, como será demonstrado a seguir.

\subsection{A política alimenta o Capital}

Historicamente, as contratações no âmbito de programas de urbanização de favelas se deu, primeiramente, dentre pequenas e médias empresas do setor da construção. Em avaliação de experiências em diversos estados brasileiros, Abiko (2009, p. 406) constata que a regra geral das ações de urbanização até então foi sua definição e condução pelo poder público através da licitação e contratação tanto de projetos como da execução das obras. Como atestam diferentes entrevistados participantes dos primórdios dessas políticas, no entanto, uma das primeiras dificuldades encontradas para serem bem sucedidas era justamente encontrar empresas dispostas a atuar na área, principalmente na década de 1980 (ENTREVISTADO 12; ENTREVISTADO 18). Isso teria levado a pioneiros, como Diadema, a estatizarem os serviços de construção em obras de urbanização ou à sua realização em regime de mutirões de moradores (ENTREVISTADO 12).

Apesar dessa experiência, empresas construtoras participaram ou foram contratadas em diferentes programas e projetos de urbanização de favelas desde então (BUENO, 2000, p. 31). Dentre essas encontravam-se, principalmente nas experiências pioneiras, pequenas (BUENO, 2000, p. 129) e médias empreiteiras (BUENO, 2000, p. 80, p. 200). Esse foi o caso da administração de Erundina em São Paulo, no início da década de 1990, conforme depoimento abaixo de integrante da gestão.

No caso de urbanização de favelas foi a mesma coisa, a gente sempre precisaria ter uma construtora fazendo o início, a parte de infraestrutura, que precisa inclusive às vezes mais de mão de obra especializada do que até edificação. Pra você ter uma ideia, uma vala pra poder colocar a rede de esgoto, as vezes você tem que fazer uma escavação, é considerada normal uma escavação até 4,5 metros, uma escavação de 4,5 metros você não pode colocar um auxiliar de pedreiro pra fazer, você tem que colocar... tem que estaquear, ter equipamentos adequados, então você não pode colocar uma rede de esgoto e ela estar fora do prumo, você precisa ter mão de obra qualificada mesmo pra fazer. Então logo no começo da gestão foi definido que nós faríamos uma contratação através de ata 
de registro de preços. (...) E esses contratos pra favela foi muito difícil, davam vazio, nenhuma empresa se interessava. Depois nós fizemos um ajustamento de colocar, vamos dizer, uma taxa, eu não me lembro agora o valor, mas um adicional de dificuldade, por ser favela, porque por exemplo, você vai fazer uma escavação em favela, mas é um terreno que pode ter embaixo lixo, pode ter sido aterrado com material inadequado, então as vezes você tem surpresas, então a obra fica mais caro do que se você fosse fazer um loteamento normal, um conjunto habitacional do zero. Então nós fizemos esse ajuste e mesmo assim, a gente queria contratar uma empresa por região da cidade, ai já tinha área que já tinha se subdividido, e no final apenas uma empresa se apresentou e ela acabou... A gente ficou num impasse, ou você demorava mais 6 meses pra fazer uma nova licitação ou imaginava que a empresa ia dar conta, porque ela tinha feito propostas pra diversas regiões da cidade, então em alguns casos essa empresa conseguiu executar, em outros casos ela atrasou, teve problema de capacidade operacional dela limitada e tal, mas foi isso, foi assim que nós agimos. Mas os projetos não eram realizados pela construtora. Nós fazíamos, nós contratávamos os projetos, os levantamentos, os projetos de engenharia, de urbanismo, de edificação sendo o caso, paisagismo e tal, e depois essa empresa entrava pra executar as obras (ENTREVISTADO 23).

Como alguns entrevistados apontam (ENTREVISTADO 30; ENTREVISTADO 23; ENTREVISTADO 18), contudo, a crise fiscal e econômica da década de 1990 de alguma forma motiva a que mais empresas se interessem pelo ramo posteriormente. De acordo com o que demonstra Campos (2012), as macroempreiteiras ${ }^{25}$ brasileiras passaram por um período de diversificação de investimentos desde o final dos anos 1970. Isso pode ser observado, por exemplo, por sua participação crescente na área de saneamento (CAMPOS, 2012), viário (MARQUES \& BICHIR, 2002), rodoviário (IACOVINI, 2013) e finalmente em intervenções em favelas. Não apenas as empreiteiras, mas também gerenciadoras passam a se interessar no tema (BUENO, 2000), de acordo com depoimento abaixo.

Só depois da crise, aquela crise dos anos 90 , que as construtoras, as grandes construtoras tiveram [interesse]... Você se lembra dessa outra crise que o mercado imobiliário paralisou e tal? E foi o Programa Guarapiranga que foi tocado pela prefeitura, no caso de São Paulo, e pela Sabesp, que empresas de maior porte começaram a se interessar em trabalhar com urbanização de favelas, antes disso era muito difícil contratar empresa pra trabalhar (...) A prefeitura sempre atua através de contratação de prestadores de serviço. (...) Ela vai criando outros campos; foi o caso também da área de gerenciamento de obras. (...) $E$ ai você encontrava [gerenciadoras em] obra que precisa EIA/RIMA, quer dizer, coisas de grande escala, loteamentos de 5 milhões de metros quadrados, coisas grandes mesmo, ferrovia, rodovia, coisa assim. Com a crise fiscal dos anos 90 na prefeitura, 80 e 90 na verdade, que as prefeituras não faziam concurso, tiveram um enfraquecimento muito grande da sua estrutura. Isso

25 Classificação de empreiteiras que abrangem as maiores e mais tradicionais empresas do ramo, com atuação em grandes projetos de desenvolvimento nacionais e internacionais, a exemplo de Andrade Gutierrez, Odebrecht, Camargo Correa, Queiroz Galvão, OAS, CR Almeida, Serveng-Civilsan e Carioca, dentre outras. Para uma análise mais detalhada da trajetória e das características do setor, consultar lacovini (2013). 
calhou junto com essa crise dos anos 90 , que essas empresas gerenciadoras da área de engenharia pesada, estavam subutilizadas e ai, inclusive a prefeitura, a gestão da Luíza Erundina se beneficiou muito, porque conseguiu ter parceiros muito bons na área de gerenciamento de obras, que no passado não teriam nenhum interesse, uma boa gerenciadora, então a gente teve algumas experiências grandes (ENTREVISTADO 23).

Dessa forma, o interesse das grandes empresas do setor da construção no campo da urbanização de favelas vem, em São Paulo, principalmente ligado a obras de drenagem no âmbito do programa Guarapiranga e, especialmente, com o Cingapura lançado por Maluf. O processo já descrito de verticalização de favelas em áreas de visibilidade em conjuntos habitacionais foi realizado sob a contratação de empreiteiras (MARQUES, PULHEZ \& PAGIN, 2018), fortalecendo com as políticas executadas pelo então prefeito sua relação com um dos seus principais grupos de apoio político, o setor empresarial da construção (TEIXEIRA, 2012). “Em 44 contratos [em São Paulo na década de 1990] participam apenas cinco empreiteiras Schaim Cury, OAS, Construbase, CBPO e Camargo Correia, de um total de 53 [licitações] do Cingapura" (BUENO, 2000, p. 82).

A opção da gestão pela substituição do tecido de favela pelo clássico produto da política habitacional brasileira - a provisão de unidades em conjuntos construídos por empreitada (MARQUES, PULHEZ \& PAGIN, 2018) - não se tratou apenas de componente ideológico quanto a uma matriz de pensamento urbanístico dominante, mas de opção política em função de ganhos econômicos e eleitorais. Depoimento de integrante da gestão Maluf confirma esse amálgama de interesses.

Ele precisava dar dinheiro pra quem elegeu ele, que foram as empresas, as empreiteiras, as OAS da vida. Então ele precisava construir unidades e não tinha terreno, então onde ele vai construir, onde tem favela, então juntou o útil ao agradável. Você já tinha aquele padrão que não é aceitável e ainda dá dinheiro pros amigos, é uma forma de devolver o custo da eleição (ENTREVISTADO 19).

Em função das limitações oferecidas pelos mecanismos de busca disponíveis pelas administrações municipais e estaduais de São Paulo e, principalmente, do Rio de Janeiro, a sistematização de empresas envolvidas nas contratações de iniciativas de urbanização realizada no âmbito desta pesquisa ${ }^{26}$ não permitiu

26 Foram sistematizados, a partir dos mecanismos de buscas online disponibilizados pelas prefeituras e governos estaduais pesquisados nesta tese, os dados de contratos relativos a ações de urbanização. No caso de São Paulo, tanto o sistema municipal quando o estadual 
uma comparação segura para confirmar o quanto esse foi ou não um momento singular na trajetória de programas de urbanização de favelas. No entanto, todos os depoimentos colhidos com gestores públicos vinculados a diferentes administrações (ENTREVISTADO 23; ENTREVISTADO 19; ENTREVISTADO 14; ENTREVISTADO 12; ENTREVISTADO 18; ENTREVISTADO 04; ENTREVISTADO 07; ENTREVISTADO 01) indicam que, tanto em São Paulo como no Rio, as empresas interessadas/envolvidas nesse tipo de contrato eram (à exceção do programa Cingapura) de porte médio ou pequeno até o início do PAC-Urbanização, momento a partir do qual se passa a ter a presença de grandes e macro-empreiteiras.

É interessante destacar a estratégia adotada pelos gestores responsáveis pela política habitacional na administração de Marta Suplicy na PMSP.

O [então Secretário de Habitação] no final da gestão, ele dizia assim "Olha, é muito importante que a gente deixe essas obras licitadas, então vamos negociar com o BID pelo menos fazer projeto, porque a gente vencendo ou não vencendo a eleição, os projetos estão prontos. O próximo que entrar pode fazer, e a gente precisa deixar isso licitado", era um compromisso do Paulo com o movimento por moradia. "A gente precisa deixar esses projetos licitados, porque o dinheiro vem, porque as empreiteiras vão pressionar pro dinheiro vir, se tiver já empreiteiras vencedoras das licitações". E dito e feito, a Marta perdeu a eleição, sabe o que as empreiteiras fizeram? Começaram a bater na porta dos deputados por emendas parlamentares, a gestão Serra começou a receber recursos pra urbanizar as favelas que já tinham projeto licitado (ENTREVISTADO 14).

Apesar de ainda ser um período no qual as empresas interessadas não eram principalmente aquelas de maior porte, a equipe decidiu licitar o máximo de projetos possíveis antes do término do mandato de forma a que a gestão municipal seguinte (em caso de a prefeita não se reeleger, como de fato aconteceu) fosse obrigada, por pressão das empresas selecionadas, a dar continuidade às iniciativas. Ou seja, mesmo que na época não se tratassem de macro-empreiteiras interessadas nos projetos de urbanização de favelas, 0 poder de pressão política exercido pelas empresas selecionadas já era

são eficientes formas de encontrar e organizar a maior parte das informações, as quais encontram-se disponíveis, entretanto, apenas a partir de 2007 em sua maioria, coincidindo com o início do PAC. Em relação ao Rio de Janeiro, destaca-se primeiramente a descentralização de diversos e incoerentes mecanismos de buscas, os quais apresentam inúmeros erros eletrônicos e formulários vazios nas buscas realizadas. As informações fornecidas, tanto no âmbito municipal quanto estadual, são incompletas e pouco transparentes, dificultando qualquer análise mais precisa sobre este objeto. Para mais informações sobre os procedimentos adotados, consultar o Anexo 01, Memorial de Pesquisa de Contratações em RJ e SP. 
suficiente para garantir a continuidade, demonstrando que essas empresas eram players a ser contemplados pela política de urbanização independentemente de qual fosse o grupo político que assumisse a gestão. Isso, entretanto, certamente seria intensificado a partir do advento do PACUrbanização e as empresas e interesses nele envolvidos.

Se não oferece comparação entre momentos anteriores e posteriores ao lançamento do PAC-Urbanização; a sistematização realizada assegura que, a partir desse momento, estão presentes nas disputas licitatórias ${ }^{27}$ e nas contratações efetivadas a grande maioria das macro-empreiteiras brasileiras. Nesse sentido, foi verificada a participação em intervenções em ambas cidades de 11 empresas, dentre essas 07 fazem parte das macro-empreteiras, sendo as outras 4 gerenciadoras conhecidas como Diagonal Urbana, Bureau de Projetos e COBRAPE. Dentre as macro-empreiteiras que aparecem em ambas cidades estão: OAS, Andrade Gutierrez, Queiroz Galvão, Carioca Engenharia, EIT e Engelux ${ }^{28}$. Há ainda um universo de 251 empresas que não coincidem nas contratações das cidades, aparecendo apenas em uma ou na outra.

A explicação para essa presença passa por diferentes dimensões segundo os entrevistados, uma delas a maior rentabilidade que as obras do PAC passam a oferecer no âmbito da intervenção em favelas, tendo em vista incluírem grandes obras conectadas à intervenção (macrodrenagem, eixos de mobilidade, etc.).

Foi com o PAC... Tinham outras, algumas outras construtoras fortes ou de médio porte, elas entraram, tinha a OAS. Mas assim, que eu lembre dos projetos todos, elas entraram mais sistematicamente a partir dos PACs, porque o negócio

\footnotetext{
27 Abrangemos na presente análise não apenas as empresas efetivamente contratadas, mas também aquelas que participaram de processos licitatórios. Embora a maior parte delas tenha, em algum momento, obtido um contrato no âmbito da urbanização de favelas, a decisão por incluir mesmo eventuais empresas que apenas teriam participado da licitação e não da contratação se deu pelo fato de que essa simples participação já demonstraria o interesse da empresa neste segmento.

${ }^{28}$ E interessante notar a ausência da Camargo Correa nos empreendimentos do PAC-UAP no Rio de Janeiro. Segundo apurado em reportagem da Folha de São Paulo, na delação feita por empresários da Andrade Gutierrez em que se denunciava o cartel para definição da repartição dos lotes de favelas no Rio de Janeiro, a Camargo Correa teria ficado insatisfeita com o percentual que caberia a ela no acordo e, por isso, teria desistido. Disponível em: https://www1.folha.uol.com.br/mercado/2016/11/1837227-andrade-gutierrez-delata-cartel-emobras-de-favelas-do-rio.shtml
} 
interessava, elas não pegavam favelinha pra fazer. Então elas só entraram na parte, principalmente depois do PAC, porque esse PAC Manguinhos, PAC Rocinha, PAC Cantagalo, outras enfim, tinham obras substanciais, o elevador do Cantagalo, olha a quantidade de concreto que tinha colocado ali, ou os teleféricos, ou levantar a linha do trem... O que foi feito em Manguinhos, então é uma obra de valor financeiro muito elevado, interessava a esses grupos, a uma OAS, a um Carioca Engenharia, a Odebrecht. Então a partir do PAC sim, porque a verba do PAC é uma verba muito grande, então eu vejo que o interesse delas aumentou a partir desse momento, financeiramente era interessante. Anteriormente eram construtoras de médio porte, construtoras mais locais, mas enfim, não lembro assim de ter grandes construtoras (ENTREVISTADO 26).

Além disso, a própria complexidade engendrada pelos projetos propostos no âmbito do PAC, principalmente no caso do Rio de Janeiro e São Paulo, tornavam necessária a presença de empresas de maior porte. Além de poderem desenvolver expertise técnica conforme a demanda, elas também disporiam de estrutura financeira para arcar com o vulto exigido pelos contratos, isso sem mencionar possíveis infortúnios ou readequações demandadas pela iniciativa.

Uma combinação de duas coisas: oportunidade de negócio (grandes licitações do governo) e eram grandes contratos, complexos. Eu tenho dúvidas se empresas menores teriam também a capacidade técnica, principalmente esses do Rio de Janeiro, por exemplo, teriam capacidade técnica de implementar. Tem empresas menores no PAC também ao longo do país, mas a empresa maior, ela tem de fato maior capacidade técnica, de trazer profissionais. Eu acho que a gente criou uma expertise no Brasil, técnica, pra trabalhar com o tema da urbanização. Essa capacidade instalada está aqui e não está em muitos países, não está na Índia, não está nas Filipinas, nem na África do Sul. Hoje se vem um outro PAC, a gente tem atores que conseguem fazer deslanchar rápido (ENTREVISTADO 01).

Então do ponto de vista operacional tem essas questões, quer dizer, você tem um volume de recursos bastante expressivo, não era só a favela. Você tem recurso pra drenagem, pra saneamento, enfim, um certo congestionamento ai dos processos de seleção. Uma coisa de execução que é mais difícil, mais complexa e que você tem que ter empresas que trabalham com isso, (...) acabaram entrando as grandes, é o famoso "é bom, mas é ruim"... Porque você tem, no caso do Rio, você tem coisas complicadíssimas, mas do ponto de vista operacional elas conseguem muitas vezes responder no tempo mais... Tem o famoso "tem bala na agulha", consegue responder de maneira mais efetiva (ENTREVISTADO 07).

Não se tratava apenas do caso do Rio de Janeiro (no qual havia mais expressamente os projetos emblemáticos já mencionados), mas também no caso de São Paulo as macro-empreiteiras foram importantes para a viabilização do porte das intervenções desenhadas pela gestão municipal, conforme depoimento abaixo de integrante da coordenação de ações de urbanização na gestão Serra/Kassab. 
Eram empresas grandes. Hoje a gente não conseguiria fazer urbanização porque estão todas na Lava Jato. Porque se tem uma equipe multidisciplinar, eles tem que ter especialistas em drenagem, contenção, tem que ter aparelhos de alto porte, as que se interessaram eram de médio e grande porte. Tinham pequenas também, mas essas tipo que fazem o Minha Casa, Minha Vida nunca se interessariam. Agora hoje, por exemplo, eu acho que se a gente tivesse recursos, porque também o cara não vai se interessar onde não tem recurso, se o Minha Casa, Minha Vida dissesse "Eu só vou dar dinheiro pra quem fizer urbanização", as empresas iam fazer, as pessoas aprendem. Eu acho que hoje na situação que está o campo dos construtores, que está super difícil, muita gente envolvida com a confusão do Lava Jato e elas estão encolhendo, eu acho que hoje você faria com médias empresas um programa grande de urbanização. Elas vão se adequando, um engenheiro aprende fazer qualquer coisa, é o que eu falei, é só um pouquinho de vontade. É um trabalho gratificante também. Eu lembro que no início dos trabalhos, quando a gente começou em Paraisópolis... primeiro tinha uma empresa, eu esqueci o nome, depois quando a gente fez uma licitação grande, vieram duas empresas, uma era a Camargo Correia, o engenheiro reclamava de tudo, não tinha nada e de repente ele começou a ver... Primeiro fica amigo de todo mundo que mora, e ele começou a ver as coisas bonitas, os prédios legais, com projetos e tal, ganhou prêmio, mudou a relação dele com a urbanização. $O$ cara também vai aprendendo, ninguém nasce burro e morre burro, então as pessoas, pelo menos as que a gente trabalhou, os engenheiros, gostaram de fazer urbanização, pelo menos o engenheiro, não estou falando o dono da empresa, o engenheiro residente, a gente sempre tinha boas relações com eles (ENTREVISTADO 09).

Outros entrevistados mencionaram igualmente a relevância de se ter o

envolvimento e o aprendizado proporcionado às empresas pela participação em projetos no âmbito do PAC-Urbanização. Além de afirmarem a dimensão macroeconômica de geração de empregos e aquecimento da economia do país, fazendo inclusive com que mais empresas se sentissem atraídas para o campo das intervenções em favelas.

As grandes empresas tem aspectos positivos e negativos. $O$ positivo é que uma geração de emprego incrível, é impressionante. Teve projetos muito legais, as empresas contratavam as pessoas das próprias áreas e tal, isso é bem bacana. (...) O lado bom também é que vira um eixo importante econômico e atrai mais empresas, enfim, aumenta a percepção disso que a gente estava falando de que é um investimento, e tem retorno, então mais atores se mobilizam pra isso acontecer e conseguem enxergar a relevância. Eu tive a oportunidade de conversar em vários lugares do país, com vários engenheiros dessas obras, trabalhando nessas obras. Tem uma parte invisível daí que é valorizar essas áreas, fazer essas áreas ficarem conhecidas com esse tipo de projeto, com esses profissionais. Por exemplo, eu conversei com um engenheiro uma vez no Rio, eu falei "Qual é a sua obra anterior?". Ele falou que estava coordenando a expansão de uma usina nuclear. Aí ele passa a coordenador de favela, mas ele era um cara comprometido e tal, trabalhava com uma empresa grande, mas era uma pessoa aparentemente ali séria, comprometida, super profissional e tal. Ele tratava 0 projeto da urbanização do mesmo jeito que a usina, que não é como a sociedade trata, então as pessoas passam a enxergar aquilo com seriedade, com relevância, inclusive desafios profissionais. "Isso aqui é muito complexo, a gente tem que achar soluções aqui", se deliciando com a complexidade e o desafio profissional que era pra você fazer um projeto de engenharia pra uma favela. Isso é muito bacana, muito bacana! Em outra situação o cara nem ia saber onde tinha favela no país porque ele está lá fazendo usinas, pontes e não sei o que. Então eu acho que ajuda com isso também da gente ampliar a conscientização da 
nossa sociedade. Depois esse cara vai sentar numa roda de clube, numa reunião da escola, vão perguntar "O que você faz?". "Eu sou engenheiro, estou atuando na obra do Cantagalo, é interessante aquela obra, é muito complexa". Poxa, eu acho que faz da favela o que ela tem que ser mesmo, é um nicho ali de investimento (...) Por outro lado tem coisas ruins. No início a empresa tinha que fazer o trabalho social, mas imediatamente se percebeu que não fazia. Ou mesmo a melhoria habitacional, a empresa não dá prioridade pra isso, ela precisa priorizar aqueles componentes da obra que dão maior lucro, e certamente não é o trabalho social, certamente não é a melhoria habitacional, vai olhar pro grandão, as obras viárias e tal. (ENTREVISTADO 01).

Da mesma forma que a entrevistada acima destaca, outros depoimentos também demonstram que, na atuação dessas macro-empreiteiras, foram sendo deixados em segundo plano outros componentes de intervenção também contratados por não serem tão lucrativos, como o trabalho social e a melhoria habitacional. Seu maior interesse estava nas obras viárias, de mobilidade e de drenagem associadas a esses projetos. Pode ser observado, assim, não apenas a priorização de determinados componentes dos contratos (CARDOSO \& DENALDI, 2018, p. 34), mas inclusive a demanda pelas empresas selecionadas de alteração de projetos contratados em função da escolha por soluções técnicas mais interessantes para elas, em detrimento do melhor atendimento às necessidades dos assentamentos e moradores.

E outra coisa que eu acho que nos últimos anos tem influenciado muito os programas é o papel das empreiteiras, que virou a bola da vez. Então agora você não vai mais fazer mega obra viária, você vai urbanizar favela, e aí as empreiteiras ditam as soluções, impõem, é uma negociação complicada. A gente viveu isso (...) Aí é que está a diferença do político que banca e do que não banca, porque se não bancar nessa hora, você sabe que empreiteira manda aqui, e elas queriam um projeto padrão, que é muito mais fácil soluções padronizadas (ENTREVISTADO 14).

Essa situação relatada para São Paulo também foi verificada no Rio de Janeiro, sendo documentada inclusive pela literatura do tema. Patrício (2017), em apurada análise sobre cinco experiências de urbanização financiadas pelo PAC-UAP, aponta como o recurso a alterações foi largamente utilizado em benefício das empresas contratadas, desde a concepção das próprias intervenções pelo Governo Estadual até o momento de realização do Projeto Executivo. Este serviço foi incluído no escopo do contrato para realização das obras, sendo o projetista contratado pela empresa, apresentando assim demandas coerentes com os interesses desta (PATRICIO, 2017, p. 223).

Alguns dos principais casos mencionados nesse sentido foram em intervenções consideradas emblemáticas, em que se interviu para a escolha de 
determinados tipos de intervenção em detrimento de outras - "saneamento versus mobilidade" (ENTREVISTADO 26) - e para a imposição de tecnologias

e modelos específicos a serem adotados, como os teleféricos.

Eu me lembro que eu entrevistei, em 2009, o responsável pela EMOP no Rio de Janeiro, ele estava excitadíssimo. Ele tinha ido em Medellin, tinha visto o teleférico, que tinha que implementar isso, tinha que fazer isso aqui, então a conexão, ela é claramente visível na paisagem, a gente identifica como pesquisador, mas também isso foi um movimento muito claro do estado, sobretudo estadual do Rio de Janeiro, de replicar esse modelo de bibliotecas parque, de equipamentos públicos culturais, a própria lógica da questão da política de segurança pública, via UPP então o modelo colombiano foi um modelo por excelência replicado no Rio de Janeiro (...) efetivamente a Colômbia foi a grande inspiração, de alguma forma, das últimas intervenções, e com algumas questões complexas. Eu acho que tem uma reflexão de mobilidade que foi mal absorvida, você deve ter visto, o caso do Alemão não funciona há mais de 1 ano, o da Providência também não, enfim. Eu andei algumas vezes no Alemão, você limpou, você tirou um montão de gente do morro, mas não é o modelo de vale, como é em Medellin, as pessoas moram em baixo muitas vezes, ninguém vai subir e pegar o teleférico. (...) Agora, na maior parte das mobilizações politicas, assembleias que eu fui, era um projeto desconectado do restante, na verdade, enfim, depois que a gente vê todo o staff do estado do Rio de Janeiro, certamente tinha uma série de interesses econômicos vinculados. Mas eu me lembro que eu fui na reunião, numa assembleia na zona portuária e que o técnico da prefeitura falou "Me desculpem os moradores, eu não posso discutir o teleférico porque isso não faz parte do meu projeto, essa é outra coisa que caiu por cima". (...) O movimento foi criado forte de acompanhamento das obras do porto e que conseguiu barrar o projeto de urbanização da Providência, mas 0 teleférico eles não conseguiram barrar, então você via que era um projeto à parte, e o que foi julgado na época era que o impacto econômico das obras já realizadas e não sei o que, e o teleférico saiu. (...) existe um caráter muito monumental das intervenções e que, por exemplo, o Favela Bairro, com todos os problemas possíveis de imaginar na década de 90 , esse caráter muita gente criticava que podia ser maquiagem e não sei o que, mas talvez até pela questão de volume de recursos, ele era mais pontual. Pra você compreender a intervenção do Favela Bairro, era praticamente necessário entrar, você tinha que entrar na favela (...) então o teleférico é um, mas não é o único. Por exemplo, se você for no Pavão Pavãozinho e Cantagalo, a construção daquele elevador em si não é ruim, é muito prático, mas não precisava ser aquela nave espacial que é, do jeito que é, enfim, existe uma monumentalidade absurda; da mesma maneira como é a passarela da Rocinha. (...) então por parte dos moradores era uma percepção claramente de que era um monumento com um objeto de interesse político muito distinto, que respondia a necessidade, enfim, porque de qualquer forma a passarela ali construída, ela realiza a mesma função, atravessar as pessoas de um lado a outro da estrada. Mas que, por parte dos moradores, eles necessitavam de uma outra coisa, tanto que a base política da mobilização contra o PAC 2 na Rocinha é justamente "A gente não quer teleférico, a gente quer saneamento básico", e o estado afirmava claramente "Se eu construir o teleférico, não tem dinheiro pra fazer o saneamento", então tem um aspecto monumental por parte, eu acho que isso foi um pouco absorvido por parte do modelo de intervenção na Colômbia, mas muito abrasileirado, ou muito cariocarizado, então a gente tem um impacto monumental de intervenção (ENTREVISTADO 21).

Embora seja longo o trecho do depoimento inserido acima, é relevante para trazer diferentes questões relacionadas às intervenções emblemáticas e como são politicamente utilizadas. Primeiramente, deve-se começar pelo próprio 
processo decisório das áreas e intervenções a serem realizadas. Houve entrevistados que mencionassem um boato anedótico de que a escolha das principais favelas e obras do PAC na cidade teriam sido definidas por Lula e Cabral em um sobrevoo de helicóptero pela cidade (ENTREVISTADO 04). Mesmo que a cena narrada não seja real, a atenção federal à cidade (inclusive depois da saída de Lula da presidência) estava realmente voltada em função da preparação dos megaeventos esportivos que lá ocorreriam, uma das estratégias de construção da imagem de país encampadas pelo governo federal. O presidente, por exemplo, teria participado de diferentes inaugurações de obras nos complexos em favelas no Rio (ENTREVISTADO 16).

Para além de rumores na escolha dos assentamentos, a relação estabelecida pelo Governo Estadual e as empresas para definição desse modelo de intervenção também é relevante para o argumento e é relatada por Patrício (2017). Segundo o autor, após o anúncio do programa, o Secretário Estadual de Governo teria se reunido com representante de uma das construtoras para informar que seriam apresentados projetos de urbanização pelo Estado para o Complexo do Alemão, Manguinhos e Rocinha. As construtoras deveriam se dirigir à EMOP (que posteriormente coordenou a implementação dos projetos) para formar grupo de trabalho que trabalhasse em cima dos lotes e projeto básico das iniciativas, de forma a modificar o edital de licitação com intuito de cumprir os requisitos necessários à obtenção do PAC ao mesmo tempo em que limitava a entrada de outras empresas não participantes deste grupo (CADE, 2016 apud PATRÍcIO, 2017).

É neste momento quando são inclusas as obras emblemáticas em articulação pelo grupo de trabalho composto pelas construtoras e Governo do Estado, assessorados pelos projetistas. As empresas incluíram, no Projeto Básico de cada um dos lotes, determinadas obras e soluções de engenharia que somente elas teriam expertise e qualificação técnica (atestação) para realizar e, consequentemente, para se habilitar no certame. Tais obras eram no Complexo do Alemão o teleférico; na comunidade da Rocinha, o plano inclinado; e, em Manguinhos, a elevação da linha férrea (ponte em balanço sucessivo estaiado). Estes esquemas às margens da legalidade distorcem, assim, a relação entre contratante (Poder público local) e contratado (empresas), invertendo a relação de subordinação. No caso do PAC-UAP, a responsabilidade de compor o escopo das intervenções por parte do poder público em resposta às necessidades das populações é substituída e sobreposta pelos interesses das construtoras (PATRICIO, 2017, p. 194).

Como a entrevista e a citação acima demonstram, mais do que as necessidades territoriais efetivamente encontradas nestes assentamentos e 
mais do que as demandas colocadas pela população, os partidos urbanísticos das intervenções estavam centrados no atendimento a uma mescla de interesses políticos e econômicos.

Um dos meios através do qual se efetivou esse atendimento foram relações de corrupção estabelecidas entre agentes da classe política e empresas contratadas. Embora o tema tenha tido um maior destaque nas últimas décadas no país, trata-se de um processo recorrente em diferentes momentos da história brasileira. No tocante à intervenção em favelas, há rumores de relações ilícitas em diferentes momentos, tanto em São Paulo (ENTREVISTADO 19) quanto no Rio de Janeiro.

A gente conseguiu fazer, praticamente, todos os Favela-Bairro no primeiro concurso. Quando chegou no segundo concurso começou a faltar dinheiro, começaram as críticas que os projetos eram muito ambiciosos. Eu particularmente nem acho que o primeiro Favela Bairro eram ambiciosos, eu acho que ambicioso ficou no segundo e no terceiro, porque aí começou a entrar dinheiro da Caixa Econômica. Aí começou aquela corrupção brava, então tinham coisas assim, a gente falava "Mas gente, pra que isso?" "Ah, vai ter que ser porque o prefeito quer". Enfim, se perdeu muito (ENTREVISTADO 18).

Em que pesem as várias críticas que devem ser tecidas à atuação do Poder Judiciário no âmbito de operações de investigação e prossecução como a Lava Jato, foram averiguados judicialmente diversos indícios que consolidavam um conjunto probatório documentado de propinas repassadas pelos agentes privados a gestores públicos estaduais em obras superfaturadas no âmbito do PAC-Urbanização, todo este processo confirmado por entrevistados para a pesquisa (ENTREVISTADO 21; ENTREVISTADO 18; ENTREVISTADO 04; ENTREVISTADO 26; ENTREVISTADO 16; ENTREVISTADO 28). A mídia ${ }^{29}$

29 Para conferir a cobertura da mídia, pode ser acessada a informalçao disponível em https://exame.abril.com.br/brasil/sergio-cabral-pega-47-anos-de-prisao-por-propinas-nas-obrasdo-pac-favelas/

https://g1.globo.com/ri/rio-de-janeiro/noticia/carioca-pagou-em-torno-de-r-30-milhoes-empropina-para-grupo-de-cabral-diz-ex-diretor.ghtml https://g1.globo.com/rio-de-janeiro/noticia/obras-da-odebrecht-foram-superfaturadas-em-maisde-r-3-bilhoes-no-ri.ghtml

https://www.valor.com.br/politica/4779065/alvo-de-corrupcao-pac-das-favelas-previainvestimento-de-r-1-bi https://noticias.r7.com/rio-de-janeiro/mp-ri-pede-que-pezao-responda-por-improbidade-no-pacdas-favelas-22122018 https://brasil.elpais.com/brasil/2016/11/17/politica/1479373747 388871.html http://agenciabrasil.ebc.com.br/geral/noticia/2017-01/tce-rj-aponta-superfaturamento-em-obrasdo-pac-na-rocinha-manguinhos-e-alemao 
também tem amplamente divulgado o objeto de todas as ações judiciais envolvidas com o tema, sendo uma simples busca suficiente para compreender a grande repercussão que o caso tomou.

Foram identificadas pelos órgão judiciários práticas não apenas de fraude de licitações e corrupção, mas também a constituição de cartel, evasão de divisas e lavagem de dinheiro atreladas aos processos de contratação. O envolvimento direto do então governador, Sérgio Cabral, e seu vice, Pezão (posteriormente eleito seu sucessor), são documentados e levaram inclusive a denúncia e condenações a ambos. Em apenas uma das dezenas de denúncias oferecidas pelo MPF, estimava-se que a cobrança de $5 \%$ de propina sobre os contratos em obras teriam rendido mais de 100 milhões de dólares (MINISTÉRIO PÚBLICO FEDERAL, 2017).

(...) a Rocinha inteira falou "Nós não queremos [o PAC]". Você já viu um negócio desse?! "Nós não queremos esse projeto, nós queremos saneamento, nós não queremos bondinho, trenzinho". "Vocês não sabem o que querem" só faltou [o governo do estado] dizer isso. Hoje em dia você sabe porque, estão todos presos, inclusive um dos coordenadores do Favela Bairro está preso. Quer dizer, quanto mais sofisticada a obra, melhor o controle, uma sofisticação doida, doida, doida (ENTREVISTADO 18)

Quando o Cabral entrou, ele resolveu pegar dinheiro do PAC Favelas pra fazer 3 grandes favelas, então ele escolheu Manguinhos, Rocinha e Alemão. Isso já era Sérgio Cabral, e aí ele nos contactou perguntando se não havia interesse da gente fazer, revisar projeto, intervir em alguma coisa, entre eles o teleférico. Nós nos recusamos "Não, não vou trabalhar com esse povo. Eu sou completamente contrária ao teleférico, eu acho um absurdo isso. Alguém está ganhando muito dinheiro com isso!" (...) Nós já sabíamos de tudo o que estava por trás, tanto que o PAC Favelas está em investigação. Não dá pra trabalhar com o estado do Rio. Infelizmente o PAC foi um acordo do PT federal com o PMDB estadual e gerou essa enorme condição de desvios, etc, etc. $O$ dinheiro... tanto que o teleférico da Rocinha não foi em frente, parou, não foi executado. (...) Quando foi feito o elevador do Cantagalo associado ao metrô, também obra da Odebrecht, a mesma coisa: nós declinamos. Nós fomos convidados pra fazer, nós declinamos "Não acredito nesse projeto, vai fazer um elevador pra turista", sendo que o custo desse elevador poderia ser revertido em questões de saneamento, de drenagem, de melhores condições, talvez algumas moradias (ENTREVISTADO 26).

O PAC Favelas no Rio de Janeiro é diferente do PAC Favelas em outros lugares, porque depende muito do arranjo político e da governança que se tem sobre esses projetos (...) 0 Governo do Estado não só não tinha recursos humanos, como já era essa quadrilha. Mas enfim, o absurdo que você está vendo hoje, só vê em página policial no Rio de Janeiro, já tomou conta há um tempinho. Você tem 20 a 30 anos com esse mesmo grupo político (ENTREVISTADO 04).

Se a tese apresentada pelo último entrevistado e pela literatura de que a situação vivida pelo Rio de Janeiro é peculiar em relação às outras cidades $e$ projetos financiados pelo PAC-UAP (CARDOSO \& DENALDI, 2018), não se trata, entretanto, de um ponto fora da curva no tocante à trajetória mais ampla 
de interação estado-empreiteiras no Brasil (IACOVINI, 2013). Há praticamente um século ou mais (CAMPOS, 2012), no Brasil, raízes profundas enlaçam empreiteiras e agentes públicos, tendo sido o próprio processo de estruturação do setor fomentado fortemente pelo Estado, numa "articulação funcional" como define Camargos (1993).

As relações entre os grandes empreiteiros de obras públicas e o estado no Brasil constituem um fenômeno sociológico que se fundamenta numa profunda "articulação funcional" setor-Estado, dadas certas características estruturais da construção pesada e a relevância do papel desempenhado pelo Estado no processo de acumulação e expansão do setor. (...) Indo mais longe, podemos dizer que as relações entre Estado e grandes empreiteiras são um dos pilares que sustentam o pacto básico de dominação capitalista no Brasil, ao lado de outras não menos poderosas articulações, como por exemplo as que existem entre Estado e frações monopolistas do capital estrangeiro. A permanência no tempo dos esquemas de poder dos grandes empreiteiros, para além das sucessões governamentais, se explica assim pelo posicionamento deste segmento do empresariado brasileiro no pacto de dominação capitalista, posicionamento derivado da articulação funcional setor-Estado (CAMARGOS, 1993, p. 159).

Desde a década de 1930 (CAMPOS, 2012; IACOVINI, 2013), o setor habitacional, junto com 0 de obras rodoviárias e grandes projetos de desenvolvimento (barragens, portos, aeroportos, etc.), é um dos principais âmbitos no qual ocorre essa articulação. No modelo de articulação funcional entre Estado e empreiteiras no país proposto por lacovini (2013, p. 148), o primeiro atua no sentido de garantir minimamente a existência de um mercado de obras públicas, cujo controle é exercido por ele próprio a partir de mecanismos econômicos, legais, institucionais e políticos. Esse mercado caracteriza-se por ser reservado quase que exclusivamente às empreiteiras nacionais e por ser altamente hierarquizado. Às empreiteiras cabe, além de servirem de instrumentos para a implementação de políticas macroeconômicas desenhadas pelo Estado, apoiar a manutenção do jogo político-eleitoral através, por exemplo, de doações de campanha e da constituição de obras de visibilidade que promovam símbolos de atuação estatal.

Diante de toda a articulação entre interesses políticos e empresariais no âmbito das intervenções em favela nas últimas décadas, especialmente e principalmente a partir do PAC-UAP, pode-se afirmar que esta política realmente possibilitou o fortalecimento e a reiteração do padrão histórico de articulação estado-setor da construção, como vem sendo proposto pelo autor desde sua dissertação de mestrado (IACOVINI, 2013). Nesse sentido, não se 
trata assim propriamente de uma relação de subordinação entre estes atores conforme Patrício (2017) acima deixa implícito no caso do Rio de Janeiro ao afirmar que haveria uma inversão na relação de subordinação entre contratante e contratada - mas de cooperação mútua, de simbiose, em que ambas partes constituem uma articulação funcional profícua para todos.

Embora seja difícil negar hoje a existência de processos de articulação Estadoempresas "às margens da legalidade" no tocante às obras do PACUrbanização no Rio de Janeiro (PATRICIO, 2017; ENTREVISTADO 21), devese ter em mente que muitas das manobras e articulações entre estes atores também acontecem dentro das margens de legalidade. Como demonstrado em lacovini (2013), esta articulação funcional historicamente reiterada ocorre sob uma simbiose em que ambos se tornam partes interessadas e contempladas com diferentes políticas, muitas vezes dentro dos parâmetros estabelecidos pela legislação. O fenômeno da corrupção não é, portanto, a única forma de interação entre estes atores, havendo outros tantos construídos dentro de parâmetros democráticos e institucionais permitidos: apoio político, doações oficiais para campanhas eleitorais, facilitação de processos burocráticos, priorização de determinadas políticas públicas em detrimento de outras, relações internacionais orientadas à expansão do capital nacional, etc..

É importante ressalvar também que nem todas as alterações verificadas em projetos de urbanização estão orientadas ao ganho das empresas contratadas e que não apenas elas se beneficiam de tais obras. O alerta a seguir é feito por entrevistada que coordenou diferentes iniciativas de urbanização de favelas no ABC paulista, relembrando a margem de imprevisibilidade realmente existente nesse modelo de intervenção (realizada em um tecido social e urbanístico vivo) e, ainda, como também não se pode esperar, muitas vezes, posturas diferentes das contratadas, as quais sempre visarão a maximização de seu lucro com cada iniciativa.

As empreiteiras que entram pra fazer urbanização de favela preferiam fazer uma ponte, preferiam fazer uma avenida, preferiam fazer uma obra de drenagem grande ou as que produzem habitação preferiam produzir... assim, é uma obra muito mais previsível, talvez mais lucrativa. Uma obra de urbanização de favela é muito mais complicada, principalmente se a gente não rever as normas de contratação. Você trata uma obra de urbanização de favela como se fosse uma obra num terreno limpo e não uma reforma, uma obra que tem alta 
imprevisibilidade. (...) Não quero dizer, o que a gente vê no Rio de Janeiro são as empreiteiras pautando, querendo fazer o teleférico e não querendo fazer o saneamento. Isso é uma outra coisa. Mas tem também uma coisa que é, na hora que você tem uma urbanização de favela que é muita alta declividade, é muita viela, é muito bordado, se você tem uma obra de drenagem, de macrodrenagem, uma coisa pra compensar aqui, vai. Se não tem, é um problema, porque os preços da tabela SINAPI ${ }^{30}$ não correspondem à complexidade da obra naquele local, por isso o pessoal reclama, foi lá e fez só aquela parte e não fez a outra. (...) Fica todo mundo repetindo só o emblemático do mal, a gente pega o emblemático do mal, que é a empreiteira ditando as regras, fazendo a grande obra e não fazendo o pequeno, mas a gente não consegue enxergar o quadro geral, que tem problemas. Então, pra você perguntar pra qualquer empreiteira, ela só vai fazer urbanização de favela se tiver dinheiro pra fazer urbanização de favela lá, e só vai ser viável se tiver alguma obra mais estrutural junto, mas ela vai preferir fazer ponte, viaduto, estrada, para essas empresas isso não é um mercado atrativo. Só é atrativo se tiver uma obra. (...) Teve vários problemas, licitação vazia, teve vários problemas de empresas que abandonam o trabalho no meio do campo, (...) a quantidade de rescisão de contrato que tem no PAC é muito grande, e ai [gestor diz] "Eu estou misturando, eu botei aqui conjunto habitacional junto com infraestrutura" (ENTREVISTADO 17).

Trata-se, dessa forma, também de uma relação importante para o Estado, pois necessita das grandes empreiteiras para viabilizar obras, havendo toda uma engenharia de "licitabilidade" (ENTREVISTADO 28) que deve equacionar uma engrenagem institucional (legislação, normativas, etc.) com elementos que despertem o interesse de atuação do privado (lucratividade, possibilidades reais de arcar com os requisitos impostos pelo projeto contratado, etc.). Não se pode, por esse motivo, interpretar como se se tratasse de uma relação em via de mão única, com beneficiamento exclusivo por parte do empresariado, há um interesse estatal também na viabilização dos projetos, até mesmo em função da limitada capacidade operacional hoje do setor público de implementar ele próprio qualquer obra (ENTREVISTADO 23).

Se por um lado é verdade que o teleférico no Morro do Alemão serviu muito mais a finalidades de marketing político do que de mobilidade, também é verdade que lá e no Morro dos Cabritos, por exemplo, se você pegar vários outros morros do Rio de Janeiro e aqui, as pessoas ficam confinadas na casa, porque elas tem escadarias. No Morro dos Cabritos, se eu não me engano, 500 metros de escadaria íngreme, ou seja, uma mulher grávida, uma pessoa idosa com mobilidade reduzida, não consegue descer e subir aquilo lá, então as pessoas estão confinadas. Então a questão de mobilidade, sei lá, vai ser o teleférico? Mas como é que você resolve? Você não vai tirar todas as favelas de área central e levar pra outros locais? (...) Por isso que a gente tem muito cuidado quando a gente discute a remoção, teleférico. Quer dizer, aqui está usando errado, mas não quer dizer que a gente precise usar, não quer dizer que eu não precise de uma escada rolante aqui (ENTREVISTADO 17).

\footnotetext{
${ }^{30}$ Sistema Nacional de Pesquisa de Custos e Índices da Construção Civil, a qual deve orientar a elaboração de orçamentos de obras e serviços de engenharia realizados com recursos da União.
} 
Esclareça-se: não se está defendendo aqui o uso efetivamente realizado com o teleférico e outras obras emblemáticas problemáticas no Rio de Janeiro, mas apenas pretendendo alertar que não se pode "tomar o todo pela parte" em diferentes sentidos. Houve uma atuação irregular do estado? Sim, mas deve-se lembrar que outros setores estatais - como a Caixa Econômica Federal (PATRÍcIO, 2017, p. 189) - não estiveram necessariamente envolvidos com esses processos e até mesmo ofereceram resistência em alguns momentos. A relação estabelecida favorecia as empresas envolvidas? Sim, mas também favorecia o estado e a classe política, que gozavam do capital político e econômico mobilizado pelos projetos. O projeto foi baseado na experiência de Medellín? Sim, no entanto na cidade colombiana outros fatores e processos de implementação tornam a experiência diversa daquela vivida no Rio de Janeiro. O teleférico no caso apontado foi/é problemático? Sim, mas não significa que não seja necessário ou interessante em tantos outros casos ou que não sejam necessárias outras tantas soluções para mobilidade dos moradores. Os projetos de urbanização de favelas foram orientados de forma a atender prioritariamente interesses econômicos e políticos em detrimento da qualidade urbanística para os moradores? Sim, o que não significa que estes não tenham experimentado algum tipo de melhora em suas condições de vida ou que todos os projetos de urbanização são apenas orientados por esses interesses. $O$ PAC-Urbanização serviu como mais um mecanismo de fortalecimento da articulação funcional entre estado-empreiteiras (IACOVINI, 2013) e de coordenação de interesses no âmbito da política habitacional (KLINTOWITZ, 2015)? Sim, mas também serviu para fomentar melhorias em diferentes cidades do Brasil (CARDOSO \& DENALDI, 2018).

Além disso, deve-se lembrar que não são apenas as macro-empreiteiras envolvidas com estas intervenções que foram beneficiadas. De acordo com o levantamento feito, há ainda outras 251 empresas que estiveram envolvidas em processos de licitação e contratação em iniciativas de urbanização de favelas no Rio e em São Paulo. Dentre os atores encontrados na sistematização e citados em depoimentos colhidos pela pesquisa (ENTREVISTADO 28; ENTREVISTADO 09; ENTREVISTADO 14; ENTREVISTADO 19) estão também, por exemplo, as gerenciadoras (BUENO, 
2000, p. 82; PULHEZ, 2014; MARQUES, PULHEZ \& PAGIN, 2018, p. 146) e os escritórios de arquitetura ${ }^{31}$. Não será possível aprofundar a participação destes outros atores no momento, apenas estão sendo apontados para demonstrar que o universo dos favorecidos economicamente (de maneira formal e dentro dos parâmetros de legalidade) é mais amplo do que necessariamente aquele favorecido sob mecanismos "às margens da legalidade" (PATRÍCIO, 2017). Lembrando que, conforme apontado anteriormente, por muitos anos as próprias empresas do setor da construção civil envolvidas em contratos de urbanização eram inclusive de pequeno e médio porte, como no caso das cidades colombianas visto a seguir.

Também na Colômbia, existe um forte entrelaçamento entre estado-setor da construção civil, os quais adquirem matizes parecidos e diferentes do caso brasileiro. Da mesma forma que aqui, existiria uma forte dependência do setor privado (ENTREVISTADO 20), desempenhando a indústria da construção principalmente as grandes empresas do setor - um papel central no financiamento dos partidos políticos (Torres, 2013). As construtoras/empreiteiras são, portanto, importantes para os governos, tanto nacional quanto locais, não apenas pela sua atividade ser um importante mecanismo de aquecimento da economia, mas também pelo seu apoio político, tanto utilizando suas redes pessoais e seu alcance enquanto grupo empresarial quanto em recursos para financiamento de campanhas eleitorais (ENTREVISTADO 25).

A grande influência do setor empresarial sobre o estado colombiano se dá principalmente no âmbito das políticas de provisão habitacional, mais do que no âmbito das políticas de intervenção em assentamentos populares. É naquela política que os interesses dos grandes grupos empresariais do segmento no país estão concentrados (PLATAFORMA DEL DERECHO A LA CIUDAD DE BOGOTÁ, 2016). Isto não significa que o mejoramiento barrial não

\footnotetext{
${ }^{31}$ Se Bueno (2000, p. 79) e. Burgos (2006, p. 51) apontam para a importância de escritórios de arquitetura também na ascensão de programas de urbanização desde a década de 1990, a literatura consultada ainda aprofunda pouco no papel desempenhado por estes atores, deixando de explicitar seus interesses, como ocorre sua entrada nos processos, etc. Apenas mais recentemente, têm aparecido alguns trabalhos que dialogam com este aspecto (FERREIRA, 2017).
} 
possua qualquer importância para a manutenção de grupos políticos nas cidades e para o seu financiamento de campanha. Em geral, são contratadas para as obras pequenas e médias construtoras, de caráter mais local (ENTREVISTADO 10; ENTREVISTADO 15; ENTREVISTADO 20), tendo em vista que as grandes não são atraídas pelo tipo de contrato oferecido.

Las empresas que participan de esos contractos normalmente son pequeñas. Normalmente son pequeñas, de pequeñas a medianas. Tú nunca veras una constructora trabajando porque es un tema de ganancia versus esfuerzo. Son empresas comunes en esos sectores. Es más fácil hacer una cosa nueva que tratar de hacer algo que ya está construido. (...) Los grandes constructores quieren desgastarse menos administrativamente y entrar directamente en una zona nueva, [lo mejoramiento] no es atractivo (ENTREVISTADO 10).

Da mesma forma que no caso brasileiro (à exceção dos projetos financiados no âmbito do PAC-UAP), portanto, as intervenções em favela não necessariamente são atraentes para as grandes empreiteiras ou construtoras nacionais. Isso possibilita que o mercado de obras públicas também contemple, de alguma forma, pequenos e médios empresários. Nesse sentido, as administrações locais têm adotado uma estratégia de contratação para a intervenção voltada à habitação de baixa renda (tanto no mejoramiento quanto na provisão/oferta de unidades para a faixa mais baixa) de maneira a diversificar e pulverizar as obras e as empresas contratadas (ENTREVISTADO 25). Esta estratégia tem como objetivo, assim, possibilitar a participação de pequenas empresas e, com isso, também cumprir com compromissos políticos assumidos com estas nos períodos eleitorais, quando buscam seu apoio político e financeiro (ENTREVISTADO 05).

Pero lo que hace ahora el distrito, como no hay recursos, se plantea cual es la estrategia de mejoramiento y empiezan a hacer acciones sueltas, por contratistas. Porque además eso le permite ampliar el abanico de la contratación (...) o sea, no contrato con uno, sino contrato con varios. Entonces le doy pedacitos de contrato acá (...) O sea, es bueno para la administración porque de alguna manera se está cubriendo todos los compromisos políticos (ENTREVISTADO 20).

Abarca-se, assim, um leque maior de empresas pequenas e médias contratadas e se contempla seus interesses através de ações de mejoramiento barrial, enquanto as grandes construtoras/empreiteiras são satisfeitas com a oferta de novas unidades. É importante destacar que Bogotá ainda apresenta uma particularidade em relação às conexões políticas estabelecidas a partir de iniciativas de mejoramiento barrial. 
Em função da força do mercado informal de terras, há diferentes casos de vereadores que foram ou são urbanizadores piratas (ENTREVISTADO 24), ou seja, promovem loteamentos informais na cidade. Em Bogotá, praticamente toda a periferia da cidade foi ocupada informalmente (TOVAR \& GARCIA, 2011; SIERRA, 2013, p. 85). Em 2009, a estimativa era que, dos 2344 bairros reconhecidos pela administração da cidade, 1533 tinham origem informal, ou seja, mais de $65 \%$ dos barrios da cidade (SECRETARIA DE PLENEACIÓN DISTRITAL, 2010) e $21,5 \%$ de seu território com assentamentos informais (ENTREVISTADO 10). No último período entre censos, por exemplo, $70 \%$ do crescimento do seu estoque habitacional ocorreu de maneira informal - mais de 600.000 unidades (SIERRA, 2013, p. 83). Este ritmo, embora ainda seja significativo, vem diminuindo nos últimos 20 anos, junto com a diminuição generalizada do ritmo de crescimento da urbanização em geral, formal e informal, no município. Isso, no entanto, parece estar atrelado à expansão da informalidade para os municípios vizinhos a Bogotá (SIERRA, 2013, p. 85).

Mercado informal de Bogotá se dá praticamente de forma exclusiva sobre propriedade privada (ENTREVISTADO 24), quase não havendo propriedade pública na cidade (ENTREVISTADO 25) e tampouco invasões de terras e imóveis, diferente das outras cidades colombianas (SIERRA, 2013, p. 83), em que se verifica uma mistura de situações.

\begin{abstract}
"Como se desarrolla el mercado informal de la ciudad no es necesariamente la misma manera como se desarrolla en otros municipios, sí? Eso es importante porque en Bogotá hay una particularidad y no existen invasiones y ocupaciones, sí? Y eso existe en otras ciudades del país. En Bogotá hay un mercado de suelo informal que opera con racionalidad especulativa y eso es distinto. Claro, en otras ciudades del país lo hay pero también está la ocupación y invasiones. En Bogotá eso no pasa, en Bogotá existe un mercado informal que hay los urbanizadores ilegales que son los que venden a las familias en el marco a la informalidad porque entienden la lógica de la necesidad un poco la que hablamos para acceder al suelo y a una vivienda. En otras ciudades será mixto. Existe el mercado informal de tierra pero también existe la ocupación y la invasión" (ENTREVISTADO 02).
\end{abstract}

$\mathrm{Na}$ cidade, como se vê, a aquisição para loteamento informal ocorre, em geral, a partir de compra e venda de glebas ou por processos de sucessão (SIERRA, 2013, p. 87), ligados a heranças, ou seja, de maneira pacífica. Vale notar que, muitas vezes, o proprietário (que vende o imóvel a ser parcelado informalmente) é conivente com a prática ou até mesmo o consiste no próprio promotor do empreendimento informal (ENTREVISTADO 24), preferindo lotear 
informalmente a ter que continuamente zelar pelo seu imóvel, pois, conquanto não sejam comuns as invasões, a vigilância sempre se faz necessária (ENTREVISTADO 25; PERVAL, 1984, in MARIN, 1991, p. 55).

Além disso, o urbanizador também oferece em alguns casos algo que se poderia considerar como um "serviço de pós-venda", a exemplo do financiamento de materiais (de forma simples e com baixas taxas) e do fornecimento de assistência técnica para os compradores desenvolverem seus imóveis (SIERRA, 2013, p. 92-96). Quanto este urbanizador ocupa o cargo de vereador ou goza de uma forte conexão com alguém que ocupe esta posição, o serviço "pós-venda" ainda inclui a promessa de que o loteamento será urbanizado, negociando as melhorias prometidas ainda como moeda eleitoral.

$\mathrm{Na}$ lógica deste mercado informal, o mejoramiento de barrios está sempre presente sob a expectativa de regularização e urbanização da área loteada, sendo utilizada pelos urbanizadores como promessa no processo de venda (ENTREVISTADO 24). Os compradores, portanto, sabem que estão adquirindo um imóvel mais barato por não apresentar todas as condições urbanísticas e jurídicas necessárias, mas acreditam que essa situação será sanada no futuro pelas ações de legalização e mejoramiento implementadas pelo poder público (SIERRA, 2013, p. 80 - 82).

Entonces cuál es la expectativa que genera el urbanizador ilegal a los hogares. Primero, luego llevarán las normas que te incorporan al perímetro, luego llevarán los programas de mejoramiento promovidos por la secretaria del hábitat (...) Y todo se depende del mercado informal que entiende la necesidad y que es más efectivo con la necesidad, entonces incluso el urbanizador ilegal especula con el precio del suelo porque vende la idea de que en el futuro llega el programa mejorado (ENTREVISTADO 02).

Ao longo do processo de produção do loteamento informal, o mejoramiento barrial está presente então em diferentes momentos: desde a expectativa/promessa utilizada na venda do produto até a implementação das melhorias e da legalização, quando efetivamente o MIB encerra o processo (SIERRA, 2013, p. 87). Seu papel de impulsionamento do mercado informal, logo, fica evidente e adquire uma centralidade para este que é um dos grandes motores da economia de Bogotá (ENTREVISTA 20; ENTREVISTADO 24).

Sua existência, mesmo quando ineficiente e de baixo impacto, permite inclusive que haja uma dinâmica especulativa dentro do próprio mercado informal 
(ENTREVISTADO 02). Tendo em vista que a principal margem de lucro dos urbanizadores piratas se dá em cima da expectativa de urbanização (SIERRA, 2013, p. 87-88), nem todos os lotes são colocados a venda de uma vez, já que, com o passar do tempo e o aumento da expectativa de urbanização e regularização, o seu valor aumenta. A urbanização (ou a sua expectativa), portanto, atua para valorizar os lotes retidos para fins especulativos nos loteamentos informais, aumentando os lucros de seus promotores.

Además, los tiempos de anticipación (el tiempo comprendido entre la adquisición del terreno y el inicio de las ventas) son en general más cortos que los tiempos de venta (tiempo comprendido entre la primera venta y la última registrada en el certificado), lo que puede evidenciar una tendencia especulativa vinculada a la retención de terrenos, en la misma forma de los llamados "Iotes de engorde", relacionada con el proceso de desarrollo informal. De este modo, los primeros lotes se venden a un precio más bajo y luego se retienen algunos lotes, y por esta vía aumentan los precios de los terrenos, con el fin de capturar las "plusvalías" generadas por el mismo desarrollo ilegal y las expectativas cada vez más cercanas de regularización (SIERRA, 2013, p. 90).

O urbanismo informal é, assim, uma empresa sofisticada, produzindo loteamentos minimamente planejados (ou seja, com lotes regulares, já realizado com traçados que os conectam aos bairros vizinhos, com espaços previstos para futura implantação de infraestrutura, etc.) e, com isso, facilitando a venda já pela expectativa de intervenção de urbanização (ENTREVISTADO 24). Se constitui em um grande negócio e alimenta a economia da cidade, pois multiplica muito o valor do solo com baixos investimentos e gera uma forte cadeia de negócios em torno dele (ENTREVISTADO 24). Seu impacto na economia também se reflete na esfera política, tendo em vista que o dinheiro produzido neste circuito alimenta o poder nesta outra esfera através do financiamento de campanhas e de grupos políticos, gerando um poder político que inclusive assegura que os promotores imobiliários informais não sejam punidos, apesar de ser considerada uma prática criminosa pela lei (ENTREVISTADO 24).

Além disso, constitui uma base muito sólida para esquemas de clientelismo político (JARAMILLO, 2008), estando seus agentes profundamente entranhados na política, seja, como já mencionado, através do financiamento de campanhas de candidatos (a vereador ou a prefeitos) ou até mesmo pela sua própria candidatura, havendo vereadores da cidade conhecidos pela sua atuação enquanto urbanizadores piratas (ENTREVISTADO 24). 
Não apenas em Bogotá o mercado imobiliário informal tem lugar de destaque, mas também em Medellín e mesmo no caso de terras que são ocupadas/invadidas. Inclusive isto tem sido, aparentemente, um dos ramos lucrativos de negócios adotados por grupos guerrilheiros e paramilitares que migraram para o meio urbano nas últimas décadas (ENTREVISTADO 08; PATIÑO, 2009).

É importante notar que, além de fortalecer atores e grupos políticos e circuitos informais da economia, as ações de mejoramiento barrial e de regularização também têm servido para inserir aquele território, antes informal, no circuito do mercado imobiliário formal, abrindo novas frentes de expansão para este mercado através da implantação de infraestrutura e da regularização jurídica dos assentamentos, incorporando assim estes solos ao mercado formal (TOVAR, 2012; ENTREVISTADO 15), o qual vai aos poucos se apropriando daquele território e dos investimentos nele realizados, expulsando a população originária (ENTREVISTADO 20).

Nesse sentido, seria já possível, embora haja alguma discordância entre os entrevistados, encontrar promotores privados comprando imóveis de assentamentos informais legalizados para desenvolver projetos para outras rendas (ENTREVISTADO 20). Contreras (2016) também afirma que são desenvolvidos, em alguns casos, empreendimentos formais em interstícios formados por terrenos vazios após a legalização e urbanização destes assentamentos, mas são poucos os casos em que o empreendedor teria comprado imóveis e demolido para construção de novos empreendimentos, lembrando apenas de exemplos como do Chapinero. Já entrevistado que pesquisa o tema há décadas é categórico ao afirmar que isso têm sido frequente e que acredita que é uma tendência a ser verificada a longo prazo nos assentamentos da cidade, tendo em vista que o solo urbanizável em Bogotá teria se esgotado.

Entonces estamos viviendo un proceso de gentrificación en torno al centro de Bogotá. Entonces todos estos barrios antiguos de origen popular que fueron, no diría invasiones por los cerros y otros por [inaudible] informal, hay una presión muy fuerte del sector inmobiliario. Esos son los que están sufriendo más desembarque. Incluso en las que fueron albos de mejoramiento barrial. Por ejemplo, uno de los que mencionaba Juan XXIII es un barrio que ya está rodeado por ese estrato, está rodeado por barrios del estrato cinco y hay una presión muy 
fuerte y vienen comprando predio a predio. Ese barrio va desaparecer (ENTREVISTADO 20).

Ainda, de acordo com entrevistada que integrava a equipe da secretaria de planejamento (ENTREVISTADO 02) e que foi responsável pela análise da evolução das condições da cidade, as ações de mejoramiento vêm ocasionando já processos de transformação nas áreas foco de intervenção. Segundo ela, isso ocorreria porque, no momento em que se faz qualquer intervenção mínima no território informal, já se criaria um diferencial daquela localidade em relação ao restante do seu entorno. Essa diferenciação já seria suficiente para que os preços se elevem e, com isso, haja uma paulatina substituição da população originária por outra de maior poder aquisitivo. Os efeitos desse processo são ainda mais intensos porque as ações de mejoramiento não conseguem - apesar do seu discurso - efetivamente promover a melhoria das condições sociais e, principalmente, econômicas dos moradores da área, o que proporcionaria que tivessem condições de permanecer na área mesmo diante da valorização desta.

Já para a representante entrevistada da prefeitura de Bogotá (HERRERA, 2016), ainda não foi possível identificar processos de transformação realmente significativos nas áreas alvo de intervenção. Embora esta seja uma preocupação da administração, ela acredita que o pouco tempo decorrido desde a intervenção e o fato de em sua maioria terem sido apenas pequenas obras pontuais, dificulta esta conclusão neste momento, havendo pouca densidade histórica para tal avaliação. O que foi possível perceber, ainda segundo ela, é a valorização dos imóveis nestas áreas, tendo sido em torno de $5 \%$ de acordo com levantamentos que a secretaria haveria realizado.

No caso de Medellín, haveria já mudanças nos moradores nas áreas de intervenção, de acordo com entrevistas (ENTREVISTADO 15; ENTREVISTADO 05), mas seria difícil ainda identificar se está realmente mudando o perfil desses moradores, apesar de a rotatividade de moradores já ser perceptível (ENTREVISTADO 15). De acordo com a liderança comunitária entrevistada em Santo Domingo (ENTREVISTADO 05), isto estaria acontecendo e haveria uma mudança com a entrada de famílias e comércio de estratos mais altos nas áreas do entorno do metrocable, tanto das linhas 
quanto no entorno das estações. Assim, um dos impactos verificado na região a partir das intervenções de mejoramiento teria sido o incremento dos valores de aluguel e a valorização dos imóveis para a compra e venda, tendo em vista que a procura teria aumentado significativamente. Para ele, isso teria acontecido em menor escala nas regiões em que havia laços comunitários mais intensos e cujas famílias participaram mais intensamente do processo de mobilização para intervenção, teria sido a permanência dos moradores originários a tendência nessas áreas.

No tocante ao comércio, as próprias famílias originárias abriram novos comércios ou expandiram aqueles que já existiam, tendo em vista que aumentou o número de visitantes na região por conta da intervenção. Já no entorno de outras estações cuja população originária era menos mobilizada, as famílias teriam aos poucos vendido ou alugado seus imóveis e teria começado a haver uma substituição por outro tipo de comércio, parte do mercado formal existente no restante da cidade ou cujos proprietários não moram no assentamento. Isso teria acontecido não apenas no entorno de algumas estações, mas também ao longo do via que se situa logo abaixo do metrocable.

Portanto, o impacto das ações de mejoramiento barrial também se verificaria no tocante à expansão do mercado de serviços e do comércio. Essa não é uma perspectiva presente apenas na Colômbia, mas trata-se de um discurso internacionalmente disseminado nas últimas décadas de que os pobres também são atrativos para investimento e para estímulo ao consumo, sendo viável sua inclusão como consumidor de bens e serviços via mercado para satisfação de suas necessidades (MEIRELLES \& ATHAYDE, 2014).

\footnotetext{
Terreno fértil para que el imaginario totalizador, que asume al mercado como principal vía de satisfacción de necesidades, superación de la pobreza y mejoramiento de la calidad de vida, se vea fortalecido y legitimado. En este contexto, se ejecuta una transformación que cobra fuerza con la crisis del capitalismo en el primer mundo: los pobres se vuelven importantes en términos de mercado. Los pobres son, en la actualidad, atractivos para la inversión y el consumo (TOVAR, 2012, p. 05).
}

Ao melhorar as vias de circulação e integração com o restante da cidade e ao promover ações voltadas à convivência e à segurança, as ações de mejoramiento permitem que a lógica do capital e do mercado formal penetre naqueles territórios antes informais e mobilize os recursos em potencial que lá 
existem (ENTREVISTADO 08). Abrem oportunidades, por exemplo, para a entrada de ramos do comércio e de serviços privados (cadeias de lojas, supermercados, bancos, etc.) que anteriormente não existiam nos assentamentos (ENTREVISTADO 05).

La proliferación de actividades económicas formales e informales es otro de los cambios referidos al uso y la apropiación del espacio público. Antes en Santo Domingo Savio el comercio predominante era constituido por tiendas de barrio, hoy no solo se ha diversificado hacia una gran variedad de unidades productivas, sino que además se concentra en los alrededores de la centralidad consolidada. Se trata principalmente de puestos de comida rápida, restaurantes y almacenes de ropa sobre la calle Puerto Rico y la vía a Guarne; a ellos se ha sumado la oferta de peluquerías, barberías, puntos de reciclaje, discotecas en la carrera 32A, la presencia de entidades bancarias como Bancamía y la oferta de servicios financieros. Su inexistencia antes de la intervención requería el desplazamiento de la población hasta el centro de Medellín (MAZO \& BALLESTEROS, 2017, p. 128).

O mesmo movimento pode ser visto no Brasil nas últimas décadas, sendo o trabalho de Meirelles e Athayde (2014) uma verdadeira ode ao tema. Dentre os entrevistados (ENTREVISTADO 18; ENTREVISTADO 04; ENTREVISTADO 09), vários deles reafirmaram esta evolução como impulsionada por ações de intervenção em favela, fazendo a conexão inclusive com a instalação das UPPs (visto em maior profundidade na seção 4.3). Vale ter em mente, no entanto, que ainda se trata de uma condição heterogênea entre as diferentes favelas brasileiras, como ressalvam os depoimentos abaixo.

Hoje tem vários dados já levantando é que o PIB interno das favelas é muito alto, então você vê banco abrindo na Rocinha. Eu estou falando da Rocinha porque é um caso forte, a microeconomia é fortíssima, então o mercado de baixo varejo, ele enxerga essas oportunidades econômicas nessas áreas também (...) Mas eu vejo muita diferença entre favelas. Nós temos 400 favelas no Rio aproximadamente, é uma variedade enorme, e temos as favelas ricas e as favelas pobres, as favelas de encosta e as favelas planas, a gente tem dois tipos, as favelas na beira de mobilidade urbana e as favelas fora da mobilidade urbana, então é um universo muito distinto. Governos estrangeiros vem pra cá ver favela, vai ver uma favela, mas na realidade ela não se replica, então vamos falar de qual favela você quer ver? Favela plana ou encosta, rica ou pobre, zona sul, zona norte ou zona oeste? Vamos escolher qual é a característica, porque elas são muito diferentes, elas parecem parecidas, elas ocupam as APPs, de morro ou de risco, isso é um padrão, elas normalmente estão em áreas de APP, isso é padrão generalizado ou algumas invasões de indústrias que abandonaram, mas normalmente é APP. Então você vai encontrar uma economia pungente na Rocinha, por questões óbvias, também as da zona sul, Cantagalo, Pavão Pavãozinho, enfim, menos nas outras comunidades (...) Então a Maré tem uma economia menor, apesar de estar na beira da Linha Vermelha, na beira da Avenida Brasil, são duas vias expressas, é diferente de estar na beira de uma Estrada da Gávea, que não é uma via expressa. (...) Então as economias são distintas, economias muito diversificadas. (...) Eu lembro na época do Favela Bairro, não podia se trabalhar com remoção, podia fornecer unidade pra residência, pra escola, mas nunca pra comércio. Então assim, só que a economia 
interna deles é muito vibrante, eles vivem com uma microeconomia interna, esse conhecimento é muito diversificado, seguia (ENTREVISTADO 26).

A expansão desses setores da economia de comércio e serviços tem sido então justamente um dos argumentos para investimentos emblemáticos em assentamentos populares, sendo adotada como diretriz o potencial inclusive turístico que podem gerar. Como já vem sendo registrado por diferentes autores (MEDEIROS, 2006; MENEZES, 2007; MEDEIROS ET AL, 2016; TELLES, 2018), a presença desse ramo da economia tem crescido no cotidiano de (algumas) favelas nas últimas décadas. Como Medeiros (ET AL, 2016) observa, o turismo tem possibilitado uma intensificação da relação entre trocas econômicas, sociais e culturais, fazendo com que diferentes localidades busquem redescobrir suas "vocações" e redefinir sua "identidade" em operações de city branding (MEDEIROS ET AL, 2016, p. 571). Explora-se assim ao máximo a economia simbólica propiciada por essas cidades, forjando novas imagens urbanas e incorporando como cenário localidades antes tidas como "não turísticas", a exemplo das favelas.

Não se trata, no entanto, de qualquer favela brasileira, enfocando aquelas que mais de adequam ao imaginário social construído internacionalmente para esses territórios. "A pobreza turística, no Brasil, encontra seu referente simbólico em uma favela imaginária, necessariamente fincada na montanha, entre a mata e o mar, de onde se podem avistar os bairros mais ricos da cidade" (MEDEIROS ET AL, 2016, p. 571).

Na Rocinha, por exemplo, desde a década de 1990 pelo menos já são realizadas atividades ligadas à exploração da "pobreza turística", de início principalmente por organizações externas à favela (MEDEIROS, 2006). Esse potencial foi largamente reiterado no bojo das intervenções promovidas pelo PAC-UAP, como a passarela assinada por Niemeyer e o teleférico; causando um grande embate com a população que reivindicava melhores condições de saneamento com o recurso mobilizado.

Eu seria contrária a intervenção que é muito maquiagem, muito pra ser visitada, virou ponto turístico, todo mundo vai lá visitar. Enfim, eu acho que havia muitos outras demandas, como volto a dizer, saneamento, trocaria qualquer coisa na Rocinha. Por que não o teleférico? Porque o valor do teleférico era pra ser destinado à parte de saneamento, a Rocinha tem um índice de tuberculose altíssimo, é um dos piores indicadores de saúde pública e ai o que se precisa é tirar as pessoas de cima do caminho de drenagem, teria que fazer uma atuação 
de desdensificar, de tirar pessoas de fato dos caminhos de drenagem. (...) A prioridade nos últimos tempos é assim, pelo viés político. Foi primeiro o que tivesse uma visibilidade muito grande. 0 esgoto fica pra baixo do chão, drenagem fica pra baixo do chão, isso não aparece, esgoto e drenagem são questões que não surgem, não aparece. Outros dão mais visibilidade, entre elas a questão do teleférico, que nós já sabíamos previamente que era uma máfia muito grande, não ia funcionar pra uma comunidade como aquela, talvez no Santa Marta, que é muito menor, mas na Rocinha não, você vai de um ponto a outro, e aí? E o povo todo que está do lado? (ENTREVISTADO 26).

Em Medellín, os PUI teriam implementado projetos com grande impacto no potencial turístico de barrios como Santo Domingo Savio (ENTREVISTADO 05), cujos moradores relatam a dinamização da economia através do aumento do fluxo de visitantes (TAMAYO \& MAZO, 2017, p. 105) e suas consequências no cotidiano, como impactos dessas dinâmicas sobre a efetivação do direito à moradia de moradores (PÉREZ \& GONZÁLEZ, 2017, p. 119).

O próprio "urbanismo social", portanto, tinha como compromisso a inclusão através do mercado e com o aumento da competitividade econômica e do potencial de atração turístico da cidade. "En Medellín, la consolidación del llamado urbanismo social como paradigma de intervención, refuerza el enfoque del mercadeo urbano, en el cual, los pobres han de ser integrados con índices de calidad que soporten la construcción de un conjunto urbano integrado, de cara a las dinámicas productivas, locales, nacionales y regionales. La competitividad es el horizonte de sentido de todas las acciones" (TOVAR, 2012).

Em entrevista para esta tese, morador de Santo Domingo Sávio (2016) afirmou que realmente o número de visitantes cresceu bastante na comunidade após a realização do PUI, com o metrocable, a biblioteca, etc. Isso inclusive teria estimulado a abertura de novos comércios e serviços voltados a atender aos turistas nos arredores das estações do metrocable. Como no momento a biblioteca está fechada para reformas, no entanto, esse público teria diminuído substancialmente, causando dificuldades aos empreendedores.

Ballesteros (2016) também avalia que essa estratégia de intervenção tem limites e que por vezes privilegiou a instalação destes equipamentos para atrair o turismo em detrimento de efetivamente buscarem a melhoria da qualidade de vida da população local. Para ele, a estratégia econômica e política da 
intervenção teria sido prioritária, portanto, em detrimento da efetivação do direito à moradia adequada da população (ENTREVISTADO 15).

O caso das cidades colombianas é importante também para apontar como o fomento econômico promovido pelas ações de mejoramiento impactam e são impactadas também pela expansão da rede de serviços públicos (ENTREVISTADO 02), possibilitando a inclusão de mais usuários nestes sistemas - de fornecimento de água, energia elétrica, telefonia, etc. (ENTREVISTADO 20).

Apesar de isto muitas vezes acontecer de maneira independente de um programa ou projeto de urbanização especificamente - tendo em vista que haveria diversos casos em que as companhias executam esta ligação de forma desconectada de intervenções mais amplas - a urbanização pode oferecer uma nova oportunidade de ampliação em localidades em que as empresas ainda não haviam conseguido entrar. Com isso, consequentemente, se melhora a arrecadação destas empresas, as quais, muitas vezes na Colômbia, ainda são empresas públicas, significando também, portanto, uma melhoria da arrecadação do próprio Estado (ENTREVISTADO 05).

Esse é o caso principalmente de Medellín, cuja capacidade de investimento nas últimas décadas está diretamente vinculada, dentre outras fontes, à arrecadação de suas empresas públicas (MAZO, 2014b, p. 53). Existe uma retroalimentação, assim, entre a expansão de serviços dessas empresas e os investimentos em urbanização. Ao longo das décadas, as empresas controladas pelo município têm cada vez mais se destacado no cenário nacional e internacional, adquirindo uma projeção: 1) inicialmente regional sendo responsáveis, através da expansão da prestação de seus serviços, pela consolidação da hegemonia política e territorial de Medellín sobre os demais municípios do Vale de Aburrá (VARELA BARRIOS, 2010); 2) uma projeção estadual - quando adquire, por exemplo, a companhia estadual de energia (Empresa Antioqueña de Energía) ainda na década de 1950 (PATIÑO, 2015, p. 156); 3) uma projeção nacional - quando num movimento de diversificação do portfólio inicia um processo de aquisição de empresas e de expansão para outras regiões do país (PATIÑO, 2015, p. 166); e 4) até mesmo uma projeção 
internacional, a partir da compra de empresas e início de operação em outros países da América Latina, como Chile, México, Guatemala, El Salvador e Panamá (EMPRESAS PÚBLICAS DE MEDELLÍN, 2017).

Sua contínua expansão e centralidade no tocante à influência territorial do município fazem com que a questão da gestão das empresas públicas de Medellín tenha se convertido em um dos principais pontos de debate da agenda política no período de eleições municipais, principalmente sobre as possibilidades de sua privatização e sobre as receitas que repassam ao município (VÉLEZ ÁLVAREZ, 2013). Sob este último aspecto, é importante destacar que se trata de uma das principais fontes de receita do município.

Em função de sua receita líquida obtida com prestação de serviços ter decuplicado desde 1990, o repasse que efetua ao município, embora sofra oscilações, cresceu continuamente ao longo do período, representando hoje cerca de um terço do orçamento total de Medellín (VÉLEZ ÁLVAREZ, 2013). Somado ao fato de que a outra principal fonte de receitas da cidade é a tributação, a qual não alcança o mesmo ritmo de crescimento, isso tem gerado uma grande dependência do município em relação às empresas (PATIÑO, 2015, p.167).

Chama a atenção também que, desde 2004, estão sendo realizadas transferências extraordinárias ao município (que chegam a mais de $30 \%$ das transferências ordinárias, ou seja, daquelas transferências estabelecidas por lei), as quais são destinadas a programas específicos. Para se ter uma compreensão da magnitude disso, em função dos repasses - ordinários e extraordinários - das empresas públicas, a capacidade de investimento de Medellín hoje é maior do que a de todo o Departamiento de Antioquia (ENTREVISTADO 15), o qual então direciona seus recursos mais a outros municípios, atuando em Medellín mais a nível de cooperação técnica (ENTREVISTADO 08).

Entonces, por supuesto, al gobierno departamental le interesa lo que pasa en Medellín y le interesa lo que pasa en el área metropolitana porque, a partir de ahí, eso va tener injerencia en el resto del departamento. Entonces hay cierta coordinación en lo que sea posible, pero, por supuesto, el gobierno departamental va estar más a cargo de los demás municipios que Medellín, pues Medellín tiene incluso una capacidad presupuestal mayor al departamento. Por las empresas públicas de Medellín. Las públicas de Medellín generan una 
transferencia directa hacia el municipio, solo que genera una gran cantidad de recursos que no llegan directos al departamento, no lo tiene el departamento. Entonces tiene una caja mayor la ciudad que el mismo departamento (ENTREVISTADO 15).

Além destes aspectos já mencionados, a gestão sob a lógica "empresarial privada" à frente destas empresas, assim como também em Bogotá, tem um outro efeito sobre a qualificação da infraestrutura dos barrios colombianos: cobertura de serviços praticamente universal em ambas cidades (PATIÑO, 2015, p. 130). O fato de funcionarem sob a lógica empresarial faz com que busquem constantemente ampliar o número de usuários ligados ao seu sistema, tendo, assim, uma relação com a atuação municipal no tocante ao mejoramiento barrial.

Mais uma vez, portanto, o entrelaçamento de interesses entre estado-setor empresarial não se dá exclusivamente em favor deste último, também havendo diferentes interesses políticos atrelados ao crescimento privado, fomentado por sua vez em iniciativas de intervenção em favelas. No caso do Brasil, Bueno (2000) apontava que "As empresas concessionárias dos serviços de água, esgoto e energia elétrica têm tido uma postura dúbia em relação às favelas" (BUENO, 2000, p. 36). Isso significava que em alguns casos se recusavam a prestar o serviço por alegar a irregularidade dos moradores ou por entenderem que eles não possuíam condições socioeconômicas que o caracterizassem como "bom consumidor", proporcionando retorno do investimento (BUENO, 2000 , p. 62 ); em outros instalavam a rede, mas não ofereciam um serviço de qualidade; podiam ainda em alguns casos pressionar gestores públicos pela intervenção nas favelas quando impediam a ampliação da rede oferecida pelas concessionárias; até mesmo chegavam a promover programas próprios de urbanização (BUENO, 2000, p. 36).

Neste último caso, enquadra-se experiência relatada por uma das entrevistadas que, após participar da equipe da elaboração do Favela-Bairro na Prefeitura do Rio de Janeiro, foi convidada pela concessionária estadual de energia elétrica, a Light, a construir um programa de implantação de redes elétricas em favelas da cidade. A companhia calculava que, à época, perdia em torno de $25 \%$ de faturamento no município em função de desvios (o famoso "gato") verificados no âmbito dos assentamentos. 
Fui para a Light, fiquei lá 10 anos fazendo um trabalho chamado PRONAI, programa de normalização de áreas informais; eu criei um programa lá pra eletrificar favelas. A Light foi privatizada, me perguntaram se eu não queria criar um programa de eletrificação para a população de baixa renda, ainda era só no Rio e também na Baixada. Aí eu fiquei 10 anos nesse negócio, nesses 10 anos é que começaram a acontecer esses projetos mais mega (...) Eu botei 25 mil medidores na Rocinha, transformadores eu perdi a conta. Eu criei, junto com os meus engenheiros, alguns carrinhos, tipo carrinho de rolimã, que a gente botava os transformadores com corda para os caras puxarem morro acima. Os franceses [que haviam adquirido a companhia] acreditavam que se a gente levasse a energia, o povo ia pagar. Eles não pagaram porra nenhuma, mas eu acreditava nisso, na época eu acreditava mesmo. (...) [A Light] Tinha acabado de ser privatizada e tal, nessa época ainda era dos franceses, os franceses tem um pouco esse lado social, depois passou para os americanos, depois passou de volta para os franceses. (...) Era até para mostrar para a ANEEL, que é o órgão regulador, que algum esforço estava sendo feito, porque até então, a ANEEL dizia assim "Vocês tem que fazer alguma coisa, tem que ter alguma política, tem que ter algum programa". Então isso era importante, porque ai depois de alguns anos, as perdas chegaram a diminuir um pouquinho, depois aumentou de novo. A Light na hora de discutir a tarifa tem um percentual de roubo que entra, pode ser maior ou menor. $O$ que se discutia com a Aneel era qual era o percentual de roubo. Enquanto a Light não fazia porcaria nenhuma, a Aneel dizia "Olha aqui, vocês não estão fazendo nada, sinto muito, eu não vou considerar isso como perda, vou considerar só a metade. Quando vocês começarem a fazer alguma coisa a gente rediscute". Então tinha um pouco essa pressão da agência reguladora (ENTREVISTADO 18).

Os interesses econômicos abrangidos por ações de urbanização não se tratam, portanto, apenas daquelas empresas diretamente beneficiadas por contratos em obras e intervenções de urbanização de favelas. Obviamente este setor é um dos maiores interessados e beneficiados com programas e políticas na área, não se nega isso, sendo isto fortemente exemplificado pelo levantamento de empresas envolvidas nos contratos de Rio e São Paulo. Por outro lado, há ainda uma miríade de outros interesses econômicos mobilizados junto a outros segmentos empresariais, desde aqueles situados na informalidade (do comércio de bens e serviços ao próprio mercado imobiliário informal) quanto aqueles no âmbito formal da economia (redes de comércio e serviços, além de concessionárias públicas).

Estes interesses se somam, assim, aos interesses políticos mobilizados (abordados anteriormente no Capítulo 01) e consubstanciam um conjunto de fatores que, seria de se imaginar, confeririam força e prioridade à urbanização de favelas. Contudo, para a grande maioria dos entrevistados envolvidos com o tema, isso não se verificaria no âmbito das gestões públicas municipais, estaduais ou nacionais. Já apontamos, na seção 2.1, que o redirecionamento 
do financiamento federal do PAC-UAP para o MCMV teve um forte papel indutor em relação ao comportamento dos governos locais.

A década de 1990 provou, no entanto, que não é estritamente necessária a liderança federal para que a intervenção em favelas seja implementada por municípios. É verdade que, muito do que ocorreu naquele período, estava justamente atrelado ao declínio de setores econômicos e a crise fiscal verificada, o que apontava para uma baixa proatividade no segmento da provisão habitacional, permitindo a ascensão da urbanização. Mas seriam esses fatores suficientes para explicar a ascensão no período? Por outro lado, se é útil para a alimentação de processos políticos (como a reprodução de mandatos eleitorais) e para o atendimento a interesses econômicos, por que ainda não se conseguiu estabelecer uma agenda pública permanente para a urbanização de favela? Espera-se responder a estas perguntas nos próximos capítulos da tese. 


\section{PARTE II - A política que se alimenta da violência e a violência que mata a política}

Apesar de com naturezas e intensidades distintas, a análise da trajetória de formação e transformação do espaço urbano nas cidades do Brasil e da Colômbia - e até mesmo em diversos outros países latino-americanos (SANTOS, 2002, p. 19) - deixa patente a centralidade da violência e da presença de grupos criminais em assentamentos precários enquanto um dos elementos estruturadores destes territórios, mesmo antes da ascensão do narcotráfico.

Mais evidente nos casos tanto de Medellín quanto do Rio de Janeiro (como será demonstrado à frente), esta situação também é relevante, no entanto, para a compreensão da formação e transformação de outras cidades como Bogotá e São Paulo, existindo assim, ao longo da história destes países, uma intrincada relação entre violência e configuração territorial nas suas diferentes regiões. Produtora e, ao mesmo tempo, produto de diversos impactos nas esferas política, econômica, social, cultural e urbanística, a violência possui uma centralidade sociopolítica especialmente no tocante à formação e, posteriormente, à intervenção nos barrios colombianos, conforme ressaltam tanto a literatura do tema (MAZO, 2014b, p. 57-60; PATIÑO, 2015) quanto as entrevistas realizadas (ENTREVISTADO 20, ENTREVISTADO 10, ENTREVISTADO 08, ENTREVISTADO 15, ENTREVISTADO 24).

No caso brasileiro, a violência é considerada endêmica por alguns autores (ADORNO, 2002, p. 84; MACHADO DA SILVA, 2008) e gramática sociocultural do país, encontrada em "camadas arqueológicas" (ZALUAR, 2006, p. 204).

O enquadramento coletivo de um problema deriva de e corresponde à produção de uma linguagem (uma "gramática") prática, que constitui a referência comum nas circunstâncias e permite um amplo, mas não infinito repertório de variações possíveis. A violência urbana é o centro de uma gramática que produz uma compreensão prático-moral de boa parte da vida cotidiana nas grandes cidades. Ninguém precisa definir a expressão, porque ela é a referência que confere sentido às atividades e ao debate coletivo. Nesse sentido, a violência urbana articula um complexo de práticas que constituem boa parte do conflito social nas cidades brasileiras (MACHADO DA SILVA, 2010, p. 285). 
Assim, a violência deixou cicatrizes profundas no tecido sociopolítico brasileiro (COSTA, 1999, p. 3) e se constituiu dimensão importante da trajetória das classes populares no país e, portanto, das favelas, principalmente a partir das últimas décadas (GONÇALVES, 2013, p. 315). Se a imagem construída socialmente hoje da violência, principalmente no Brasil, remete diretamente à violência urbana e, mais especificamente, ao enfrentamento do tráfico de drogas e aos crimes dele decorrentes, é necessário ampliar e explicitar essa concepção. O que seria então a violência? Adotaremos aqui a definição trazida por Zaluar (1999, p. 8) bem como os alertas sobre seus múltiplos significados.

\begin{abstract}
A dificuldade na definição do que é violência e de que violência se fala é o termo ser polifônico desde a sua própria etimologia. Violência vem do latim violentia, que remete a vis (força, vigor, emprego de força física ou os recursos do corpo em exercer a sua força vital). Esta força torna-se violência quando ultrapassa um limite ou perturba acordos tácitos e regras que ordenam relações, adquirindo carga negativa ou maléfica. É, portanto, a percepção do limite e da perturbação (e do sofrimento que provoca) que vai caracterizar um ato como violento, percepção esta que varia cultural e historicamente. (...) Além de polifônica no significado, ela é também múltipla nas suas manifestações (ZALUAR, 1999, p. 8).
\end{abstract}

Segundo a autora, portanto, não apenas o significado da palavra violência é múltilplo, mas são múltiplas suas manifestações. Ao analisar o cenário de violência no Brasil, Adorno (2002) vai sistematizando algumas destas espécies de violência: a delinqüência urbana, em especial dos crimes contra 0 patrimônio (roubo, extorsão mediante seqüestro) e de homicídios dolosos (voluntários); a criminalidade organizada, em particular em torno do varejo e do tráfico internacional de drogas; as violações de direitos humanos, com homicídios causados por policiais militares em operações contra o tráfico de drogas; a violência ilegal e privada, com linchamentos, execuções sumárias, grupos de extermínios e chacinas; e a violência causada por conflitos nas relações intersubjetivas, como aqueles decorrentes de conflitos de vizinhança, familiares, econômicos, dentre vários outros que redundam em violência nas escolas, violência das galeras e bailes funks, violência doméstica, em violência contra a população LGBTQ+, etc. (ADORNO, 2002, p. 88 a 100).

Dentre todas estas diferentes facetas, a violência urbana (principal enfoque da presente seção) possui significados, representações e impactos particulares em relação às outras formas. Como Marcelo Lopes de Souza (2010, p. 52) alerta, a adjetivação urbana não significa que se trata de todo e qualquer crime 
cometido no âmbito da cidade, tendo em vista que este procedimento faria com que o termo perdesse qualquer função analítica. Nesse sentido, será adotado no presente trabalho o conceito de violência urbana proposto pelo autor como

as diversas manifestações da violência interpessoal explícita que, além de terem lugar no ambiente urbano, apresentem uma conexão bastante forte com a espacialidade urbana e/ou com problemas e estratégias de sobrevivência que revelam ao observador particularidades ao se concretizarem no meio citadino (...) (SOUZA, 2010, p. 52).

Dentro deste conjunto de manifestações, segundo o autor, caberiam ainda uma grande variedade de fenômenos, desde a violência no trânsito, passando por quebra-quebras" e linchamentos e indo até ações violentas promovidas por grupos criminais. Nesse universo, tem destaque para a análise que se pretende realizar nesta tese a violência urbana e suas representações mais estreitamente conectadas com o tráfico de drogas, tendo em vista a hipótese que pretende demonstrar - como a violência ligada ao narcotráfico (com a qual a população favelada é associada) é central para a compreensão tanto da ascensão da urbanização de favelas na Colômbia e no Brasil quanto das dificuldades do estabelecimento de uma atuação permanente no campo por parte do estado.

Assim, tão importante quanto o conceito de violência urbana são suas representações socialmente construídas, tendo em vista que estas estariam diretamente relacionadas às formas de intervenção do estado sobre o tema e, mais especificamente, sobre as favelas.

Analisada em seus conteúdos de sentido mais essenciais, a representação da violência urbana seleciona e indica um complexo de práticas que são consideradas ameaças a duas condições básicas do sentimento de segurança existencial que costuma acompanhar a vida cotidiana rotineira - integridade física e garantia patrimonial. Ela aponta para o crime comum, mas o foco de atenção é a força nele incrustada, a qual é definida como responsável pelo rompimento da "normalidade" das rotinas cotidianas, isto é, de seu caráter cognitiva e axiologicamente não-problemático e moralmente lícito. Esta é a razão pela qual violência urbana não é simples sinônimo de crime comum nem de violência em geral. Trata-se, portanto, de uma construção simbólica que destaca e recorta aspectos das relações sociais que os agentes consideram relevantes, em função dos quais constróem o sentido e orientam suas ações. Desta perspectiva, possui um significado instrumental e cognitivo, na medida em que representa, de maneira percebida como objetivamente adequada a determinadas situações, regularidades de fato relacionadas aos interesses dos agentes nestes contextos. Mas, como toda representação, a violência urbana é mais do que uma simples descrição neutra. (MACHADO DA SILVA, 2004, p. 57-58). 
Em outra obra, Machado da Silva (2008, p. 20) é ainda mais explícito, afirmando que a noção construída socialmente sobre a violência urbana alteraria profundamente o lugar das favelas no imaginário das cidades. Embora em um sentido amplo ela esteja conectada a diversas práticas que ameaçam a integridade físico-pessoal e patrimonial, quase sempre a representação da violência urbana se restringiria às atividades de criminosos, mais especificamente do traficante de drogas, diretamente associados às favelas. Um dos efeitos perversos, portanto, do enquadramento atual do debate sobre segurança e violência seria, segundo o autor, a criminalização das populações residentes nos "territórios da pobreza", representados pelas favelas (MACHADO DA SILVA, 2010, p. 284). Pode-se então perceber que a cadeia de noções vai então tomando o todo pela parte e sobre essa incidirão seus efeitos

- Violência > Violência Urbana > Tráfico de drogas > Favelas - como será visto à frente.

No caso da Colômbia, temos um conceito ainda mais polissêmico, tendo em vista que a expressão "violência" é comumente usada de forma genérica para vários temas (como impulsionador da formação dos assentamentos informais ${ }^{32}$, por exemplo), abarcando uma diversidade ainda maior de conflitos. Ao longo da trajetória de formação do país, há uma violência gerada por conflitos de ordem política, como aqueles entre liberais e conservadores; ideológica, como o enfrentamento de grupos guerrilheiros (PATIÑO, 2015, p. 188); econômica, a exemplo da disputa entre diferentes facções narcotraficantes e paramilitares; territorial, caso de enfrentamento entre Estado e grupos criminais e entre diferentes espécies dentre estes grupos; etc. (MAZO, 2014, p. 23-24).

Dentre estas diferentes formas e significados, merece destacar que também se inclui nesta expressão os processos de proletarização e de conflitos pela posse da terra ocorridos no campo em função da expansão das fronteiras agrícolas em meio rural. "En Colombia se llamó con el nombre de "la violencia" a la

\footnotetext{
32 "En Colombia, esencialmente hasta los años ochenta, noventas, y antes en los años cincuenta, tuvo unos sucesos migratorios tremendamente masivos, gran parte producidos por el fenómeno de la violencia. Entonces, el desplazamiento es una cosa, digamos, tremendamente incidentes en la formación de ciudades colombianas. Colombia es un país de ciudades, entonces por los emigrantes, no solamente migran a grandes metrópolis sino también en las ciudades intermedias" (ENTREVISTADO 24).
} 
etapa generada en las zonas rurales de proletarización campesina, a la implantación do las relaciones capitalistas en el campo y a la expropiación violenta de las tierras que los minifundistas explotaban" (PEVAR, 1984, in, MARIN, 1991, p. 52). Este processo teve como base, portanto, a tomada à força de extensões de terra e a expulsão de milhares de famílias do campo, sendo um dos grandes responsáveis pelo processo de crescimento acelerado dos centros urbanos.

Embora o crescimento acelerado destes centros se dê a partir principalmente da década de 1950, já no início do século XX (mais precisamente nas duas primeiras décadas), ocorrem diferentes ondas de migração para as cidades em função de conflitos vividos no campo (CADENAS, 2010, p. 72). Desde então e ao longo de todo o restante do século, os processos de violência vividos nas diferentes regiões do país forçaram grandes contingentes populacionais a migrarem para as cidades, tanto para aquelas de porte médio como principalmente para as grandes, caso de Bogotá e Medellín.

A inclusão tardia de novos territórios à expansão da fronteira agrícola na região de Antioquia na metade do século XX, por exemplo, foi um dos grandes impulsionadores do crescimento informal de Medellín. Ao contrário das etapas anteriores de expansão, que se deram principalmente em regiões pouco ou até mesmo não habitadas, este ciclo teria ocorrido majoritariamente através da expulsão de milhares de famílias.

\footnotetext{
"El despegue urbano de Medellín, que lo podemos ubicar como ya consolidado en los años cincuenta, coincide con el incremento de la violencia en los territorios de exclusión, aquellos ubicados en las tierras bajas de Antioquia (...). Allí, la integración de estas tierras a las economías internas y externas se produjo bajo la modalidad del llamado capitalismo salvaje (...) Todos estos procesos han estado marcados por fuertes formas de violencia y han sido escenarios de atroces masacres que solo recientemente han recibido la acción de la justicia. El efecto en Medellín ha sido directo. De una parte, el desplazamiento forzado de los pobladores buscando protección y refugio a la expulsión violenta, en su gran mayoría, se han dirigido a la capital. De otra parte, la mayoría de ellos, con baja escolaridad, con dificultades para la inserción formal en la vida urbana, entran a engrosar el ejército de informales" (PATIÑO, 2015, p. 72-85).
}

Este fenômeno, que continua afetando ainda hoje o crescimento das cidades no país (ENTREVISTADO 10), estava evidentemente atrelado aos outros tipos de conflitos vividos nestas regiões - aqueles já mencionados ligados a disputas políticas, ideológicas, etc. - tendo trasladado muito destes conflitos e de suas 
características para o meio urbano e, assim, alimentado a violência urbana (PATIÑO, 2015, p. 64).

Sob outras formas, a violencia também possui um papel na formação dos centros urbanos brasileiros. Para além dos estereótipos e representações sociais que associam favela à criminalidade, ela tem sido componente articulador importante de relações políticas, sociais e culturais desses territórios.

Se por um lado é possível observar nuances diferentes entre os conflitos vividos nos dois países (tendo em vista a natureza marcadamente política de muitos conflitos vividos no campo na Colômbia), é simbólico que o mito de origem da considerada primeira favela brasileira esteja conectado com a (ir)resolução de um conflito armado de natureza política. O Morro da Providência, de acordo com a história reiterada por diferentes autores, teria sido originado por ex-combatentes do exército brasileiro envolvidos na Guerra de Canudos. Uma comunidade, que por sua crença e configuração messiânica, desafiou o nascente Estado brasileiro (VALLADARES, 2000). Não se tratava propriamente de refugiados do conflito, tendo em vista o massacre vivido por aquela população, mas de todo um grupo de pessoas que, embora estivessem no lado vitorioso da contenda, foram desconsiderados na administração da situação pós-conflito.

Não se pode esquecer, ainda, o processo violento através do qual foi implementada a Reforma Passos no Rio de Janeiro, através da qual, sob um viés higienista e autoritário, houve uma considerável expulsão da população pobre da área central da cidade (Azevedo, 2003). Essa violência marca fortemente o início da trajetória de expansão e consolidação das favelas, tendo em vista que a ação pública de derrubada de cortiços em áreas centrais do Rio de Janeiro, por exemplo, teria redundado no primeiro movimento de crescimento da população pobre nos morros cariocas (ZALUAR \& ALVITO, 2006, p. 07). Gonçalves (2013, p. 45) esclarece que, mais do que Canudos e o Morro da Favella, o "surgimento das favelas é uma consequência direta da política higienista contra os cortiços". 
É importante lembrar que se tratava também do contexto pós-abolição. Depois de séculos de um regime escravocrata que subjugou e oprimiu a população negra trazida da África, vivia-se neste período o drama daqueles que alcançaram a liberdade sem contarem, no entanto, com qualquer processo de inserção no mercado de trabalho, por exemplo. Uma violência de séculos e, com isso, uma dívida política e social histórica da sociedade brasileira é, portanto, um importante impulsionador da formação de territórios de favelas.

Em São Paulo, por outro lado, também é marcante a violência promovida no momento de intervenções na região central quando do processo de eliminação de cortiços a partir do século XIX (ROLNIK, 2007), dando início a um processo de autoconstrução nas regiões periféricas. Exemplo também eloquente é a expulsão promovida pelo município na remoção de favelas localizadas em regiões centrais pelo governo Jânio Quadros na década de 1980.

A presente parte buscará demonstrar como a violência urbana, principalmente aquela ligada ao narcotráfico com a qual a população favelada é associada, é central para a compreensão tanto da ascensão da urbanização de favelas na Colômbia e no Brasil quanto das dificuldades do estabelecimento de uma atuação permanente neste setor por parte do estado. Nesse sentido, no primeiro capítulo, serão explorados principalmente os contextos de Medellín e Rio de Janeiro no tocante à violência urbana a partir das décadas de 1980 e 1990 para evidenciar como, em algumas situações, ela conflui com a agenda e a implementação de ações de urbanização de favelas. No segundo capítulo, serão abordados aspectos conflitantes entre a violência (e as políticas de segurança implementadas com o pretexto de combatê-la) e a urbanização de favelas, demonstrando como progressivamente está se verificando a submissão desta e de outras políticas sociais ao processo de militarização da sociedade sob o argumento de combate à violência. 


\section{Capítulo 3 - A política que se alimenta da violência: como a urbanização de favelas é impulsionada pela violência urbana}

\subsection{Medellín}

No caso da Colômbia, se, por um lado, a violência no campo gerou um fluxo migratório que alimenta até hoje o crescimento dos assentamentos informais nas cidades, por outro, a precarização característica da formação do espaço intraurbano destas cidades também alimentou o ciclo de reprodução da violência no meio urbano. A ascensão da violência na Colômbia está ligada, portanto, também à incapacidade de o estado prover condições mínimas de vida para sua população - fracasso da infraestrutura física e social, incapacidade de prestação de serviços públicos de qualidade, etc. (ENTREVISTADO 15)

Todas estas condiciones, altas tasas de migración de pobladores provenientes
de territorios de exclusión, altas tasas de desempleo, crisis industrial,
crecimiento de la pobreza urbana, incremento del contrabando y un Estado
minusválido, se convirtieron en el caldo de cultivo de la violencia que apareció
en los setenta, creció en los ochenta e hizo metástasis en los noventa. La
violencia se convirtió en otra forma de vida urbana y permitió la inserción en la
ciudad de amplios grupos de población, con fuertes expresiones de subculturas,
con sus propios mitos, sus ritos bien definidos y una simbología propia. El
narcotráfico se insertó en las fracturas de la sociedad urbana, no las creó. Se
aprovechó de los intersticios que dejaba el modelo que estaba en crisis y sobre
ellos creció (PATIÑO, 2015, p. 78) É justamente no momento em que o narcotráfico se instala nestas fraturas sociais e se alastra para os mais diferentes âmbitos da vida social que ocorre a ascensão da violência como emergência social, especialmente no caso de Medellín. Em função da centralidade que esta questão adquire para o impulsionamento das ações de mejoramiento barrial na cidade, vale a pena aprofundar este tema a seguir.

As fronteiras entre a legalidade e a ilegalidade no campo econômico de Medellín começam muito tempo antes do narcotráfico. Já no século XVIII, o comércio de minérios (especialmente o ouro) era o centro da economia da região e se dava, em grande parte, de modo ilegal (contrabando), existindo um 
forte esquema de evasão para que não fosse necessário passar pela coroa espanhola (PATIÑO, 2015, p. 46). Com isso vão se construindo três características que vão marcar a história da região e da cidade: o ethos mercantil da região, a expertise de circulação de mercadorias por fora dos circuitos legais e a violência a elas associada.

"el modelo mercantil especulativo, base de la acumulación de riqueza en Antioquia e instrumento para la construcción de una red que conectaba a los grandes y pequeños mineros, a los comerciantes de Medellín con los de los pueblos pequeños, a los importadores y exportadores. Integraba a las gentes, a los territorios y a las poblaciones con la capital regional. Fue el vehículo de integración del espacio geodemográfico antionqueño en una trama de relaciones sociales, económicas y políticas" (PATIÑO, 2015, p. 51)

A região da Antioquia como um todo, segundo autores, tem sua história marcada pela violência, tendo sido a guerra um elemento de grande importância na conformação da região (PATIÑO, 2015, p. 56). Desde o século $\mathrm{XIX}$, Antioquia se viu envolvida em diversos conflitos, como as guerras federais entre liberais e conservadores, que parecem marcar a estruturação do tecido político e sociocultural da região (BOTERO HERRERA, 2003, p. 19).

Trata-se, portanto, de uma rede intrincada de dimensões sociais, políticas, econômicas e territoriais que constituem a identidade da região e que se mostrarão importantes ao longo da história - primeiramente (MARTIN, 2012, p. 59) quando se estabelecem o comércio e as rotas de contrabando de produtos importados (em função do mercado fechado) e, posteriormente, o comércio e as rotas do narcotráfico (PATIÑO, 2015, p. 64 e 74), o qual floresce principalmente a partir da década de 1970, no contexto da crise econômica enfrentada pela cidade (ALCALDIA DE MEDELLíN, 1996, p. 39) e pelo país.

"En la década de los años 70 , todos los esfuerzos políticos y financieros del Estado son conducidos a favorecer el proyecto de la diversificación de las exportaciones como una vía para superar la crisis en la que había entrado el modelo de desarrollo con base en la sustitución de las importaciones. Tanto el ahorro nacional, sobre todo el proveniente de la bonanza cafetera que le correspondió al gobierno de López Michelsen, como los grandes empréstitos en los que se embarcará el país, son utilizados fundamentalmente para la modernización de los "sectores de punta" en los campos minero, manufacturero y agroindustrial que ofrecían ventajas comparativas. Sólo un pequeñísimo sector de colombianos se beneficiará realmente con el incremento de las exportaciones, pero todo el país sí tendrá que asumir las consecuencias de la crisis que implica el crecimiento de la deuda externa y la reducción significativa de la inversión social durante la siguiente década. El viraje "hacia afuera" del modelo de desarrollo dejará sin posibilidades el desarrollo interno. Las consecuencias se agudizarán en sectores como la educación, la vivienda, la salud y el campo" (VELÁSQUEZ ET AL, 1994, p. 03). 
Neste contexto de crise e associado a outras formas prévias de contravenção, como o contrabando (PATIÑO, 2015), o narcotráfico passa a fazer parte da atuação de diferentes grupos criminais e vai aos poucos se tornando sua principal atividade, tendo em vista sua alta lucratividade. No contexto de crise econômica da época, particularmente do setor industrial (na época um dos motores econômicos da cidade), ele se torna também uma fonte de renda para uma grande população de desempregados e passa a injetar grandes quantidades de dinheiro na economia local.

Cria-se, assim, uma microbolha de melhoria das condições econômicas e de vida da população, pois possibilitou um respiro momentâneo da economia da região. Com isso, os diferentes grupos sociais adotaram uma postura permissiva / leniente em relação ao narcotráfico, que então passa a permear a estrutura social, econômica e política de Medellín.

O Estado já possuía na época uma débil relação com a sociedade civil, havendo poucos canais de diálogo entre atores públicos e privados e uma situação de crescente deterioração da vida urbana a partir do crescimento acelerado causado pelas ondas migratórias das décadas anteriores (ALCALDIA DE MEDELLíN, 1996, p. 40), para a qual o governo local não conseguia apresentar uma solução adequada e, nos poucos momentos em que atuava, praticamente apenas focava em ações de remoção de assentamentos informais. Nesse sentido, o Estado também adota uma postura omissa diante do crescimento do narcotráfico, enfraquecendo ainda mais sua presença nos territórios informais e debilitando progressivamente sua credibilidade perante a sociedade.

Diante dessa passividade do Estado, o território passa a ser utilizado pelo narcotráfico, portanto, como meio de controle sobre a população sob duas formas: coação e cooptação. Sob a primeira forma, ao contrário do que acontecia com as organizações estatais, adquiria cada vez mais poder na medida em que atuava a partir da imposição de regras no território e outras formas de controle social.

"Estas estructuras no institucionales han pretendido usurpar la función del Estado y obtener, generalmente, legitimidad política por medio de prácticas como la intermediación en los conflictos y mediante la imposición de castigos y 
otras formas de regulación y control social, que finalmente se convierten en elementos de un orden local que no ha podido garantizar el Estado" (PATIÑO, 2015, p. 176).

Sob o segundo aspecto, promovem a construção de uma base de apoio através da realização de intervenções e melhorias no território, as quais o poder público também vinha falhando em prover. Em entrevista com morador de uma das áreas mais envolvidas nessa trama (ENTREVISTADO 05), Pablo Escobar (um dos mais famosos chefes do narcotráfico colombiano) promovia e financiava diversos investimentos como uma forma de compensar a violência imposta e, assim, constituir uma base de apoio nestes territórios, ganhar legitimidade junto à população. "Com as doações que fazia para melhorias nos barrios, Pablo Escobar legalizava dinheiro e comprava consciências" (ENTREVISTADO 05).

Desta forma, a escassez de investimentos públicos agravava a crise urbana que se formava nos setores populares das cidades e servia de oportunidade para o fortalecimento do narcotráfico, visto como uma alternativa para aqueles que moravam nestas condições (SALAZAR ET JARAMILLO, 1992, p. 33). O Estado demorou a compreender a complexidade da situação e em que medida ela limitava sua capacidade de intervenção nos mais diferentes âmbitos, seja no alcance do seu poder político, na implementação de políticas, etc. Demorou, principalmente, a mudar sua postura diante dela e a adotar uma proatividade no tocante à melhoria dos assentamentos informais. "El reconocimiento a esta nueva realidad se demoró en aparecer. La existencia de otra ciudad - la de las comunas - produjo una intervención del Estado orientada hacia las obras materiales, de urgente realización, es cierto, pero con frecuencia se quedaron ahí, sin un componente social” (SALAZAR ET JARAMILLO, 1992, p. 33).

É importante salientar que, se até a década de 1970 a maior parte das intervenções públicas nos assentamentos visava sua remoção, começa a haver uma inflexão a partir de então, sendo iniciadas algumas ações nas comunas (subdivisões administrativas adotadas pelo município de Medellín) - instalação da rede de água, energia elétrica e de equipamentos sociais, como escolas, centros esportivos e de saúde. Apesar disso, aparentemente não possuem a mesma escala e, muito menos, o mesmo objetivo que se buscaria com ações 
de peso como o PRIMED a partir da década de 1990: disputa de poder entre estado e organizações criminais a partir da intervenção no território.

A influência destas organizações criminosas dentro do próprio estado (SÁNCHEZ TORRES, 2003, p. 179) gozava de notoriedade, principalmente no âmbito dos governos locais da região (PATIÑO, 2015, p. 160). Ainda segundo entrevista já citada com morador (ENTREVISTADO 05), Escobar por exemplo mantinha relações diretas com os governantes, as quais iam além do financiamento (PATIÑO, 2015, p. 187). Embora os gestores não falassem, a população sabia qual era a origem daquele recurso, a exemplo de um campo de futebol implantado na área em que residia, Santo Domingo Savio. Este era uma demanda antiga dos moradores, tendo sido viabilizada com dinheiro fornecido por Escobar à prefeitura (ENTREVISTADO 05).

O narcotráfico, portanto, se insere nas diferentes estruturas da vida social de Medellín, impactando as esferas política, econômica, social, cultural e urbanística, esta última na medida em que passa também a influenciar o desenvolvimento do espaço urbano da cidade e nas possibilidades de aproveitamento dele por parte da população (PATIÑO, 2015, p. 81). Com a notoriedade da sua influência no âmbito político, inclusive diminui ainda mais a credibilidade do estado perante a sociedade.

"El tema del narcotráfico se mete tanto en el Estado, que el Estado queda totalmente deslegitimado. Entra en el Senado, el los Ministerios, en las campañas políticas. Entonces, el Estado colombiano queda deslegitimado ante los ciudadanos" (ENTREVISTADO 08).

Com o crescimento das operações de tráfico engendradas pelos grupos e a escalada da violência utilizada em suas ações a década de 1980 assiste à ascensão do narcoterrorismo. A manobra geopolítica fomentada pelos EUA de declarar guerra às drogas impactou o cenário internacional e a situação do tráfico internamente em vários países, principalmente na Colômbia, um dos principais pontos de exportação da cocaína. Com a pressão norteamericana para que se tornasse possível a extradição de traficantes colombianos para outros países, estes atores começam a recrudescer sua pressão sobre o governo, promovendo diversos ataques terroristas a bomba, sequestros, assassinatos, etc. Pressionado pelos EUA e pela gravidade da atuação imposta pelo narcoterrorismo, o Estado se vê na obrigação de alguma forma 
enfrentar a questão e responder de forma repressiva. Isso força os grupos narcotraficantes a entrarem na clandestinidade e instala uma guerra entre eles e o Estado, com graves sequelas para a população em geral. No final desta década, vivencia-se em Medellín uma situação de emergência social (ALCALDIA DE MEDELLíN, 1996, p. 39 e 40).

Ao final dos anos 1980 e início dos 1990, a força dos cartéis e a violência em Medellín atingem seu auge (ENTREVISTADO 08; PATIÑO, 2015). Não apenas resultante das ações dos grupos ligados ao narcotráfico, mas também da atuação de outros grupos criminais ligados à delinquência comum e a grupos paramilitares, esta época marca a cidade como uma das mais violentas do país e do mundo (PATIÑO, 2015, p. 214-224). Segundo dados da Alcaldia de Medellín (1996, p. 38), a região, que concentrava em 1988 18\% dos homicídios do país, passou a concentrar mais de 30\% apenas três anos depois, em 1991. No período de 1990 a 1999, foram registrados 45.370 homicídios na cidade (ALCALDIA DE MEDELLÍN, 2005), tendo se concentrado 51\% desses homicídios apenas nos três primeiros anos da década.

Para se ter uma noção da ordem de grandeza, no ano com o maior número de ocorrências (1991), houve 6.349 homicídios, correspondendo a uma taxa de 380 assassinatos para cada 100.000 habitantes. Os 45.370 homicídios da década correspondia a aproximadamente $2,3 \%$ da população total residente no município ao final dos anos 1990 (DEPARTAMENTO NACIONAL DE ESTATÍSTICA DE COLOMBIA, 2011). Ao final deste período, a taxa de homicídios de Medellín era mais de 4 vezes maior do que a de Bogotá (ÁVILA MARTINEZ, 2012) e era a principal causa de morte, sendo considerada a principal questão de saúde pública à época (ALCALDIA DE MEDELLÍN, 1996, p. 37).

Além do homicídio, outras espécies de crime também cresciam vertiginosamente na cidade, a exemplo de práticas como a extorsão e o sequestro. A região concentrou nesse período do início dos anos 1990 a maior parte dos sequestros do país e o registro de casos de extorsão cresceu $45 \%$ ao ano, enquanto esse incremento foi de $20 \%$ no restante da Colômbia (ALCALDIA DE MEDELLÍN, 1996, p. 38). Contribuíam para esse quadro o fato 
de a cidade contar com um aparato policial deficiente - com baixo efetivo, mal equipada e corrupta - e uma alta taxa de impunidade em processos judiciais, segundo análise da Alcaldia de Medellín (1996, p. 38).

É importante destacar que esta situação de violência atinge de maneira mais forte as áreas da cidade caracterizadas pela maior presença de assentamentos informais, afetando, portanto, fortemente a população de baixa renda e especialmente os jovens.

"Entre los años 1985 y 2003, la ciudad de Medellín y las comunas 1 y 2, registraron los más altos índices de violencia e inseguridad gracias al narcotráfico, a la confrontación armada y disputa de territorios por parte de grupos al margen de la ley (guerrilla y paramilitares) y, a la conformación de bandas delincuenciales al servicio de dichos grupos. La zona nororiental y en particular, las comunas 1 y 2, registraron las mayores tasas de homicidios en la ciudad; y, al 2001, se tenía registro de los más altos niveles de crimen organizado: 164 bandas criminales identificadas de las cuales, 65 operaban en la zona nororiental (VCPDM, 2008, pp. 32-33), la mayoría de ellas, en las comunas 1 y 2, siendo la población joven la más afectada por este fenómeno" (MAZO, 2014b, P. 57-60).

Apesar de afetar especialmente a esta população, a cidade como um todo também sofria com os diferentes impactos produzidos pela violência. A economia da cidade, por exemplo, era afetada pelo desincentivo a investimentos externos causados por este contexto (ENTREVISTADO 08). Impactava também os diferentes setores da elite e da classe média, tanto do ponto de vista da possibilidade de usufruir a cidade, quanto também da manutenção de seus negócios, como comércio, serviços, negócios imobiliários, etc. - todos extremamente afetados pela falta de segurança e pela queda no convívio social causados pela violência.

"la crisis movilizó incluso las elites de la ciudad porque los estaba afectando, les estaban matando en los parques, ellos no podían salir tranquilos en la calle porque los podían matar en un atentado" (ENTREVISTADO 15).

"Entonces qué es, el estado todo sale a perseguir a este hombre, y eso pasa en esta ciudad. Entonces, en esta ciudad lo que teníamos era una guerra entre el estado y el (Pablo Escobar), y en la cual nosotros nos veíamos afectados porque cuando Pablo Escobar se sentía acorralado, ponía una bomba, 'pum'. Pero eso no era una guerra contra nosotros, sino que entre ellos, pero nos afectaba. Qué repercusiones tuvo eso en la ciudad? Primero, el disentivo total de la inversión. Segundo, unas condiciones de inviabilidad social (...)" (ENTREVISTADO 08).

Todo este cenário começou então a mobilizar a agenda pública e possibilitou a formação de uma ampla mobilização social para enfrentar a crise social instalada pelo narcotráfico. 
"Eso movilizó mucho los actores sociales de aquí, que se organizaban en pro de tener que atender la crisis social nuestra. $Y$ ante esa crisis, que afectó incluso el sector privado, entonces empresarios, líderes comunitarios, entes gubernamentales, el mismo gobierno nacional hizo presencia fuerte con un programa que se llamó La Personería para Medellín y Antioquia. Todos estaban de acuerdo en que había que resolver la crisis de Medellín y resolver la crisis de Medellín no era simplemente poner más policías y atender el origen del sicariato, sino que se dieron cuenta que las canteras de donde salían los muchachos que mataban por este hombre y por otros narcotraficantes eran los barrios populares que no tenías servicios públicos, que no tenían calidad de vida, que no tenían vivienda adecuada, que no tenían no sé qué. Entonces, digamos, había una orientación hacia tenemos que atender esto, si no resolverlo, por lo menos a minorarlo, disminuirlo lo más que podamos y salen acciones integrales para atender ese tipo de cosas (...)" (ENTREVISTADO 15).

Se por um lado, isso se baseava e reforçava o estigma dos barrios como os lugares da violência em Medellín (COUPÉ, s/d, p. 93-94); por outro, demandou da sociedade uma resposta do ponto de vista dos assentamentos informais. Portanto, esta situação despertou os mais diferentes atores sociais - inclusive - Estado - para a necessidade de formular e implementar diferentes intervenções (públicas, privadas, comunitárias, etc.) orientadas ao melhoramento das condições de vida da população residente nestas áreas (MAZO, 2014b, P. 57-60).

Percebe-se então que era necessário intervir sobre as diferentes precariedades características destes assentamentos, como a ausência de serviços públicos, condições inadequadas de moradia, espaços públicos reduzidos e deteriorados, situação socioeconômica precária das famílias, ou seja, baixa qualidade de vida em geral. "En el caso de Medellín, la incidencia del narcotráfico y la violencia en el crecimiento de la ciudad y la informalidad son determinantes para el impulso de acciones institucionales de intervención en áreas urbanas vulnerables física y socialmente desde fines de los años 80" (TOVAR, 2012, p. 11).

Se desde a década de 1980 já se ensaiavam algumas ações de intervenção nesta direção, como aquela realizada pelo município no barrio de Moravia com apoio da cooperação alemã (TOVAR, 2012, p. 11), é o PRIMED que representa então uma grande mudança de paradigma nas intervenções públicas em barrios, impulsionada pela crise instalada pela violência urbana ligada ao narcotráfico e reforçada pelo que estabelecia então a nova Constituição do país. 
"Su propósito fue atender de manera integral el problema urbano de los asentamientos precarios, generando transformaciones en las condiciones físicas de la vivienda y del entorno, contribuyendo a elevar la calidad de vida como medio para mejorar la convivencia ciudadana, construir y fortalecer el tejido social, mediante inversiones en infraestructura física y en programas sociales con altos grados de participación comunitaria" (MAZO, 2014, p. 127-128).

Vale lembrar que em 1991 se adota uma nova Constituição para o país a partir de um processo de mobilização nacional - a qual trazia uma série de direitos como obrigação do Estado e que é utilizada para embasar a formulação do PRIMED (ALCALDIA DE MEDELLÍN, 1996, p. 08 e 125) e legitimar a ação da municipalidade no discurso público. "Los actores ante esa crisis aprovechan la coyuntura de la Constitución y dicen 'tenemos que hacer valer la Constitución' y montan el sistema municipal de lo PRIMED" (ENTREVISTADO 15).

Se coloca, então, a necessidade de se intervir integralmente nos assentamentos da cidade, de se intervir para melhorar o espaço público para convivência, de serem construídos equipamentos sociais e espaços de lazer e interação, de gerar processos de fortalecimento da economia da região, etc (ENTREVISTADO 15). O Estado tinha que se fazer presente através da melhoria das condições de vida da população, essencial para o resgate de sua legitimidade e para a disputa territorial com o narcotráfico. "Medellin foi uma disputa de território também, porque eles aproveitaram o vácuo da morte do Pablo Escobar pra entrar com uma política maciça de bem estar social, em que o carro-chefe era a urbanização dos assentamentos precários" (ENTREVISTADO 14). Isso estará novamente em jogo a partir dos Proyectos Urbanos Integrales (PUI), os quais, contudo, serão abordados no próximo capítulo, já que representam o princípio de uma mudança na relação entre as intervenções em favela e a violência urbana.

\subsection{Rio de Janeiro}

É interessante notar que a trajetória desta relação em Medellín entre "precariedade dos assentamentos, ascensão de grupos criminais, explosão da 
violência e intervenção naqueles assentamentos" encontra paralelo no Brasil, principalmente na cidade do Rio de Janeiro.

diferentes autores (ADORNO, 2002; COSTA, 1999; CHAUÍ, 2000; MISSE, 2008; ZALUAR, 2006) frequentemente destacam que a violência geral, no entanto, é parte da sociedade brasileira há muito mais tempo, sendo até mesmo considerada estruturante desta sociedade.

Não se pode falar de violência no país, por exemplo, sem mencionar o genocídio indígena sobre o qual se funda o Brasil (RIBEIRO, 1970 e 1995). Tampouco é possível ignorar o histórico escravocrata que dominou o país por séculos (FAUSTO, 1994), o qual, ainda hoje, é um período maior do que os 130 anos contados da abolição até o presente. Por fim, para aqueles que afirmam ser a natureza dessa violência brasileira diferente da colombiana (tendo em vista que esta seria de natureza estritamente política, como se o genocídio indígena e a escravidão não possuíssem esse caráter), é necessário relembrar a miríade de conflitos e revoltas populares vividas no país com caráter político e econômico - como a Revolução Farroupilha (RS), a Revolução Praieira (PE), a Revolta dos Malês (BA), a Cabanagem (PA), o Caldeirão (CE), dentre outras (DANTAS, 2011) - muitas "solucionadas" a partir da chave da "pacificação" em voga no país desde então, como demonstra Valente (2016).

[Até o início] dos anos 1970, não se falava de violência urbana no Brasil. Havia pouquíssimos estudos sobre criminalidade. Dizia-se com naturalidade que 0 Brasil era um país povoado por gente cordial, um país sem violência, um país pacifico. (...) Hoje sabemos, passados 30 e tantos anos, que havia muito de ilusão nessa auto-concepção que se tinha do nosso país. Afinal, nela, nós recalcávamos, como se estivessem superados, séculos de escravidão, séculos daquela escravidão que permaneceu vigente como uma das últimas do mundo a ser abolida. (MISSE, 2008, p. 372)

Todo esse histórico violento brasileiro, muitas vezes submerso na versão oficial da própria história que o país constrói para si mesmo de maneira dissociativa, não estava conectado ou era alimentado pelo tráfico de drogas. A venda da maconha sempre gozou de maior tolerância e aceitação social, sendo inclusive pouco conflitivo e um comércio pouco rentável e protagonizado por criminosos 
desorganizados e independentes, com armamento de baixo custo (SOUZA, 2010, p. 51).

\begin{abstract}
Note-se que o tráfico de drogas (...) não surge nas favelas do Rio apenas na década de 80 . Seu aparecimento foi muito anterior a isso. Antes, porém, sua visibilidade política era muito pequena, pois ele não tinha ainda despertado a atenção e o temor da classe média e das elites, a não ser do ponto de vista da preocupação de alguns pais com a possibilidade de seus filhos tornarem-se usuários de drogas, drogas essas muitas vezes compradas nas favelas. 0 tóxico adquirido nas favelas era, então, sobretudo a maconha; a cocaína, à cuja comercialização gradualmente se associaram maiores lucros e poder, desempenhava um papel pouco relevante. (SOUZA, 2010, p. 59 e 60).
\end{abstract}

É importante notar que já havia, portanto, a comercialização de drogas muito antes da escalada da violência. Como Souza (1994, p. 30; 2010, p. 49 e 50) aponta, é possível encontrar indícios da utilização (e logicamente da comercialização) de maconha e cocaína desde a primeira metade do século XX. Além disso, já se sabia de alguns "donos" das favelas, conforme relato da infância nos morros conferido por Ailton Batata, um dos primeiros grandes traficantes do Rio de Janeiro.

No morro, tinha também os caras que mandavam, como se diz agora - dono do morro. Naquela época, tinha um dono e a vagabundagem, mas era uma coisa muito escondida, e não tinha nenhum bambambã que fosse mais poderoso que as outras pessoas. Não tinha esse tráfico de hoje não, tinha só boca de fumo. Tinha uns caras que a gente ouvia falar que eram malandros (ZALUAR \& FREITAS, 2017).

O trecho destacado é relevante para indicar que, embora com nuances e escalas diferentes, tanto o comércio de drogas (as "bocas") quanto figuras de autoridade (o "dono" ou "malandro) que utilizavam da violência para manter seu domínio já existiam nas favelas da cidade do Rio de Janeiro há décadas, mesmo antes da escalada da violência na década de 1980 (ZALUAR \& FREITAS, 2017, p. 139). Como lembra Misse ${ }^{33}$ (2011), desde o período imperial, já era "uma peculiaridade do Rio de Janeiro sempre ter em sua história social "valentes" e "donos" de morros", como no Império, em que a cidade era dividida em duas bandas das maltas de capoeiras, os territórios dos bicheiros, dentre outros.

A violência urbana, como entendida hoje, não está propriamente na simples existência do comércio de drogas em si e do domínio e disputas territoriais

\footnotetext{
${ }^{33}$ Disponível em: https://diplomatique.org.br/os-rearranjos-de-poder-no-rio-de-janeiro/
} 
observados nas favelas. Ambos existiam já há muitos anos quando se verifica a escalada da violência nas cidades brasileiras.

Até a década de 1950, por exemplo, os crimes que eram comumente observados eram apenas as contravenções penais e crimes de menor potencial lesivo: brigas com ferimentos leves, pequenos furtos, estelionato, a sedução, o adultério, o lenocínio. Tratavam-se, em geral, de crimes que na maioria das vezes não faziam uso da violência. Os homicídios praticados, por outro lado, tinham principalmente motivação passional (MISSE, 2008, p. 375).

Misse (2008, p. 375) situa o início da violência urbana no Brasil, em geral, justamente em meados da década de 1950. A partir de então, os padrões de criminalidade começam a mudar lentamente em cidades brasileiras como Rio de Janeiro e São Paulo, passando a serem noticiados com mais frequência assaltos à mão armada, por exemplo, a postos de gasolina, bancos e residências. A imprensa, inclusive, começa a chamar mais atenção à existência do crime organizado no jogo do bicho e no contrabando (MISSE, 2008, p. 376).

Começavam também nessa época a crescer as periferias, favelas e outros assentamentos populares no país, conforme já abordado na introdução desta tese. Esse crescimento, contudo, não foi acompanhado, como lembra Feltran (2018, p. 152), de garantia de segurança para seus moradores, tendo em vista que o crescimento dos serviços policiais não seguia o mesmo ritmo do crescimento da cidade de São Paulo, por exemplo, e a violência já começava a espreitar.

Ainda assim, até o período da ditadura militar, o controle dessas atividades criminais - como contravenções, crimes contra o patrimônio, prostituição, contrabando, comercio de drogas ilícitas (quase exclusivamente maconha) não gozava de centralidade na agenda pública. Segundo Machado da Silva (2010, p. 289), ainda "era uma questão socialmente periférica e submersa, que despertava pouca atenção pública, cujo controle sempre foi delegado ao arbítrio da autoridade policial".

Somente a partir da década de 1970 e, principalmente, a partir da década de 1980, esse panorama se altera. Dois elementos chave surgem no debate 
público desde então e são fundamentais para a discussão do crescimento da violência no país e sua ligação com a intervenção em favelas: 1) a violência institucional; e 2) a violência promovida pelo crime organizado, principalmente ligado ao tráfico de drogas.

A ditadura militar instalada despertou, pela primeira vez, inquietações na sociedade em geral acerca da violência institucional como "forma rotineira e organizada de conter os crimes" (ADORNO, 2002, p. 108). Se até este momento apenas os sujeitos diretamente atingidos por esta violência (em geral, de classe baixa) estavam atentos para a forma de repressão promovida pelo estado; com a repressão política promovida pela ditadura militar, a classe média brasileira passa a ser diretamente atingida.

Com o advento dos governos militares, a ideologia da segurança nacional progresivamente destacou, politizou e trouxe para o escrutínio público o tema do controle social. (...) A reorganização da atividade repressiva a partir da Lei de Segurança Nacional trouxe à tona as péssimas condições de vida nos presídios. Embora nunca tivessem sido segredo, só naquele momento elas se tornaram objeto de intenso debate, estimulado pelas notícias de tortura que se avolumaram com o enfraquecimento do poder dos militares e com a presença, nas cadeias, de membros menos desprovidos de recursos materiais, sociais e simbólicos do que os que costumavam frequentá-las. Não é de estranhar, portanto, que a questão das formas legítimas e ilegítimas de manutenção da ordem social, como tópico específico de debate, entre na consideração pública e se torne parte integrante da campanha pela redemocratização (MACHADO DA SILVA, 2010, p. 289).

Cresce, dessa maneira, o questionamento da violência enquanto mecanismo do estado de controle social durante a redemocratização, deixando mostras de que essa utilização não se restringia à vigência do regime de exceção (ADORNO, 2002, p. 108). Paralelamente a esse questionamento, o segundo elemento chave mencionado acima - a violência promovida pelo crime organizado, tomada como motor principal da violência urbana - cresce sobremaneira a partir da década de 1970 e, principalmente, década de 1980, como será abordado a seguir.

Um primeiro movimento de ascensão da violência se dá ainda na década de 1970 pela atuação e conflitos causados pelos bicheiros (BURGOS, 2006, p. 43). Apesar disso, a estrutura de funcionamento do jogo do bicho (que se basearia no pacto territorial em que cada bicheiro controla um setor territorial da loteria clandestina) e a tolerância e até mesmo a legitimidade social que gozavam (GONÇALVES, 2013, p. 334) - em função de suas conexões com as 
escolas de samba (MACHADO DA SILVA, 2010, p. 285) - era muito diferente daqueles gozados pelo tráfico.

Outro elemento que inicia o crescimento da violência na década de 1970 foi a atuação dos "esquadrões da morte", inclusive noticiado por jornais e revistas da época (MISSE, 2008, p. 378). Formados por policiais justificando, a princípio, sua atuação homicida como "limpeza da sociedade de criminosos indesejáveis", foram cada vez mais se envolvendo com quadrilhas de criminosos, grupos de extermínio e delitos de todos os tipos (COSTA, 1999, p. 03 e 11).

O verdadeiro salto, no entanto, viria com as transformações observadas a partir do final da década de 1970 no comercio de drogas ilícitas (que até então, girava quase exclusivamente em torno da maconha), através da prática do tráfico de cocaína e de armas (ZALUAR, 1994, p. 215; BURGOS, 2006, p. 43; MISSE, 2008, p. 383; MACHADO DA SILVA, 2010, p. 284). Nesse período, em que o comércio de cocaína se expande que a violência urbana no Brasil explode, com uma ênfase particular no caso das favelas e a territorialização dessa violência a partir das facções.

Segundo Machado da Silva (2008, p. 21), o crescimento da violência no cotidiano das favelas a partir da década de 1980 teria se dado principalmente em função de a venda de drogas (especialmente da cocaína) em pontos fixos ter se tornado ostensiva e, com isso, aumentaram os conflitos em torno da disputa por esses pontos. Entrevistado (ENTREVISTADO 13) envolvido com a política das UPPs no Rio de Janeiro faz inclusive comparação, neste ponto, com Medellín.

(...) o Rio e Medellin nesse caso, você tem uma dinâmica que é particular dessas cidades e de muito poucas outras pelo mundo. É o fato de nós não estarmos só falando de alta incidência de violência e de insegurança nessas grandes cidades, mas estamos falando de controle territorial armado de determinadas áreas da cidade, ostensivas. (...) no Alemão, na Maré, em lugares mais emblemáticos, mas em quaisquer áreas, a gente está falando de áreas que se você passar por lá as 10 da manhã de uma terça-feira ou as 4 da tarde de uma quinta feira, você cruzará com uma fronteira armada. Haverá garotos com fuzil na mão demarcando aquele território, controlando e muitas vezes disputando entre si, com outros grupos, eventualmente com a polícia (ENTREVISTADO 13).

Esse conflito se dá em um novo patamar de violência em função da lucratividade maior propiciada pela cocaína em relação à maconha vendida 
anteriormente, levando os grupos traficantes a buscarem controlar militarmente seus territórios e ocorrendo, assim, a substituição do binômio "maconha+38" por "cocaína+AR-15", conforme afirmado por Souza (1994, p. 31). Misse (2008), ao falar dessa territorialização, explicita também como está intimamente ligada à dimensão econômica.

Apenas no Brasil, especialmente no Rio de Janeiro, tornou-se comum uma extensa territorialização do comércio de drogas. Esses territórios, operados por traficantes varejistas, são constituídos, no Rio, pelos pontos de venda nos morros ("bocas de fumo"), defendidos por "soldados" armados com fuzis, metralhadoras, granadas e até, em alguns casos, com armas anti-aéreas, tudo isso em meio urbano, com alta densidade demográfica e constantes incursões policiais. Aos conflitos armados com a polícia, seguem-se os conflitos armados com outras quadrilhas, que tentam invadir e tomar o "território" do outro. Nos últimos trinta anos, uma verdadeira corrida armamentista levou a uma concentração de armamentos de guerra nesses morros e favelas que até hoje ainda desafia a polícia e as forças armadas. Mas não há qualquer objetivo político ou coletivo em defender esses "territórios", o interesse é apenas econômico e militar. Um viés "guerreiro" incorporou-se a essas redes de pequenos traficantes, que enfrentam-se entre si e à polícia, demarcando-se por facções sustentadas por sua função como agências de proteção dentro do sistema penitenciário. (MISSE, 2008, p. 383)

Machado da Silva (2010, p. 284) igualmente atribui a expansão da violência urbana à economia internacional das drogas, especialmente a cocaína, o qual não poderia prescindir do recurso ao uso da violência para defesa de seus interesses. Além disso, verifica-se, ao mesmo tempo, o crescimento também de todo uma série de práticas criminais associadas a ele (homicídios, extorsão, etc.) no mesmo período, a qual, apesar de afetar o conjunto da população da cidade, afeta sobremaneira os moradores de favela, que desde a década de 1980 vive no cotidiano os piores efeitos desse processo (ENTREVISTADO 30).

Deve-se destacar que, com a diferença de apenas alguns anos, o mesmo movimento era verificado na Colômbia, conforme relatado anteriormente para o caso de Medellín. Como afirma Souza (1994, p. 31), não se trata de mera coincidência o fato de este fenômeno se dar tanto em cidades brasileiras, como o Rio de Janeiro, quanto em cidades colombianas, como Medellín, nesta mesma época.

Primeiramente, lembre-se que da mesma forma que no Brasil, a participação da cocaína no comércio de drogas na Colômbia aumenta principalmente a partir da década de 1970 (RESTREPO, 2005, p. 183 e segs.), 
concomitantemente também com a escalada da violência, como visto anteriormente. No caso de ambos países, não se tratou apenas de um crescimento de mercado consumidor interno, cujo aumento da demanda influenciaria na ampliação da atividade. Até mesmo porque a cocaína esteve inicialmente associada ao consumo pelas elites, tendo em vista seu valor (SOUZA, 2010).

Conectam ambos os casos o fato de fazerem parte das rotas de escoamento da produção realizada na América do Sul para os efetivos centros consumidores: EUA e Europa (SOUZA, 2010, p. 54). Desde os anos 1970, no caso colombiano (RESTREPO, 2005, p. 195), e especialmente na década de 1980 no Brasil (LEITE, 2008, p. 115), os grupos envolvidos com a atividade cresceram e movimentaram bilhões de dólares em estreita conexão com os cartéis internacionais para venda destes produtos nos países considerados centrais.

\begin{abstract}
Não era de esperar que a sociedade brasileira estivesse imune a este movimento de tendências crescentes, sobretudo porque o país se encontra no circuito das rotas do tráfico internacional de drogas e de outras modalidades de crime organizado em bases transnacionais como o contrabando de armas, atividades que parecem constituir-se na bomba de combustão do crescimento da criminalidade violenta (ADORNO, 2002, p. 88).
\end{abstract}

Outra "não-coincidência" entre estes países: da mesma forma que relatado para o caso de Medellín, o tráfico de drogas no Rio de Janeiro cresce intimamente conectado com a expansão e adensamento das favelas da cidade. É importante desde o início que se entenda que se trata, da mesma forma como demonstrado no caso de Medellín, de um processo profundamente ligado à política e à relação estabelecida entre moradores, grupos criminais e Estado no Rio de Janeiro. As interações entre estes atores foram múltiplas e com diferentes sinais ao longo das décadas de 1970 a 1990: desde o afastamento da população em relação ao Estado pelas políticas de "ausência seletiva" (LEEDS, 2006) e pela repressão imposta por ele a esta população; passando por momentos em que os grupos criminais se aproveitam dessa desassistência e desconfiança para suprir necessidades de moradores e, com isso, comporem uma base de apoio a esses territórios; até finalmente a formulação de políticas voltadas a favelas com o intuito de incidir sobre a questão da violência e da segurança pública. Esses e outros movimentos serão abordados a seguir. 
Primeiramente, apesar do respeito a visões analíticas divergentes, não se adota neste trabalho a ideia de "ausência" do Estado nas favelas. Tratava-se, no período analisado de ascensão do tráfico, de um afastamento da população em relação ao Estado, e não ausência deste nem sua substituição por parte do tráfico. Da mesma forma que preconizado por Machado da Silva (2008, p. 19), acredita-se que existia (e possivelmente ainda existe) um fraco adensamento da presença pública nesses assentamentos, não sendo possível identificar tampouco um verdadeiro projeto político por parte dos grupos criminais de substituir totalmente o poder público (SOUZA, 2010). Da mesma forma como ocorreu na Colômbia, o Estado nunca esteve completamente ausente, como afirma Leeds (2006, p. 235), sendo necessário matizar a questão da sua presença e da ausência seletivas.

"Dificilmente podemos falar numa ausência anterior do Estado nas favelas. Ainda que de maneira pontual ou incipiente, desde a década de 1940, o Estado, em todos os seus níveis, esteve presente realizando pequenas obras nas favelas cariocas, tais como uma escadaria, a instalação de bicas d'água e redes de encanamento, entre outras pequenas ações. Mas a cada novo governo ou nova ação, o mito é reatualizado pelo próprio Estado (ou mais especificamente, por quem o ocupa) que apresenta quase sempre que a "nova ação marca a entrada definitiva do estado nas favelas'." (BRUM, 2014, p. 03).

São estabelecidas, portanto, continuamente relações entre favelas e Estado, seja de forma oficial, seja através de práticas clientelistas, quando não havia uma política pública ou quando a legislação não permitia a intervenção. De toda forma, em todos os autores, está evidente a postura de que a responsabilidade pelas ações de urbanização evidentemente recai sobre o Estado. Dessa forma, todo este processo de afastamento e desconfiança em relação ao Estado e à institucionalidade em geral que propiciou a instalação do tráfico nas favelas se associa à ausência seletiva deste mesmo Estado em relação à favela.

Nesse sentido, Burgos (2006, p. 43) justamente propõe que a presença de grupos criminais se alastrou nas favelas neste período pelo fato de terem se aproveitado do afastamento da população habitante desses assentamentos da vida política e da institucionalidade do estado em função da repressão sofrida por ela desde o início da ditadura. Além disso, a própria violência praticada historicamente pelo Estado no cotidiano desta população, segundo o autor, 
também contribuiria para aumentar este afastamento, sob as inúmeras formas através das quais se manifesta (ZALUAR \& ALVITO, 2006, p. 07).

Um exemplo disso é a constante ameaça e realização de despejos, muitas vezes promovidos por particulares, mas sob a chancela do estado, a partir de um judiciário pouco sensível à situação daqueles moradores e a atuação de uma polícia truculenta na execução de medidas de reintegração de posse. Prática reiterada de remoções forçadas ao longo do tempo, apenas diminuindo ou aumentando em frequência e intensidade em diferentes momentos desta história e sob diferentes justificativa: sob um viés inicialmente de expresso higienismo, no momento em que se identificava a favela como uma doença a ser eliminada (ZALUAR \& ALVITO, 2006, p. 11); sob o argumento do risco, quando em tese a segurança à vida da população serviria de motivo para sua retirada, mesmo quando se argumenta que haveria alternativas possíveis de mitigação ou saneamento do risco; sob a premência da realização de obras de infraestrutura necessárias ao suposto desenvolvimento da cidade; dentre inúmeros outros casos.

Pode ser citada ainda a presença muitas vezes nefasta do aparelho policial em favelas (LEEDS, 2006, p. 243), a qual apresentava já na época práticas autoritárias e truculentas com seus moradores (LEEDS, 2006, p. 252). De lá para cá, observou-se o crescimento da violência promovida pelo aparato policial (MISSE, 2008, p. 384), como será abordado no próximo capítulo. Isso ocorreu, especialmente, em assentamentos populares nos quais há maior ocorrência de homicídios, em que os indicadores socioeconômicos são mais baixos, em que a população goza de menor acesso a serviços e equipamentos públicos, etc. (PERES, ADORNO ET AL, 2008, p. 269). Além disso, a própria corrupção da corporação, frequentemente ligada ao próprio tráfico, também afastava ainda mais a população (ALVITO, 2006, 192).

São, assim, inúmeros os exemplos de batidas policiais, operações militares, achaques, extorsões, injustiças, remoções etc. promovidos pelo Estado que promoveram ao longo do tempo o afastamento e a desconfiança da população de favelas, possibilitando uma brecha social para que a instalação do tráfico ocorresse nestes assentamentos. 
Nos argumentos de Gonçalves (2013, p. 315) sobre o crescimento do tráfico nas favelas do Rio de Janeiro, também é possível enxergar a importância das relações estabelecidas pela tríade moradores-grupos criminais-Estado. Destaca, por exemplo, a importância que o surgimento do Comando Vermelho ${ }^{34}$ teve na consolidação do tráfico e o papel do Estado nisso, tendo em vista que se tratava de resultante inesperada dos processos de repressão institucional promovida pela ditadura militar, a qual juntou presos comuns já envolvidos com este comércio com presos políticos. O Estado fomentou, dessa maneira, a constituição de uma convivência de grupos que possibilitou a formação da primeira organização criminal de porte, essencial para a coordenação de interesses e ações posteriormente fora do presídio e para a expansão do tráfico no Rio de Janeiro. Aproximava-se, assim, os pequenos criminosos entre si e eles com uma poderosa cadeia produtiva que se utiliza violência privada para reproduzir-se (MACHADO DA SILVA, 2010, p. 291).

De um lado com uma violência institucional já notória (atingindo principalmente naquele momento a população favelada, ressabiada então do aparelho estatal), e de outro com o crescimento do crime organizado em torno do tráfico de drogas, Brizola assume pela primeira vez o governo do estado do Rio de Janeiro. Conforme aponta Machado da Silva (2010), o governo Brizola (19831986) trouxe particularidades no tocante à atuação policial em favelas e também em relação a investimentos nesses assentamentos.

Tendo em vista o pouco que podia influenciar em aspectos da economia nacional e dos interesses dos trabalhadores, aos quais a sua trajetória estava ligada; Brizola buscou incidir sobre temas de sua competência enquanto governador que beneficiasse de alguma maneira sua base de apoio popular. Além da intervenção física para melhoria da infraestrutura de favelas (GONÇALVES, 2013, p. 272-274), buscou reorientar a atuação da polícia

\footnotetext{
${ }^{34}$ Criado ainda na década de 1970 na penitenciária da llha Grande, estado do Rio de Janeiro, o Comando Vermelho (CV) foi uma das primeiras organizações criminosas de peso surgidas no país. Teve como objetivo, na sua origem, promover a união entre os detentos para proteção contra abusos (estupros, espancamentos, etc.) (Souza, 1994, p. 38). Posteriormente, a organização extravasa o âmbito do presídio e comanda, durante muitos anos, o tráfico de drogas no Rio de Janeiro (SOUZA, 1994, p. 28). Posteriormente, são verificadas cisões internas ao CV, bem como o surgimento de grupos rivais, que passam a disputar poder $\mathrm{e}$ territórios, como Terceiro Comando, dentre outros.
} 
nesses assentamentos. A partir de um diálogo estabelecido com lideranças locais, estabeleceu o respeito aos direitos civis como premissa da atuação policial nos assentamentos populares e proibiu operações massivas das forças policiais nas favelas, objetivando proteger a integridade física de seus moradores (MACHADO DA SILVA, 2010, p. 290-291; VALENTE, 2016, p. 11). Para alguns, essa atuação estaria caracterizada claramente como uma presença positiva do Estado nas favelas, as quais gozariam tanto de investimentos em infraestrutura quanto da melhoria do tratamento policial para com sua população. Valente (2016, p. 11) inclusive menciona tentativa de introdução de procedimentos de policiamento comunitário.

Apesar dessa perspectiva adotada na gestão de Brizola, há autores que, como Gonçalves (2013, p. 273), paradoxalmente, esta iniciativa teria incidido no surgimento de uma dinâmica de (re)segregação marcada pela escalada da violência. Souza (2010) é ainda mais incisivo em sua análise.

O primeiro governo de Leonel Brizola (1983-1986) pode, é certo, ser considerado (...) uma flutuação decisiva, uma pequena perturbação mais ou menos contingente que propiciou o fortalecimento do crime organizado no Rio. Em nome de uma - em si mesma, evidentemente, correta - política de humanização do aparato policial e respeito aos direitos humanos e civis dos favelados, Brizola acabou por enfraquecer a presença das "forças da ordem" nas favelas, ao diminuir 0 abuso e a truculência policiais, sem, contudo, substituir essa presença atrabiliária por uma outra (do policiamento comunitário eficaz a um engajamento social mais profundo do poder público, por exemplo, mediante a urbanização). $O$ vazio de poder foi preenchido, eficientemente, pelos traficantes (SOUZA, 1994, 32).

Se por um lado, há diferentes formas de interpretação sobre a atuação de Brizola em relação ao tráfico, parece ser certo que, de uma forma ou de outra, foi um momento decisivo para o estabelecimento da pauta da relação entre segurança e favelas na agenda pública. Como Machado da Silva (2010, p. 290 e segs.) relata, a tentativa de recomposição de uma base de apoio popular foi efetuada através de seu posicionamento e adoção de medidas no sentido do tratamento digno a moradores de favelas e presos comuns.

Nesse período, já se verificava o ocaso do regime autoritário, sendo progressivamente recompostos os privilégios que as classes média e alta historicamente gozaram de estarem salvaguardadas dos efeitos mais violentos da repressão estatal, o que as levou a retomar o desinteresse pelos bastidores da repressão ao crime (MACHADO DA SILVA, 2010, p. 291). Isso não 
significou, no entanto, o desaparecimento por completo do interesse/sensibilização delas para o tema desde então. Diferentes pesquisadores e organizações da sociedade civil passaram a se dedicar ao tema e inclusive a construir um paradigma do controle social exercido pelo estado com base nos direitos humanos (FELTRAN, 2018). Isso significou que, de alguma forma, a violência entrou na agenda de setores da sociedade civil (NERY, 2016, p. 47) que, desde então, tem buscado pautar os debates públicos sob esta perspectiva, tentando incidir, inclusive, sobre políticas de segurança e encarceramento.

Por outro lado, uma expressiva parcela das classes média e alta passou não apenas a ignorar a violência institucional cometida principalmente contra moradores de favela, como inclusive a apoia ou no mínimo a considera um mal necessário no combate à violência urbana (FRIDMAN, 2008, p. 77), ressentidas pela expansão dos crimes violentos na cidade como um todo. Assim, não bastasse a figura polêmica do próprio Brizola - "O Brizola vai ser considerado sempre quem deixou o narcotráfico subir" chega a afirmar um entrevistado especialista no tema (ENTREVISTADO 21) -, consolida-se de vez a polarização que dominará nacionalmente o debate sobre as perspectivas de enfrentamento à violência através de políticas de segurança - efetivação e respeito a direitos ou recrudescimento da repressão e encarceramento (FELTRAN, 2018, p. 178; NERY, 2016, p. 59).

(...) creio ser possível afirmar que na primeira metade da década de 1980 armaram-se os termos da disputa que dá origem ao debate atual sobre 0 problema da segurança pública. (...) Em síntese, na primeira metade da década de 1980, a radicalização dos termos da competição político-eleitoral consolidou o enquadramento do debate em torno do controle do crime violento, desnaturalizando, explicitando e trazendo para a disputa o tradicional recurso à coerção e à violência física que sempre caracterizou o disciplinamento das camadas populares. Isso ocorreu em um momento de sobrepolitização da experiência histórica, com forte ênfase no quadro jurídico-institucional e intensa disputa político-partidária. Polarizaram-se, assim, as tomadas de posição que criticavam a violência ilegítima, mas institucionalizada, característica da prática policial, e as que criticavam a violência contida na prática criminal, propondo uma forma militarizada e excludente de tratar essas questões (MACHADO DA SILVA, 2010, p. 292).

Se por um lado, estão dados os termos relativos à polarização verificada daí para a frente na ação do Estado no tocante à violência; por outro, sua presença do ponto de vista da melhoria das condições materiais de vida da população favelada ainda podia ser considerada incipiente. Apesar das ações 
empreendidas pelo governo Brizola nesse sentido; como Gonçalves (2013, p. 315) observa, na segunda metade da década de 1980 e se extendendo praticamente até o início do Favela-Bairro, não houve uma ação significativa voltada às favelas em âmbito federal, estadual ou municipal, apesar da criação e existência de alguns programas e iniciativas pontuais (GONÇALVES, 2013, p. 322-323). Com isso, se fortalecem as relações que já vinham sendo estabelecidas entre grupos criminais e moradores nos morros do Rio de Janeiro.

Essas quadrilhas de traficantes foram se impondo progressivamente nas favelas, aliando à força das armas as engrenagens clientelistas. Ao preencherem o vazio político existente no interior das favelas, desempenhando o papel de árbitros, policiais, patrões e benfeitores, os traficantes foram ganhando, paulatinamente, 0 apoio da população local. (...) $\mathrm{O}$ assistencialismo associado à lógica do medo permitiram aos traficantes assumirem 0 controle das favelas e de seus moradores (GONÇALVES, 2013, p. 315-316).

Já abordado também no caso de Medellín, as benfeitorias promovidas por traficantes no Rio de Janeiro foram significativas, em face da baixa presença de iniciativas do Estado, para uma primera ampliação de sua base de apoio social em favelas. Como Souza (2010, p. 62-64) observa ao analisar os grupos de indivíduos de alguma forma beneficiados pelo tráfico nas favelas ${ }^{35}$, trata-se em alguns casos de generosidade e em outras, especialmente,

de um cálculo estratégico efetuado pelos criminosos, com o fito de granjear a simpatia da população local. A busca de algum suporte junto à população residente no espaço que serve de apoio logístico é importante. Um traficante bem quisto, porque paternalista, pode contar com uma certa cobertura por parte dos moradores, ao passo que um traficante truculento pode acabar sendo denunciado pelos próprios favelados (SOUZA, 2010, p. 62).

35 Souza (2010, p. 61-67) tenta diferenciar os principais grupos de indivíduos de alguma maneira beneficiados pelo tráfico de drogas, com objetivo de dialogar com algumas teorias generalizantes em que no interior das favelas os grupos se distinguiriam entre "trabalhadores" e "bandidos. O autor enumera, assim, cinco grupos: A) formado por aqueles atores sociais regularmente remunerados em dinheiro por seus serviços prestados a um "dono" no âmbito de uma quadrilha; B) aqueles que recebem "presentes", individualizados ou não, de algum traficante, por ato de generosidade e/ou para obtenção de apoio social; C) aqueles que são os familiares e dependentes diretos dos atores do grupo A ou, mais amplamente, que fazem parte do mesmo domicílio para cuja renda um dado ator do grupo A contribui; D) aqueles que, sem trabalhar diretamente para os atores do grupo $A$, são diretamente beneficiados pela maior circulação de renda propiciada pela economia ilegal (desde birosqueiros até vendedores de quentinhas para traficantes); E) dependentes diretos dos atores do grupo D ou que fazem parte do mesmo domicílio para cuja renda um ator do grupo D contribui. A utilidade desta diferenciação está em deixar evidente que há diferentes graus de envolvimento e, ao mesmo tempo, de beneficiários do tráfico nas favelas. 
Os traficantes, assim, se utilizaram largamente da prestação de assistência aos moradores (ALVITO, 2006, p. 187) ou da criação de serviços de proteção e melhorias (LEEDS, 2006, p. 256) para construir uma base de apoio perante a população. A conquista da simpatia e boa vontade desta foi essencial para o estabelecimento da autoridade e, dessa maneira, da manutenção da hierarquia dentro dos grupos criminais (ALVITO, 2006, p. 201), utilizando-se, para isso, o financiamento de atividades culturais, esportivas, intervenções na área, etc..

Foram oferecidos, em troca da 'proteção' e do anonimato para os grupos criminais, serviços como segurança interna, dinheiro para ambulância ou táxi até o hospital, dinheiro para remédios, sopa para os pobres, creches, festas infantis em ocasiões especiais, auxílio financeiro para construção de quadras esportivas, churrascos para os moradores, etc. (LEEDS, 2006, p. 243; SOUZA, 2010, p. 62; ENTREVISTADO 09). Em outros casos, tratava-se, em vez de benefícios materiais, simplesmente da realização de papéis de árbitros ou impositores de uma determinada "ordem" (GONÇALVES, 2013, p. 316; ENTREVISTADO 09), como demonstra o depoimento abaixo.

A mulher apanhava direto do marido (...). Um dia não aguentou, foi na cabine [da PM, na entrada da favela]: - "Meu marido (...) está bêbado, me bate, bate nas crianças" (...) [o policial] - "Eu não vou lá, não, para tirar ele, está quebrando tudo, é a casa dele mesmo." Ela (...) foi lá no tráfico: - "Acontece isso com meu marido." O cara mandou falarem com ele. Deram uma coça no marido dela: -"Não quero você mais no morro." Ela está tendo sossego... Então, onde você não tem um órgão competente para resolver os problemas, o tráfico controla a favela" (in MACHADO DA SILVA \& LEITE, 2008, p. 63).

Por outro lado, da mesma forma como observado em Medellín, como a categorização de Souza (2010, p. 62) explicitada acima já deixa claro, a atividade do tráfico possuiu (e ainda possui) um impacto econômico significativo nestes assentamentos. A crise econômica vivida pelo país à época promovia a deterioração da qualidade de vida dos pobres urbanos nos anos 1980, que ficaram conhecidos como a "década perdida" (SOUZA, 1994, p. 30).

Nesse sentido, o tráfico foi útil aos moradores de favela tanto pela promoção de trabalho remunerado para indivíduos que na época não possuíam chances de obter emprego na economia formal quanto pela injeção de recursos nas atividades comerciais e de serviços existentes nas favelas, gerando benefícios que não estavam restritos àqueles que faziam parte diretamente da atividade 
ou seus familiares (SOUZA, 1994, p. 34). Há diversos outros moradores grupo $D$ (ver nota de rodapé sobre os grupos propostos por Souza) - que se beneficiam do aquecimento da economia local promovida pela atividade, tendo em vista o estabelecimento de relações imobiliárias (ao alugar diversos imóveis para suas atividades, para a instalação de parentes e conhecidos em situação de necessidade, etc.), de fomento ao comércio local (ao promover festas, realizar grandes compras nas lojas dos assentamentos, etc.), dentre outras (ALVITO, 2006, p. 188).

Diante desse panorama, verifica-se no Rio de Janeiro da década de 1980, portanto, dispositivo muito similar à situação descrita anteriormente em relação à expansão do tráfico em Medellín, na qual justamente o tráfico se insere nas fraturas econômicas, sociais, urbanísticas e políticas dos territórios de favela. A precariedade do território e das condições de vida desta população, historicamente utilizados para manutenção de práticas clientelistas pela classe política, serviu também como mecanismo de relação entre traficantes e moradores (SILVA ET AL, 2008, p. 19 in CANO, 2008).

Como Machado da Silva (2010) coloca, o fato de as bocas serem estabelecidas nas favelas está intimamente conectado com a fragilidade do funcionamento dos sistemas político-institucionais de controle e proteção social nas favelas comparado com as demais regiões da cidade. Contribuíram para isso, portanto, serviços públicos deficientes, subalternidade política relacionada a uma incorporação social que ocorreu pela via do clientelismo, longa tradição de informalidade do trabalho, etc. (MACHADO DA SILVA, 2010, p. 285).

Outro fator associado a estes segundo diferentes autores (MACHADO DA SILVA \& LEITE, 2008, p.44; SILVA ET AL, 2008, p. 19 in CANO, 2008; SOUZA, 2010, p. 74-76; GONÇALVES, 2013, p. 315-316) e entrevistados (ENTREVISTADO 13; ENTREVISTADO 12; ENTREVISTADO 19) seria a morfologia urbana característica das favelas, a qual seria propícia ao desenvolvimento das atividades do tráfico e ao controle de suas operações. Os grupos criminais se aproveitariam de sua estrutura física, principalmente no que diz respeito às dificuldades de acesso a esses espaços, para enraizar seu domínio, utilizando uma lógica de apropriação territorial (GONÇALVES, 2013, 
p. 315-316). Nas palavras de um entrevistado (ENTREVISTADO 13), existiria uma "correlação entre desenho urbano e a configuração de meios que serão mais ou menos favoráveis às dinâmicas de conflito e criminais".

Machado da Silva e Leite (2008, p.44) afirmam que, para além dos já bastante difundidos fatores sociopolíticos, a sociabilidade violenta, em grande parte trazida pelos atores ligados ao crime, afetaria mais profundamente as favelas do que o restante da cidade em função da "forma urbana típica desses locais". A densidade excessiva, o traçado viário precário, a baixa acessibilidade, dentre outros fatores, favoreceriam o controle do território por parte destes agentes.

\begin{abstract}
(...) afora as características geodemográficas (elevada densidade populacional) e sócio-econômicas (a enorme pobreza da grande maioria de sua população), a própria estrutura espacial de uma favela e (no caso de uma favela de morro) seu sítio - e não tanto a estrutura dos loteamentos ou conjuntos habitacionais contribuem, tremendamente, para conferir-lhe um valor único enquanto esconderijo: as vielas estreitas (em alguns casos, sem saída), os acidentes capitais (pontos dominantes, como lajes e elevações naturais, cuja posse permite a observação e o controle das rotas de entrada e saída), a estrutura viária labiríntica; tudo isso representa vantagens para o defensor e desvantagens para um eventual invasor (...) (SOUZA, 1994, p. 33).
\end{abstract}

Em que pese a reiteração dessa tese pelos diferentes atores e estudiosos envolvidos com o tema, faz-se necessário algumas ressalvas sobre essa hipótese. Longe de contestar a importância da morfologia urbana para a atuação territorial do tráfico identificada por estes interlocutores, é necessário, contudo, ponderar o grau de generalização adotado. É necessário, primeiramente, refletir sobre o que de fato significaria essa "morfologia típica" desses assentamentos. Seria necessária, ainda, uma melhor compreensão das reais dinâmicas de dominação espacial efetuada por estes atores, o que se torna difícil em função das dificuldades de contato com estes agentes.

Há que se levar em consideração, por fim, que já são vários os casos em que o tráfico está instalado e atuando fortemente também em conjuntos habitacionais e loteamentos populares (ENTREVISTADO 14) [INSERIR REFERÊNCIAS AO CASO DE OSASCO], sendo este último historicamente o caso da disseminação do tráfico na cidade de São Paulo (FELTRAN, 2018). Como será relatado mais à frente (seção 4.1), houve casos inclusive de projetos de urbanização com componentes de provisão em que o tráfico pressiona 
fortemente o poder público para obter unidades habitacionais dentro dos conjuntos edificados.

\begin{abstract}
Por exemplo, você fez a remoção de uma família, fez um conjuntinho habitacional, o tráfico vai junto, é muito louco. Aí os caras continuam vendendo droga dentro do prédio, e ai dá confusão, é difícil lidar com isso (...) eu tive que lidar com uma situação dessas. A mulher foi removida, foi colocada no conjunto habitacional. $O$ povo veio reclamar, uma velhinha, senhora assim, você fica com pena dela, morando em um barraquinho na favela e foi pra um apartamento bonitinho. A velhinha vende droga, o pessoal fazia fila lá no corredor da velha... uma velhinha que dava dó, vovó do tráfico (ENTREVISTADO 12).
\end{abstract}

Se os aspectos mofológicos das favelas (becos, vias estreitas, etc.) fossem realmente um fator determinante para a atividade, esse movimento do tráfico para obtenção de unidades e dominação de conjuntos não faria sentido, levando a crer que não há uma diferença substancial na sua atuação em função da configuração morfológica. Embora o tráfico, enquanto ação comercial baseada na transação de mercadorias físicas, efetivamente não possa prescindir da dimensão espacial, pode-se argumentar que não é o espaço - a morfologia, o traçado, etc. - que importa, mas, sim, territorialidades específicas $^{36}$ possíveis de serem estabelecidas pelo tráfico a partir de cada favela e, ainda, de cada região interna à favela. Infelizmente, foge ao escopo do presente trabalho esta investigação, mas trata-se de questão de pesquisa extremamente relevante de ser enfrentada para a real compreensão dos limites das ações de urbanização de favelas como forma de enfrentamento destes grupos criminais e da violência vivida nesses assentamentos.

Feita esta breve digressão acerca da problematização da influência da questão morfológica sobre a instalação do tráfico nas favelas, é preciso enfocar agora o revés dessa questão: a consolidação da ideia de que a intervenção para qualificação desse território era fundamental para o combate à violência. Retome-se que a polarização dos termos do debate sobre a violência no governo Brizola haviam colocado, mais do que nunca, a intervenção em favelas no centro das discussões sobre segurança pública no Rio. Tendo em vista que, desde então, o próprio sistema político-eleitoral passa a se alimentar das discussões em torno da violência - com ações de enfrentamento a grupos

\footnotetext{
${ }^{36}$ Utiliza-se aqui o conceito de territorialidades no sentido adotado pela geografia, como campos de força, os quais não se devem confundir com configurações espaciais (SANTOS, 1986; SOUZA, 2010; HAESBART, 2010).
} 
criminais (BURGOS, 2006, p. 43) com a intenção de gerar capital político em momentos eleitorais (ALVITO, 2006, p. 187; LEEDS, 2006, p. 254) - e esta temática passa a ser identificada cada vez mais fortemente com as favelas, estava dada a equação: intervenções em favelas significam intervenções na questão da segurança. A grande questão em jogo era quais seriam o caráter ou os tipos de intervenção em favelas a serem levados a cabo.

Já desde a década de 1980, a Prefeitura vinha notando a crescente dificuldade de realização de intervenções pontuais em favelas em função do crescimento do tráfico e a expansão do domínio territorial, uma questão que precisava urgentemente ser enfrentada (ENTREVISTADO 18). Nesse sentido, é eloquente o depoimento de uma técnica da Prefeitura do Rio de Janeiro à época.

Mas com a cocaína e o crack mudou o Rio totalmente. [Antes] a gente entrava em qualquer favela da cidade, todo mundo conhecia, a gente ligava pro presidente [da associação de moradores] e falava "Estamos subindo no não sei onde", aí ele falava "Não tem problema". Quando entrou o crack e a cocaína, dificílimo de você ter uma independência (ENTREVISTADO 18).

Conforme já mencionado na seção 1.3 do primeiro capítulo, o Favela-Bairro nasceu a partir de uma iniciativa de técnicos de diferentes setores da Prefeitura, os quais, nesse contexto de recrudescimento da violência, observavam cada vez mais obstáculos à sua intervenção nos assentamentos. Uma forma então de fortalecer suas atuações era justamente promover uma coordenação das ações iniciadas individualmente, tornando-as integradas, como relatado por entrevistada participante da elaboração do programa (ENTREVISTADO 18; ENTREVISTADO 26).

Embora ausentes do decreto de criação do programa os temas da violência e segurança, desde o início, como colocado por alguns entrevistados (ENTREVISTADO 21; ENTREVISTADO 16), o Favela-Bairro possuía um forte apelo para a questão da segurança pública a partir do impacto dos projetos.

O Favela-Bairro foi lançado em 1994 como desdobramento de um contexto político e técnico favorável e de convergência acerca das intervenções da Prefeitura do Rio de Janeiro em favelas. No plano político, circunstâncias adversas geradas pelo crescimento da violência urbana e da exclusão social e suas consequências para a economia urbana e o bem-estar social levaram diferentes forças políticas, lideranças locais e empresariais e movimentos sociais a incluírem a questão das favelas como uma prioridade na agenda de discussões sobre a cidade (IBAM, 2002, p. 141). 
Lembrando que, assim como a Colômbia, vivia-se no Brasil um movimento de expansão da democracia com o processo de redemocratização, como apontado no capítulo 01. Havia, dessa maneira, à semelhança do caso apresentado em Medellín, tanto uma demanda social (pelas diferentes classes) de intervenção no âmbito do enfrentamento ao crescimento da violência quanto uma mobilização social em torno da pauta da urbanização de favelas (ENTREVISTADO 30). Isso ocasiona, assim, que as ações de urbanização ascendam no Rio de Janeiro no bojo de ações voltadas ao combate à violência, o que tem apelo político junto às classes média e alta. Assim, o Favela-bairro, por exemplo, teria sido impulsionado nos anos 90 na agenda política como uma ação também sob o ângulo da segurança pública (BURGOS, 2006, p. 49).

\begin{abstract}
"E não é por acaso que a revalorização do problema favela pelo poder público vem sendo imposta muito mais pelo transbordamento das consequências da violência, que hoje atinge a cidade como um todo, do que pela presença de um ator político, defensor de interesse dos excluídos. De fato, ao extravasar os limites da favela, a violência produzida pelos braços armados do tráfico tem forçado um debate mais amplo acerca do modelo de cidade que se quer para 0 Rio de Janeiro. Nessa hora, faz-se necessário redefinir o problema favela, e o repertório produzido ao longo da história - a favela como problema de saúde pública, como um quilombo cultural ou como um cancro moral, representações correntes nos anos 40 e 50 - parece não fazer mais sentido; por outro lado, tratála como questão de segurança nacional, como ocorreu no período militar, não parece compatível com o momento democrático. Por isso, o problema favela está a exigir uma nova resposta, que supõe o enfrentamento do dilema de democratizar a cidade" (BURGOS, 2006, p. 45).
\end{abstract}

Burgos (2006, p. 49) considera, deste modo, que, se houve influência da mobilização da própria população favelada pela reivindicação de direitos sociais e de melhoria das condições do território, talvez teria sido mais forte 0 impulso para o desenvolvimento do programa Favela-bairro, na verdade, a situação de violência que a cidade vivia no início da década de 1990. De maneira similar, Gonçalves (2013) também argumenta pela preponderância da questão da violência urbana na ascensão do Favela-Bairro quando afirma que "a questão específica das favelas impôs-se politicamente no início dos anos 1990 no Rio de Janeiro, mais pela dificuldade de gerir as repercussões trazidas pela violência urbana do que pela emergência de um discurso reivindicatório no interior das favelas" (GONÇALVES, 2013, p. 327).

Assim, a partir de um determinado ponto em que se percebe as possibilidades (tanto de resultados do programa, quanto de capital político gerado a partir dele), ele passa a gozar de efetiva centralidade na agenda da gestão municipal 
(BURGOS, 2006, p. 51), como aprofundado na seção 2.1 desta tese. Isso, principalmente, em função dos retornos políticos que o tema conferia aos gestores públicos, como teria sido o caso de César Maia e do seu sucessor Luis Paulo Conde.

\begin{abstract}
Você não gosta de ver coisa bonita? Aquela coisa que a gente estava falando do imaginário, de você melhorar a sensação de segurança, de você melhorar a autoestima, tem retorno imediato, era isso o que o Favela-Bairro queria. Ele sempre tinha uma obra de impacto na entrada principal, então tinha a coisa de abrir o território, a coisa da praça, do box de pequenos comércios para fazer a integração com o bairro, pra fazer o bairro entrar na favela, a pracinha pra levar as crianças. Acontece é que você não resolvia a questão da moradia, então tinha um quê de make-up; a pavimentação das travessas, a escadaria, mas você não resolvia os fatores de metro quadrado sem banheiro e sem janela, é isso. Mas pra quem morava do lado você mudava, era um respiro, você aumentava, ampliava a sensação de que tinha mudado (...).O prefeito Conde se elegeu a base disso, Conde foi o prefeito do Favela-Bairro e do Rio Cidade. (...) é que você mexe com a autoestima e com as sensações de segurança, de estabilidade, de melhoria e de progresso da população como um todo (ENTREVISTADO 16) [grifos nossos].
\end{abstract}

De fato, a campanha de Conde à Prefeitura foi baseada no fato de que, como então Secretário de Urbanismo de César Maia, havia sido fundamental para o desenvolvimento do Rio Cidade e do Favela-Bairro (ALDÉ \& DIAS, 1996, p. 14). Embora com um apelo explícito dessa plataforma aos moradores de favela, também angariava apoio político junto à classe média em função das questões de segurança trazidas pelo programa, como mencionado acima.

Com isso, percebe-se a partir de então o aprofundamento da perspectiva do Favela-Bairro como estratégia de entrada do poder público nas favelas da cidade e de disputa territorial com os grupos criminais. Estudo realizado pelo IBAM (2002) afirmava que, após o período inicial de implementação do programa, a própria Prefeitura já havia passado a incorporar dentre os objetivos sociais dele "ações preventivas do envolvimento da população em risco social - jovens, crianças, mulheres e famílias que possam se envolver em algum tipo de criminalidade, violência ou insegurança". Isso se aprofunda a ponto de, no Decreto № 33.277 de 2010, que atualiza o regulamento de operação do programa, constar um componente de "Prevenção de Violência e 
Convivência Cidadã (PVCC)"37. Assim, como demonstra fala de morador entrevistado por Machado da Silva e Leite (2008, p. 68).

[O] secretário de segurança diz que não existe poder paralelo, que a polícia está ali para combater, vai fazer, acontecer. Mas, por debaixo do pano, vão e 'Cara, olha, a gente vai entrar'. Favela-bairro e alguma coisa: "Tem que ser assim, senão não entra' (...) então é uma loucura, como é que a gente que está lá dentro vai correr se o próprio poder público é refém do tráfico.

Como Cavalcanti (2013, p. 201) lembra, o atrelamento entre projetos de urbanização e ocupação policial se dá no Rio de Janeiro desde o advento do Favela-Bairro e vai ser observado inclusive na conexão entre o PAC e as UPPs (como será visto no próximo capítulo). É importante já apontar, entretanto, que no caso do Favela-Bairro a escala e a perspectiva adotadas são bem diferentes daquelas que serão verificadas com o PAC e as UPPs.

Primeiramente, numa questão de escala, as ações especificamente relacionadas à violência/segurança gozaram naquela época de uma escala menor, sendo implementado um programa de policiamento comunitário apenas no final da década de 1990 e início dos anos 2000, o Grupamento de Policiamento em Áreas Especiais (GPAE) (CAVALNCATI, 2013, p. 201). Em segundo lugar, percebe-se pela cronologia e pela fala do morador citada acima que, nos anos 1990, a perspectiva adotada era uma primazia da política de urbanização sobre as ações de policiamento. Conforme será visto no próximo capítulo, as UPPs trazem exatamente uma inversão dessa lógica, submetendo as políticas sociais às demandas da agenda da segurança. O Favela-Bairro, portanto, ocupava a liderança da ação e possuía, em si mesmo, uma função

\footnotetext{
37 "O componente de urbanização integrada inclui a implantação de um projeto de prevenção de violência e convivência cidadã em uma das favelas do Programa, com o objetivo de reduzir os fatores associados à violência e melhorar as condições de segurança dos residentes nesta comunidade. As ações do projeto poderão incluir: (i) a melhoria das condições físicoambientais, incluindo o ordenamento urbanístico, a eliminação de espaços escuros e isolados, a abertura de praças e áreas esportivas etc.; (ii) atenção a jovens em situação de vulnerabilidade social, com ações destinadas a prevenir comportamentos indutores à violência, especialmente o uso de drogas; (iii) prevenção e atenção a vítimas de violência doméstica; (iv) ordenamento e fiscalização urbana (implantação de POUSO); (v) atividades para a conformação de redes comunitárias de convivência. O projeto terá um sistema de monitoramento para medir seus resultados, que estará baseado numa pesquisa sobre o perfil da violência a ser realizado previamente na comunidade. Este projeto pretende oferecer estabelecer um modelo de intervenção que possa ser estendido a outras áreas da cidade com problemáticas de violência" (PREFEITURA MUNICIPAL DO RIO DE JANEIRO, DECRETO № 33.277 DE 16 DE DEZEMBRO DE 2010 - APROVA REGULAMENTO OPERACIONAL DO PROAP III).
} 
geoestratégica de intervenção para o enfrentamento à situação de dominação pelo tráfrico vivida então (SOUZA, 1994, p. 35).

Em função de todo esse contexto da ascensão da violência, o Favela-Bairro desempenhou, ainda, outro papel (ENTREVISTADO 21; ENTREVISTADO 16). Mais do que somente disputar as territorialidades com o tráfico nas favelas e dar uma resposta à sociedade carioca em relação ao tratamento da questão da segurança, o programa foi útil do ponto de vista da projeção internacional da cidade (ENTREVISTADO 04). Da mesma forma que o PRIMED e os PUI no caso de Medellín (os quais inclusive expressamente buscaram inspiração na experiência do Rio de Janeiro, conforme indicado na seção 2.1 da tese), o Favela-Bairro possibilitou à administração municipal ocupar um lugar de vanguarda no cenário nacional e internacional no tocante a políticas urbanas voltadas ao enfrentamento da questão da violência, a qual tinha justamente conferido notoriedade internacional a ambas cidades, pelas estatísticas alarmantes de homicídios.

o Favela Bairro acaba influenciando de alguma forma [na experiência de outros municípios], porque é um programa financiado pelo BID, na cidade maravilhosa do Rio de Janeiro, e que vai dizer que a solução para a favela é a urbanização e a urbanização ali com equipamentos, não é só o saneamento, então eu acho que isso ajuda. Não sei o quanto o Favela-Bairro influencia, mas que ele é importante, é, porque assim, a experiência em Diadema circula de um jeito, a do Rio de Janeiro Favela Bairro circula de outro. Eu lembro, eu peguei um avião na Varig e a matéria de capa da Varig era o Favela-Bairro (ENTREVISTADO 17).

Se da mesma forma que Medellín, o Rio estava sendo conhecido pela ascensão brutal da violência, o governo municipal busca fomentar uma contranarrativa demonstrando que estavam tentando fazer do limão uma limonada. Segundo gestora municipal entrevistada, membros da equipe percorreram diversos espaços e eventos de divulgação internacional disseminando a iniciativa (ENTREVISTADO 18). Nos arquivos pesquisados sobre o programa, foi possível até mesmo encontrar um vídeo-propaganda sobre o Programa de mais de 10 minutos, contando, inclusive, com depoimento de moradores e a fala do então prefeito. Além disso, é notável ainda o fato de o programa constar como um dos eixos de atuação do plano estratégico formulado com consultoria de Borja e Castels (GONÇALVES, 2013), precisamente uma das mais expressas tentativas de marketing urbano desenvolvido pela Prefeitura à época (VAINER, 2002). Utilizava-se, portanto, o 
Favela-Bairro como um dos elementos estratégicos de construção de uma nova imagem do Rio de Janeiro perante a comunidade internacional, impactada com as notícias da violência crescente experimentada pela cidade ${ }^{38}$.

É importante mencionar, ainda, que posteriormente outras iniciativas mobilizaram ainda, de maneira positiva para a urbanização, o tema da violência como mote para a intervenção em favelas. Como colocado por alguns entrevistados, o tema perpassou não apenas o Favela-Bairro, mas a maior parte das iniciativas públicas de intervenção em favelas desde então.

(...) nos anos 90 é um ano que a mídia bate pesado na ideia da favela como o lugar do perigo. Nos anos 80 a droga se internacionaliza, o tráfico de drogas e 0 tráfico de armas começam a adentrar nesses territórios de forma mais intensa. Então os anos 90 são anos onde a imprensa noticia o tempo todo a questão da ação dos grupos criminosos, dos comandos e tal (...) então assim, eu acredito que esse elemento da segurança pública, de como você projeta a cidade do Rio de Janeiro, é um elemento que atravessou o tempo todo as politicas voltadas para esses territórios. Como você garante com que o capital se sinta confortável em se expandir nesse território - se você ainda tem áreas conflagradas, quando você não tem o controle sobre o ir e vir, quando você não tem controle sobre as atividades - então certamente as intervenções urbanas [de urbanização e segurança] se conjuminam... (ENTREVISTADO 30 ).

Um desses exemplos tratou-se da elaboração da iniciativa de elaboração de um "Plano Diretor" para a Rocinha. Motivada por um incidente de extrema violência ocorrido (PATRICIO, 2017, p. 61), a iniciativa foi proposta no âmbito de um fórum constituído para debater o episódio que contava com a presença tanto de moradores da favela quanto de associações de moradores de classe média e classe alta dos bairros do entorno, como São Conrado (TOLEDO ET AL., 2014).

A história como surgiu essa ideia do plano, que é completamente diferente do tipo Favela Bairro e Rio Cidade, foram coisas criadas pelo Sérgio Magalhães e pelo Conde, a ideia de fazer o plano diretor da Rocinha surgiu dos moradores da Rocinha, dos moradores de São Conrado e dos moradores da Gávea, eles se reuniram, a associação de moradores dos 3 bairros, convidaram o IAB, convidaram o CREA e se juntaram pra fazer uma proposta pra melhorar as condições da Rocinha, era uma reação do que se chamou mais tarde, em 2005, da guerra da Rocinha, uma situação muito parecida com a de hoje, a Rocinha foi invadida por um grupo armado de outra favela, e ai a guerra rolou, contaminou São Conrado, o túnel foi fechado e pela primeira vez viu-se que uma coisa que atingia a Rocinha parava a cidade, e parou aquela ligação com a zona oeste, e ai os moradores de São Conrado ficaram isolados, sentindo na carne, se juntaram os 3 e surgiu a primeira ideia de fazer o plano (ENTREVISTADO 03).

\footnotetext{
${ }^{38}$ Ver na seção 1.3 mais elementos dessa discussão.
} 
Obviamente, é necessário dizer, que não se está argumentando que apenas o debate público em torno da violência urbana tenha sido responsável pelo impulsionamento desse plano ou mesmo do Favela-Bairro. Contudo, pretendese aqui demonstrar como esta dimensão da vida política e social da cidade e do país é importante para a compreensão desse processo, relacionando-se, assim, as pautas da violência e da urbanização de favelas de maneira confluente em determinados períodos, principalmente naqueles que, como no caso da Colômbia e do Brasil, se verifica um contexto de ampliação da democracia e de um discurso de efetivação de direitos.

A institucionalização da política de urbanização das favelas legitimou-se na esfera pública como uma resposta ao domínio territorial exercido pelo tráfico de drogas no Rio de Janeiro. Em outras palavras, a lógica subjacente é a de que a violência justifica a melhoria na infraestrutura das favelas. Assim, paradoxalmente, a violência e o estigma associados a essas áreas acabam por criar as condições para a melhoria material e também para o reconhecimento político de seus moradores - ao mesmo tempo que se reproduzem como estereótipos e sustentam as relações de poder que reforçam a ideia de alteridade cultural perante a cidade dita "formal" (CAVALCANTI, 2013, p. 194).

Por fim, deve-se ter em mente que existem também relações políticas estabelecidas pelos grupos criminais com políticos e agentes do Estado no âmbito de processos eleitorais. Estes grupos podem chegar mesmo a orientar o voto de moradores da área sob seu controle de acordo com seus interesses, sendo, portanto, também valiosos recursos políticos para candidatos. São negociados, assim, por assessores dos candidatos apoios e permissões para campanhas nos territórios dominados por estes grupos (LEEDS, 2006, p. 254255).

Outra forma mais gritante são as alianças entre candidatos a cargos públicos e grupos de traficantes, as quais costumam ocorrer nas comunidades onde estes últimos são particularmente poderosos. (...) É sabido que candidatos inescrupulosos passam por cima da autoridade legítima nas favelas [lideranças comunitárias], preferindo obter um acesso mais exclusivo através de grupos de traficantes que Ihes permitam fazer campanha à vontade ou que pressionem a associação de moradores a proibir campanha de outros candidatos (LEEDS, 2006, p. 255).

Nesse sentido, pode-se inferir que, eleitos tais candidatos, a cobrança do apoio estendido pelos grupos criminais (tanto traficantes como milicianos) poderá vir sob a forma de determinadas orientações sobre a política de segurança, mas certamente também a implementação de outras políticas com impacto sobre o domínio territorial destes grupos, caso da urbanização de favelas. Como visto na seção 2.1, vereadores ainda possuem considerável influencia sobre a 
implementação de melhorias em favelas. Ora, se há parlamentares conectados com grupos criminais e com poder de orientar investimentos, está clara a possibilidade de que tais grupos efetivamente possam influenciar limites e alcances das intervenções físicas em favelas. A gramática da violência possui, em suma, um considerável impacto na formulação e desenvolvimento de experiências de urbanização de favelas, especialmente no caso de Medellín e do Rio de Janeiro. Como será visto a seguir, os casos de Bogotá e São Paulo são ligeiramente diferentes.

\subsection{Bogotá}

Em Bogotá, a violência parece ocupar um lugar distinto na consolidação do espaço urbano e na atuação do Estado sobre os barrios, embora também possua aparentemente uma importância considerável.

A cidade, em função de sua posição como capital e uma das maiores cidades da Colômbia, tem sua história entrelaçada com a do país, sendo influenciada pelos acontecimentos políticos, econômicos e sociais vividos nacionalmente em disputas e guerras entre liberais e conservadores (FORERO, 2013, p. 106), nos conflitos civis em função da limitação do poder da Igreja Católica (FORERO, 2013, p. 120) e em confrontos sociais que afetam até mesmo sua estrutura física e urbana (FORERO, 2013, p. 140).

A exemplo de Medellín, Bogotá também sofre um impulso no seu crescimento durante o século $\mathrm{XX}$, havendo uma explosão no seu processo de urbanização a partir da década de 1950 (JOYA, 2014), em função de questões ligadas à violência no campo e a priorização das cidades do ponto de vista da política econômica (ENTREVISTADO 25). Este processo afeta as diferentes cidades colombianas no período, gerando em grandes centros, como Bogotá e Medellín, um maior influxo migratório de contingentes populacionais 
deslocados em função de conflitos sociais (ALCALDIA DE MEDELLÍN, 1996; ENTREVISTADO 02).

En el transcurso de la segunda mitad del siglo XX, la ciudad de Bogotá se convirtió rápidamente en la "ciudad de migrantes", fenómeno que ha conllevado un crecimiento urbano ininterrumpido desde entonces. (...) En el transcurso de la década siguiente [1970] la población capitalina se triplicó, el crecimiento de las nuevas zonas de poblamiento suburbanas desbordó las capacidades de los entes administrativos y territoriales, razón por la cual los distintos barrios comenzaron a desarrollarse alrededor del casco urbano, lo cual condujo a dificultades en la prestación de servicios educativos, de vivienda, de transporte y de salud, que aun en el presente aquejan a los bogotanos (FORERO, 2013, pp. 154-155).

Embora este fenômeno atinja a capital desde os anos 1950, denominada como a época de "La Violencia" - em que o conflito político se acirra e se testemunha a radicalização dos movimentos de esquerda e o surgimento das guerrilhas (FORERO, 2013, pp. 140-142); é a partir da década de 1980 que o movimento migratório a Bogotá é intensificado.

De igual manera, un fenómeno persistente y que se continua presentando, es el alto número de población en condición de desplazamiento forzado que llega a Bogotá, que si bien se remonta a la denominada época de la violencia en los años 1950, son los procesos de más reciente aparición desde mediados de la década de 1980 y sobre todo en la de 1990, por efectos del conflicto social y armado interno que se vive en Colombia, lo que genera este fenómeno de atracción poblacional a la ciudad. El número de desplazados por esta violencia generada y la agudización del conflicto en Colombia, da cuenta que entre 1985 y 2013 han llegado a Bogotá más de 795364 de desplazados (10\% de los habitantes de Bogotá), principalmente a los cinturones de miseria en los barrios de origen informal, correspondiendo al $15,3 \%$ del total nacional de población en condición de desplazamiento forzado. Esta es una realidad que impacta a la ciudad y de manera particular a la vivienda, ya que esta población no retorna a sus lugares de origen y requiere solucionar el acceso a la vivienda (JOYA, 2014, p. 591).

O fato de ser a cidade que mais recebeu pessoas deslocadas pela situação de violência vivida no país (ENTREVISTADO 20) e a incapacidade de absorver todo este fluxo de maneira a prover condições mínimas de vida (FORERO, 2013) levou a um crescimento acelerado principalmente dos assentamentos de origem informal em Bogotá.

Neste caso, praticamente todos são absorvidos pelo potente mercado imobiliário informal existente no Distrito, inicialmente em condições de aluguel e posteriormente com a aquisição de lotes, alimentando a máquina econômica e política existente em torno deste mercado (conforme detalhado no item 2.2).

Bogotá es la ciudad que más recibió población en condición de desplazamiento forzado, más o menos, nosotros tenemos una relación de 1 a 10 . 0 sea, por cada 
10 habitantes en Bogotá, 1 de ellos es desplazado, ¿sí? Del conflicto. No migrante, sino desplazado. (...) Entonces ya estamos hablando de que en los sectores populares tenemos una relación de 2 a 10 . 0 sea, por cada 10 habitantes, 2 son desplazados. Y la gente, como se dice acá, llega con una mano adelante y una mano atrás, o sea, no llega con nada (ENTREVISTADO 20).

Além de contribuir para a formação destes assentamentos e para as precárias condições urbanísticas da área e socioeconômicas de sua população, a violência é presente também nas relações estabelecidas no território bogotano, sendo as zonas da periferia informal da cidade os locais onde se vivencia mais fortemente a violência e os impactos dos conflitos armados urbanos (ENTREVISTADO 02).

Nesse sentido, parece também que a violência urbana parece ser, em Bogotá, um dos elementos que impulsionam as ações de mejoramiento de barrios. Não possui, no entanto, a mesma centralidade no discurso como no caso de Medellín, mas está presente em diferentes momentos, do ponto de vista principalmente da melhoria das condições de segurança (SECRETARIA DISTRITAL DEL HABITAT, 2008) e da construção de uma convivência pacífica (TORRES, 2009, p. 152).

Percebe-se, a partir da análise dos documentos e notícias veiculados no âmbito da Secretaria Distrital de Habitat, a mobilização do enfrentamento à violência e da promoção de uma convivência pacífica e respeitosa como justificadores de ações de mejoramiento. Alguns exemplos podem ser encontrados abaixo:

Durante el proceso del mural, la comunidad constituyó un comité de sostenibilidad para su cuidado e incluso adicionaron objetivos como el de establecer mecanismos pacíficos para la resolución de conflictos, que aborda problemas como la estigmatización de los jóvenes, la escasa formación ecológica y ambiental y las distintas formas de violencia, entre otros (ALCALDIA DE BOGOTÁ, 2012a, p. 01).

'Plan 75Cien' busca atacar las causas primarias de los delitos que se presentan en la ciudad. Esta iniciativa se implementará en 75 puntos estratégicos de Bogotá donde se genera el mayor número de casos de violencia. Así mismo, Barrios de Colores pretende integrar a la comunidad, generar sentido de pertenencia y sensibilizar a la sociedad acerca de la importancia de cuidar y mejorar su entorno. (ALCALDIA DE BOGOTÁ, 2014b, p. 01)

Tras un recorrido del alcalde Gustavo Petro y de entidades distritales por los sectores mejorados del Área Prioritaria de Intervención Lucero en Ciudad Bolívar, el burgomaestre manifestó que las obras de Mejoramiento Integral de Barrios son la estrategia de seguridad para los barrios más vulnerables de Bogotá. "La estrategia que busca ofrecer educación a los jóvenes, pintar las calles con arte, mejorar en el entorno, incluir a la población y superar la segregación es nuestra política de seguridad humana. No la que viene con 
fusiles ni bombardeos", dijo el Alcalde Mayor. (...) "Queremos que lo que ha pasado en esta zona se replique en las 26 zonas que tengan los más altos índices de homicidio en la ciudad, porque estamos convencidos que en el mediano plazo esto provocará una disminución sustancial de la violencia y un cambio a zonas pacíficas”, agregó Gustavo Petro. (ALCALDIA DE BOGOTÁ, 2015a, p. 01).

El alcalde Mayor de Bogotá, Gustavo Petro en compañía de las secretarias de Hábitat, Helga María Rivas Ardila y de Gobierno Gloria Flórez y el director de la Caja de Vivienda Popular, José Andrés Ríos entregaron 149 títulos de propiedad a hogares, como parte de las acciones de mejoramiento integral que se desarrollan en el sector Chiguaza al Sur de Bogotá. "Vamos a seguir mejorando el hábitat para que la gente pueda vivir mejor. Los territorios de convivencia 0 priorización son un ejemplo de cómo construir la paz. Nuestra política de seguridad humana es que el Estado le de la mano al joven en vulnerabilidad, a la persona en condición de discapacidad, a la recicladora, que le de la mano al que es débil en la sociedad. El resultado es que este método es mucho más exitoso para reducir la violencia y hay que exportarlo a toda Colombia y al conjunto de toda Bogotá. Hemos descubierto las claves demostrables de cómo construir la paz", afirmó el Alcalde (ALCALDIA DE BOGOTÁ, 2015g, p. 01).

Apesar de não ser possível encontrar componentes relacionados à questão da segurança e convivência em todos os programas ligados ao mejoramiento (estando ausente em programas como PIDUZOB, Obras con Saldo Pedagógico, Programa de Desarrollo Institucional y Comunitario Ciudad Bolivar), desde 1997 até os dias de hoje esta dimensão está de alguma forma presente através de componentes dos programas Sur con Bogotá (entre 1997 e 2001), Desmarginalización (1998 a 2001) e Programa de Mejoramiento Integral de Barrios (2000 até a atualidade) (TORRES, 2009, p. 198).

La convivencia se ha venido posicionando como una mirada para enfrentar los problemas de violencia y delincuencia, propios de la ciudad. (...) Este tema, al igual que el de la participación, se ha convertido en un componente casi obligatorio para las experiencias del MIB (TORRES, 2009, p. 152).

Sua presença no discurso e nos componentes dos programas, contudo, não significa que a intervenção do Estado na questão esteja efetivamente acontecendo ou que realmente seja realizado de forma articulada às intervenções de melhorias na infraestrutura física, de equipamentos públicos, etc. Segundo entrevistados (ENTREVISTADO 20; ENTREVISTADO 02), essa conexão na implementação das iniciativas de mejoramiento variaria ao longo do tempo, em função das prioridades dadas ao tema em cada uma das gestões municipais.

Bogotá y muchas de las ciudades grandes colombianas crecieron de una manera muy fuerte en la segunda mitad del siglo veinte, producto de la banda del desplazamiento por el conflicto armado. Eso digamos que tampoco ha sido tratado de una manera responsable por parte del Estado. Hubo un intento hace cuatro años de montar un programa que se llamaba Programa de Seguridad y Convivencia, que estaba articulado al Programa de Mejoramiento. Entonces 
generaba como espacio bueno, hacia actividades deportivas, trataba de insertarlos en el mercado laboral, pero eso se abandona. (...) Entonces, buen, pero eso tampoco se le dio mucha prioridad en términos de política pública. Parte de los problema que nosotros tenemos acá es que no hay continuidad de los procesos porque cada vez que llega una alcalde vine con unas prioridades y hay procesos que se abandonan (ENTREVISTADO 02).

Aparentemente, portanto, o tema da segurança e convivência entra e sai da agenda da urbanização de favelas em Bogotá, em alguns momentos sendo efetivamente um motor da intervenção nos assentamentos - como acontece no período (2004 a 2010) em que se fundem os programas Sur con Bogotá e PMIB (TORRES, 2009, p. 114-116) - e em outros (2012 a 2015) é visto como uma questão a parte, estando presente no discurso (como visto acima nos trechos citados), mas ausente nas ações concretamente implementadas.

Merece menção, por fim, o fato de que esta relação não está restrita aos casos de Medellín e Bogotá. De acordo com Garcia (2010) e entrevistados (ENTREVISTADO 21; ENTREVISTADO 20), as cidades de Cali e Villavicencio também teriam buscado de alguma forma intervir nos assentamentos informais como forma de enfrentamento à violência que vivenciam, como acontece nas mais variadas cidades e regiões (PATIÑO, 2015, p. 246). Além disso, o programa de mejoramiento integral de barrios do Governo Nacional inclui, dentro do componente de desenvolvimento social, a possibilidade de financiar ações relacionas à segurança e convivência (MINISTÉRIO DE VIVIENDA, 2014, p. 76).

No entanto, como o próprio Governo admite, isso está sujeito à disponibilidade de recursos, o que significa, de acordo com entrevistados (ENTREVISTADO 20; ENTREVISTADO 02; ENTREVISTADO 25; ENTREVISTADO 10), um baixo repasse para as grandes cidades (como Bogotá e Medellín) no tocante ao MIB e o financiamento, nas poucas cidades efetivamente apoiadas, principalmente de intervenções físicas (ENTREVISTADO 20). O resultado de melhorias nos índices de segurança e convivência nas intervenções financiadas pelo Governo Nacional são desdobramentos, segundo sua própria publicação (MINISTERIO DE VIVIENDA, 2014, p. 77-78), das obras físicas realizadas, e não do financiamento dos componentes sociais. 


\subsection{São Paulo}

Em São Paulo, também se verifica uma conexão mais tímida entre a agenda e a implementação de programas e iniciativas de urbanização de favelas e a dimensão da violência urbana vivida. Da mesma forma que as demais cidades estudadas, seu crescimento se deu de maneira mais acentuada na segunda metade do século XX a partir de um grande processo de migração, resultando na multiplicação de favelas e grandes periferias autoconstruídas. Conforme apontado na introdução (Tabela 01), o Censo de Favelas, realizado pela Prefeitura de São Paulo e publicado em 1989, indicava que o incremento de moradores de favela entre 1973 e 1987 teria sido da ordem de 1031\%, enquanto da população da cidade como um todo teria sido de $61 \%$, apenas para dar um exemplo. Se a grande questão na metrópole foi o crescimento horizontal periférico autoconstruído, as favelas deixaram de ser a partir de então um fenômeno que se pudesse desconsiderar.

Esse processo, de acordo com o abordado na seção 1.2, foi gerando reivindicações pela atuação do poder público no sentido de promover melhorias desde a década de 1970, ao final da qual, inclusive, passaram a ser implementados programas como Pró-Luz e Pró-Agua (PREFEITURA MUNICIPAL DE SÃO PAULO, 1989). Diferentemente do Rio e de Medellín, contudo, a intervenção promovida nesses assentamentos esteve menos vinculada a questões relacionadas ao crescimento da violência urbana e do tráfico de drogas, apesar de já se verificar naquele momento uma crescente percepção social em São Paulo sobre o avanço da criminalidade urbana violenta (NERY, 2016, p. 49).

No final da década de 1980, a Prefeitura Municipal de São Paulo delimitava como objetivos do Programa de Urbanização de Favelas, em seu programa de Ação Imediata, "promover a regularização jurídica e física da ocupação de áreas de favelas situadas em terrenos municipais ou particulares, possibilitando a fixação da população moradora no local, bem como a inserção gradativa do 
assentamento no tecido urbano" (PMSP, 1989, p. 102). Isso envolvia a regularização da posse, o parcelamento do solo, a implantação de infraestrurura, financiamento de materiais para autoconstrução, regularização do traçado viário, estando ausente, portanto, componentes sociais no seu escopo. O próprio Censo de Favelas (1989), embora enfocasse temas como a economia e comércio no âmbito das favelas (PMSP, 1989, p. 94) e a organização política comunitária (PMSP, 1989, p. 96) com mais cuidado e detalhamento, apenas menciona, de passagem, a questão da violência quando trata, em dois parágrafos, sobre a existência de postos policiais em favelas.

É crescente a apreensão da população moradora em favelas com relação às condições de segurança, dada a evidência de alto grau de violência registrados nos grandes centros urbanos. A concentração espacial dos trabalhadores em cidades e áreas metropolitanas cada vez mais extensas, caracterizando o que se chamam de "periferização da cidade" e o crescente acirramento das condições de vida nos grandes conglomerados urbanos propiciam o aumento de todo o tipo de violência e atingem de forma direta a população de baixa renda e moradora nas favelas da cidade.

O Censo teve a preocupação de verificar a existência ou não de posto policial nas proximidades das favelas. Os dados apontam que apenas $344(21,61 \%)$ favelas possuem o equipamento no bairro e $1.245(28,20 \%)$ apontam a falta desse atendimento (PMSP, 1989, p. 93).

O que se verifica nessa passagem, no entanto, é um tratamento genérico no discurso, colocando a apreensão dos moradores de favela no âmbito das preocupações da cidade em geral, não especificando situações atinentes às próprias favelas em si. Entrevistada que esteve na coordenação das ações destinadas a favelas no governo de Luiza Erundina (1989-1992) confirma a análise de essa questão não estar incluída na agenda da gestão naquele momento.

Sim, já havia isso [presença do tráfico nas favelas e o crescimento da violência], mas eu confesso que nós não víamos isso institucionalmente. Não era tão discutido dentro da HABI, dentro da hierarquia da prefeitura e tal, mas as equipes sociais e as equipes técnicas, que atuavam nas favelas acompanhando as obras, já tinha diversos casos. Nós, todos de classe média, nos impactava muito ver a violência interpessoal entre marido e mulher, a gente chegou a encontrar esconderijo de armas dentro de favela em São Paulo. Na época, começava a ter essa discussão de favelas que estão próximas às rodovias tem mais espaço, interesse da criminalidade, isso já era um assunto sim. (...) Já era então presente [o tema], mas acho que a gente não tinha nenhuma clareza disso entrar, a não ser pelo pessoal do serviço social, que já entrava com esse tema mesmo (ENTREVISTADO 23).

De acordo com essa e outras entrevistas realizadas com técnicos envolvidos em gestões municipais nas décadas de 1980 e 1990 (ENTREVISTADO 23; 
ENTREVISTADO 09; ENTREVISTADO 12; ENTREVISTADO 19; ENTREVISTADO 17), tratava-se ainda de uma fase em que o tráfico ainda não impactava a possibilidade de realização de iniciativas de urbanização de favelas. As intervenções eram realizadas de maneira relativamente tranquila, com entrada fácil das equipes no território. A presença do tráfico ainda não era ostensiva e pouco hostil, havendo até mesmo cooperação por parte de seus integrantes em algumas iniciativas. Havia, evidentemente, casos em que discordavam de algumas propostas de abertura de vias e acessos, tendo em vista mexerem com seus interesses na geografia do comércio que realizavam, mas eram facilmente negociados, de acordo com os entrevistados.

Da mesma forma, as gestões municipais de Paulo Maluf (1993-1996) e de seu sucessor, Celso Pitta (1997-2000), também não conectaram a intervenção em favelas à pauta da violência. Da análise dos discursos ao longo de seus mandatos e das campanhas eleitorais de ambos (em 1992, 1996 e 2000), por exemplo, verifica-se que tanto o Projeto Cingapura (principal intervenção voltada a favelas no período, conforme visto na seção 2.1) quanto o tema da segurança pública (pautado sempre na perspectiva da maior repressão ao crime, maior policiamento, etc.) foram exaustivamente utilizados, mas não se fazia qualquer relação entre eles (ALDÉ \& DIAS, 1996; FIGUEIREDO ET AL, 1997; SANTOS, 2006).

São Paulo viveu, no entanto, o crescimento do tráfico e da violência de maneira intensa ao longo da década de 1990. Maia (1999), ao analisar a evolução dos homicídios no estado de São Paulo ao longo das décadas de 1980 e 1990, compara a taxa de homicídio paulista com os demais estados (ficando atrás apenas de Rio de Janeiro, Pernambuco e Espírito Santo) e com aquela apresentada por países (situando a taxa paulista entre uma das maiores do mundo, atrás apenas daquela apresentada pela Colômbia). Além disso, demonstra como o crescimento dos homicídios verificado ao longo da década ocorre de maneira mais intensa entre os homens, na faixa etária de 15 a 34 anos, solteiros, moradores de distritos periféricos da capital, sendo a maioria dessas mortes causadas por arma de fogo. 
Se esses dados já permitiriam, por si só, entrever a conexão entre o aumento dos homicídios e o perfil de integrantes da cadeia do tráfico de drogas, Feltran (2018, p. 187) aponta como efetivamente o crescimento da violência vivido nesse período na cidade - verificado nessa explosão das taxas de homicídio estava de fato conectado ao crescimento dos mercados ilegais, principalmente o tráfico de drogas, como no caso do Rio de Janeiro, Medellín e Bogotá. Da mesma forma que esses centros, São Paulo também passa a fazer parte das principais rotas de tráfico internacional com destino à Europa e EUA (NERY, 2016, p. 62). Isso ocorre em um período em que a situação econômica pela qual o país passava era delicada e que afetava particularmente a população de São Paulo, centro que sofria de maneira mais intensa as mudanças econômicas e da distribuição das atividades industriais e que passava por um contexto de empobrecimento e aumento do desemprego (ROLNIK, 2017, p. 57).

(...) a abertura da economia nacional, seguida de intensa reestruturação produtiva, impunha a necessidade de profissionalização e aumentava 0 desemprego, a transnacionalização e a flexibilização da gestão de todos os mercados operando no país, inclusive os ilegais e ilícitos. 0 desemprego estrutural chegou a $22 \%$ da população economicamente ativa na região metropolitana de São Paulo no final dos anos 1990; a informalização dos mercados e as altíssimas taxas de lucro das atividades ilegais elevaram os índices de criminalidade violenta a patamares impensáveis uma década antes. Se um entre cinco dos moradores de São Paulo que teriam idade para trabalhar estava sem emprego, muitos dentre os desempregados encontrariam renda - e muito mais do que poderiam ganhar no mercado formal - no tráfico de drogas. Esse é o principal mercado emergente nesse período de crise econômica na cidade de São Paulo. E o tráfico de maconha e cocaína era, como continua sendo, dos mais lucrativos. A mercadoria chega a São Paulo e seus pontos de comércio privilegiado se estabelecem, territorialmente, em especial e não por acaso, nas periferias da cidade. Ali, como já vimos, as famílias vinham passando por transformações intensas e muito de seus trabalhadores - em maior parte os dos segmentos mais pobres e mais negros entre os migrantes - tinham visto frustrado seu sonho de integração social. Alguns não acreditavam mais nessa integração havia anos, e viram no tráfico uma saída (FELTRAN, 2018, p. 189).

Da mesma forma que no caso do Rio de Janeiro, também em São Paulo o tráfico se desenvolve sobre as condições precárias (de renda, moradia, educacional, etc.) vividas nas favelas a partir dos anos 1990 (FELTRAN, 2018, p. 93). Uma série de estudos começa a investigar (ROLNIK, 1999; CARDIA \& SCHIFFER, 2000; ADORNO, 2002; LABHAB, 2003; HUGHES, 2004; PERES, ADORNO ET AL, 2008), então, as conexões entre a violência crescente nos assentamentos populares (tanto favelas quanto loteamentos irregularres autoconstruídos) e a situação de vida de sua população. Para Adorno (2002), 
era essencial reconhecer a reiterada relação, no Brasil como um todo, entre a concentração da riqueza, a precária qualidade de vida coletiva nas periferias dos grandes centros e a explosão da violência fatal. Com base na análise de mapas da violência elaborados à época, o autor observa que as taxas de homicídios eram constantemente mais elevadas nessas áreas do que nos bairros incluídos nas zonas históricamente melhor atendidas pela infraestrutura urbana, pela oferta de postos de trabalho e por serviços de lazer e cultura (ADORNO, 2002, p. 112).

Rolnik (1999 e 2017) também aborda o tema sob a perspectiva da exclusão territorial, a partir de pesquisa realizada em diversos municípios do estado de São Paulo na segunda metade da década de 1990. A conclusão a que chega é que a exclusão territorial tornaria tanto indivíduos, quanto famílias e até mesmo comunidades inteiras mais vulneráveis, abrindo espaço para a violência (ROLNIK, 1999, p. 107). Ao viver permanentemente sob condições de privação de necesidades básicas, os habitantes sentiriam como se suas vidas não tivessem valor. Esse seria o caso especialmente de jovens nascidos e que cresceram em situação de exclusão territorial ao longo dos anos 1970 e 1980, os quais, após passarem por diferentes privações, veem o sonho da incluso social através do emprego abortado pela situação vivida pelo país à época. Da mesma forma que Feltran (2018), a autora afirma que essa frustração de expectativa contribuiu para que então a violência se propagasse, "com seu sentido ambíguo de desespero e heroísmo" (ROLNIK, 1999, p. 108).

Não há dúvida de que a bomba-relógio da violência que explodiu nos anos 1990 na cidade guarda um nexo forte com essa estrutura urbana (...) de radical exclusão territorial a que foram condenados os moradores da extrema periferia guetos de baixa renda, educação precária, desemprego alto, serviços urbanos deficientes, claramente fora dos locais onde circulam as oportunidades (ROLNIK, 2017, p. 46).

Apesar disso, é importante observar que o caso do estado de São Paulo e de sua capital são pontos fora da curva no tocante à evolução das taxas de homicídio. Ao contrário do que se verificou na maioria dos outros estados, houve uma considerável redução nas taxas de homicídio no estado, a qual decresce mais de 70\% durante os anos 2000 (FELTRAN, 2018, p. 228), inclusive nas regiões periféricas e em assentamentos populares da capital (NERY, 2016, p. 69). 
Gráfico 1 - Evolução das taxas de homicídios dolosos, por 100 mil habitantes. Município de São Paulo, 1981 a 2013.

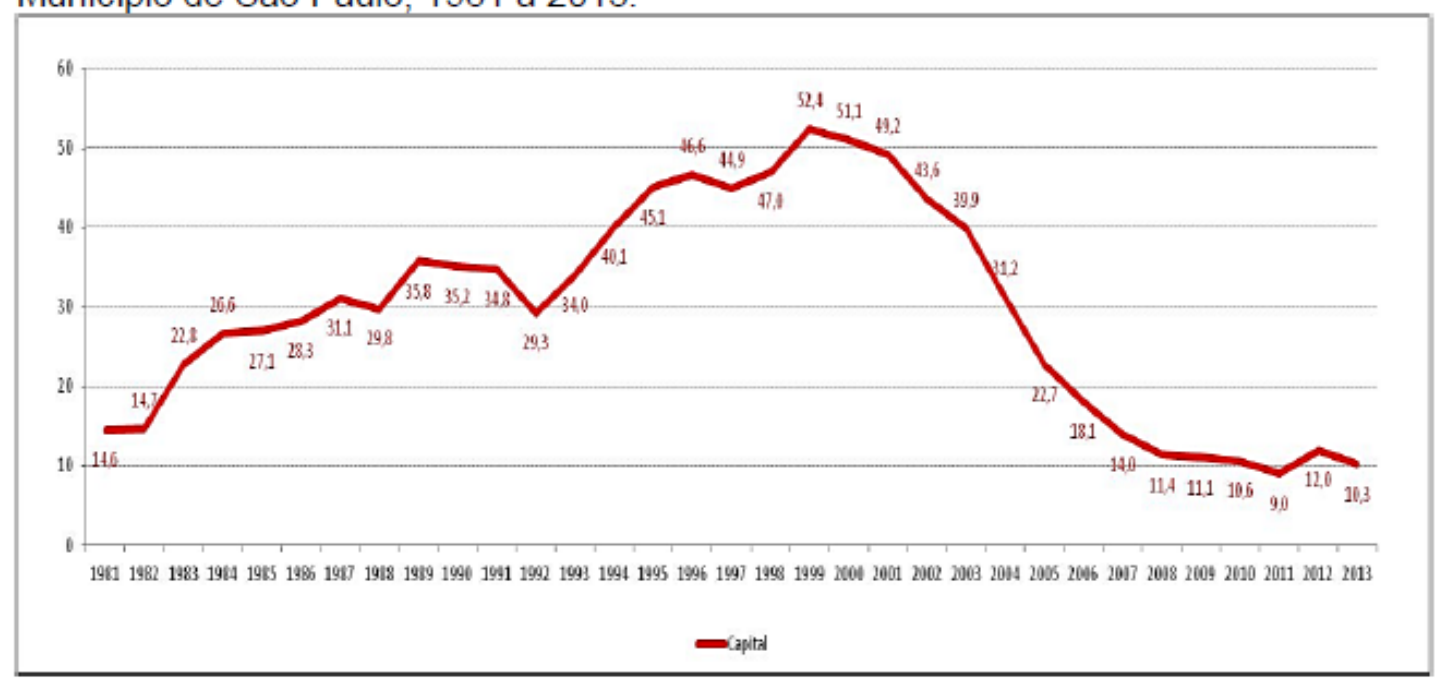

Fonte: CALDEIRA, 2000 (homicídios de 1981-1995); SSP-SP - RES SSP 160/01 (homicídios de 1996-2013); Fundação Seade (população de 1981-2013)

Elaboração: Marcelo Batista Nery/NEV-USP

Feltran (2018) oferece como hipótese a consolidação da hegemonia do Primeiro Comando da Capital (PCC) no estado para explicar essa redução, tendo em vista o estabelecimento pelo Comando de regras que controlavam o uso da força tanto pelos seus integrantes quanto por aqueles que apenas vivem ou operam nos territórios sob seu controle. Em que pesem inúmeros outros fatores passíveis de serem levantados como explicação ou contribuição a esta redução, como aqueles apontados por Nery (2016), este é o único, segundo o autor (FELTRAN, 2018, p. 229) que isoladamente consegue explicar como essa redução acontece apenas neste estado da federação e como, simultaneamente, não significa a redução da violência no geral em São Paulo, tendo em vista o crescimento ou estabilização de outras espécies de crime (latrocínio, roubos, furtos, etc.).

Criado ainda na década de 1990 dentro dos presídios do estado com o objetivo de estabelecer uma dinâmica de ajuda mútua entre os "irmãos" (NERY, 2016, p. 62), o PCC tornou-se desde então um ator relevante para a discussão sobre favelas (ou "quebradas") em São Paulo, especialmente quando se pretende tratar da dimensão da violência urbana em comparação com o Rio de Janeiro. Diferentemente do que ocorreu na capital fluminense - na qual uma entrevistada afirmou que apenas ocorria pacificação em um determinado 
território quando um comando conquistava o controle dele (ENTREVISTADO 26) -, o PCC conquistou a hegemonia das quebradas de São Paulo, sendo esse processo, no entanto, profundamente diferente da perspectiva de controle territorial, pelo qual disputam os comandos cariocas (FELTRAN, 2018, p. 20).

Como Feltran (2018, p. 89) coloca, a disputa pela hegemonia política feita pelo PCC se dá através da luta ideológica e cultural travada pelo Comando pelo consentimento ativo de uma parcela significativa da população nas cadeias e nas quebradas, somada à coerção dos seus opositores. Dessa maneira, uma favela é considerada do PCC quando a ampla maioria dos seus moradores respeita as políticas da facção, ou seja, quando suas políticas de fato regulam a ordem local.

Isso, no entanto, não significa o controle territorial dessa favela, podendo haver uma variedade de atores locais e atividades sendo exercidas que não possuem vínculos com o Comando ou que não necessitam pagar qualquer quantia a ele, apenas obedecendo à ordem estabelecida. Não são observadas, ainda, fronteiras armadas nas favelas de São Paulo atuando na defesa dos interesses e dos negócios do PCC, conforme observa Feltran (2018, p. 148 e segs.). À exceção de pouquíssimos períodos de conflito aberto, uma "norma de paz deve reger os territórios do Comando" (FELTRAN, 2018, p. 150), sendo possível circular por esses assentamentos sem visualizar qualquer armamento. Além de favorecer os negócios desenvolvidos nessas regiões (FELTRAN, 2018, p. 149), o hasteamento da bandeira branca pelo comando certamente tem um impacto positivo tanto no desenvolvimento de políticas sociais quanto principalmente no cotidiano e na qualidade de vida dos moradores das quebradas, diferentemente do que o que ocorre nos morros na capital carioca.

Para diferenciar do Rio de Janeiro, Feltran (2018, p. 89) utiliza o exemplo de um entrevistado que roubava carros na mesma região da cidade há oito anos sem saber quem é o irmão do PCC na favela em questão, o que nunca aconteceria no Rio. Além de saber exatamente quem controla as atividades da região, muito provavelmente seria obrigado a repassar parte do dinheiro obtido com o roubo. Há no Rio, portanto, "fronteiras guardadas por traficantes armados submetidos a um poder centralizado. Todos os pontos de venda de 
drogas nesse território fazem dinheiro fluir para um caixa único, comandado pelo líder local, que se torna também milionário: o dono do morro" (FELTRAN, 2018, p. 147).

Em São Paulo, não há por parte do PCC uma cobrança sobre uma porcentagem do lucro, ou dos negócios, a ser dividido com a fraternidade; ao contrário, cada irmão estabelece iniciativas autônomas em relação à organização política e à economia interna do Comando. O PCC, diferentemente das outras facções existentes, por exemplo, no Rio, não almeja o domínio territorial completo, expulsando seus concorrentes (tendo, por exemplo, mantido parceria com o Comando Vermelho por mais de 23 anos, até 2016 - FELTRAN, 2018, p. 44), ele negocia para que passem a adotar as suas políticas e, em troca, oferecem segurança aos negócios de todos. "Cada um no seu corre, mas com princípios comuns de atuação" (FELTRAN, 2018, p. 85).

\begin{abstract}
Quando se diz que $\mathbf{9 0 \%}$ das cadeias de São Paulo "são PCC", o que a enorme maioria das quebradas do estado de São Paulo "é PCC", não se está dizendo que todos os presos da cadeia, ou todos os moradores daquela favela ou região, sejam batizados no Comando ou mesmo que façam parte de suas redes. Muito menos que esses territórios sejam dominados ou controlados pela facção. É possível dizer, entretanto, que por ali se acatam, aceitam, concordam ou ao menos se toleram as políticas do PCC. O que se afirma sem margem de dúvida é que não há oposição aberta às políticas do Comando, que se tornam, por isso mesmo, hegemônicas. Um território PCC é, portanto, um local politicamente hegemonizado pela facção. As áreas de negócio do PCC são o mundo todo (FELTRAN, 2018, p. 90-91).
\end{abstract}

Souza (2010, p. 76) também aponta nesse sentido ao comparar a estrutura e territorialidade do tráfico no Rio de Janeiro e São Paulo. Para o autor, o tráfico no varejo na capital paulista seria menos organizado que no Rio (com uma estrutura menos centralizada, menor disputa por domínios territoriais, etc.), à exceção apenas de algumas regiões da periferia paulistana. Como isso rebate então na urbanização de favelas?

Se por um lado, houve uma redução nos índices de homicídio no estado de São Paulo e um maior controle de outros tipos de violência reguladas pelo PCC; por outro, isso não significa necessariamente a diminuição da violência urbana como um todo, como visto já para Medellín. Também não significa uma redução da disputa entre estado e grupos criminais no âmbito dos assentamentos populares, como será abordado na seção 4.1 a seguir. No momento, é relevante destacar que a expansão dessa hegemonia do PCC 
sobre a violência em São Paulo, proporcionando uma redução de alguns índices e, assim, também a pressão pública sobre o assunto, parece significativa para compreender o fato de as iniciativas de urbanização de favelas continuarem menos conectadas ao tema na cidade nos anos 2000 do que nas outras metrópoles estudadas. Em São Paulo, a questão da violência continuava a ser tratada mais sob a ótica do policiamento do que no âmbito de políticas sociais (HUGHES, 2004, p. 99).

A análise de materiais institucionais produzidos pela Prefeitura Municipal de São Paulo sobre as ações no campo habitacional em 2004 (resumindo as ações do governo de Marta Suplicy) e em 2008 (sistematizando as experiências de urbanização de favelas na gestão Serra/Kassab) demonstram a baixa centralidade da questão da violência no âmbito dessa política. Em ambas publicações, há literalmente apenas uma menção ao tema em cada, de maneira vaga e genérica sobre a violência como um problema que afeta algumas favelas (PMSP, 2004) ou a generalidade dos assentamentos informais (PMSP, 2008). Nada mais, no entanto, indicando alguma conexão ou como a dimensão da violência/segurança de alguma forma conferiria força ao tema da urbanização.

As entrevistas realizadas com gestores públicos envolvidos durante a década de 2000 com o tema reforçaram essa perspectiva (ENTREVISTADO 14; ENTREVISTADO 09; ENTREVISTADO 12; ENTREVISTADO 28). Perguntada sobre a existência ou não de propostas relacionadas ao enfrentamento à violência no âmbito de programas de urbanização em São Paulo, técnica integrante da equipe responsável pelo tema no governo Marta Suplicy afirmou em entrevista que

[O tema da segurança/violência] Nunca teve entrada nenhuma. Tinha coisas do dia a dia, assim, as equipes que iam fazer levantamento de campo, de topografia, a gente tinha que conversar com as lideranças da favela antes, tomar uma série de cuidados, porque era tenso. Em São Paulo nunca teve [a dimensão da violência na construção dos programas]. Não sei se hoje tem, não sei se nas últimas experiências tem, mas naquela ocasião não tinha. Isso não estava colocado, a única coisa que estava colocada era que se acreditava que esse diálogo direto com a população minimante criaria uma trégua e de fato criava, a gente se sentia seguro indo lá, porque a secretaria era muito parceira. Se pegava fogo, a gente estava lá, era uma relação muito de confiança mesmo e o próprio tráfico, que também mora lá, reconhece isso. Eles também não querem esse tipo de problema, mas também porque a gente não colocou como objetivo expulsálos dali, essa dinâmica. era um pisar em ovos constante (ENTREVISTADO 14). 
Cumpre deixar registrado, no entanto, uma iniciativa realizada pelo Laboratório de Habitação e Assentamentos Humanos (LABHAB - FAUUSP) sob contratação da Cities Alliance e mediação da Secretaria de Habitação da PMSP que, de alguma forma, buscava conectar os temas no escopo dos Planos de Ação Habitacional e Urbana ${ }^{39}$. Tais planos objetivavam, contrapondo-se às peças tradicionais do planejamento urbano, apresentar soluções para os problemas urbanos locais, as quais, com base em diagnóstico profundo de cada região, fossem capazes de romper a fragmentação e o distanciamento da realidade que caracterizam as políticas públicas nas periferias dos grandes centros urbanos, com especial ênfase no enfrentamento à questão da violência (LABHAB, 2003).

No plano elaborado pelo Laboratório para o distrito do Jardim Ângela, em que predominava "um quadro generalizado de violência urbana" segundo diagnóstico elaborado, estavam previstas uma série de possíveis ações a serem realizadas no âmbito de políticas já executadas pela municipalidade (Educação, Cultura, Transporte, Habitação, etc.) com potencial impacto sobre a violência (LABHAB, 2003, p. 113), considerada "elemento motivador do Plano" (LABHAB, 2003, p. 17). Um dos anexos ao Plano, inclusive, é o texto "A violência urbana e o Plano de Ação Bairro Legal", que aprofunda conceitualmente a questão, elucida as conexões e estabelece possíveis linhas de ação diretas e indiretas do Plano nesse âmbito.

Apesar de ter constituído uma experiência interessante do ponto de vista de processo de planejamento e que justamente trazia à baila, em São Paulo, a relação entre investimentos em assentamentos populares e o enfrentamento à violência, aparentemente tratou-se de uma iniciativa marginal dentro da gestão municipal. Nenhum dos gestores públicos entrevistados sequer havia mencionado a iniciativa (a qual ainda se restringiu a apenas planos elaborados para outras duas localidades além do Jardim Ângela) e tampouco constava de publicação de balanço da gestão municipal no campo habitacional (PMSP,

${ }^{39}$ Para ler mais sobre a iniciativa, consultar publicações (LABHAB, 2003) disponíveis em: http://www.labhab.fau.usp.br/pesquisa/concluidas/2003-2/plano-de-acao-habitacional-e-urbanapara-areas-em-situacao-de-risco-pela-exclusao-socioespacial-e-a-violencia/ 
2004). Segundo um dos participantes da equipe do $L A B H A B$ na execução e envolvido até hoje com intervenções em favela, a experiência ficou restrita à elaboração dos planos e "não foi mais pra frente". Pode-se argumento que se tratava do final da gestão Marta Suplicy, a qual foi derrotada nas urnas a seguir, e que esse seria o motivo da sua descontinuidade. No entanto, como visto na seção 2.1, diversos outras iniciativas de urbanização de favelas iniciadas na gestão Marta foram continuadas ou até mesmo integralmente implementadas na gestão Serra/Kassab. Assim, não parece ser a troca de governantes a questão fundamental dessa descontinuidade, mas sim o fato de que o tema da segurança/violência em São Paulo nunca ter sido fortemente considerado parte da agenda de urbanização de favelas (ENTREVISTADO 28).

Outros entrevistados também afirmaram essa perspectiva, deixando claro que, nem mesmo para a implementação da própria intervenção física em si, a centralidade da violência era tão forte em São Paulo quanto no caso do Rio de Janeiro, pelo menos durante a década de 2000. "Você nunca teve problema na obra. Alguém entrar na área e ir lá reivindicar, 'Quero tanto pra ficar'. Nunca, zero. Tinha às vezes, de vez em quando um cara enchia o saco, mas a gente nunca levou a sério" (ENTREVISTADO 09).

Como será visto na seção seguinte, houve casos de conflitos com o tráfico relatado por alguns entrevistados, mas eles de forma alguma seriam obstáculos para a realização das iniciativas. Mencione-se que, em três entrevistas (ENTREVISTADO 12; ENTREVISTADO 28; ENTREVISTADO 19), foi relatado rumores da realização de acordo (mais do que ocasionais e eventuais negociações projetuais) entre a gestão municipal e lideranças do tráfico, o que potencialmente explicaria a relativa tranquilidade para implementação dessas iniciativas ${ }^{40}$. Conforme afirmado por pessoa entrevistade partícipe da gestão, "você percebe que em Heliópolis foi totalmente negociada a construção de unidades lá pra reassentamento, a

\footnotetext{
${ }^{40}$ Embora se trate apenas de um rumor e sem possibilidade de comprovação, decidimos apresentar essas falas em função da relevância para o argumento construído e pelo fato de que ganhou notoriedade na época (2006) outro acordo semelhante, realizado entre o PCC e o Governo do Estado de São Paulo (ao qual à gestão municipal era politicamente alinhada no período) para a solução de rebeliões e conflitos armados exacerbados naquele momento entre o Comando e a Polícia Militar (NERY, 2016, p. 128).
} 
urbanização foi totalmente negociada com o tráfico, não tinha outra forma" (ENTREVISTADO 19).

Dessa forma, embora o tráfico esteja presente na maioria das favelas enfocadas, por exemplo, pelo Renova ${ }^{41}$, a questão da violência e da atuação dos grupos criminais nesses assentamentos está ausente do escopo contratado pela Prefeitura de São Paulo (ENTREVISTADO 28).

\begin{abstract}
Isso [discussão sobre a violência/criminalidade em São Paulo] está muito desconectado do território (...), a coisa da violência é um assunto subdimensionado na discussão, é um sub-assunto, quando deveria ser um assunto central. Se você pegar o escopo de trabalho da gente aqui, não existe, não é um assunto. Segurança, violência, jovem, não é tema. Tema é o que é tradicionalmente tema: pobreza de infraestrutura, assistente social, etc., mas não tem essa questão da violência, a ação da polícia nesse território... Até porque tem um componente urbanístico que poderia ser trabalhado, os pancadões, tudo isso poderia ser assunto, a cultura, o lazer na periferia (ENTREVISTADO 28).
\end{abstract}

Conlui-se, portanto, que, à exceção de algumas iniciativas pontuais (Planos de Ação Habitacional e Urbana para 3 distritos) e de ser mencionada em alguns momentos pelo poder público, a violência urbana e a atuação do tráfico não são tão significativos para o impulsionamento da urbanização de favelas em São Paulo quanto em Medellín e no Rio de Janeiro, estando um pouco mais próxima à experiência de Bogotá. Souza (2010, p. 77) também advogada que, de uma maneira geral, São Paulo e Rio de Janeiro diferem no tocante ao lugar da favela para a discussão da violência.

Primeiramente, o tema da violência gozaria, perante a população na cidade, de uma visibilidade diferente do que no caso da metrópole carioca (SOUZA, 2010, p. 79), ainda mais levando em consideração a redução dos homicídios e de alguns outros tipos de crime pela expansão da hegemonia do PCC na década de 2000. Em segundo lugar, enquanto no Rio a favela ocuparia um lugar central no discurso cotidiano sobre violência, criminalidade e tráfico de drogas; no caso de São Paulo, o ônus dessa discriminação seria carregado não apenas pelas favelas, mas seria dividido também com cortiços e loteamentos irregulares.

\footnotetext{
${ }^{41}$ Para mais detalhes sobre o Renova, consultar a seção 2.1 e 2.2 dessa tese.
} 
Contudo, é importante ressalvar que, apesar de diferente do Rio de Janeiro, a percepção sobre a questão da violência por parte das classes paulistanas mais abastadas promoveu uma mudança significativa no território da cidade, principalmente em relação aos seus próprios modos de vida. Essa percepção levou a alterações profundas na "convivência urbana e impessoal, produzindo o enclausuramento das classes média e alta em seus condomínios fechados e shopping centers, o abandono do espaço das ruas" (ROLNIK, 2017, p. 59).

Essa dimensão diz respeito, assim, ao impacto da violência na forma de ocupação e "segregação" das classes média e alta paulistana, e não das classes baixas. Portanto, a conexão entre "favelas < > violência" e "intervenção em favelas < > intervenção em segurança" foi menos evidente no caso paulista, tanto pela mídia quanto pelas classes média e alta. Isso explica, dessa forma, o fato de os programas de urbanização em São Paulo não enfocarem explicitamente essa questão e gozarem, ainda, de uma visibilidade e destaque menor do que a experiência carioca.

No sentido contrário, no entanto, pode-se perceber que a manutenção da precariedade de vida nesses assentamentos tem sido combustível importante para o funcionamento e crescimento do tráfico de drogas na cidade, bem como para o estabelecimento da hegemonia política do PCC.

Tendo incendiado as cadeias nos anos 1990 e o mundão das periferias e favelas de São Paulo nos anos 2000, o fogo das ideias do PCC foi angariando apoio ideológico ou instrumental entre miseráveis, ladrões e traficantes de muitos lugares (...) Quem são os que atendem ao aceno do PCC, de sua ideologia e de sua disciplina? São homens e mulheres, mas também adolescentes e mesmo crianças que passaram anos a fio vendo o sol nascer e sumir na rotina monótona de barracos de madeirite (...) As ideias incendiárias do PCC se alimentam dessa experiência marginal (FELTRAN, 2018, p. 48).

A confluência demonstrada em São Paulo, em síntese, atua menos no sentido de a violência/criminalidade impulsionarem a urbanização de favelas e mais no sentido de a ainda insuficiente intervenção pública em favelas continuar a fornecer um campo fértil para a proliferação da atividade nesses assentamentos. Comparando ainda com as circunstâncias vividas pelos seus pares nos morros cariocas - que vivem cotidianamente um ambiente hostil e armado sob um regime de obediência pelo medo, não pelo consentimento ativo aos comandos e facções (FELTRAN, 2018, p. 148) - e com a violência 
promovida constantemente pela ação repressiva da polícia paulista, é compreensível que a ordem implementada pelo PCC tenha encontrado ressonância entre os moradores de favelas em São Paulo. No entanto, como será visto a seguir, nem em São Paulo, nem em qualquer das outras três cidades, essas relações estabelecidas entre a tríade "grupos criminaismoradores-estado" são isentas de conflitos.

\section{Capítulo 4 - A violência que mata a política: como a violência urbana dificulta e pode dominar a política de urbanização de favelas}

No capítulo anterior buscou-se demonstrar como, em cada uma das quatro cidades estudadas, há diferentes formas de retroalimentação entre as pautas da urbanização de favelas e da violência/segurança pública, em alguns casos mais evidentes (como Medellín e Rio de Janeiro) e em outros menos (Bogotá e São Paulo). No entanto, mesmo diante da diminuição dos índices de homicídio verificados em Medellín e São Paulo e apesar dos esforços empreendidos para conectar tais questões do ponto de vista da intervenção em favelas no Rio e em Bogotá, a violência continua sendo gramática importante na constituição e intervenção em assentamentos populares dessas cidades.

\subsection{A violência apesar da política}

Hoje a violência continua entranhada, por exemplo, nas diversas esferas da vida social em Medellín, apesar do enfrentamento promovido em diversas frentes de atuação pública, dentre elas o mejoramiento. Embora diversas estatísticas tenham melhorado ao longo das últimas duas décadas, a violência continua estruturando particularmente as relações estabelecidas nos assentamentos informais. Ela ainda é presente, por exemplo, em Santo 
Domingo, havendo trechos em que a liderança que conduzia nossa visita solicitava que fossem guardadas as câmeras. Não se tratava de evitar o furto (que, segundo ele, não aconteceria enquanto estivéssemos em sua companhia), mas por conta de não ser "aconselhável" tirar fotografias, aparentemente deixando subentendido que poderia haver problemas com as organizações presentes no território.

Se a urbanização de favelas, como parte de um pacote de políticas implementadas (PATIÑO, 2015, p. 215), parece ter de fato contribuído de alguma forma para o enfrentamento da questão, não extinguiu a violência enquanto gramática territorial.

"Lo paradójico del asunto es que en el país pocas ciudades han destinado, como Medellín, tantos recursos públicos - más de ocho billones entre 2004 y 2011 para desarrollar un urbanismo social y ejecutar los Proyectos Urbanos Integrales (PUI) como lo han hecho los últimos gobiernos locales. Sin embargo - contrario a las tesis que argumentan que atacando las causas que generan exclusión social, a partir de la inversión estatal, se resuelven las condiciones generadoras de violencia -, la experiencia de Medellín muestra resultados con enormes contrastes: a pesar de desarrollar un ambicioso plan de políticas públicas para resolver los grandes problemas sociales y buscar oportunidades para sus ciudadanos, la ciudad mantiene unos índices elevados de inseguridad y violencia colectiva, que es liderada por mafias y organizaciones criminales que ponen en jaque la gobernabilidad en la ciudad" (PATIÑO, 2015, p. 178).

Não apenas não extinguiu, portanto, a violência, como também não pode ser considerada, como se tenta fazer em alguns casos, o principal motivo de redução das estatísticas de homicídios na cidade, reduzida em torno de $80 \%$ de 1990 (ALCALDIA DE MEDELLIN, 2005; CETRÉ CASTILLO, 2013). Segundo Patiño (2015, p. 215), essa queda estaria relacionada com outros fenômenos não relacionados (não diretamente, pelo menos) com a intervenção do Estado nas favelas, como a captura de grandes líderes das organizações, a subsequente reacomodação de forças e até mesmo acordos realizados entre estes grupos. Dentre estes, cabe destacar aqui o chamado atualmente "pacto del fusil", expressão que se refere a um acordo realizado diretamente entre os diferentes grupos da cidade para diminuir o número de vítimas por assassinatos entre os membros das próprias organizações (PATIÑO, 2015, p. 34). Os principais líderes teriam se encontrado pessoalmente para chegar a um acordo que possibilitasse que não continuassem a se confrontar e a se matar pelo controle das áreas de ação criminal. 
De acordo com Quijano (2013) entre outros motivos (como a diminuição do número de membros das organizações assassinados e a redução dos seus custos financeiros com tais conflitos), estava também o fato de que estas disputas estavam levando a uma violência não mais suportada pela população residente nas áreas. A diminuição da tolerância da população estava fazendo com que cada vez mais denunciassem aos organismos estatais a ação das organizações, gerando diferentes tipos de perdas para eles e desestabilizando seu controle sobre as diferentes áreas da cidade.

O declínio das taxas de homicídio também não pode ser tomado como indicador de sucesso das intervenções de mejoramiento pelo fato de não significar a redução da violência estrutural, apenas uma reacomodação desta (PATIÑO, 2015, p. 237). Um exemplo disso é a ascensão de duas outras manifestações desta mesma violência estrutural: a prática de extorsões e 0 deslocamento intraurbano forçado ${ }^{42}$, tendo esta última modalidade um claro rebatimento territorial.

Portanto, que pesem todos os esforços engendrados através de políticas de mejoramiento, os grupos criminais e a violência continuam presentes nos barrios e exercendo controle sobre diferentes aspectos de sua vida social. Segundo Patiño (2015), estes grupos exercem ainda hoje três tipos de controle: i) social e político; ii) econômico; e iii) territorial.

El control social y político consiste en el establecimiento de un sistema de valores, normas y prácticas cotidianas que convengan al buen funcionamiento

\footnotetext{
42 Ligado fundamentalmente às disputas e negócios ligados ao tráfico de drogas, o "desplazamiento forzado intraurbano (DFI) (...) consiste en la huida de una persona de una zona hacia otra dentro de la misma ciudad y supone la pérdida de la vivienda, del empleo y de la red de apoyo social, lo que causa, tal y como se ha demostrado, un descenso en el nivel socioeconómico de las personas con cada desplazamiento dentro de la ciudad. Además, la urbanización del desplazamiento forzado genera una gran cercanía con los actores armados que lo producen de manera que los barrios que expulsan a gente son a su vez zonas de llegada de personas desplazadas de otros sectores de esa misma ciudad. Este desplazamiento, por lo tanto, tiene un carácter circular que produce una constante revictimización y re-desplazamiento que se perpetúa por la ausencia de mecanismos efectivos de protección" (FERRANDEZ, 2016, p. 2). Assim, é uma prática dos grupos criminais eminentemente associada ao exercício do controle territorial e sobre as relações sociais exercidas por eles, a qual vem constantemente crescendo ao longo da última década. Segundo dados da Personeria de Medellín (2013), este número teria constantemente subido desde 2007 (quando 1.229 pessoas se deslocaram forçadamente) até 2012 (que atingiu a marca de 9.941 deslocados), somando no período aproximadamente 30.747 pessoas forçadas a deixarem suas residências em função da violência urbana.
} 
del grupo criminal y al libre ejercicio de sus actividades ilícitas. Tal objetivo se cumple por medio de la violencia armada y la intimidación social, o a través de medios pacíficos como la interlocución en los conflictos, la intermediación de necesidades que no cubre el Estado, promoviendo así una apariencia de legitimidad y ascenso de poder político y social dentro de las comunidades en las que operan. El control económico se refiere a los medios y recursos que los grupos criminales buscan y obtienen por medio de la intimidación para lograr su consolidación territorial y armada en la ciudad. Las actividades económicas pasan de lo legal a lo ilegal y de lo formal a lo informal. El control territorial es el poder sobre el espacio vital en el cual se desarrollan y se despliegan los miembros y actividades del grupo armado. (...) El dominio sobre el territorio implica el control sobre la población que en él se asienta y sobre la cual se generan relaciones de dominación, obediencia y regulación coactiva. Es evidente como la ciudad presenta un alto porcentaje de zonas en disputa, que son controladas por las bandas criminales, que, imponiendo un método antagónico de fronteras invisibles, dividen el territorio con el fin de crear una suerte de cinturones infranqueables, dentro de los cuales controlan a la población y desarrollan sus actividades ilícitas, sin que el Estado represente un poder suficiente para controlar sus actuaciones criminales (PATIÑO, 2015, p. 209-210).

No Brasil, como um todo, a violência também continua sendo dimensão relevante do cotidiano da população, principalmente dos moradores de assentamentos populares. Dados do Fórum Brasileiro de Segurança Pública (2018) demonstram como, mesmo levando em considerações variações nas estatísticas em alguns dos anos estudados, verifica-se a continua tendência de crescimento de índices de violência no país ao longo da última década. A taxa de Mortes Violentas Intencionais (a qual agrega homicídios, latrocínios e lesões corporais seguidas de morte) cresceu, por exemplo, de 29,9 mortes para cada 100.000 habitantes para 30,8 entre 2016 e 2017 no território nacional. Se em 2005 contávamos com uma taxa de 22,5 homicídios dolosos para cada 100.000 habitantes no país, em 2017 essa taxa já chegava a 26,9. Outro crime crescente no Brasil e que contribui para a percepção do tema (tendo em vista a violência com que muitas vezes é realizado) é o roubo de veículos, executado a mão armada. 


\section{Roubo de veículos}

Taxa / 100 mil veículos

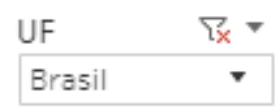

300

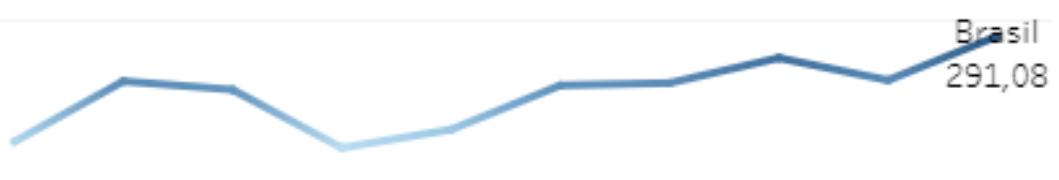

200

0

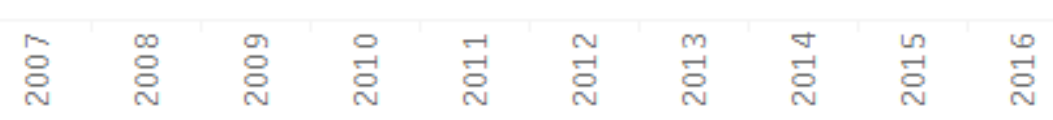

Além de vários outros crimes contra o patrimônio (como o furto, etc.) e crimes não letais contra a pessoa (a exemplo do estupro e lesões corporais) que também impactam na violência urbana vivida no Brasil, é importante salientar aqui a crescente violência policial verificada nos últimos anos, a qual, de maneira ainda mais forte, impacta diferenciadamente a população de assentamentos populares (FELTRAN, 2018).

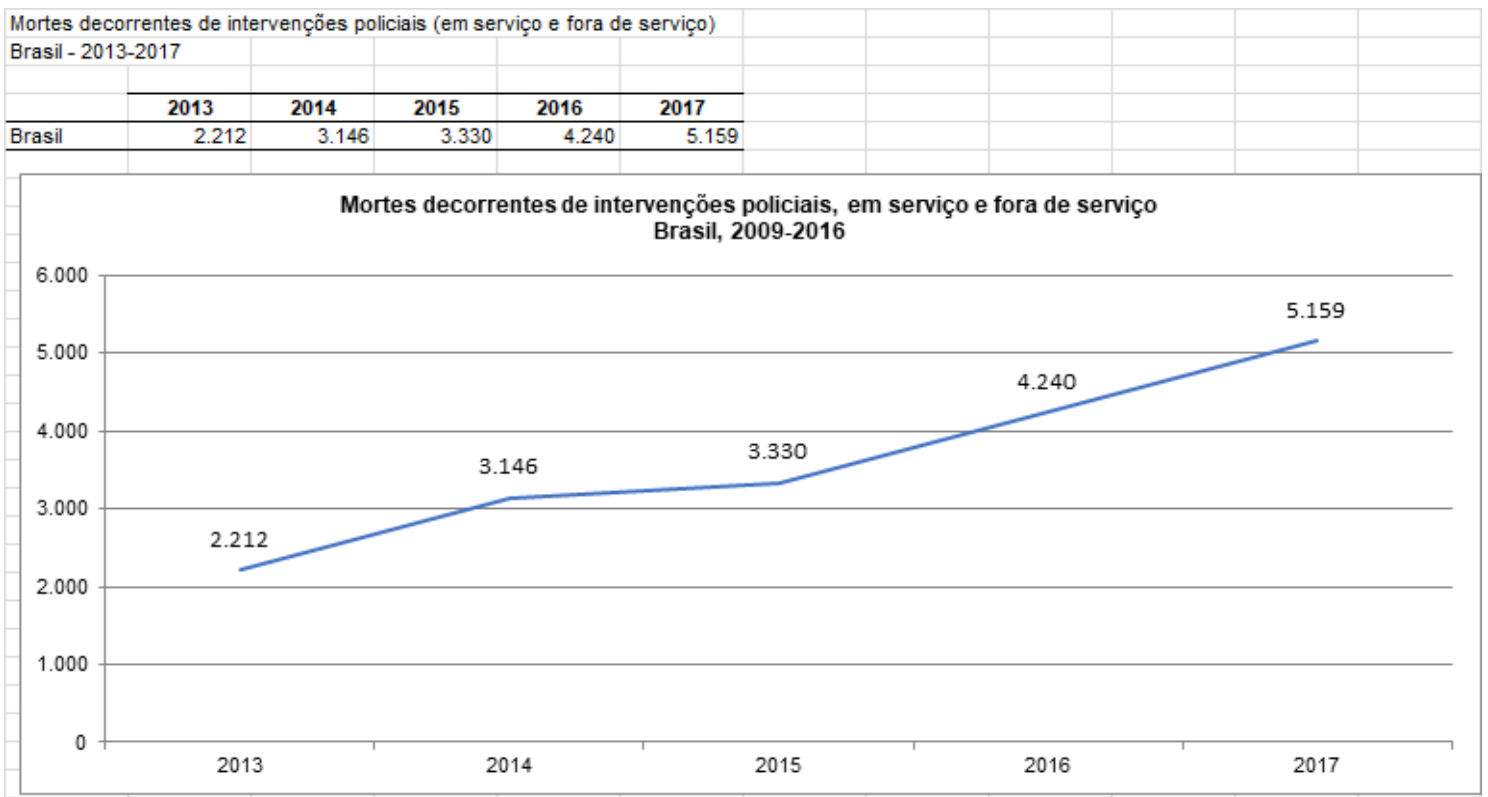

Fonte: Anuário Brasileiro de Segurança Pública; Fórum Brasileiro de Segurança Pública.

De uma forma geral, a violência no país continua, portanto, sendo alimentada pela violência policial e mesmo por índices de crimes como roubos, assaltos, 
arrastões, que permanecem no mesmo patamar ou mesmo crescem ao longo dos últimos anos, mesmo naqueles lugares em que há declínio dos homicídios (FELTRAN, 2018, p. 229). Continua ainda também estruturando os noticiários, estigmatizando favelas e oprimindo os moradores de assentamentos populares (idem).

Todo esse panorama continua impactando o cotidiano da população, bem como sua percepção acerca da segurança pública e a centralidade do tema na agenda política. Pesquisa realizada pela Fundação Perseu Abramo (2015) afirma que $82 \%$ da população acredita que a criminalidade teria aumentado no país nos dois anos anteriores e demonstra que os temas da Violência (como assalto, roubo, furto, tráfico de drogas, etc.) e da Segurança Pública (falta de policiamento, etc.) ocupam respectivamente $02^{\circ}$ e $03^{\circ}$ lugar no ranking dos principais problemas do país segundo a população ${ }^{43}$, perdendo apenas para a Saúde. A Violência é o principal problema para 19,8\% dos entrevistados e a Segurança para 18,1\%. A Habitação, por exemplo, aparece apenas em 12ำ lugar, sendo o principal problema do país apenas para $0,4 \%$ dos entrevistados.

É importante, ainda, destacar como a questão do tráfico de drogas também possui impacto na percepção social sobre a criminalidade. A partir da análise do gráfico abaixo, pode-se perceber que, apesar de não estarem nas faixas mais altas, os crimes envolvendo entorpecentes são os mais recorrentes nas respostas espontâneas dos entrevistados (tráfico de drogas, homicídio devido às drogas, violência devido às drogas, jovens envolvidos com drogas e até mesmo apenas "drogas").

\footnotetext{
${ }^{43}$ Resposta espontânea dos entrevistados em pesquisa realizada em 2015 com 2.400 pessoas em todo o país.
} 


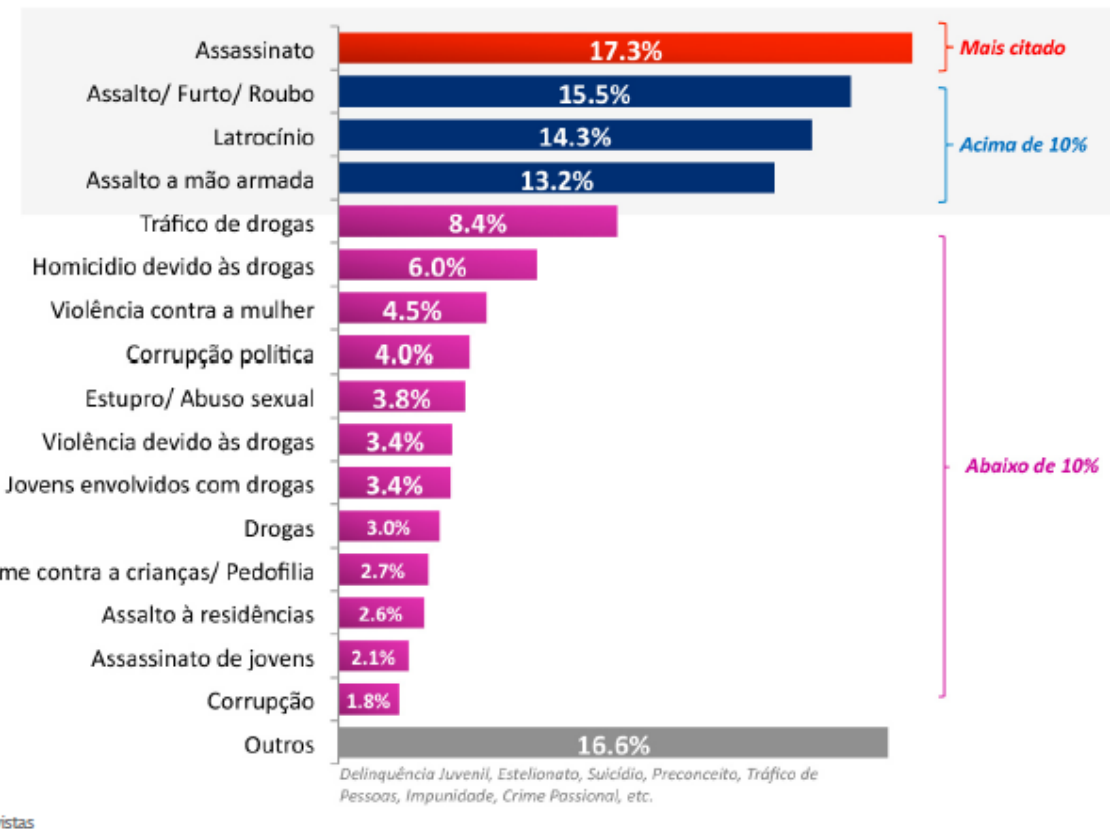

Por fim, as ações indicadas pela população para o enfrentamento da violência por parte do governo (gráfico abaixo) são bem ilustrativas de como esta é percebida, principalmente, como uma questão apenas de segurança pública. Dentre as várias possíveis atuações do estado perante o tema, apenas duas dentre as mais citadas ("criar políticas de apoio a jovens" e "promoção de uma cultura de paz e resolução dos conflitos") teriam relação mais direta com a implementação de outras políticas públicas. 


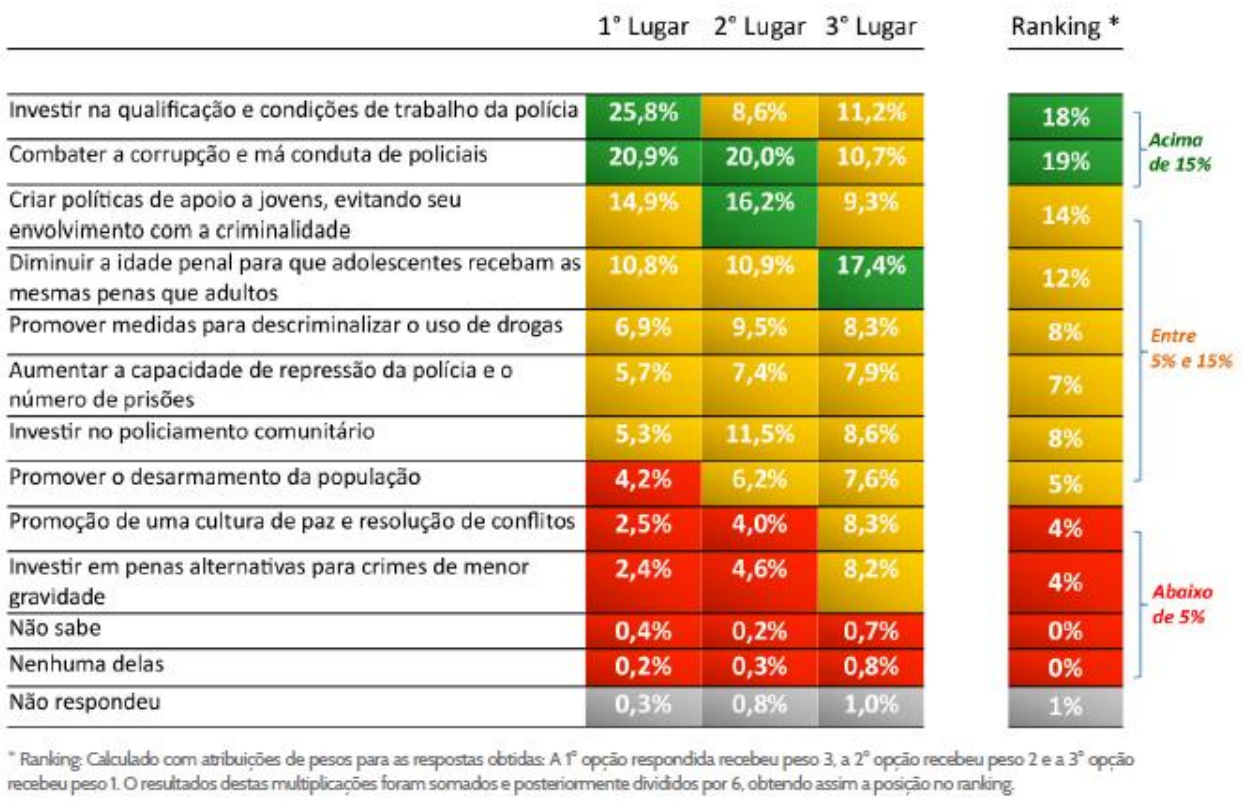

Especificamente no que tange à violência nos estados e capitais de São Paulo e Rio de Janeiro, deve-se ter em mente, primeiramente, que se tratam de casos singulares perante o restante do país. Por serem as duas maiores e mais importantes cidades, Rio e São Paulo dispõem de atenção nacional sob diferentes aspectos, irradiando para os outros estados e cidades tanto exemplos de políticas públicas quanto o imaginário nelas construído sobre a violência e igualmente sobre as favelas.

Os acontecimentos vividos nelas são amplamente noticiados pelos telejornais de alcance nacional, produzidos em geral em uma destas cidades. Se muitos brasileiros têm ciência da existência, por exemplo, do Comando Vermelho ${ }^{44}$ ou

44 Das mais de 80 notícias recentes encontradas no portal G1 (portal de notícias nacional g1.globo.com - consultado em Janeiro de 2019) para a busca por "Comando Vermelho", pelo menos 15 delas falavam exclusivamente sobre alguma situação vivida no Rio de Janeiro ou em sua região metropolitana, além de outras reportagens em que o estado do Rio de Janeiro aparecia citado juntamente com outros estados. 
do $\mathrm{PCC}^{45}$ se deve a notícias veiculadas em relação a estas cidades, apesar de a atuação desses atores se dar em distintas regiões do território brasileiro.

A própria indústria cultural também está fortemente embebida da realidade vivida nelas. Exemplos banais - mas poderosos - sobre esse lugar que ocupam no cenário nacional é o fato de a Rede Globo (principal emissora de televisão do país) já ter exibido telenovelas ambientadas em favelas de ambas cidades, contribuindo assim para a formação de uma imagem pela população brasileira sobre o cotidiano, por exemplo, do Complexo do Alemão e de Paraisópolis ${ }^{46}$. No cinema, filmes como Cidade de Deus (2002) e Tropa de Elite (2007), dentre inúmeros outros, apresentaram para o país e, até mesmo, para o mundo sua perspectiva sobre a questão. Conforme bem observado por Feltran (2018, p. 173), essa indústria também contribui para a própria imagem construída em torno do traficante a partir do Rio de Janeiro - o homem, jovem, negro ou pardo, sem camisa e de bermuda, de boné, cordões de ouro e um fuzil nas mãos - apesar de muitas vezes a realidade seja bem mais diversa do que essa redução mesmo no caso carioca, mas ainda mais em outras cidades, como São Paulo. Isso sem mencionar a redução da vida social das favelas que os retratos fornecidos por essa indústria disseminam para a sociedade, alvo de diversas críticas por parte de seus moradores (BIRMAN, 2008, p. 111).

Como colocado na seção 2.1, Rio de Janeiro e São Paulo são também estados e cidades importantes para a difusão de políticas no país e para o contexto político eleitoral como um todo, sendo talvez os principais centros a partir dos quais são lançadas candidaturas à presidência do país. Não por acaso o Rio de Janeiro foi alvo da intervenção federal decretada em 2018 pelo governo Temer. Embora acima da média nacional, a taxa de Mortes Violentas Intencionais do estado do Rio de Janeiro foi a $12^{\mathrm{a}}$ e a $11^{\mathrm{a}}$ no país inteiro nos anos de 2016 e 2017 (FBSP, 2018), respectivamente com 37,6 e 40,4 mortes para cada

\footnotetext{
${ }^{45}$ Das mais de 60 notícias recentes encontradas no portal G1 (portal de notícias nacional g1.globo.com - consultado em Janeiro de 2019) para a busca por "PCC" de 30 estavam relacionadas a São Paulo e região metropolitana.

${ }^{46}$ Trata-se respectivamente do retrato formado nas telenovelas Salva Jorge (2013) e I love Paraisópolis (2015), além de outras telenovelas que retrataram também favelas fictícias, como Duas Caras (2008) e Lado a Lado (2012), a qual inclusive mostrou o início da formação das favelas no Rio de Janeiro a partir da demolição de cortiços no centro da cidade.
} 
100.000 habitantes, atrás de diversos outros estados como Sergipe, Rio Grande do Norte, Alagoas, Pernambuco, Bahia, Ceará, dentre outros. Ainda em números absolutos, também não se trata do estado com maior número de ocorrências, tendo ficado atrás da Bahia em 2016 e 2017 da mesma forma, por exemplo.

No tocante à cidade do Rio de Janeiro, apesar de, em números absolutos, o número de ocorrências nela tenha sido o maior do país nos anos de 2016 e 2017; a capital ficou em $20^{\circ}$ e $18^{\circ}$ no ranking das capitais brasileiras com maiores taxas de Mortes Violentas intencionais em 2016 e 2017 respectivamente, inclusive abaixo da média nacional nos dois anos. Lembre-se, ainda, que a taxa de homicídios da capital carioca era de 65,79 homicídios para cada 100.000 habitantes em 1997 (ADORNO, 2002, p. 91). Diferentes análises (LEITE \& FARIAS, 2018; ROCHA, 2018) têm apontado estes dados e outros fatos para concluir que se trata de uma decisão baseada mais em critérios políticos - uma tentativa de melhoria da imagem do Governo Federal brasileiro diante dos baixos níveis de aprovação da gestão de Michel Temer - do que efetivamente um enfrentamento à violência vivida pela cidade.

Como afirmado anteriormente, o caso de São Paulo é peculiar no que diz respeito aos indicadores tradicionais para medir a violência. Desde o início dos anos 2000, em que pese algumas oscilações, o nível verificado de homicídios no estado e na capital tem decrescido e se apresentado significativamente abaixo da média nacional. Se em 1997 a taxa de homicídio da cidade era de 56,69 homicídios para cada 100.000 habitantes (ADORNO, 2002, p. 92) e, juntamente com o Rio de Janeiro, eram responsáveis por mais de $21 \%$ de todos os homicídios cometidos no país; em 2016 e 2017, as taxas de Mortes Violentas Intencionais (ou seja, que inclui também as vítimas de latrocínio e lesão corporal seguida de morte) na capital foram respectivamente de 12,0 e 11,1 , as menores taxas verificadas dentre todas as capitais do país (FBSP, 2018).

(...) entre 2001 e 2006, a facção [o PCC] passou a ser cada vez mais comentado nas periferias do estado [de São Paulo]. Negociavam-se ativamente, em cada quebrada, o tabelamento do preço das drogas no varejo, a discrição e o controle estrito do uso de armas, além da presença local dos irmãos, batizados na facção, como zeladores de uma justiça específica. Baseada em debates e deliberações rápidas, os debates do PCC ofertavam uma possibilidade de justiça popular, 
mais eficiente que a estatal, para todas as periferias. Os irmãos se tornavam instância de poder importante nos bairros populares; os moradores admitiram, temeram, consentiram, aprovaram, reagiram. (...) Seja como for, desde que o PCC chegou aos bairros populares, o tráfico de drogas foi instado a desarmar seus vendedores no varejo, o preço da droga foi congelado para evitar concorrência, e deu certo. Não se podia mais matar sem o aval do Comando; as vinganças estavam interditadas. A bandeira branca subiu, estava hasteada em cada favela, em cada conjunto, em cada bairro periférico do estado de São Paulo. A fórmula mágica da paz, cantada pelo rap desde 1997, se fazia mais e mais presente. As taxas de homicídio despencaram bruscamente a partir de 2001 (...) Eram as políticas do crime em ação, instrumentalizando as políticas estatais de segurança para seu crescimento (FELTRAN, 2018, p. 285).

FIGURA 1. Evolução da taxa de mortalidade por causas externas ajustada por idade, São Paulo (SP), Brasil, 1996 a 2008

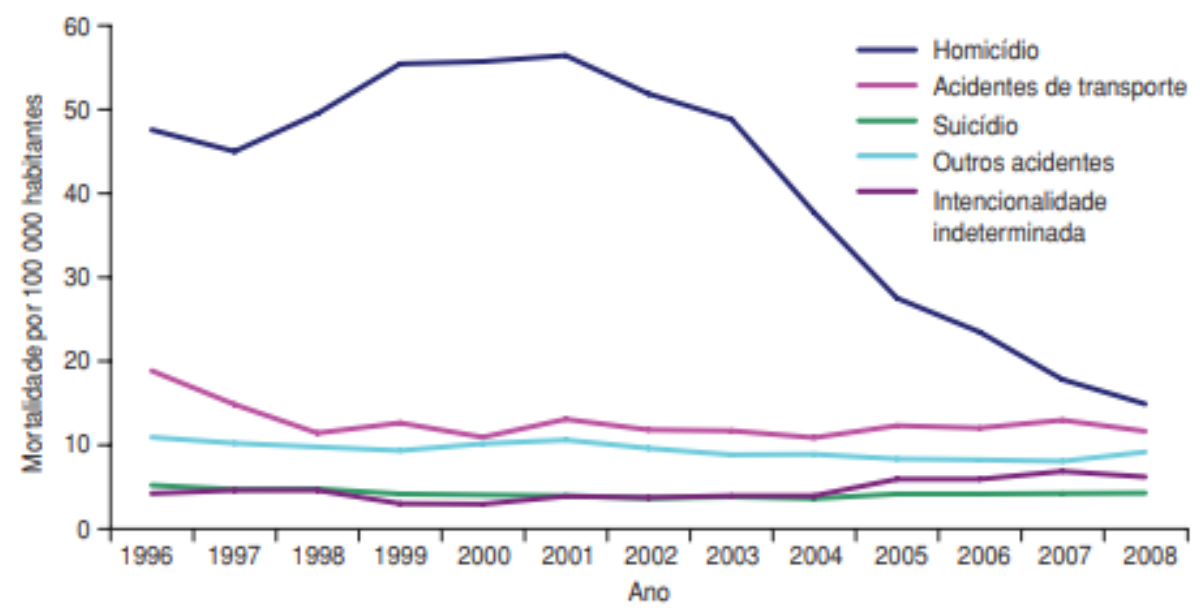

Fonte: Programa de aprimoramento das informaçōes sobre mortalidade (PRO-AlM) da Prefeitura do Municipio de Sáo Paulo.

(PERES ET AL, 2011, p. 20)

Esses dados, contudo, precisam ser avaliados com cautela, principalmente para a perspectiva estudada na presente tese. Do ponto de vista territorial, a descrição da pacificação da periferia de Feltran (2018) reproduzida acima deve ser cotejada com a distribuição dos homicídios no espaço de São Paulo, verificando-se que a violência ainda não ocorre de maneira homogênea, conforme mapa abaixo (NERY ET AL, 2012, p. 409). Verifica-se, portanto, uma maior presença de setores com alta incidência de homicídios em regiões mais periféricas da capital ou que circundam seu centro expandido. 


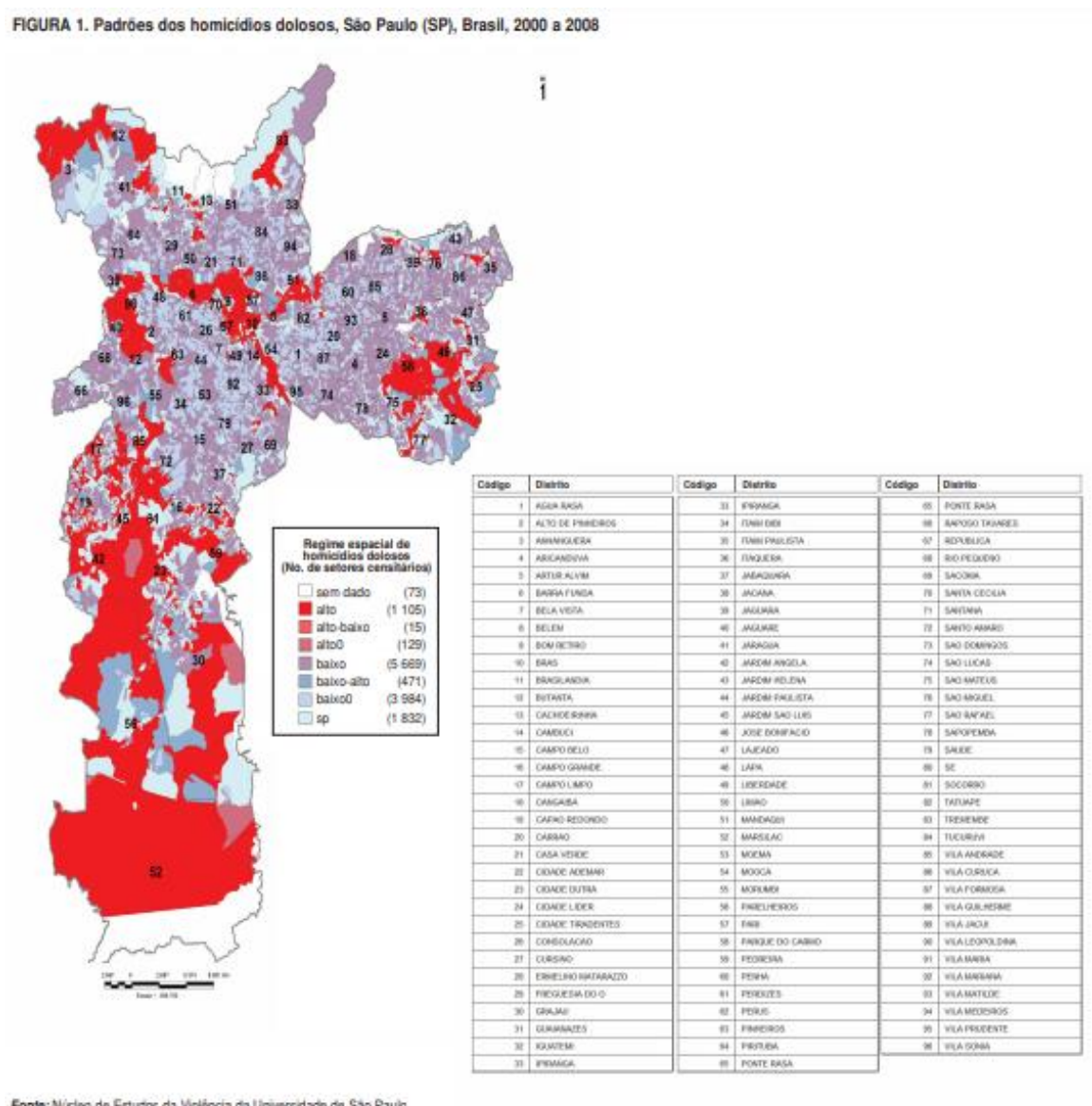

Da mesma forma no Rio de Janeiro, no qual a violência tem um impacto maior sobre os assentamentos populares, principalmente no que tange às favelas. Se os indicadores muitas vezes são melhores que aqueles verificados na década de 1990 e início dos anos 2000 e se não necessariamente se trata da capital ou território mais violento do país, a situação vivida hoje na cidade é ainda preocupante, particularmente nas suas favelas. Pesquisa realizada pelo IPEA (IMANISHI RODRIGUES \& RIVERO, 2012) confirma que ainda se observa uma forte coincidência entre as áreas de favelas e outros tipos de assentamentos precários e as áreas de maior número esperado de vítimas de homicídios no município do Rio de Janeiro, conforme mapa abaixo. 


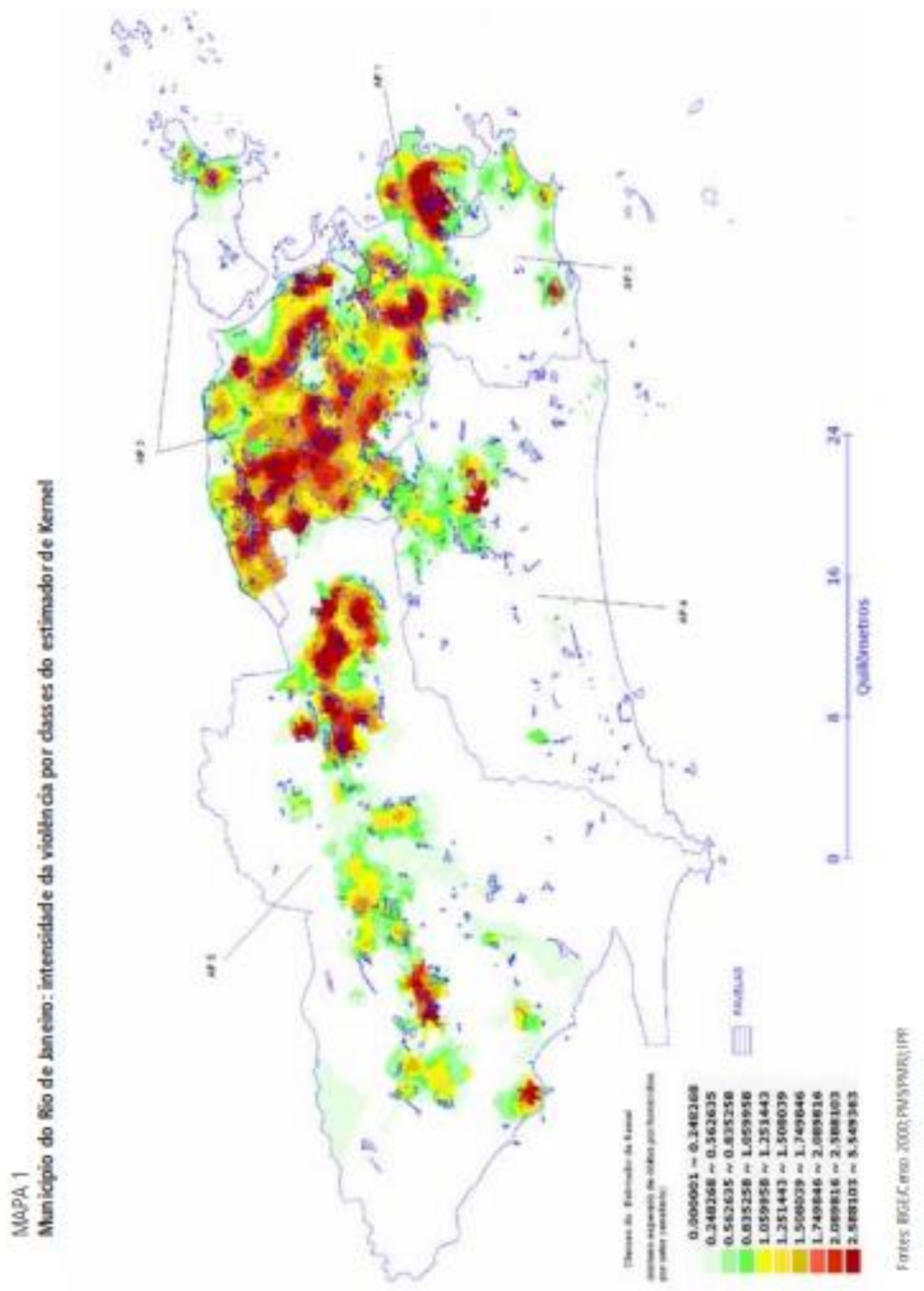

Como no caso relatado acima para Medellín (de recomendação de não fotografar por parte do morador que guiou a visita), a pesquisa de campo de nossa pesquisa propiciou alguns exemplos da situação vivida no Rio de 
Janeiro. Primeiramente, vários dos entrevistados para a pesquisa afirmaram categoricamente que não entram mais nos assentamentos populares com a mesma facilidade ou frequência que antes. Muitos deles, embora tenham se dedicado durante anos ao tema da intervenção em favelas e tenham vivido o cotidiano de vários assentamentos ao longo de sua carreira, acreditam que o contexto hoje não permite mais a mesma circulação que possuíam anteriormente nesses espaços. Os donos dos morros já não são mais os mesmos de antes e a hostilidade é mais intensa do que costumava ser, fazendo com que alguns entrevistados não estejam mais hoje tão envolvidos com a prática da intervenção em campo. Alguns deles, inclusive, chegaram a recomendar extrema cautela ao pesquisador na escolha e forma de entrada nos assentamentos.

Eu não entro hoje em favela. Não vou nem na Rocinha. Na Rocinha eu até tenho como entrar, mas eu falei "Gente, não dá!". Não tenho como entrar numa favela hoje dependendo da situação, porque está muitíssimo complicado, não sei nem com que traficante eu vou conversar (ENTREVISTADO 26).

Não apenas eles, mas diferentes colegas moradores da capital (situados em diferentes campos de atuação: academia, organizações da sociedade civil, fundações, etc.) recomendaram fortemente que não fosse realizado campo nas favelas. Em outra ocasião, a título de exemplo, o motorista de taxi se recusou a entrar na Maré, mesmo que o local da reunião estivesse situado a apenas 200 metros da Avenida Brasil. Por fim, em visita guiada por morador da Providência (ele próprio um guia turístico especializado em turismo nesses assentamentos) a esta favela, recomendou que o ponto de encontro fosse na Central do Brasil, fora do seu território. Após uma conversa inicial, conduziu a visita pela Providência e explicou o motivo pelo qual as ruas do morro estavam mais desertas do que de costume em pleno horário comercial em dia de semana: um policial militar havia sido assassinado ali na semana anterior, então os moradores acreditavam ser apenas questão de dias para ocorrer a retaliação por parte dos policiais, alterando assim profundamente a rotina dos moradores (ENTREVISTADO 27).

Diferentes entrevistados (ENTREVISTADO 04; ENTREVISTADO 21; ENTREVISTADO 26; ENTREVISTADO 03; ENTREVISTADO 18) creditam a situação vivida hoje no Rio principalmente a dois fatores: uma mudança na 
conduta do próprio tráfico em relação à forma de dominação do território e sua relação com moradores e o rearranjo/reterritorialização das forças criminais promovido pelas UPPs. O primeiro fator será tratado a seguir e o segundo, mais à frente ao fim do capítulo.

Como a literatura aponta (MACHADO DA SILVA, 2008; SOUZA, 2010, p. 68), tem sido observada, ao longo do tempo, uma mudança significativa nos modos de atuação dos grupos criminais nas favelas cariocas e até mesmo, mais recentemente, no caso paulistano (FELTRAN, 2018, p. 121). Além de uma progressiva ostensividade no domínio armado sobre os morros e de uma disputa mais acirrada entre facções pelos diferentes territórios do tráfico no Rio de Janeiro, a própria relação entre traficantes e moradores das favelas por eles dominadas teria substancialmente mudado. Isso é possível de ser notado, por exemplo, em diferentes relatos de moradores extensamente documentados por Machado da Silva (2008) e Leite (2008), como exemplificado na fala de moradora reproduzida a seguir.

\begin{abstract}
"Um quer ter o direito do outro. [Os traficantes] não querem saber se tem uma criança no meio da rua, não querem saber se tem um morador na rua, eles querem o quê? Tomar o território do outro. Antigamente era diferente, esperavam cair a noite para poder fazer essas coisas, esperavam. Hoje em dia, o traficante senta na porta da pessoa, se droga na frente da pessoa sem ter aquele respeito. No meu tempo era proibido" (MACHADO DA SILVA, 2008, p. 57).
\end{abstract}

Leite $(2008$, p.127) resume as mudanças apontadas pelos moradores, segundo os quais anteriormente o tráfico de drogas era conduzido nos morros com respeito aos moradores. Conhecida como "Lei do tráfico", as regras impostas eram claras e seguidas por todos e envolviam um menor nível de violência. Hoje, ao contrário, existiria um número maior de imposições, pouco claras e com diversas restrições ao cotidiano dos moradores. Além disso, a fragmentação das facções ao longo dos anos e o acirramente da disputa estre elas estaria dificultando ainda mais o trânsito dos moradores em outras favelas e o estabelecimento de relações com outros moradores.

Igualmente, os entrevistados por nós para essa pesquisa afirmaram mudança significativa nessa atuação e impactos no dia a dia dos moradores. Foram colhidos relatos de crescimento paulatino da agressividade com moradores e com qualquer contrariedade apresentada por esses, um maior descaso com as condições materiais de vida desses moradores e da favela como um todo, 
menor prestação de auxílio ou assistência a eles em casos de necessidade, expulsão de moradores de favelas, assédio, dentre outros (ENTREVISTADO 21; ENTREVISTADO 26; ENTREVISTADO 04; ENTREVISTADO 03).

\begin{abstract}
Alguns códigos de comportamento, típicos do "bandido formado" clássico (respeitar os trabalhadores, suas famílias e seus lares, não usar a força bruta desnecessariamente etc.), estão sendo mais e mais transgredidos pelos criminosos. Isso se deixa explicar, em parte, pela maior distância que existe entre traficantes armados e os demais moradores quando aqueles não são originários da mesma favela onde operam; em parte, tem a ver também com a diminuição da idade média dos traficantes armados (devido à prisão ou morte dos mais velhos), os quais, cada vez mais, são simples adolescentes (SOUZA, 2010, p. 73).
\end{abstract}

Os mesmos fatores foram apontados por moradores entrevistados por Leite (2008, p. 127) para a modulação às práticas violentas em favelas: a existência de uma diferença na forma de atuação entre traficantes "de dentro" ou "crias" do morro e os "de fora da comunidade", esses últimos apresentando na atuação uma maior violência e menor respeito aos moradores. O segundo fator apontado foi, da mesma maneira, a pouca idade ou maturidade dos encarregados do tráfico hoje nas favelas. A mudança seria perceptível até mesmo na crueldade dos crimes cometidos no interior das favelas por esses agentes, os quais são classificados muitas vezes como "bichos loucos" - "sem regras, sem sentimentos, sem respeito aos outros" (LEITE, 2008, p. 127).

Toda essa transformação na atuação dos grupos criminais, há algum tempo já observada por pesquisadores e moradores, impacta a urbanização de favelas em diferentes níveis - desde uma perspectiva mais micro/local (em que essa mudança na atuação do tráfico incidiu na forma como toleram obras de urbanização) até uma esfera macro/nacional (tendo em vista o processo de militarização com consequente predomínio das agendas de segurança sobre a de urbanização no tocante à intervenção pública em favelas).

Do ponto de vista micro/local, desde o começo das intervenções à época da ascensão do tráfico, os grupos criminais estavam atentos ao que se estava propondo, para que não conflitasse com seus interesses. Entrevista com técnica da Prefeitura do Rio, muito ativa na virada dos anos 1980 para os anos 1990, aponta que já naquele período, com a mudança do tráfico do comércio de maconha para o de cocaína, a atuação de traficantes em relação ao trabalho da administração municipal na realização de intervenções em favelas 
já era um fator dificultante (ENTREVISTADO 18). Souza (1994, p. 35) documentava dificuldades (ameaças, pressões, etc.) enfrentadas pelo FavelaBairro ainda no início em função de interesses do tráfico serem afetados justamente pelas transformações pretendidas pelo programa (alargamento de vias, etc.).

Em Medellín igualmente eram observadas dificuldades diante da nova postura de disputa do Estado em face das organizações criminais a partir de ações de mejoramiento nos anos 1990. Conforme relatos, a própria experiência do PRIMED observou uma dificuldade de implementação dos projetos em função da presença e controle exercido por diferentes grupos criminais nos assentamentos alvo de intervenção (ALCALDIA DE MEDELLín, 1996, p. 93), os quais impuseram diversos obstáculos - através de ações violentas - à realização de obras e atividades.

Em São Paulo, também havia alguns relatos de resistência à realização de iniciativas de urbanização. Estas encontravam na violência instalada no território uma gramática com a qual necessitavam dialogar, tendo em vista que podiam gerar grandes dificuldades e até mesmo inviabilizar certas intervenções. "As comunidades, pressionadas pelos traficantes, solicitam que sejam usadas grelhas de drenagem móveis, pois, se retiradas, impedem o acesso de carros às ruelas. Lixeiros são impedidos de levar restos de aparelhos domésticos - geladeiras, fogões, etc. - pois estes funcionam como barricadas quando espalhados pelos marginais" (BUENO, 2000, p. 293).

No caso do Rio e de São Paulo, no entanto, as ações do tráfico não buscavam bloquear a realização de melhorias, entendendo que estas eram necessárias para a própria população com que, de alguma forma, estavam envolvidos e conectados.

Alguém perguntou pro Toledo [na segunda metade da década de 2000],
provavelmente era alguém de fora do Rio que levantou uma questão como era
trabalhar no Rio, nos territórios dominados pelo tráfico ou pela milícia. Aí foi uma
resposta sincera do Toledo, "É igual a qualquer lugar: você chega, na primeira
reunião, na primeira assembleia que você faz, você vai ver lá no fundo uns 3 ou 4
caras, na hora você já vai identificar quem é o tráfico. Aí você começa a fazer a
reunião e você vai perceber que eles vão concordar com tudo, não vão discordar
de nada. Eles vão voltar em outra reunião, uma hora ou outra eles vão colocar
alguma coisa, mas você está trabalhando numa realidade que precisa de uma
intervenção, o tráfico não vai se opor a isso. Talvez num dia numa frente de obra 
eles falem "Não vai ter obra e tal", mas é igual à chuva". Foi a fala dele. Tem território que é tão precário que uma hora o poder paralelo abre mão do domínio que de fato exerce ali, porque aquilo ali é em prol da população (ENTREVISTADO 28).

Mesmo as eventuais objeções que iam aparecendo, foram sendo negociadas pelas equipes técnicas muitas vezes, sendo esse um relato frequente tanto para o caso do Rio de Janeiro quanto de São Paulo.

A gente foi diariamente, era um dia no Cantagalo e um dia no Pavãozinho. A gente pegou as duas favelas ao mesmo tempo, é um complexo, fazendo isso de negociar com traficante para a gente conseguir entrar, é aquela coisa toda que a gente conhece (...) a gente teve que negociar também com o Nem, na época, que era o traficante da Rocinha. $O$ Toledo negociou com ele para a gente conseguir fazer e ainda montou um escritório de campo, que foi o grande sucesso do negócio, equipes mistas, pessoas de lá, de campo, com pessoas da Rocinha e pessoas do escritório, treinou todo mundo junto $e$ foi feito com ele (ENTREVISTADO 26).

$\mathrm{Na}$ época não tinha UPP, quem mandava na favela era o Nem, então não tinha discussão. Nunca tive problema. Como na equipe de levantamento sempre tive 1 ou 2 pessoas da própria Rocinha, nunca nos impediram de andar pela Rocinha. Nós encontrávamos os soldados do tráfico, mas nunca houve problema, e a gente passava por áreas de pico, bocas de fumo e nunca teve problema. Não deixavam fotografar eles, isso não deixavam. Agora, nunca fomos impedidos de andar lá. Hoje seria impossível, com a guerra que está dentro, é impossível. (ENTREVISTADO 03).

No entanto, a mudança na forma de atuação do tráfico, constatada por diferentes pesquisas e interlocutores (ENTREVISTADO 04; ENTREVISTADO 26; ENTREVISTADO 03; ENTREVISTADO 12; ENTREVISTADO 28), demonstram como já há alguns anos o tráfico tem dificultado ou até mesmo impedido a realização de ações de urbanização de favelas. Para entrevistado que esteve à frente de equipes em diferentes fases do Favela-Bairro/PROAP, essa situação foi piorando ao longo dos anos, a ponto de em determinados contratos ter sido obrigado a informar à Prefeitura da necessidade de ajustes contratuais e produtos acordados para não colocar as vidas das equipes em risco. Passam então a tentar fazer levantamentos iniciais com fotos de helicóptero, informações formais, etc., com o mínimo de campo possível, até um ponto que praticamente se tornou inviável em função principalmente do recrudescimento da disputa de territórios entre as facções (ENTREVISTADO 04).

Durante muito tempo os grupos que estavam à frente, o tráfico e tal, eles toleraram o processo. $O$ problema é que quando se tem um conflito, ninguém predomina, tudo gera pânico entre eles, inclusive, então um grupo estranho. Obviamente ele gera insegurança e ele está totalmente vulnerável no território, assim como a população hoje. Ela fica totalmente vulnerável, mas não na mão só 
do tráfico, na mão dos policiais, enfim, mesmo nas comunidades pacificadas, as comunidades pacificadas geram um inferno para as comunidades, principalmente quando tem algum conflito, e um conflito é gerado por que? Em geral porque o acordo, o acordo definido entre os policiais e os traficantes não está sendo respeitado por algum dos dois. $O$ arrego é menor do que se imaginava, ou "Precisei passar com uma carga ali e vocês não deixaram e eu pago o arrego em dia, vocês não passaram". Esse tipo de contradição, o maluco do submundo, ele aflora em altíssima violência, quem sofre é fundamentalmente a população, e claro, os profissionais que atuam nesses territórios enfrentam isso como uma restrição (ENTREVISTADO 04).

O caso da disputa entre diferentes facções como fator praticamente impeditivo para realização de intervenções no território é também mencionado por outra entrevistada quando exemplificando a complexidade da Maré. Diferentemente da Rocinha, cuja topografia apresentava grandes desafios para a consolidação de uma nova estrutura viária e de mobilidade, a Maré apresentaria a facilidade de ser plana e com uma configuração territorial que permitiria o redesenho de suas vias. O fato de historicamente ser dividida por três facções rivais (ao contrário da Rocinha, que em geral é toda dominada por um único grupo) teria tornado muito mais difícil qualquer intervenção na área, tendo em vista ser praticamente impossível alcançar uma nova configuração viária e de mobilidade que agrade a todos os interesses e seja consensuada entre os três grupos rivais (ENTREVISTADO 26).

Além de dificuldades ou conflitos impostos pelo tráfico ao diagnóstico, planejamento e implementação das iniciativas de urbanização, os grupos criminais também incidem na gestão do espaço no pós-intervenção, impactando sua efetividade. Em Medellín, foi observado que, mesmo depois da implantação de infraestrutura, construção de equipamento, abertura de espaços públicos etc., ainda existia como desafio a questão da gestão e utilização destas melhorias em face da dominação do território por esses grupos, que muitas vezes impedem ou dominam sua utilização (ENTREVISTADO 05). Como relatado também para São Paulo por entrevistado, "Outra coisa que o tráfico promove é a degradação dos espaços públicos, porque eles meio que... aparece gente lá precisando de moradia e eles, "ocupa aí, ocupa aqui". Eles têm um controle assim miudinho das áreas onde tem um cantinho sobrando" (ENTREVISTADO 12). Da mesma forma no Rio (LEEDS, 2006, p. 240), onde exercem um grande controle sobre a vida social e o uso dos espaços públicos, restringindo também a realização de 
atividades por parte dos moradores em determinadas regiões da favela mesmo após as intervenções (ALVITO, 2006, p. 190).

(...) essa disputa armada coloca limites importantes às possibilidades de integração, o Favela Bairro é um exemplo muito claro de certas coisas. Se eu for a Vigário Geral nos anos 2000, por exemplo, você terá com todas as limitações um ganho grande de infraestrutura urbana, são áreas em boa medida passaram por processos de pavimentação, tem um saneamento que existe, tem abastecimento de água, você tem o pacote básico de infraestrutura e de serviços urbanos colocados, alguma presença de serviços sociais e etc. Mas a hipotese de que aquilo teria um condão de desfazer a apartação, é tremendamente minada pelas fronteiras armadas. Eu tenho acesso a Vigário cruzando a linha do trem, mas ninguém usa aquela via de acesso. Foi um bloqueio da via de acesso, alguém botou ali ou alguém jogou uma mesinha de jogar dominó ou baralho, ou uma barricada mesmo e põe lá pessoas armadas. Então eu não vou ganhar acessibilidade com essa limitação, e assim com $\mathbf{N}$ outros aspectos do dia a dia (ENTREVISTADO 13).

Outras evidências de como ações de urbanização de favelas muitas vezes conflitam com a necessidade de controle territorial pelo tráfico são casos relatados por entrevistados em São Paulo, nos quais houve fortes tensionamentos em projetos que ensejavam reassentamento de famílias em novas unidades habitacionais produzidas no escopo da iniciativa (ENTREVISTADO 12; ENTREVISTADO 14; ENTREVISTADO 28). No momento em que unidades construídas no âmbito da intervenção em Heliópolis, São Paulo, começaram a ficar prontas no início dos anos 2000, por exemplo, o tráfico sequestrou duas assistentes sociais da Secretaria Municipal de Habitação ${ }^{47}$. Sua condição para libertação era a destinação de unidades habitacionais inauguradas naquele conjunto em específico, não aceitando outra localidade (ENTREVISTADO 14). Na segunda metade da década de 2000, também teria havido conflito por unidades no caso da intervenção em Paraisópolis (ENTREVISTADO 12) e, já em 2016, o tráfico invadiu o canteiro

\footnotetext{
47 Um ponto colocado por diferentes entrevistados (ENTREVISTADO 12; ENTREVISTA LUÍS FIOCRUZ, 2017; ENTREVISTADO 14; ENTREVISTADO 17) foi relacionado à segurança da equipe do poder público no território. Tanto o tensionamento gerado pelas obras de urbanização quanto principalmente os próprios conflitos inerentes à atividade criminal (como disputas por território entre as diferentes facções, conflitos com a polícia, etc.) tornam complexa a atuação em favelas, tendo em vista que a violência pode atingir os profissionais situados em campo e, do ponto de vista da gestão do projeto, se anda numa linha tênue entre os diferentes mandos que se sobrepõem na área. Nesse sentid, um dos exemplos citados é a importância de nunca deixar que a equipe técnica da urbanização seja associado com a repressão policial. "Se tem uma equipe técnica trabalhando e tiver a informação de que a polícia está chegando na área, a equipe técnica tem que sair, porque nunca a gente pode associar a equipe técnica com o trabalho da polícia de repressão ao tráfico, senão você queima a equipe, a equipe não entra mais na área. Ultimamente a negociação com o tráfico está sendo difícil..." (ENTREVISTADO 12).
} 
de obras na intervenção da Real Parque várias vezes para impedir que a obra continuasse, porque exigiam que a Prefeitura atendesse 80 famílias indicadas por eles no assentamento.

Claramente, propostas de intervenções espaciais (seja de melhorias ou de provisão de novas unidades em favelas) mexem com os interesses de traficantes em função de a própria atividade que exercem ser fortamente dependente de fatores de localização e condições de mobilidade. $O$ alerta feito anteriormente na presente tese (a questionabilidade do aparente consenso sobre a morfologia das favelas favorecer o comércio de drogas) não significa de forma alguma que se possa desconsiderar a dimensão espacial da atividade (dimensão esta presente tanto quando a atividade é exercida na favela quanto quando é realizada no restante da cidade). Não apenas é impossível ignorar, como é imprescindível considerar que o rearranjo territorial promovido por urbanizações pode vir a impactar nos lucros de suas atividades, na logística de armazenamento e distribuição, na estratégia de defesa contra outros grupos e contra o Estado, não sendo estranho - dado o contexto de acirramento das disputas nos últimos tempos - que progressivamente esses grupos estejam mais e mais resistindo a tais iniciativas.

Deve-se apontar, contudo, que não se trata unicamente da ameaça ao domínio territorial exercido por esses grupos que está em jogo em urbanizações de favela. Embora não seja estritamente ligado às cidades estudadas na pesquisa, é interessante trazer à tona aqui a entrevista realizada com pesquisadora sobre o tempo em que atuou como gestora responsável pela realização de ações de urbanização de favelas no ABC paulista, ilustrativo de outra faceta dos conflitos vividos entre essa ação e o tráfico de drogas. Considerado nacionalmente como uma experiência interessante justamente pela integração de políticas sociais a intervenções físicas, o depoimento fornece indícios de que, sob algumas circunstâncias, a urbanização pode ser ameaçadora não apenas do ponto de vista do domínio territorial do tráfico, mas também sob a perspectiva do domínio social e político que exerce.

(...) no âmbito do Santo André Mais Igual, isso era uma preocupação, a violência e tudo o mais. Então você tinha, junto com a urbanização, diversos programas sociais. Em geral o que eu percebia era que a obra de infraestrutura não era empecilho, ou seja, de alguma forma, apesar de conectar melhor a favela ao 
bairro, a obra de infraestrutura em geral é bem vinda (...) Agora, na hora que entrava a mobilização e o programa social, aí tinha uma disputa, tinha uma disputa... Eu lembro que a gente tinha vários programas voltados para a criança. $\mathrm{Na}$ época, por exemplo, não tinha ainda o Bolsa-Família, então a gente tinha a complementação de renda. 0 município pôs dinheiro pra ampliar o programa de complementação de renda, condicionando a criança estar na escola e participar de programas da educação, era assim, uma disputa com os jovens, seria participar da venda lá da droga ou... Nesse sentido, os programas sociais ficavam ali disputando as crianças, você tem uma complementação de renda da família (...) mais problemático era o desenvolvimento dos programas sociais, que foram desenvolvidos, mas sempre tinha uma certa tensão (ENTREVISTADO 17).

Pode-se ver pelo depoimento que, em alguns momentos, mais conflitivo seriam os programas sociais atrelados à urbanização do que propriamente a intervenção física. Se a iniciativa implementada em Santo André é destacada pelo fato de ter tentado promover uma ação integrada entre intervenção física e programas sociais, como uma "urbanização de favelas integral" (DENALDI, 2013a); essa perspectiva de urbanização pode ser dificultada, como no exemplo apresentado, precisamente pelo fato de as políticas sociais disputarem, de alguma forma, a base de apoio e sustentação do tráfico atualmente, a juventude.

Souza (1994, p. 35) já previa essa possibilidade quando dissertava sobre como os interesses do tráfico passariam cada vez mais a conflitar e, com isso, bloquear o desenvolvimento sócio-espacial de favelas no Rio de Janeiro. Naquele momento ainda de ascensão de programas de urbanização de favelas, o autor já vaticinava que, ao propiciar condições melhores de vida para a população, esses programas poderiam não ser bem aceitos pelos traficantes, os quais utilizavam justamente a pobreza dos moradores como fonte de poder social e político. A redução da dependência paternalista entre moradores e traficantes e até mesmo o aumento da autoestima e perspectivas de futuro por parte daqueles seriam perigosos, portanto não seriam tolerados. O autor (1994, p. 37) vai mais longe ainda e problematiza o impacto disso na própria capacidade de atuação política dos moradores, como se vê a seguir.

A dominação localmente exercida pelos traficantes de favelas possui consequências sérias em termos de bloqueio do desenvolvimento sócioespacial. (...) a tutela asfixiante imposta pelos traficantes aos moradores das favelas é, nitifdamente, um fator enormemente inibidor e negativo. As dificuldades postas a programas de urbanização são um aspecto importante nesse contexto, mas vários outros, mais cotidianos, como a castração da liberdade dos moradores e, especialmente, o encolhimento ou a supressão do espaço político das associações de moradores, são elementos de um processo 
de transformação das condições de vida das favelas do Rio de Janeiro (SOUZA, 1994, p. 37).

Saindo um pouco das dificuldades impostas pelo tráfico em iniciativas específicas no plano micro/local como vinha sendo feito, é preciso, portanto, destacar que a forma como o tráfico se imiscui ao longo das últimas décadas nas associações de moradores acrescenta um novo obstáculo à consolidação da pauta da urbanização, tema muito presente tanto na literatura quanto nas entrevistas realizadas, especialmente no caso do Rio de Janeiro (ENTREVISTADO 03; ENTREVISTADO 18; ENTREVISTADO 04; ENTREVISTADO 09).

\subsection{A violência silencia a política}

Dentre as várias formas de opressão e controle impostos por grupos criminais sobre o cotidiano de moradores de favela, talvez um dos mais perversos seja o "silenciamento" (SILVA E ROCHA, 2008, p. 38 in CANO, 2008) e, consequentemente, a restrição às possibilidades de uma verdadeira e efetiva articulação política. Utiliza-se aqui a ideia de "silenciamento" amplamente empregado por grupo de pesquisadores liderados por Machado da Silva (2008), o qual enfocou a lei do silêncio que impedia os moradores de favela de verbalizar a violência cotidiana imposta pelos grupos traficantes. Esse processo de silenciamento se revelou ao longo da pesquisa, no entanto, muito mais complexo, tendo em vista que era promovido não apenas pelo medo de retaliação por parte dos traficantes, mas também pela criminalização dos moradores e de suas organizações por parte do poder público quando apresentavam suas demandas e denúncias, como será visto à frente (ROCHA, 2018, p. 228).

Sob distintos enfoques e com perspectivas por vezes significativamente diversas (como acerca do grau de autonomia e/ou de participação direta do tráfico nas associações), estes e outros autores registram as tensões existentes há décadas entre associações de moradores e traficantes. Zaluar 
(2006), por exemplo, afirma que foi ainda nos idos dos anos 1980, mais precisamente na segunda metade da década, que os traficantes teriam entrado nas disputas pelas associações de moradores como forma de aumentar seu controle sobre o território e poder, assim, realizar suas atividades com maior segurança (ZALUAR, 2006, p. 212). Inúmeras lideranças que começam a contestar esse movimento desaparecem, são assassinadas ou expulsas a partir da década de 1980 (ZALUAR, 2006, p. 218; ROCHA, 2018, p. 481), assim torna-se prática que estas lideranças silenciem em torno das atividades do tráfico (ZALUAR, 2006, p. 215).

Silva e Rocha (2008, p. 40, in CANO, 2008) demonstram como esse silêncio é difícil de ser rompido mesmo em ambientes de confiança e entre as próprias lideranças. Ao realizarem grupos focais com lideranças de favelas para pesquisa que buscava entender o impacto do tráfico sobre seu trabalho à frente de associações e outras organizações comunitárias, os autores notaram uma grande dificuldade em abordar o tema junto a elas. Se com outros participantes (moradores em geral, não ligados a organizações) o tema fluía relativamente com facilidade, no momento dos debates com dirigentes das organizações foram constatadas diversas estratégias discursivas tanto para desviar 0 assunto, como para evitá-lo ou até mesmo para relativizá-lo. Poucos teriam sido os dirigentes que de fato abordaram os problemas vividos por eles, enquanto lideranças, em face do tráfico, fornecendo ainda muitos desses relatos apenas de forma genérica, sem dar concretude às ocorrências.

(...) De vez em quando, você tem que dar satisfações pra pessoas que não tem nada a ver com o trabalho. Você tem uma linha de trabalho, alguém quer te puxar, sabe? Infelizmente... Infelizmente você é presidente, você não é dono da comunidade. (...) $O$ dono da comunidade é o tráfico. Não tem como fugir disso, se alguém falar que é diferente, não é. Porque não é mesmo. (Depoimento de liderança comunitária em SILVA E ROCHA, 2008, p. 41, in CANO, 2008).

Embora sejam relatadas situações de enfrentamento por parte das lideranças e essas busquem constantemente relativizar o poder dos grupos criminais sobre eles numa tentativa de minimizar o comprometimento das associações (SILVA \& ROCHA, 2008, p. 45, in CANO, 2008), o registro geral parece apontar para sua submissão diante do tráfico. Como Souza (1994, p. 35) coloca, trata-se de uma ausência de alternativas diante de um poder que pode, na melhor das hipóteses, destituir a liderança do cargo na associação caso seja contrariado, 
havendo relatos ainda de expulsão e assassinatos de lideranças pelos grupos criminais (SILVA E ROCHA, 2008, p. 40; SOUZA, 1994, p. 35 e 43). Assim, as lideranças buscam, como fizeram mesmo no período ditatorial (ROCHA, 2018, p. 227), de alguma forma preservar uma margem de manobra diante do tráfico - vide relatos em Silva e Rocha (2008) - mas são forçados a reconhecer o tráfico como a real instância decisória na prática, significando a necessidade de notificar ou pedir autorização para realização de atividades, a cessão do espaço da associação como apoio logístico, a obrigação de aceitar financiamento de atividades pelos traficantes e, até mesmo, defender por vezes seus interesses em fóruns públicos (SOUZA, 1994, p. 35; SILVA \& ROCHA, 2008, p. 42).

Morador entrevistado para esta tese (ENTREVISTADO 27) confirma essa perspectiva ao avaliar que, dentre os favelados, não se confia mais nas associações e lideranças como atores interessados na promoção da melhoria das condições de vida do assentamento. Para eles, elas estariam hoje principalmente a serviço do tráfico, o qual inclusive o dominaria as eleições realizadas nas associações.

Outras variáveis certamente também incidiram sobre o declínio da mobilização em torno das associações de moradores ${ }^{48}$, mas resta clara a relevância da influência do tráfico para tanto, afetando diretamente, assim, a pauta da urbanização de favelas. Primeiramente porque muitas das negociações e mediações necessárias para a implementação de iniciativas de urbanização de favelas são feitas justamente através das associações, desde o Favela-Bairro até as obras realizadas no âmbito do PAC (CAVALCANTI, 2013, p. 219).

\footnotetext{
${ }^{48}$ A respeito do tema, vale a pena conferir a síntese feita por Rocha (2018, p. 479 e segs.) sobre como a dinâmica do movimento associativo de favelas variou ao longo das décadas no Brasil, de acordo com as conjunturas políticas locais e nacionais. Utilizando a proposta de "controle negociado" de Machado da Silva (2002), a autora demonstra como, desde sua origem na década de 1940, as associações passam por períodos de maior e menor autonomia, articulação, representatividade e capacidade de incidência política, tendo sido verificado um constante declínio nas últimas décadas. Importante também o trabalho de Souza (2010, p. 145169) que elenca outros fatores responsáveis por esse declínio das associações além do impacto dos grupos criminais armados, dentre eles: cooptação de líderes e de organizações, influência partidária sobre associações, burocratização das organizações de bairro (no sentido de passarem a funcionar na lógica da burocracia pública), desapontamento com administrações municipais e fadiga da base social das associações, personalismo, clientelismo, dentre outros.
} 
A mediação com os traficantes feita pelas associações é requisitada por todos os agentes externos que pretendem entrar nas favelas, desde ongs, pesquisadores e até o próprio poder público. Esses agentes, desde os anos 1990, vêm realizando atividades dentro das favelas que dependem desse contato, e fazer essa mediação se tornou umas das principais tarefas dos dirigentes de associações de moradores. $O$ formato das políticas públicas executadas em favelas - como, por exemplo, o Projeto Favela-Bairro - acontecem através das associações de moradores, e são muitas vezes por elas executadas, exatamente porque dependem dessas negociações. (SILVA \& ROCHA, 2008, p. 45, in CANO, 2008).

Tem-se assim um ator - as associações - que se tornam responsáveis pela negociação e, por vezes, implementação de ações ligadas à urbanização e que estão submetidos pessoalmente aos desígnios do tráfico, sob ameaças à vida e integridade física dos seus dirigentes (ROCHA, 2018, p. 481). Não se pode considerar, portanto, que esses atores disponham de uma verdadeira autonomia para que exerçam a representação política dos interesses dos moradores nas iniciativas de urbanização de favelas, tendo em vista que estariam submetidos a uma ordem que os impede de problematizar determinados assuntos (FREIRE, 2008, p. 172), como também afirma entrevista envolvido com políticas de segurança no Rio.

(...) na organização comunitária local, eu vou pensar duas vezes antes de decidir o que eu falo e o que eu não digo, o que eu proponho ou o que eu não proponho, porque de fato eu estou intimidado com o Leviatã armado, criminoso, que colocará limites à minha liberdade de expressão e de associação. Se eu sou uma organização da sociedade civil, eu certamente negociarei de forma direta ou tácita, ou indireta, imediata, a minha presença naquele território e o mesmo vale em várias dimensões do Poder Público (ENTREVISTADO 13)

Morador de favela e pesquisador entrevistado para a pesquisa questiona, diante disso, justamente a representatividade das associações em função desse contexto.

(...) o movimento associativo nas favelas hoje, ele não é mais o movimento associativo dos anos $\mathbf{7 0}$, dos anos $\mathbf{8 0}$. O movimento associativo nas favelas hoje é muito dominado por, ou determinados grupos foram cooptados pelo poder público ou estão sob o julgo dos grupos civis armados, então o movimento associativo hoje não é mais representativo das favelas (ENTREVISTADO 30).

Se por um lado eles já se encontravam limitados por seus interesses individuais (nomeação para cargos, obtenção de recursos, etc.) e pelas conexões estabelecidas por eles com a classe política (citado pelo entrevistado); por outro, também tem sua atuação limitada porque sua própria vida também está em jogo, como lembra gestora pública entrevistada para essa tese. 
Mas com a cocaína e o crack mudou o Rio totalmente. A gente entrava em qualquer favela da cidade, todo mundo conhecia. A gente ligava pro presidente e falava "Estamos subindo no não sei onde", aí ele falava "Não tem problema". Quando entrou o crack e a cocaína, dificílimo de você ter uma independência, inclusive em relação aos próprios moradores e as lideranças. As lideranças começaram a ser comandadas por esses caras, e não tinha outro jeito deles não serem assim. Como é que você vai enfrentar um cara que vende cocaína e tem lá uma porrada de armas? Não tem como, não tem como. Eu nem sei porque eu não fui assassinada, porque eu reagi muito. Muito presidente de associação de moradores desapareceu, outros tiveram que trocar de comunidade, muito, muito. $O$ presidente da associação, ele tem que normalmente prestar contas ao chefe do morro, os chefes do morro. E eles sempre ficam numa situação super frágil, porque os caras ameaçam a família, eles querem esconder armas na associação, eles querem... (...) Então fica muito difícil o cara ter uma opinião, ir de encontro com os bandidos, é muito difícil. Você não escuta mais uma liderança de associação de moradores que seja importante. Você não escuta, você não sabe mais. Antigamente você abria o jornal, estava acontecendo alguma coisa, sempre tinha o presidente da associação de moradores da comunidade tal falou isso, isso e isso. Não existem mais essas pessoas. (ENTREVISTADO 18).

que se verifica diante desse controle ou influência exercida pelo tráfico, portanto, é uma asfixia das associações (MACHADO DA SILVA, 2008, p. 18; SOUZA, 1994, p. 34), as quais passam progressivamente a perder sua base social e legitimidade (LEITE, 2008, p. 119). Passam a progressivamente testemunhar o descrédito por parte dos próprios moradores, tendo em vista sua dificuldade em organizar ações de mobilização comunitária, de incidência coletiva e de defesa dos interesses dos moradores na esfera pública (LEITE, 2008, p. 119).

É gerada, inclusive, uma dificuldade que está além do nível de incidência individual de cada associação, dificultando mesmo o fortalecimento de uma frente ampla de associações, como já aconteceu em outros períodos, a exemplo da FAFERJ, conforme lembrado por dois entrevistados de diferentes campos de atuação.

Esse nível de violência que tem sido observado nas comunidades de uma forma geral - ocupadas ou não ocupadas por UPPs, tendo milícia ou não tendo milícia, tendo tráfico, etc, - gerou uma desmobilização da organização de moradores. Você sabe tão bem quanto eu que as associações de moradores foram cooptadas completamente, não é de hoje, tem muito tempo. Tem muito tempo, 20,25 anos, que os caras já são completamente cooptados, era raríssimo você perceber uma associação de moradores que não fosse cooptado. Mas eu estou entendendo que você está trabalhando num outro nível, num outro patamar. No patamar da organização de representantes de favela junto a determinados movimentos, FAFERJ, etc e tal, são movimentos enfraquecidos exatamente porque você não tem mais uma representação forte, porque esses caras são os caras que são pressionados por esses grupos de poder (ENTREVISTADO 04).

Mas, assim, o movimento associativo em si, a Faferj perdeu muito do seu poder. Nos anos 70 ela era muito forte, mas a Faferj hoje perdeu muito o seu poder. A Pastoral de Favelas exerceu o seu processo, mas também perdeu muito o seu 
poder, agora dos anos 2000 pra cá. E eu não sei, eu não consigo identificar assim um grupo, um ou outro coletivo que discute a questão do direito a cidade, que pode existir, sobretudo, nas grandes favelas, mas não tem uma incidencia política assim que eu consiga enxergar assim como movimento político (ENTREVISTADO 30).

Não bastasse o tecido associativo de moradores de favelas e articulação entre lideranças de diferentes assentamentos para a organização de frentes ou movimentos de favelados ser dificultada por essa contiguidade com o tráfico; 0 poder público ainda a utiliza para a desqualificação de diversas de suas demandas, dentre elas aquelas ligadas à urbanização. Ainda dentro do processo de silenciamento mencionado anteriormente, tanto o estado quanto a mídia passam a classificar qualquer iniciativa dessas organizações (atos e manifestações) como "comandados pelo tráfico" (MACHADO DA SILVA \& LEITE, 2008, p. 59). Rocha (2018) demonstra como se perpetua a criminalização e a deslegitimação de lideranças (adjetivadas como "envolvidas") como forma de cerceamento político e, até mesmo, se intensifica na última década no contexto das UPPs no Rio de Janeiro.

Um exemplo citado pela autora foi a grande repercussão de informações falsas compartilhadas logo em seguida ao assassinato da vereadora Marielle Franco (mulher, negra, moradora e militante de favela) sobre seu suposto envolvimento com traficantes de drogas. Mais uma vez, tratava-se do mecanismo de criminalização de lideranças faveladas como forma de deslegitimação de sua atuação, sendo, nesse caso, específico atacada a memória de Marielle com o objetivo de desacreditar seu legado e o cunho político de seu assassinato (ROCHA, 2018, p. 486).

Para além, portanto, da real perda de base social experimentada por essas associações e dos limites impostos pela convivência e contiguidade com os grupos criminais armados; a criminalização de lideranças pelo estado como supostamente coniventes com o tráfico afeta diretamente a sua legitimidade enquanto atores demandantes de políticas em geral, como ressalta Machado da Silva (2008).

Os líderes de associações de moradores, por sua função pública de representação, são interpelados concomitantemente pelos traficantes a respeito de diversos assuntos ligados a suas atribuições que podem ser vistos como interferindo no varejo de drogas na localidade e por diferentes atores e instituições, a respeito da violência nas favelas. Silêncio, evitação e diferentes 
formas de omissão em relação ao tráfico não podem ser tomados como evidência de passividade ou desinteresse. Constituem, antes, dispositivos de defesa diante de ameaças à segurança pessoal. Entretanto, isto gera acusações às lideranças de "ambiguidade" e/ou conivência, impedindo os dirigentes de exprimirem tanto os riscos que correm quanto os problemas de suas localidades, reduzindo sua legitimidade diante dos moradores, das autoridades e da mídia e provocando a desconfiança do público em geral. (...) sua legitimidade como interlocutor nas arenas políticas tem sido muito prejudicada pelos estereótipos atuais sobre as classes perigosas, que, por uma indevida generalização, criminalizam toda população favelada - e, portanto, sua ação coletiva - como um perigo potencial (MACHADO DA SILVA, 2008, p. 25).

Com isso, mais uma vez, como tem sido demonstrado ao longo desse capítulo, a atuação do tráfico no caso do Rio de Janeiro enfraquece especificamente a agenda da urbanização de favelas, tendo em vista que sua influência sobre as associações diminui as possibilidades de auto-organização e demanda desses atores e da população favelada em geral pela realização de melhorias no território e, principalmente, por uma pauta reivindicativa mais ampla da urbanização como efetivação de direitos (ENTREVISTADO 04), situação largamente utilizada pelo poder público como forma de desqualificação dessas demandas apresentadas (MACHADO DA SILVA, 2008; GONÇALVES, 2013; ROCHA, 2018). Fridman (2008, p. 80) vai além e afirma que, dessa forma, consolida-se a negação do direito à cidade à população favelada no sentido de possibilidade de vocalizar seus interesses, propostas e críticas, disputando politicamente as políticas que acreditam necessárias para redução das desigualdades e ampliação das possibilidades de efetivação de condições dignas de vida.

Apesar de as associações e movimentos de favelas terem perdido força e presença na incidência sobre políticas de urbanização, é importante mencionar que, por outro lado, a pauta da violência (tanto a institucional como aquela promovida por grupos civis armados) e da segurança tem também fomentado o surgimento de outras formas de ativismos nas últimas décadas, protagonizadas por seus moradores. No entanto, é ainda deficiente a reflexão sobre as conexões entre os temas ou reivindicações trabalhadas por esses grupos e questões urbanas mais amplas, do processo de produção das cidades e da reivindicação da urbanização de favelas, como atesta a fala de ativista entrevistado a seguir.

Aqui no Rio existem grupos que surgem, não só na Maré, tem um grupo chamado Movimentos, que discute, por exemplo, a questão da periferia e tem um 
debate sobre a questão da violência, de como a segurança pública é uma pauta importante para a favela, e tudo o mais. Tem um grupo chamado A Favela não se Cala. São alguns grupos, alguns movimentos que surgiram nas favelas que são atores, que dialogam, que tentam cumprir uma incidencia sobre o Estado. (...) Tem uma galera, tem os grandes grupos de slam, tem uma galera hoje trabalhando com cultura, que pauta a questão urbana, mas eles não se constituem como uma força de incidencia política sobre as politicas públicas. Não consigo enxergar desse modo. Eles conseguem fazer o seguinte, eles vão debatendo a questão dos espaços públicos para a socialização, essa pauta eles têm. Eles querem retomar o espaço público para a socialização como um direito, as praças, as ruas. Isso é uma coisa que vem crescendo no Rio de Janeiro, mas não é um debate mais amplo sobre a cidade, ainda (ENTREVISTADO 30).

Essa dimensão das atuais formas de incidencia coletiva a partir das pautas da violência, da segurança pública e da cultura nas favelas é um debate importante que não foi possível de ser aprofundado no escopo desse trabalho, mas que pode ser consultado em trabalhos de fôlego sobre o tema como Amoroso (2012) e Vargas (2016). O que nos toca destacar nesse trabalho é a percepção de que, conforme avaliam entrevistados, esses novos atores, no entanto, muitas vezes não estruturam sua reivindicação política a partir da chave da urbanização de favelas, mesmo que muito de seu debate tangencie inúmeras questões relacionadas a ela e enfoque, diversas vezes, a questão do espaço público. Violência, segurança e urbanização de favelas estariam desconectados e, com isso, aprofunda-se o déficit de demandantes da política de urbanização.

Não se pode cobrar, no entanto, essa postura de tais atores, tendo em vista que se trata de um processo muito mais amplo de (re)enquadramento das favelas dentro da economia política da cidade, em que nos parece há uma generalizada e acentuada ênfase na dimensão da chave "violência/segurança/repressão" em detrimento da "efetivação de direitos/urbanização de favelas" através de um processo de militarização em curso, por exemplo, no Rio de Janeiro, como visto a seguir.

\subsection{A violência mata a política}

Embora não seja um movimento de fato novo e já há muitas décadas moradores de favelas venham sendo enquadrados a partir de representações 
ligadas à criminalidade e à violência (SANTOS, 1984, p. 31; ZALUAR \& ALVITO, 2006, p. 14 e 34; OLIVEIRA \& MARCIER, 2006, p. 96; BURGOS, 2006, p. 34), foi utilizada a expressão "(re)enquadramento" justamente porque trata-se de uma nova etapa.

Ao longo deste século, a favela foi representada como um dos fantasmas prediletos do imaginário urbano: como foco de doenças, gerador de mortais epidemias; como sítio por excelência de malandros e ociosos, negros inimigos do trabalho duro e honesto; como amontoado promíscuo de populações sem moral. Com a chegada de levas de nordestinos, que traziam outra bagagem cultural, a favela também passou a ser vista como reduto anacrônico de migrantes de origem rural mal adaptados às excelências da vida urbana (...) Assim, a despeito de diferentes roupagens, sempre de acordo com um contexto histórico específico, o favelado foi um fantasma, um outro construído de acordo com o tipo de identidade de cidadão urbano que estava sendo elaborada, presidida pelo higienismo, pelo desenvolvimentismo ou, mais recentemente, pelas relações auto-reguláveis de mercado e pela globalização (ZALUAR \& ALVITO, 2006, p. 14-15, grifo nosso).

Dessa maneira, é constantemente construído como um "outro", mas seu lugar e o papel a desempenhar enquanto esse outro se transfigura ao longo do tempo conforme as condições políticas, sociais e econômicas dominantes. No caso específico do Rio de Janeiro, esse "outro" tem sido ressignificado como "inimigo" a ser controlado e, em última instância, eliminado em um processo progressivo de militarização (da segurança pública, do território, da política, do cotidiano e, mesmo, da vida como um todo), conforme identificado por diferentes autores (VALENTE, 2016; LEITE \& FARIAS, 2018; BARROS, 2018; $\mathrm{ROCHA}, 2018)$. Esse processo vivido pela capital fluminense será enfocado a seguir em função dos impactos profundos verificados sobre a urbanização de favelas na cidade, mas igualmente pelo alerta que traz para a possibilidade de expansão da experiência para outras cidades e pela luz que coloca em alguns processos sociais mais amplos verificados no país como um todo.

O processo de militarização da vida - no controle social sobre os favelados, na segurança pública, na política, no urbanismo - não é novo.

$\mathrm{Na}$ questão do enfrentamento à violência, boa parte dos moradores vive um processo em que se valoriza o direito à segurança dos moradores da cidade dita formal, mas se desconsidera esse sujeito [os moradores de favela] como um sujeito que também tem direito a segurança; como os grupos civis armados passaram, depois dos anos 80 , passaram a dominar, usar da estratégia de controle territorial nas favelas do Rio de Janeiro, (...) isso reforça a ideia de que esses moradores, ou que esses territórios não deveriam existir na cidade, que são territórios conflagrados, são territórios do perigo, são territórios ameaçadores. Há muito tempo então o Estado estabeleceu uma relação de enfrentamento militar (ENTREVISTADO 30). 
Se não é uma situação nova, como aponta o entrevistado acima, pode-se afirmar que tem atingido novos patamares, como avalia Rocha (2018, p. 226), principalmente desde a experiência das forças armadas brasileiras no Haiti a partir de 2004 (GONÇALVES, 2017 apud LEITE \& FARIAS, 2018, p. 257). Diferentes autores têm arguido que o Brasil e, principalmente, o Rio de Janeiro vivem uma nova e mais profunda etapa desse processo de militarização (VALENTE, 2016; LEITE \& FARIAS, 2018). Militarização aqui, como proposta por Barros (2018, p. 283), é definida como o "espraiamento das práticas, símbolos, narrativas e tecnologias, que tem na força bélica o aspecto principal".

É essencial destacar que o projeto político e ideológico da militarização depende da constituição de um objeto: a existência de um inimigo comum a ser combatido, derrotado e, até mesmo, eliminado. Ao longo da história brasileira, o processo de construção do aparato militar nunca prescindiu da definição de um "inimigo" a ser combatido como fundamento de ação. Valente (2016, p. 100) resgata os diferentes sujeitos transformados em inimigos ao longo dos tempos: socialistas, anarquistas, comunistas, inimigos do regime e, recentemente, traficantes. Para a autora, ao longo da ditadura militar a figura do subversivo interno (comunistas, terrorista, etc.) vai perdendo força na "gramática do inimigo" ao mesmo tempo em que, paralelamente, os EUA também precisando reconstruir um "outro" mais convincente que alimentasse sua máquina militar e sua estratégia geopolítica - declaram "guerra às drogas", conclamando a América Latina.

A metáfora da "guerra", essencial para essa nova etapa do processo de militarização do controle dos moradores de favela (ROCHA, 2018, p. 226), é definida por Leite e Farias (2018, p. 242) como o "dispositivo discursivo que, desde os anos 1980, mobiliza e justifica políticas de segurança pública que nomeiam os moradores de favela como potenciais inimigos da cidade, tipificados como "classes perigosas" sem direitos a preservar ou vozes a ouvir" (LEITE \& FARIAS, 2018, p. 242). Se é verdade que os pobres - e em especial os moradores de favela - são vistos como "classes perigosas" há décadas (CONCEIÇÃO, 2018, p. 132), desde pelo menos a primeira metade do século XX (VALENTE, 2016, p. 56); acreditamos ser relevante destacar que a transição de sua classificação de "classes perigosas" para "inimigo" na 
atualidade - como o faz a doutrina do setor de inteligência do exército brasileiros e de seus intelectuais (GONÇALVES, 2017 apud LEITE \& FARIAS, 2018, p. 257) - traz novas nuances para o seu enquadramento e para a atuação do estado em relação a eles. Trata-se, como apontado por entrevistado, do aperfeiçoamento da "construção do discurso hegemônico que vai contendo toda uma simbologia da favela como um mal, da favela como um perigo e o seu morador como uma ameaça à sociedade" (ENTREVISTADO $30)$.

Dessa maneira, a criação de um novo inimigo permitiu, primeiramente, a manutenção das engrenagens militares em andamento e, posteriormente, até mesmo sua expansão. Ao discorrer sobre massacres que embasaram a história brasileira, Valente (2016, p. 70) vai afirmar que há séculos a base da solução de todos os conflitos verificados foi um processo de substancialização que converteu o "outro" em inimigo. Os traficantes e todos os potencialmente envolvidos com a atividade, com isso, se tornam alvo da guerra contra todos os "bandidos", bodes expiatórios de todos os problemas de segurança pública do Rio de Janeiro. (VALENTE, 2016, p. 70).

Nesse campo dos que "podem ser uma ameaça" estão incluídos todos os moradores de favelas, vistos sempre pelas autoridades como potencialmente envolvidos, como abordado anteriormente. Com essa transição da população favelada de "classes perigosas" para "inimigo", opera-se uma mudança fundamental na atuação do estado em relação às políticas destinadas a essa população, se reatualizando a permissão dada pelos grupos dominantes para matar os considerados inimigos (FRIDMAN, 2008, p. 77).

Seria possível descrever essa mudança como uma passagem da imagem das
"classes perigosas" para a de "inimigo próximo". No primeiro caso, a metáfora
liga-se ao perigo de subversão político-econômica e de status; no segundo, ao
perigo de ruptura das rotinas cotidianas mais imediatas, e não da estrutura social
como um todo. O fantasma pode ser o mesmo - a luta de classes -, mas sua
roupagem (junto com o modo de lidar com essa nova forma) muda
significativamente. (MACHADO DA SILVA, 2010, p. 287). Verifica-se, portanto, uma mudança na relação entre violência e conflito de classes, migrando de uma perspectiva que trazia o medo da ruptura através da revolução (solucionado consequentemente através de políticas sociais integradoras, que buscavam aumentar a adesão das classes subalternas ao 
sistema através da melhoria de suas condições materiais de vida) para a noção de ruptura do cotidiano pelo inimigo próximo (em que a solução vem através do isolamento, distanciamento, extermínio do outro a partir do endurecimento de políticas de segurança) (MACHADO DA SILVA, 2008, p. 117). Mais do que o "outro" sobre o qual se constrói identidades de urbanidade e de sociabilidade e das "classes perigosas" que fundamentavam um projeto político conservador de controle social; o favelado passa a ser o inimigo a ser controlado e, em muitos casos, eliminado no âmbito do processo de militarização da pauta da segurança pública, do urbanismo e até mesmo da vida, como propõe Cavalcanti (2013).

Com isso, submetem-se as políticas voltadas à população favelada aos ditames das ações de segurança pública, situada nos termos da guerra travada pelo estado contra o crime, o traficante favelado como inimigo e o território a ser recuperado (VALENTE, 2016, p. 102). Assim, mesmo as políticas sociais voltadas aos moradores de favela hoje não são mais prioritariamente orientadas à proteção social, mas são principalmente orientadas por objetivos de ordenamento da vida social, controle territorial, de imposição da soberania estatal (FRIDMAN, 2008, p. 81).

O caso da implementação da política das UPPs no Rio de Janeiro é um excelente exemplo disso, mais uma vez em diálogo com a experiência colombiana. Nesse caso, a Operación Orion foi uma inspiração para a estratégia implementada a partir das UPPs ${ }^{49}$, a qual consistiu na ocupação militar promovida por uma frente de organismos de segurança nacionais e locais em 2002 na Comuna 13, conjunto de favelas da cidade de Medellín com forte presença de grupos traficantes e guerrilheiros. Em cooperação com grupos paramilitares de ultra direita, o governo promoveu uma operação que resultou na eliminação desses grupos e no estabelecimento do domínio militar na região (VALENTE, 2016).

Diante deste quadro, em outubro de 2002, o governo colombiano, na esteira dos acordos bilaterais assinados com o governo dos EUA, deu início a chamada "Operación Orión", uma iniciativa realizada através de parceria firmada entre o

\footnotetext{
${ }^{49}$ Disponível em: https://www1.folha.uol.com.br/fsp/cotidian/ff0201201110.htm
} 
Exército, a polícia e outros órgãos de segurança colombianos. A operação objetivava fundamentalmente retomar o controle territorial do conjunto de favelas da "Comuna 13", que há anos sofria os efeitos da disputa territorial entre traficantes de drogas, paramilitares e guerrilheiros. Desde 2002, a Comuna passou a ser ocupada permanente pela polícia e pelo Exército através da presença armada ostensiva de regimentos ligados às duas corporações (CINEP \& JUSTICIA Y PAZ, 2003). Além disso, a ocupação militar abriu caminho para o início dos chamados "Proyectos Urbanos Integrales" (PUI) na Comuna 13, um conjunto de iniciativas que visam simultaneamente melhorar a infraestrutura urbana da área, além de articular iniciativas "sociais" para a população através de parcerias por parte do Poder Público e a iniciativa privada. O programa possui objetivos bastante semelhantes com a versão "brasileira" do projeto (RODRIGUES, 2013, p. 84).

É importante notar que se tratava de iniciativa que buscava articular também um componente de intervenção territorial, no caso os PUI, e que via no urbanismo social a possibilidade de ampliar a prevenção à criminalidade. Da mesma forma que o PRIMED na década de 1990, a prática do Urbanismo Social dos anos 2000 também tinham como objetivo enfrentar a questão da violência, segundo autores envolvidos com sua formulação e implementação (RESTREPO \& ORSINI, p. 138). Esta prática tinha como pretensão ser um mecanismo de inclusão social e uma ferramenta para costurar, conectar, integrar e articular a cidade e seus diferentes atores, intervindo integralmente de forma a tornar as comunidades beneficiadas orgulhosas do seu barrio e possuidoras de um sentimento de pertencimento (CELIS, 2008, apud PATIÑO, 2015, p. 178).

A partir dos Proyectos Urbanos Integrales (PUI), são promovidas intervenções estruturais de intervenção no território, combinando infraestrutura física (desde a melhoria de vias e espaços públicos até a implementação de equipamentos comunitários) com programas de educação, cultura e incentivo ao empreendedorismo.

"El proyecto urbano se volvió el dinamizador de procesos de inclusión y desarrollo social como alternativa a la violencia y a la indiferencia que imperaron durante décadas en el sector. Es así como los puentes de quebradas, por ejemplo, además de simples conectores peatonales, se volvieron integradores de comunidades hasta ese momento divididas por líneas fronterizas imaginarias e intransitables" (RESTREPO \& ORSINI, p. 142).

Para a administração municipal, os PUI seriam "un instrumento de intervención urbana que abarca la dimensión de lo físico, lo social y lo institucional, con el objetivo de resolver problemáticas específicas sobre un territorio definido, donde se haya presentado una ausencia generalizada del Estado" (ALCALDIA DE MEDELLÍN, 2013, apud PATIÑO, 2015, p. 178). 
Fica evidente, portanto, que este tipo de intervenção colocava, mais uma vez, em disputa o território, demonstrando que este objetivo permanece no centro das ações de mejoramiento barrial formuladas e implementadas na cidade desde a década de 1990 até a atualidade. Estas aparecem como uma ação contundente do Estado em face às organizações ligadas ao crime, tendo em vista que desafia o controle destas sobre os assentamentos ao fazê-lo presente perante a população da área.

“(...) el control territorial es el nudo central (...). La situación del control del territorio es un asunto apremiante, pues de esto depende la capacidad real de gobierno que el Estado local y nacional puedan ejercer en la ciudad, implicando que las directrices político-administrativas se puedan aplicar a todos los ámbitos de la sociedad, empezando por el más básico como es la seguridad, así como con las diversas medidas de uso del territorio" (PATIÑO, 2015, p. 35).

Não se trata apenas de resgatar o controle do Estado sobre o território, mas também uma disputa pela adesão da população à base de apoio do poder público. Não apenas em relação aos jovens, que encontravam no narcotráfico e hoje encontram em outros grupos uma opção de vida que possibilita obtenção de dinheiro sem requisitos que nunca conseguiriam cumprir - grau universitário, experiência, etc. (ENTREVISTADO 08) - mas da população em geral, que até então havia se acostumado com todo controle, mediação e até mesmo suprimento de necessidades pelos grupos criminais.

Contudo, é importantíssimo salientar, para os objetivos dessa tese, que se inicia com a Operación Orion e os PUI uma inflexão na relação construída entre intervenção em favelas e o enfrentamento da violência urbana. Ao contrário do que havia se passado com o PRIMED (em que os investimentos no território constituíam a porta de entrada através da qual posteriormente melhorariam a presença do estado no tocante à segurança), neste último caso a ação de ocupação militar precedeu a realização das melhorias. Não apenas precedeu como teve um forte impacto nas vidas de muitos atingidos pela operação, no cotidiano de moradores e até mesmo perante toda sociedade colombiana (ARDILA, 2017), sucedido depois por intervenções urbanísticas de caráter espetacular e simbólicas. Germinava, assim, um modelo de intervenção ainda mais lastreado na geração de uma nova imagética em torno das favelas do que aquela preconizada nos anos 1990 e, principalmente, começava a promover uma inversão na ordem da equação entre "investimentos em favela > 
investimentos em segurança" para "investimentos em segurança > investimentos em favela". Modelo esse que, internacionalmente difundido a partir dos anos 2000, vai inspirar diferentes políticas, planos e programas no Brasil, do Ceará $^{50}$ ao Rio de Janeiro, sua versão mais conhecida no Brasil.

Criado no final de 2008 pelo Governo do Estado do Rio de Janeiro, o programa de Unidades de Polícia Pacificadora teria como objetivo "a retomada permanente de comunidades dominadas pelo tráfico, assim como a garantia da proximidade do estado com a população" (GOVERNO DO ESTADO DO RIO DE JANEIRO, 201951). Estaria baseado nos princípios da polícia de proximidade, buscando a consolidação de uma parceria entre a população e as instituições da área de Segurança Pública; e englobaria parcerias entre os governos - municipal, estadual e federal - e diferentes atores da sociedade civil organizada com o papel de promover o desenvolvimento social e econômico das comunidades. Buscaria, para tanto, potencializar a entrada de serviços públicos, infraestrutura, projetos sociais, esportivos e culturais, investimentos privados e oportunidades.

Inicialmente, o projeto das UPPs avançou sem um plano previamente desenhado, menos de forma oficial e institucionalizado e mais de forma experimental e pragmática (CANO, 2012, p. 22). Havia naquele momento da ocupação do Morro Santa Marta, em 2008, apenas a Nota 202 do Comandante Geral que inseria a UPP dentro da Coordenadoria de Assuntos Especiais (CANO, 2012, p. 22). Sua criação respondia, mais especificamente, às demandas políticas sobre o tema da segurança pública que recaíam à época sobre o então governador, Sérgio Cabral, como atesta entrevistado envolvido com o programa.

No primeiro mandato do Sérgio Cabral, quando ele ali assume, haviam pelo menos duas dimensões em que ele foi pautado para agira e, sem avançar, nisso teria sido apenas mais um governador. [As duas dimensões eram] o ajuste da política fiscal (precisa ter capacidade pra organizar isso) e na segurança era "Se

50 Disponível em: https://www.ceara.gov.br/wp-content/uploads/2017/12/CP Livro1 Experie\%CC\%82ncias-Exitosas-de-Enfrentamento-a\%CC\%80-Viole\%CC\%82ncia-ea\%CC\%80-Criminalidade.pdf

${ }^{51}$ Disponível em: http://www.ri.gov.br/web/seseg/exibeconteudo?article-id=1349728 
você não produzir nenhum avanço aqui você não avança politicamente". E houve ali uma decisão. Beltrame e sua equipe, você pode ter qualquer juizo sobre a qualidade ou a orientação da atuação deles, mas são setores públicos, no sentido forte do termo, comprometidos lá com tentar conseguir avanços na sua agenda. Todo mundo, mesmo os mais críticos, não conheço ninguém que não reconheça isso. Aquilo junta toda uma massa crítica que vem de impulsos variáveis que dá na construção das UPPs e de outras coisas, meta de diminuição de homicídios, enfim, há uma configuração de coisas meritórias e aquilo é bancado. Há uma decisão política de dizer "Nós vamos fazer isso" (...) (ENTREVISTADO 13).

Neste início, as UPPs contam com forte apoio da mídia, sendo amplamente televisionada a iniciativa (VALENTE, 2016, p. 11); do setor privado (OST \& FLEURY, 2013); e mesmo de diversos setores progressistas da sociedade civil e da academia envolvidos com a temática (MALAGUTTI, 2016). Ao longo dos primeiros anos de implantação, foram sendo apontados diversos resultados positivos, inclusive pelos moradores. Em 2010, segundo pesquisa feita pelo governo estadual (VALENTE, 2016, p. 14), eles apontavam como efeitos positivos sentidos em seu cotidiano o aumento da percepção de segurança, a diminuição de crimes de morte, a melhoria da circulação no âmbito dos assentamentos, etc. Esses dados são reforçados alguns anos depois em pesquisa feita por Cano (2012, p. 113) no tocante à percepção dos moradores.

As UPPs também eram louvadas por estarem reativando os potenciais econômicos das favelas ocupadas (BARROS, 2018, p. 289). Nas palavras de um entrevistado "A gente começa a entender que favela também consome [constitui mercado consumidor], toda a dimensao da UPP vinculada também aos serviços pagos [e sua expansão]" (ENTREVISTADO 21). Diversos ramos do comércio e de serviços finalmente conseguem ampliar seu público e consumidores a partir das ocupações promovidas pelas UPPs e esperava-se que promovessem a incorporação na economia formal de mais de $\mathrm{R} \$ 38$ bilhões provenientes das favelas pacificadas (VALENTE, 2016, p. 144). Muitas dessas empresas inclusive teriam participado, em diferentes momentos, do planejamento da própria política das UPPs (OST\& FLEURY, 2013, p. 638).

Com isso, as UPPs foram sendo disseminadas para diversas outras favelas, sendo implantadas 6 unidades em 2009 (Cidade de Deus, Babilônia, PavãoPavãozinho, Cantagalo, etc.), 8 unidades em 2010 (Providência, Borel, Salgueiro, dentre outras) e assim por diante até chegar a um total de 38 unidades em 2014. É interessante apontar que, apenas em 2011, este 
processo é realmente estruturado enquanto programa a partir do Decreto-Lei Estadual № $42.787^{52}$ de 06 de janeiro de 2011, o qual finalmente avança na estrutura, nos objetivos e na organização do programa (CANO, 2012).

Com este Decreto-Lei o programa busca coadunar duas lógicas que, até então, haviam dominado e polarizado as diferentes vertentes sobre o debate da segurança pública no estado e, mesmo, no Brasil: a da guerra às drogas e a dos direitos humanos (ROCHA, 2018, p. 233), as quais serão aprofundadas a frente. No momento, é importante apontar que o texto legal, em seu art. $1^{\circ}$ vincula as UPPs à "filosofia de polícia de proximidade ", enquanto que o art. $6^{\circ}$ estipula que os policiais destas unidades deverão ter formação com ênfase em "Direitos Humanos e na doutrina de Polícia Comunitária". Os objetivos centrais das UPPs de acordo com o decreto (Art. $1^{\circ}, \S^{\circ} 2^{\circ}$ ) seriam naquele momento: a) consolidar o controle estatal sobre comunidades sob forte influência da criminalidade ostensivamente armada; b) devolver à população local a paz e a tranquilidade públicas necessárias ao exercício da cidadania plena que garanta o desenvolvimento tanto social quanto econômico.

Cano (2012) avaliava que, além dos objetivos expressamente enumerados pelo decreto, era possível encontrar outros objetivos secundários a partir da análise sistemática do diploma legal e das declarações públicas das autoridades: "1. Permitir a entrada ou a expansão dos serviços públicos e da iniciativa privada, tradicionalmente limitada pela ação do poder paralelo dos grupos criminosos; 2. Aumentar a formalização das atividades econômicas e dos serviços no local, bem como da vida dos moradores em geral, historicamente submetidos a condições de informalidade; 3. Contribuir a uma inserção maior desses territórios e seus habitantes no conjunto da cidade, desativando a visão tradicional de 'cidade partida' que caracteriza o Rio de Janeiro" (CANO, 2012, p. 23).

Como apontam diferentes autores (VALENTE, 2016; ROCHA, 2018; CONCEIÇÃO, 2018), percebe-se expressamente, ao menos na dimensão do

52 Posteriormente revogado pelo Decreto-Lei Estadual № 45.186/2015. Anteriormente ao Decreto-lei de 2011, havia apenas os decretos no 41.650 de 21 de janeiro de 2009 (que apenas criava o programa) e o Decreto-lei no. 41.653 de 22 de janeiro de 2009 (que estabelecia uma bonificação para os policiais participantes). 
discurso, uma intenção de coadunar a lógica de controle social/territorial e a lógica de efetivação de direitos da população. Mesmo sendo longa, merece destaque fala de entrevistado para a tese envolvido com a coordenação do programa das UPPs, onde essa hipótese é corroborada. Crítico dos rumos conferidos ao programa posteriormente, não deixa de destacar como essa intenção estava realmente colocada em seu início e como se acreditava estar diante de uma inflexão nas políticas de segurança.

E eu não tenho dúvida que as UPPs, elas hoje tem limites grandes (tiveram sempre), mas representaram a inflexão, uma oportunidade muito positiva nessa direção. Essencialmente naquele momento era um momento que se afirma como algo de muita convergência, de muito entusiasmo. Você teve um impasse durante duas décadas. Você tinha duas abordagens: uma abordagem no campo progressista, que era de Direitos Humanos; e uma abordagem conservadora que era "Tem que entrar atirando, só na bala, no conflito e tal". Uma aposta na truculência como se fosse alguma coisa que vá levar a algum lugar, sem se dar conta de que é ineficaz, é a coisa de enxugar gelo sempre. (...) Por outro lado, você tinha historicamente no campo progressista uma abordagem que era "Polícia para quem precisa, a gente não precisa de polícia. A gente precisa de investimento social, urbano". Uma recusa da presença e da atuação dos serviços da segurança pública como algo relevante e necessário naquele contexto. Por boas razões históricas, imaginar que essa presença possa ser virtuosa, positiva, historicamente é difícil, mas isso leva a uma descrença de que ela possa ser desejável, ou necessária. $E$ aí todo o argumento que eu tentei construir aqui é um argumento de que em qualquer circunstância eu quero um bom serviço de educação, de saúde, etc e também de segurança. Quero também no meu bairro, quero no de todo mundo, então isso é parte da dimensão do aparato de serviço público, porque visa garantir no dia a dia liberdades, integridades, direitos que são fundamentais pras pessoas. Então esse serviço configurado de maneira desejável, ao se fazer presente nas favelas, ajuda a fazer mais um serviço público, como outros que a gente tem que fazer, a reduzir as desigualdades. $E$, segundo, esse contexto de território como o que eu descrevi, eles [os serviços de segurança pública] são não obviamente uma condição plena, absoluta, mas uma condição, uma variável importante para que a expansão de outros serviços e oportunidades possam se fazer de maneira plena e os esforços de integração urbana, social e econômica possam se realizar de maneira plena. Sem eles [os serviços de segurança pública], como vimos, inclusive nas experiências históricas de urbanização de favelas no Rio, há um limite grande dado. Você pode fazer a integração da infraestrutura urbana, criar condições de acessibilidade, expandir serviços, tentar fazer a integração, mas quando você tem uma fronteira demarcada com armas, com fuzis na mão, você vai ter um limite grande do potencial disso. Então desfazer isso é uma tarefa importante pra que a gente possa avançar na integração social, urbana e econômica (ENTREVISTADO 13).

Nesse sentido, o governo estadual cria, em 2010, a UPP Social, programa com o objetivo de coordenar as ações relacionadas a diferentes políticas e investimentos sociais, públicos e privados, nos territórios ocupados pelas UPPs. Poucos meses depois, o programa e seu coordenador - o economista Ricardo Henriques - são transferidos para a Prefeitura do Rio de Janeiro, que assume a condução da UPP Social buscando articular a ação das UPPs com 
as políticas municipais, como o Morar Carioca (programa de urbanização já mencionado).

A princípio, a UPP Social possuía como principal preocupação (ROCHA, 2018, p. 230) a regulação da vida social no período de transição estabelecido pelo novo regime proveniente da instalação das upps e o fim do domínio pelos traficantes. Propunha-se a criar, para tanto, fóruns e espaços de debates locais onde essa nova regulação seria definida coletivamente, de forma a realizar a transição para uma nova regulação social diferente daquela estabelecida sob o regime imposto pelos grupos traficantes (ROCHA, 2018, p. 230).

Podem ser verificados, no entanto, diferentes enfoques na UPP Social ao longo de sua implementação. Em um primeiro momento, enfocava efetivamente a perspectiva de conformação dos moradores à nova ordem e resgate da cidadania, enquanto o programa encontrava-se sob o comando de Ricardo Henriques.

Lá em 2010, 2011, até início de 2012, você tem todo aquele contexto das UPPs no Rio, tem a configuração do Morar Carioca, como potencialmente um pós Favela Bairro, vamos dizer assim. Nesse cenário de favelas no Rio, então você tinha um contexto grande ali de esforços de segurança pública em áreas de favela no Rio e de, naquele momento, potenciais atualizações e impulsionamento de politicas de urbanização e integração social urbana e econômica nas favelas do Rio. Naquele momento eu estive então um pouquinho na Secretaria de Assistência Social do Estado, mas foi tudo no Instituto Pereira Passos, dirigindo o que na época se chamou Programa UPP Social, quando o Ricardo Henriques, que é economista social, dirigia lá o IPP e antes a Secretaria de Assistência de Direitos Humanos. Havia esse pleito de que desenhássemos uma política que pudesse, para além das UPPs, promover a expansão e coordenação de serviços sociais e urbanos nas áreas de UPP, e uma conexão grande também com o Morar Carioca, como política macro de urbanização de favelas que se desenhava na época. Com isso, naquele momento, eu me dedico mais no cerne a uma agenda que era essencialmente de humanização e de expansão, de qualificação de políticas sociais e urbanos nas favelas no Rio, a partir da IPP, que é o órgão da prefeitura (ENTREVISTADO 13).

Credita-se seu declínio, em parte, a uma segunda fase em que se conferiu à UPP Social uma ênfase maior a iniciativas de fomento à cultura do empreendedorismo e consultoria a pequenos negócios, a cargo da economista Eduarda La Rocque, quando esta assume a direção do IPP, motivando inclusive a saída de boa parte da equipe que até então compunha o programa (ROCHA, 2018, p. 231). Assim, alguns autores como Valente (2016, p. 07), chegam posteriormente a denominar a UPP Social como "biombo estratégico" 
de serviços sociais a serem implementados após a pacificação, fazendo alusão com isso a uma fachada aos processos de militarização impostos pelas UPPs.

Desde o princípio, como pode ser visto inclusive no depoimento do próprio coordenador da UPP Social entrevistado, o objetivo de ocupação e controle do território gozava de primazia. Parafraseando frase que ficou notória no período do impeachment de Dilma Rousseff, uma espécie de "Primeiro a gente ocupa, depois a gente leva os serviços", ao contrário do que havia acontecido, por exemplo, na época do Favela-Bairro. Este programa construiu sua base de apoio sobre a questão da violência urbana, mas utilizava justamente a realização primeiramente de investimentos sociais como forma de entrada nos territórios, como apontado anteriormente.

No caso das UPPs, estava claramente colocada a sua primazia sobre as políticas sociais, admitida mesmo pelos mais entusiastas defensores de seus efeitos positivos. "A política está apoiada na ideia de que as ações de recuperação do controle sobre o território têm primazia com relação a intervenções urbanísticas e socioeconômicas, umas que sem um efetivo desmantelamento das organizações criminosas no território, qualquer política pública teria baixo impacto para o desenvolvimento humano" (CARNEIRO, 2012, p. 442). A experiência e as dificuldades encontradas pelo Favela-Bairro nos conflitos com o tráfico nos anos 1990 são justamente utilizadas como argumento para essa inversão da lógica, conforme pode ser notado no depoimento já mencionado.

Dessa forma, se o atrelamento entre urbanização e ocupação policial não é nova e já existe desde o Favela-Bairro; a inversão operada na equação - com a primazia das diretrizes de segurança e combate à violência - demonstra que se vive uma nova fase nessa relação (CAVALCANTI, 2013, p. 201). Essa nova fase, caracterizada por Cavalcanti (2013) por um projeto de "PACificação", reflete e, ao mesmo tempo, contribui para o aprofundamento do processo de militarização.

o acoplamento entre as intervenções em larga escala do PAC e as UPPs articula uma gramática de controle social das favelas, que constitui a política de remodelação urbana prevista pelo projeto do Rio como cidade olímpica: é a gramática da PACificação (...) se as intervenções do PAC-Favelas não são novas em si mesmas, sua justaposição com o programa das UPPs no Rio de Janeiro 
aponta para uma experiência em escala sem precedentes (CAVALCANTI, 2013, p. 197).

Dessa forma, apesar de a percepção sobre a violência urbana já impactar as propostas e experimentos de variadas políticas há décadas (LEITE, 2008, p. 115) e de a política habitacional ser utilizada como forma de disciplinar os pobres e, especialmente, os favelados há mais de meio século pelo menos (CONCEIÇÃO, 2018, p. 132); a combinação PAC-MCMV-UPPs parece não apenas renovar, mas aprofundá-la. Conforme Cavalcanti (2013) propõe, o objetivo de promover uma transformação na paisagem das favelas cariocas no contexto de construção de uma nova imagem da cidade para o mundo, conforme visto anteriormente na seção 2.1, estava vinculado ao projeto de pacificação proposto pelas UPPs.

Do ponto de vista do planejamento estratégico, o maior obstáculo para esse processo foi a dita "crise da segurança pública", que nas últimas três décadas vem convergindo com a ideia do chamado "problema da favela". Nesse sentido, as obras do PAC constituem apenas um aspecto da sintaxe maior de "pacificação" das favelas ora em construção (CAVALCANTI, 2013, p. 196).

Conceição (2018) corrobora para essa visão ao analisar os aspectos da política habitacional promovida no âmbito do PAC/MCMV que contribuem para o projeto de gestão e controle da população pobre da cidade. Desde a escolha projetual e da forma condomínio até o trabalho social realizado no âmbito desses programas, fica evidente a partir da análise do autor que a favela e 0 modo de vida de seus habitantes eram a forma principal a ser superada ou, mesmo, aniquilada (CONCEIÇÃO, 2018, p. 136 e 137).

Por outro lado, as obras grandiosas do PAC - ou "intervenções emblemáticas" (CARDOSO ET AL, 2018) - no Rio marcam simbolicamente, ao mesmo tempo, a presença do estado e o espetáculo da integração da favela (CAVALCANTI, 2013, p. 203). Importante, portanto, para a demonstração da integração perante os favelados, mas mais importante ainda como símbolo da presença do estado naqueles territorios perante a sociedade como um todo. Deve-se ressaltar que o projeto de "pacificação" no âmbito do processo de militarização generalizada não prescinde do apoio de uma base social. Assim, se os moradores de favela são talvez os principais objetos desse projeto, ele deve alimentar, no entanto, o imaginário do restante da sociedade ao mesmo tempo. 
Os projetos do PAC têm fortes efeitos sobre a paisagem urbana ao combinar os seguintes recursos: eles conferem ênfase à favela como cenário, são visíveis a grandes distâncias e enfatizam as conexões ou passagens entre a favela e a chamada cidade formal. Desse modo, eles produzem um regime ambíguo de (in)visibilidade desse espaço, na medida em que não é a favela, como tal, que sobressai na paisagem, mas o espetáculo de sua "integração" à cidade (...) Os edifícios das UPPs também são visíveis de longe, a partir da dita cidade formal, de modo a também "pacificar" a ansiedade da classe média, que por mais de duas décadas testemunhou os tiroteios constantes nas favelas e considerou-se vítima virtual do comércio de drogas (CAVALCANTI, 2013, p. 205).

O recurso estético proporcionado pelas obras do PAC está, dessa forma, dirigido à construção de um espetáculo do urbanismo a partir de uma suposta integração da favela à cidade, mas sob a lógica do controle territorial no âmbito de um projeto de pacificação. O PAC, a partir da inscrição espetacularizada da favela como elemento na paisagem urbana carioca (CAVALCANTI, 2013, p. 206), torna-se a faceta visível do projeto de pacificação e, consequentemente, do processo de militarização vivido no Rio de Janeiro. A força política desse projeto consegue, até mesmo, reeleger o governador Sérgio Cabral no primeiro turno nas eleições de 2010 (ROCHA, 2018, p. 234).

Tanto essa espetacularização quanto a dimensão de submissão das políticas sociais à lógica da segurança podem ser observada na narrativa de Barros (2018) sobre a ocupação de Manguinhos pela UPP. Um dos aspectos enfatizado pela operação e amplamente divulgado pela mídia no momento da ocupação foi a quantidade de lixo retirada durante o processo de ocupação. Como a autora corretamente avalia (ROCHA, 2018, p. 285), "a relação com precariedade foi acionada como argumento que reforçava a ideia de que somente uma intervenção militarizada poderia ordenar territórios marcados pela existência do crime violento".

Esse aspecto corriqueiro é eloquente para abordar a mudança de perspectiva na conexão entre intervenções de urbanização e na segurança em favelas. Mais uma vez, ao contrário do que se preconizava com o Favela-Bairro nos anos 1990, o relato e a análise corroboram para a tese de que foi verificada uma inversão na equação de que a urbanização (realizada, primeiro, como porta de entrada) significaria posteriormente a melhoria das condições de segurança. Aqui, invertendo a ordem, a entrada dos corpos militares na favela é vendida como essencial para a melhoria das suas condições territoriais. As condições de criminalidade/violência e a segurança pública justificam a 
militarização do território, a qual nos discursos expressamente abre caminhos para outras intervenções e, na prática não proclamada, submete todas as outras políticas, dentre elas a urbanização.

Um dos elementos [utilizados pela militarização] é a subordinação das pastas e ações "sociais" da administração estadual e municipal às demandas por segurança e o disciplinamento da cidade e da sociedade. Os investimentos sociais, especialmente em favelas, só têm legitimidade pública quando pretendem resolver o "problema-favela", colocado em termos do risco que esses territórios e seus moradores representam para a paz da cidade e dos "cidadãos de bem" (ROCHA, 2018, p. 234).

Isso se dá, principalmente, naqueles territórios situados justamente nas zonas de contato com os estratos sociais de maior renda. A distribuição espacial das UPPs demonstrava a priorização de locais turísticos (em particular na Zona Sul) (CAVALCANTI, 2013, p. 197), mesmo que os critérios estabelecidos pelo artigo $1^{\circ}$ do decreto de 2011 para a seleção dos locais fossem apenas: a) comunidades pobres; b) de baixa institucionalidade e alto grau de informalidade; e c) com a presença de grupos criminosos ostensivamente armados. Cano (2012, p. 26 a 29) se detem sobre a avaliação das localizações das UPPs progressivamente instaladas, concluindo que gozavam de uma clara seletividade.

Dessa forma, parece evidente que a seleção dos locais foi fortemente influenciada pela celebração dos grandes eventos na cidade, marcadamente a Copa do Mundo de 2014, incluindo a área em torno do estádio e as zonas turísticas e de grande circulação. Por outro lado, as áreas de maior violência letal do estado se concentram na Região Metropolitana, isto é, nos municípios da Baixada Fluminense, até agora não incluídas no projeto de pacificação que está restrito ao município do Rio de Janeiro. Contudo, mesmo dentro do município do Rio de Janeiro, as regiões com maior taxa de homicídio são tradicionalmente a Zona Oeste e a Zona Norte, justamente as menos contempladas pelo programa de pacificação. Nessas regiões, as unidades estabelecidas parecem ter seguido critérios bastante seletivos, tanto geográfica quanto substantivamente. Assim, na Zona Oeste, as duas UPPs respondem, como já foi mencionado, a situações particulares, e na Zona Norte estão concentradas na região da Tijuca (CANO, 2012, p. 29).

Valente (2016) também aponta, em sua análise sobre o significado da estratégia adotada pelas UPPs, que as favelas beneficiadas teriam sido aquelas localizadas nas comunidades no entorno do Maracanã, da Zona Sul carioca e nos corredores de trânsito entre os principais aeroportos e esses locais (VALENTE, 2016, p. 14). O intuito era promover uma ocupação militar nas áreas de pobreza que se localizavam em regiões estratégicas aos eventos desportivos anunciados (VALENTE, 2016, p. 13). Como afirmava Misse (2011), 
esses territórios, sob controle policial, "constituíam o que o secretário de Segurança Pública, José Mariano Beltrame, tem chamado de "cinturão de segurança”, com vistas à Copa do Mundo e aos Jogos Olímpicos" (MISSE, 2011). Entrevistado para a tese afirma que, justamente, um dos limites do projeto das UPPs (do qual havia participado) teria sido "um curto prazismo e as limitações de uma agenda pública absolutamente atrelada aos grandes eventos naquele momento, como as próprias Olimpíadas" (ENTREVISTADO 13).

Essas e outras escolhas que foram sendo feitas ao longo do programa foram impactando o conjunto de favelas das diferentes regiões da cidade, a exemplo de Manguinhos. Esta passa a sofrer a partir de 2010 com a ocupação da UPP no Complexo do Alemão. Antes o Complexo era base de operações do Comando Vermelho e exercia diversas funções de logística para operação da facção. A partir da sua ocupação em 2010, muitas dessas funções foram transferidas pelo CV para Manguinhos, que passou ainda a sofrer com uma maior afluência de usuários de droga, além da ampliação da presença de traficantes, conforme registrado em pesquisa etnográfica realizada por Cavalcanti (2013, p. 213). Nas entrevistas realizadas para esta tese, diferentes entrevistados (ENTREVISTADO 26; ENTREVISTADO 21; ENTREVISTADO 03; ENTREVISTADO 04, dentre outros) também confirmaram os mesmos impactos sobre diferentes assentamentos.

É importante frisar, contudo, que a geografia das UPPs demonstra também a escolha de enfrentamento a apenas algumas facções criminais e não a outras (VALENTE, 2016, p. 08), praticamente não enfocando, por exemplo, os territórios ocupados por milícias ${ }^{53}$.

(...) a UPP fortaleceu a milícia. Não teve nenhuma favela com a milícia abordada. E eu me lembro que na época dos jogos pan-americanos o César Maia falando assim "As milícias são a auto defesa das comunidades", ele falava. E teve uma expansão das milícias na baixada, Jacarepaguá, que era parte dos jogos pan-

\footnotetext{
${ }^{53}$ Importante mencionar que também no caso de Medellín, tem se verificado o crescimento de grupos milicianos nas últimas décadas. Da mesma forma, gozaram da complacência do estado colombiano no sentido de que possuíam discurso de enfrentamento aos grupos narcotraficantes (VALENTE, 2016, p. 146-150). Em Medellín, as milícias emergem das estruturas derivadas dos grupos paramilitares e remanescentes do narcotráfico e pretenderiam, hoje, controlar o microtráfico de entorpecentes (de caráter mais local) - construindo e gerenciando os espaços em que ocorre a sua comercialização - bem como a realização de diversas outras práticas, como roubos, extorsões, etc. (PATIÑOS, 2015, p. 179).
} 
americanos. Pra ele foi estratégia pública. Era melhor milícia, tanto que a área da baixada de Jacarepaguá, que é tudo milícia, a única favela que é tráfico é a Cidade de Deus, foi a única que teve a UPP na região (ENTREVISTADO 21).

Cano (2012), Zaluar \& Conceição (2007) e Misse (2011), dentre outros autores, coincidem em afirmar que o fenômeno das milícias tem raízes antigas, conectando-se com esquadrões de extermínio formados por policiais e outros agentes de segurança fora de serviço e que eliminavam pessoas consideradas criminosas, geralmente sob pagamento de comerciantes locais. Sobre esquadrões da morte, fenômeno que atinge tanto Rio de Janeiro como São Paulo e outros centros urbanos brasileiros, vale a pena conferir Bicudo (1976).

Com atuação crescente nas últimas duas décadas, as milícias foram se conformando, na atualidade, como grupos ligados aos mesmos atores da segurança pública e com fortes laços com a classe política, controlando territórios principalmente na Zona Oeste do Rio de Janeiro dentro dos quais cobram de comerciantes e moradores taxas para a prestação de diferentes serviços. Não mais restritos à provisão de segurança e ao suposto combate a grupos ligados ao tráfico de drogas, as milícias atualmente atuam na extorsão da população do território dominado em função do controle que exercem sobre a distribuição de gás em botijão, os serviços clandestinos de internet e televisão a cabo, o transporte público ilegal e, até mesmo, o comércio de entorpecentes (CANO, 2012, p. 14).

Em função da conveniência do discurso apresentado como justificativa para sua ação - o extermínio de grupos ligados ao tráfico e a defesa de moradores pobres - elas contaram com a complacência e até mesmo reconhecimento público de diferentes autoridades (como citado na entrevista acima). No entanto, as milícias são denunciadas a partir do sequestro e tortura de jornalistas perpetrado em 2008, cuja repercussão, conjuntamente com pesquisa de CANO (2008), promoveu instauração de Comissão Parlamentar de Inquérito na Assembleia Legislativa do Estado e alertou a sociedade para os perigos que os grupos há anos representavam em diversas regiões da cidade.

Houve, assim, um período de repressão mais intensa aos grupos milicianos por parte do estado, com diversas denúncias e líderes presos. As milícias, a partir desse momento, passam a atuar de maneira mais discreta, aproveitando-se de 
como a atenção pública se volta novamente à "guerra" aos grupos traficantes a partir do início das UPPs (CANO, 2012, p. 11 e 12). Mas, se as milícias também dominam e oprimem diversos assentamentos populares e são responsáveis por índices que impactam a violência urbana, por que não foram enfrentadas também pelas UPPs?

Conforme aponta Cano (2012, p. 194), até aquele momento, a Zona Oeste teria recebido apenas duas UPPs, Batam e Cidade de Deus, por circunstâncias diferentes das escolhas das outras favelas ocupadas. É importante apontar que, dentre as favelas da Zona Oeste, a única comandada pelo tráfico à época era justamente a Cidade de Deus (ENTREVISTADO 21). Dessa forma, como o autor aponta "A [Cidade de Deus] foi resultado da iniciativa de um comandante local e a [Batam] foi escolhida em função de um famoso episódio de tortura de jornalistas por um grupo de milicianos. De fato, Batam é a única UPP em território de milícias, o que confirma que se trata basicamente de um projeto contra o narcotráfico" (CANO, 2012, p. 194).

A resposta, portanto, à pergunta está dada: a UPP se tratava de um projeto de enfrentamento aos grupos do narcotráfico, não a todos os grupos criminais que de alguma forma impactam a violência urbana e exercem o controle territorial sobre a população de favelas. Mas, mais do que isso, é importante apontar que as milícias respondem de forma positiva ao processo mais amplo da militarização em curso à qual as UPPs estavam atreladas. Exemplo eloquente sobre isso está na análise feita por Cano (2012) sobre como a UPP do Batam (única realizada em território controlado por milícias) viveria um processo melhor de aceitação por parte da população em relação às diretrizes trazidas pela nova unidade implementada e haveria uma melhor convivência entre moradores e policiais.

Isso pode ser atribuído a vários fatores, o primeiro deles é que a milícia parece ser mais fácil de desarticular pela presença ostensiva da UPP do que o tráfico. Embora existam no Batam pessoas associadas com a milícia, elas não possuem uma rede comparável à do tráfico que possa resistir a presença da polícia da mesma forma. Em segundo lugar, a milícia nunca foi hostil em relação à polícia, pois muitos dos seus membros são policiais. Em terceiro lugar, relacionado com a afirmação anterior, o verdadeiro inimigo da polícia é tradicionalmente o tráfico e não a milícia, e o próprio projeto das UPPs está dirigido a áreas de tráfico com a única exceção do Batam. E em quarto lugar, a milícia pareceria ter realizado já, durante o seu domínio, parte do 'projeto moral' da polícia anteriormente citado, 
acabando com o consumo de drogas, os bailes funks e outras condutas reprovadas (CANO, 2012, p. 181).

Há, portanto, convergências entre os projetos das milícias e da militarização promovida pelas UPPs naquele momento, não havendo, dessa forma, necessidade de que estas combatessem aquelas. Especialmente no tocante ao "projeto moral", como mencionado pelo autor, sua coincidência seria evidente, fazendo com que seja possível afirmar que tratam-se - milícia e UPPs - de diferentes faces do mesmo processo de militarização da gestão e controle social dos moradores de favela. A conexão entre milícia e estado no Rio de Janeiro está clara para os investigadores que se dedicam ao tema (ALVES, 2019), sendo a sua própria existência dependente das conexões que estabelece com 0 aparelho estatal através de deputados, vereadores, secretários ${ }^{54}$.

A forma de controle sobre o cotidiano dos moradores registrada se utiliza de diferentes dispositivos: imposição de toque de recolher, horário limite para fechamento de bares, necessidade de autorização para a realização de festas e eventos, controle sobre as formas de lazer, obrigatoriedade de abertura das residências à revista policial a qualquer momento, desmantelamento de meios informais de provisão de serviços (como mototaxi e garis comunitários), etc. (VALENTE, 2016, p. 110). As UPPs buscavam instituir uma nova regulação no território também no tocante à formalização e regularização dos negócios, dos comércios, do trabalho e dos serviços, partindo do pressuposto de que o alto grau de informalidade favoreceria o crime (VALENTE, 2016, p. 104). Para o comando das UPPs, os moradores de favela teriam que aprender a fazer parte da cidadania (ROCHA, 2018, p. 233).

Ao longo dos anos, foram surgindo diversas denúncias sobre violações e problemas verificados na implementação das UPPs - cerceamento e controle excessivo da vida pública e da utilização dos espaços públicos, inibindo a vida social; imposição muito estrita de regras para a vida local; desmobilização

54 Disponível em: https://apublica.org/2019/01/no-rio-de-janeiro-a-milicia-nao-e-um-poderparalelo-e-o-estado/ 
política dos moradores; aumento da incidência de violência e abuso policial (VALENTE, 2016, p. 15).

(...) se dizia "Esses policiais que estão ali estão acharcando jovens, estão intimidando, dão tapa na cara, tem violência física. Isso é muito grave, isso é muito sério! Estão arbitrando a possibilidade de ter festas e tal". Não, enquanto estão presentes ali, isso tem que ser arbitrado mesmo. Em um espaço qualquer da cidade, se tem um bar que faz barulho, os vizinhos vão dizer "Tem barulho" $e$ você vai ter que negociar qual é o limite do barulho possível, até onde vai 0 direito das pessoas dormirem e até onde vai 0 direito das pessoas se confraternizar e celebrar. Quando não tem isso, é na força. $O$ baile se faz, quem quiser vá lá e dê o seu jeito. Quando tem, você vai ter que entrar no pacto do dia a dia. "Estão fazendo isso com um viés discriminatório. Barulho de determinados gêneros musicais pode, funk não pode porque há um preconceito". Isso tudo é verdade, isso tudo são desafios importantes. Ao mesmo tempo você passa em muitas das áreas - durante 2 ou 3 anos - sem nenhuma morte violenta registrada. Então, quando eu parei de discutir conflito armado e tiroteio no dia a dia, execução como parte do cotidiano ou uma situação de agressão física, eu continuo tendo um problema importantíssimo, mas eu produzi avanços importantes. Eu preciso saber reconhecer isso (ENTREVISTADO 13).

Apesar desses avanços, o rompimento do consenso sobre as UPPs começa a ser notado a partir de 2013, quando esses abusos passam a ser frequentemente noticiados em diferentes meios de comunicação (BARROS, 2018, p. 291). Os próprios dados relativos à violência urbana voltam a ter destaque, como aumento da ocorrência de roubo e furtos (antes coibido pelo tráfico) (VALENTE, 2016, p. 15). A partir de 2015, diferentes documentos dos órgãos de segurança começam a apontar dificuldades na manutenção das UPPs (VALENTE, 2016, p. 08) Em 2016, circulam diversas noticias sobre a crise do programa nos jornais (ROCHA, 2018, p. 224) e, finalmente, em 2018 já são fechadas metade delas a partir da intervenção federal (ROCHA, 2018, p. 224). Embora seja dado como um fato pelos autores que analisaram o programa desde então, o fim das UPPs não é anunciado oficialmente, mas vai aos poucos ficando evidente a partir das atitudes do Governo do Estado em relação a elas, desde o descuido com a articulação das políticas sociais e da UPP Social até mesmo o próprio abandono das UPPs em si (ROCHA, 2018, p. 234).

Apesar de todos os problemas do Beltrame e das politicas das UPPs, ele mesmo sempre falou "A gente entra com a UPP, mas, se 1 ou 2 anos depois não tiver estabelecida uma política clara (...), se o governo não vem, se a polícia for 0 governo nas comunidades, aquilo falirá, vai falir, vai dar água em 1 ou 2 anos". Foi o que aconteceu e agora não tem volta, não tem volta. Enfim, é uma política praticamente falida (ENTREVISTADO 04). 
Embora as falhas da UPP e sua crise sejam muitas vezes creditadas aos cortes orçamentários sofridos pela segurança pública em função da crise financeira do governo estadual, Barros (2018, p. 292) demonstra como o volume de recursos da pasta da segurança permaneceu um dos maiores dentre as secretarias e ainda em patamares superiores ao período anterior ao das UPPs. Mais do que crise orçamentária, o declínio das UPPs parece se dar em função da perda de prioridade dentro das gestões estadual e municipal e também pela perda do caráter de consolidação da cidadania em detrimento de sua dimensão de "guerra" ao tráfico e controle territorial. O primeiro ponto fica evidente a partir de fala registrada de entrevistado envolvido com o programa.

\begin{abstract}
Não tem inércia [nesse tipo de política pública]. Quando a gente dizia lá atrás que aquilo era o primeiro passo e que tinha uma trilha a ser seguida; com o passar do tempo (ainda mais quando você está querendo ganhar escala), se você não desdobrar isso, aquilo tende a declinar. É isso o que aconteceu. (...) No começo você tinha lá as UPPs, os policiais com condições de trabalho super precárias e tal. É incompreensível como, anos depois, num programa que é a menina dos olhos e tal, em boa parte a gente sequer foi capaz de enfrentar. Isso por si só atesta o quanto a gente não avançou. (...) Primeiro, essa agenda de integração [social, através da implementação integrada de políticas de segurança e políticas sociais] nunca foi a agenda fundamental dessa política. Não era o programa fundamental do Eduardo Paes, não era do governador. Mas eu acho que tem duas coisas. (...) no segundo mandato [do governador Sérgio Cabral] era pensado "Agora a gente tem que avançar de forma estruturada", entre tudo isso que eu descrevi. E a decisão que vem naquele momento, no meu modo de ver é "Olha, o jogo está ganho do ponto de vista político. Faz mais uma UPP a cada 3 meses, está legal, não vou queimar cartão político comprando as brigas novas que eu vou ter que brigar por tudo isso que vocês estão falando aí [ampliação da estrutura das UPPs e integração de políticas sociais]". Há uma acomodação perversa, do ponto de vista aqui da segurança. (...) Além de que a agenda e as demandas dos eventos da Copa, Olimpíadas passam a colonizar quase integralmente a pauta pública, há uma acomodação, que eu descrevo aqui de maneira muito pueril. E isso vale para boa parte da sociedade do Rio de Janeiro, sobretudo a elite, que é "Mas não precisa fazer tudo o mais. Parou de ter tiro, a vida está assentada". Há uma acomodação, uma certa negligência em relação ao "Mas tem que fazer tudo isso". Na real as coisas estabilizaram. "Deixa assim" (ENTREVISTADO 13).
\end{abstract}

Além disso, contribuiu também para o declínio das UPPs, como sugerido também pelo entrevistado, a pouca atenção dada à coordenação com investimentos sociais. Se, por um lado, como analisado anteriormente, a política das UPPs e o processo de militarização submeteram diferentes investimentos sociais à lógica da segurança; por outro, esta dimensão foi progressivamente dominando a pauta em detrimento da primeira.

Na visão de Barros (2018, p. 292), ao longo da experiência das UPPs houve um acentuado deslocamento dos objetivos ligados à vertente de direitos 
humanos (regate territorial, promoção da cidadania, etc.) para a lógica do controle, sendo seu principal efeito o reconhecimento social das forças de segurança como "ente fundamental sob o qual repousa a responsabilidade da gestão das favelas e seus moradores". Valente (2016, p. 113) também avalia que a politica de ocupação militarizada do território não foi bem sucedida do ponto de vista de possibilitar a ampliação da cidadania e da efetivação de direitos humanos. Teria significado, na realidade, apenas uma concentração de equipamentos policiais em detrimento de outros serviços e direitos sociais, no máximo representando a possibilidade de potencialização do morador enquanto consumidor.

Com essa crise das UPPs, grupos traficantes retornam aos morros e acentuam aqueles aspectos de mudança no comportamento dos traficantes já mencionado anteriormente.

$E$, assim, nada contra atesta mais isso do que acontece quando as UPPs colapsam. A evidência de quando regressamos a um momento incrivelmente mais dramático, mais perverso, mais cruel, diante do colapso delas, atesta por si só o fato que elas embutiram algum avanço em relação a dinâmicas pregressas que a gente tinha (ENTREVISTADO 13).

Como avalia outro dos entrevistados (ENTREVISTADO 21), as UPPs teriam promovido um rearranjo de forças. "Você retirou lideranças, então você tem uma reconfiguração do tráfico".

Essa pacificação via UPP, ela teve uma primeira atuação, eu acho que foram acordos entre traficantes, na minha opiniao, só que o resto não veio e quando você não tem o restante vindo junto, não vai funcionar um postinho de UPP ali, eu acho que depende do comando que está ali na hora, então eu sou muito cética dessas tentativas. (...) Hoje a gente está vivendo um momento muito complicado (...) o PCC está querendo entrar, o $3^{\circ}$ Comando está querendo recuperar as áreas, então na verdade a gente está com o território conflagradíssimo. Nós temos 4 facções, em São Paulo tem o PCC. Nós temos 4 facções aqui, $3^{\circ}$ Comando, Comando Vermelho, Amigos dos Amigos... Então assim, como é que a gente vai sobreviver sob a égide de 4 comandos? Sendo que um deles tem um acordo com a PM, então a PM ajuda a proteger quando o Comando Vermelho invade. Enfim, estamos nesse momento, e ai o impacto é violentíssimo (ENTREVISTADO 26).

Eu vejo moradores angustiados porque não conhecem mais o tráfico, não conhece as pessoas, e pra eles é uma angústia. Foi o que ele falou, tem morador que está sendo pressionado pelo traficante. Ele fala "Você não é morador daqui". "Eu sou, moro aqui há 50 anos". E eles não conhecem ninguém. Essa relação orgânica que existia, pro bem ou pro mal, existia uma certa previsibilidade. Se eu não fizer tais coisas, tais coisas e tais coisas, o tráfico funciona. Se eu não me meter com eles, eles não vão se meter comigo. Mas agora eu não sei quem são eles, que fulano invadiu. Não é mais o traficante que nasceu, foi criado, que mora lá há 30 anos (ENTREVISTADO 21). 
Dessa forma, quando elas colapsam, ocorre um acirramento da disputa no processo de reconfiguração das redes criminais estabelecidas pelas facções nos territórios de favelas anteriormente ocupadas pelas unidades. Um dos fatores que teria contribuído para esse acirramento, segundo entrevistado (ENTREVISTADO 21), seriam investimentos imobiliários promovidos por grupos traficantes no mercado informal das favelas cariocas.

(...) cada vez mais a gente vê muita intervenção do tráfico, investindo no mercado imobiliário, que eu acho que isso vai ser mais complexo então no conflito [pósUPPS], porque você tem impactado reinvestir no tráfico na própria favela. Então a questão do Rio de Janeiro que é a luta, o conflito, não é mais só pela boca, eu estou deixando a minha riqueza aqui. Então eu escutei muitas pessoas falando "O fulano, fulano e fulano é tudo laranja do Rogerinho 157 lá da Rocinha [em Rio das Pedras]. Teve muito investimento no mercado imobiliário, então quando é patrimônio, a briga territorial é muito mais intensa, e a UPP bagunçou isso tudo, teve uma reconfiguração (ENTREVISTADO 21).

Esses grupos, portanto, também teriam se aproveitado do aquecimento do mercado imobiliário como um todo no Rio de Janeiro nas últimas décadas [REFERÊNCIA] e do fato de que o domínio territorial exercido por eles faz com que não necessitem recorrer ao judiciário para exercer a cobrança de aluguéis em atraso ou despesjar inquilinos, por exemplo. Com a implantação e posterior falência das UPPs, o domínio sobre as favelas teria se reconfigurado e impulsionado uma maior disputa pela sua retomada por se tratar também de uma disputa em torno de um capital imobilizado em parques imobiliários informais situados nesses assentamentos ${ }^{55}$.

O fato de as UPPs terem entrado em crise e os grupos traficantes terem retornado às favelas ocupadas anteriormente significa o fracasso do projeto de militarização? De forma alguma, este momento parece ser mais um estágio deste processo, necessário inclusive ao seu aprofundamento.

\footnotetext{
${ }^{55}$ Infelizmente não foi possível aprofundar esse tema no âmbito da presente tese em função da dificuldade relacionada em obter mais dados acerca do objeto. De toda forma, é importante mencionar que outras entrevistas também mencionaram o papel do tráfico como agente imobiliário, não apenas no Rio de Janeiro, mas também em Medellín (ENTREVISTADO 05) e em São Paulo (ENTREVISTADO 14; ENTREVISTADO 09). "Hoje em dia ali na Nova Jaguaré, por causa da USP, fizeram um montão de barraco irregular pra vender, pra alugar, o prefeito regional e a polícia disseram que não podem entrar lá, que é muito perigoso. É uma inversão de valores. (...) Já se tornou [um agente imobiliário]. Eu diria que se formos calcular o que eles tem construído de unidades, pode ser que eles tenham uma produção maior do que a do mercado normal, porque é muito rápido, é uma coisa impressionante" (ENTREVISTADO 09).
} 
Primeiramente, as transformações no modo de relação entre traficantes e favelados já vinham acontecendo antes mesmo das UPPs, como demonstrado anteriormente nesta tese e em depoimentos colhidos por Machado da Silva (2008). Além disso, ao reterritorializarem o tráfico em um primeiro momento e posteriormente entrarem em crise (causando uma nova disputa por territórios e a dominação por "estrangeiros" a cada morro), a falência das UPPs aprofundam esse processo e criam os elementos necessários à construção da narrativa que legitima a etapa seguinte da militarização: a intervenção federal.

Não é à toa que o então presidente Michel Temer usa palavras como "ordem", "desordem", "guerra", "metástase" em seu pronunciamento sobre a decisão relativa à intervenção federal (ROCHA, 2018, p. 235). A crise das UPPs permite justamente a utilização desse vocabulário clássico para construção do discurso que justificaria uma ação federal cujo principal intuito era político. Como já descrito anteriormente, não eram os índices de violência que de fato motivavam a intervenção federal, tendo em vista a existência de estados com os índices piores do que aqueles apresentados pelo Rio de Janeiro. A intervenção federal possuía objetivo político: o governo de Michel Temer gozava de baixos níveis de popularidade e buscava aprovar reformas impopulares (ROCHA, 2018, p. 236), necessitando canalizar a atenção pública para algo que rendesse capital político positivo.

Com isso, a intervenção federal marca o encerramento do ciclo das UPPs ao mesmo tempo em que radicaliza a lógica de militarização (ROCHA, 2018, p. $235)^{56}$. Se o processo de ocupação das UPPs já contava com diversas simbologias ligadas à concepção militar (VALENTE, 2016, p. 103) de retomada da soberania pelo estado sobre o território no âmbito das favelas (hasteamento de bandeiras no local escolhido para sediar as unidades, eventos e atos políticos, etc.) (BARROS, 2018, p. 286); a intervenção federal eleva isso para a escala da cidade. Consolida-se, dessa maneira, a ideia de que apenas 0

56 Resultados da Intervenção Federal até Dezembro de 2018 (OBSERVATÓRIO DA INTERVENÇÃO, 2019): 53 chacinas, 213 mortes em chacina, 4.127 homicídios dolosos, 1.287 pessoas mortas pela polícia, 8.193 tiroteios, sendo observado crescimento de praticamente todos esses índices em relação ao período anterior à Intervenção, à exceção dos homicídios dolosos. 
investimento em tecnologias e práticas militares seriam a solução efetivamente possível para o problema da violência urbana no Rio de Janeiro (BARROS, 2018, p. 286). É um passo importante no processo de naturalização junto à população (em termos de aceitação) do acionamento do aparato militar como solução para o tema da segurança pública (ROCHA, 2018, p. 237), vide posicionamento do Comandante do Exército Brasileiro em entrevista a jornal quando perguntado sobre o chamamento das forças armadas a essa atuação.

Havia um certo preconceito, um patrulhamento. "Ah, está militarizando", diziam, falavam em fascismo. Eu vejo de forma positiva. Agora, o nível de gravidade está tão alto que deixou de ser segurança pública e já se transformou numa questão de segurança nacional. Mais de 60 mil pessoas assassinadas por ano, todos os indicadores, o narcotráfico, o crescimento das organizações criminosas, isso tem de ser tratado com abrangência. Naturalmente, de acordo com o que a Constituição prevê, os militeres inexoravelmente terão de participar desse esforço nacional. Quer como protagonistas, quer como coadjuvantes. Vai ter de participar (FOLHA DE SÃO PAULO, 2018, ENTREVISTA GENERAL VILLAS BOAS) ${ }^{57}$.

Isso já vem acontecendo, havendo cada vez mais convocações para atuar em diferentes estados a partir do dispositivo de "Garantia da Lei e da Ordem" (ROCHA, 2018, p. 236). Nesse sentido, vide solicitação do Governador do estado do Ceará, Camilo Santana (filiado ao Partido dos Trabalhadores, portanto oposição ao recém eleito governo federal), de apoio das forças armadas nacionais para normalização do conflito vivido no estado em função de situações provocadas por facções criminais descontentes com 0 recrudescimento da repressão no sistema penitenciário ${ }^{58}$.

Alimenta-se, com isso, o projeto de militarização, que se estende para muito além da política de segurança e do controle social e territorial dos moradores de favela. Os militares têm progressivamente ocupado mais espaços na política nos últimos anos (ROCHA, 2018, p. 237). Participaram do processo das UPPs, da ocupação no Alemão e na Maré, mas foram também importantes atores no esquema de segurança de diferentes eleições, na segurança em megaeventos esportivos e na repressão a manifestações. Sua atuação política, contudo, tem

57 Disponível em: https://www1.folha.uol.com.br/poder/2018/11/bolsonaro-nao-e-volta-dosmilitares-mas-ha-o-risco-de-politizacao-de-quarteis-diz-villas-boas.shtml

58 Disponível em: https://g1.globo.com/ce/ceara/noticia/2019/01/03/governador-do-cearasolicita-apoio-da-forca-nacional-apos-onda-de-ataques.ghtml 
ido além do envolvimento na implementação de políticas de segurança, inclusive assumindo cargos em diferentes órgãos (FUNAI, Casa Civil, ABIN, STF, etc.) (ROCHA, 2018, p. 236).

Nos últimos anos, o Comandante do Exército Brasileiro, General Villas Boas, se manifestou em momentos de tensionamento político através de sua assessoria de imprensa ou mesmo de sua conta pessoal no Twitter no sentido de posicionar o Exército como mantenedor da ordem no país, mesmo quando isso significou exercer, inconstitucionalmente, pressão no julgamento do STF sobre possibilidade de habeas corpus para o ex-presidente Lula. Como suspeitado por alguns setores naquele momento e confirmado posteriormente em entrevistas de diferentes comandantes das forças armadas, tratava-se mais de uma manifestação que visava aplacar pressões internas de setores militares que ansiavam por um posicionamento mais contundente por parte do Exército brasileiro $^{59}$. Evitava-se com isso movimentos políticos mais radicais por parte desses setores.

Eu precisei ter o domínio da narrativa. Por isso, às vezes nós éramos mais enfáticos na expressão, sempre no limite para não invadir o espaço de outras instituições. Eu reconheço que houve um episódio em que nós estivemos realmente no limite, que foi aquele tuíte da véspera da votação no Supremo da questão do Lula. Ali, nós conscientemente trabalhamos sabendo que estávamos no limite, mas sentimos que a coisa poderia fugir ao nosso controle se eu não me expressasse. Porque outras pessoas, da reserva e civis identificados conosco, estavam se pronunciando de maneira mais enfática (FOLHA DE SÃO PAULO, 2018, ENTREVISTA GENERAL VILLAS BOAS)60.

Enquanto esta tese é finalizada, o recém empossado vice-presidente é general das forças armadas e em repetidas ocasiões tem se colocado como porta-voz dos militares na nova gestão à frente do Governo Federal. Diferentes analistas políticos já têm considerado em suas análises este como o grupo ou o bloco militar, o qual tem influenciado, inclusive, nomeações em diferentes pastas do executivo federal ${ }^{61}$.

\footnotetext{
${ }^{59}$ Revista Piauí. O vice a cavalo. Ed 147. Dezembro, 2018

60 Disponível em: https://www1.folha.uol.com.br/poder/2018/11/bolsonaro-nao-e-volta-dosmilitares-mas-ha-o-risco-de-politizacao-de-quarteis-diz-villas-boas.shtml

${ }^{61}$ Desde indicações de cargos burocráticos em ministérios, como no Ministério da Educação, até altos postos ligados à presidência da República - como o Gabinete Institucional da Presidência (ocupado pelo general Augusto Heleno), a Secretaria de Governo (ocupada pelo general Santos Cruz) e a Secretaria Geral da Presidência (pelo general Floriano Peixoto Neto)
} 
O presidente Jair Bolsonaro também se identifica como proveniente da carreira militar, capitão da reserva. Além disso, a própria base de apoio do seu partido, Partido Social Liberal (PSL), inclui diversos integrantes historicamente vinculados a órgãos de segurança. Sem em 2014, o PSL havia conseguido eleger apenas um senador e um deputado, no pleito de 2018 alcançou a segunda maior bancada, com 56 parlamentares, sendo 4 senadores e 52 deputados federais. Dentre esses, de acordo com levantamento realizado pela Agência Pública (PÚBLICA, 2019) ${ }^{62}, 21$ deputados trabalham ou já atuaram em órgãos públicos de segurança ( 6 policiais militares, 6 militares do Exército, 5 policiais federais e 4 policiais civis), contando ainda com pelo menos outros três deputados sócios em empresas de segurança privada.

Por fim, no caso específico do estado do Rio de Janeiro, foi eleito para o governo pelo Partido Social Cristão (PSC), na coligação intitulada "Mais ordem, mais progresso", Wilson Witzel, juiz federal e ex-fuzileiro naval (GOVERNO DO ESTADO DO RIO DE JANEIRO, 2019) ${ }^{63}$. Além do próprio título da coligação, em seu programa de governo, registrado junto ao TSE durante a campanha, estava consignado que a segurança pública (primeiro eixo de ação do documento e considerado o principal problema do estado) "precisa voltar a ser caso de polícia, e não mais caso de política” (TSE, 2019, p. 08) ${ }^{64}$. Prometia, por outro lado, transformar a Polícia Militar e a Polícia Civil em secretarias do estado diretamente sob seu controle, buscando supostamente demonstrar a centralidade que o tema gozaria em sua gestão. Incluía como propostas para o tema: uso da escala de outras forças de segurança junto à PMERJ, na medida do possível e aproveitamento do legado da intervenção; a autorização para

\footnotetext{
- os militares têm se destacado enquanto grupo político influente no governo Bolsonaro, como a própria campanha eleitoral já prenunciava. Apenas um civil ocupa posto no núcleo estratégico do governo (Onyx Lorenzoni na Casa Civil, completando 4 cargos que trabalham diretamente dentro do Palácio do Planalto), tendo sido nomeados no total 8 militares dentre os 22 postos com status de ministério nos primeiros 60 dias de governo.

${ }^{62}$ Disponível em: https://apublica.org/2019/01/a-tropa-de-choque-de-bolsonaro-no-congresso/

${ }^{63}$ Disponível em: http://www.ri.gov.br/web/govest/exibeconteudo?article-id=281418 
abate de criminosos portando armas de uso exclusivo das forças armadas, nos termos do que determina o art. 25 do Código Penal; e aproveitamento de Oficiais com formação jurídica para defesa institucional dos militares que tiverem seus atos questionados na justiça (idem, p. 11 e 12). Portanto, além de expressamente propor a utilização do legado da intervenção no tocante às forças armadas, ainda propunha o "abate de criminosos" e a defesa dos militares que assim agirem.

As favelas também aparecem no diagnóstico da situação consignada no programa de governo.

O Rio de Janeiro tem gasto muito dinheiro e muito mal na segurança pública, enquanto os problemas fundamentais não são resolvidos. A topografia das comunidades dificultam as operações nos locais íngremes. Não há controle no tráfico de fuzis ou drogas que não são produzidos no Estado. Facções rivais continuam a pôr a população em risco. $O$ efetivo da polícia é insuficiente. Por outro lado as milícias são uma força tão ou mais perigosa que o tráfico de drogas e são favorecidas pela corrupção policial que não é combatida com a devida necessidade (TSE, 2019, p. 10).

Vê-se assim, mais uma vez, reiterada a relação das favelas, sob "comunidades", com a questão da segurança pública, mencionando inclusive sua "topografia". É interessante destacar que o documento ainda menciona como ação prioritária ${ }^{65}$ no campo da segurança que "O plano habitacional do Estado vai garantir que as comunidades tenham infraestrutura viária que possam facilitar a ação policial” (p. 11).

Vitorioso em uma campanha que repercutiu fortemente essa pauta, o governador, em seu discurso de posse, deu novamente grande ênfase ao tema da segurança.

\footnotetext{
${ }^{65}$ É importante destacar que não se trata da única proposta relacionada às favelas, as quais também aparecem no eixo relacionado à Habitação. Contudo, este eixo é um dos menos desenvolvidos no documento, sequer contando com ações propostas como os outros, tendo ainda muito menos ênfase do que o aspecto da segurança. Segue o que se encontra no documento. "Em relação às favelas é preciso trabalhar junto com as prefeituras e captar recursos do Governo Federal, para realizarmos um programa de urbanização consistente dessas localidades. Urbanizar as favelas como política pública inter-setorial para a provisão de serviços urbanos e para melhoria das habitações, por meio de assistência técnica, jurídica e administrativa, com a participação dos moradores em todo o processo. Abandonar as políticas de remoção e deslocamento forçado de populações, substituindo-as pela regularização integral, afinada com o Estatuto da Cidade. Será criado um programa de legalização fundiária desses imóveis, de forma que possam ser oficialmente incorporados ao patrimônio dos seus donos, aumentando o capital dos cidadãos fluminenses. Vamos aprofundar a parceria com 0 Governo Federal para a construção de casas populares e valorização da Companhia Estadual de Habitação do Rio de Janeiro" (idem, p. 43).
} 
Eu espero que o Congresso Nacional aprove uma lei antiterrorismo que enquadre os traficantes como terroristas para que eles possam ser abatidos de fuzil e a gente possa, de vez, encerrar essa polêmica. Já falei [com Bolsonaro] e estamos trabalhando nisso. Ele deve encaminhar para o Congresso, e nós vamos apoiar (...) Vamos focar no trabalho investigativo da lavagem de dinheiro e também na questão dos homicídios. Vamos retirar o poder do tráfico de drogas (GOVERNO DO ESTADO DO RIO DE JANEIRO, 2019)66.

Trata-se, portanto, da reiteração do discurso do narcotraficante como o inimigo a ser aniquilado a partir do uso da força, aprofundando o processo de militarização e, certamente, o controle social e territorial sobre os moradores de favela especialmente na capital.

Conforme apontam alguns pesquisadores (LEITE \& FARIAS, 2018, p. 245; BARROS, 2018, p. 283), este processo vivido pelo Rio de Janeiro configura uma espécie de laboratório para sua ampliação enquanto projeto de nação. "(...) há décadas, a cidade [do Rio de Janeiro] é considerada como "laboratório" de experiências em termos das políticas governamentais que configuram, no mínimo, a imaginação brasileira de como gerir territórios, populações e situações tidos como inajustáveis e/ou ingovernáveis" (LEITE \& FARIAS, 2018, p. 245)

Dessa forma, apesar de estar sendo enfocado ao longo das últimas páginas a situação de militarização vivida mais especificamente pela capital fluminense, é realmente possível enxergar indícios de que se trata de um fenômeno crescente em nível nacional. Além dos exemplos já citados anteriormente (relativos ao plano federal e ao caso específico do Ceará), as eleições para governador do estado de São Paulo também apontam nesse sentido.

Há anos a vertente da maior repressão e "guerra ao crime" já vem ganhando espaço no estado em detrimento de uma vertente baseada no discurso de direitos, como demonstra Feltran (2018). Nesse sentido, a campanha para governador de 2018 trouxe fortemente o discurso do recrudescimento da violência e repressão policial como estratégia para o combate aos grupos criminais, com ênfase sobre narcotraficantes. Diferentes declarações do candidato eleito, João Dória Jr., apontavam nesse sentido, a exemplo de 
quando afirmou em 02 de outubro, poucos dias antes da votação do primeiro turno, que a polícia militar atiraria para matar a partir de Janeiro de 2019, caso fosse eleito ${ }^{67}$. Afirmou ainda que iria "pagar melhor o salário de advogados que defenderem policiais que matarem bandidos", em vídeo divulgado no dia em que foi eleito ${ }^{68}$. Recém empossado, reafirmou suas intenções ao declarar, em 11 de janeiro de 2019, que "a partir de agora, em São Paulo, imobilização do bandido que estiver armado, se ele ainda assim reagir, ele não vai para a delegacia, nem para a prisão, ele vai para o cemitério"69.

Se a repressão recorre no plano discursivo à retórica do enfrentamento aos "bandidos", a prática demonstra que a classificação como bandido é estendida a partir dos interesses políticos supervenientes. A repressão às manifestações políticas já começam a ser novamente endurecidas por parte da Polícia Militar em Janeiro de $2019^{70}$ e o governador emite decreto que apresenta restrições inconstitucionais ao direito de manifestação com intuito de desmobilizar ações coletivas $^{71}$, como a imposição de trâmites burocráticos à realização de atos públicos, dentre outros. Até mesmo manifestações culturais, não estritamente políticas, estão sendo combatidas com uma atuação truculenta por parte da polícia, como a dispersão de blocos carnavalescos nas semanas anteriores à festa sob balas de borracha, confronto físico e até mesmo detenção de foliões e equipamentos musicais. Nem mesmo a maior das tradições culturais brasileiras parece conseguir passar incólume ao processo de militarização em curso.

67 Disponível em: https://www1.folha.uol.com.br/poder/2018/10/a-partir-de-janeiro-policia-vaiatirar-para-matar-afirma-joao-doria.shtml

68 Disponível em: https://noticias.r7.com/sao-paulo/advogados-criticam-fala-de-doria-sobrepagar-defesa-de-pms-29102018

${ }^{69}$ Disponível em: https://www.cartacapital.com.br/opiniao/joao-doria-orienta-pm-a-aplicar-penade-morte-em-sp/

70 Disponível em: https://www.redebrasilatual.com.br/cidadania/2019/01/policia-cercamanifestacao-contra-aumento-da-passagem-em-sao-paulo

71 Disponível em: http://www.justificando.com/2019/01/23/decreto-aviso-previo-mascarasmanifestacoes-inconstitucional/ 
Conclui-se esse capítulo, assim, reiterando que esta lógica de crescente militarização que se espraia progressivamente pelos diferentes setores da vida política no plano nacional e em diferentes estados tem irradiado das próprias intervenções em favelas, como demonstrado para o caso do Rio de Janeiro. Neste exemplo, inclusive, as iniciativas de urbanização de favelas foram utilizadas para o projeto de "PACificação" do poder público, reposicionando a relação entre a pauta da violência urbana/segurança pública e a intervenção em favelas/urbanização de favelas.

Toma-se a liberdade de utilizar, para encerrar este capítulo uma frase de Cavalcanti (2013, p. 198), explicitando a perspectiva vivida em Manguinhos com a implementação das UPPs e do PAC-Urbanização de Favelas "em Manguinhos, em tempos de PAC e UPP, tudo está mudando e pode mudar, mas, por enquanto, nada mudou. É o que contam os moradores". No momento atual do Brasil, a perspectiva é diferente no sentido de que, se parece que a violência e a questão da segurança no Rio de Janeiro e em outras cidades brasileiras não mudou, na verdade tudo está mudando e pode ainda não mudar. O experimento no Rio de Janeiro pode se aprofundar e se disseminar para outras cidades como modelo, ou não. Trata-se de um projeto em experimentação, seu alcance ainda não está dado, embora seus indícios já sejam muito preocupantes. 


\section{CONCLUSÃO - por que é difícil o estabelecimento de uma agenda permanente para a urbanização de favelas hoje?}

Ao longo da tese, procurou-se comprovar a hipótese inicial de que a satisfação de direitos e necessidades habitacionais nos assentamentos populares seria mediada politicamente, submetendo os processos de formulação e implementação das iniciativas de urbanização de favelas às necessidades políticas e ao ciclo eleitoral, a interesses econômicos e de grupos empresariais e a processos sociais mais amplos, como a violência urbana. Com sinceridade e sem demérito nenhum, é preciso apontar que esta hipótese mostrou-se, ao menos em parte, errada.

Seria uma conclusão simplista que pouco contribuiria para a reflexão sobre os alcances e limites desse campo de atuação pública. Não se trata de um processo de submissão das políticas de urbanização de favelas a processos políticos, econômicos e sociais, mas sim de uma relação de mútua alimentação entre eles, com oscilações no peso conferido a cada uma das partes da equação em diferentes momentos e/ou contextos.

O primeiro capítulo provou, justamente, que foram as condições políticas colocadas pelo contexto de redemocratização, do discurso de direitos e da reivindicação/efetivação de uma maior autonomia dos governos locais que favoreceram a ascensão das primeiras iniciativas que efetivamente conseguiram alcançar escala e importância no Brasil, na Colômbia e internacionalmente. Portanto, a política e processos amplos de mobilização social não submeteram ou dominaram as ações de urbanização de favelas no período. Ao contrário, foram justamente fatores que impulsionaram estas iniciativas, serviram de base a elas.

Isso, de forma alguma, significou que se tratavam de iniciativas que não atendiam a interesses políticos e/ou econômicos de atores pertencentes às gestões públicas e ao setor empresarial, como demonstrado no segundo capítulo. Como todas as ações praticadas no âmbito de governos democráticos, renderam maior ou menor capital político para essas 
administrações e foram por isso mobilizadas em momentos de disputa eleitoral. É "a vida como ela é", é o jogo democrático.

Maior prova de que as iniciativas de urbanização gozam de um local específico na reprodução de mandatos políticos e na dinâmica econômica de grupos empresariais é o fato de ser verificada a participação de todo o tipo de atores políticos e econômicos ao longo dos últimos trinta anos. Inicialmente alguns autores (ARRETCHE, 1990 e 1996; CARDOSO E RIBEIRO, 2002, p. 15) classificavam a urbanização de favelas como característica ou mais propensa de acontecer em gestões progressistas ou de esquerda, discurso ainda hoje reproduzido por alguns entrevistados.

Em que pese o Maluf também ter feito urbanização de favela, eu acho que ela é sempre uma pauta de governos com uma agenda mais à esquerda, em termos de, digamos, de uma agenda que tenha como seu componente o tema da desigualdade, porque a favela, ela é a expressão território dessas igualdades de uma maneira bastante evidente, então eu acho que tem esse componente, ele é importante como uma questão (ENTREVISTADO 07).

Se é verdade que inicialmente a ascensão da urbanização de favelas está de algum modo conectada com o movimento das prefeituras progressistas ou democráticas (MARQUES, PULHEZ \& PAGIN, 2018), esta forma de intervenção pode ser encontrada tanto em gestões públicas de partidos de esquerda (como Erundina) quanto de centro ou direita (vide exemplos de César Maia e das gestões Serra/Kassab). Ou mesmo pode estar ausente ou gozar de baixa prioridade em gestões de esquerda (como no caso dos governos de Marta Suplicy e Haddad).

Ocorreu assim, desde a década de 1980, uma mudança no perfil das intervenções em favelas, de acordo com Marques, Pulhez \& Pagin (2018, p. 148). De início a postura de administrações municipais de direita tendiam a defender a remoção destes assentamentos, enquanto as de esquerda advogavam pela sua urbanização e regularização. Ao longo do tempo, contudo, essa diferença vai se diluindo, sendo esta última forma de intervenção também incorporada por governos de direita. Para os autores seria uma evidência tanto da incidência de agências internacionais sobre o tema, como de um aprendizado institucional entre governos de partidos rivais, gozando de enfoques e ênfases distintas na implementação de projetos. 
Se se tomar como ideia que remoções seriam características de governos de direita e urbanização, de governos de esquerda; também se poderia argumentar que a esquerda passa por um processo de incorporação de formas de atuação da direita, havendo uma ascensão das remoções forçadas no período de preparação de cidades brasileiras para os megaeventos esportivos da década de 2010, processo fomentado pelo governo federal administrado pelo PT. A afirmação pode ser exagerada, tendo em vista que muitos desses processos de remoção se deram em função de decisões em âmbito local, enquanto o governo federal se ocupava principalmente do financiamento das iniciativas. Mesmo assim, é irônico perceber a ascensão de uma nova onda de remoções de favelas (como há décadas não se via) no período do governo do Partido dos Trabalhadores no governo federal, o qual gradualmente vai também reduzindo o financiamento de ações de urbanização e migrando sua energia para a provisão habitacional, como demonstrado no segundo capítulo.

A ideia de aprendizado permanece, contudo, válida em termos de análise da atuação de governos de direita, explicitando pelo menos uma análise mais matizada sobre os fatores que levam a esta atuação do que se pode encontrar na literatura sobre o tema. Akaishi (ET AL, 2018), por exemplo, apontam alguns possíveis fatores para a inclusão de ações de urbanização por administrações de direita: pressão realizada por movimentos sociais, inércia de projetos iniciados em gestões progressistas anteriores e diretrizes de financiamento internacional. Todos os motivos apontados seriam externos à administração local, colocando a motivação das ações de urbanização em ações capitaneadas por outros sujeitos que não os agentes políticos das administrações conservadores. No limite, parece haver uma necessidade, por parte dos autores, de justificar a existência de ações de urbanização em governos de direita, partindo de um pressuposto não expresso que estas administrações não têm interesse em executar esse tipo de política. O segundo capítulo da tese buscou, precisamente, demonstrar como existem motivações endógenas a esses governos conservadores para fomentar iniciativas de urbanização de favelas.

Além disso, a análise efetuada na tese também buscou explicitar que, como apontado por Marques, Pulhez e Pagin (2018), há fatores institucionais que 
contribuem para a permanência e até mesmo aprofundamento das experiências de urbanização em diferentes gestões. Para além de programas ou projetos porventura iniciados, o corpo técnico das administrações, a experiência acumulada por ele e até mesmo um componente de empenho pessoal e militância (FERREIRA, 2017) podem ser muito significativos, como demonstra o caso do Favela-Bairro.

Na análise do caso colombiano, demonstrou-se também que todas as gestões mesmo com diferentes orientações políticas e partidárias - têm constantemente atuado de alguma forma neste tema. Serve também, no entanto, para demonstrar que essa atuação tem enfoques diferentes de acordo com a orientação política e, em geral, goza de uma baixa prioridade em detrimento da oferta/provisão independentemente do espectro político partidário (ENTREVISTADO 20; ENTREVISTADO 25).

O caso de Bogotá demonstra que, se a prioridade do mejoramiento em relação a outras políticas não se altera muito em função do partido, já o enfoque e a prioridade dada aos diferentes componentes dentro dos próprios programas de mejoramiento barrial mudariam de acordo com a orientação política da administração municipal.

Digamos, en los gobiernos que son considerados de izquierda se ha preocupado más por la cobertura en términos de educación de la periferia informal digamos, que aunque no se parta el programa de mejoramiento, en la práctica es mejoramiento pero no de manera articulada. Entonces se han preocupado con la cobertura escolar o sea, preocupado con la educación en primera instancia, en los temas de alimentación. Se han preocupado con temas de bienestar social, digamos que ha habido programas sociales efectivos, educación, salud, bienestar social no vinculados a los problemas territoriales. (...) la administración de Bogotá que más ha construido parques fue la primera administración de Peñalosa [de derecha]. Entraron proyectos políticos de izquierda y ninguno le dio prioridad al tema de espacio público y de calificación de la calidad urbanística de la periferia. (...) Lastimosamente se ha venido asociando a que los temas de infraestructura (como intervenciones duras físicas visibles duradas en el tiempo) con un enfoque más de derecha que de izquierda y que las preocupaciones de las políticas públicas de izquierda son los programas sociales que tienen que ver con la reproducción de la sociedad pero a mí me parece que eso es un enfoque raro. (...) Es a partir de la polarización entonces, Peñalosa dice "yo tengo que recuperar Bogotá de la alcaldía de Petro", entonces cuál es la manera de venderse? Y es que desmonta lo que el otro viene haciendo y monta cosas que el otro no hacía (ENTREVISTADO 02).

Haveria, assim, uma polarização nas intervenções e na agenda política de partidos de esquerda e direita, cabendo aos primeiros mais ações relacionadas à reprodução social (educação, alimentação, etc.) e aos últimos temas mais 
ligados à intervenção física (vias, etc.). Em todo caso, a prioridade ao mejoramiento barrial é baixa nos diferentes espectros partidários, cabendo mais as intervenções do ponto de vista da proximidade com suas agendas, seja de políticas sociais, seja de realização de obras físicas.

No Brasil, e especialmente no caso de São Paulo, também é possível enxergar alguns matizes que diferenciam as intervenções promovidas por partidos de esquerda e direita. Os primeiros tenderiam, a exemplo da gestão de Erundina, buscar intervir com uma mão mais leve e com uma precisão mais cirúrgica, consolidando o tecido existente que pode ser consolidado e intervindo apenas onde haveria essa necessidade (ENTREVISTADO 19; ENTREVISTADO 12). Algumas intervenções de administrações conservadoras teriam, ao contrário, um viés mais higienista e uma perspectiva civilizatória (como no caso do Cingapura implementado por Maluf) ou uma perspectiva estética que adota padrões provenientes de outras formas de morar (pertencentes a outras classes sociais) descolados em relação à cultura e ao contexto local (como conjuntos promovidos nas administrações Serra/Kassab). Muitas vezes, desconsidera-se completamente as dinâmicas locais estabelecidas na configuração histórica do território alvo de intervenção, no qual existem lógicas e racionalidades para além dos padrões estéticos e urbanísticos dominantes (NISIDA, 2017).

Não é só os governos progressistas que aderiram a urbanização de favela, 0 governo conservador fez, tipo o Maluf fez o Cingapura, essas coisas assim (...) Tem um segmento sanitarista, que visa também um pouco eliminar um incômodo, sei lá, é uma visão segregacionista, mas que a ideia de investir é um pouco que a favela desvaloriza o entorno, essas coisas. Teve uma fase de algumas gestões que talvez priorizaram em função disso. Eu vejo muito a operação urbana, a Águas Espraiadas, por exemplo, como um grande desastre, fizeram, ainda tem lá uns resquícios de favela, mas a ideia de investir em favela, produzir moradia pra quem mora na favela pra viabilizar... a Água Espraiada é como um eixo de desenvolvimento imobiliário... (...) Os tipos de intervenções também são diferentes [entre esquerda e direita]. [Aqueles de direita] são um pouco mais assim com essa visão elitizada da cidade; por exemplo, os projetos do Renova tem muito disso, assim, de você colocar aqueles prédios bonitinhos, substitui barraco por predinhos bonitinhos, tem muitas áreas de favela. A gente estava analisando junto com o João [secretário de habitação no final da gestão Haddad], que daria pra fazer uma urbanização clássica, do tipo entrar com a infraestrutura... Tem projeto que tirava todo mundo e põe prédio no lugar. Aí você vai ver, assim, tira 400 famílias e constrói 300 unidades (ENTREVISTADO 12).

No caso das administrações estadual e municipal no Rio de Janeiro nas últimas décadas lideradas pelo PMDB, de centro, o partido urbanístico das 
intervenções nos grandes complexos teve grande influência do financiamento do PAC. Assim, menos do que o espectro político-partidário, a perspectiva de urbanização foi influenciada pelo componente emblemático e fatores econômicos trazidos pelo programa federal em conjugação com o contexto político local.

Outro ponto que merece ser destacado da análise é que as disputas dentro de cada partido também podem fazer com que as políticas desenhadas por diferentes prefeitos sejam diferentes mesmo que pertençam ao mesmo partido político. Ou até mesmo que, dentro da gestão de um mesmo prefeito, seja possível encontrar diferentes enfoques e prioridades em relação à urbanização de favelas.

No caso de Bogotá, por exemplo, entre 2004 e 2011 duas gestões consecutivas pertenciam ao partido Polo Democrático Alternativo - os alcaldes Luis Eduardo Garzón e Samuel Moreno Rojas - e às quais a gestão de Gustavo Petro (Progresistas) de 2012 a 2015 também estava alinhada, o que, no entanto, não significou de forma alguma a manutenção, continuidade ou aprimoramento dos programas existentes. Ao contrário, em cada uma delas se promoveram novos programas ou mudanças substanciais aos programas existentes para que tivessem a marca da respectiva gestão.

Porque además, en las tres últimas administraciones - no la que está ahorita - las que eran de izquierda, cada uno bailaba distinto. Entonces, a pesar de que todos eran de un partido, uno ha venido a borrar lo que había hecho el otro. 0 sea, no le dieron continuidad a eso, y es un fracaso (ENTREVISTADO 20).

Um exemplo também apresentado por entrevistados se relaciona a diferenças encontradas no âmbito do Favela-Bairro entre as gestões de César Maia e Conde, consideradas continuidade política tendo em vista que este havia sido eleito sucessor por indicação daquele.

Não é sutil, as vezes são diferenças bem grandes. Do próprio César Maia pro Conde, que foi o substituto do César Maia, teve diferenças. O César Maia tinha uma lógica muito de intervenção urbana, de infraestrutura urbana, mas ele nunca se colocou diante da ideia dos Ecolimites. Os ecolimites pelas favelas, nos anos 90, foram discutidos no governo do Conde, que ele dizia o que, as favelas estavam crescendo, ocupando as áreas das encostas da Floresta da Tijuca, então você tinha que estabelecer um limite, só que você estabelece um limite para a expansão de favelas, mas não estabelece o limite para a expansão de condomínios de luxo. Aqui na Maré, por exemplo, quem vem do aeroporto vê a mureta na Linha Vermelha, tem uns painéis assim, que é o tal do isolamento acústico, foi apresentado como isolamento acústico pra proteger a comunidade, 
mas ele quer o que, é pra atrapalhar a favela. Aquilo foi uma política do Conde, diferente da política do César Maia. A gestão do Conde é substituta do César Maia, a equipe política e a equipe técnica que está às vezes faz diferença (ENTREVISTADO 30).

Não apenas entre prefeitos, há disputas de visão, por exemplo, também dentro das secretarias ou entre gestores diferentes numa mesma gestão. Em Bogotá, houve secretarias mais propensas ao viviendismo e outras mais propensas ao mejoramiento na gestão do mesmo prefeito (ENTREVISTADO 25). No caso de São Paulo, isso também se verifica na administração de Fernando Haddad. Enquanto os três primeiros anos a Secretaria de Habitação teve um enfoque muito mais dedicado à oferta/provisão habitacional, em função do perfil político do secretário (comentado no capítulo 2); no final da gestão houve uma tentativa de guinada na política a partir da entrada de um novo secretário conectado com setores mais progressistas e sensíveis a outros temas habitacionais, expressos na proposta de Plano Municipal de Habitação encaminhado à Câmara de Vereadores ao final de sua gestão (ENTREVISTADO 19; ENTREVISTADO 12; ENTREVISTADO 28).

Além de terem sido iniciativas implementadas por diferentes correntes políticas ao longo das últimas décadas (ressalvadas as diferenças quanto aos enfoques conferidos), a urbanização de favelas também contou com a participação de diferentes atores privados neste período. Contemplando setores diversos da economia (desde o mercado imobiliário informal, passando pelo setor de comércio e serviços e o setor do turismo, chegando até a concessionárias e empresas de serviços públicos), a intervenção em favelas ofereceu negócios para uma grande diversidade de atores privados, desde pequenas até macroempreiteiras, propiciando assim a manutenção das relações historicamente estabelecidas entre "estado-setor da construção civil". Serviam, dessa forma, como mecanismo macroeconômico de aquecimento da economia e, ao mesmo tempo, de fonte de capital político (com a construção de obras e projetos emblemáticos, símbolos da inovação e do compromisso de gestões públicas com as favelas e a cidade) e financeiro para a reprodução de mandatos políticos (através de doações de campanha). Todos esses elementos situados plenamente dentro do campo da legalidade e do esperado no jogo democrático dentro dos quais se situam as políticas públicas. 
Por outro lado, não se pode omitir que as ações de urbanização de favela também fomentaram, e ainda fomentam, processos políticos e econômicos que justamente minam a institucionalidade democrática. Embora não tenha sido propositamente enfatizado o tema da corrupção nesta tese (basta para tanto abrir os jornais dos últimos anos no Brasil), é um fato com impactos significativos para a delimitação e resultados dessas intervenções (PATRICIO, 2017).

Não apenas a corrupção, mas também aspectos clientelistas de utilização das intervenções em favela como fonte de capital eleitoral também continuam a minar essa institucionalidade democrática. Diferentes gestores entrevistados apontaram como tais relações, ainda hoje estabelecidas nas quatro cidades investigadas, minam o estabelecimento de um processo planejado e universal de atendimento às demandas complexas apresentadas pelos assentamentos populares. Em maior ou menor grau, todas as administrações à frente do executivo municipal foram obrigadas a dialogar com estas demandas, estratégicas para o estabelecimento de relações com membros do legislativo local, do qual dependem muitos aspectos da execução de políticas municipais. A urbanização de favela está relacionada (mas mais uma vez, não submetida) às conexões políticas entre membros da classe política (entre si) e entre estes e a população moradora dos assentamentos.

É preciso atentar, contudo, que não se tratam de relações estabelecidas unidirecionalmente, em nenhum dos casos, em nenhum dos momentos. Mesmo relações clientelistas estabelecidas fortalecem e são úteis, em alguma medida, às populações ou, no mínimo, às lideranças que trabalham na intermediação. As conexões entre Executivo e Legislativo idem, havendo ganhos políticos para ambos de maneira a reproduzir seus mandatos ou, até mesmo, conseguir realizar políticas que efetivamente contribuam para a efetivação de direitos. A simbiose entre "estado-setor da construção" também é profícua para ambas as partes, crescendo juntas e se retroalimentando.

A conclusão a que se chega, portanto, é de que há uma inexorável dimensão política que atravessa as várias camadas de urbanização de favelas (ADAUTO \& DENALDI, 2018) abordadas nesta tese. Composta de feixes de relações 
bilaterais ou multilaterais estabelecidas entre os diferentes atores, essa dimensão entrelaça a política (com "p", a política setorial) com a Política (com "P", na acepção ampliada de sistema político), ambas alimentando e sendo simultaneamente alimentadas uma pela outra.

Diante desse entrelaçamento, o que explicaria então as oscilações de prioridade conferida à urbanização de favelas no âmbito dos governos municipais? Para responder a essa questão, é preciso imergir na gestão pública e compreender que esta - para longe de ser monoliticamente controlada pela vontade de prefeitos e gestores - é conformada por interesses e posicionamentos diversos, por vezes até mesmo conflitantes. Além da disputa com interesses em outras pastas, a urbanização de favela lida, desde seu próprio nascimento, com uma contenda no seio familiar, quase uma competição entre irmãs ou frenemies $^{72}$ : oferta/provisão habitacional $\mathrm{x}$ urbanização $^{73}$.

A comparação entre ambas formas de atuação no campo habitacional, conquanto constantemente mencionadas como complementares (boas irmãs, que se harmonizam e se completam, um "ganha-ganha"), revela-se muitas vezes de "ganha-perde" em função de um sopesamento dos diferentes benefícios provenientes da implementação de cada uma delas em contexto de suposta limitação de recursos para a habitação como um todo.

Em um trade-off entre ambas formas de intervenção, a oferta/provisão atenderia melhor a diferentes interesses. Enquanto classicamente compreendida como instrumento de intervenção macroeconômica do estado (KLINTOWITZ, 2015), a oferta/provisão pode ser considerada como a irmã mais velha e portadora de maior popularidade, atendendo historicamente a

\footnotetext{
${ }^{72}$ Frenemy ou frenemies de acordo com o Urban Dictionary "A person in your life (usually friend of friend or coworker) that you get along with and enjoy overall company but will cut you down with virtually any opportunity with mostly backhanded compliments or jabs. Always roots for you to do good, but just not better than them. Normally stemmed from some jealousy to any or all aspects of your life". Disponível em:

https://www.urbandictionary.com/define.php?term=Frenemy

73 Pede-se desculpas ao leitor pela licença poética (inspirada em séries e filmes hollywoodianos, de perspectiva muitas vezes machista e heteronormativa) adotada para a comparação realizada a seguir entre provisão e urbanização de favelas.
} 
interesses de grupos empresariais que cresceram sob seu auspício. A urbanização de favelas passou por uma fase em que era praticamente a irmã feia e rejeitada que precisa de validação externa (internacional, no caso) para obter a atenção dos pais, além de precisar provar seu valor constantemente para manter esta atenção. Rejeitada por pretendentes em sua adolescência, a urbanização precisou florescer para se mostrar interessante e atrair empresas em sua implementação. De princípio, inclusive, atraía também aqueles pretendentes pouco destacados, empresas de pequeno e médio porte, passando apenas anos depois, com seu debut promovido na escala propiciada pelo PAC, a atrair os campeões do setor, como as macro-empreiteiras.

A escolha de um programa de produção de moradia como estratégia para um momento de crise vai ao encontro de duas diretrizes do governo do presidente Lula. Primeiro, realizar desenvolvimento e crescimento eco nômico com inclusão social. No PAC, isso foi marcado quando pusemos a urbanização de favelas como um dos eixos na infraestrutura urbana e social. E agora, num momento de crise, considerar não apenas a construção civil, mas a produção de moradia como estratégia reforça novamente esse compromisso. A construção civil responde muito rápido aos investimentos, é uma área de mão-de-obra intensiva, em que os insumos são quase todos nacionais. Em segundo lugar, a diretriz de estimular o mercado também foi contemplada. É um programa que tem questões imediatas e outras estruturais. A instituição, por exemplo, do Fundo Garantidor é um dos componentes que já estava previsto no Plano Nacional de Habitação (PlanHab), uma estratégia de longo prazo. A elaboração do programa contou com o diálogo de todos os segmentos que têm uma interface com a questão da moradia, desde movimentos sociais até a cadeia da construção, tentando tirar uma fotografia dos principais gargalos que temos para dar conta dessa meta de construir 1 milhão de moradias no menor prazo possível (ENTREVISTA INÊS MAGALHÃES, 2009) ${ }^{74}$.

Ainda no aspecto da popularidade entre as irmãs rivais, a oferta/provisão é a mais "bonita" e com maior apelo junto à população. Sua visibilidade rende maior capital político junto à população em geral, além de render fotografias para ações de divulgação e marketing, com imagens síntese muito mais eficientes. "É obvio que pra um gestor é mais fácil entregar a chavinha na inauguração, na favela isso é mais difícil, então concentrou tudo" (ENTREVISTADO 09).

Claro, é muito mais impactante inaugurar um conjunto habitacional do que inaugurar uma urbanização de favela. É lógico que politicamente falando, do ponto de vista político, é mais interessante, tem uma conjugação de fatores que leva muito mais o Minha Casa, Minha Vida do que favela. (...) Se comparar com

${ }^{74}$ Entrevista com Inês Magalhães, então Secretária Nacional de Habitação, realizada pela Fundação Perseu Abramo, ligada ao PT. https://teoriaedebate.org.br/2009/05/01/moradia-promove-inclusao-social-e-combate-a-crise/ 
urbanização de favela, você inaugura o Minha Casa, Minha Vida... Você vai inaugurar urbanização de favela como? Vai passar a fita onde na urbanização de favela, na rua que abriu? Então não aparece, a urbanização não aparece, urbanização de fato, correta, com regularização fundiária, com saneamento, isso não surge (ENTREVISTADO 26).

E a questão política, porque é muito mais fácil construir casinha e entregar a chave, e aparece. O Minha Casa, Minha Vida você está passando na estrada, você vê ele lá, o cara passando na avenida e vê ele lá. $O$ que acontece dentro da favela, aqui em São Paulo ainda por cima, ninguém sabe. Quem sabe de Cantinho do Céu? Zero visibilidade política. Quem sabe o que aconteceu em Heliópolis? Zero. Quem sabe o que aconteceu em Real Parque? Zero, só quem mora ali vizinho que viu (ENTREVISTADO 01).

O apelo da entrega e inauguração é sedutor demais como característica da oferta/provisão, encantando não apenas à população (principalmente sob a perspectiva da ideologia da casa própria, historicamente mobilizada no país e no mundo), mas encantando os próprios gestores como candidatos. Os atores políticos vivem um estado de permanente candidatura que é beneficiado com os dividendos políticos das mais diversas fontes, incluindo a urbanização. No entanto, são constantemente confrontados com escolhas e exigências de priorização. Como uma irmã com gênio considerado "mais difícil" (highmaintenance), a urbanização de favelas oferece maior complexidade na sua implementação e, com isso, um maior desgaste político também, lidando com um território já ocupado e que goza de dinâmicas próprias.

A lógica é que você não consegue dar conta de tudo, você nem tem tanta gente pra organizar tudo isso, trabalhar com tudo isso. E grana também, você não tem dinheiro, urbanização de favela é um negócio caríssimo, não tão caro quanto fazer essas porcarias do Minha Casa, Minha Vida, mas é caro. E é muito mais caro politicamente até do que financeiramente, eu acho. É, porque você tem que mexer com pessoas, tem que tirar gente daqui, tem que tirar gente de lá... Realoca, discute... (ENTREVISTADO 18).

Diferentemente da oferta/provisão, geralmente realizada em terra rasa, a ação de urbanização é obrigada a lidar com essas dinâmicas territoriais consolidadas muitas vezes há décadas (NISIDA, 2017). Com isso, este tipo de intervenção "roda" mais devagar e perde no quesito celeridade de entrega de resultados, uma das razões observadas, por exemplo, para o crescimento do MCMV sobre o PAC-Urbanização ainda na gestão do PT à frente do governo federal. O tempo da urbanização (PETRAROLLI, 2015) é outro, é mais parecido com o tempo da vida. O tempo da oferta/provisão está mais próximo ao tempo do capital e sua necessidade de circulação.

Ela [oferta/provisão] tem uma governabilidade maior, você constrói em um terreno limpo, você licita, você entrega. Ela tem uma velocidade maior do que a 
urbanização da favela, ela mostra resultados "mais rápidos" (...) [A urbanização] tem um outro tempo, o tempo não é o mesmo, o território é diferente, a complexidade da obra é diferente. Não tem o mesmo tempo de uma obra nova, e isso é complicado pros tempos de governo (ENTREVISTADO 17).

Toda essa competição entre as irmãs ou frenemies, a oposição "oferta/provisão x urbanização de favelas" não explica sozinha as oscilações da prioridade conferida à urbanização ou a dificuldade em se estabelecer uma agenda pública permanente de intervenção estatal no tema. Há outros fatores políticos e institucionais que não necessariamente estão conectados com essa disputa.

Um elemento central quando se analisa os argumentos da literatura e dos atores entrevistados acerca da formulação e implementação de iniciativas de urbanização de favelas nas quatro cidades é a questão orçamentária, sendo sempre apresentada a falta de recursos ou a continuidade deles como um dos principais gargalos para esta política. No entanto, poucas delas problematizam a o real significado dessa questão e abordam suas causas, não fazendo qualquer ligação com ciclos ou crises econômicas/orçamentárias e geralmente apenas apontando de forma genérica a diminuição da prioridade da urbanização na agenda política ou a saída de recursos internacionais (empréstimos, financiamentos, doações, etc.).

No caso da Colômbia, historicamente, a grande parte das ações de mejoramiento barrial é feita com recursos próprios dos municípios, como afirmam quase todos os entrevistados (ENTREVISTADO 25; ENTREVISTADO 02; ENTREVISTADO 20; ENTREVISTADO 24; ENTREVISTADO 10; ENTREVISTADO 15). Este fato traz algumas consequências para 0 mejoramiento, sendo a primeira delas o fato de então estar incluído na disputa por orçamento, entre as diferentes demandas e necessidades que a cidade apresenta. Nesta disputa, entre as diferentes secretarias e suas demandas, cada uma delas tem que demonstrar que fez mais ou está gerando mais capital político para justificar que receba uma parcela maior do orçamento (ENTREVISTADO 25). Nesse sentido, a provisão oferece novamente mais vantagens do que a urbanização de favelas (como já analisado), tendo em vista que apresentam resultados mais rapidamente e, assim, justificam uma maior liberação de recursos. 
Embora a maior parte dos programas seja financiada por recursos dos próprios municípios, há outras fontes de receita que também compõem sua sustentabilidade, como recursos internacionais, do governo nacional e até mesmo da própria população. Exemplo deste último caso foi o programa Obras con Participación Ciudadana, implementado em Bogotá entre 2003 e 2008, através do qual foram realizadas 169 obras públicas - dentre parques, vias peatonais, escadarias, etc. - em que a participação da comunidade se dava tanto na definição e implementação das intervenções quanto no seu financiamento. Esta era responsável por aportar em torno de 5\% do orçamento total através da disponibilização de mão de obra, de materiais ou de recursos financeiros angariados, objetivando com isso aumentar o sentimento de apropriação e o fortalecimento comunitário (CADENA, 2010, p. 112-114). Além disso, em casos de reassentamento de famílias em novas unidades produzidas no contexto de intervenções de urbanização, estas se vêm muitas vezes na obrigação de contribuir, mesmo que pouco, para o valor total da unidade (ENTREVISTADO 15).

Do ponto de vista do financiamento, o papel assumido pelo governo nacional é muito tímido na Colômbia. Segundo informações do próprio Ministério de Vivienda (2014, p. 75), o seu Programa de Mejoramiento Integral de Barrios (PMIB) promoveria apoio técnico, jurídico e financeiro a municípios para a realização de intervenções físicas, sociais, ambientais, econômicas e jurídicas em assentamentos de origem informal, tendo financiado ações em "nueve municipios representativos del territorio nacional, la incorporación de 62,74 ha a las dinámicas del desarrollo urbano y el impacto directo a una población de 14.301 habitantes en condiciones de extrema pobreza y vulnerabilidad. La inversión fue de \$ 40.421 millones, de los cuales el Ministerio aportó el 72,42\% de los recursos (...)" (MINISTERIO DE VIVIENDA, 2014, p. 76-77). Este governo estaria, assim, praticamente ausente na temática, financiando apenas em alguns casos muito específico somente intervenções físicas em pequenas e médias cidades (ENTREVISTADO 20).

Uma fonte de financiamento que se mostrou efetivamente central para a formulação e implementação de iniciativas de mejoramiento em Medellín, Bogotá, São Paulo e Rio de Janeiro são os empréstimos, financiamentos e 
doações obtidos junto a bancos e agências internacionais captados diretamente pelos próprios municípios, beneficiando programas que obtiveram destaque como PRIMED, PMIB, Favela-Bairro, Programa Guarapiranga, dentre outros. A disponibilidade destes recursos, segundo entrevistados teria sido um dos elementos centrais para explicação da ascensão ou descenso das iniciativas de urbanização de favelas em algumas cidades. Dentre essas iniciativas financiadas, seria importante destacar alguns elementos que possibilitem matizar a real dependência desses recursos.

O caso do programa Dermaginalización em Bogotá - construído a partir do plan de desarrollo de 1998, sendo seu programa prioritário (SAENZ, 2013, p. 28) - é interessante em função de ter construído um esquema em que, além dos recursos orçamentários ordinários previstos, baseava-se na estimativa de venda da empresa pública de telefonia da cidade (ENTREVISTADO 10). Em função de diversas resistências, a venda terminou não sendo concretizada e a forma encontrada para complementação do recurso necessário foi o remanejamento de recursos provenientes de um empréstimo do Banco Mundial para outro programa. Isso demonstra que, quando o programa goza de fato de prioridade na agenda política (mesmo que por pouco tempo), a falta de recurso pode ser sanada com remanejamentos a partir de outros programas, não constituindo, portanto, um verdadeiro empecilho (SAENZ, 2013, p. 37).

Por outro lado, no caso do PMIB em Bogotá, entre os anos de 2001 e 2006, a presença de recursos internacionais, fornecidos pelo banco KFW - que desde o ano 2000 apoiava a implementação de projetos sociais e investimentos em equipamentos comunitários e espaços públicos, como forma de melhorar condições de segurança e convivência (CADENA, 2010, p. 114-115) e pelo Banco Mundial (que disponibilizou recursos para implantação de sistemas de mobilidade e saneamento), possibilitaram um nível de investimento sem precedentes para a cidade (ENTREVISTADO 10; SAENZ, 2013, p. 47). No entanto, a partir da metade da década, tanto a cooperação alemã quanto 0 Banco Mundial suspenderam os créditos anteriormente aprovados e pararam a liberação de recursos, segundo entrevistados por não verem claridade no desenvolvimento das ações financiadas, as quais estariam sendo mal conduzidas e apresentando poucos resultados (ENTREVISTADO 20). Neste 
momento, diferentemente do que aconteceu com o Desmarginalización, a diminuição dos recursos significou a redução da atuação de mejoramiento por parte do município (SAENZ, 2013, p. 74; ENTREVISTADO 20).

No caso das cidades brasileiras, é importante mencionar a centralidade apontada em relação à dependência de financiamento e transferências de recursos externos ao município para a realização de urbanizações de favelas. Certamente, trata-se de componente que foi fundamental para a ampliação da escala de intervenção das iniciativas municipais. No entanto, também é importante apontar que muitas delas foram iniciadas sem qualquer fonte externa. No caso, por exemplo, do Favela-Bairro e do programa de urbanização implantado na gestão de Luiza Erundina, ambos começaram no contexto de uma crise fiscal e sem recursos de outros atores, apenas posteriormente obtendo financiamentos internacionais.

Vale salientar, ainda, que na gestão de Fernando Haddad, como já mencionado, recurso que estava destinado a obra de implantação de infraestrutura em urbanização financiada pelo PAC foi remanejado para a construção de hospital. Embora completamente legal e dentro do escopo de provisão de equipamentos sociais previsto pelo programa federal, não deixa de ser interessante o exemplo para discutir como, por vezes, mesmo com recursos em mãos para o tema, ele não é prioritário.

Frente a este panorama, está claro que o tema dos recursos vai muito além e é muito mais complexo do que simplesmente a existência ou não de recursos para ações de urbanização de favelas. É uma questão, por exemplo, de utilização racional, efetiva e eficaz do orçamento, sob o risco de perder a possibilidade de receber e utilizar empréstimos e doações internacionais. Tratase também de um elemento profundamente atrelado com a agenda política de cada uma das administrações municipais e de cada gestor à frente das secretarias envolvidas com o tema. Depende ainda da existência de uma agenda pública mobilizadora e aglutinadora de atores e interesses.

$\mathrm{Na}$ realidade, quando se coloca a questão orçamentária como um aspecto quase decisivo da existência ou não de uma política de urbanização de favelas, se está esquecendo ou encobrindo inúmeros outros fatores que também 
contribuem para esta questão. A existência de recursos pode se tratar, dessa forma, de uma espécie de cortina de fumaça utilizada para não se tocar em outros tantos fatores que não são interessantes de serem desnudados nesta análise: componentes políticos (agendas políticas, intermediação de interesses), econômicos (grupos empresariais beneficiados), institucionais (disputas e falta de coordenação entre diferentes setores da estrutura do estado), sociais (opinião pública desfavorável a intervenções de consolidação), etc.

Não se está querendo dizer que a questão dos recursos é menor ou pode ser desconsiderada, tendo em vista que, se estes não existirem, a ação pode ser inviabilizada. Por outro lado, a simples existência de recursos não garante 0 sucesso das intervenções de urbanização, ou seja, diversos outros fatores têm que estar alinhados juntamente com este e é importante que todos estes sejam devidamente considerados e analisados de maneira consistente.

Outra questão apontada pelos entrevistados e pela literatura como decorrente da demanda por visibilidade para alimentar o ciclo de reprodução dos mandatos eleitorais é a baixa continuidade e alta fragmentação das políticas e programas. Trata-se de uma característica não apenas da urbanização de favelas, mas de diferentes políticas e, até mesmo, de projetos considerados em tese prioritários, tendo em vista as necessidades de constituição ou desconstituição de marcas de gestões municipais ou da adoção de diferentes perspectivas de atuação para as políticas.

Apesar de Medellín apresentar períodos de continuidade de políticas e programas em diferentes gestões municipais (ZUQUIM, 2013, p. 04; ENTREVISTADO 08), a análise geral parece apontar uma tendência das cidades colombianas de mudarem, a cada nova gestão, os programas e seus enfoques (MAZO, 2014b, p. 54-55), sob a tentativa de apagar a experiência da gestão anterior e constituir a marca/símbolo da nova gestão, além de direcionar para temas que seriam prioritários na agenda política do novo prefeito.

No caso de Bogotá, em que isto é muito marcante, a Secretaria de Habitat está, por exemplo, formulando apenas ações de mejoramiento que possam ser executadas em um período de 03 anos, priorizando aquelas que estejam de 
alguma forma conectadas aos temas e projetos prioritários dos prefeitos: sejam estes relacionados a temas hídricos, como no caso da gestão de Petro; sejam de corredores de mobilidade, como no caso da gestão Peñalosa (ENTREVISTADO 10). Esta característica da falta de continuidade está, portanto, servindo como uma espécie de "seleção natural", impactando diretamente as escolhas das áreas prioritárias e a escolha dos problemas a serem enfrentados, de forma que se consigam implementar os projetos sem interrupção e que gozem de prioridade.

No caso das cidades brasileiras, a questão da continuidade é fortemente apontada como fator negativo para São Paulo por entrevistado e pela literatura. Vivendo de "soluços" (termo usado por gestora pública da cidade entrevistada), a política de urbanização sofreu com os diferentes partidos urbanísticos adotados nas gestões municipais. Maluf desconstrói em boa parte a intervenção de consolidação de Erundina e cria um programa de verticalização. Pitta continua o programa após Maluf, é verdade; mas Marta tentará promover o redirecionamento das intervenções em favelas na gestão seguinte. Conquanto continue algumas pendências deixadas pela administração anterior, busca construir as bases para retomar uma ação de consolidação do território existente, deixando vários projetos prontos para tanto. Serra/Kassab utilizam parte desse acúmulo institucional deixado, mas buscam imprimir uma marca própria da gestão através do redesenho de projetos e a garantia da "boa arquitetura" de grife. Deixam como legado o Renova, com inúmeros projetos licitados e contratados com a perspectiva de continuidade de recursos do PAC. A gestão Haddad, sofrendo em parte com o descenso dos recursos federais para urbanização, em parte com uma secretaria ligada à oferta/provisão e com - MCMV a pleno vapor, em parte com uma baixa sensibilidade para o tema dentro da gestão, passa a levar o Renova de maneira lenta e com pouco impacto. O pouco que se tenta mudar de rumos no final de sua gestão não foi suficiente para reverter esse quadro.

O Rio de Janeiro, por outro lado, ficou conhecido internacionalmente por sua continuidade no tocante à urbanização. Observando um período de praticamente 16 anos de continuidade de gestões políticas (de 1993 com César Maia a 2008 com o mesmo, apenas havendo 4 anos de seu afilhado, Conde), 
mesmo nesta cidade houve diferenças entre as formas de intervenção no escopo do mesmo programa, como já mencionado. A entrada do PAC e do governo do estado no tema também propiciou que se crescesse não apenas a escala de intervenção, mas a ampliação da escala dos interesses e objetivos das intervenções. Eduardo Paes, posteriormente, lança o Morar Carioca como uma versão em tese aprimorada do Favela-Bairro, quando na realidade a proposta metodológica praticamente não sai do papel, tornando-se apenas uma label e convivendo com uma atuação de remoções forçadas possibilitada pelo MCMV no contexto de preparação para os megaeventos esportivos.

É preciso, no entanto, matizar também essas descontinuidades, como exemplo da atuação do governo federal citado por entrevistada.

É ali, por volta da década de 90 , onde você tem, pela primeira vez, você tem o Itamar Franco e o HBB, que é depois aprimorado no FHC pra virar HBB BID e depois é aprimorado no PAC. Mas, se você olhar o programa, ele é, um é o aprimoramento do outro, vai na mesma linha, não é uma outra coisa. É uma continuidade, com aprimoramentos, retrocessos (como foi tirar a produção habitacional quando lançaram o Minha Casa, Minha Vida 2), mas avanços, se você olhar o programa, o programa é tudo o que nós lutamos uma vida inteira (ENTREVISTADO 17).

Assim, mesmo a descontinuidade precisa ser matizada que, sob algumas circunstâncias, pode ser interpretada como aprendizados institucionais também. Obviamente, como exposto acima, não se trata de todos os casos, como exemplificado principalmente pela experiência de São Paulo. Poderíamos assim tentar falar que a urbanização de favelas nas cidades brasileiras viveu, mais do que uma descontinuidade, descontinuidades no plural. Ou continuidades descontínuas.

Mais um elemento que impacta na consolidação da agenda pública da urbanização, e que inclusive também se relaciona a essas continuidades, está na mobilização social em torno do tema. Conforme abordado no primeiro capítulo, entre as décadas de 1970 a 1990 principalmente, movimentos associativos, comunitários e de favelas foram importantes atores para 0 primeiro impulso de políticas de intervenção em favelas, principalmente com reivindicações relacionadas à implementação de melhorias, direito de permanência e da regularização de sua situação jurídica. No entanto, esses movimentos sofreram uma grande perda de poder político desde então, com 
uma diminuição da sua legitimidade perante os moradores que representariam e com o duplo silenciamento imposto pelos grupos criminais dominantes nos assentamentos populares e pelo próprio estado brasileiro, de acordo com o que se relatou no capítulo quatro. Assim, conquanto ainda existam associações e movimentos que agreguem estas, como o MDDF, já não possuem a vitalidade de outros tempos.

Se esses atores perdem sua capacidade de influencia e reivindicação, é importante apontar que outros atores sociais que, por vezes, incluíam estas pautas e reivindicações em suas próprias agendas (como movimentos de moradia ligados ao campo da reforma urbana) vão progressivamente deixando de lado o tema. Como Klintowitz (2015) observa, inicialmente estes atores sentiam-se contemplados com um PAC que possibilitava a intervenção em favelas. Com o advento do MCMV, no entanto, eles têm sua atenção capturada pela modalidade MCMV-Entidades.

Fruto de reivindicação histórica desses atores de financiamento à autogestão, o programa possibilitou que atendessem com maior força sua base social, fazendo parte do processo de coordenação de interesses implementado pelo governo Lula no campo habitacional. Diversos são os limites do programa nessa modalidade, mas, ainda assim, ele redireciona a energia desses atores para a oferta/provisão, os quais constituíam as principais vozes sociais na área dentro da gestão petista.

Eu acho que tem dois tipos de movimento, movimento de moradia e movimento da favela, não são iguais. (...) algumas lideranças que saíram, teve origem em urbanização de favela, meio que se destacaram mais e passaram a atuar com movimento fora da favela, ai com movimento de moradia mesmo, reivindicando moradia, unidades habitacionais e a demanda não era de favela. Era uma demanda que a gente chama de demanda dispersa, demanda de aluguel acessível, cohabitação, que a gente não consegue identificar onde estão os caras morando. E como esses caras aparecem? Aparecem através do movimento, porque esses movimentos de moradia, eles fazem um trabalho de mobilização e de divulgação deles, assim "Precisa de moradia? Vem batalhar com a gente". Os caras vão lá e se inscrevem no movimento, a gente fica conhecendo essa demanda a partir desses caras ai, eles formam associações, eles formam associações de luta pela moradia e vão atrás. Mais recentemente o que eles estavam fazendo, comprando terreno, apresentando projeto pra receber 0 recurso do Minha Casa, Minha Vida, por exemplo. Quando não tinha o Minha Casa, Minha Vida, eles apresentavam projeto para a prefeitura ou pro governo do estado, CDHU, eles estavam nessa luta. (...) Em São Paulo o movimento organizado é mais forte o movimento por moradia, da UMM e etc, praticamente não tem organização nas favelas. A organização na favela, o que tem são os conselhos gestores que foram organizados pela própria prefeitura, pra viabilizar 
a intervenção nas áreas. É um pouco diferente, é o caminho inverso, mais institucional nas favelas em São Paulo (ENTREVISTADO 12).

Tem-se assim uma diminuição de demandantes de políticas de urbanização de favelas nas últimas décadas, o que fortemente impacta as chances de consolidação de qualquer agenda no campo dessa política, ainda mais diante das dificuldades apresentadas em função dos arranjos do PAC na última década. No caso do Rio de Janeiro, ainda, a própria sociedade civil se tornou receosa da modalidade de urbanização de favelas. Entrevistados apontaram que a baixa demanda por urbanização da parte de movimentos de favelados ocorre também por uma quebra de confiança em relação a essas políticas, tendo em vista que implicaram, muitas vezes nas últimas décadas, em diversas remoções na cidade. Por isso, até reivindicam melhorias, mas não um projeto de intervenção integral, sob o temor de que acabem ensejando remoções de famílias, um custo politicamente alto para essas organizações.

O que é interessante é que, por parte dos moradores de favela, a impressão que me dá é que a mobilização política evitava entrar no farol das politicas públicas de urbanização, já que o custo a pagar numa reurbanização poderia ser a remoção de muitas casas e não sei o que. Então é interessante que não existia por parte dos moradores, existia, é claro, melhoria, mas no contexto do governo atual, ninguém queria ser o objeto de um projeto como tal. "Eu queria que a prefeitura viesse aqui através da Secretaria de Obras e consertasse aqui o muro, consertasse a tubulação", mas pensar em um grande projeto era sempre muito arriscado, porque poderia se voltar inclusive... Então existia uma quebra de legitimidade, de confiança entre população de favelas e a prefeitura, muito clara (ENTREVISTADO 21).

São, portanto, vários fatores políticos, institucionais e sociais que têm dificultado as possibilidades de consolidação de uma agenda permanente no campo da urbanização de favelas, constituindo a sociabilidade violenta também um importante fator impactante, conforme abordado na segunda parte da tese. $O$ processo de crescimento de assentamentos populares ocorre em paralelo com o processo de ascensão da violência urbana enquanto fenômeno. Se por um lado, a pauta da urbanização de alguma maneira foi impulsionada pela questão da segurança pública e do combate à violência urbana; por um revés, essa associação reforçou, concomitantemente e de forma perversa, o estigma de favelas como lugar da violência, reforçando a possibilidade de intervenções arbitrárias e autoritárias, de carater militarizado.

A gramática da violência possui, dessa forma, um considerável impacto na formulação e desenvolvimento de experiências de urbanização de favelas. 
Tanto do ponto de vista das dinâmicas políticas, sociais e econômicas que os grupos criminais estabelecem no território quanto do lugar que a questão ocupa mais amplamente na política, social e economia local, regional e nacional. No caso da Colômbia, foi possível demonstrar que a formulação e a implementação de iniciativas de mejoramiento de barrios em Bogotá e, principalmente, em Medellín foram influenciadas inicialmente de maneira positiva pela questão da violência. Vista como processo estruturador da experiência sociocultural do país, constituiu tanto um impulso à formação dos assentamentos informais das maiores cidades do país quanto serviu de elemento justificador das intervenções públicas nos seus assentamentos informais, tendo em vista a situação de violência urbana vivida por estes.

Apesar da sua importância para compreensão da ascensão das ações de mejoramiento barrial, especialmente no caso de Medellín, a violência não pode ser tomada como único ou principal fator impulsionador, fazendo apenas parte de um conjunto de diferentes fatores. Até um determinado momento (situado entre a década de 1980 e o início da década de 1990), estas iniciativas aparentemente serviram inclusive como elemento de costura das relações entre organizações do narcotráfico e o Estado, o qual chegou a atuar em assentamentos precários com recursos disponibilizados por estes grupos.

No entanto, a partir do momento em que o Estado, pressionado por uma ampla mobilização social e incentivado por uma estratégia geopolítica norteamericana de "guerra às drogas", enxerga a necessidade de disputar o controle destes territórios e o apoio da população em face dos grupos criminais instalados, o mejoramiento de barrios se torna instrumento de enfrentamento entre estes atores, com a emergência do primeiro programa em escala, o PRIMED. Desde então, com intensidades variadas e oscilações ao longo do tempo, o tema do enfrentamento à violência permeia as diferentes ações conectadas ao mejoramiento barrial.

Para o caso das cidades brasileiras, foi demonstrado como esta dimensão social também possui relevância para a compreensão do lugar ocupado pela urbanização de favela na economia política da cidade. Por um lado, em São Paulo, o tema não entra fortemente enquanto um fator legitimador das 
iniciativas de urbanização. Apesar de em alguns momentos essa conexão ter sido ensaiada, como na gestão de Marta Suplicy, não foi explicitamente mobilizada como nos outros centros urbanos estudados. Mesmo assim, ficou evidente a centralidade da reprodução da precariedade em territórios populares como combustível da hegemonia construída pela PCC nas quebradas paulistanas, fator que influencia a queda verificada nos índices de violência a partir dos anos 2000. Isso não significa que as iniciativas de urbanização tenham se abstido de dialogar com esta dimensão, muitas vezes conflitando com interesses dos grupos criminais e, por isso, sendo obrigado a negociar com estes atores para dar continuidade a projetos.

No caso do Rio de Janeiro, a violência foi propulsionador importante da experiência pioneira do Favela-Bairro. O seu espraiamento na cidade a partir do crescimento do tráfico de cocaína e da consolidação de comandos articulando diferentes quadrilhas - associado com uma polêmica em torno, primeiramente, da questão da violência institucional promovida pela ditadura militar e, em segundo lugar, pela polarização do debate acerca das possíveis soluções à violência a partir do mandato de Brizola - conferiram destaque ao tema. Desde então, a questão da violência e a política de segurança vêm progressivamente dominando a intervenção do estado direcionada às favelas. Até mesmo diversas organizações e coletivos protagonizados pelos moradores focam na pauta da segurança e da violência (incluída aqui a violência cometida pelo estado contra eles), diminuindo a atenção conferida à reivindicação da urbanização (ENTREVISTADO 28; ENTREVISTADO 30).

Reafirme-se: não se trata de simples submissão de um processo ao outro. Ou, pelo menos, ainda não se trata de uma simples e completa submissão, entrelaçando-se ambos processos. A diferença que nos parece primordial entre o contexto vivido nos anos 1990 (em que políticas como o Favela-Bairro e o PRIMED buscaram se legitimar a partir da melhoria das condições de violência vividas na época) e o contexto vivido hoje é que, naquele momento, o discurso da urbanização como efetivação de direitos gozava de primazia e encontravase em ascensão, ao passo que hoje a chave dos direitos humanos como base da implementação de políticas está sendo cada vez mais questionada, tendo sido progressivamente abandonada na implementação das UPPs, como 
abordado. A crítica ao discurso de direitos foi, inclusive, um dos impulsionadores de diversas campanhas políticas de candidatos de direita no Brasil nas últimas eleições (caso das candidaturas vitoriosas à presidência e aos governos estaduais do Rio de Janeiro e de São Paulo, dentre outras).

$\mathrm{Na}$ década de 1990, as iniciativas de urbanização de favelas supostamente buscavam abrir brechas, através da melhoria do território, para a ampliação da presença do estado nos assentamentos populares e, com isso, ampliar sua legitimidade perante seus moradores. Nos últimos anos, a política-laboratório experimentada no Rio de Janeiro buscava primeiramente ocupar militarmente esses assentamentos como uma retomada da soberania estatal sobre eles, influenciando fortemente as outras políticas posteriormente implementadas ao objetivo de consolidação dessa retomada. As intervenções sociais em favela, dentre as quais a urbanização de favelas, a exemplo do PAC na cidade, aparentam estar cada vez mais voltadas ao controle social e ao combate à criminalidade, construídas em torno da guerra às drogas no âmbito do discurso, mas se estendendo à toda população favelada na prática cotidiana.

Não apenas a agenda de urbanização de favelas encontra-se cada vez com maior dificuldade de se consolidar frente aos fatores políticos e institucionais abordados, mas a violência está pronta para matá-la. É preciso, mais do que nunca, resgatar a urbanização de favelas como um processo de efetivação de direitos humanos - do direito à moradia adequada e do direito à cidade - e como pressuposto do regime democrático, tendo em vista que o processo de militarização que tenta dominá-la justamente significa a gestão dos conflitos territoriais a partir da eliminação do "inimigo", e não da negociação democrática de interesses e propostas como mecanismo de produção de consensos. 


\section{REFERÊNCIAS BIBLIOGRÁFICAS}

ABIKO, A. Estudos de caso de urbanização de favelas no Brasil. In: Denaldi, R. (org.) Ações integradas de urbanização de assentamentos precários. Brasília: Ministério das Cidades, 2009.

. COELHO, L. O. Urbanização de favelas: procedimentos de gestão. Recomendações Técnicas Habitare. Porto Alegre. 2009.

COELHO, L., WERNA, E. O novo papel do Estado na oferta de habitação e parcerias de agentes públicos e privados. In: ABIKO, A. K., ORNSTEIN, S. W. Inserção urbana e Avaliação Pós Ocupação (APO) de habitação de interesse social. Coletânea Habitare. Rio de Janeiro. 2002. p. 34-56.

ABRUCIO, F. L. et al. As eleições municipais de 2012 e seus efeitos nacionais. Cadernos Adenauer XIV, no 2, p. 194-207. Rio de Janeiro. 2013.

ADORNO, S. Exclusão socioeconómica e violência urbana. Sociologias, ano 4, no 8 p. 84-135. Porto Alegre. 2002.

AFONSO, M. R. et al. O Programa "Morar Carioca" e a experiência de intervenção em favelas na cidade do Rio de Janeiro: da remoção à urbanização. XIV Encontro nacional da ANPUR. Rio de Janeiro. 2011.

AGUILAR, A. "Los asentamientos humanos y el cambio climático global" in Cambio climático: una visión desde México: Instituto Nacional de Ecología, 2004.

AKAISHI, A. G. et al. O Programa de Aceleração do Crescimento: urbanização de assentamentos precários (pac-uap) na região do $A B C$ : característica e execução. Seminário UrbFavelas. São Bernardo do Campo. 2014.

G., DENALDI, R. Tipologias de assentamentos precários. In: DENALDI, R. Planejamento habitacional: notas sobre a precariedade e terra nos planos locais de habitação. Annablume editora. São Paulo. 2013. p. 127- 149.

G.; CARDOSO, L. C.; SARAIVA, C. P.; SILVA, P. C. O Programa de Aceleração do Crescimento no contexto das urbanizações de favela em São Paulo. In: CARDOSO, A. L.; DENALDI, R. (Org.). Urbanização de favelas no Brasil: um balanço preliminar do PAC. Rio de Janeiro: Letra Capital, 2018. p. 49-74.

DENALDI, R., LEITÃO, K. O recente processo de elaboração de planos locais de habitação de interesse social no brasil: limitações e perspectivas. XIV Encontro nacional da ANPUR. Rio de Janeiro. 2011.

ALCADIA DE MEDELLÍN. Plan Integral de Seguridad y Convivencia 20122015. Vicealcaldía de Gobernabilidad, Seguridad y Servicio a la Ciudadanía. Medellín. 2012. 
Acuerdo 48 de 2014 "Por medio del cual se adopta la revisión y ajuste de largo plazo del Plan de Ordenamiento Territorial del Municipio de Medellín y se dictan otras disposiciones complementarias". Gaceta Oficial. Medellíin. 2014.

PRIMED - Una experiencia exitosa en la intervención urbana. Medellín: UNICEF, 1996.

Proyectos Urbanos Integrales PIU: contra la exclusión y la desigualdad. Medellín. 2015.

ALCALDÍA MAYOR DE BOGOTÁ. Política Vivienda y Habitat. ALCALDÍA MAYOR DE BOGOTÁ: Bogotá, [s.d.].

ALCALDIA MAYOR DE SANTAFÉ DE BOGOTÁ. Plan de mejoramiento integral de cuidad Bolívar y áreas subnormales del sur y alternativas para la localización de la población pobre de Bogotá. Bogotá. 1993.

ALDÉ, A., DIAS, H. Intervalo surpresa: spots eleitorais na campanha municipal de 1996. Comunicação e Política. V. 5 , no 1 , p. 83-99. Rio de Janeiro. 1998.

ALIANÇA DAS CIDADES. O desafio para transformar assentamentos precários em bairros. Cidade de todos - Política para favelas: Brasília, 2007.

ALMEIDA, M., MANOEL, A. Estrutura das finanças públicas do estado do Rio de Janeiro. In: PINHEIRO, A. C., VELOSO, F (orgs). Rio de Janeiro - um estado em transição. Editora FGV. R Rio de Janeiro. 2012. p. 357-387.

ALMEIDA, R., D'ANDREA, T. Pobreza e redes sociais em uma favela paulistana. Revista Novos Estudos, no 68. São Paulo. 2004.

ALMEIDA, V. M. et al. Intervenção em favelas na perspectiva de uma regularização fundiária sustentável: limites e avanços. $V$ Encontro nacional e III Encontro latino americano sobre Edificações e Comunidades Sustentáveis. Recife. 2009.

ALMEIDA, V., BUENO, L. Urbanização de favelas: 0 desafio dos grandes complexos. XIV Encontro de Iniciação Científica da PUC-Campinas: Campinas, 2009.

ALVES, J. C. S. Religião, violência e poder político numa favela da baixada fluminense. Revista Ciencias Sociales y Religión/Ciências Sociais e Religião. Ano 6, n. 6, p.153-178. Porto Alegre. 2004.

ALVES. J. A. Topografias da violência: necropoder e governamentalidade espacial em São Paulo. Revista do Departamento de Geografia - USP. V. 22, p. 108-134. São Paulo. 2011.

ALVITO, M. Um bicho-de-sete-cabeças. In: ZALUAR, A., ALVITO, M. Um século de favela (pp.181-208). Rio de Janeiro: Editora FGV, 2006. 
AMARAL, L. O Imaginário do Medo: violência urbana e segregação espacial na cidade do Rio de Janeiro. Revista Contemporânea. V. 8, no 1, p.34-45. Bahia. 2010.

AMORE, C. S. Entre o nó e o fato consumado, o lugar dos pobres na cidade um estudo sobre as ZEIS e os impasses da Reforma Urbana na atualidade. Dissertação de Doutorado apresentado à Faculdade de Arquitetura e Urbanismo da Universidade de São Paulo. São Paulo. 2013.

et al. Precariedades habitacionais: um ensaio de qualificação e quantificação, uma metodologia de projeto para intervenção em favelas. Seminário UrbFavelas. São Bernardo do Campo. 2014.

AMOROSO, M. Caminhos do lembrar: a construção e os usos políticos da memória no morro do Borel. Tese de Doutorado apresentada ao Centro de Pesquisa e Documentação de História Contemporânea do Brasil - CPDOC. Rio de Janeiro. 2012.

ANCONA, A. L., LAREU, S. Avaliação do Programa Guarapiranga - Custos e Componentes de Infra-estrutura. . Seminário de avaliação de projetos IPT, p. 51-68. São Paulo, 2005.

ANDRADE, S., RODRIGUES, J. A terceirização de projetos em políticas de urbanização de favelas - um olhar comparativo entre o Programa FavelaBairro (Rio de Janeiro) e o Projeto Terra (Vitória). [s. I.], [s.d.].

ANGEL, S. Upgrading slum infrastructure Divergent Objectives in Search of a Consensus. Ad-hoc Expert Group Meeting on Appropriate Infrastructure Services, Standards and Technologies for Upgrading Slums and Squatter Areas and Rural Settlements, United Nations Centre for Human Settlements (HABITAT). Nairobi. 1981.

ARAGÃO, T. A., MARGUTI, B. O. Habitação e assentamentos precários no Brasil: trajetória e desafíos para o alcance da justiça espacial. In: COSTA, M. A. (org).O Estatuto da Cidade e Habitat III: Um balanço de quinze anos da política urbana no Brasil e a nova agenda urbana. IPEA. Brasília. 2016. p. 325-345.

ARANTES, O.; VAINER, C.; MARICATO, E. A cidade do pensamento único: desmanchando consensos. 3 ed. Rio de Janeiro: Vozes, 2002.

ARANTES, P. F. O ajuste urbano: as políticas do Banco Mundial e do BID para as ciudades latino-americanas. Dissertação (mestrado). Faculdade de Arquitetura e Urbanismo da Universidade de São Paulo. São Paulo, 2004

ARANTES, P. F.; FIX, M. Como o governo Lula pretende resolver o problema da habitação. Correio da Cidadania. São Paulo. 2009.

ARICAPA, R. Comuna 13: crónica de una guerra urbana - de Orión a la Escombrera. Ediciones B. Bogotá D.C. 2015. 
ARISTIZABAL, N.C.; ORTIZ, A. "Improving security without titles in Bogotá." Habitat International, 2004.

ARRETCHE, M. T. S. Intervenção do Estado e setor privado: o modelo brasileiro de política habitacional. Revista de Estudos Regionais e Urbanos. Ano X, no 31. [s. I.] 1990. p. 21-37.

. Democracia, federalismo e centralização no Brasil / Marta Arretche. - Rio de Janeiro: Editora FGV; Editora Fiocruz, 2012. 232 pg.

Desarticulação do BNH e autonomização da política habitacional . In: AFFONSO, R. B. A., SILVA, P. L. B. S. (orgs); ALMEIDA, M. H. T. et al. Descentralização e políticas sociais. Fundap. São Paulo. 1996. p.107-139.

ATHAYDE, C., MEIRELLES, R. Um país chamado favela. Gente Editora. São Paulo. 2015.

AUDEFROY, J. Eviction trends worldwide and the role of local authorities the right to housing. Fonte: Sage Publications: http://eau.sagepub.com/content/6/1/8. 1994.

ÁVILA CASTAÑEDA, A. D. Lineamientos para el mejoramiento integral de barrios en áreas informales. Dissertação de Mestrado (Planejamento Urbano e Regional. Bogotá: Pontifícia Universidad Javeriana de Bogotá, 2012. Disponível em: http://hdl.handle.net/10554/15626

ÁVILA, M. A cooperação internacional nas experiências de urbanização de favelas em Belo Horizonte. Versão modificada do capítulo 2 da dissertação de Mestrado "Vila Nossa Senhora de Fátima: a incorporação da questão ambiental às formas de intervir urbanísticamente em favela". IGC/UPMG. Belo Horizonte. 1997.

AZEVEDO, S. de; ANDRADE, L. A. G. de. Habitação e Poder: da fundação da casa popular ao Banco Nacional da Habitação. Rio de Janeiro: Centro Edelstein de Pesquisas Sociais, 2011.

AZEVEDO, A. N. de. A reforma Pereira Passos: uma tentativa de integração urbana. Revista Rio de Janeiro. N. 10. Maio-agosto de 2003.

Desafios da Habitação Popular no Brasil: políticas recentes

e tendencias. In: CARDOSO, A. L. (coord.). Coleção Habitare - Habitação Social nas Metrópoles Brasileiras - Uma avaliação das políticas habitacionais em Belém, Belo Horizonte, Recife, Rio de Janeiro e São Paulo no final do século XX. Porto Alegre. 2007.

BAKEN, R.J., LINDEN, J. Getting the incentives right: banking on the formal private sector. TWPR, vol. 15, ano 1993.

BALBIM, R. Urbanização de assentamentos precários: considerações acerca de avaliações. Anais do XIV ENANPUR. Rio de Janeiro: ANPUR, 2011. 
. NADALIN, V. G., KRAUSE, C. Urbanização de assentamentos precários: considerações acerca de avaliações. XIV Encontro nacional da ANPUR. Rio de Janeiro. 2011.

FILIPPI, F., GONÇALVES, S., MELLO, A. Slum(e)scape: The Osasco Design Studio. Universidade Politécnica de Turim: [s. I.], [s.d.].

Da habitação como direito ao 'direito à moradia'. In: $\overline{B A R B B O S A}$, J. L. FAUSTINI, M. V., SILVA, J. S. O novo carioca. Mórula editorial. Rio de Janeiro. 2012. p. 93-109.

. Rio Democracia. In: BARBOSA, J. L., FAUSTINI, M. V., SILVA, J. S. O novo carioca. Mórula editorial. Rio de Janeiro. 2012. p. 109-131.

Da habitação como direito ao "direito à moradia". In: SILVA, J., Mórula Editorial, 2012. FAUSTINI, M. V. O novo carioca (pp.93-108). Rio de Janeiro:

Rio Democracia. In: SILVA, J., BARBOSA J. L., FAUSTINI, M. V. O novo carioca (pp.109-130). Rio de Janeiro: Mórula Editorial, 2012.

BARBOSA, I. S. O lugar do Movimento de Moradia na mudança da política pública paulistana para as favelas (1979-1989). Dissertação de Doutorado apresentado à Faculdade de Filosofia, Letras e Ciências Humanas da Universidade de São Paulo. São Paulo. 2014.

A identidade do movimento por urbanização e legalização do Pantanal (MULP). Seminário UrbFavelas. São Bernardo do Campo. 2014.

BICUDO, H. P. Meu depoimento sobre o esquadrão da morte. 3. ed. São Paulo: Pontifícia Comissão de Justiça e Paz de São Paulo, 1976.

BIRMAN, P. Favela é comunidade? In: SILVA, L. A. M. (Org.). Vida sob cerco: violência e rotina nas favelas do Rio de Janeiro. - Rio de Janeiro: Nova Fronteira, 2008. p. 99-114.

MACHADO, C. A violência dos justos: evangélicos, mídia e periferias da metrópole. Revista brasileira de Ciências Sociais. V. 27, no. 80, p. 55-69. São Paulo. 2012.

$\mathrm{BLOCH}, \mathrm{J}$. A. O direito à moradia. Um estudo dos movimentos de luta pela moradia no centro de São Paulo. Dissertação de Mestrado apresentado à Faculdade de Filosofia, Letras e Ciências Humanas da Universidade de São Paulo. São Paulo. 2007.

BONDUKI, N. Origens da habitação social no Brasil. São Paulo: Estação Liberdade, 1998.

Política habitacional e inclusão social no Brasil: revisão histórica e novas perspectivas no governo Lula. Revista Eletrônica de Arquitetura e Urbanismo, São Paulo, n.1, p.70-104, 2008. 
. Tendências e Perspectivas na Avaliação de Políticas e

Programas Sociais - Uma metodologia para avaliar programas de habitação. São Paulo: IEE/PUC-SP, 2002.

BONELLI, R., VELOSO, F. Rio de Janeiro: um crescimento econônico e mudança estrutural. In: PINHEIRO, A. C., VELOSO, F (orgs). Rio de Janeiro um estado em transição. Editora FGV. R Rio de Janeiro. 2012. p. 25-63.

BORGES, D., CANO, I., RIBEIRO, E. (org). Os donos do morro: uma avaliação exploratória do impacto das unidades de policía pacificadora (UPPs) no Rio de Janeiro. Fórum Brasileiro de Segurança Pública; Laboratório de Análise da Violência (LAV-UERJ) \& Fundação Heinrich Böll. Rio de Janeiro. 2012.

BRAKARZ, J., GREENE, M., AND ROJAS, E. "Ciudades para todos. La experiencia reciente en Programas de Mejoramiento de Barrios." InterAmerican Development Bank, 2002.

BRULON, V., LACERDA, D. S. Política das UPPS e espaços organizacionais precários: uma análise de discurso. Revista de Administração de Empresas. V.53, no 2, p. 130-141. São Paulo. 2013.

BRUM, M. S. I. A urbanização de favelas como política de Estado e seus impactos no movimento comunitário das favelas cariocas (1980 - 1990). I Seminário nacional sobre urbanização de favelas - URBFAVELAS: São Bernardo do Campo, 2014.

Opção pelos pobres: a Pastoral de Favelas e a reorganização do Movimento de Favelas no Rio de Janeiro na redemocratização. Estudos Históricos. V. 31, no 65, p 413-432. Rio de Janeiro. 2018.

BRUNO, A. P. Desdobramentos do Estatuto da Cidade no nível federal: a atuação do Ministério das Cidades em política urbana. In: ROSSBACH, A., BRUNO, A.N., CARVALHO, C., MONTANDON, D., FERNANDES, E., MAGALHÂES, I., SAULE JR, N. A velha e a nova agenda urbana. Uma análise de 15 anos da lei (pp. 51-68). Cities Alliance: São Paulo, 2016.

BUENO, L. M. de M (2009). Intervenção em favelas na perspectiva de uma regularização fundiária sustentável: limites e avanços. Anais do III Encontro Latino-americano sobre Edificações e Comunidades Sustentáveis, Recife.

(2009). Normas específicas e metodologia para projetos e obras de urbanização e recuperação ambiental de assentamentos precários. In: Denaldi, R. (org.) Ações integradas de urbanização de assentamentos precários. Brasília: Ministério das Cidades.

(2011). O programa "Morar carioca" e a experiência de intervenção em favelas na cidade do Rio de Janeiro: da remoção à urbanização. Anais do XIV Encontro Nacional da ANPUR, Rio de Janeiro. 
Projeto e favela: metodologia para projetos de urbanização. Tese de Doutorado apresentada à Faculdade de Arquitetura e Urbanismo. São Paulo: Universidade de São Paulo, 2000.

Reflexões sobre o futuro da sustentabilidade urbana com base em um enfoque socioambiental. Cadernos Metrópole, p. 99-121.São Paulo. 2008.

Parâmetros e tipologias. In: MINISTÉRIO DAS CIDADES. Política habitacional e a integração urbana de assentamentos precários: Parâmetros conceituais, técnicos e metodológicos (pp. 47-60). Ministério das Cidades: Brasília, 2008.

Parâmetros para avaliação de vida urbana e qualidade habitacional em favelas urbanizadas. Coletânea Habitare, vol. 1. [s. d.].

BURGOS, M. Dos parques proletários ao Favela-Bairro: as políticas públicas nas favelas do Rio de Janeiro. In: ZALUAR, A., ALVITO, M. Um século de favela (pp.25-60). Rio de Janeiro: Editora FGV, 2006.

BURKE, P. Violência urbana e civilização. In: OLIVEIRA, N. V. (org). Insegurança pública - Reflexões sobre a criminalidade e a violência urbana. Nova Alexandria. São Paulo. 2002. p. 32-53.

CADENA, N. L. Planeacion participativa, eje de desarrollo del Programa de Mejoramiento Integral de Barrios. Formulación y análisis en el contexto de Bogotá. Pontificia Universidad Javeriana: Bogotá, 2010.

CALDAS, M. F. Política urbana, ação governamental e a utopia da reforma urbana no Brasil. . Dissertação de Doutorado apresentado à Escola de Arquitetura da Universidade Federal de Minas Gerais, Belo Horizonte. 2015.

, VALE, M. L. O Programa de Aceleração do Crescimento e as obras de infraestrutura urbana - avanços e desafíos. Seminário UrbFavelas. São Bernardo do Campo. 2014.

Contextualização/ Caracterização. In: MINISTÉRIO DAS CIDADES. Política habitacional e a integração urbana de assentamentos precários: Parâmetros conceituais, técnicos e metodológicos (pp. 13-46). Ministério das Cidades: Brasília, 2008.

O Programa de Aceleração do Crescimento e as obras de infrarestrutura urbana - avanços e desafios. I Seminário nacional sobre urbanização de favelas - URBFAVELAS: São Bernardo do Campo, 2014.

Rio de Janeiro: Letra Capital, 2013.

O programa MCMV e seus efeitos territoriais.

CANO, I. Seis por meia dúzia? Um estudo exploratório do fenômeno das chamadas 'milícias' no Rio de Janeiro. P. 49- 83. In: RIBEIRO, C. et al. Segurança, tráfico e milícias. Laboratório de Análise da Violência (LAV-UERJ). Rio de Janeiro. 2015. 
., DUARTE, T. No "sapatinho": a evolução das milicias no Rio de Janeiro (2008-2011). Laboratório de Análise da Violência (LAV-UERJ) \& Fundação Heinrich Böll. Rio de Janeiro. 2012.

CARDOSO, A. L Urbanização de favelas no Brasil: revendo a experiência e pensando os desafíos. XII Encontro da associação nacional de pósgraduação e pesquisa em planejamento urbano e regional. Belém. 2007.

Avanços e desafios na experiencia brasileira de urbanização de favelas. Cadernos Metrópole, pp. 219-240. São Paulo. 2007.

. Necessidades habitacionais no Brasil. In: Denaldi, R. (org.) Ações integradas de urbanização de assentamentos precários. Brasília: Ministério das Cidades, 2009.

O Programa Favela-Bairro: Uma Avaliação. Seminário de avaliação de projetos IPT, p. 37-50. São Paulo, 2002.

Risco urbano e moradia: a construção social do risco em uma favela do Rio de Janeiro. Cadernos IPPUR, Ano XX, № 01. Rio de Janeiro: UFRJ, 2006.

, PATRíCIO, N. A., YASSU, A. A Urbanização de Favelas na Política Habitacional Brasileira: A experiência do Rio de Janeiro. Seminario latinoamericano Teoría y política sobre asentamientos populares. Buenos Aires. 2018.

RIBEIRO, L. C. Q. Os municipios e as políticas habitacionais. In: ABIKO, A. K., ORNSTEIN, S. W. Inserção urbana e Avaliação Pós Ocupação (APO) de habitação de interesse social. Coletânea Habitare. Rio de Janeiro. 2002. p. 14-34.

- DENALDI, R. Urbanização de favelas no Brasil: um balanço preliminar do PAC. In: (Org.). Urbanização de favelas no Brasil: um balanço preliminar do PAC. Rio de Janeiro: Letra Capital, 2018. p. 17-48.

. JAENISCH, S. T.; PATRÍCIO, N. A.; XIMENES, L. A. O PAC nas favelas do Rio de Janeiro: Caracterização das intervenções e arranjo institucional. In: CARDOSO, A. L.; DENALDI, R. (Org.). Urbanização de favelas no Brasil: um balanço preliminar do PAC. Rio de Janeiro: Letra Capital, 2018. p. 107-138.

A política de pacificação do Rio de Janeiro: um estudo sobre liderança e inovação. In: PINHEIRO, A. C., VELOSO, F (orgs). Rio de Janeiro - um estado em transição. Editora FGV. R Rio de Janeiro. 2012. p. 441-469.

CARVAJAL C. P. et al. "Determinantes socio-económicos y financieros del acceso a vivienda de interés prioritario: un estudio para el caso colombiano durante el período 2009-2012." Revista Investigacion Operacional: 3(2), pp. 169-177, 2015. 
CARVAJAL, J. M., NIÑO, M. Participación ciudadana implementada en las intervenciones de mejoramiento integral en Colombia durante los últimos diez años. Revista Traza, n. 9, ano 2013.

CARVALHO, C.; PEREIRA, R., CASTRO, A., RODRIGUES, D., RODRIGUES, F., PEREIRA, M., HORIGOSHI, M. R. Entre a necessidade e a gestão: 0 lugar das melhorias habitacionais nas políticas de urbanização de favelas. I Seminário nacional sobre urbanização de favelas - URBFAVELAS: São Bernardo do Campo, 2014.

CARVALHO, M. B. "Bem-aventurados os pacificadores": práticas de militarização e disciplinarização dos corpos no programa de pacificação de favelas do Rio de Janeiro. In: Militarização no Rio de Janeiro: da pacificação à intervenção. FARIAS, J. ... [et al.]. - 1. ed. - Rio de Janeiro: Mórula, 2018. p. 92-110.

CASTAGNA, A., RAPOSO, I. AND WOELFIN, M. "Evolución de los asentamientos irregulares en Rosario. Análisis de una problemática compleja de revertir en el ámbito local." Scripta Nova: Electronic Journal of Geography and Social Sciences: (14), p. 81, 2010.

CASTILHO, J. V. A favelização do espaço urbano em São Paulo: Estudo de caso: Heliópolis e Paraisópolis. Dissertação de Mestrado apresentado à Faculdade de Arquitetura e Urbanismo da Universidade de São Paulo. São Paulo. 2013.

CASTRO, R. V. et al. Violência, favela e pacificação: representações sobre a Unidade de Polícia Pacificadora no Morro do Andaraí do Rio de Janeiro. Revista Emancipação. V. 16, no 1, p. 61-79. Ponta Grossa. 2016.

CAVALCANTI, M. À espera, em ruínas: Urbanismo, estética e política no Rio de Janeiro da 'PACificação'. Revista Dilemas. V. 6, no 2, p. 191-228. Rio de Janeiro. 2012.

Tiroteios, legibilidade e espaço urbano: Notas etnográficas de uma favela carioca. Revista Dilemas, p. 35-59. Rio de Janeiro. 2008.

Centro de Políticas Sociais Fundação Getúlio Vargas. Desigualdades e Favelas Cariocas: A Cidade Partida está se integrando? Rio de Janeiro. 2010.

CEPAL. "De la urbanización acelerada a la consolidación de los asentamientos humanos en América Latina y El Caribe: EI Espacio Regional." CEPAL, 2000.

CERVI, E. U., SOUZA, N. R., VEIGA, L. F. As estratégias de retórica na disputa pela Prefeitura de São Paulo em 2004: PT, mandatário, versus PSDB, desafiante. Revista Opinião Pública, V.13, no 1, p. 51-74. Campinas. 2007.

COELHO, E. C., HERLING, T. Instrumentos de planejamento da política habitacional na cidade de São Paulo: HABISP e PMH. In: DENALDI, R. Planejamento habitacional: notas sobre a precariedade e terra nos planos locais de habitação. Annablume editora. São Paulo. 2013. p. 149-173. 
COELHO, F., FONTES, A. Urbanização de favelas e o Projeto Mutirão: solução ou problema? Revista de Administração Municipal Rio de Janeiro. V. 36, no.192, p.40-60. Rio de Janeiro. 1989.

COELHO, M. C. Rio de Janeiro, Sexta-Feira Santa de 2004, Parte 2: as elites cariocas e os conflitos na Rocinha. Revista Teoria e Cultura. V 3, no $1 / 2$, p. 21-31. Juiz de Fora. 2008.

COLOMBAS, S. M. Power relations perceptions in a brazilian favela: a case study of vila nova esperança inhabitants association directors. Dissertação de Mestrado apresentado à Escola de Administração de Empresas da Fundação Getúlio Vargas. São Paulo. 2014.

CONCEIÇÃO, W. S. As políticas de moradia do PAC/PMCMV e os condomínios como dispositivos de controle e "pacificação". In: Militarização no Rio de Janeiro: da pacificação à intervenção. FARIAS, J. ... [et al.]. - 1. ed. Rio de Janeiro: Mórula, 2018. p. 129-141.

CONTI, A. A Política de intervenção nos assentamentos informais em Belo Horizonte nas décadas de 1980 e 1990 e o "Plano Global Específico". Cadernos de Arquitetura e Urbanismo. V. 11, no 12, p. 189-216. Belo Horizonte. 2004.

CORDEIRO, D. O. Políticas de intervenção em favelas e as transformações nos programas, procedimentos e práticas: A experiência de atuação do município de Embu. Dissertação de Mestrado apresentado à Faculdade de Arquitetura e Urbanismo da Universidade de São Paulo. São Paulo. 2009.

CORREA, C. A. Slum upgrading using participatory and inclusive land readjustment: Defining the rules of the game. UN-Habitat: Nairobi, 2013.

COSTA, H. S. M. O lugar ambíguo das políticas de urbanização e regularização fundiária nas políticas urbanas. In: ENCONTRO NACIONAL DA ANPUR, 13. Florianópolis: Anpur, 25 a 29 de maio de 2009. Mesa Redonda Regularização fundiária e política habitacional.

COSTA, M. R. A violência urbana é particularidade da sociedade brasileira? Revista São Paulo em Perspectiva. V. 13, no 4, p. 3-12. São Paulo. 1999.

COUPÉ, F. Capacitacion para la planeacion participativa. El programa de mejoramiento de asentamientos humanos, proyecto del Río Otún en Pereira y Dosquebradas. Tercer Seminario Internacional Habinet sobre Participación Comunitaria: Medellín, 1991.

La participacion comunitaria en procesos de produccion y mejoramiento del habitat popular. Primer Encuentro Nacional sobre Vivienda Popular: Equador, 1987.

COUPÉ, F. Villa Tina: Recuperación de la memoria de uma tragédia. [s. I.], [s.d.]. 
COUTO, C. G., ABRUCIO, F. L. A dialética da Mudança: o PT se confronta com a Institucionalidade. Cadernos CEDEC no 31. São Paulo. 1993

$A$ redefinição do papel do Estado no ámbito local. Revista São Paulo em Perspectiva. V. 10, no 3, p. 40-47. São Paulo. 1996.

Cravino, M. 2006. "Las villas de la ciudad. Mercado e informalidad urbana." Instituto del Conurbano.

CUNHA, C. V. A cidade para os civilizados: Significados da ordem pública em contextos de violência urbana. Revista Dilemas. V. 5, no 2, p. 211-232. Rio de Janeiro. 2012.

Evangélicos em ação nas favelas cariocas: um estudo sócio-antropológico sobre redes de proteção, tráfico de drogas e religião no Complexo de Acari. Dissertação de Doutorado apresentado à Faculdade de Ciências Sociais da Universidade do Rio de Janeiro. Rio de Janeiro. 2008.

CUNHA, J. B. "Nossa casaca é dupla-face": dinâmica sócio espacial e política local no processo de implementação do PAC e da UPP em uma favela da cidade do Rio de Janeiro. Dissertação de Doutorado apresentado à Faculdade de Filosofia, Letras e Ciências Humanas da Universidade de São Paulo. São Paulo. 2014.

CUNHA, M. Cenas históricas da participação popular na constituição de um campo de fronteira nas favelas do Rio de Janeiro. In: RODRIGUES, $R$. Vida social e política nas favelas: pesquisas de campo no Complexo do Alemão (pp.15-42). Rio de Janeiro: Instituto de Pesquisa Econômica Aplicada, 2016.

CUNHA, N. V., MELLO, M. A. S. Novos conflitos na cidade: A UPP e o processo de urbanização na favela. Revista Dilemas. V. 4, no 3, p. 371-401. Rio de Janeiro. 2011.

D'ALESSANDRO, M. L. S. Avaliação da política de urbanização de favelas em São Paulo no período de 1989/1992. Dissertação apresentada à Escola de Administração de Empresas de São Paulo. São Paulo: Fundação Getúlio Vargas, 1999.

. Estratégias de enfrentamento do problema: favela. In: MINISTÉRIO DAS CIDADES. Política habitacional e a integração urbana de assentamentos precários: Parâmetros conceituais, técnicos e metodológicos (pp. 61-78). Ministério das Cidades: Brasília, 2008..

D'OTTAVIANO, M. C. Política habitacional no brasil e Programa de Locação Social paulistano. Caderno CRH. V. 27, no 71, p. 255-266. Salvador. 2014.

SILVA, S. L. Regularização fundiária no Brasil: Velhas e novas questões. Planejamento e Políticas Públicas, n. 32, 2009. 
DANIEL, C. As administrações democráticas e populares em questão. Espaço e Debates: Revista de Estudos Regionais e Urbanos. Ano X, no 30. [s. I.] 1990. p. 11-28.

DANTAS, M. D. Revoltas, Motins, Revoluções: Homens livres e libertos no Brasil do século XIX. Alameda Casa Editorial. São Paulo, 2011

Declaración de Bogotá sobre mejoramiento barrial y urbano como respuesta a una ciudad para todos. Revista Bitácora UrbanolTerritorial, vol. 23, n. 2, ano 2013.

Declaración sobre mejoramiento barrial. La ciudad desde la perspectiva de derechos. Revista Bitácora UrbanolTerritorial, vol. 11, ano 2007.

DEPARTAMENTO NACIONAL DE PLANEACÍON. Autorizacíon para contratar un crédito alemán hasta por D.M. 13,5 millones para el Programa Integral de Mejoramiento de Barrios subnormales de Medellin. Santafé de Bogotá. 1992.

DENALDI, R. Assentamentos precários do tipo favela e loteamento: identificação, dimensionamento e tipologias de intervenção. In: Denaldi, R. (org.) Planejamento habitacional - Notas sobre a precariedade da terra nos planos locais de habitação. São Paulo: Annablume, 2013a.

Favela Sacadura Cabral: participação da população no processo de urbanização e remoção. In: Denaldi, R. (org.) O desafio de planejar a cidade. São Paulo: Annablume, 2012b.

Intervenção municipal em favelas: aprimoramento e limitações. Anais do XI Encontro Nacional da ANPUR, Salvador, 2005.

O Programa de Aceleração do Crescimento-Urbanização de Assentamentos Precários (PAC-UAP) na região do $A B C$ : característica e execução. Anais do I URBFAVELAS, Santo André, 2014.

. Plano de ação integrada em assentamentos precários. In: Denaldi, R. (org.) Ações integradas de urbanização de assentamentos precários. Brasília: Ministério das Cidades, 2009.

Políticas de Urbanização de Favelas: Evolução e Impasses. Tese de Doutorado apresentada à Faculdade de Arquitetura e Urbanismo. São Paulo: Universidade de São Paulo, 2003.

Santo André: urbanização de favelas e inclusão social. Ambiente Construído. V. 4, no 4, p. 7-20. Porto Alegre 2004.

Urbanização de favelas no âmbito do programa Santo André Mais Igual. In: Denaldi, R. (org.) O desafio de planejar a cidade. São Paulo: Annablume, 2012a.

Urbanização de favelas: estratégias para ampliar a escala e elevar a qualidade das intervenções. Anais do XVI Encontro Nacional da ANPUR, Belo Horizonte, 2015. 
. MORETTI, R. Relatório científico do projeto "Urbanização de assentamentos precários no âmbito do Programa de Aceleração do Crescimento na Região do ABC". Santo André: UFABC. (mimeo), 2015.

AKAISHI, A. G.. Tipologias de assentamentos precários. In: Denaldi, R. (org.) Planejamento habitacional - Notas sobre a precariedade da terra nos planos locais de habitação. São Paulo: Annablume, 2013b.

DEUS, P., TERLIZZI, M. M., GOMES, M., LIMA, N., SILVA, R., VIDAL, T. Avaliação do programa de urbanização: A percepção dos moradores dos bairros Parque Fernanda I, Jardim Irene II e Jardim Das Rosas. I Seminário nacional sobre urbanização de favelas - URBFAVELAS: São Bernardo do Campo, 2014.

DíAZ, I.,JIMÉNEZ M. E., GRINDLAY M. A., TORRES C. A. Procesos de mejoramiento barrial participativo en asentamientos informales: Propuestas de integración en la ciudad de lbagué (Colombia). Revista INVI, vol. 25, n. 68, ano 2010.

DIÓGENES, N. M. Do cortiço à favela: A violência na literatura brasileira em perspectiva. ContraCorrente, [S.I.], n. 2, p. 141-158. 2017.

DUTRA, L. G. As (re)ações, incertezas e perspectivas dos "invadidos" com a política de "pacificação" do Complexo da Mangueirinha. Dissertação de Mestrado apresentado ao Centro de Pesquisa e Documentação de História Contemporânea do Brasil - CPDOC. Rio de Janeiro. 2017.

ECHEVERRÍA, M. C. Ascensos y descensos em la vivienda: mirada desde Medellín. Medellín, Colombia. Abril de 2004.

ENZENSBERG, H. M. Sociabilidade violenta: por uma interpretação da criminalidade contemporânea no Brasil urbano. Revista Sociedade e Estado. V. 19, no. 1, p. 53-84. Brasília. 2004.

ESCOBAR, G. Programa de rehabilitacion de los barrios aledaños a la antigua montaña de basura. Taller Latinoamericano n. 12 del Programa de Estudios de Vivienda en América Latina - PEVAL: Medellín, 1985.

SÁNCHEZ, N. E., COUPÉ, F., TOBÓN, D., MEJíA, P. Mejoramiento barrial en Medellin, 1964-1984. Programa de Estudios de Vivienda en América Latina - PEVAL: Medellín, 1984.

EVERS, T., PLANTENBERG, C. M., SPESSART, S. Movimentos de bairro e Estado: Lutas na esfera da reprodução na América Latina. In: MOISÉS, J. A. et al. Cidade, povo e poder. Paz e Terra. Rio de Janeiro. 1982. p. 110-165.

FARAH, M. F. S. Disseminação De Políticas Públicas e Programas Governamentais no nível subnacional de governo. Revista Administração em Diálogo. V. 2, no 11, p. 69-89. São Paulo. 2008.

FAUSTINI, M. V. A peleja da invenção do imaginário. In: BARBOSA, J. L., FAUSTINI, M. V., SILVA, J. S. O novo carioca. Mórula editorial. Rio de Janeiro. 2012. p. 63-69. 
. Passinho do menor. In: SILVA, J., BARBOSA J. L., FAUSTINI, M. V. O novo carioca (pp.75-78). Rio de Janeiro: Mórula Editorial, 2012.

FAUSTO, B Historia do Brasil. Fundação para o Desenvolvimento da Educação, 1ed. 1994.

FAZZIONI, N. H. Entre novos e velhos síntomas: apontamentos sobre saúde e doença. In: RODRIGUES, R. I. (org). Vida social e política nas favelas: pesquisa de campo no Complexo do Alemão. IPEA. Rio de Janeiro. 2016. p.115- 129.

FELIX, C. B. As guerras do Rio: mídia, favela e militarização do cotidiano. Reciis - Revista Eletronica de Comunicação, Informação e Inovação em Saúde. Rio de Janeiro. 2017.

FELTRAN, G. S. Desvelar a política na periferia: histórias de momimentos sociais em São Paulo. Dissertação de Mestrado apresentado à Faculdade de Filosofia e Ciências Humanas da Universidade Estadual de Campinas. Campinas. 2003.

Política e violência nas margens da cidade: um experimento político numa favela de São Paulo. Revista Estudos Políticos, no 1. Rio de Janeiro. 2010.

. Vinte anos depois: a construção democrática brasileira vista da periferia de São Paulo. Revista Lua Nova, no72, p. 83-114. São Paulo. 2007.

. Irmãos: Uma história do PCC. / Gabriel Feltran - $1^{\mathrm{a}}$ ed. - São Paulo: Companhia das Letras, 2018. ISBN 978-85-359-3161-7.

Ferguson, B. 1999. "Microfinance of Housing: A key to housing the moderate or low income majority?" Environment and Urbanization: 11(1), pp.185-200.

FERRÁNDEZ, P. La ciudad, un nuevo espacio humanitario. Violencia urbana y desplazamiento forzado intraurbano (DFI), una aproximación desde soacha (Colombia). Congreso Internacional Contested Cities: Madri, 2016.

FERREIRA, I. C. B., VASCONCELOS, A. M. N., PENNA, N. A. Violência urbana: a vulnerabilidade dos jovens da periferia das cidades. Trabalho apresentado no XVI Encontro Nacional de Estudos Populacionais. Caxambu. 2008.

FERREIRA, L. I. C. Arquitetos militantes em urbanização de favelas. Dissertação (Mestrado em Habitat) - Faculdade de Arquitetura e Urbanismo, Universidade de São Paulo, São Paulo, 2017.

FERREIRA, P. E. B. O filé e a sobra: as favelas no camino do capital imobiliário. Dissertação de Doutorado apresentado à Faculdade de Arquitetura e Urbanismo da Universidade de São Paulo. São Paulo. 2017.

. Urbanização de favelas: metodologias e ação no contexto contemporâneo. XVI Encontro Nacional da Associação Nacional de Pós- 
Graduação e Pesquisa em Planejamento Urbano e Regional - ENANPUR: Belo Horizonte, 2015.

FICHINHO, D. A. S. Pasárgada reconquistada? Estudo sobre o processo de implementação das Unidades de Polícia Pacificadora. Dissertação de Mestrado apresentado à Escola de Direito da Fundação Getúlio Vargas. São Paulo. 2012.

FICHINO, D. ROCHA, Lia de Mattos. 2013. Uma favela "diferente das outras"? Rotina, silencia mento e ação coletiva na favela do Pereirão, Rio de Janeiro. Rio de Janeiro: Quartet \& Faperj.

FIELD, E., KREMER, M. Impact evaluation for slum upgrading intervations. The World Bank Revista Doing Impact Evaluation, no 3. 2005

FIGUEIREDO, M., VASCONCELLOS, F. Divisão social e preferência política na disputa pela prefeitura na cidade do Rio de Janeiro em 2008. In: LAVAREDA, A., TELLES, H. Como o eleitor escolhe seu prefeito: campanha e voto nas eleições municipais. Editora FGV. Rio de Janeiro. 2011. p.55-81.

ALDÉ, A.; DIAS, H.; JORGE, V. L. Estratégias de persuasão eleitoral: uma proposta metodológica para o estudo da propaganda eleitoral. V. IV, no 3, p.182-203. Campinas. 1997.

FILHO, M. N. M. B. Modelos da estrutura socioespacial urbana e práticas estatais de intervenção em favelas no Recife. X Encontro Nacional da Anpur. Belo Horizonte. 2003.

FILHO, P. M. D., et al. Indicação e intermediação de interesses: uma análise da conexão eleitoral na cidade do Rio de Janeiro, 2001-2004. Revista Sociologia e Política. V.22, no. 49, p.39-60. Curitiba. 2014.

FINANCIADORA DE ESTUDOS E PROJETOS, CAIXA ECONÔMICA FEDERAL. Parâmetros técnicos para a urbanização de favelas relatório final parte I- Volume I. LabHab e FUPAM. São Paulo. 1999.

FIQUE, L. "La habitabilidad de la vivienda de interés social en Colombia en los años noventa. Uma explicación a partir de las políticas públicas". Dissertação de mestrado apresentada à Facultad de Artes. Bogotá: Universidad Nacional de Colombia, 2005.

FLEURY, S. Militarização do social como estratégia de integração: o caso da UPP do Santa Marta. Sociologias, ano 14, no 30 p. 194-222. Porto Alegre. 2012.

Rio: marca registrada da participação pacífica Revista le Monde Diplomatique Brasil. São Paulo. 2013.

OST, S. O Mercado Sobe o Morro. A Cidadania Desce? Efeitos Socioeconômicos da Pacificação no Santa Marta. Dados revista de Ciências Sociais. V. 56, no 3, p. 635-671. Rio de Janeiro. 2013. 
FONSECA, F., VIANA, L. Impactos Sociais e Econômicos da Atuação do Banco Interamericano de Desenvolvimento nas Políticas Públicas. Cadernos do Desenvolvimento. V. 6, no 9, p. 199-213. Rio de Janeiro. 2011.

FORERO, M. Breve Historia de Bogotá. Bogotá: Editorial Planeta Colombiana, 2016.

FÓRUM BRASILEIRO DE SEGURANÇA PÚBLICA. Anuário do Fórum Brasileiro de Segurança Pública. São Paulo. 2007.

Paulo. 2008.

Anuário do Fórum Brasileiro de Segurança Pública. São

Paulo. 2009.

Anuário do Fórum Brasileiro de Segurança Pública. São Paulo. 2010.

Anuário do Fórum Brasileiro de Segurança Pública. São Anuário do Fórum Brasileiro de Segurança Pública. São Paulo. 2011.

Paulo. 2012.

Anuário do Fórum Brasileiro de Segurança Pública. São Anuário do Fórum Brasileiro de Segurança Pública. São Paulo. 2013.

Paulo. 2014.

Anuário do Fórum Brasileiro de Segurança Pública. São Anuário do Fórum Brasileiro de Segurança Pública. São Paulo. 2015.

Anuário do Fórum Brasileiro de Segurança Pública. São Paulo. 2016.

Paulo. 2017.

Anuário do Fórum Brasileiro de Segurança Pública. São Anuário do Fórum Brasileiro de Segurança Pública. São Paulo. 2018.

Segurança pública em números. Infográfico. 2018.

FRANCO, M. UPP - A redução da favela a três letras: uma análise da política de segurança pública do Estado do Rio de Janeiro. Dissertação de Mestrado apresentado à Administração, Ciências Contábeis e Turismo da Universidade Federal Fluminense, Niterói. 2014.

FREIRE, J. "2009" na Cidade de Deus: os pontos de vista dos moradores sobre a UPP e o "problema-favela". In: Militarização no Rio de Janeiro: da pacificação à intervenção. FARIAS, J. ... [et al.]. - 1. ed. - Rio de Janeiro: Mórula, 2018. p. 111-128. 
FREIRE-MEDEIROS, B. A construção da favela carioca como destino turístico. Centro de Pesquisa e Documentação de História Contemporânea do Brasil - CPDOC / FGV. Rio de Janeiro. 2006.

FRIDMAN, F. Propriedade fundiária, habitação e processo de urbanização no Rio de Janeiro. In: Cadernos do Instituto de Pesquisa e Planejamento Urbano e Regional da Universidade Federal do Rio de Janeiro - IPPUR/ UFRJ (pp.79-94), vol. VIII, n. 2/3, ano 1994.

FRIDMAN, L. C. Morte e vida favelada. In: SILVA, L. A. M. (Org.). Vida sob cerco: violência e rotina nas favelas do Rio de Janeiro. - Rio de Janeiro: Nova Fronteira, 2008. p. 77-98.

FUNDAÇÃO PERSEU ABRAMO. Pesquisa de opinião: segurança pública. Fundação Rosa Luxemburgo e Pesquisas FPA. São Paulo. 2015.

GARCIA, J. J. R., TOVAR, C. A. T. ¿Y qué querrá el gobernante de turno? Vaivenes en las políticas y programas de mejoramiento barrial y urbano en cinco ciudades colombianas. X Seminario Investigación Urbana y Regional. Bogotá. 2012.

García, N. 2006. "La formación de asentamientos informales: Un proceso gestado por diferentes actores sociales." Scripta Nova: revista electrónica de geografía y ciencias sociales: (10), p.50.

Universidad de Barcelona.

2007. "Asentamientos Precarios: ¿Erradicación y Mejora?." 2001. "Asentamientos irregulares en Monterrey, 1970-2000. Divorcio entre planificación y gestión urbana." Colegio de la Frontera Norte.

GOLÇALVES, R. S. Favelas do Rio de Janeiro: história e direito / Rafael Soares Gonçalves. - Rio de Janeiro: Pallas: Ed. PUC-Rio, 2013. 408 p. : il..

GOMES, M. F. C. M. Sonhos urbanos e pesadelos metropolitanos: violência e segregação na cidade do Rio de Janeiro (Resumo). Revista electrónica de geografía y ciencias sociales Universidad de Barcelona, V. 7, no. 146. Barcelona. 2003.

GOMEZ, E. Algunas consideraciones sobre implementación de Programas de Vivienda o Mejoramiento Barrial. ICHPB - Special Programme. Report n. 860: Rotterdam, 1981.

GOMEZ, L. A. Mejoramiento integral de barrios: Un discurso de hábitat en Bogotá. Bogotá: Universidad Nacional de Colombia, 2013.

GRANADOS, M. A. Participacion ciudadana: Alcances y limitaciones en el desarrollo de Programas de Mejoramiento Integral de Barrios, en la ciudad de Bogotá D.C. Estudio de caso: La UPZ Patio Bonito. Pontificia Universidad Javeriana: Bogotá, 2011.

GROSBAUM, M. O espaço público no proceso de urbanização de favelas. Dissertação de Mestrado apresentado à Faculdade de Arquitetura e Urbanismo da Universidade de São Paulo. São Paulo. 2012. 
GUARÍN, A. 2003. "Cartagena de Indias: Asentamientos informales en la década de los 90." Revista Bitácora Urbano-Territorial: (7), pp.101-109.

HAESBAERT, R. Desterritorialização: entre as redes e os aglomerados de exclusão. In: CASTRO, I. E.; GOMES, P. C. C.; CORRÊA, R. L. (Orgs.). Geografia: Conceitos e Temas. 13a ed. Rio de Janeiro: Bertrand Brasil, 2010. p.165-206.

HENRIQUES, M. N. et al. Enquadramento Jornalístico: enxergando a favela pelos olhos da mídia. XIII Congresso de Ciências da Comunicação na Região Sul. Chapecó. 2012

HERRERA, C. Análisis de los procesos de inclusión social a partir de los programas de mejoramiento urbanístico. Estudio de caso Línea J Metrocable (2007-2010). Universidad Colegio Mayor de Nuestra Señora Del Rosario: Bogotá, 2012.

HIRATA, D.V., TELLES, V. S. Cidade e práticas urbanas: nas fronteiras incertas entre o ilegal, o informal e o ilícito. Revista Estudos Avançados. V. 21, no 61, p. 173-191. São Paulo. 2007.

HUERTA, E., SOLÍS, H. Oportunidades y retos de las urbanizaciones consolidadas de origen informal em el área metropolitana de Guadalajara. In: WARD, P., HUERTA, E., VIRGILIO, M., SIERRA, A. Políticas de vivienda en ciudades latinoamericanas. Una nueva generación de estratégias y enfoques para 2016. ONU-Hábitat III (pp.65-94). Bogotá: Editorial Universidad del Rosário, 2015.

HUGGINS, M. K. Violência urbana e privatização do policiamento no brasil: uma mistura invisível. Caderno $\mathrm{CRH}$. V. 23, no 60, p. 541-558. Salvador. 2010.

HUGHES, P. J. A. Segregação socioespacial e violência na cidade de São Paulo. Revista São Paulo em Perspectiva. V. 18, no 4, p. 93-102. São Paulo. 2004.

IACOVINI. R. F. G. Rodoanel Mário Covas: atores, arenas e processos. Dissertação de Mestrado apresentado à Faculdade de Arquitetura e Urbanismo da Universidade de São Paulo. São Paulo. 2013.

IACOVINI. V. Economia política das remoções forçadas urbanas: expropriação, espoliação e exploração na produção do espaço urbano (o caso da Comunidade Aldaci Barbosa, Fortaleza/CE). Dissertação de Mestrado apresentado à Faculdade de Arquitetura e Urbanismo da Universidade de São Paulo. São Paulo. 2017.

IGNÁCIO, M. T., RUBIO, V. M. Urbanização de favelas: o descompasso de uma política pública. III Encontro da Associação Nacional de Pesquisa e Pósgraduação em Arquitetura e Urbanismo. São Paulo. 2014.

INSTITUTO BRASILEIRO DE ADMINISTRAÇÃO MUNICIPAL - IBAM. Estudo de Avaliação da Experiência Brasileira sobre Urbanização de Favelas e 
Regularização Fundiária. Relatório final Vol. I: Resultados das Análises. Rio de Janeiro. 2002

Estudo sobre inovações públicas locais em projetos de urbanização de assentamentos informais, localizados nas cidades do Rio de Janeiro e Medellin: relatório final. IBAM/ENSUR/CRMP. Rio de Janeiro. 2009.

INSTITUTO DE PESQUISA ECONÔMICA APLICADA. Políticas sociais acompanhamento e análise. Brasília. 2007.

INSTITUTO DE PLANEJAMENTO URBANO PEREIRA PASSOS. Rio's Favelas: Past, Present and Perspectives. Governo do Estado do Rio de Janeiro. Rio de Janeiro. 2015.

JACOBI, P. R. Carência de saneamento básico e demandas sociais: os movimentos por água na cidade de São Paulo na década de 70. In: COSTA, N., SILVA, R., GUILHERME, M.L. Espaço e Debates (pp. 54-65). Revista de Estudos Regionais e Urbanos, vol. 1, n. 22, ano 1987.

JUNIOR, A. C., LIMA, S. P. M., NOTINI, H. H.Características dos ciclos econômicos do estado do Rio de Janeiro. In: PINHEIRO, A. C., VELOSO, F (orgs). Rio de Janeiro - um estado em transição. Editora FGV. R Rio de Janeiro. 2012. p. 63-87.

JUNIOR, H. F. A questão da centralidade em São Paulo: o papel das associações de caráter empresarial. Revista Sociologia e Política, no.16, p.51-66. Curitiba. 2001.

JUNIOR, J. P., PENTEADO, C. L. C.Predisposições, avaliação de governo e campanha eleitoral: a vitória de Kassab em São Paulo. In: LAVAREDA, A., TELLES, H. Como o eleitor escolhe seu prefeito: campanha e voto nas eleições municipais. Editora FGV. Rio de Janeiro. 2011. p.25-55.

JUNIOR, W. B. Planejamento de urbanização de favelas: Caracterização sócio-econômica-ambiental de favelas a partir de dados censitários do IBGE. Dissertação de Mestrado apresentada à Escola Politécnica da Universidade de São Paulo. São Paulo. 2005.

KLEIMAN, M. Intervenções públicas em favelas para dotação de redes Serviços de água e esgoto: perspectivas e limites de acesso ao mundo urbanizado. Cadernos de Pós-Graduação em Arquitetura e Urbanismo. 2010.

KLINTOWITZ, D.C. Entre a reforma urbana e a reforma imobiliária: A coordenação de interesses na política habitacional brasileira nos anos 2000. Dissertação de Doutorado apresentado à Escola de Administração de Empresas de São Paulo da Fundação Getúlio Vargas. São Paulo. 2015.

KRAHENBUHL, L. Cingapura: o encontro de São Paulo com a cidadania. São Paulo: Bix Editora, 1996.

KUNTZ, R. A., 1954 - Manual de campanha eleitoral: marketing político / Ronald A. Kuntz. - 9ae ed. - São Paulo: Global, 2002. ISBN 85-260-0116-7. 
LA ROCQUE, E., ZUMPANO, P. S. The Sustainable Development Strategy of the Municipal Government of Rio de Janeiro. Woodrow Wilson International Center for Scholars. Washington, D.C. 2014.

LABCIDADE, ITDP BRASIL. Ferramenta de avaliação de inserção urbana para os empreendimentos da faixa 1 do programa Minha Casa Minha Vida. Ford Foundation: [s. I.], 2014.

LABORATÓRIO DE ANÁLISE DA VIOLÊNCIA. Segurança, tráfico e milícias no Rio de Janeiro. Relatório Final. UERJ. Rio de Janeiro. 2008.

Laboratório de Habitação e Assentamentos Humanos da FAUUSP. Plano de ação habitacional e urbano: Jardim Ângela. São Paulo. 2003.

urbano. São Paulo. 2003.

Programa Bairro Legal: Plano de ação habitacional e

LAGO, L. C. Os instrumentos da Reforma Urbana e o ideal de cidadania: as contradições em curso. XI Encontro nacional da associação nacional de pós graduação e pesquisa em planejamento urbano e regional - ANPUR. Salvador. 2005.

ROMEIRO, L. C. Q. A oposição Favela-Bairro no espaço social do Rio de Janeiro. Revista São Paulo em Perspectiva. V. 15, no 1, p. 144-154. São Paulo. 2001.

LAVAREDA, A., Principais marcas das eleições municipais brasileiras de 2008. In: LAVAREDA, A., TELLES, H. Como o eleitor escolhe seu prefeito: campanha e voto nas eleições municipais. Editora FGV. Rio de Janeiro. 2011. p.11-25.

TELLES, H. Apresentação. In: LAVAREDA, A., TELLES, H. Como o eleitor escolhe seu prefeito: campanha e voto nas eleições municipais. Editora FGV. Rio de Janeiro. 2011. p. 7-11.

LEEDS, A. LEEDS, E. Favelas e comunidade política: A continuidade da estrutura de controle social. In: LEEDS, A. LEEDS, E. A sociología do Brasil urbano. Editora Fiocruz. Rio de Janeiro. 2015. p. 243-327.

Poder local em relação com instituições de poder supralocal. In: LEEDS, A. LEEDS, E. A sociología do Brasil urbano. Editora Fiocruz. Rio de Janeiro. 2015. p. 63-97.

de Janeiro, 2015.

LEEDS, E. A sociologia do Brasil urbano. Editora Fiocruz: Rio

LEEDS, E. Cocaína e poderes paralelos na periferia urbana brasileira: ameaças à democratização em nível local. In: ZALUAR, A., ALVITO, M. Um século de favela (pp.233-276). Rio de Janeiro: Editora FGV, 2006.

LEITÃO, K. O. A dimensão territorial do Programa de Aceleração do Crescimento: um estudo sobre o PAC no Estado do Pará e o lugar que ele reserva à Amazônia no desenvolvimento do país. Tese de Doutorado 
apresentada à Faculdade de Arquitetura e Urbanismo da Universidade de São Paulo. São Paulo. 2009.

LEITE, M. P. Da "metáfora da guerra" ao projeto de "pacificação": favelas e políticas de segurança pública no Rio de Janeiro. Revista Brasileira de Segurança Pública. V. 6, no 2, p. 374-389. São Paulo. 2012.

Entre a 'guerra' e a 'paz': Unidades de Polícia Pacificadora e gestão dos territórios de favela no Rio de Janeiro. Revista Dilemas. V. 7, no 4, p. 625-642. Rio de Janeiro. 2014.

Violência, risco e sociabilidade nas margens da cidade: percepções e formas de ação de moradores de favelas cariocas. In: SILVA, L. A. M. (org.). Vida sob cerco: violência e rotina nas favelas do Rio de Janeiro. - Rio de Janeiro: Nova Fronteira, 2008. p. 115-142.

FARIAS, J. Militarização e dispositivos governamentais para lidar com os "inimigos" do/no Rio de Janeiro. In: Militarização no Rio de Janeiro: da pacificação à intervenção. FARIAS, J. ... [et al.]. - 1. ed. - Rio de Janeiro: Mórula, 2018. p. 240-261.

SILVA, L. A. M. Violência, crime e polícia: o que os favelados dizem quando falam desses temas? In: SILVA, L. A. M. (Org.). Vida sob cerco: violência e rotina nas favelas do Rio de Janeiro. - Rio de Janeiro: Nova Fronteira, 2008. p. 47-76.

LEMOS, R. L. C. N. O complexo industrial-militar e o Estado brasileiro. In: MATTOS, M. B. Estado e formas de dominação no Brasil contemporâneo. Consequência Editora. Rio de Janeiro. 2017. p. 33-67.

LIMA, R. M. O tempo desvelado: a autoconstrução de moradia. In: Cadernos do Instituto de Pesquisa e Planejamento Urbano e Regional da Universidade Federal do Rio de Janeiro - IPPUR/ UFRJ (pp. 71-98), vol. XXI, n. 1 , ano 2007.

LOBO, F. Operação favela. Revista Página 22, p. 43-49. São Paulo. 2007

LOPES, J. M., PULHEZ, M. De molde a contramolde: (re)construindo questões sobre a urbanização de favelas. In: Cadernos do Instituto de Pesquisa e Planejamento Urbano e Regional da Universidade Federal do Rio de Janeiro - IPPUR/ UFRJ (pp.67-88), vol. 22, n. 2, ano 2008.

LOPEZ, B. La concertacion en un proceso de mejoramiento barrial - el caso de Moravia en Medellín. Tercer Seminario Internacional Habinet sobre Participación Comunitaria, Medellín, 1991.

PELÁEZ, P. P., VILLEGAS, D. La concertacion en un proceso de mejoramiento barrial - El Caso de Moravia en Medellín. Tercer Seminario Internacional Habinet sobre Participación Comunitaria: Medellín, 1991. 
LUNA, S. B. A Estética cinematográfica e a construção do produto turístico "turismo em favela". XI Encontro Nacional de Turismo com Base Local. Niterói. 2010.

MAGALHÃES, A. A lógica da destruição sufocamento, asfixia e resistências nas favelas do Rio de Janeiro. In: Militarização no Rio de Janeiro: da pacificação à intervenção. FARIAS, J. ... [et al.]. - 1. ed. - Rio de Janeiro: Mórula, 2018. p. 262-282.

0 "legado" dos megaeventos esportivos a reatualização da remoção de favelas no Rio de Janeiro. Horizontes Antropológicos. Ano 19, no 40, p. 89-118. Porto Alegre. 2013.

MAIA, P. B. Vinte anos de homicidios no Estado de São Paulo. Revista São Paulo em Perspectiva. V. 13, no 4, p. 121-129. São Paulo. 1999.

MARANHÃO, J. B. P. Biblioteca Parque da Rocinha: cotidiano, cultura e cidadania num equipamento cultural carioca. Tese de Mestrado apresentada ao Centro de Pesquisa e Documentação de História Contemporânea do Brasil - CPDOC. Rio de Janeiro. 2015.

MARICATO, E. A bomba relógio das cidades brasileiras. Revista Democracia Viva. Rio de Janeiro. 2001.

A terra é um nó na sociedade brasileira...também nas cidades. Folha de São Paulo, 27 de julho de 1997.

Metrópole legislação e desigualdade. Revista Estudos Avançados, vol. 17, n. 48, ano 2003.

Metrópole na periferia do capitalismo: llegalidade desigualdade e violência. São Paulo: 1995.

MARÍN, I. E. Mejoramiento barrial en América Latina. Programa de Estudios de Vivienda en América Latina - PEVAL: Medellín, 1991.

MARQUES, E. (coord.) et al. Assentamentos precários no Brasil urbano. Ministério das Cidades. Brasília. 2007.

, SARAIVA, C. As políticas de habitação social, segregação e as desigualdades sociais na cidade. In: MARQUES, E., TORRES, H. (orgs). São Paulo: segregação, pobreza e desigualdades sociais. Editora SENAC. São Paulo. 2005. p. 267-297.

MARQUES, E.; BICHIR, R. As políticas públicas na ciência política. In: Marques, E. e Faria, C. (org.) A política pública como campo multidisciplinar. São Paulo: Unesp/Ed. Fiocruz, 2013.

Políticas Urbanas em São Paulo (1978-98). DADOS Revista de Ciências Sociais. Rio de Janeiro, Vol. 46, № 1, 2003, pp. 39 a 74. 
PAGIN, S.; PULHEZ, M. Produção pública de habitação. In: MARQUES, E. (Org.). As políticas do urbano em São Paulo. São Paulo: Editora Unesp; Centro de Estudos da Metrópole, 2018. p. 141-172.

MATIOLLI, T. Notas sobre o surgimento do bairro do Complexo do Alemão. In: RODRIGUES, R. Vida social e política nas favelas: pesquisas de campo no Complexo do Alemão (pp.71-94). Rio de Janeiro: Instituto de Pesquisa Econômica Aplicada, 2016.

PINHEIRO, A. Urbanização e "Pacificação": Políticas de consolidação da reprodução global do capital nas Favelas Cariocas. I Seminário nacional sobre urbanização de favelas - URBFAVELAS: São Bernardo do Campo, 2014.

MATTOS, C. S. Da valentia à neurose: Criminalização das galeras funk, 'paz' e (auto)regulação das condutas nas favelas. Revista Dilemas. V. 5, no 4, p. 653-680. Rio de Janeiro. 2012.

MAUTNER, Y. A periferia como fronteira de expansão do capital. In: DEÀK, C., SCHIFFER, S. R. (orgs). O processo de urbanização do Brasil. Edusp. São Paulo. 1999, p. 247-259.

MAZIVIERO, M. C., SILVA, A. S. O caso do Complexo Paraisópolis em gestões: diferenças conceituais em programas de intervenção em favelas em São Paulo. Revista Brasileira de Gestão Urbana (Brazilian Journal of Urban Management). V. 10, no 3, p.500-520. [s. I.]. 2018.

MAZO, L. M. S., ZUQUIM, M. L. (org), MAUTNER, Y. (colab). Barrios populares Medellín, favelas São Paulo. FAUUSP. 2017.

BALLESTEROS, L. A. O espaço público nas intervenções urbanas em assentamentos populares de Medellín - Colômbia Transformações no cotidiano da população. IV Encontro da Associação Nacional de Pesquisa e Pós-graduação em Arquitetura e Urbanismo ENANPARQ: Porto Alegre, 2016.

TAMAYO, A. Potencialidades de la participación en la construcción de ciudad desde intervenciones urbanas en asentamientos precários. Universidad de Salamanca: [s. I.], 2014.

BALLESTEROS, L. A. Medellín, una ciudad construida a varias manos. Universidad de Antioquia: Medellín, [s.d.].

MEDEIROS, B. F. A favela e seus tránsitos turísticos. Observatório de Inovação de Turismo. Rio de Janeiro. 2007.

A favela que se vê e que se vende: reflexões e polémicas em torno de um destino turístico. Revista brasileira de Ciências Sociais. V. 22, no. 65, p. 61-72. São Paulo. 2007.

et al. A pobreza turística no mercado de pacificação: reflexões a partir da experiência da Favela Santa Marta. Caderno CRH. V. 20, no 78, p. 571-585. Salvador. 2016. 
MELO, I. D. O. O espaço da política e as políticas do espaço. XIV Encontro nacional da ANPUR. Rio de Janeiro. 2011.

MENEZES, P. Turismo e favela: reflexões sobre ética e fotografía. Revista Dialogando no Turismo - Rosana. V. 1, no 3, p. 10-30. Rosana. 2007.

"Vivendo entre dois deuses": a fenomenologia do habitar em favelas "pacificadas" In: Militarização no Rio de Janeiro: da pacificação à intervenção. FARIAS, J. ... [et al.]. - 1. ed. - Rio de Janeiro: Mórula, 2018. p. 70-91.

MESQUITA, W. Os pentecostais e a vida em favela no Rio de Janeiro A batalha espiritual na ordem violenta na periferia de Campos dos Goytacazes. Estudos de Religião. V. 23, no 37, p. 89-103. São Paulo. 2009.

MIAGUSKO, E. A pacificação vista da Baixada Fluminense: violência, mercado político e militarização. In: Militarização no Rio de Janeiro: da pacificação à intervenção. FARIAS, J. ... [et al.]. - 1. ed. - Rio de Janeiro: Mórula, 2018. p. 161-178.

Esperando a UPP: Circulação, violência e mercado político na Baixada Fluminense .Revista Brasileira de Ciências Sociais. V. 31, no. 91, pp. 1-15. São Paulo. 2016.

MINISTÉRIO DAS CIDADES. Ações integradas de urbanização de assentamentos precários. síntese do curso à distancia. Cities Alliance Project Output. Brasil. 2010.

Cidade para todos: políticas para favelas. Cities Alliance Project Output. Brasil. 2008.

Regularização Fundiária Urbana: Como aplicar a Lei Federal no11.977/2009. Brasília. 2012.

2010.

Urbanização de favelas: a experiência do PAC. Brasília.

MINISTERIO DE AMBIENTE, VIVIENDA Y DESARROLLO TERRITORIAL DNP - DDUPA Lineamientos para la consolidación de la política de mejoramiento integral de barrios-mib. Consejo Nacional de Política Económica y Social República de Colombia Departamento Nacional de Planeación. Bogotá. 2014.

Lineamientos para la consolidación de la política de mejoramiento integral de barrios-mib. Consejo Nacional de Política Económica y Social República de Colombia Departamento Nacional de Planeación. Bogotá. 2009.

MINISTERIO DE VIVIENDA, CIUDAD Y TERRITORIO. Colombia: Cien años de políticas habitacionales. Séptimo Foro Urbano Mundial: Bogotá, 2014.

MISSE, M. Cinco Teses Equivocadas sobre a Criminalidade Urbana no Brasil- Uma Abordagem Crítica, Acompanhada de Sugestões para uma Agenda de Pesquisas. Exposição apresentada à mesa redonda: "violência no 
público e privado" no seminário "violência ou participação social no Rio de Janeiro. IUPERJ. Rio de Janeiro. 1995.

Sobre a acumulação social da violência no Rio de Janeiro. Revista de Ciências Sociais. V. 8, no 3, p. 371-385. Porto Alegre. 2008

MONTEIRO, S. Desvendando dinámicas locais: o caso da Favela Rio das Pedras. Revista Saúde Coletiva. V. 14, no 2, p. 395-423. Rio de Janeiro. 2004

MORAES, R. P. Intervençoes governamentais sobre movimentos de invasoes de terrenos urbanos: estudo de casos no município do Rio de Janeiro em 1983. Dissertação de Mestrado apresentado à Escola Brasileira de Administração Pública e de Empresas. Rio de Janeiro. 1983.

MOREIRA, F. F. Heliópolis e as estratégias de enfrentamento da cidade real. Dissertação de Mestrado apresentado à Faculdade de Arquitetura e Urbanismo da Universidade de São Paulo. São Paulo. 2017.

MOREIRA, R. M. P. Entre a casa e a rua: consolidação de experiências do Programa de Melhorias Habitacionais em Favelas. XV Encontro da ANPUR. Recife. 2013.

MORETTI, J. Áreas de Risco Ocupadas por Assentamentos Informais: Conflito entre Enfrentamento de Riscos Ambientais e Afirmação do Direito à Moradia. In: Revista Magister de Direito Ambiental e Urbanístico (pp. 37-58), n. 50, ano 2013.

, MAGNANI, N., REIS, N. Urbanização de favelas em Áreas de Preservação Permanente: 0 caso da comunidade Jurubatuba e os embates entre preservação ambiental e efetivação do direito à moradia. XVI Encontro Nacional da Associação Nacional de Pós-Graduação e Pesquisa em Planejamento Urbano e Regional - ENANPUR: Belo Horizonte, 2015.

MORETTI, R. (coord.). Urbanização de assentamentos precários no âmbito do Programa de Aceleração do Crescimento na Região do $\mathrm{ABC}$ : relatório final. Chamada MCTI/CNPq/MCidades. 2012.

infraestrutura" em I OFICINA FAVELAS. LabLaje: São Paulo, 2016.

COMARU, F.; SAMORA, P. Definição de diretrizes de intervenção. In: Denaldi, R. (org.) Ações integradas de urbanização de assentamentos precários. Brasília: Ministério das Cidades, 2009.

MOTTA, E. Casas e econômia cotidiana. In: RODRIGUES, R. I. (org). Vida social e política nas favelas: pesquisa de campo no Complexo do Alemão. IPEA. Rio de Janeiro. 2016. p.197-215.

O eleitorado carioca não vai morrer de tédio. Jornal da Cidadania. V.14, no 142, p.8-9. Rio de Janeiro. 2008.

MOULIN, C., TABAK, J. Humanitarismo e a Favela Global: Violência Urbana e Ação Humanitária no Rio de Janeiro. Revista Contexto Internacional. V. 36, no 1, p. 43-74. Rio de Janeiro. 2014. 
NAIFF, L. A. M., NAIFF, D. G. M. A favela e seus moradores: culpados ou vítimas? Representações sociais em tempos de violências. Revista Estudos e Pesquisas em Psicologia, UERJ. Ano 5, n.2. Rio de Janeiro. 2005.

NERI, M. C. As consequências económicas da paz. Valor económico. São Paulo. 2011.

Social. São Paulo. 2011.

UPP e a economía da Rocinha e do Alemão. Conjuntura

NERY, M. B. Crime e violência no cenário paulistano: o movimento e as condicionantes dos homicidios dolosos sob um recorte espaço-temporal. Dissertação de Doutorado apresentado à Faculdade de Filosofia, Letras e Ciências Humanas da Universidade de São Paulo. São Paulo. 2016.

, et al. Regimes espaciais: dinâmica dos homicídios dolosos na cidade de São Paulo entre 2000 e 2008. Revista Panamericana Salud Publica. V. 32, no 6, p. 405-412. Brasil. 2012.

NISIDA, V. C. A autorregulação na produção do espaço nas favelas: reflexões sobre as práticas cotidianas de ocupação e construção da moradia. Anais do II UrbFavelas: Rio de Janeiro, 2016.

Desafios da regulação urbanística no território das favelas. Dissertação (Mestrado em Habitat) - Faculdade de Arquitetura e Urbanismo, Universidade de São Paulo, São Paulo, 2017.

NOGUEIRA, F., PAIVA, C., MORETTI, R. Construindo indicadores para o tratamento de riscos em urbanização de favelas. I Seminário nacional sobre urbanização de favelas - URBFAVELAS: São Bernardo do Campo, 2014.

NUNES, G. Rio, metrópole de $\mathbf{3 0 0}$ favelas. Editora Vozes: Petrópolis, 1976.

OBANDO, C. Movimientos barriales: reivindicación del derecho a la ciudad. Panorama, 9 (16), 66-76.

OLIVEIRA, B. C. S. Políticas públicas e participação social no PAC das favelas. In: RODRIGUES, R. I. (org). Vida social e política nas favelas: pesquisa de campo no Complexo do Alemão. IPEA. Rio de Janeiro. 2016. p. 95-115.

OLIVEIRA, F. L. UPPs, direitos e justiça: Um estudo de caso das favelas do Vidigal e do Cantagalo. Editora FGV. Rio de Janeiro. 2012.

OLIVEIRA, G., BUENO, L. Assentamentos precários em áreas ambientalmente sensíveis. Fonte: Site Vitruvius: http://www.vitruvius.com.br/jornal. 2009.

OLIVEIRA, J., MARCIER, M. A palavra é favela. In: ZALUAR, A., ALVITO, M. Um século de favela (pp.61-114). Rio de Janeiro: Editora FGV, 2006.

OLIVEIRA, M., FADUL, E. Perspectivas e Possibilidades de Intervenções Públicas em Assentamentos Subnormais. XIII Encontro Nacional da Associação Nacional de Pós-Graduação e Pesquisa em Planejamento Urbano e Regional - ENANPUR: Florianópolis, 2009. 
OLIVEIRA, N. A., REGINO, T. M. Urbanização de assentamentos precários e integração de investimentos municipais com o PAC e o PMCMV - 0 caso de São Bernardo. Seminário UrbFavelas. São Bernardo do Campo. 2014.

OLIVEIRA, P. N. A "Guerra" e a "Paz" no discurso midiático sobre segurança pública na cidade do Rio de Janeiro. Revista Cidades, Comunidades e Territórios, pp. 68 - 82. Lisboa. 2012.

OLIVEIRA, R. S. G. Agenda social nos territórios pacificados: um estudo sobre o Programa Territórios da Paz à luz da construção teórica em gestão social. Dissertação de Mestrado apresentado à Escola Brasileira de Administração Pública e de Empresas. Rio de Janeiro. 2014.

OLIVEIRA, S. S. R. A Cruzada São Sebastião e a política de favelas no Rio de Janeiro. XVIII Encontro Regional de História da ANPUH-MG. Mariana. 2012.

, "Trabalhadores Favelados": identificação das favelas e movimentos sociais no Rio de Janeiro e em Belo Horizonte. Dissertação de Doutorado apresentado ao Centro de Pesquisa e Documentação de História Contemporânea do Brasil - CPDOC. Rio de Janeiro. 2014.

, Movimento dos "trabalhadores favelados" e o Morro do Querosene: uma análise do trabalho de narrativa de Vicente Gonçalves sobre as décadas de 1950 e 1960. Revista Mosaico. V.5, no 8, p. 26-45. Rio de Janeiro. 2014.

OSPINA, J. A. Condiciones cualitativas y habitabilidad de las viviendas de los sectores de bajos ingresos en el occidente de Cúcuta. II Semana Internacional y X Semana de Ciencia, Tecnología e innovación: Cúcuta, 2015.

PAIVA, C. C. De olho nos traficantes, malandros e celebridades: um estudo de mídia e violência urbana. BOCC - Portugal. BOCC. Biblioteca Online de Ciências da Comunicação, Portugal, v. 1, n.1, p. 1-15, 2004.

PASTERNAK, S. São Paulo e suas favelas. Revista pós, FAU USP, no 19, p. 176- 197. São Paulo. 2006.

PATERNIANI. "Movimento é movimento, governo é governo"?: a luta por moradia e a política habitacional em São Paulo. IV Colóquio Internacional de Doutorandos/as do CES, Cabo dos Trabalhos. Coimbra. 2013

PATIÑO VILLA, C. A. Medellín: Território, Conflito y Estado. Análisis geoestratégico urbano. Bogotá: Universidad Nacional de Colômbia, 2015.

PATRÍCIO, N. A. V. F. Contradições da politica habitacional "lulista": Uma perspectiva relacional através da análise morfológica do PAC-UAP no Rio de Janeiro. Dissertação de Mestrado apresentado ao Programa de Planejamento Urbano e Regional da Universidade Federal do Rio de Janeiro. Rio de Janeiro. 2017.

PAULA, C. Construindo vínculos de representação política: uma análise do HGPE de quatro candidatos ao Senado pelo Rio de Janeiro em 2010. 
Trabalho apresentado no "GT - Mídia e Eleições", V Congresso da COMPOLITICA, Curitiba. 2013.

PAULANI, L. M. A nserção da economia brasileira no cenário mundial: uma reflexão sobre a situação atual à luz da história. Boletim de Economia e Política Internacional, IPEA. Rio de Janeiro. 2012.

PAULANI, L., TEIXEIRA, R. A. O Mais político dos temas económicos: Um verdadeiro plano passaria pela recuperação da capacidade do país de fazer política económica. Jornal Folha de São Paulo, caderno Dinheiro. São Paulo, 10 de fevereiro de 2007.

PEREIRA, C., RIBEIRO, M. C. Instituições políticas no Rio de Janeiro: a inflluência dos checks \& balances e da competição política nas políticas públicas. In: PINHEIRO, A. C., VELOSO, F (orgs). Rio de Janeiro - um estado em transição. Editora FGV. R Rio de Janeiro. 2012. p. 289-313.

PEREIRA, L. A. S. O Programa Favela-Bairro no Parque Royal e no Grotão. XIII Encontro Da Associação Nacional De Pós-Graduação E Pesquisa Em Planejamento Urbano E Regional. Santa Catarina. 2009.

PERES M. F. T., et al. Homicídios, desenvolvimento socio-econômico e violência policial no Município de São Paulo. Revista Panamericana Salud Publica. V. 23, no 4, p. 268-276. Brasil. 2008.

et al. Queda dos homicídios em São Paulo, Brasil: uma

análise descritiva. Revista Panamericana Salud Publica. V. 29, no 1, p. 17-26. Brasil. 2011.

PÉREZ, Y. Alternativas para el mejoramiento urbano incluyente del asentamiento humano Alcázar del Café. UGCiencia 21, 60-72.

PÉREZ-VALECILLOS, T. et al. 2013. "Creación del espacio público en asentamientos informales: Nuevos desafíos urbanos." Bitácora Urbano Territorial: 2(23).

PERLMAN, J. E. O Mito da Marginalidade: favelas e política no Rio de Janeiro; tradução de Waldívia Marchiori Portinho / prefácio de Fernando Henrique Cardoso / Rio de Janeiro: Paz e Terra, 1977. 377 p. Ilustr. (Estudos brasileiros, v.18). Tradução de: The myth of marginality.

PETRAROLLI, J. O tempo nas urbanizações de favela: contratação e execução de obras do PAC no Grande ABC. Dissertação de mestrado apresentada à UFABC. Santo André: UFABC, 2015.

PICANÇO, F. Filhos de suas mães: notas preliminares de pesquisa sobre a juventude e 0 tráfico de drogas no contexto de pacificação. In: RODRIGUES, R. Vida social e política nas favelas: pesquisas de campo no Complexo do Alemão (pp.175-196). Rio de Janeiro: Instituto de Pesquisa Econômica Aplicada, 2016.

PINTO, L. F. La política pública de vivienda en Colombia - Conflicto de objetivos. Revista Bitácora UrbanolTerritorial, vol. 13, ano 2008. 
PREFEITURA MUNICIPAL DE SÃO PAULO. Plano Municipal de Habitação. São Paulo. 2011.

Urbanização de Favelas: A experiência de São Paulo. São Paulo: Boldarini Arquitetura e Urbanismo, 2008.

PULHEZ, M. M. O arranjo gerencial. Estado, empresas de engenharia e arquitetos nos cotidianos de gestão da política habitacional em São Paulo. Dissertação de Doutorado apresentado ao Instituto de Arquitetura e Urbanismo da Universidade de São Paulo. São Carlos. 2014.

RAMOS, O. L. La cualificación de la periferia urbana y el espacio público. Una reflexión desde las políticas públicas de Bogotá. Revista Territorios, $n$. 18-19, ano 2008.

REIS, A. A dança dos números: 0 impacto das pesquisas eleitorais nas estratégias de comunicação do HGPE nas eleições de 2000 em São Paulo. In: XXVI Congresso Brasileiro de Ciências da Comunicação. Belo Horizonte. 2003.

RESTREPO, A., ORSINI, F. Informalidad y urbanismo social en Medellín. Medellín: Medio Ambiente, Urbanismo Y Sociedad: [s. I.], [s.d.].

RESTREPO, E. Reforma Constitucional y Progreso Social: La "Constitucionalización de la Vida Cotidiana" em Colombia. Seminario en Latinoamérica de Teoría Constitucional y Política - SELA: [s. I.], 2002.

RESTREPO, N. El urbanismo social en Medellín o la utilización estratégica de los derechos. [s. I.], [s.d.]. Revista Bitácora UrbanolTerritorial, vol. 26/2, ano 1997.

REVISTA DE ADMINISTRAÇÃO PÚBLICA DO RIO DE JANEIRO. Documentação Associativismo na Favela. V. 8, no 4, p. 103-152. Rio de Janeiro. 1974.

REZENDE, H. D. Forma reforma desforma: o novo formato da política pública para favelas. Dissertação de Mestrado apresentado à Faculdade de Arquitetura e Urbanismo da Universidade de São Paulo. São Paulo. 2015.

RIBEIRO, A. P. V. O ethos discursivo do PT e do DEM em spots da campanha eleitoral à Prefeitura de São Paulo em 2008. Dissertação de Mestrado apresentado à Faculdade de Filosofia, Comunicação, Letras e Artes da Universidade Católica de São Paulo. São Paulo. 2011.

RIBEIRO, D. Os índios e a civilização - A integração das populações indígenas no Brasil moderno. São Paulo: Companhia das Letras, 1996 (1970)

RIBEIRO, D. O povo brasileiro. A formação e o sentido do Brasil. 1995.

RIBEIRO, F. As contradições das políticas de urbanização de favelas. Revista de Economia Política e História Econômica, n. 14, agosto de 2008.

RIFIOTIS, T. Violência policial e imprensa: o caso da Favela Naval. Revista São Paulo em Perspectiva. V. 13, no 4, p. 28-41. São Paulo. 1999. 
RIO DE JANEIRO (CIDADE). Decreto no14332 de 07 de novembro de 1995. Diário Oficial da Cidade do Rio de Janeiro. Poder Legislativo. Rio de Janeiro, RJ, [s.d].

RIO DE JANEIRO (ESTADO). Decreto no42787 de 06 de janeiro de 2011. Diário Oficial do Estado do Rio de Janeiro. Poder Legislativo. Rio de Janeiro, RJ, 07 jan 2011. Ano XXXVII, no 5, parte 1. p. 2.

RIVERO, P. S., RODRIGUES, R. I. Áreas de concentração das vítimas da violência no Município do Rio de Janeiro (2002-2006). IPEA. Brasília. 2012.

RIZEK, C. Intervenções recentes na cidade de São Paulo: processos, agentes, resultados. Anais do XIII Encontro Nacional da ANPUR, Florianópolis, 2009.

ROCHA, C. Eleitorado paulistano: continuidades e descontinuidades entre 1947 e 2004. Paraná Eleitoral, v. I p. 249-278. Curitiba. 2008.

ROCHA, L. M. Associativismo de moradores de favelas cariocas e criminalização. Estudos Históricos. V. 31, no 65, p. 475-494. Rio de Janeiro. 2018.

Democracia e militarização no Rio de Janeiro: "pacificação", intervenção e seus efeitos sobre o espaço público. In: Militarização no Rio de Janeiro: da pacificação à intervenção. FARIAS, J. ... [et al.]. - 1. ed. - Rio de Janeiro: Mórula, 2018. p. 223-239.

ROCHA, S. M. Debate público e identidades coletivas: a representação de moradores de favela na produção cultural da televisão brasileira. Revista Intexto, UFRGS. V. 1, n. 14, p. 1-21. Porto Alegre. 2006.

RODRIGUES, E. O. Um "campo de pacificação?" Algumas considerações sobre o programa das Unidades de Polícia Pacificadora (UPPs) no Rio de Janeiro. Dissertação de Mestrado em Geografia pela Universidade Federal do Rio de Janeiro. Rio de Janeiro. 2013.

RODRIGUES, R. I. Uma construção complexa: necessidades básicas, movimentos sociais, governo e mercado. In: RODRIGUES, R. I. (org). Vida social e política nas favelas: pesquisa de campo no Complexo do Alemão. IPEA. Rio de Janeiro. 2016. p. 43-71.

RODRIGUES, R. P. et al (org). Legado de Megaeventos esportivos. Ministério dos Esportes e CONFEF. Brasília. 2008.

RODRIGUES, S. Casa própria ou apropriada? Duas abordagens: o FUNAPS Comunitário e o Projeto Cingapura. Dissertação de Mestrado apresentado à Faculdade de Arquitetura e Urbanismo da Universidade de São Paulo. São Paulo. 2006.

RODRIGUEZ, C. F., PORRAS, S., UBAQUE, C. A. La producción de vivenda de interés social en Bogotá. Análisis de dos de sus modelos. Bogotá: Universidad Distrital Francisco José de Caldas, 2014. 
ROLDÁN, S. M. Acercamiento al significado del urbanismo social en Medellín. XIV Encontro Nacional da Associação Nacional de Pós-Graduação e Pesquisa em Planejamento Urbano e Regional - ENANPUR: Rio de Janeiro, 2011.

ROLNIK, R. Exclusão territorial e violência. Revista São Paulo em Perspectiva. V. 13, no 4, p. 100-111. São Paulo. 1999.

A cidade e a lei: legislação, política urbana e territórios na cidade de São Paulo. São Paulo: Studio Nobel, 2007.

, IACOVINI, R. F. G., et al. Relatório Científico da pesquisa "Ferramentas para avaliação da inserção urbana de empreendimentos do MCMV. No prelo. São Paulo: FAUUSP, 2014.

IACOVINI, R. F. G., \& KLINTOWITZ, D. C. Habitação em municípios paulistas: construir políticas ou rodar programas? Revista Brasileira de Estudos Urbanos. No prelo. Rio de Janeiro: ANPUR, 2014.

A guerra dos lugares. A colonização da terra e da moradia na era das finanças. Boitempo: São Paulo, 2015.

Territórios em conflito: São Paulo: espaço, história e política / Raquel Rolnik. - São Paulo: Três Estrelas, 2017. ISBN 978-85-6849343-4.

ROMAÑA, M., and MARIANA, E. 2011. "Habitabilidad de la vivienda de interés social prioritaria en el marco de la cultura. Reasentamiento de comunidades negras de Vallejuelos a Mirador de Calasanz en Medellín, Colombia." Cuadernos de Vivienda y Urbanismo: 4(8).

ROMEIRO, P. S.; FROTA, H. B. (orgs.). Megaprojetos de Impacto Urbano e Ambiental: violação de direitos, resistência e possibilidades de defesa das comunidades impactadas. São Paulo: IBDU, 2015.

RONALD, R. The ideology of home ownership. Basingstoke: Palgrave Macmillan, 2008.

RONCANCIO, C. Evaluación del mejoramiento integral de barrios: el caso Proyecto SUR con Bogotá. Bogotá: Universidad Politécnica de Valencia, 2016.

ROSA, T. T. Favelas, Periferias: uma reflexão sobre conceitos e dicotomías. 33o Encontro Anual da Anpocs. Caxambu. 2009.

ROSSBACH, A., MAGALHÂES, I. A política habitacional e o Estatuto da Cidade. In: ROSSBACH, A., BRUNO, A.N., CARVALHO, C., MONTANDON, D., FERNANDES, E., MAGALHÂES, I., SAULE JR, N. A velha e a nova agenda urbana. Uma análise de 15 anos da lei (pp. 91-98). Cities Alliance: São Paulo, 2016. 
ROYER, L.O. Financeirização da política habitacional: limites e perspectivas / Luciana de Oliveira Royer. Apresentação de Ermínia Maricato. São Paulo: Annablume, 2014. 214 p. II; 16×23 cm. ISBN 978-85-391-0588-5.

RUOTTI, C. Pretensão de legitimidade do PCC: justificação e reconhecimento de suas práticas nas periferias da cidade de São Paulo. Dissertação de Doutorado apresentado à Faculdade de Filosofia, Letras e Ciências Humanas da Universidade de São Paulo. São Paulo. 2016.

SÁENZ, L. C. Análisis de la evolución en las prácticas de Mejoramiento Integral de Barrios (MIB) en la gestión urbana de Bogotá entre 1995-2011. Universidad Colegio Mayor de Nuestra Señora Del Rosario: Bogotá, 2013.

SALAZAR, B., TORO, M. C., VALLEJO, G. A. Políticas estatales em el habitat popular 1968 - 1988. El caso de Medellín. Programa de Estudios de Vivienda en América Latina - PEVAL: Medellín, 1989.

SAMORA, P. R. Projeto de habitação em favelas: especificidades e parâmetros de qualidade. 2010. Tese (Doutorado em Habitat) - Faculdade de Arquitetura e Urbanismo, Universidade de São Paulo, São Paulo, 2010.

SÁNCHEZ, N. E. Proceso de desarrollo de los asentamientos populares "no controlados". Estudios de caso: Medellín - Colombia. Taller Latinoamericano n. 12 del Programa de Estudios de Vivienda en América Latina - PEVAL: Medellín, 1985.

SANTIAGO, V., VELOSO, S. Ninguém entra, ninguém sai: Mobilidade urbana e direito à cidade no Complexo do Alemão. Fundação Henrich Böll Brasil. Rio de Janeiro. 2017.

SANTO AMORE, C., CASTRO, A., PEREIRA, R., RODRIGUES, F., RODRIGUES, D., PEREIRA, M., HORIGOSHI, M. R. Precariedades habitacionais: um ensaio de qualificação e quantificação, uma metodologia de projeto para intervenção em favelas. I Seminário nacional sobre urbanização de favelas - URBFAVELAS: São Bernardo do Campo, 2014.

REIS, N., PEREIRA, R., HORIGOSHI, M. R., ZILIO, D. De entrave ao desenvolvimento a pessoas com direitos: A experiência do plano popular alternativo da Favela da Paz em Itaquera. I Seminário nacional sobre urbanização de favelas - URBFAVELAS: São Bernardo do Campo, 2014.

SANTOS, C. N. Em trinta anos passou muita água sob as pontes urbanas. In: BENJAMIN, W., SANTOS, C. N., WHITAKER, F. Espaço e Debates (pp.2840). Revista de Estudos Regionais e Urbanos, n. 11, ano 1984.

SANTOS, J. V. T. Violências, América Latina: a disseminação de formas de violência e estudos sobre conflitualidades. Sociologias, ano 4, no 8 p. 1632. Porto Alegre. 2002.

SANTOS, L. F. A. A identidade Malufista: bases da proposta política de Maluf nas eleições de 2000 em São Paulo. Dissertação de Mestrado 
apresentado à Faculdade de Filosofia e Ciências Humanas da Universidade Estadual de Campinas. Campinas. 2006.

SANTOS, M. Por uma Economia Política da Cidade. Editora da Universidade de São Paulo: São Paulo, 2009.

SANTOS, M. $O$ território e a nação. Revista de Administração Pública, v. 20 n. 4, Rio de Janeiro: out./dez. 1986. p. 65-69.

SANTOS, T. G. Favela, audiovisual e a cufa: reflexões sobre "Soldado do Morro"', "Falcão-meninos do tráfico" e " 5 x favela - agora por nós mesmos". Dissertação de Mestrado apresentado ao Centro de Pesquisa e Documentação de História Contemporânea do Brasil - CPDOC. Rio de Janeiro. 2015.

SANTOS JUNIOR, O. A. dos; GAFFNEY, C.; RIBEIRO, L. C. de Q. (orgs.). Brasil: os impactos da Copa do Mundo 2014 e das Olimpíadas 2016. Rio de Janeiro: E-Papers, 2015.

SARAIVA, C. As favelas nos 2000. In: Marques, E. (org.) A metrópole de São Paulo no século XXI. São Paulo: Ed. Unesp/CEM.

SCHWARZT, M. P. B., XAVIER, C. E. As favelas de São Paulo e grande São Paulo na visão dos jornais Folha e Estadão (1987 - 2007). Dissertação de Iniciação Científica, apresentado durante a VI Jornada de Iniciação Científica, na modalidade de Comunicação Oral, Mackenzie. São Paulo. 2007.

SECRETARÍA DISTRITAL DEL HÁBITAT. Política Integral del Hábitat 20072017. Revista Bitácora UrbanolTerritorial, vol. 12, ano 2008.

SHIMBO, L. Z. Habitação social, habitação de mercado: a confluência entre Estado, empresas construtoras e capital financeiro. Tese (Doutorado em Arquitetura e Urbanismo) - Escola de Engenharia de São Carlos, Universidade de São Paulo, São Carlos, 2010.

SHLUGER, E. Os caminhos da participação popular - uma reflexão sobre experiências em favelas cariocas. In: BENJAMIN, W., SANTOS, C. N., WHITAKER, F. Espaço e Debates (pp.41-55). Revista de Estudos Regionais e Urbanos, n. 11, ano 1984.

SIERRA, A. Hacia um nuevo enfoquede intervención en la ciudad construída informalmente en Bogotá. In: WARD, P., HUERTA, E., VIRGILIO, M., SIERRA, A. Políticas de vivienda en ciudades latinoamericanas. Una nueva generación de estratégias y enfoques para 2016. ONU-Hábitat III (pp.185-214). Bogotá: Editorial Universidad del Rosário, 2015.

SIERRA, A. P., TARAZONA A. Urbanización informal en Bogotá: Agentes y lógicas de producción del espacio urbano. Revista INVI, vol. 28, n. 78, ano 2013.

SILVA, H. F. R. The "Heliópolis Case" and the political urban dispute in Brazil. Brazilian journal of public administration. V. 52, no 6, p. 1073-1089. Rio de Janeiro. 2018. 
SILVA, H. Programas de urbanização e desenvolvimento do mercado em favelas brasileiras. São Paulo: Lincoln Institute of Land Policy, 2000.

SILVA, J. As Unidades de Polícia Pacificadora. In: SILVA, J., BARBOSA J. L., FAUSTINI, M. V. O novo carioca (pp.131-150). Rio de Janeiro: Mórula Editorial, 2012.

Novos paradigmas para ver a favela. In: SILVA, J., BARBOSA J. L., FAUSTINI, M. V. O novo carioca (pp.79-92). Rio de Janeiro: Mórula Editorial, 2012.

Um espaço em busca de seu lugar. In: BARBOSA, J. L., FAUSTINI, M. V., SILVA, J. S. O novo carioca. Mórula editorial. Rio de Janeiro. 2012. p. 43-63.

SILVA, L. A. M. "Violência urbana", segurança pública e favelas: o caso do Rio De Janeiro atual. Caderno CRH. V. 23, no 59, p. 283-300. Salvador. 2010.

A experiência das UPPs: Uma tomada de posição. Revista Dilemas. V. 8, no 1, p. 7-24. Rio de Janeiro. 2015.

MACHADO DA SILVA, L. A. Apontamentos metodológicos. In: (Org.). Vida sob cerco: violência e rotina nas favelas do Rio de Janeiro. - Rio de Janeiro: Nova Fronteira, 2008. p. 27-34.

Introdução. In:

(Org.). Vida sob cerco: violência e rotina nas favelas do Rio de Janeiro. - Rio de Janeiro: Nova Fronteira, 2008. p. 13-26. Violência urbana, sociabilidade violenta e agenda pública. In: - (Org.). Vida sob cerco: violência e rotina nas favelas do Rio de Janeiro. - Rio de Janeiro: Nova Fronteira, 2008. p. 35-46.

Criminalidade violenta: por uma nova perspectiva de análise. Revista Sociologia e Política, no.13, p.115-124. Curitiba. 1999.

SILVA, M. C. A. Pacificação de favelas: as Unidades de Policiamento Pacificador como a solução para a violência carioca, na ótica do jornal $O$ Globo. Revista Três Pontos. V. 7, no 1, p. 29-38. Belo Horizonte. 2010.

SIMPSON, M. 2013. "Urbanising favelas, overlooking people: Regressive housing policies in Rio de Janeiro's progressive slum upgrading initiatives." University College London.

SOARES, V. B. (Des)organizando o espaço social de favelas: o campo burocrático do estado em ação no contexto da "pacificação". Dissertação de Doutorado apresentado à Escola Brasileira de Administração Pública e de Empresas Fundação Getúlio Vargas. Rio de Janeiro. 2015.

SONODA. K. "Liderança muito perigosa": relatos de líderes comunitários vítimas da violência urbana no Rio de Janeiro. Revista EPOS. V.3, no 2. Rio de Janeiro. 2012. 
SOUZA, M. J. L. O tráfico de drogas no Rio de Janeiro e seus efeitos negativos sobre o desenvolvimento sócio-espacial. In: Cadernos IPPUR/UFRJ, ano 1, no 1. Rio de Janeiro. 1986. p. 25-41.

SOUZA, M. J. L. 0 território: sobre espaço e poder, autonomia e desenvolvimento. In: CASTRO, I. E.; GOMES, P. C. C.; CORRÊA, R. L. (Orgs.). Geografia: Conceitos e Temas. 13a ed. Rio de Janeiro: Bertrand Brasil, 2010. p. 77-116.

SOUZA, M. J. L. Morar Carioca, a intenção e o gesto: limites do planejamento na gestão urbana contemporânea. Seminário UrbFavelas. São Bernardo do Campo. 2014.

0 tráfico de drogas no Rio de Janeiro e seus efeitos negativos sobre o desenvolvimento sócio-espacial. In: Cadernos do Instituto de Pesquisa e Planejamento Urbano e Regional da Universidade Federal do Rio de Janeiro - IPPUR/ UFRJ (pp.25-40), vol. VIII, n. 2/3, ano 1994.

SOUZA, M. L. O desafio metropolitano: um estudo sobre a problemática sócio-espacial nas metrópoles brasileiras / Marcelo Lopes de Souza - $3^{\mathrm{a}}$ ed. - Rio de Janeiro: Bertrand Brasil, 2010. 368 p. ISBN 978-85-286-0766-6.

TATAGIBA, L., TEIXEIRA, A. C. C. Os efeitos do movimento de moradia sobre as políticas públicas. Núcleo de Pesquisa em Participação, Movimentos Sociais e Ação Coletiva (NEPAC-UNICAMP). Campinas. 2011

TEIXEIRA, M. A. Paulo Maluf: ascensão e declínio de uma liderança política. Aurora: revista de arte, mídia e política. V.5, no 14, p.31-45. 2012.

TELLES, M. B. Turismo e pobreza na Era da "Favela Global". Revista Sociedade e Estado. V. 33, no 1. Brasília. 2018.

TELLES, V. S. Favela, favelas: interrogando mitos, dogmas e representações. Revista brasileira de Ciências Sociais. V. 21, no. 62. São Paulo. 2006.

TOBÓN, D., MEJÍA P., SÁNCHEZ, N. E. Instituiciones que intervienen en el mejoramiento barrial. Universidad Nacional de Colombia: Medellín, 1985.

TOLEDO, L. C., 1943 - Repensando as habitações de interesse social / Luiz Carlos Toledo, Verônica Natividade, Petar Vrcibradic. -1. ed. - Rio de Janeiro: Letra Capital: FINEP; Brasília, DF: CNPq, 2014. 96 p.: il. ; $30 \mathrm{~cm}$. ISBN 978857753151.

TORRES, C. A. T, La ciudad en la sombra: barrios y luchas populares en Bogotá 1950-1977. Bogotá: Universidad Piloto de Colômbia, 2013.

"Legalización de barrios: acción de mejora o mecanismo de viabilización fiscal de la ciudad dual." Bulletin de l'Institut français d'études andines: 41(3), pp. 441-471.

TOVAR, C. A. Mejoramiento barrial y urbano. Inclusión social y físico espacial o habilitación de nuevos mercados locales y globales. XII 
Seminario Internacional Red Iberoamericana de Investigadores sobre Globalización y Territorio - RII: Belo Horizonte, 2012.

GARCÍA J. J. ¿Y qué querrá el gobernante de turno? Vaivenes en las políticas y programas de mejoramiento barrial y urbano en cinco ciudades colombianas. X Seminario Investigación Urbana y Regional: Bogotá, 2012.

MORENO, J. E. Pobreza urbana y mejoramiento integral de barrios en Bogotá. Universidad Nacional de Colombia: Bogotá, 2007.

Suelo urbano y vivenda social em Bogotá: la promacía del mercado y el sacrifício del interés general 1990-2010. Bogotá: Universidad Nacional de Colômbia, 2011.

, JOYA, S. Estrategias de inclusión-exclusión de la ciudad colombiana autoproducida mediante políticas de reasentamiento barrial. Fonte: Bulletin de l'Institut français d'études andines - BIFEA: http://bifea.revues.org/5975. 2014

TORRES, E. A. La metamorphosis de la cuestión espacial em Colômbia. Bogotá: Universidad Nacional de Colômbia, 2010.

TORRES, H. Políticas sociais e Território: uma abordagem metropolitana. In: Marques, E. e Torres, H. (org.) São Paulo: segregação, pobreza urbana e desigualdade social. São Paulo: Ed. Senac, 2005.

TOVAR, E. Asentamientos precários. Una aproximación para su mejoramiento integral y prevención. Fonte: Revista Dearq: http://dearq.uniandes.edu.co. 2010.

TRINDADE, C. O Programa de Aceleração do Crescimento -Infraestrutura/ Urbanização de Favelas. XXV Simpósio Nacional de História - ANPUH: Fortaleza, 2009.

UEMURA, M. M. Programa Guarapiranga: alternativa para a proteção dos Mananciais? Dissertação de Mestrado. Campinas: PUCCAMP, 2000.

UN-Habitat. 2003a. "Guide to Monitoring target 11: improving the lives of 100 million slum dwellers. Nairobi, Kenya.." UN-Habitat.

UN-HABITAT. Slum Almanac 2015/2016. Tracking Improvement in the Lives of Slum Dwellers. Nairobi: PSUP, [s.d.].

UNITED NATIONS CENTRE FOR HUMAN SETTLEMENTS. Cities in a globalizing world: global report on human settlements. Londres: Earthscan Publications Ltd, 2001.

UNITED NATIONS HUMAN SETTLEMENTS PROGRAMME. The challenge of slums. Londres: Earthscan Publications Ltd, 2003.

VAINER, C. ET AL. (orgs). Os megaeventos e a cidade: perspectivas críticas. Rio de Janeiro: Letra Capital, 2016. 
VALENTE, J. L. Upps: governo militarizado e a ideia de pacificação / Júlia Leite Valente. - 1. ed. Rio de Janeiro: Revan, 2016. 192 p.; 21cm. ISBN 978-857106-563-5.

VALLADARES, L. P. Passa-se uma casa: Análise do Programa de Remoção de Favelas do Rio de Janeiro. Rio de Janeiro: Zahar Editores, 1978. $142 \mathrm{p}$.

A gênese da favela carioca: a produção anterior às ciências sociais. RBCS. Vol. 15. N. 44. 2000.

A invenção da favela: do mito a origem da favela.com / Licia do Prado Valladares - Rio de Janeiro: Editora FGV, 2005. 204 p.

VARGAS, A. L. B. Fala Manguinhos! A construção de uma agência de comunicação comunitária em favelas e conjuntos habitacionais cariocas. Dissertação de Mestrado apresentado ao Centro de Pesquisa e Documentação de História Contemporânea do Brasil - CPDOC. Rio de Janeiro. 2016.

VARGAS-DÍAZ, I. C., Jiménez-Morales, E. Integración socio-espacial de asentamientos informales en Ibagué, Colombia. Revista Bitácora UrbanolTerritorial, vol. 23, n. 2, ano 2013.

VELÁSQUEZ-CASTAÑEDA, C. A. Intervenciones estatales en sectores informales de Medellín. Experiencias en mejoramiento barrial urbano. Revista Bitácora UrbanolTerritorial, vol. 23, n. 2, ano 2013.

VILLA, M. L. La política de vivienda de interés social en Colombia en los noventa. Naciones Unidas: Santiago de Chile, 1999.

VILLAROSA, F.; MAGALHÃES, F. (eds.) Urbanização de favelas - lições aprendidas no Brasil. New York: Banco Interamericano de Desenvolvimento, 2012.

VIVES, R. C. A. Quem faz uma rádio comunitária? Estudo de caso em uma favela da zona oeste do Rio de Janeiro. Dissertação de Mestrado apresentado ao Centro de Pesquisa e Documentação de História Contemporânea do Brasil - CPDOC. Rio de Janeiro. 2009.

ZALUAR, A. Crime, medo e política. In: ZALUAR, A., ALVITO, M. Um século de favela (pp.209-232). Rio de Janeiro: Editora FGV, 2006.

Democratização inacabada: fracasso da segurança pública. Revista Estudos Avançados. V. 21, no 61, p. 31-49. São Paulo. 2007.

Um debate disperso: violência e crime no Brasil da redemocratização. Revista São Paulo em Perspectiva. V. 13, no 4, p. 3-17. São Paulo. 1999. 
,. Violência: questão social ou institucional? In: OLIVEIRA, N. V. (org). Insegurança pública - Reflexões sobre a criminalidade e a violência urbana. Nova Alexandria. São Paulo. 2002. p. 75-86.

ALVITO, M. Introdução. In: ZALUAR, A., ALVITO, M. Um século de favela (pp.7-24). Rio de Janeiro: Editora FGV, 2006.

ZALUAR, A.; NORONHA, J. C. \& ALBUQUERQUE, C. Violence: Poverty or Institutional Failure? Cad. Saúde Públ., Rio de Janeiro, 10 (supplement 1): 213-217, 1994

ZICCARDI, A. Procesos de urbanización de la pobreza y nuevas formas de exclusión social. Los retos de las políticas sociales de las ciudades latinoamericanas del siglo XXI. Siglo del Hombre Editores. Bogotá. 2008.

ZUQUIM, M. Avanços e retrocessos de modelos de intervenção urbanística em assentamentos precários: A experiência de Cubatão - SP. I Encontro Nacional da Associação Nacional de Pesquisa e Pós-Graduação em Arquitetura e Urbanismo: Rio de Janeiro, 2010.

, D'OTTAVIANO C. Práticas recentes de intervenções contemporâneas em cidades da América Latina. Faculdade de Arquitetura e Urbanismo da Universidade de São Paulo: São Paulo, 2014.

,. Urbanização de assentamentos precários no município de São Paulo: quem ganha e quem perde?. II Encontro da Associação Nacional de Pesquisa e Pós-graduação em Arquitetura e Urbanismo - ENANPARQ: Natal, 2012.

, MAZO, L. M., BRANDÃO, A. J. Intervenções contemporâneas em cidades da América Latina: práticas recentes de intervenção urbana em áreas informais. São Paulo. 2013. 